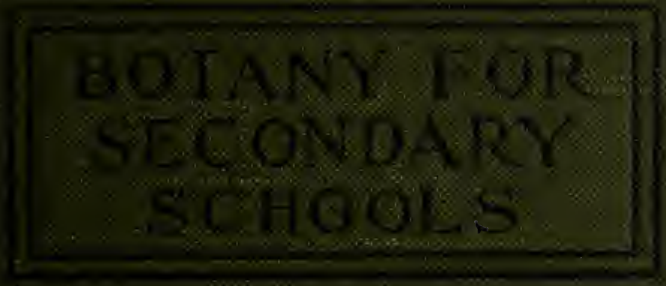




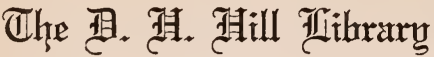

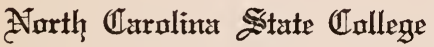

$$
\begin{aligned}
& \text { QK47 } \\
& \text { B155 }
\end{aligned}
$$

\section{3}

\section{ij}

$\therefore=$

NORTH CAROLINA STATE UNIVERSITY LIBRAR 
This book is due on the date indicated below and is subject to an overdue fine as posted at the circulation desk.

EXCEPTION: Date due will be earlier if this item is RECALLED. 




$$
\text { 對 }
$$


- 


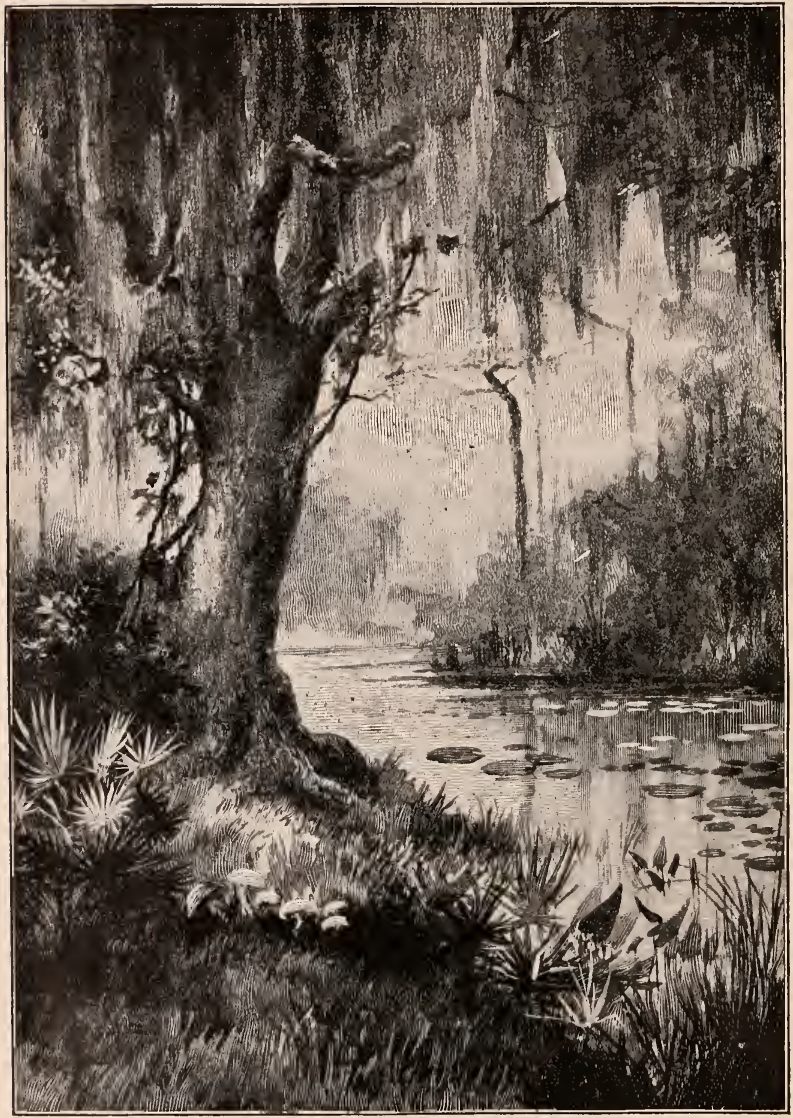

1 "From fragile mushrooms, delicate water-weeds and pond scums, to floating leaves, soft grasses, coarse weeds, tall bushes, slender climbers, gigantic trees and hanging moss." See Chapter I. 


\section{BOTANY FOR \\ SECONDARY SCHOOLS}

A GUIDE TO THE

KNOWLEDGE OF THE VEGETATION

OF THE NEIGHBORHOOD

L. H? BAILEY

Dew Mork

THE MACMILLAN COMPANY

LONDON: MaCMILLAN \& CO., Ltd.

1913

All rights reserved 


\section{Copyright 1900, 1907, 1913}

By L. H. BAILEY

New edition set up and electrotyped July, 1913

Reprinted October, 1913 


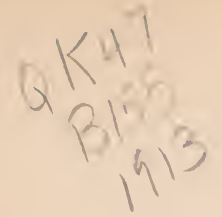

\section{PARAGRAPHS FOR THE TEACHER}

The purpose of this book is to lead the pupil to an understanding of the vegetation of his neighborhood.

There are four general subjects in the book: the nature of the plant itself; the relation of the plant to its surroundings; histological studies; determination of the kinds of plants. From the pedagogical point of view, the third is the least important: th? writer has inserted it because so many schools want it. Each of the subjects is practically distinct, so that the teacher may begin where he will. Few schools will desire to pursue all the four parts.

The notes in small type at the ends of the chapters are intended as suggestions and to supply information to teachers: they are not necessarily for class use. The "Notes" suggest additional experiments and corollary observations.

$$
* \quad * \quad * \quad * \quad *
$$

The schools and the teachers are not ready for the text-book that presents the subject from the viewpoint of botanical science. Perhaps it is better that the secondary schools attempt only to teach plants.

A book may be ideal from the specialist's point of view, and yet be of little use to the pupil and the school.

Every statement in an elementary text-book has two values, - the teaching value and the scientific value. An elementary text exists primarily for the 
purpose of teaching; and good teaching results in quickened perception rather than in accumulation of facts.

The pupil should come at first to the study of plants and animals with little more than his natural and native powers. Study with the compound microscope is a specialization to be made when the pupil has had experience, and when his judgment and sense of relationships are trained.

One of the first essential conceptions to the study of natural history is the fact that no two things are alike. This leads to the understanding that every animal and plant contends for an opportunity to live; and this is the central fact in the study of living things. The world has a new meaning when this fact is understood.

The ninety and nine cannot and should not be botanists, but everyone can love plants and nature. Every person is interested in the evident things, few in the abstruse and recondite. Education should train persons to live, rather than to be scientists.

Now and then a pupil develops a love of science for science's sake. He would be an investigator. He wo:ld add to the sum of human knowledge. He should be encouraged. There are colleges and universities in which he may continue his studies.

In the secondary schools, botany should be taught for the purpose of bringing the pupil closer to the things with which he lives, of widening his horizon, of intensifying his hold on life. It should begin with familiar plant forms and phenomena. It should be related to the experiences of the daily life. It should not be taught for the purpose of making the pupil 
a specialist: that effort should be retained for the few who develop a taste for special knowledge. It is often said that the high-school pupil should begin the study of botany with the lowest and simplest forms of life. This is an error. The microscope is not an introduction to nature. It is said that the physiology of plants can be best understood by beginning with the lower forms. This may be true: but technical plant physiology is not a subject for the beginner. Other subjects are more important.

The youth is by nature a generalist. He should not be forced to be a specialist.

$$
* * * * *
$$

A great difficulty in the teaching of botany is to determine what are the most profitable topics for consideration. The trouble with much of the teaching is that it attempts to go too far, and the subjects have no connection with the pupil's experience.

Good botanical teaching for the young is replete with human interest. It is connected with the common associations.

The teacher often hesitates to teach botany because of lack of technical knowledge of the subject. This is well; but technical knowledge of the subject does not make a good teache.. Expert specialists are so likely to go into mere details and to pursue particular subjects so far, when teaching beginners, as to miss the leading and emphatic points. They are so cognizant of exceptions to every rule that they qualify their statements until the statements have no force. There are other ideals than those of mere accuracy. In other words, it is more important that the teacher be a 
good teacher than a good botanist. One may be so exact that his words mean nothing. But being a good botanist does not spoil a good teacher; and the ideal teacher is one who has careful knowledge and knows how to teach.

An imperfect method that is adapted to one's use is better than a perfect method that cannot be used. Some school laboratories are so perfect that they discourage the pupil in making inquiries when thrown on his own resources. Imperfect equipment often encourages ingenuity and originality. A good teacher is better than all the laboratories and apparatus.

Good teaching devolves on the personality and enthusiasm of the teacher; but subject-matter is a prime requisite. The teacher should know more than he attempts to teach. Every teacher should have access to the current botanical books. The school library should contain these books. By consulting the new books the teacher keeps abreast of the latest opinion and points of view.

$$
\text { * * * * * * }
$$

When beginning to teach plants, think more of the pupil than of botany. The pupil's mind and sympathies are to be expanded: the science of botany is not to be extended. The teacher who thinks first of his subject teaches science; he who thinks first of his pupil teaches nature-study.

Teach first the things nearest to hand. When the pupil has seen the common, he may be introduced to the rare and distant. We live in the midst of common things.

The old way of teaching botany was to teach the 
forms and the names of plants. It is now proposed that only function be taught. But one cannot study function intelligently without some knowledge of plant forms and names. He must know the language of the subject. The study of form and function should go together. Correlate what a plant is with what it does. What is this part? What is its office, or how did it come to be? What are its relations? It were a pity to teach phyllotaxy without teaching light-relation: it were an equal pity to teach light-relation without teaching phyllotaxy.

$$
\text { * * * * * * }
$$

Four epochs can be traced in the teaching of elementary botany: (1) The effort to know the names of plants and to classify. This was the outgrowth of the earlier aspect of plant knowledge, when it was necessary to make an inventory of the things in the world. (2) The desire to know the formal names of the parts of plants. This was an outgrowth of the study of gross morphology. Botanies came to be dictionaries of technical terms. (3) The effort to develop the powers of independent investigation. This was largely a result of the German laboratory system, which developed the trained specialist investigator. It emphasized the value of the compound microscope and other apparatus. This method is of the greatest service to botanical science and to mankind, but its introduction into the secondary schools is usually unfortunate. (4) The effort to know the plant as a complete organism living its own life in a natural way. In the beginning of this epoch we are now living. 
There is a general protest against the teaching of "big names" to pupils; but the pupil does not object to technical terms if he acquires them when he learns the object to which they belong, as he acquires other language. When a part is discovered, the name becomes a necessity, and is not easily forgotten. He should be taught not to memorize the names. The "hard" words of today are the familiar words of tomorrow. There are no words in this book harder than chrysanthemum, thermometer, and hippopotamus.

The book should be a guide to the plant: the plant should be a guide to the book.

Plants should not be personified or endowed outright with motives; but figures of speech and parables may often be employed to teach a lesson or to drive home a point.

Excite the pupil's interest rather than his wonder.

The better the teacher, the less he will confine himself to the questions at the end of the lesson.

Botany always should be taught by the "laboratory method:" that is, the pupil should work out the subjects directly from the specimens themselves. It is easy, however, to carry the laboratory method too far. With beginners, it is rarely good teaching merely to set a young pupil a task, expecting him to work it out. The pupil needs suggestions, help, and the enthusiasm inspired by a good teacher.

Specimens mean more to the pupil when he collects them.

No matter how commonplace the subject, a specimen will vivify it and fix it in the pupil's mind.

A living, growing plant is worth a score of herbarium specimens. 
Every opportunity should be taken to send the pupils to the fields to see the plants naturally as they grow.

Remember that garden plants and field crops are as "botanical" and as well worth the attention of botanists as are wild plants.

$$
* * * * *
$$

Many persons have aided in the making of this book as it has gone through its various editions. In this present revision the author has had the help of Lewis Knudson, Assistant Professor of Plant Physiology, and acting head of the department, in the New York State College of Agriculture at Cornell University, assisted by M. F. Barrus, Assistant Professor of Plant Pathology in the same institution, who have reviewed the work from first to last with much care.

ITHACA, NEW YORK,

$$
\text { L. H. BAILEY. }
$$

MAY 20, 1913. 



\section{CONTENTS}

\section{PART I}

\section{The Plant Itselp}

CHAPTER

PAGE

I. The Plant as a Whole . . . . . . . . 1

II. The Root . . . . . . . . . . . . . 7

III. The Stem . . . . . . . . . . . . 13

IV. Propagation by Means of Roots and Stems . . . 18

V. How the Horticulturist Propagates Plants by Means of Roots and Stems . . . . . . . . 23

VI. Food Reservoirs . . . . . . . . . . . 31

VII. Winter Buds . . . . . . . . . . . 36

VIII. Plants and Sunlight . . . . . . . . . . 42

IX. Struggle for Existence amongst the Branches . $\quad 52$

X. Pruning . . . . . . . . . . . . . 59

XI. The Forms of Plants . . . . . . . . . 64

XII. Water and Mineral Nutrients.-Root Action . . 69

XIII. Water and Mineral Nutrients.-Action above the Roots . . . . . . . . . . . 75

XIV. Food Elaboration, and Respiration . . . . . 82

XV. Dependent Plants . . . . . . . . . . 90

XVI. Leaves and Foliage . . . . . . . . . . 95

XVII. Morphology, or the Study of the Forms of Plant Members . . . . . . . . . 105

XVIII. How Plants Climb . . • • . . . . 112

XIX. Flower-Branches . . . . • . . . 118

XX. The Parts of the Flower . . . . . . 127

XXI. Fertilization and Pollination . . . . . . 133

XXII. Particular Forms of Flowers . . . . . . 143

XXIII. Fruits . . . . . . . . . . 155 
XXIV. Dispersal of Seeds . . . . . . . . . 166

XXV. Germination . . . . . . . . . . 171

XXVI. Phenogams and Cryptogams . . . . . . 179

XXVII. Studies in Cryptogams . . . . . . . . 185

\section{PART II}

The Plant in Its Relation to Environment AND TO MAN

XXVIII. Where Plants Grow . . . . . . . . 205

XXIX. Contention with Physical Environment . . . . 212

XXX. Competition with Fellows . . . . . . . . 218

XXXI. Plant Societies . . . . . . . . . . 228

XXXII. Variation and Its Results . . . . . . . 236

XXXIII. Weeds . . . . . • . . • • . 241

XXXIV. Crops . . . . . . . . . . . . 249

XXXV. The Forest . . . . . . . . . . 256

\section{PART III}

Histology, or the Minute Structure of Plants

XXXVI. The Cell . . . . . . . . . . . 263

XXXVII. Contents and Products of Cells . . . . . 270

XXXVIII. Tissues . . . . . . . . . . . 278

XXXIX. Structure of Stems and Roots . . . . . . 285

XL. Structure of Leaves . • • • • • • . 297

\section{PART IV}

The Kinds of Plants (p. 307) 


\section{BOTANY FOR SECONDARY SCHOOLS}

\section{PART I-THE PLANT ITSELF \\ CHAPTER I}

\section{THE PLANT AS A WHOLE}

1. A plant is a living, growing thing. It partakes of the soil and air and sunshine. It propagates its kind and covers the face of the earth. It has much with which to contend. It makes the most of every opportunity. We shall learn its parts, how it lives, and how it responds.

2. The Parts of a Plant.-Our familiar plants are made up of several distinct parts. The most prominent of these parts are root, stem, leaf, flower, fruit and seed. (Fig. 2.) Familiar plants differ wonderfully in size and shape,--from fragile mushrooms, delicate water-weeds and pond-scums, to floating leaves, soft grasses, coarse weeds, tall bushes, slender climbers, gigantic trees, and hanging moss. See frontispiece.

3. The Stem Part.-In most of the familiar plants there is a main central part or shaft on which the other or secondary parts are borne. This main part is the plant axis. Above ground, in familiar plants, the axis bears

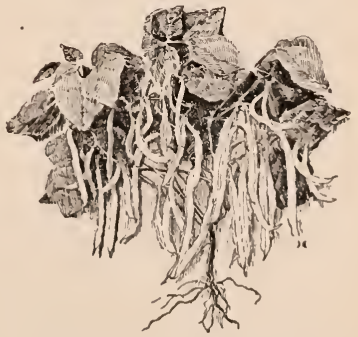

2. The parts of a plant, -root, stem, leaves, pods (or fruit, following the flower). Bean.
A 
the branches, leaves and flowers; below ground, it bears the roots.

4. The rigid part of the plant, which persists over winter and which is left after leaves and flowers are fallen, is the framework of the plant. The framework is composed of both root and stem. When the plant is dead, the framework remains for a time, but it slowly decays. The dry winter stems of weeds are the upper part of the framework or skeleton of the plant. (Figs. 3, 4.) The framework of trees is the most conspicuous part of the plant.

5. The Root Part.-The root bears the stem at its apex, but otherwise it normally bears only root-branches. The stem, however, bears leaves, flowers and fruits. Those living surfaces of the plant that are most exposed to light are green or highly colored. The root tends to grow downward, but the stem tends to grow upward toward light. The plant is anchored or fixed in the soil by the roots.

6. The Foliage Part.-The leaves precede the flowers in point of time or in the life of the plant, although the flowers may come first in the season (note that peach trees bloom before they leaf). The flowers always precede the fruits and seeds. Many plants die when the seeds have matured. The whole mass of leaves of any plant or any branch is known as its foliage.

7. The Plant Generation.-The course of a plant's life, with all the events through which the plant naturally passes, is known as the plant's life-history. The life-history embraces various stages or epochs, as dormant seed, germination, growth, flowering, fruiting. Some plants run their course in a few weeks or months, and some live for centuries.

8. The entire life-period of a plant is called a generation. It is the whole period from birth to normal death, without reference to the various stages or events through which it passes.

9. A generation begins with the young seed, not with 
germination. It ends with death - that is, when no life is left in any part of the plant, and only the seed or spore remains to perpetuate the kind. In a bulbous plant, as a lily or an onion, the generation does not end until the bulb dies, even though the top is dead.

10. When the generation is of only one season's duration, the plant is said to be annual. When it is of two seasons, it is biennial. Biennials usually bloom the second year. When of three or more seasons, the plant is perennial. Examples of annuals are pigweed, bean, pea, garden sunflower, maize; of biennials, evening primrose, mullein, teasel, parsnip, carrot; of perennials, dock, meadow grass, alfalfa, cat-tail, and all shrubs and trees. The biennial and perennial weeds are the most difficult to eradicate.

\section{Duration of the} Plant Body.-Plant structures that are more or less soft and that die at the close of the season are said

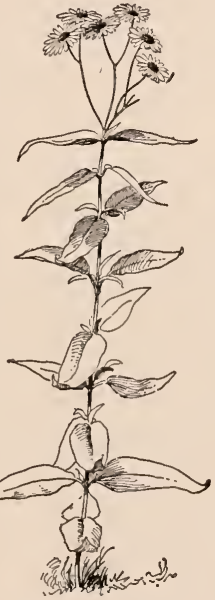

3. Plant of a wild sunflower.

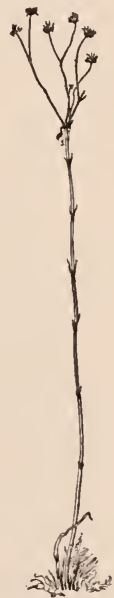

4. Framework of No. 3. to be herbaceous, in contradistinction to being ligneous or woody. A plant that is herbaceous to the ground is ealled an herb; but an herb may have a woody or perennial root, in which case it is called an herbaceous perennial. Annual plants are classed as herbs. Examples of herbaceous perennials are buttercup, bleeding-heart, violet, water-lily, many grasses, dock, dandelion, goldenrod, asparagus, rhubarb, many wild sunflowers (Figs. 3, 4). 
12. Many herbaceous perennials have short generations. They become weak with one or two seasons of flowering and gradually die out. Thus common red clover begins to fail after the second year. Gardeners know that the best bloom of hollyhock, larkspur, pink, and many other plants, is secured when the plants are only two or three years old.

13. Herbaceous perennials that die away each season to bulbs, corms or tubers, are sometimes called pseud-annuals (that is, false annuals). Of such are lily, crocus, onion,

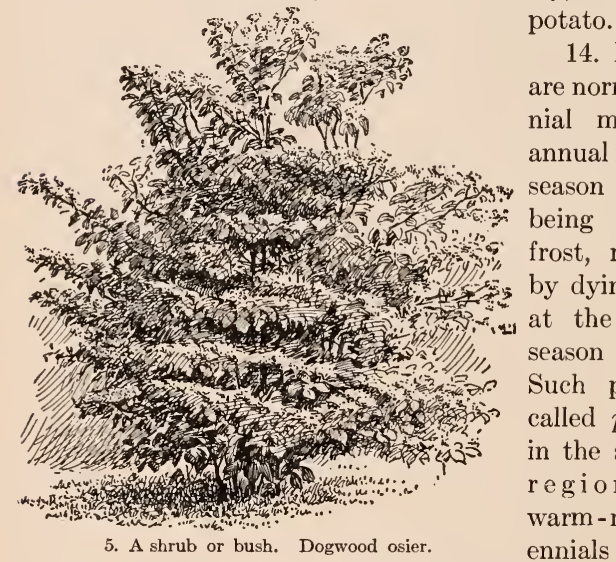

14. Plants that are normally perennial may become annual in a shorterseason climate by being killed by frost, rather than by dying naturally at the end of a season of growth. Such plants are called plur-annuals in the short-season region. Many warm-region perennials are plurannuals when grown in the North, but they are treated as true annuals because they ripen sufficient of their crop the same season in which the seeds are sown to make them worth cultivating, as tomato, red pepper, castor-bean.

15. Woody or ligneous plants are usually longer lived than herbs. Those that remain low and produce several or many similar shoots from the base are called shrubs, as lilac, rose, elder, osier. (Fig. 5.) Low and thick shrubs are 


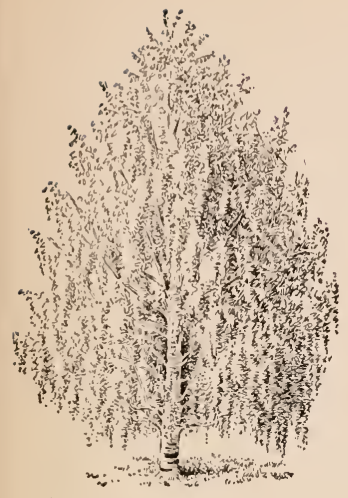

6. A Tree. The weeping birch.

bushes. Plants that produce one main trunk and a more or less elevated head are trees. (Fig. 6.)

16. Plants are Modified by the Conditions in Which They Grow.In most plants, the size, form and general appearance vary or change with the conditions in which the plant grows. That is, there is no uniform or necessary form into which all plants shall grow. No two plants are exactly alike. Observe plants of the same kind and age, and see how they differ or vary. The farmer and gardener can cause plants to be large or small of their kind, by changing the conditions or circumstances under which they grow.

17. No two parts of the same plant are exactly alike. No two parts grow in the same conditions, for one is nearer the main stem, one nearer the light, and another has more room. Try to find two leaves or two branches on the same plant that are exactly alike. (Fig. 7.)

18. Every plant makes an effort to propagate or to perpctuate its kind; and so far as we can sce, this is the end for which the plant itself lives. The seed or spore is the final product of the plant.

19. Every plant, -and every part of a plant-undergoes vicissitudes. Every

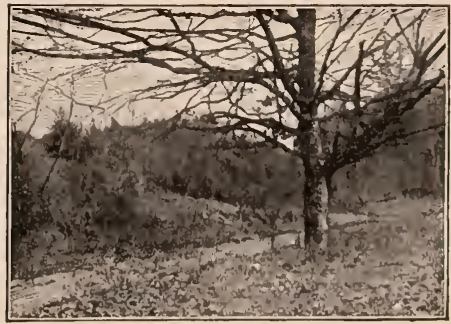

7. There are no two branches alike. 
plant is so constituted as to withstand the diverse conditions of the circumstances in which it is placed. The plant contends for place in which to grow, and for air and light. Its life is eventful. Every plant, therefore, has a history.

Review.-Of what parts is a plant composed? What is the axis? What parts are borne on the stem? On the root? On what part are the mostly highly colored parts found? What direction does the root take? The stem? How are plants anchored in the earth? In what order do the different parts appear? What is meant by the life-history? What are some of the stages or events in the life-history? At what poirt does a generation begin? When end? By what means does the rext generation begin? What is an annual? Biennial? Perennial? Herbaceous perennial? Pseud-annual? Shrub? Bush? Tree? Give three examples of each of these classes, not mentioning any given in the book.

What is a plur-annual? Why are no two parts or plants exactly alike? What is the final effort of every plant? Why is the life of a plant eventful?

Note.-The teacher may assign each pupil to one plant in the school-yard, field, garden, or in a pot, and ask him to bring out the points in the lesson. 


\section{CHAPTER II}

\section{THE ROOT}

20. The Root System.-The offices of the root are to hold the plant in place, and to absorb water and mineral substances. Not all roots, however, absorb water and mineral nutrients.

21. The entire mass of roots of any plant is called its root system. The root system may be annual, biennial or perennial, herbaceous or woody, deep or shallow, large or small.

22. Kinds of Roots.A strong leading central root, which runs directly downwards, is a tap-root. The side or spreading roots are usually smaller. Plants that have such a root system are said to be tap-rooted. Examples are red clover, beet, turnip, radish, burdock, dandelion, alfalfa. (Fig. 8.)

23. A fibrous root system is one that is composed of many nearly equal, slender branches. The greater number of plants have fibrous roots. Examples are many common grasses, wheat, oats, corn, and most trees. The bean in Fig. 2 has a fibrous root system.

24. Shape and Extent of the Root System.-The depth to which roots extend depends on the kind of plant and the 
nature of the soil. Of most plants the roots extend far in all directions and lie comparatively near the surface. The

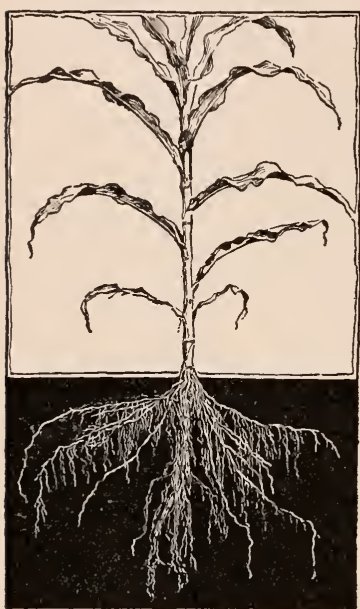

9. The abundant roots of maize. Note that the root branches are much more numerous than the leaves. roots usually radiate from a common point just beneath the surface of the ground.

25. The roots may be of considerable extent, ramifying in the soil, and often extending much farther in all directions than the spread of the top of the plant. Roots tend to spread farther in poor soil than in rich soil. The root has no such definite form as the stem has. Roots are usually very crooked, because they are constantly turned aside by obstacles. Examine roots in stony or gravelly soil.

26 . The extent of root surface is usually very large, for the absorbing roots are fine and very numerous. An ordinary plant of Indian corn
may have a total length of root (measured as if the roots were placed end to end) of hundreds of feet. (Fig. 9.)

27. The finest feeding roots are in the richest soils. It is commonly stated that they are attracted by the nutrients of the soil. This is not strictly true. The roots may grow toward a supply of water. Notice that in a moist soil the roots are short; in a

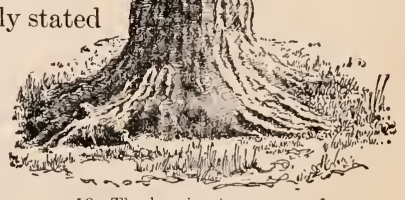

10. The bracing buttresses of a field pine. 
dry soil they are usually long. Roots of the willow run into wells and drains and into the margins of creeks and ponds. Roots may frequently eause trouble by clogging drain-pipes. Grow plants in a long, narrow box, in one end of which the earth is kept very dry and in the other moist: observe where the roots grow.

28 . The absorbing surface of the roots is near their ends. As the roots become old and hard, they serve only as channels through which water and substances in

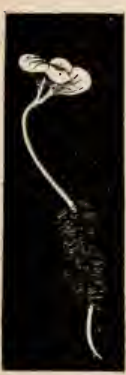
11. Root-hairs 11. Root-hairs
of the radish. solution pass, and as holdfasts or supports for the plant. The root-hold of a plant is very stong. Slowly pull upwards on some plant, and note how firmly it is anchored in the earth. With the increase in diameter, the upper roots often protrude above the ground and become bracing buttresses. These buttresses are usually largest in trees that always have been exposed to strong winds. (Fig. 10.)

29. The Root-hairs.-The larger part of the water and mineral nutrients absorbed by the root is taken in through root-hairs. (Fig. 11.) These are very delicate prolonged surface cells of the roots. They are borne for a short distance just back of the tip of the root.

30 . The root-hairs are very small, often invisible. They, and the young

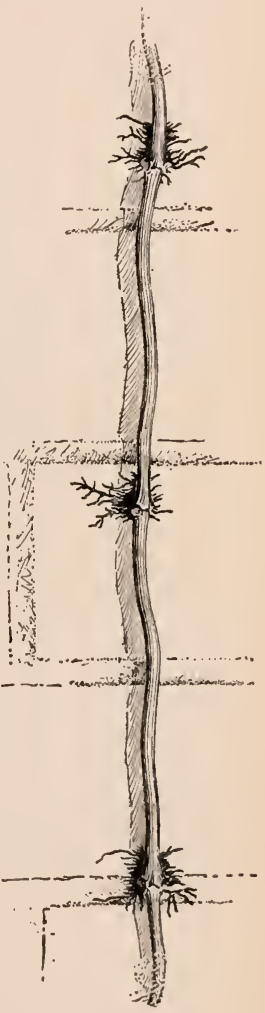

12. Aërial roots of trumpet creeper or tecoma. 
roots, are usually broken off when the plant is pulled up. They are best seen when seeds are germinated between layers of dark blotting-paper or flannel. On the young roots, they will be seen as a mould-like or gossamer-like

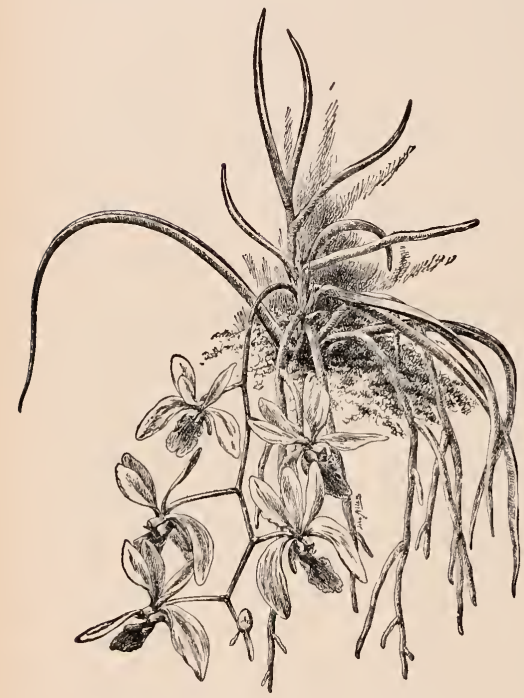

13. Drooping aërial roots of an orchid.

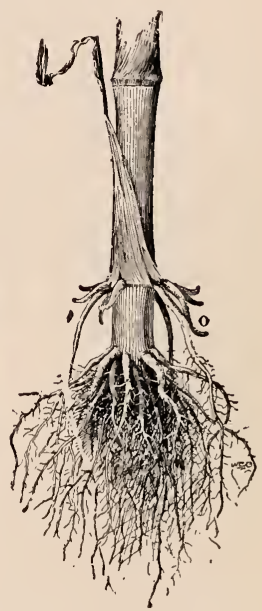

14. Indian corn, showing the aërial roots.

covering. Root-hairs soon die: they do not grow into roots. New hairs form as the root grows.

31. Aërial Roots.-Although most roots grow in the earth, there are some that grow above ground. These usually occur on climbing plants, the roots becoming supports or fulfilling the office of tendrils. These aërial roots usually grow away from the light, and therefore enter the crevices and dark places of the wall or tree over which the plant climbs. The trumpet-creeper (Fig. 12), true or English ivy, 
and poison ivy climb by means of roots. The roots often remain on the wall or other support after the plant is torn off.

32. In some plants, all the roots are aërial; that is, the plant grows above ground, and the roots absorb water from the air and from the bark of the tree on which they grow. Such plants are known as epiphytes or air-plants (Chapter $\mathrm{XV}$ ). The most familiar examples are some of the tropical orchids, which are grown in glasshouses. (Fig. 13.)

33. Some plants throw out aërial roots that propagate the plant or act as braces. The roots of Indian corn are

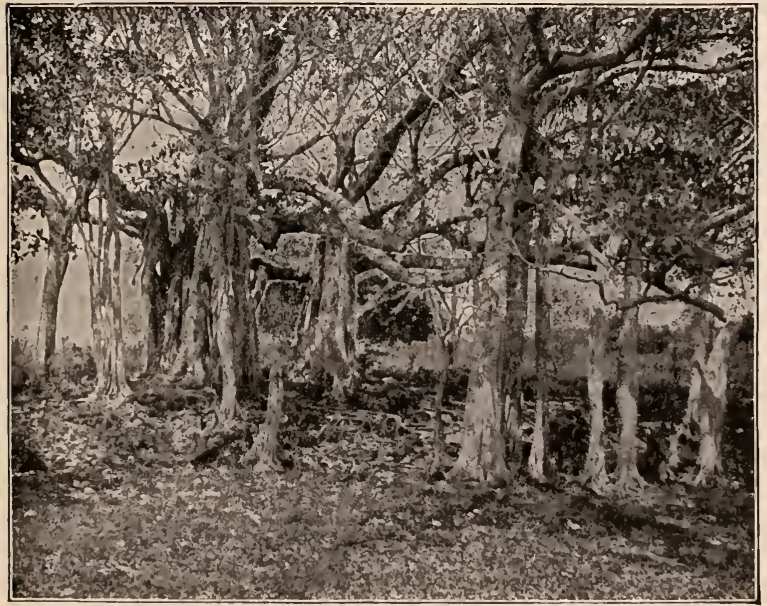

15. A banyan tree in India. The old trunk is seen (at the left), together with many trunks formed from the aërial roots.

familiar. (Fig. 14.) Many ficus trees, as the banyan of India (Fig. 15), send out roots from their branches; when these roots reach the ground they take hold and become great trunks, thus spreading the top of the parent tree over large 
areas. The mangrove tree (Fig. 16) of the tropics grows along seashores and sends down roots from the overhanging branches into the shallow water. and thereby gradually

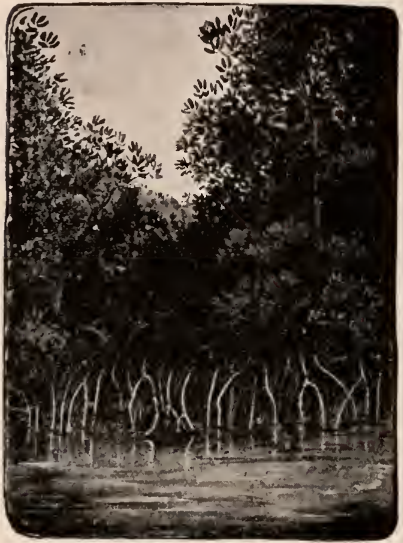

16. Mangroves marching into the sea. marches into the sea. The tangled mass behind catches the drift, and soil is formed.

Review.-What is the root for? What is a root system? Define tap-root. Fibrous root. What determines how deep the root may go? How far does the root spread? Explain what form the root system may assume; also what extent. Where is the greatest number of fine roots found? Where is the absorbing surface of roots? Of what use to the plant are the old woody roots? What are root-hairs? What do they do and what becomes of them? What are aërial roots? Where found? What are epiphytes, and where do their roots grow? What are brace roots? How do the banyan and mangrove spread (aside from seeds)?

Note.-The pupil should see the root-hairs. A week before this lesson is studied, the pupil should place seeds of radish, turnip or cabbage between folds of thick cloth or blotting-paper. Keep the cloth or paper moist and warm. The hairs show best against a dark background. In some of the blotting-papers, sprinkle sand: observe how the root-hairs cling to the grains (compare Chapter XII).

The pupil also should study the root-hold of a plant. Let him carefully pull up a plant. If a plant grows alongside a fence or other rigid object, he may test the root-hold by securing a string to the plant, letting the string hang over the fence and then adding weights to the string. Will a stake of similar size to the plant and extending no deeper in the ground, have such firm hold on the soil? 


\section{CHAPTER III}

\section{THE STEM}

34. The Stem System.-The stem of a plant is the part that bears the buds, leaves, flowers and fruits. Its office is to hold up these parts to the light and air; and through its tissues the various food-materials and nutrients in solu-

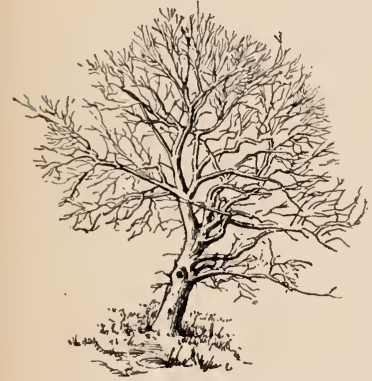

17. Stem system of an apple tree. Deliquescent trunk. tion in water are distributed to the parts of the plant.

35 . The entire mass or fabric of stems of any plant is called its stem system. (Figs. 4, 17.) The stem system may be herbaceous or woody, annual, biennial, or perennial; and it may assume many different sizes and shapes. (Paragraphs 11 to 13.)

36. Stems are of many forms. The general way in which a plant grows is called its habit. The habit is the appearance or looks. Its habit may be open or loose, dense, straight, crooked, compact, straggling, climbing, erect, weak, strong; and the like. The roots and leaves are the important functional or working parts: the stem merely connects them, and its form is exceedingly variable.

37. Kinds of Stems.-The stem may be so short as to be scarcely distinguishable. In such cases the crown of the plant-that part just at the surface of the ground-bears the leaves and flowers; but this crown is really a very short stem. The dandelion (Fig. 8) is an example. Such plants 
are often said to be stemless, however, in order to distinguish them from plants that have long or conspicuous stems. These so-called stemless plants die to the ground every year.

38. Stems are erect when they grow straight up. (Figs. 3, 9.) They are trailing or creeping when they run along on the ground. (Fig. 18.) They are decumbent when they lop over to the ground. They are ascending when they lie mostly or in part on the ground but stand more or less upright at their 18. A trailing plant (Abronia, grown in flower-gardens).

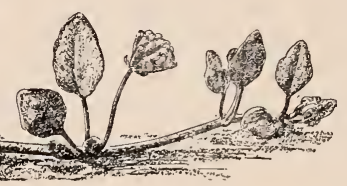

ends. They are climbing when they cling to other rising objects for support. (Fig. 12.)

39. Trees in which the main trunk or the "leader" continues to grow from its tip are said to be excurrent in growth. The branches are borne along the sides of the trunk, as in common pines (Fig. 19) and spruces. Excurrent means "running out" or "running up."

40. Trees in which the main trunk does not continue are said to be deliques cent. The branches arise from one common point or from each other. The stem is lost in the branches. The apple tree (Fig. 17), maple, elm, oak, are familiar examples. Deliquescent means "dissolving" or "melting away."

41. Each kind of plant has its own peculiar habit or direction of growth.

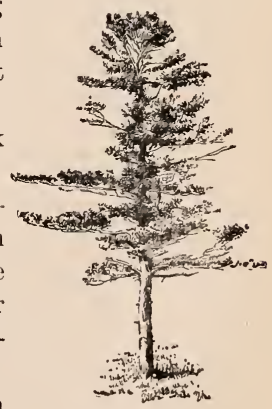

19. Excurrent trunk. A pine. 
Spruces always grow to a single stem or trunk: pear trees are always deliquescent, morning-glories are always climbing, strawberries are always creeping. We do not know why each plant has its own habit; but the habit is in some way associated with the plant's genealogy or with the way in which it has been obliged to live.

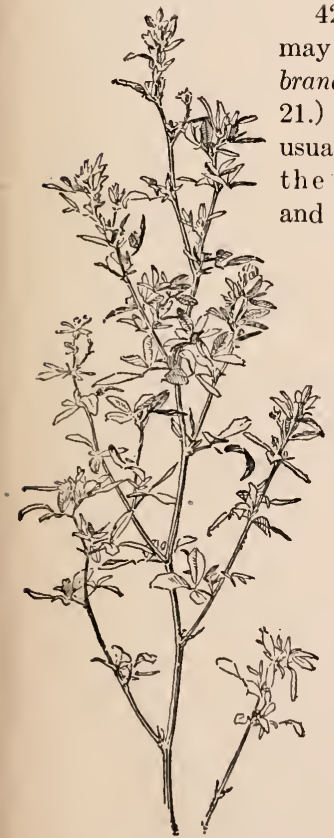

21. Branched stem of alfalfa.

42. The stem may be simple or ranched. (Figs. 20,

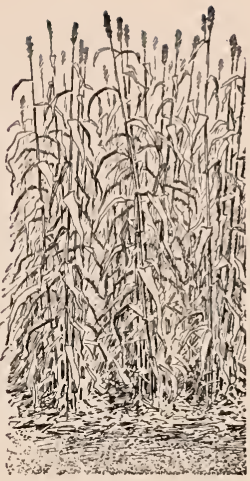

20. Simple stems of sorghum. and side branches either do not start, or, if they start, they soon perish. Mulleins are usually simple. So are palms.

43. Branched stems may be of very different habit and shape. Some stem systems are narrow and erect: these are said to be strict. Others are diffuse, open, branchy, twiggy.

44. Stems vs. Roots.-Roots sometimes grow above ground (31$33)$; so, also, stems sometimes grow underground, and they are then known as subterranean stems, rhizomes, or rootstocks. (Figs. 22, 23.)

45. Stems normally bear leaves and buds, and thereby are they distinguished from roots. The leaves, however, may be reduced to mere 


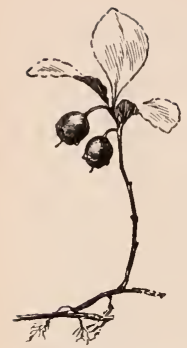

scales, and the buds beneath them may be scarcely visible. Thus the "eyes" on an Irish potato are cavities with a bud or buds at the bottom. (Fig. 24.) Sweet potatoes have no evident "eyes" when first dug (but they may develop buds before the next growing season). The Irish potato is a stem; the sweet potato is an enlarged root.

46. How Stems Elongate.-Roots elongate by growing near the tip. Stems elongate by 22. Wintergreen, growing more or less throughout the young or showing rootstock. soft part or "between joints." But any part of the stem soon reaches a limit beyond which it cannot grow, or becomes "fixed;" and the new parts beyond elongate until they, too, become

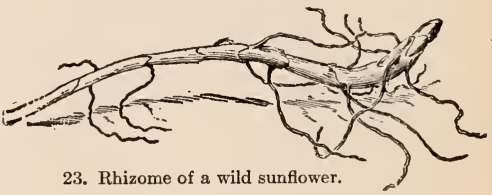
rigid. When a part of the stem once becomes fixed or hard,

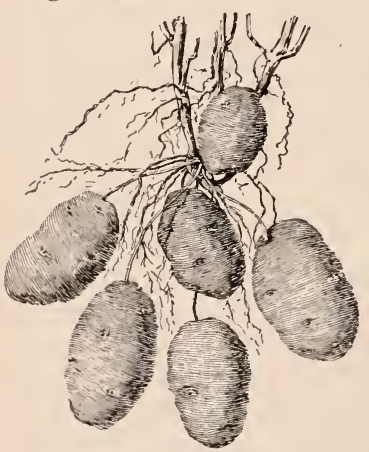

24. Potato. Stems (where?), fine roots, and rootstocks. it never increases in length: that is, the trunk or woody parts never grow longer or higher; branches do not become farther apart or higher from the ground.

47. The different regions of growth in stems and roots may be observed in seedling plants. Place seeds of radish or cabbage between layers of blotting-paper or thick cloth. Keep them damp and warm. When the stem and root have grown an inch and a half long 
each, with waterproof ink mark spaces exactly one-quarter inch apart. Keep the plantlets moist for a day or two, and it will be found that on the stem some or all of the marks are more than one-quarter inch apart; on the root the marks have not separated. The root has grown beyond the last apical mark. (Figs. 25, 26.)

Review.-What is the stem system? What does the stem do? How long may the stem persist? What is meant by the habit of a plant? Name some kinds of habit. What are so-called stemless plants? What is the crown? What becomes of the tops of stemless plants? What are erect, trailing, decumbent, ascending, climbing stems? What are excurrent trunks? Deliquescent? What is a simple stem? What are strict stems? What are subterranean stems? How are stems. distinguished from roots? What is the difference in mode of growth between stems and roots?

Note.-The pupil should make marks with waterproof ink (as Higgins' ink or indelible marking ink) on any soft growing stems - as geranium, fuchsia, grass, the twigs of trees. Note that the separation of the marks is most evident on the youngest shoots.

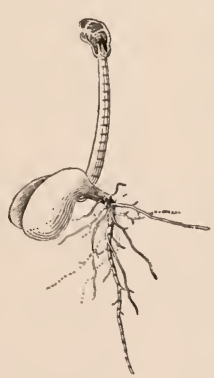

25. The marking of the stem and root.

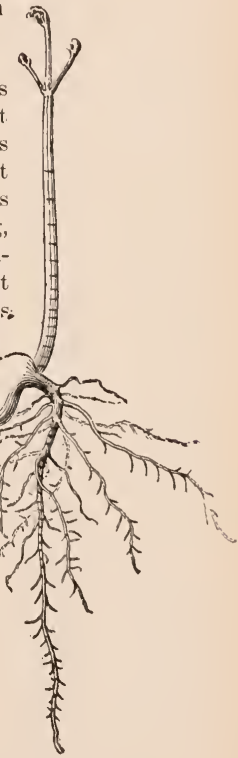

26. The result.

The pupil should observe the fact that a stem of a plant has wonderful strength. Compare the proportionate height, diameter and weight of a grass stem with those of the slenderest tower or steeple. Which has the greater strength? Which the greater height? Which will withstand the most wind? Note that the grass stem will regain its position even if its top is bent to the ground. Split a cornstalk and observe how the joints are tied together and braced with fibers. Note how plants are weighted down after a heavy rain. 


\section{CHAPTER IV}

\section{PROPAGATION BY MEANS OF ROOTS AND STEMS}

48. The primary function of roots and stems is to support and maintain the plant; but these parts may also serve to propagate the plant, or to produce new individuals.

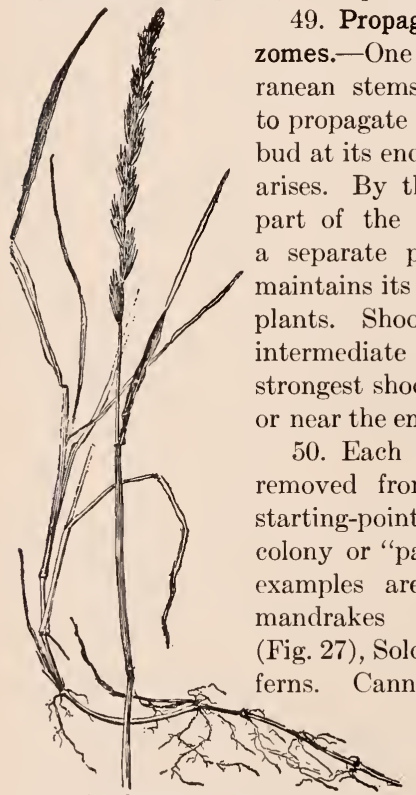

27. Quack-grass or couch-grass. Point out the rootstock.

49. Propagation by Means of Rhizomes.-One function served by subterranean stems or rhizomes (rootstocks) is to propagate the species. Each stem has a bud at its end, and from this bud a shoot arises. By the dying away of the older part of the rhizome, this shoot becomes a separate plant, although the rhizome maintains its connection for years in some plants. Shoots may also arise from the intermediate or lateral buds, but the strongest shoots usually arise from the end or near the end of the rhizome. (Fig. 23.)

50. Each successive plant is farther removed from the original plant or the starting-point of the colony. Thus the colony or "patch" grows larger. Familiar examples are the spreading patches of mandrakes or may-apples, quack-grass (Fig. 27), Solomon's seal, lily-of-the-valley, rhizomes; so does ginger, and the "roots" can be purchased at the drug-store. Fig. 28 illustrates the spread of a 


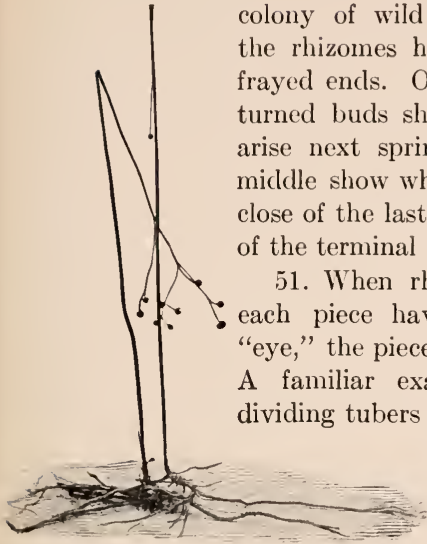

28. Creeping rhizomes of wild sunflower.

of plant designed to be used to propagate the plant is a cutting. See Fig. 29.

52. Cuttings of rhizomes are often made undesignedly or accidentally when land is cultivated. The cultivator or harrow breaks up the rhizomes of quack-grass, Canada-thistle, toadflax, and other weeds, and scatters them over the field.

53. Propagation by Means of Roots.Roots sometimes develop buds and

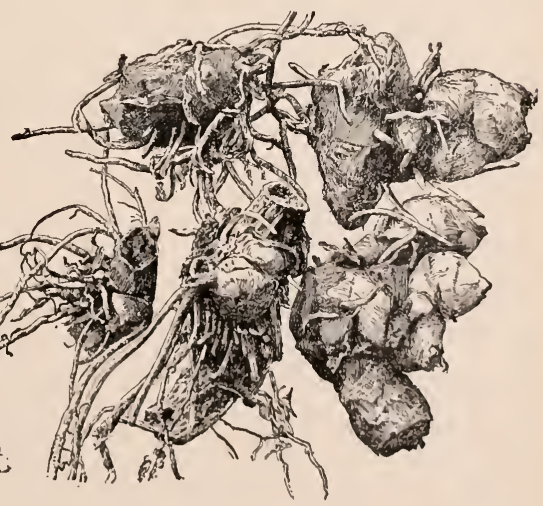

29. Cuttings of canna rhizome. 
throw up shoots or new plants. Severed roots often grow. Blackberries, raspberries, and many plums and cherries, throw up shoots or "suckers" from the roots; and this propensity is usually increased when the roots are broken, as by a plow. Broken roots of apples often sprout. Plants may propagate by means of root-cuttings.

54. Occasional Buds. - The buds that appear on roots are unusual or abnormal,--they occur only occasionally and in no definite order. Buds appearing in unusual places on any part of the plant are called adventitious buds. Such are the buds that arise when a large limb is cut off, and from which suckers or watersprouts arise, as on the apple tree.

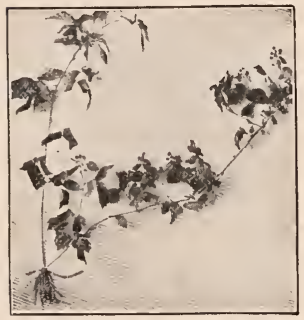

30. A layer of dewberry. The new plant has arisen at the left.

55. Layers.-Roots sometimes arise from aërial stems that are partially buried. If a branch touches the ground and takes root, it is called a layer. Gardeners often bend a limb to the ground and cover it for a short distance, and when roots have formed on the covered part, the branch is severed from its parent and an independent plant is secured. See Fig. 30.

56. There are several kinds of layers: a creeper, when a trailing shoot takes root throughout its entire length; a runner, when the shoot trails on the ground and takes root at the joints, as the strawberry; a stolon, when a more or less strong shoot bends over and takes root, as the black raspberry or the dewberry (Fig. 30); an offset, when a few very strong plants form close about the base of the parent, particularly in succulent or bulbous plants, as house-leek (old-hen-and-chickens) and some lilies. The rooting branches of the banyan and mangrove (Figs. 15, 16) may be likened to layers. 
57. Natural Cuttings.--Sometimes cuttings oecur without the aid of man. Some kinds of willows shed their twigs, or the storms break them off: many of these twigs take root in the moist earth where willows grow, and they are often carried down the streams and are washed along the shores of lakes. Observe the willows along a brook, and determine whether any of

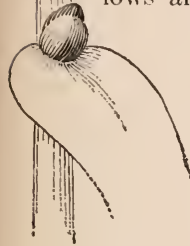

31. Bulblet of tiger lily.

them may have come down the stream.

58. Propagation by Means of Leaves.Even leaves may take root and give rise to new plants. There are examples in warm countries. The lake-cress of northern streams also propagates in this way: the leaves with little plants attached may often be seen floating down stream. Gardeners propagate some kinds of begonias by means of leaf-cutting; also gloxinias and bryophyllums. (Paragraph 69.)

59. Propagation by Means of Buds.-Buds often become detached and propagate the plant. Familiar examples are the bulblets of tiger lilies, borne amongst the foliage; for all bulblets and bulbs are only special kinds of buds. Fig. 31 . Some water plants make heavy winter buds, which become detached on the approach of cold weather and sink to the bottom. In spring, they give rise to new plants.

60. Grafts.-Sometimes a plant may unite with another plant. A branch or a trunk may lie against another plant of the same kind, or of a very closely related kind, and grow

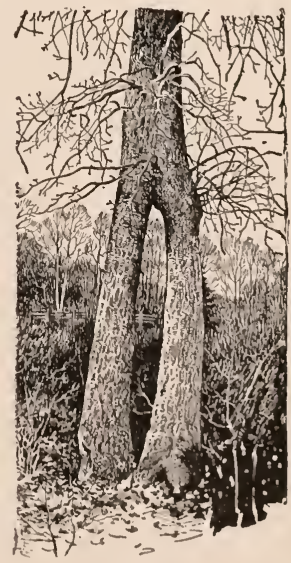

32. A native graft. 
fast to it; and if its original trunk die away, the part will be growing on an alien root. A branch that grows fast to a branch of another plant, the wood of the two knitting together, is called a graft. (Fig. 32.) It is necessary to distinguish between a graft and a parasite: a parasite preys upon another plant, robbing it of its food, but a graft becomes an integral part of the stock on which it grows, and does its full work in elaborating food for itself and for the stock.

Review.- What are primary and secondary functions of roots and stems? What are the functions of rhizomes? How does propagation by rhizomes proceed? Why does the colony spread? Name some plants that propagate by means of rhizomes. What is a cutting? May cuttings be made of rhizomes? How are rhizomatous weeds often spread? Name some of them. How do roots serve to propagate the plant? Name instances. What are adventitious buds? What is a layer? Define some of the kinds of layers,-runner, creeper, stolon, offset. Explain how cuttings may occur without the aid of man. How may leaves serve to propagate the plant? Explain how plants propagate themselves by means of detachable buds. What is a graft? How may grafting take place without the aid of man?

Noтe.-If there is an accessible "patch" of toad-flax, Canada thistle, may-apple, or other perennial plant, the pupil should determine by what means it enlarges from year to year. "Patches" are always instructive when considered with reference to propagation and dissemination. 


\section{CHAPTER V}

\section{HOW THE HORTICULTURIST PROPAGATES PLANTS BY MEANS OF ROOTS AND STEMS}

61. Cuttings in General.-A bit of plant stuck into the ground stands a chance of growing; and this bit is a cutting. (Compare 51.) Not all plants can be propagated by the same kind of cutting. The means is determined by experiment or experience. In some cases the part to be used and the conditions necessary for growing the cutting have not been discovered, and we say that the plant is not propagated by cuttings. It is probable that some plants cannot be grown from cuttings, eveñ under the greatest skill.

62. Most plants propagate from cuttings made of the soft or growing parts (called "wood" by gardeners), of which the "slips" of geranium and coleus are examples. Others grow equally well from cuttings of the hard or mature parts or wood, as currant and grape; and in some instances this mature wood may be of roots, as in the blackberry. Pupils should make cuttings now and then. If they can do nothing more, they can make cuttings of potato, as the farmer does; and they can plant them in a box in the window.

63. The Softwood Cutting.- The softwood cutting is made from tissue that is still growing, or at least from that which is not dormant. It comprises one or two joints, with a leaf attached. (Figs. 33, 34,35 .) It must not be allowed to wilt. Therefore, it must be protected from direct sunlight and dry air until it is well

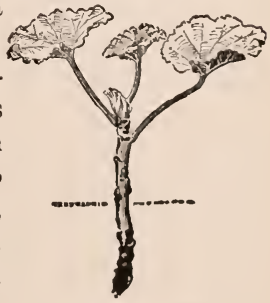

33. Geranium cutting. 
established in the earth; and if it has many leaves, some of them should be removed, or at least cut in two, to reduce the evaporating surface. Most of the common window-plants

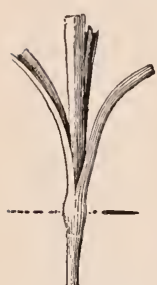

34. Carnation rutting.

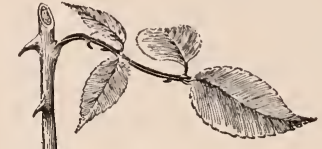

35. Rose cutting. may be propagated easily by means of softwood cuttings or slips.

64. For most plants, the proper age or maturity of wood for the making of cuttings may be determined by giving the twig a quick bend: if it snaps and hangs by the bark, it is in proper condition; if it bends without breaking, it is too young and soft or too old; if it splinters, it is too old and woody. The tips of strong upright shoots usually make the best cuttings. Preferably, each cutting should have a joint or node near its base; and if the internodes (or spaces between joints) are very short, it may comprise two or three joints.

65. The stem of the cutting is inserted one-third or more its length in clean sand or gravel, and the earth is pressed firmly about it. A newspaper may be laid over the bed to

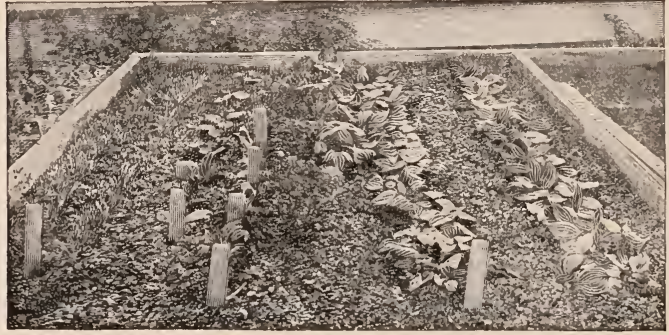

36. Cutting-bed, showing carnations and roses. 
exclude the light-if the sun strikes it-and to prevent too rapid evaporation. The soil should be moist clear through, not on top only.

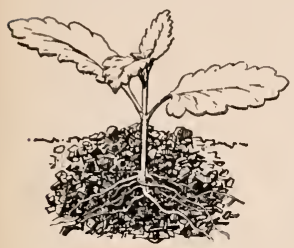

37. Verbens cutting ready for transplanting.

66. Loose sandy or gravelly soil is used. Mason's sand is good earth in which to start most cuttings; or fine gravel-sifted of most of its earthy matter-may be used. Soils that contain much decaying organic matter are avoided, for these soils are breedingplaces of fungi, which attack the soft cutting and cause it to "damp off," or die at or near the surface of the ground. If the cuttings are to be grown in a window, put three or four inches of the earth in a shallow box or a pan. A soap box cut in two lengthwise, so that it makes a box four or five inches deep - like a gardener's flat-is excellent. A cutting-bed may be made on a greenhouse bench or in a good shaded window, as in Fig. 36. Cuttings of common plants, as geranium, coleus, fuchsia, carnation, are kept at a livingroom temperature. As long as the cuttings look bright and green, they are in good condition. It may be a month before roots form. When roots have formed, the plants begin to make new leaves at the tip. Then they may be transplanted into other boxes or into pots. The verbena in Fig. 37 is just ready for transplanting.

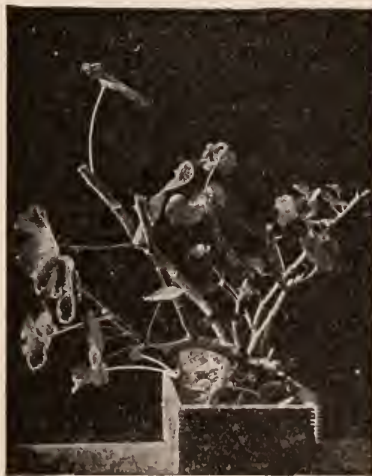

35. Old geranium plant cut back to make it throw out shoots from which cuttings can be madc. 
67. It is not always easy to find growing shoots from which to make the cuttings. The best practice, in that case, is to cut back an old plant, then keep it warm and well watered, and thereby force it to throw out new shoots. The old geranium plant from the window-garden, or the one taken up from the lawn bed, may be treated this way. See Fig. 38. The best plants of geranium and coleus and most window-plants are those that are not more than one

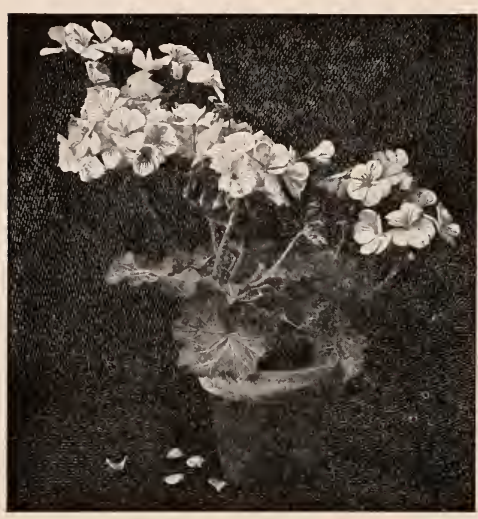

39. Early winter geranium, from a spring cutting. year old. The geranium and fuchsia cuttings that are made in January, February, or March will give compact blooming plants for the next winter; and thereafter new ones take their places. (Fig. 39.)

68. The Hardwood Cutting.Best results are secured when the cuttings are made in the fall and then buried until spring in sand in the cellar. These cuttings are usually 6 to 10 inches long. They are not idle while they rest. The lower end calluses or heals, and the roots form more readily when the cutting is planted in the spring. But if the proper season has passed, take cuttings at any time in winter, plant them in a deep box in the window, and watch. They will need no shading or special care. Grape, currant, willow and poplar readily take root from the hardwood. Fig. 40 shows a currant cutting. It has only one bud above the ground. 


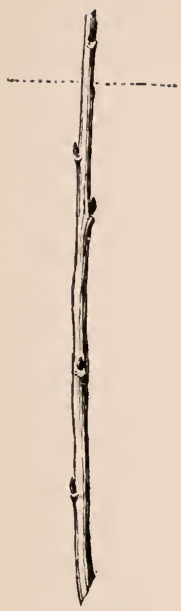

40. Currant cutting.

69. Cuttings of Leaves.-Some plants are regularly propagated by leaf-cuttings. See paragraph 58. Begonias of the "foliage" kinds are the most frequent examples. Sometimes the leaf is cut to wedge-shaped parts, each part with a midrib and a bit of the leaf-stalk; from the point which is put in the earth a new plant arises, as shown in Fig. 41. Gardeners often cut the begonia leaf across and set the severed edge in the earth; sometimes they lay the leaf flat on the earth and peg it down at intervals. The leaf should be nearly or quite mature, but still full of vigor.

70. The Graft.-When the cutting is inserted in a plant rather than in the soil, we have a graft; and the graft may grow. In this case the cutting grows fast to the other plant, and the two become one. When the cutting is inserted in a plant, it is no longer called a cutting, but a cion; and the plant in which it is inserted is called the stock. Fruit trees are grafted in order that a certain variety or kind may be perpetuated.

71. Plants have preferences as to the stocks on which they will grow; but we can find out what their choice is only by making the experiment. The pear grows well on the quince, but the quince does not grow so well on the pear. The pear grows on some of the haw-

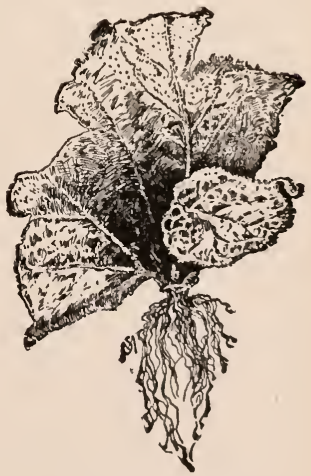

41. Triangular leaf-cutting of begonia or "beefsteak geranium," with the leaf of a young plant starting from the apex. 
thorns, but it is an unwilling subject on the apple. Tomato plants will grow on potato plants, and potato plants on tomato plants. When the potato is the root, both tomatoes and potatoes may be produced; when the tomato is the root, neither potatoes nor tomatoes will be produced. Chestnut will grow on some kinds of oak.

72. The forming, growing tissue of the stem (on the plants we have been discussing) is the cambium, lying on the outside of the woody cylinder, beneath the bark. In order that union may take place, the cambium of the cion and of the

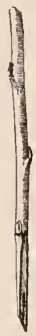

42. Cion of apple.

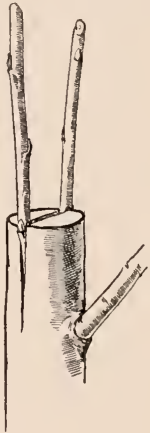

43. The cion inserted.

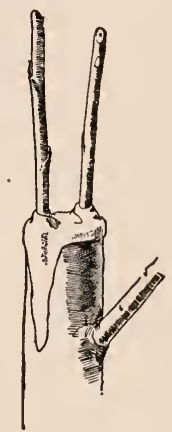

44. The parts waxed.

stock must come together. Therefore the cion is set in the side of the stock. There are many ways of shaping the cion and of preparing the stock to receive it. These ways are dictated largely by the relative sizes of cion and stock, although many of them are matters of mere personal preference. The underlying principles are two: securing close contact between the cambiums of cion and stock; covering the wounded surfaces to prevent evaporation and to protect the parts from disease.

73. On large stocks, the commonest form of grafting is 
the cleft-graft. The stock is cut off and split; and in one or both sides a wedge-shaped cion is firmly inserted. Fig. 42 shows the cion; Fig. 43, the cions set in the stock; Fig. 44, the stock waxed. It will be seen that the lower bud-that lying in the wedge-is covered by the wax; but being nearest the food supply and least exposed to weather, it is the most likely to grow: it will push through the wax.

74. Cleft-grafting is performed in spring, as growth begins. The cions are cut previously, when perfectly dormant, and from the the tree which it is desired to propagate. The cions are kept in sand or moss in the cellar. Limbs of various sizes may be cleft-grafted,--from one-half inch up to four inches in diameter; but a dianeter of one inch is the most convenient size. All the leading or main branches of a tree-top may be grafted. If the remaining parts of the top are gradually cut away and the cions grow well, the entire top will be changed over to the new variety.

Review.- How do we determine how a plant may be propagated? Mention any plants that grow from euttings. What are softwood cuttings? Hardwood? Describe a geranium cutting. What is the proper condition of wood for making a softwood eutting? How is it planted? Where? In what kind of soil? Give directions for watering. How may cutting-wood be secured? Deseribe a hardwood eutting. When is it made? Name plants that can be propagated easily by means of hardwood euttings. Deseribe a leaf-cutting. What is a cion? Stock? How do we find out what stoeks are eongenial to the cion? Describe a eleftgraft. When is eleft-grafting performed? Why do we graft?

Note.-The cutting-box may be set in the window. If the box does not reeeive direct sunlight, it may be corered with a pane of glass to prevent evaporation. Take care that the air is not kept too elose, else the damping-off fungi may attack the cuttings, and they will rot at the surface of the ground. See that the pane is raised a little at one end to afford ventilation; and if water collects in drops on the under side of the glass, remove the pane for a time.

Grafting-wax is made of beeswax, resin, and tallow. The hands are greased, and the wax is then worked until it is soft enough to spread. For the little grafting which any pupil would do, it is better to buy the wax of a seedsman. However, grafting is hardly to be recommended 
as a general school diversion, as the making of cuttings is; and this account of it is inserted chiefly to satisfy the general curiosity on the subject. But now and then a pupil may make the effort for himself, for nothing is more exciting than to make a graft grow all by one's self. The pictures of the cuttings (Figs. 33-35, 37, 40) and the grafts (Figs. 42-44) are one-third natural size.

The many forms of grafting and budding are too special for discussion in this book. Descriptions of them may be found in "The Nursery-Book" and other works. 


\section{CHAPTER VI \\ FOOD RESERVOIRS}

75. Storehouses.-All greatly thickened or congested parts are reservoirs for the storage of plant-food. This food is mostly starch or sugar. Potatoes, beets, turnips, thick rhizomes, seeds, are examples. Recall how potatoes sprout in the cellar (Fig. 45): the sprouts are produced from the stored food.

76. The presence of starch can be determined by applying diluted tincture of iodin to the part: if a blue or purplish brown color appears, starch is present. Cut the part open and moisten the fresh surface with iodin (to be had at the drug store). The test will usually give the best reaction when the part is perfectly dormant. Starch may be found in nearly all twigs in fall and winter. Test thin cross-sections.

77. This stored plant-food enables the plant to start quickly in the spring, without waiting for food elaboration to begin in the leaves; and it enables the plantlet in the

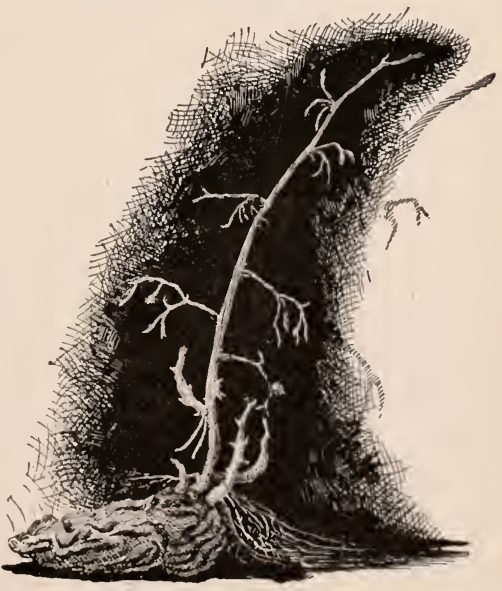

45. Potato sprouts. The sprouts have used the food stored in the tuber. and the tuber has shriveled.

(31) 
seed to grow until it establishes itself in the earth. The flowers of early-blooming trees are developed mostly from the nourishment stored in the twigs, not from the materials

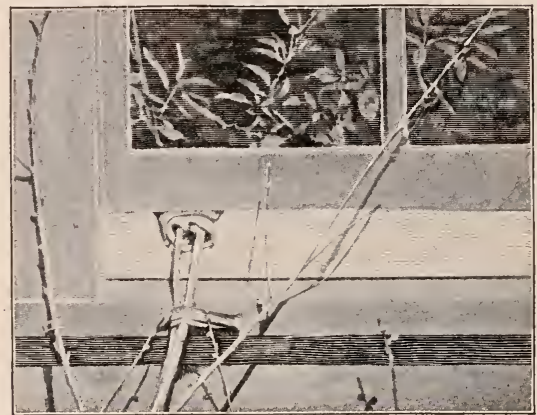

46. A winter branch bearing leaves inside a window, while still attached to the tree outside.

taken in at the time by the roots, nor from food being made by the newly forming leaves. This can be demonstrated by bringing branches of peach, apple, and other earlyblooming plants into the house in the winter and keeping them in water; they will bloom and sometimes even make leaves. Study Fig. 46.

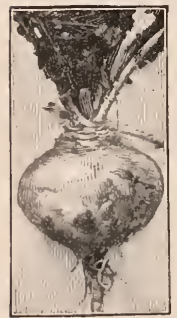

47. Crown-tuber.Turnip.

78. Kinds of Storage-organs.- Short and much thickened or swollen parts of roots or stems are known as tubers. These may be stem-tubers, as the potato, or root-tubers, as the sweet potato (45). Most tubers are subterranean.

79. Many tubers are stem at the top and root in the remaining part: these are called crown-tubers, because the upper part comes to the surface of the ground, or is a crown. Leaves and stems arise from the upper part. 
Beet, radish parsnip, turnip, salsify, carrot, dahlia roots, are examples. These tubers are usually much longer than

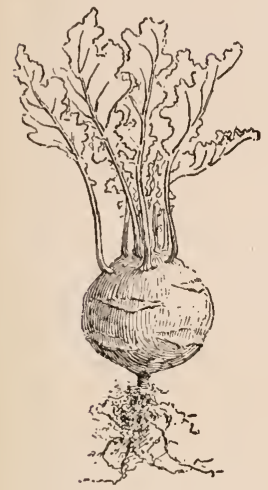

48. Stem-tuber above ground.Kohlrabi. broad, and generally taper downwards. (Fig. 47.) A good example of stem-tuber is the kohlrabi. (Fig. 48).

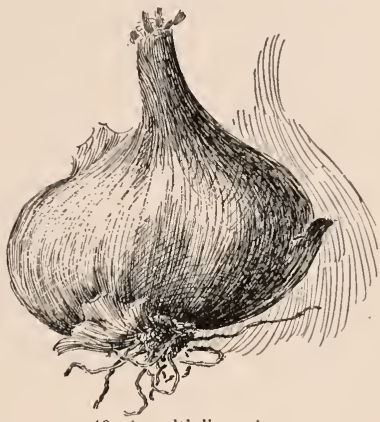

49. A multiplier onion.

80. A much thickened part eomposed of scales or plates is a bulb. The bulb may be scaly, as in the lily; or it may be tunicated,-made up of plates or layers within layers, as the onion.

81. Small bulbs borne amongst the foliage or flowers are known as bulblets. Such are the "top onions," and the little bulbs that the tiger lily (Fig. 31) bears on its stem. Bulbs that grow around the main bulb or which are formed by the breaking apart of the main bulb, are known as bulbels. Many bulbous plants propagate by means

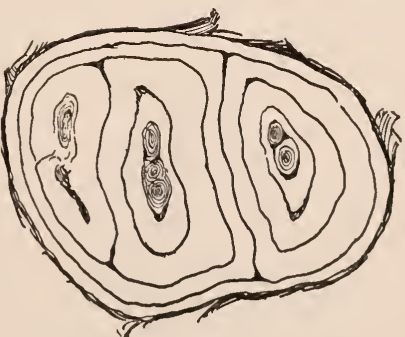

50. Seetion of a multiplier onion. Natural size. 
of bulbels. The multiplier or potato onion (Fig. 49) is an example. If the bulb is cut across, it is found to have two or more "hearts" or cores (Fig. 50). When it has been

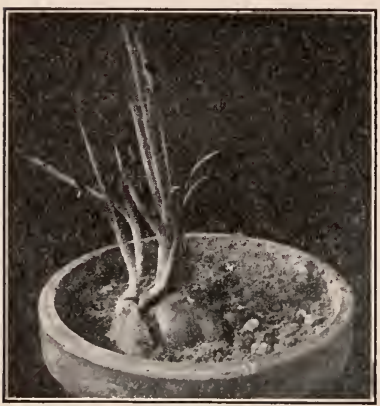

51. Beginning to separate into its parts. Each part will be a little onion. planted a week, each core or part begins to separate (Fig. 51), and there are soon as many onions as there are cores. Potato onions can be bought of seedsmen. They are used for the raising of early onions.

82. Solid bulb-like parts are known as corms. These usually have a loose covering, but the interior is not made up of scales or plates. Of such are gladiolus and crocus corms. (Figs. 52, 53.) Corms multiply by cormels or small corms, as bulbs do by bulbels; or the plant may bear cormlets amongst the branches and foliage. Fig. 54 shows an old gladiolus corm on which three new corms have grown.

83. We have seen that thickened parts may serve one or both of two purposes: they may be storage-organs for

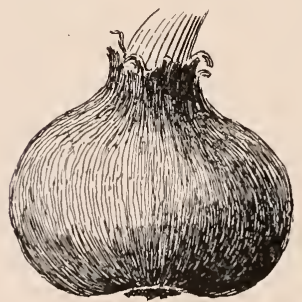

52. Corm of crocus. Nat. size.

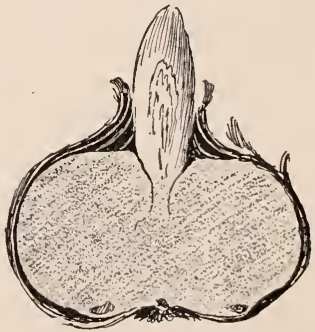

53. Section of a crocus corm. 
food; they may be means of propagating the plant. The storage of food carries the plant over a dry or eold season. By making bulbs or tubers, the plant persists until spring. Future growth is, therefore, provided for by the storage. Bulbous plants are charaeteristic of many dry countries.

Review.-What do you understand by food reservoirs? How is the presence of starch determined? Where may starch be found? Of what service to the plant is this stored food? How are the flowers and leaves enabled to start so early in spring?

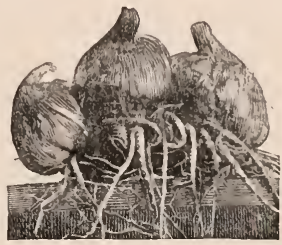

54. Three corms growing on an old one.-Gladiolus.

Define tuber. Root-tuber. Stem-tuber. Crown-tuber. Give examples. Define bulb. Scaly bulb. Tunicated bulb. Bulblet. Bulbel. Give examples. Define corm. Cormel. What two purposes do congested parts serve?

Note.-The pupil should examine various kinds of bulbs and tubers. If these are not at hand, many kinds can be purchased of secdsmen or florists. Secure onion, narcissus, hyacinth, gladiolus, crocus, potato. Cut them in two. Study the make-up. Test them for starch. Plant some of them in pots or boxes. Observe how they grow. In the onion and some other plants, most of the stored food is sugar. Place a potato tuber in a tumbler or cup in a window so that the bottom of the tuber will be in the water. 


\section{CHAPTER VII}

\section{WINTER BUDS}

84. What Buds Are--Because of cold or dry weather, the plant is forced into a period of inactivity. We have seen that it stores food, and is ready to make a quick start in the spring. It also makes embryo branches and packs them away underneath close-fitting scales: these branchlets and their coverings are winter buds. The growing points of the plant are at rest for a time. In the warm season, the growing point is active, and the covering of scales is not so pronounced. A winter bud may be defined as a resting covered growing point.

85. A resting bud, therefore, is a shortened axis or branch, bearing miniature leaves or flowers, or both, and protected by a covering. Cut in two, lengthwise, a bud of the horsechestnut or other plant that has large buds. With a pin, separate the tiny leaves. Count them. Examine the big

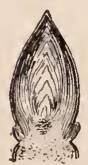

55.

Bud of apricot showing the miniature leaves. bud of the rhubarb as it lies under the ground in winter or early spring. Dissect large buds of the apple and and pear. (Figs. 55, 56.)

86. The bud is protected by firm and dry scales; but these scales are only modified leaves. The scales fit close. Often the bud is protected by varnish (see horse-chestnut and

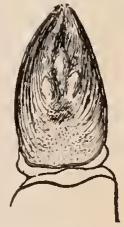

56. Bud of pear showing both leaves and flowers. The latter are the little knobs in the center. more or less woolly. Examine them under a lens. As we might expect, bud-coverings are most prominent in cold and dry climates. 
87. Where Buds Are--Buds are borne in the axils of the leaves,-in the acute angle that the leaf makes with

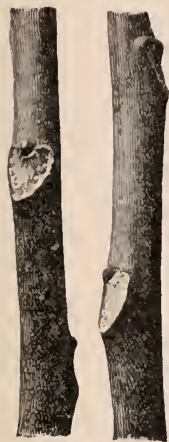

57. Leaf-scars.Ailanthus. the stem. When the leaf is growing in the summer, a bud is forming above it. When the leaf falls, the bud remains, and a scar marks the place of the leaf. Fig. 57 shows the large leaf-scars of ailanthus. Observe those on the horsechestnut, maple, apple, pear, basswood, hickory, or any tree or bush.

88. Sometimes two or more buds are borne in one axil: the extra ones are accessory or supernumerary buds. Observe them in the Tartarian honeysuckle (common in

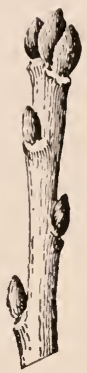

58. Terminal bud between two other buds. Currant. maple, honey locust, and sometimes in the apricot and peach.

89. Shoots of many plants bear a bud at the tip: this is a terminal bud. It continues the growth of the axis in a direct line. Very often three or more buds are clustered at the tip (Fig. 58); and in this case there may be more buds than leaf-scars. Only one of them, however, is strictly terminal.

90. Bulbs and eabbage hearls may be likened to buds: that is, they are condensed stems, with seales or modified

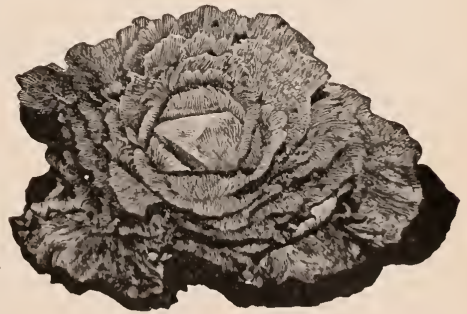

59. A gigantic bud.-Cabbage. leaves densely overlapping and forming a rounded body. (Fig. 59.) They differ from true buds, however, in the fact 
that they are condensations of main stems rather than embryo stems borne in the axils of leaves. But bulblets

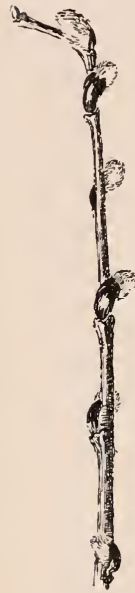

6. Willow.

The "pussies" are pushing out, and a large black bud scale is ready to fall from the base of each. may be scarcely distinguishable from bucls on the one hand and from bulbs on the other. Cut a cabbage head in two lengthwise, and see what it is like.

91. What Buds do.-A bud is a growing point. In the growing season it is small, and persons do not notice it. In the winter it is dormant and wrapped up and is plainly

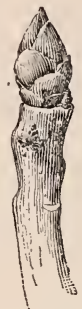

61. Fruitbud of pear.

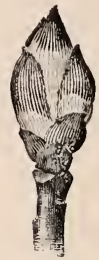

62.

The opening of the pear bud. seen: it is waiting. All branches spring from buds.

92. All winter buds give rise to branches, not to leaves alone: that is, the leaves are borne on the lengthening axis. Sometimes the axis, or branch, remains very short,--so short that it may not be noticed. Sometimes it grows several feet long.

93. Whether the branch grows long or not depends on the chance it has, - position on the plant, fertility of soil, rainfall, and many other things. The new shoot is the unfolding and enlarging of the tiny axis and leaves that we saw in the bud. (Figs. 55,

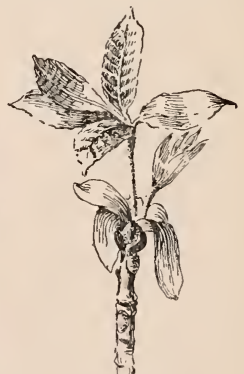

63. Hickory buds.

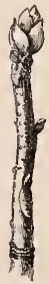

64. Growth is progressing.

56.) If the conditions are congenial, the shoot may form more leaves than were tucked away in the bud, but commonly 
it does not. The length of the shoot usually depends more on the lengths between joints than on the number of leaves.

94. How Buds Open.-When the bud swells, the scales are pushed apart, the little axis elongates and pushes out. In most plants, the outside scales fall very soon, leaving a little ring of scars. Notice peach, apple, plum, willow, and other plants. (Fig. 60.) In others, all the scales grow for a time, as in the pear. (Figs. 61, 62.)

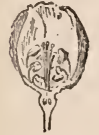

66. A single flower in the pear cluster as seen at 7 A. $\mathrm{M}$. on the day of its opening. At 10 o'clock it will be fully expanded.

In other plants, the inner budscales beeome green and almost leaf-like. See the maple and hickory. Fig. 63 shows a hickory bud. Two weeks later, the young shoot had pushed out

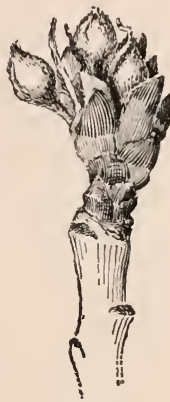

65. Opening of the pear bud.

and the enlarged scales were hanging. (Fig. 64.)

95. Sometimes flowers come out of the buds. Leaves may or may not accompany the flowers. We saw the embryo flowers in Fig. 56. The bud is shown again in Fig. 61. In Fig. 62 it is opening. In Fig. 65 it is more advanced, and the woolly unformed flowers are appearing. In Fig. 66 the growth is more arlvanced. In Fig. 67 the flowers are full blown; and the bees have found them.

96 . Buds that contain or produce only leaves are leaf-buds. Those that contain only flowers are flower-buds or fruit-buds. The latter occur on peach, almond, apricot, and many very early spring-flowering plants.

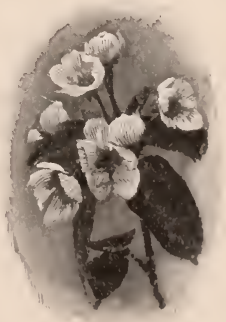

67. Pear in full bloom. (Fig. 68.) The single flower is emerging from the apricot bud in Fig. 69. Those that contain both leaves and flow- 
ers are mixed buds, as in pear (Fig. 67), apple, and most late spring-flowering plants.

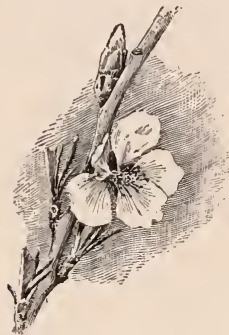

68. Almond flower-the sole occupant of a bud.

97. Fruit-buds are usually thicker or stouter than leaf-buds. They are borne in different positions on differ-

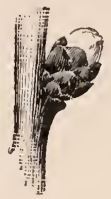

69.

The opening of the flower-bud of apricot. ent plants. In some plants (apple, pear) they are mostly on the ends of short branches or spurs; in others (peach, red maple) they are mostly along the sides of the last year's growths. In Fig. 70 are shown three fruit-buds and one leafbud on $e$, and leaf-buds on $a$. In Fig. 71 a fruit-bud is at the left, and a leaf-bud at the right.

\section{The "Burst of Spring"} means chiefly the opening of the buds. Note the process in Fig. 72 . Everything was made ready in the previous growing season. The embryo shoots and flowers were developed in the buds, and the food was stored. Spring comes on. The warm rain falls, and the shutters open and the sleepers wake: the frogs peep and the birds come.

Review.-What are resting buds? What are they for? What is their covering? Where are they borne? When are they formed? What is a leaf-sear? What are accessory buds? What other name is applied to them? Define terminal bud. What does it do? What are bulbs and cabbages? How do they differ from buds? What do buds do? From what do

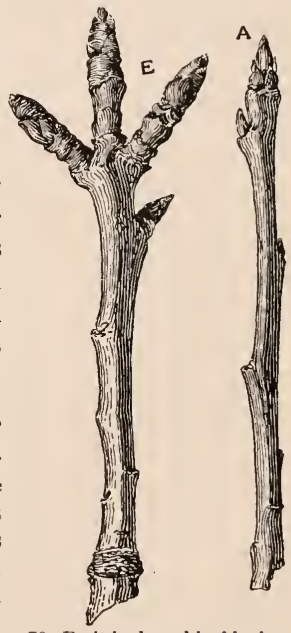

70. Fruit-buds and leaf-buds of pear. 
branches arise? To what do winter buds give rise? What determines whether the branch shall be long or short? Deseribe the opening of a bud. What are flower-buds? Leaf-buds? Mixed buds? How may fruit-buds be distinguished? What is the "burst of spring?"

Note.-It is easy to see the swelling of the buds in a room in winter. Secure branches of trees and shrubs, two to three feet long, and stand them in vases or jars, as you would flowers. Renew the water frequently and cut off the lower ends of the shoots occasionally. In a week or two the. buds will begin to swell. Of red maple, peach, apricot, and other very early-flowering things, flowers may be secured in ten to twenty days. Try it.

The shape, size, and color of the winter buds are different in every kind of plant. By the buds alone botanists are often able to distinguish the

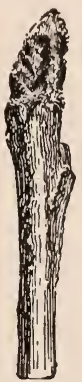

71. Fruit-bud and leafbud of apple. kinds of trees. Even such similar plants as the different kinds of willows have good bud eharacters. The study of the kinds of buds affords excellent training of the powers of observation.

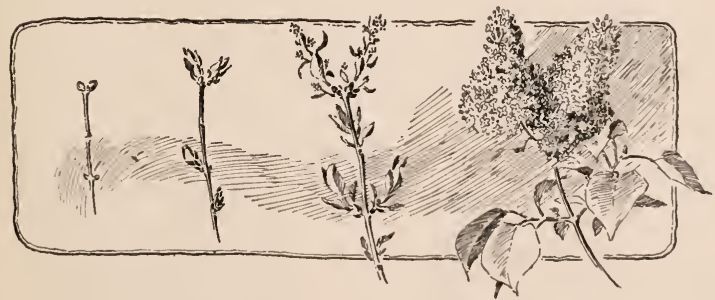

72. The burst of spring in the lilac. 


\section{CHAPTER VIII}

\section{PLANTS AND SUNLIGHT}

99. Each Plant Responds to Light.-Green plants live only in sunlight, direct or indirect. The gradual withdrawal of light tends to weaken the plant; but the plant

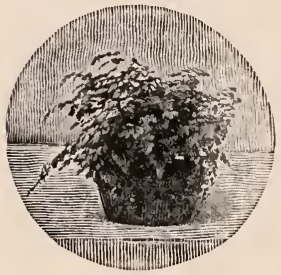

73. Sufficient light. makes an effort to reach the light and therefore grows toward it. The whole habit of a plant may be changed by its position with reference to sunlight. Choose two similar plants. Place one near the window and the other far from it. Watch the behavior from day to day. Fig. 73 shows a fern that grew near the glass in a conservatory: Fig. 74 shows one that grew on the floor of a conservatory. Fig. 74 also teaches another lesson, which is to be explained in another chapter (Chapter XXVIII).

100. Plants grow toward the light. The most vigorous branches, as a rule, are those that receive most light.

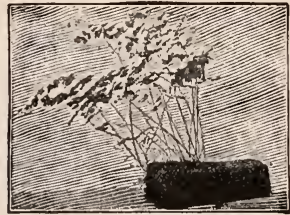

74. In need of light.

Same kind of fern as No. 73.

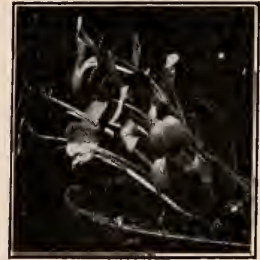

75. Growing toward the light. 
Climb a tree and observe where the thriftiest shoots are; or observe any bush.

101. When plants or their parts are not stiff or rigid,

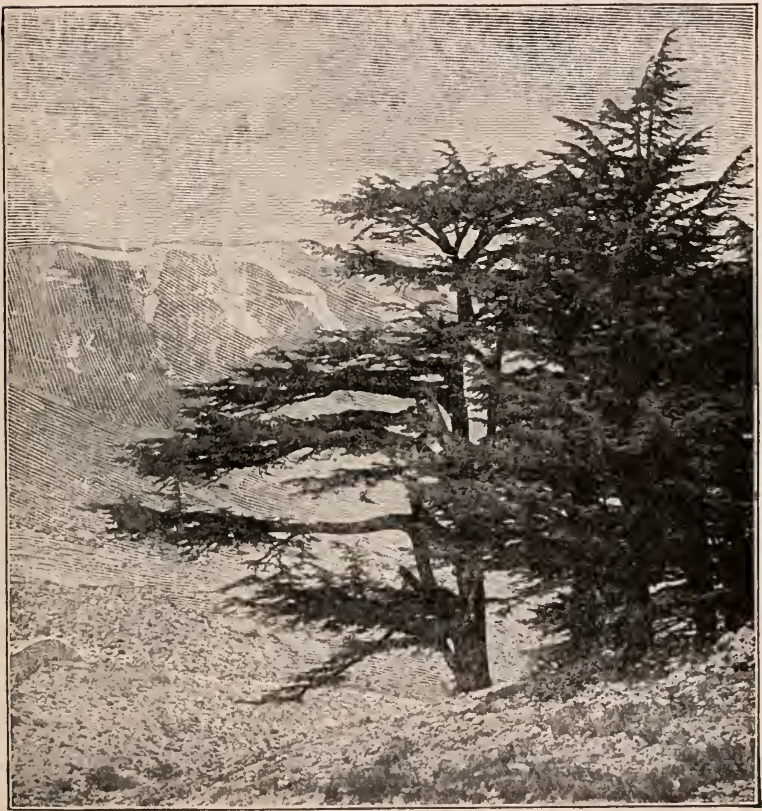

76. Branches of the cedar reaching for light.

they turn toward the light, if the light comes mostly from one direction. The geraniums and fuchsias in the window are turned around occasionally so that they will grow symmetrical. Plant radish in a pot or pan. When the plants are three or four inches high, place the pan in a tight box 
which has a hole on one side. The next day it will look like those in Fig. 75. This turning toward the light is called heliotropism (helios is Greek for "sun").

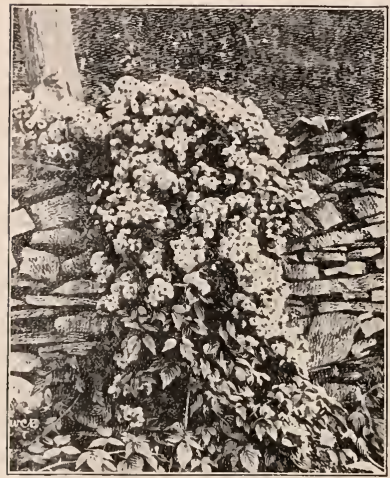

77. Mantle of clematis. The leaves, and later the flowers, spread themselves to the light.

102. Even under natural conditions, plants become misshapen or unsymmetrical if the light comes mostly from one direction. On the edge of a forest, the branches grow out toward the light. (Fig. 76.) Trees tend to grow away from a building. Branches become fixed in their position, so that even in winter they show the influence of light.

103. Some plants climb other plants in order to reach the sunlight; or they climb rocks and buildings. Notice that the vine on the house luxuriates where it is lightest. Climbing plants may injure or even kill the plant on which they climb. This they may. do by throwing their mantle of foliage over it, and smothering it, or by sending their roots into its trunk and robbing it of food. Sometimes they do both, as in Fig. 78 .

104. Each Branch Grows Toward Light.-The plant is made up of branches. There is a struggle amongst the branches for sunlight. We have seen (Fig. 7) that no two branches are alike: we now know one reason why. Notice that the small branches die in the center of the tree. Look on the inside of a pine, spruce or other dense tree. Every branch has a story to tell of the value of sunlight.

105. Each Leaf Grows Toward Light.-Leaves are borne toward the ends of the branches. This is particularly 
marked when the struggle is severe. If the outside of a plant is densely thatched with leaves, the inside will be found to be comparatively bare. Contrast Figs. 79 and 80, both being views of one tree. We know the tree as seen in Fig. 79: the squirrel knows it as seen in Fig. 80.

106. On any branch in a very thick-topped tree or bush, leaves of equal age usually tend to be largest where the light is best. Leaves that grow in full sunlight tend to persist later in the fall than those that grow in poor light. This fact is sometimes obscured because the outermost leaves are most exposed to autumn winds.

107. Plants that start in cellars, from sceds, bulbs, or tubers, grow until the stored food is exhausted and then die: the leaves do not develop to full size in darkness. Figs. 81 and 82 show this. Fig. 81 is rhubarb forced in a cellar for the winter market; Fig. 82 is a plant grown out-of-doors. Compare Fig. 45.

108. The position or direction of leaves is determined largely by exposure to sun-

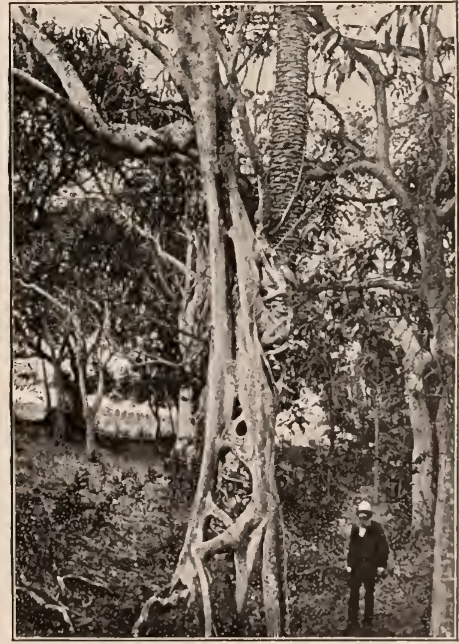

78. A climbing fig choking a palm. light. In temperate climates, they usually hang in such a way that they receive the greatest amount of light. Observe the arrangement of leaves in Fig. 83. One leaf shades the 


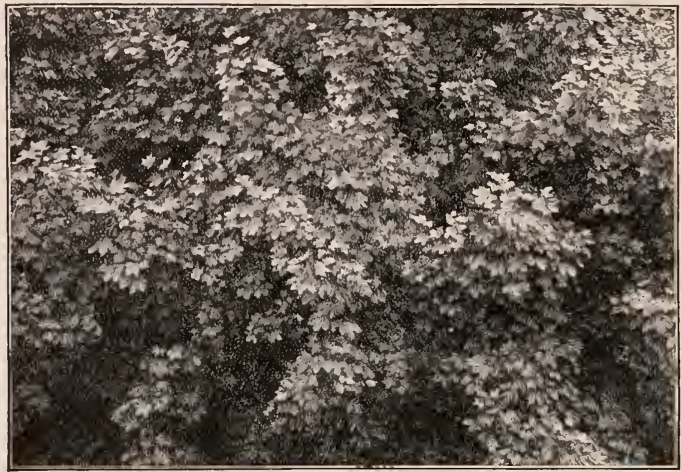

79. Looking at the top of a Norway maple.-As the bird sees it.

other to the least possible degree. If the plant were placed in a new position with reference to light, the leaves would make an effort to turn their blades. Observe the shingle-like arrangement in Fig. 79. If the pupil were to examine the

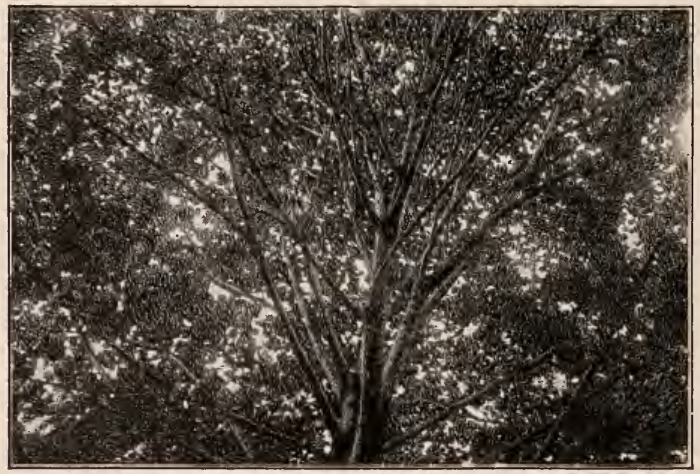

80. Looking up into the same tree.-As the squirrel sees it. 
leaves on the Norway maple, which is photographed in Fig. 79 , he would find that leaves which are not on the outside lengthen their leaf-stalks in order to get the light. See Fig. 157. Norway maple is common on lawns and roadsides.

109. We have seen (85) that a large part of the leaves of any one year are packed away in the buds of the previous winter. It is almost impossible that these leaves should be packed away hit or miss. They are usually arranged in a mathematical order. We can see this order when the shoot has grown. We can see it by studying the buds on recent

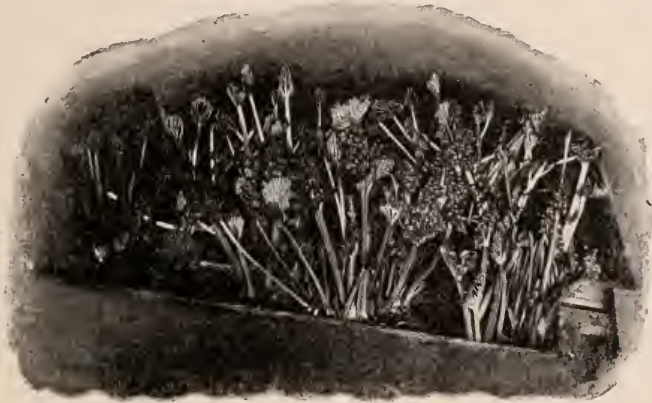

81. Rhubarb grown in the dark. The leaf-blades do not develop.

shoots, since there was a leaf for each bud. The leaves (or buds) may be opposite each other on the stem, or alternate. (Fig. 84.)

110. When leaves are opposite, the pairs usually alternate. That is, if one pair stands north and south, the next pair stands east and west. See the box-elder shoot, on the left in Fig. 84. One pair does not shade the pair beneath. The leaves are in four vertical ranks.

111. There are several kinds of alternate arrangement. In the elm shoot in Fig. 84, the third bud is vertically above the first. This is true, no matter which bud is taken as the 
starting point. Draw a thread around the stem until the two buds are joined. Set a pin at each bud. Observe that the two buds are passed (not counting the last) and that the thread makes one circuit of the stem. Representing the number of buds by a denominator, and the number of circuits by a numerator, we have the fraction $1 / 2$, which expresses the part of the circle that lies between any two buds.

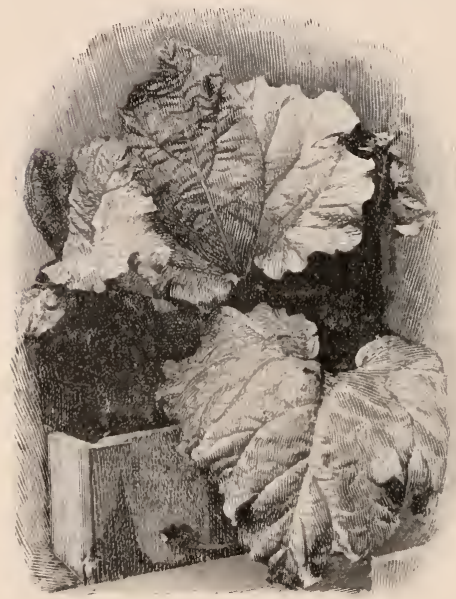

82. Rhubarb growing in the light. That is, the buds are one-half of 360 degrees apart, or 180 degrees. Looking endwise at the stem, the leaves are seen to be 2-ranked. Note that in the apple shoot (Fig. 84, right), the thread makes two circuits and five buds are passed: two-fifths represents the divergence between the buds. The leaves are 5-ranked. 112. Every plant has its own arrangement of leaves. For opposite leaves, see maple, box-elder, ash, lilac, honeysuckle, mint, fuchsia. For 2-ranked arrangement see all grasses, Indian corn, basswood, elm. For 3-ranked arrangement see all sedges. For 5-ranked (which is one of the commonest), see apple, cherry, pear, peach, plum, poplar, willow. For 8-ranked, see holly, osage orange. More complicated arrangements occur in bulbs, house-leeks, and other condensed parts. The arrangement of leaves on the stem is known as phyllotaxy (literally 


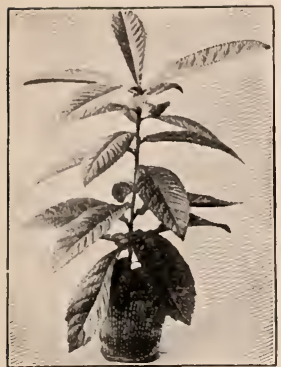

83. All the leaves are exposed to light.

"leaf-arrangement"). Make out the phyllotaxy on any plant. Try it on a long potato tuber.

113. In some plants, several leaves occur at one level, being arranged in a circle around the stem. Such leaves are said to be verticillate or whorled. Leaves arranged in this way are usually narrow.

114. Although a definite arrangement of leaves is the rule in most plants, it is subject to modification. On shoots that receive the light only from one side or that grow in difficult positions, the arrangement may not be definite. Examine shoots that grow on the under side of dense tree-tops or in other partially lighted positions.

115. The direction or "hang" of the leaf is usually fixed, but there are some leaves that change their direction between daylight and darkness. Thus, leaves of clover (Fig. 85), bean, locust, and many related plants, "sleep" at night; also oxalis. It is not a sleep in the sense in which animals sleep, however, but its function is not well understood.

116. Leaves usually expose one particular surface to the light. This is be-

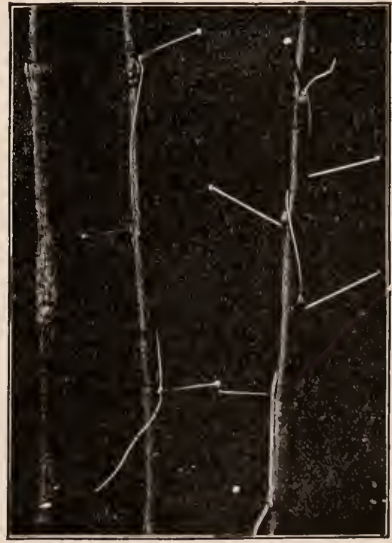

84. Phyllotaxy of box-elder, elm, apple. 
cause their internal structure is such that light is most efficient when it strikes this surface, as we shall learn later on. Some plants, however, expose both surfaces to the light, and their leaves stand vertical. Others avoid the intense light of midday and turn in the direction of least light. Leaves standing edgewise are said to exhibit polarity.

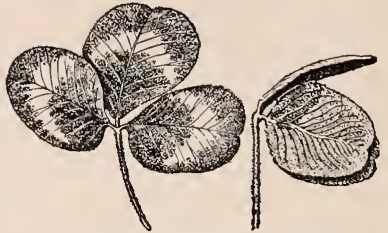

85. Day and night positions of the elover leaf.

They are "compass plants" if they point north and south.

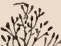

3). 1 , 15

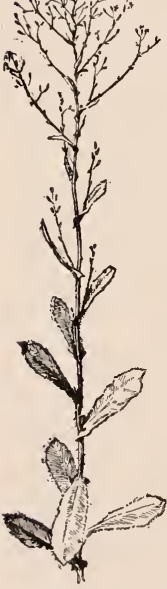

86. Wild or prickly lettuce, a weed of roadsides a n d waste places. Leaves more or less vertical.
The famous compass plant or silphium of the prairies, and the wild lettuce (Fig. 86), are examples of plants having polar leaves. Every leaf has a story to tell of the value of sunlight.

\section{Winter Buds Show What Has Been} the Effect of Sunlight.-Buds are borne in the axils of the leaves (87), and the size or vigor of the leaf determines to a large extent the size of the bud. Notice that, in most instances, the largest buds are nearest the tip. (Fig. 87.) If the largest ones are not near the tip, there is some special reason for it. Examine the shoots on trees and bushes.

118. The largest buds usually start first in spring, and the branches that arise from them have the advantage in the struggle for existence. Plants tend to grow most vigorously from their ends. Observe that only the terminal bud grew in the hickory twig in Fig. 64. If the side buds or lower buds grew more vigorously than the end buds, the plant would become exceedingly branched 
and its whole form might be ehanged. Consider how such a mode of branching would affect any small tree that you know. Every bud has a story to tell of the value of sunlight.

REview.-What is the relation of the plant to sunlight? Does its form ever depend on its relation to light? In what direction do the tops of plants grow? Where are the most vigorous branches? What is heliotropism? Why are trees sometimes unsymmetrical? Do you know any instanees yourself? What is one way in which plants profit by the climbing habit? Explain. Where are leaves borne in reference to light? Where are leaves usually largest? Do they develop in darkness? Are leaves borne directly above one another? How may leaves be arranged? Explain what phyllotaxy is. Are leaves always arranged definitely? Explain the arrangement in some plant that is not mentioned in this lesson. What is the "sleep" of leaves? Which surface of the leaf is exposed? What are compass plants? How do buds show what the effect of sunlight has been? What buds start first in spring?

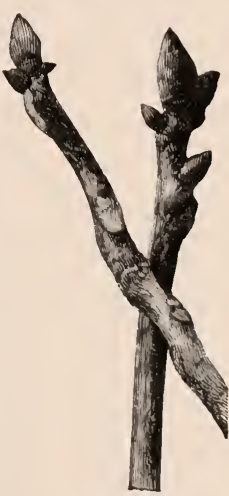

87. The big terminal buds.-Hickory. 


\section{CHAPTER IX}

\section{STRUGGLE FOR EXISTENCE AMONGST THE BRANCHES}

119. No Two Branches are Alike.-Every twig has a history. It has to contend for sunlight and a place in which to grow. Its size and shape, therefore, depend on the conditions under which it lives. Observe the long, straight, big-leaved shoots on the top of the plant, and the short, weak, crooked ones on the inside or under side.

120. There is struggle for existence for every twig and every leaf. Those finding the best conditions live and thrive;

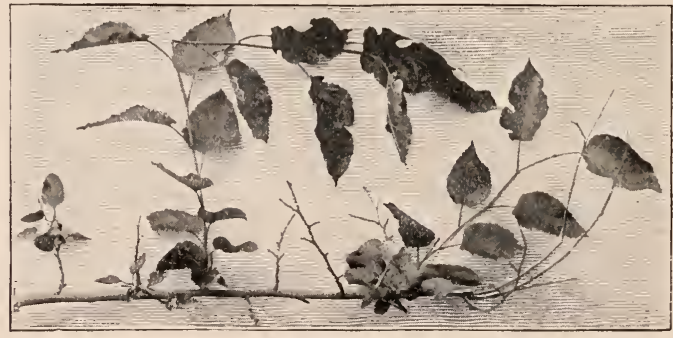

88. The struggle for life.-Mulberry shoot.

those finding the poorest die. The weak are overpowered and finally perish: this prunes the tree, and tends to make the strong the stronger. Observe the competition in the branch photographed in Fig. 88. Pick out the dead twigs, the weak ones, the strong ones. See also Fig. 7.

121. The Buds May Not Grow.-There is not room in a tree-top for all the buds to grow into branches. Some buds 
are suppressed. Branches die. So it comes that branches are not arranged regularly, although the buds may be. In

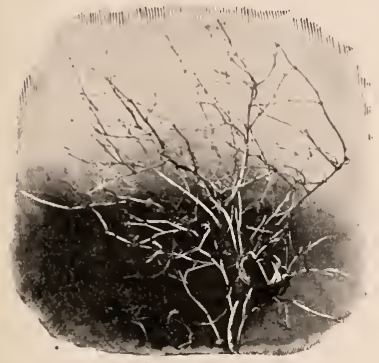

89. The branehing is erooked and irregular. the Tartarian or "tree" honeysuckle the buds are opposite; Fig. 89 shows how the branches are. Even though the branch or plant is apparently regular in shape (as in Fig. 90), nevertheless many of the buds have been suppressed, else there would be a branch from every axil.

122. The results of the struggle for existence in the tree-top can be expressed in figures. Consider that every bud is the germ or starting point of a branch. Observe at what distances apart the buds are usually borne on any plant, and estimate the number of buds that the plant has borne: count the number of branches which the tree actually bears. It will be found that the number of buds is far in excess of the number of branches: the difference between the numbers shows how many buds or branches have failed. Or, count the buds on any branch, and figure up the possibilities. A branch 12 inches long, for example, has 10 buds. If each bud grows, at the end of the next

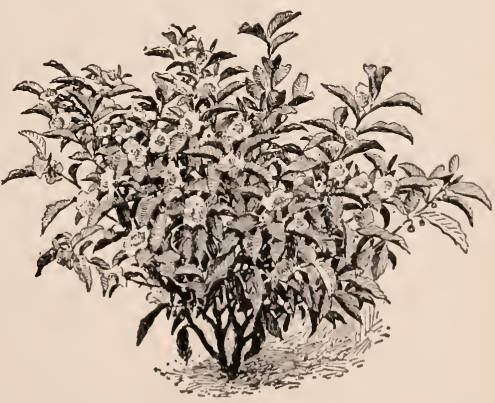

90. Not all the buds have produced branches.-Tea plant. 
season, there will be 10 branches, each of which may have 10 buds. At the end of the second year there will be 100 branches; at the end of the third, 1,000. Can 1,000 branches be borne on a 4-year-old branch 12 inches long, as a base? Or, count the old bud-scars on the branches-for the places of the buds persist as wrinkles in the bark, often for many

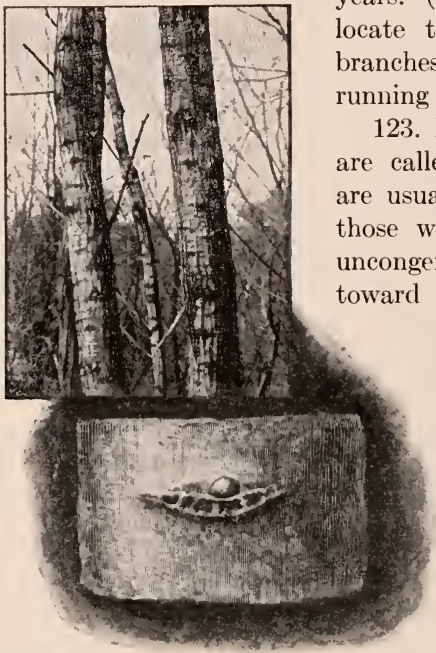

91. Sears of the dormant buds.-Willow.

years. (Fig. 91.) One can often locate these bud-scars on old branches with his eyes closed by running his fingers over the bark.

123. Buds that fail to grow are called dormant buds. They are usually the weakest ones,those which grew in the most uncongenial conditions. They are toward the base of the shoot.

We have seen (118) that it is the terminal or uppermost buds which are most likely to grow. The dormant buds gradually die. They may live four or five years on some plants. If the other buds or branches fail or are injured, they may grow, but usually they do not.

124. Dormant buds must not be confounded with adventitious buds. We have learned (54) that adventitious buds are those formed at unusual times or places, because of some disturbance of the part. If a large branch is cut off, suckers or watersprouts are thrown out near the wound: these arise from buds that are made for the occasion. These buds did not exist there. In many countries it is a custom 


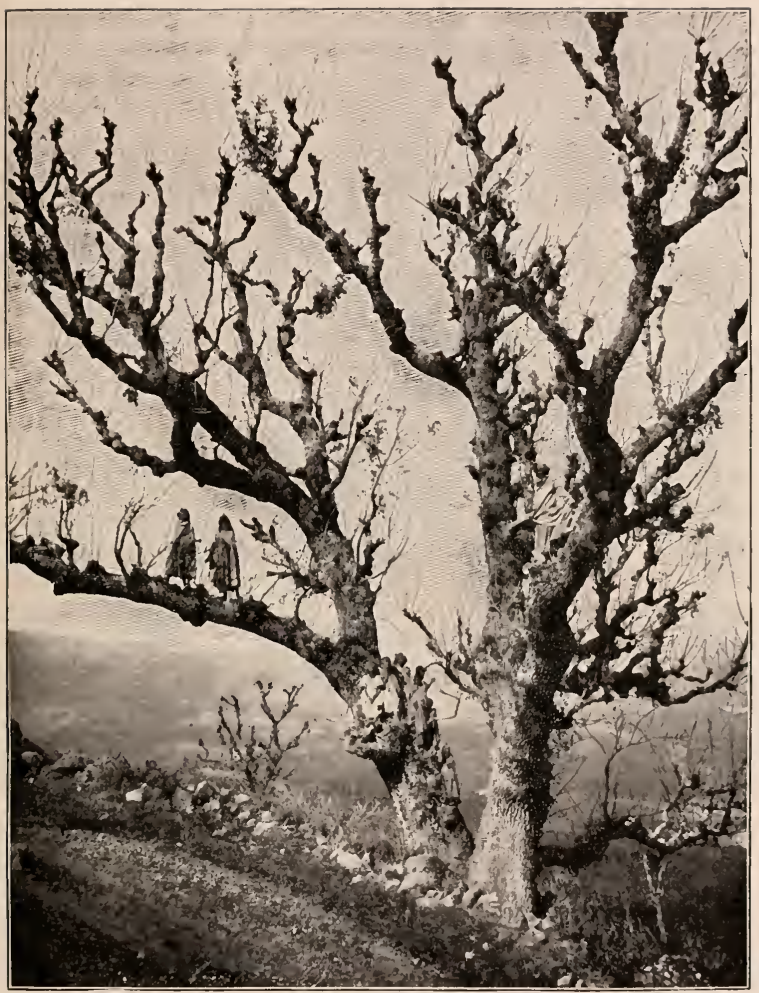

92. A pollard tree

In this ease, man has added to the struggle for existence. An ash tree in Algeria. The shoots are eut for forage. 
to "pollard" or cut off the tops of trees every few years for the firewood or other uses, and strong adventitious shoots

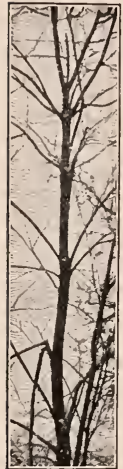

93. Tiers of branches on young tree.

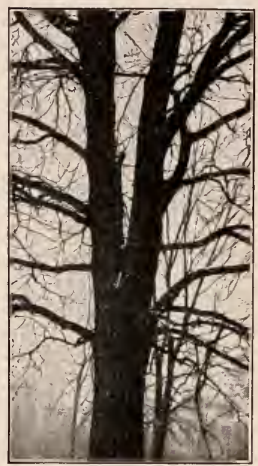

94. Even in old trees the tiers can be traced. arise along the trunk. (Fig. 92.)

125. Where the Branches Grow.-Because new shoots tend to arise from the top of the twigs, the branches of most trees are in tiers or layers. These tiers often can be traced in trees 50 and 100 years old. Try it in any oak, maple, ash, or other tree. For practice, begin with young, vigorous trees. (Figs. 93 and 94.)

126. When part of a top is removed, the remaining branches fill the space. The branches are attracted by the light, and grow in that direction. A pruned or injured top always tends to come back to equilibrium.

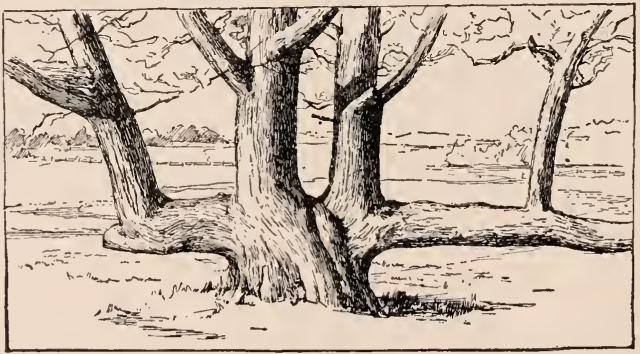

95. Crushed by storm, the tree still shoots upward. 
127. A mangled or broken plant tends to regain its former position. From fallen trees, upright shoots arise. In Fig. 95 observe the new trunks arising from the older prostrate trunks.

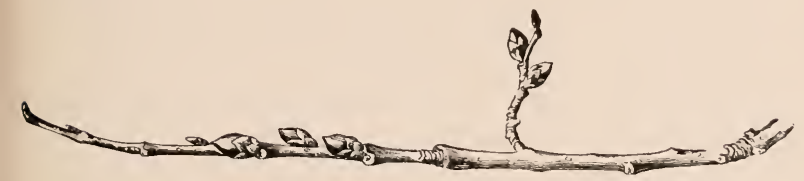

96. An elm shoot, April 10.

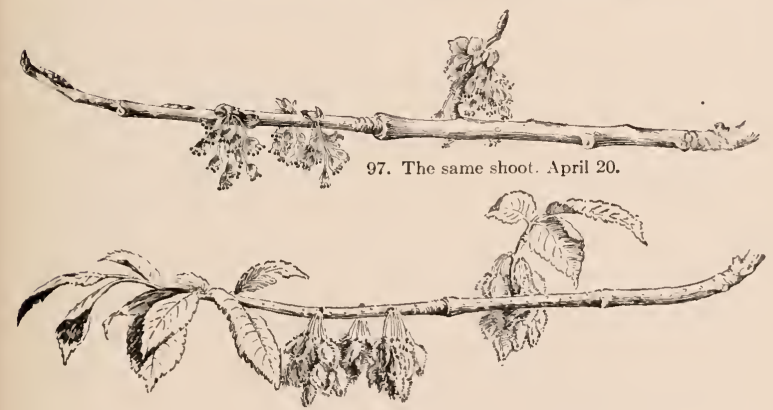

98. May 20.

Review.-What is meant by the statement that every twig has a history? Upon what does the shape and size of a branch depend? Explain what you mean by the struggle for existence. Why do not all buds grow? If buds are arranged in mathematical order, why are not branches so arranged? How may the effect of struggle for existence be expressed in figures? Choose some branch and explain. Define dormant buds. Adventitious buds. Why are branches in tiers, or borne at intervals? How do plants tend to regain their form and position, when injured?

Note.-Let the pupil work out the history of some branch. It is better to choose a branch that is vigorous. Ile should first determine, if the shoot is dormant, how much grew the previous season. The last year's growth bears buds on the main axis, not on side branches; 
and the "ring" (sears or bud-scales) marks the junetion between the different years' growth. Notice this ring in the front shoot in Fig. 87. The teacher will find many twigs worked out in "Lessons with Plants." Figs. 96-100 show an actual ease. These drawings were all made with the greatest care from one elm twig. The twig (Fig. 96) shows three years' growths. The side branch is evidently only one year old, for it did not arise until the twig which bears it was one year old. Note that only one of the buds made a branch. There are five blossom-buds. Fig. 97 shows the twig in bloom. Fig. 98 shows it in fruit and leaf. Fig. 100 shows the net result. The side branch grew from $a$ to $s$ and made two blossom buds. The tip of the main shoot (Fig. 96) was broken in a storm. The two buds next in suceession grew. Each made flowerbuds. Observe how many buds on this elm shoot have failed.
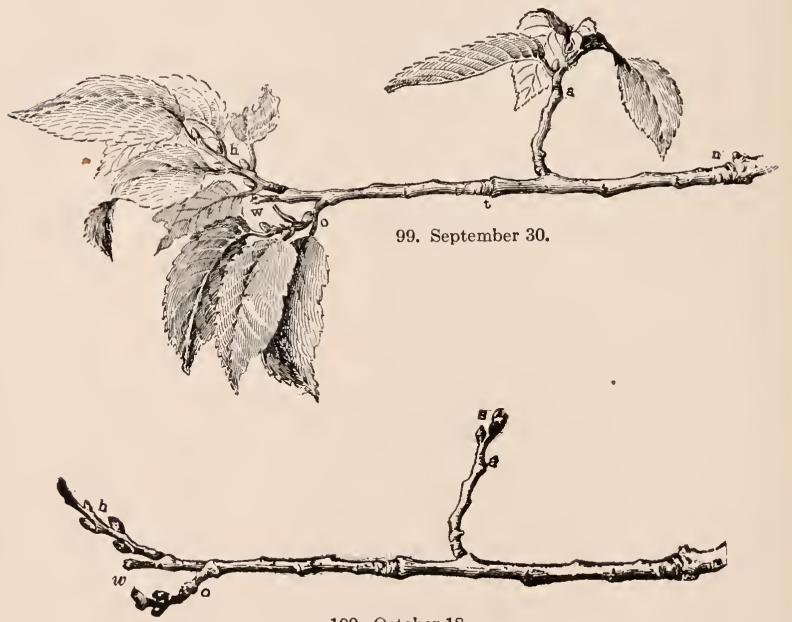

100. October 18. 


\section{CHAPTER $\mathrm{X}$}

\section{PRUNING}

128. We are now ready to diseuss the reasons for pruning, and how the work should be performed. We have discovered that there is competition between different plants and also

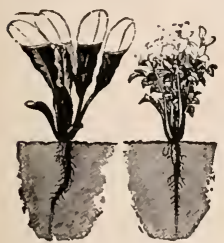

101. Showing how much the leaves or top of a young plant may be removed on transplanting. between branches on the same plant. When one or more of the eompetitors is removed, the remaining plants or parts have better conditions and will probably inerease in vigor. Pruning is a means of allowing the remaining branches a better opportunity to develop.

129. Pruning should therefore inerease the vigor of remaining parts. In fruit trees it also thins the fruit, increasing its size. It opens a tree-top to air and light; removes superfluous fruit-buds; allows more thorough spraying; inereases ease of aceess into the tree by the pickers. Pruning also keeps plants within bounds, and corrects misshapen or awkward forms.

130. The first pruning is performed when the plant is set or planted. The broken and dead roots are removed, and part of the top is taken away. There should be a proper balance between root

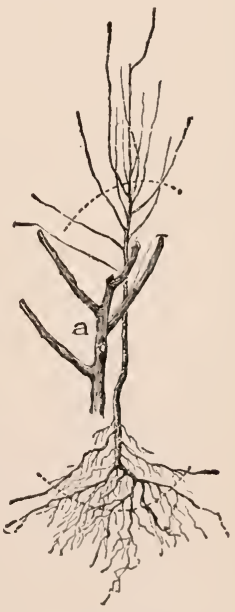

102. Suggestions for pruning root and top of an apple tree when it is transplanted. A pruned top is shown at $a$. 
and top, when a tree is dislodged from the earth and taken to another place. We have found that the leaves of cuttings are sometimes reduced for a similar reason (63). In most
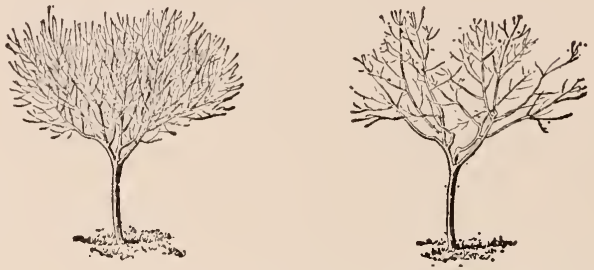

103. Peach tree unpruned and pruned.

trees and shrubs (except conifers) the top is cut back as much as one-half on transplanting. (Figs. 101, 102.)

131. Young trees may be so pruned that so many branches will not grow as to confuse and crowd the tree-top later on. A few framework or scaffold branches should be left. (Fig. 103.) An effort should be made to shape the tree symmetrically; and if the trees are to constitute an orchard, they should be uniform in shape and height of top. (Figs. $104,105$.$) "As the twig is bent the tree's inclined."$

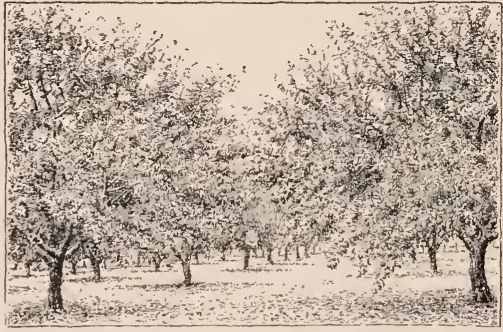

104. Well-shaped apple trees. In regions of intense heat and sunshine, as in parts of the western United States and Canada, apple trees are usually trained lower than this, to shield the trunks.
132. Fru it plants should be so pruned as to encourage and spare sufficient bearing wood to insure a good crop. We have identified the fruit-buds (Chapter VII). The strongest and best placed buds 
should be saved. Thinning the fruit-buds thins the fruit. In some fruit plants, the bearing wood is on eanes that live

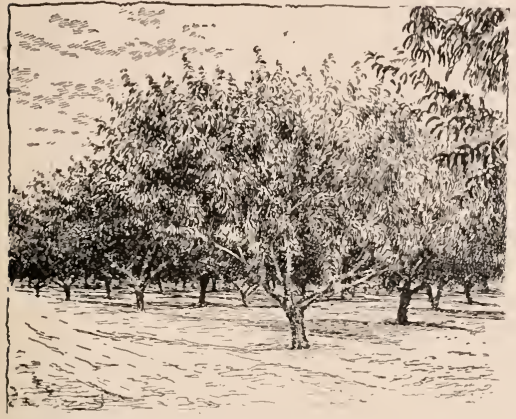

105. Well-formed peach trees in the eastern region. or that bear for a single year only. Of such are blackberries and raspberries. The raspberry eane that springs from the root this year, bears fruit next year, and then dies or beeomes so weak as to be worthless; and the eane that comes

up next year bears fruit the year after, thus maintaining the suceession. Therefore, every fall or spring the eanes that have borne should be eut away near the ground; a certain number (four to eight) of the new ones should be allowed to remain; and these new ones are later eut back to make them upright and to eoncentrate the bearing area. (Figs. 106, 107.)

133. Shrubs and trees grown for bloom may bear their flowers from winter or resting buds, or from growing shoots of the season; if the former, they bloom very early in spring, as lilae, flowering almond, dentzia, weigela, forsythia or golden bell; if the latter, they bloom later after active twig growth begins, as rose of sharon or hibiseus, hydrangea, privet, moek orange, rose aeacia, most honeysuckles. If it is desired not to remove the bloom, those bushes that bloom from resting buds should be pruned or headed back (if at all) after flowering or when in leaf; the other class should be pruned before flowering, or when the plant is dormant. 
134. Pruning is sometimes employed to increase the vigor of weak or injured plants, and to renew and reshape old trees. Woody plants severely injured by frost are often cut back

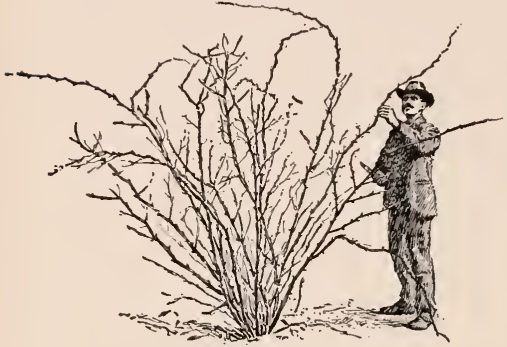

106. Raspberry before pruning.

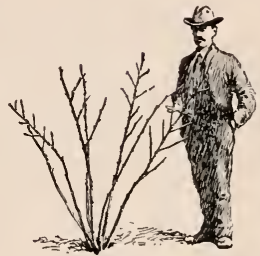

107. Same bush after the spring pruning.

heavily to fresh clean wood. (Fig. 108.) The vigor of the plant is condensed into a smaller area, new shoots arise, and a renewed top may be formed.

135. In pruning, all long stubs should be avoided, and the cut should be smooth and not splintered. The "healing" of such a wound is merely the covering of the stub or cut area by a callus or ring of tissue that arises from the cambium region (between wood and bark); this callus does not form

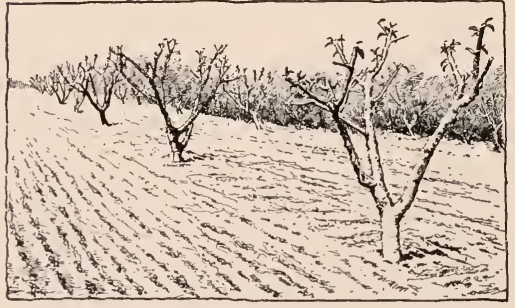

108. Peach trees heavily cut back after a freeze. readily on long and leafless stubs. An uncovered wound tends to rot, and a hole is formed into the tree. Figs. 109 and 110 show poor and good pruning. The limb should 
be severed practically parallel to its parent branch and close to it. Some of the worst examples of pruning (or of tree butchery) are to be found along streets where trees have been cut to allow the passage of telephone and telegraph wires and other improvements. Only careful and practiced persons should be allowed to prune street trees.

136. Pruning may be performed at any time of the year, depending on the climate and the objects to be attained. Fruit trees and shade trees are usually pruned in spring, before the leaves appear. Sometimes the heading in of fruit trees is performed in late summer or fall, but late winter and spring pruning for all trees is most favored in cold climates.

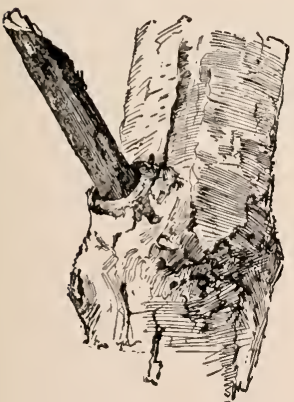

109. Poor pruning

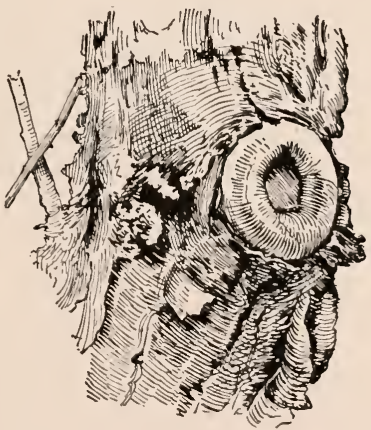

110. Good pruning.

REVIEw.-What do you understand by pruning? What does pruning accomplish? Is it "unnatural"? How should newly set trees and plants be pruned? Why? What relation has pruning to the bearing wood? What are the considerations in the pruning of flowering shrubs? What kind of pruning is practised on weak or injured plants? How should the pruning wounds be made? How do wounds heal? When may pruning be performed? How would you prune a bearing apple tree (ask some one who knows)? A raspberry or blackberry bush? 


\section{CHAPTER XI \\ THE FORMS OF PLANTS}

137. Although the form of the branch, and to some extent the entire plant, is determined by a struggle with the conditions in which it grows, nevertheless each kind of plant has its own peculiar habit of growth. The lum-

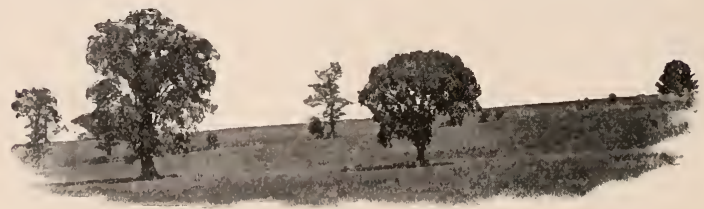

111. Different forms of trees.

berman distinguishes the kinds of trees by their "looks," rather than by their leaves or flowers, as the botanist does. The farmer usually does the same with his cultivated plants.

138. The habit of a plant is determined by its size, general style or direction of growth, form of head, and method of branching. The general style or stature

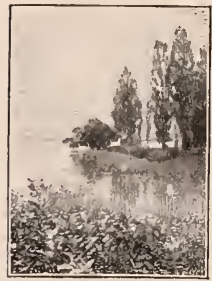

112. Round-headed and fastigiate trees. of plants has been mentioned in Chapter III-they may be erect, strict, ereeping, decumbent, and the like. The shape of the top or head is well illustrated in trees. Note the general effect of the mass, as seen at a distance. The elm is vase-form or round-headed. (Fig. 111.) So are maple, beech, and apple trees. The Lombardy poplar (Fig. 112) is columnar or fastigiate. Young spruces and firs are conical. 


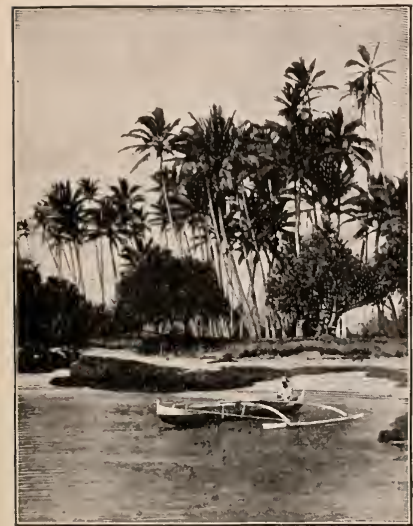

113. The unbranched trunks of palms.

Heads may be narrow, wide, flat, symmetrical, irregular or broken.

139. The general leafage or furnishing of the top is different for each kind. The top may be dense or thin. The foliage may be heavy, light, large, small. Compare maples and elms, apples and peaches, and other trees.

140. The trunk or bole of the tree is one of its most conspicuous features. Observe the strict straight trunk of the palm (Fig. 113), and the forking trunk of elms and maples. Observe that no two trees have trunks quite alike. The bark is different for each kind of plant.

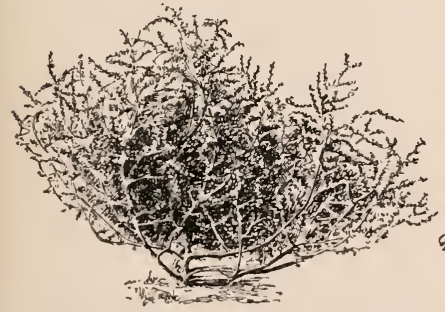

114. The plant form in winter.-Russian thistle.

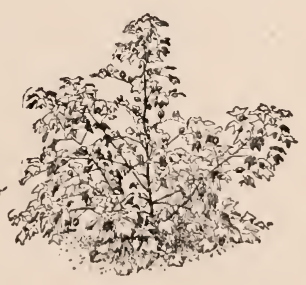

115. A plant form.-Cotton.

141. Plants awaken certain thoughts or feelings: they are said to have expression. This expression is the source of much of our pleasure in them. Trees are particularly expressive. One suggests restfulness, because of its deep, 
shady top; another gaiety, from its moving, small, lightcolored leaves; another heaviness, from its very large, dull foliage; another strength, from the massive branches; another grace, from the flowing outline or flexile growth. We think of the oak as strong, the willow as lithe, the aspen as weak,

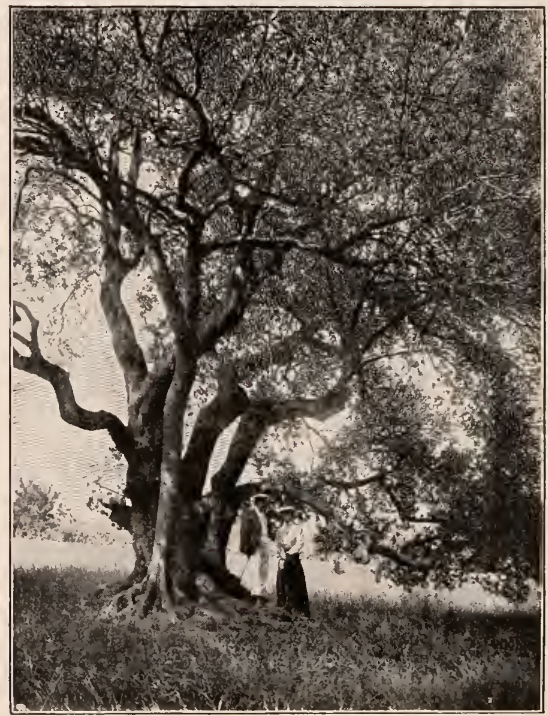

116. The many trunks of an old olive tree. Italy.

and the like. Irregular or gnarly trees suggest struggle. If all plants, or even all trees, were alike, we should have little pleasure in them.

142. The expression of a plant depends to some extent on the character of the shadows in the top. These shadows (or lights and shades) are best seen by looking at the plant 
when the sun is low and behind the observer. Stand at some distance. Look at the dark plaees in the old pasture maple: they are lumpy and irregular. In the pasture beech they are in layers or strata. The shadows depend mostly on the method of branching. Those who take photographs know how the "high lights" and shadows develop on the plate. (Fig. 117.)

143. The habit of a plant is usually most apparent when it is leafless. The framework is then revealed. Woody plants are as interesting in winter as in summer. Observe their forms as outlined against the sky-every one different from every other. Notice the plant forms as they stand in the snow. (Fig. 114.) Compare this form with that of the eotton in Fig. 115; or with that of any other plant. How do stems of

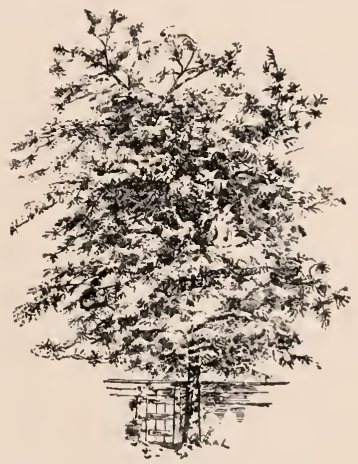

117. The lights and shades.-Honey locust tree. the pigweed differ from those of burdoek and grasses? Observe how the different plants hold snow and ice.

144. The more unusual the shape of any tree or other plant, the greater is our interest in it, because our euriosity is awakened. Some unusual circumstance or eondition has produced the abnormal form. Such plants should be preserved whenever possible. (Fig. 116.)

Review.-What do you mean by the statement that each kind of plant has its own habit (36)? How do plants differ in habit? Name some of the forms of tree-tops. How may plants differ in the furnishing of the top? Is the trunk characteristic? Bark? Bring in and describe the bark of three kinds of trees. What is the expression of a tree? Name some of the expressions? Explain what you understand by the shadows in the top. On what do the shadows chiefly depend? What is there to see in plants in winter? Why are we interested 
in plants of unusual form? Tell how any two trees differ in "looks." NoтE.-One of the first things the pupil should learn about plants is to see them as a whole. He should get the feeling of mass. Then he should endeavor to determine why the mass is so and so. Trees are best to begin on. No two trees are alike. How do they differ? The pupil can observe as he comes and goes from school. An orchard of different kinds of fruits shows strong contrasts. Even different varieties of the same fruit may be unlike in habit. This is especially true in pears (Figs. 118, 119). It is well, also, to develop the feeling for the mass, and to apprehend the expression, in a field of wheat or of clover, a field of potatoes, an apple orchard, a vegetable garden: distinguish the various plant forms and also the impression that the entire field or garden or woodland makes on you.

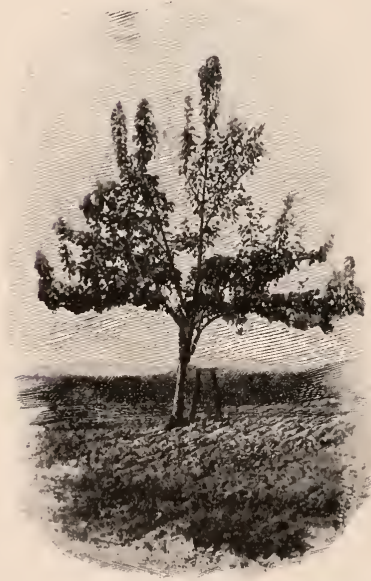

118. A young pear tree of the Kieffer variety.

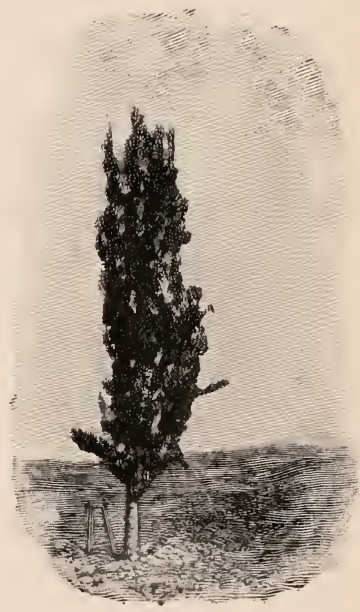

119. A pear tree of the Hardy variety. 


\section{CHAPTER XII}

\section{WATER AND MINERAL NUTRIENTS.-ROOT ACTION}

145. Plant-food.-Having learned what a plant is and having seen it as a whole, we may now inquire how it secures food with which to live. We can discuss only the outlines of the subject here: the pupil may consider the question again when he takes up Part III. The plant secures water and mineral nutrients from the soil. It also takes up mineral elements which are not nutrients, but which enter the plant because they are in solution in the soil-water. The word plant-food is used commonly to include the water and mineral nutrients taken in by the roots. Technically, the word plant-food is used to designate such products as stareh, sugar, fats and other substanees elaborated by the plant. The latter usage is unfortunate, but we shall follow it here, according to botanical usage, to avoid confusion.

146. Root Structure.-Roots divide into the thinnest and finest fibrils: there are roots and there are rootlets. The large, fleshy root of the radish (Fig. 120) terminates in a common-sized root to which little rootlets are attached. There are also little rootlets attached to the fleshy root at various places near the base. But the rootlets that we see are only intermediary, and there are numerous yet smaller struetures.

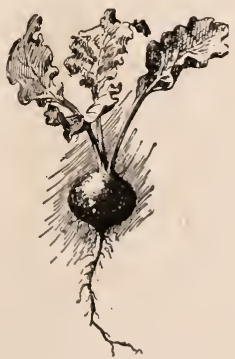

120. Root and rootlets.

147. The rootlets, or fine divisions, are elothed with root-hairs (29), which are very delicate structures. Carefully 
germinate radish or other seed, so that no delicate parts of the root will be injured. For this purpose, place a few seeds in packing-moss or in the folds of cloth or blotting-

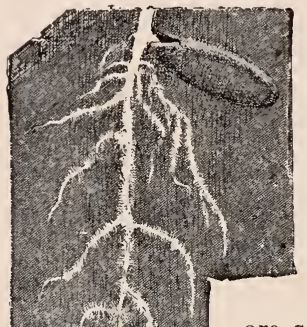
paper, being careful to keep them moist. In a few days the seed has germinated, and the root has grown an inch or two long. Notice that, excepting at a distance of about a quarter of an inch behind the tip, the root is covered with minute hairs (Figs. 11, 121). They are actually hairs, that is, root-hairs. Touch them and they collapse, they are so delicate. Dip one of the plants in water; remove it,-the hairs are not to be seen. The water mats them together along the root and they are no longer evident. Root-hairs usually are destroyed when a plant is pulled out of the soil, be it done ever so carefully. They cling to the minute particles of earth. Under a microscope, observe how they are flattened when 121. Root of pumpkin seedling, showing the covering of root-hairs. they come in contact with grains of sand (Chapter II). These root-hairs clothe the young rootlets, and a great amount of soil is thus brought into actual contact with the plant. Root-hairs are not young roots: they soon die.

148. Rootlet and root-hair differ. The rootlet is a compact, cellular structure. The root-hair is a delicate tube (Fig. 122), within the cell-wall of which is contained living matter (protoplasm); the wall and the lining membrane permit water and substances in solution to pass in. Being long and tube-like, these root-hairs are especially suited for taking in the largest quantity of solutions; and they are the principal means by which material is absorbed from the soil, although 
the surfaces of the rootlets themselves do a small part. Water-plants probably absorb a great quantity of water through the leaves and stems. Most of the higher plants, however, growing in water, are provided with roots and root-hairs and considerable absorption is effected by these. Certain of the water-plants have roots but produce no root-hairs; others. as the utricularia or bladderwort, have no roots whatever.

149. Osmosis.-To understand how water enters the root-hair, it is necessary that

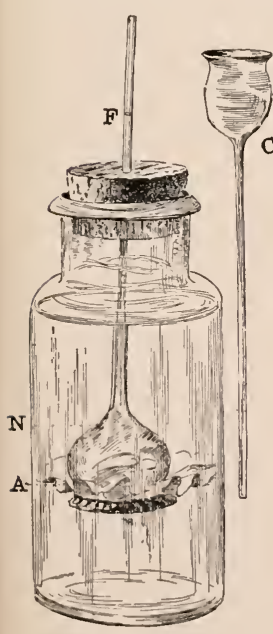

123. To illustrate osmosis.

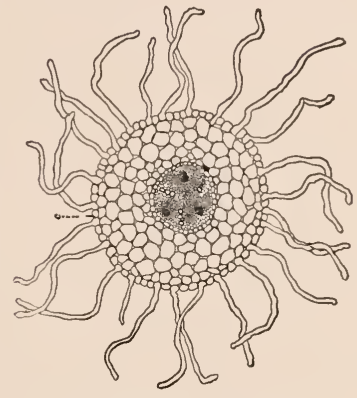

122. Cross-section of root, enlarged, showing root-hairs. we study the process of osmosis. A salt or sugar solution, separated from water by a semi-permeable membrane, will in$\mathrm{C}$ crease its volume, due to the passage into the solution of some of the water. This can be easily demonstrated. (Fig. 123.) Dissolve in one pint of water, one ounce of either eommon household salt (sodium (hlorid) or saltpeter (sodium nitrate). Saltpeter is a valuable plant fertilizer. Tie securely over the large mouth of the tube a piece of animal membrane (hog's bladder is excellent for the purpose). Now fill the enlarged end of tube with either the common salt or the saltpeter. Then sink the tube, as in Fig. 123, in the bottle $A$, of water, until the level of the water in the tube stands at the same height as that 
in the bottle. The tube may be readily secured in this position by passing it through a hole in the cork. In a short time, we notice that the liquid in $\mathrm{N}$ begins to rise, and in an hour or so it stands at F, say. The diffusion of water through this membrane into the salt solution is known as osmosis. Under these conditions, there is pressure in the tube and this pressure is known as osmotic pressure. We may have osmosis taking place from a weak solution to a stronger solution.

150. The root-hairs secure water from the soil.-The above experiment enables us to understand how the countless little root-hairs act,- - each one like the tube $\mathrm{N}$, if only the whole surface of the tube were a bladder membrane, or something acting similarly. The soil-water does not contain much of the soil fertility; that is, it is a very weak solution. The active little root-hair, on the other hand, is always filled with cell-sap, a more concentrated solution; hence soil-water must come in, and along with it come also small quantities of dissolved food materials. Some of these materials may be fertilizers that have been applied to the land.

151. This principle of absorption of water by osmosis may now be demonstrated by another experiment. Fleshy pieces of root or stem will absorb water from weak solutions and become rigid; in strong solutions such fleshy parts will give up their water and become flexible. Cut several slices of potato tuber about one-eighth of an inch in thickness, and let them remain in the air half an hour. Make up two solutions of cane-sugar: (1) dissolve four ounces of sugar in a quart of water; (2) dissolve one-half ounce of sugar in a quart of water. Place pieces of the potato tuber in these solutions. In half an hour those pieces in the weak solution will be rigid or stiff (turgid); those in the strong solution will be flexible (flaccid). The potato tuber is composed of thousands of minute cells, each with a cell wall, protoplasm, starch grains, and cell-sap. The cell-șap contains sugars and various salts in solution. When the slice of tuber is 
placed in weak sugar solution (each cell having a concentration greater than the outside solution), it takes up water. The slices of tuber in the strong solution lose water beeause the concentration of the external solution is stronger than that of the cell-sap.

152. The root-hairs are able to take up water from the soil because the soil solution is extremely dilute. If the soil : solution were strong, the plant might give up water to the soil. It would be possible to add so much fertilizer to the land as to cause the plant to lose water by exosmosis. There is seldom, however, any danger that the farmer or gardener will add so much fertilizer to the soil, in practice, as to cause a wilting of the plant due to loss of water by exosmosis.

153. The water and salts in solution taken up by the root-hairs pass into the root proper and finally into definite routes that are continuous from the root through the stems to the leaves. To illustrate the path of water-ascent, insert a growing shoot in water that is colored with eosin. (Eosin may be had of dealers in microscopic supplies. Common aniline may answer very well.) The tissues stained with the dye are the conducting tissues. In woody plants, the water is conclucted in the young wood, not between the bark and wood as commonly supposed.

154. The absorption of water by a root may be so rapid as to give rise to distinct pressure. This foree is root- or sap-pressure. It varies in different plants and in the same plant at different times. The "bleeding" of plants is a manifesta124. To show sap-pressure. tion of this pressure. In the spring, the 
maple and grape particularly exhibit strong sap-pressure. To illustrate root-pressure, grow squash or cucumber plants, and when they are about a foot or more in height cut off the plant close to the ground. To the plant stem attach a small piece of rubber tubing. Fill it with water and then connect it to a glass tube. (Fig. 124.) At intervals note the rise of water due to root-pressure. The root-pressure in a large cucumber plant may force sap to a height of five feet or more in a tube of five millimeters diameter.

Review,-What is meant by plant-food? Plant nutrient? Describe the root structure. What are root-hairs? Their function? How do water plants secure water? Do they have roots and root-hairs? Explain osmosis. Exosmosis. How does water enter the root? Why? How can you illustrate the path of water-ascent? What is root- or sappressure? Why do plants "bleed?" Have you ever actually seen roothairs? Explain where and when. Make a drawing as they appeared to you. 


\section{CHAPTER XIII}

\section{WATER AND MINERAL NUTRIENTS.-ACTION ABOVE THE ROOT}

155. The water in the soil is not usually present as free water, but in the form of films that adhere to the individual particles of soil. The root-hairs are in eontact with the soil particles and films of water. (Fig. 125.) The finer the soil, the greater the number of soil-particles and the greater the film-moisture. The film-moisture surrounding the grains may not be pereeptible, yet the plant can utilize it. Absorption by roots may eontinue in a soil that seems to be dust dry.

156. The root mist be' warm if it is to perform its functions. A proper temperature is essential to the life processes. Should the soil of fields or greenhouses be much colder than the air, the plant suffers. When in a warm atmosphere, or in a dry atmosphere, plants need to absorb much water from the soil, and the roots must be warn if the root-hairs are to supply the water as rapiclly as it is neeled. If the roots are chilled, the plant may wilt or die. Try this with two potted plants, as radish, coleus, tomato. Put one pot in a dish of ice water, and the other in a dish of warm water, and keep them in a warm room. In a short time notice how stiff and vigorous is

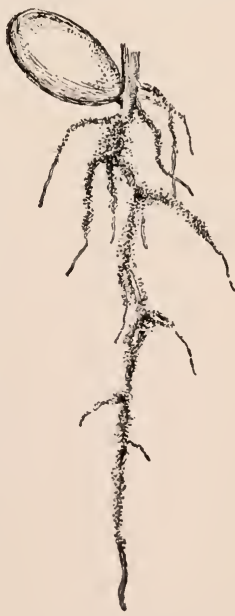

125. The rootlets and root-hairs cling to the particles of soil. 
the one whose roots are warm, whereas the other may show signs of wilting.

157. Plants take from the soil an immense quantity of water. A single corn plant may require in a growing season 200 to 500 pounds of water. From 250 to 400 or more pounds of water are required for the production of one pound of dry matter in plants. Most of the water absorbed by the roots is given off by the plant as water vapor in a process of evaporation called transpiration (166).

158. Water serves the plant in a number of ways. It is a nutrient for the plant and takes part in the formation of substances manufactured by the plant. The cell sap is water with substances in solution. The water serves as a carrier of the materials derived from the soil and also for the manufactured food made within the plant. Let us see what nutrients the ordinary green plants secure from the soil.

159. Nutrient Materials Secured from the Soil.-We have seen that all nutrient material must be in solution in water to be taken in by the root. The ordinary green plant obtains from the soil the following essential elements:

Nitrogen, chemical symbol N.

Phosphorus, P.

Sulfur, S.

Iron, Fe.
Potassium, K.

Calcium, Ca.

Magnesium, Mg.

Chlorin is also an essential element for buckwheat. The elements in the above list (except nitrogen) are known as the mineral elements. All of the above elements are taken up not in their elemental form but in the form of salts.

160. Ten elements are essential for the growth of all green plants. In addition to the seven above mentioned, the plant requires hydrogen, $\mathrm{H}$, oxygen, $\mathrm{O}$, and carbon, $\mathrm{C}$. Hydrogen and oxygen are supplied in the form of water, which has the chemical formula $\mathrm{H}_{2} \mathrm{O}$. Carbon for the green 
plant is provided in the earbon dioxid $\left(\mathrm{CO}_{2}\right)$ of the air. Oxygen is also derived from air (187). When the plant is burned, the six mineral elements remain in the ash.

161. The ash is but a very small part of the total weight of the plant. In a corn plant of the roasting-ear stage, the ash (what remains after ordinary burning) is about one per cent of the total substanee. A good wheat crop will require per acre about ten pounds of phosphoric acid and about thirty pounds of potash. The amount of phosphoric acid removed by 200 bushels of potatoes is nine pounds; and of potash sixty pounds.

162. The farmer does not add all the elements to the soil in the shape of fertilizers. Some of the nutrient elements are used in such small quantities and are present in the soil to such an amount that the addition of them is not necessary. The farmer adds nitrogen, potash and phosphorus to the land to provide nutrients, and he also adds caleium in lime or land-plaster because of its chemical and physical effect on the soil. Some of the fertilizers are mined, others are by-products of packing-houses and

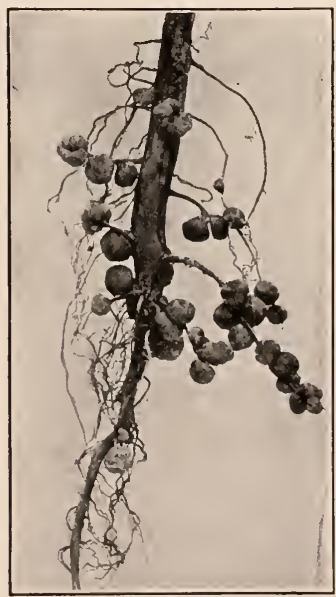

126. Nodules on soybean. other manufacturing establishments. Stable manure is generally considered to be the best single fertilizer.

163. Nitrogen is one of the most essential elements required by the plant. It is expensive to add to the soil as fertilizer. Fortunately, nature has provided a method whereby some of the inexhaustible nitrogen supply of the 
air is taken into the soil. Dig up a clover, vetch, pea, bean, cowpea, alfalfa or other legume plant. Carefully wash the soil away from the roots. Nodule swellings will probably

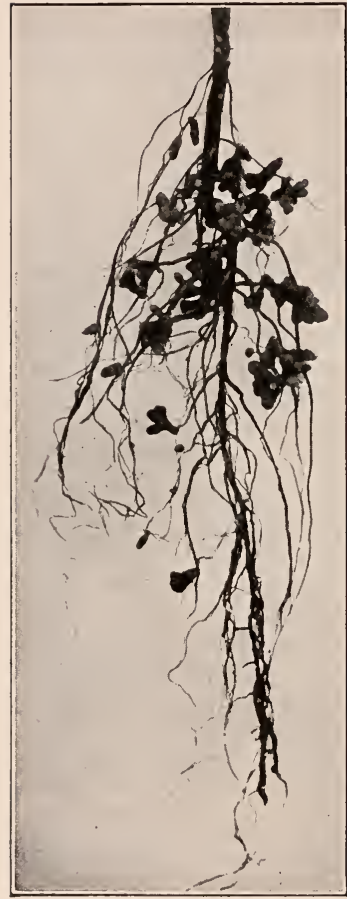

127. Nodules on root of Canada field pea. be found on the roots. (Figs. $126,127$.$) In these nodules are$ certain bacteria that secure nitrogen from the air, and from which they build up more complex nitrogenous compounds. The legume host-plant then appropriates some of the nitrogen fixed by bacteria and the remaincler, of course, remains in the bacteria.

164. Only the leguminous plants bear these nodules. The legumes are plants of the great family Leguminosæ, comprising all pea-like, beanlike, clover-like, acacia-like and other pod-bearing plants. It has been demonstrated that over 100 pounds of nitrogen per acre can be fixed by these norlule-forming bacteria during a growing season. These bacteria are not present in all fields. They must be introduced to fields on which legumes have not grown. Moreover, the bacteria that infect the alfalfa will not infect the cowpea. A different "strain" or variety is necessary for almost every legume. So important are the bacteria that the farmer who desires to enrich his soil and secure good 
crops introduces these bacteria into his field by the application of soil taken from a field known to have them, or possibly in some cases he introduces the bacteria by the use of commereial cultures. Certain legume crops, as alfalfa, will do poorly unless the bacteria are present.

165. A simple experiment will demonstrate the growth of plants in a nutrient solution, such as may exist in the soil. Secure from the druggist the following chemicals and make a solution of them, using the amounts here indicated:

Potassium nitrate, $\mathrm{KNO}_{3} \ldots \ldots \ldots \ldots \ldots \ldots 2$ grains

Calcium phosphate, monobasic, $\mathrm{CaH}_{4}\left(\mathrm{PO}_{4}\right)_{2} \ldots \ldots 1$ grain

Or Calcium phosphate dibasic $\mathrm{Ca}_{2} \mathrm{H}_{2}\left(\mathrm{PO}_{4}\right)_{2} \ldots \ldots 1$ grain

Magnesium sulfate, $\mathrm{MgSO}_{4} \ldots \ldots \ldots \ldots \ldots \ldots .50$ grain

Ferric chloride, very slight trace.

Water (distilled) $\ldots \ldots \ldots \ldots \ldots \ldots \ldots \ldots \ldots$ quarts

Fill four or five tumblers with this solution and cover the tumblers with paraffined paper. Germinate peas or seeds of a similar plant, and when the roots are two inches long punch holes in the paper and insert the roots through the holes into the nutrient solution. Place the cultures in good light and allow the seedlings to grow three or four weeks. For comparison, grow some of the plants in distilled water in place of the nutrient solution.

166. Transpiration.- We have found that the plant takes nutrients from the soil in very dilute solutions. Much more water is absorbed by the roots than is used in growth, and this surplus water is given off from the leaves into the atmosphere by the evaporation process known as transpiration (157). The transpiration takes place more abundantly from the under surfaces of leaves in most plants, and through the pores or stomates. It has been found that a sunflower plant of the height of a man, during an active period of growth, gives off more than a quart of water per day. A large oak tree may transpire 150 gallons per day 
during the summer. For every ounce of dry matter produced, it is estimated that fifteen to twenty-five pounds of water must pass through the plant. Cut off a succulent shoot of any plant, press the end of it through a hole in a cork

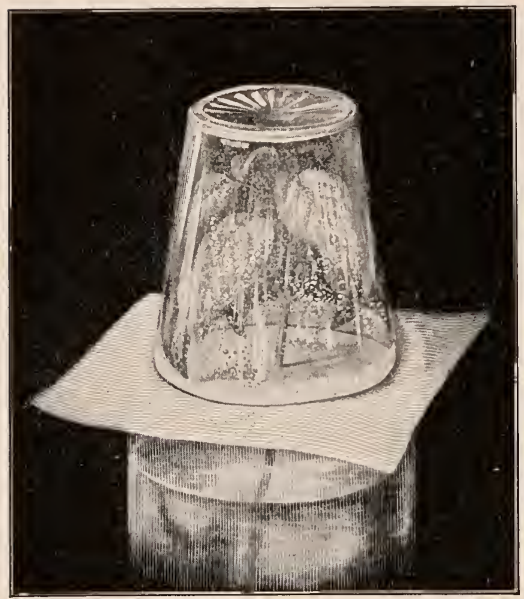

128. To illustrate transpiration. and stand it in a small bottle of water. Invert over this bottle a large-mouthed bottle (as a fruitjar), and notice that a mist soon accumulates on the inside of the glass. In time, drops of water form. The experiment may be varied as shown in Fig. 128. Or invert the fruitjar over an entire plant, as shown in Fig. 129, taking care to cover the earth with oiled paper or rubber cloth to prevent evaporation.

167. Even in winter, moisture is given off by leafless twigs. Cut a twig, seal the severed end with wax, and allow the twig to lie several days: it shrivels. There must be some upward movement of water even in winter, else plants would shrivel and die.

168. When the roots fail to supply to the plant sufficient water to equalize that transpired by the leaves, the plant wilts. Transpiration from the leaves and delicate shoots is increased by all of the conditions that increase evaporation, 
as higher temperature, dry air or wind. In especially hot weather, when the wind is brisk and the air dry, the roots may be very active and yet fail to absorb suffieient moisture to equalize that given off by the leaves. Any injury to the roots or even chilling them (156) may eause the plant to wilt. On a hot, dry day, note how the leaves of corn "roll" toward afternoon. Early the following morning, note how fresh and vigorous the same leaves appear. Water is also forced up by root-pressure (154). Some of the dew on the grass in the morning may be the water forced up by the roots; some of it is the condensed vapor of the air.

169. The wilting of a plant is due to the loss of water from the cells. The cell walls are soft, and they col-

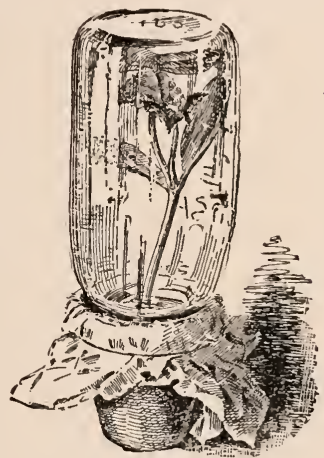

129. To illustrate transpiration. lapse. A toy balloon will not stand alone until it is inflated with air or liquid. In the woody parts of the plant the cell walls may be stiff enough to support themselves, even though the cell is empty. Measure the contraction due to wilting and drying by tracing a fresh leaf, and then tracing the same leaf after it has been dried between papers. The softer the leaf, the greater will be the contraction.

Review.-What relation do root-hairs have to soil-partieles? What is the effect of the chilling of roots? Of what use to the plant is water? What essential elements are taken from the soil? How many elements are essential for the plant? What is the ash? What elements does the farmer add as fertilizers? How may the nitrogen supply of the soil be increased? What plants possess the root nodules? What is soil inoculation? What is transpiration? When does a plant wilt? 


\section{CHAPTER XIV}

\section{FOOD ELABORATION AND RESPIRATION}

170. Sources of Raw Material.-The ordinary green plant, as we have seen, secures water and certain substances from the soil. It also secures from the air raw material which it utilizes in the elaboration of food material. When a plant is thoroughly dried in an oven, the water passes off; this water came from the soil. The remaining part is called dry substance or dry matter. If the dry matter is burned in an ordinary fire, only the ash remains; this ash came from the soil. The part that passed off as a gas in the burning contained the elements that came from the air. It also contained some of those that came from the soil-all those (as nitrogen, hydrogen, chlorin) that are transformed into gases by the heat of a common fire.

171. Carbon.-Carbon enters abundantly into the composition of all plants. Note what happens when a plant is burned without free access of air, or smothered, as in a charcoal pit. A mass of charcoal remains, almost as large as the body of the plant. Charcoal is almost pure carbon, the ash being so small in proportion to the large amount of carbon that we look on it as an impurity. Half or more of the dry substance of a tree is carbon. The carbon goes off as a gas when the plant is burned in air. It does not go off alone, but in combination with oxygen, and in the form called carbon dioxid gas, $\mathrm{CO}_{2}$.

172. The green plant secures its carbon from the air. In other words, much of the solid matter of the plant comes from one of the gases. By volume, carbon dioxid forms only about three-hundredths of 1 per cent of the air. It 
would be very disastrous to animal life, however, if this small percentage were much increased, for it excludes the life-giving oxygen. Carbon dioxid is often called "foulgas." It may accumulate in old wells, and an experienced person will not descend into such wells until they have been tested with a torch. If the air in the well will not support combustion, that is, if the torch is extinguished, it usually means that carbon dioxid has drained into the place. The air of a closed schoolroom often contains far too much of this gas along with little solid particles of waste matters. Carbon dioxid is often known as carbonic acid gas.

173. Appropriation of the Carbon.-The earbon dioxid of the air readily diffuses into the leaves and other green parts of the plant. The leaf may be delicate in texture, and air may diffuse directly into the leaf-tissues. There are, however, special inlets adapted for the admission of gases into the leaves and other green parts. These inlets consist of numerous pores (stomates or stomata), which are especially abundant on the under surface of the leaf. They may also be present on the upper surface. The apple leaf contains about one hundred thousand of these pores to each square inch of the under surface. Through these pores the outside air enters into the air-spaces of the plant, and finally into the little cells containing the living matter. In Chapter XL these stomata will be studied.

174. Chlorophyll.-The green color of leaves is due to a substanee called ehlorophyll. Purchase at the drug store about a gill of (grain) alcohol. Secure a leaf of geranium, elover, or other plant that has been exposed to sunlight for a few hours and, after dipping it for a minute in boiling water, put it in a white cup with sufficient aleohol to cover the leaf. Place the cup on the stove where it is not hot enough for the alcohol to take fire. After a time the chlorophyll is dissolved by the alcohol, which has become an intense green. Save this leaf for a future experiment. Without 
chlorophyll, the plant can not appropriate the carbon dioxid of the air.

175. In most plants, this chlorophyll or leaf-green is scattered throughout the green tissues in little oval bodies, and these bodies are most abundant near the upper surface of the leaf, where they secure a large amount of light. Without this green coloring matter, there would be no reason for the large flat surfaces that leaves possess, and no reason for the fact that the leaves are borne most abundantly at the ends of the branches, where the light is most available. Plants with colored leaves, as coleus, have chlorophyll, but it is masked by other coloring matter. 'This other coloring matter is usually soluble in hot water. Boil a coleus leaf and notice that it becomes green and the water becomes colored.

176. Plants grown in darkness are yellow and slender, and do not reach maturity. Compare the potato sprouts that have grown from a tuber lying in the dark cellar with those that have grown normally in the bright light (Fig. 45). The shoots have elongated until the food which is stored in the tuber is exhausted. These shoots have lived useless lives. A plant that has been grown in darkness from the seed will soon die, although for a time the little seedling will grow very tall and slender. Light induces the production of chlorophyll. Sometimes chlorophyll is found in buds and seeds, but it is probable in most cases that these places are not perfectly dark. Notice how potato tubers develop chlorophyll, or become green, when exposed to light.

177. Photosynthesis.-Carbon dioxid diffuses into the leaf (173) and is used during sunlight, and oxygen is given off. We have seen (172) that carbon dioxid will not support animal life. Experiments show that carbon dioxid is absorbed and that oxygen is given off by all green surfaces in the hours of sunlight. How the carbon dioxid may be used in making organic food is a complex question and need be considered here only in a general way. 
178. Chlorophyll absorbs ecrtain of the sun's rays and the energy thus derived is used in uniting the carbon dioxid with some of the water brought up from the roots. The process is complex, with some kind of sugar or starch as the ultimate product. Glucose is probably the first carbohydrate formed. In most plants, the first visible product is starch. Certain plants do not produce starch. The common onion, amaryllis and iris are of this class. The process of using the carbon dioxid of the air has been known as carbonassimilation, but the term now commonly used is photosynthesis (from Greek words, meaning "light" and "put together").

179. Glucose or grape sugar is composed of carbon, hydrogen, and oxygen $\left(\mathrm{C}_{6} \mathrm{H}_{12} \mathrm{O}_{6}\right)$. Starch is likewise composed of carbon, hydrogen, and oxygen, but differs in the percentages. Its chemical formula is generally given $\left(\mathrm{C}_{6} \mathrm{H}_{10} \mathrm{O}_{5}\right)$. Cane sugar, malt sugar, woody substances are very similar in composition. They are called carbohydrates. In making the glucose sugar from the carbon dioxid and water, the oxygen gas is given off by the plant as a waste product. The general chenical formula for the process is: $6 \mathrm{CO}_{2}+$ $6 \mathrm{H}_{2} \mathrm{O}=\mathrm{C}_{6} \mathrm{H}_{12} \mathrm{O}_{6}+6 \mathrm{O}_{2}$.

180. In the daytime the plant, therefore, takes in carbon dioxid and gives off oxygen. It is not so easy to demonstrate this fact. Chemical analysis is the only way of proving it. The escape of oxygen can best be demonstrated by employing water plants. Make an experiment as illustrated in Fig. 130. Under a funnel in a deep glass jar containing fresh spring or stream water, place fresh pieces of the common water-weed, elodea (or anacharis). In sunlight, bubbles of oxygen will arise and collect in the test-tube. Some of the bubbles may be only air, particularly if marked changes in the temperature of the water occur. A simple experiment is to immerse a stem of elodea in a test-tube of water and hold the tube in bright sunlight. Bubbles of gas will arise from 
the cut end of the twig. This gas has been found to be largely oxygen. The water-plant gets its carbon dioxid gas from that which is dissolved in the water. A gas, as well as a solid, may be dissolved in water. Observe the bubbles on

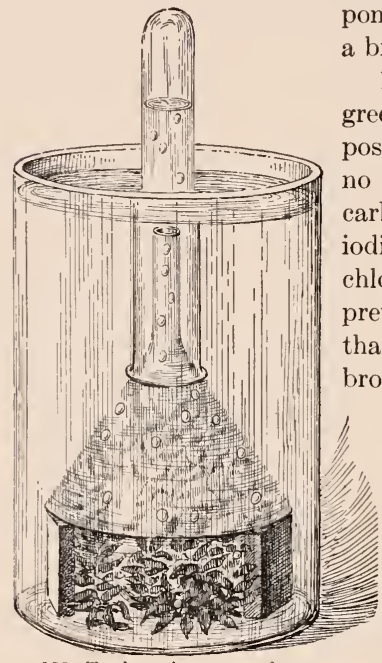

130. To show the escape of oxygen. pond-scums and water-weeds on a bright day.

181. Starch is present in the green leaves that have been exposed to sunlight; but in the dark no starch ean be formed from carbon dioxid and water. Apply iodin to the leaf from which the chlorophyll was dissolved in a previous experiment (174). Note that the leaf is colored purplish brown throughout. Starch gives a blue coloration with iodin. The leaf contains starch (76). Secure a leaf from a plant that has been in the darkness for about two days. Dissolve the chlorophyll, as before, and attempt to stain this leaf with iodin. No purplish brown color is produced.

182. Plants or parts of plants that have developed no chlorophyll can form no starch. Secure a variegated leaf of coleus, ribbon-grass, geranium, or of any plant showing both white and green areas. On a day of bright sunshine, test one of these leaves by the alcohol and iodin method for the presence of starch. Observe that the parts devoid of green color have formed no starch. However, after starch has once been formed in the leaves, it may be changed into soluble substances and removed to be again converted into starch in other parts of the living tissues. 
183. Digestion.-The starch made by the leaf during the daytime is present in the form of insoluble granules. In order to be carried from the leaf to other parts of the plant for purposes of storage or growth, it must be made soluble. The starch of the leaves at night is converted into sugars by the action of enzymes, or ferments, and is then conveyed to other parts of the plant. This conversion is a process of digestion. It is much like the change of starchy foods to sugary foods by the saliva.

184. After being changed to the soluble form, this material is ready to be used in growth, either in the leaf, in the stem, or in the roots. With other more complex products it is then distributed throughout all of the growing parts of the plant; and when passing down to the root it passes readily through the inner bark, in plants that have a definite bark. This gradual downward diffusion of materials suitable for growth through the inner bark is the process referred to when the "descent of sap" is mentioned. Stareh and other products are often stored in one growing season to be used in the next season (Chapter VI). If a tree is constricted or strangled by a wire around its trunk, the digested food cannot readily pass down and it is stored above the girdle, causing an enlargement.

185. Assimilation.- The food from the air and the nutrients from the soil unite in the living tissues (see Photosynthesis, 178). The sap that passes upwards from the roots in the growing season is made up largely of the soil-water and the salts that have been absorbed in the diluted solutions. We have found that this upward-moving water is conducted largely through certain tubular cells of the young wood (153). These cells are never continuous tubes from root to leaf; but the water passes readily from one eell to another in its upward course.

186. The upward-moving water gradually passes to the growing parts, and it comes in intimate contact with the 
soluble carbohydrates and products of photosynthesis. In the building-up or reconstructive and other processes it is therefore available. There is a series of changes, gradually increasing in complexity. There are formed substances containing nitrogen, in addition to carbon, hydrogen and oxygen. Others will contain also sulfur and phosphorus, and the process may be thought of as culminating in protoplasm. Protoplasm is the living matter in plants. It is in the cells, and is usually semifluid. Starch is not living matter. The process of building up the protoplasm is called assimilation.

187. Respiration.-In the maintenance and growth of the plant, energy is required. This energy is derived from the food that the plant has manufactured; and its ultimate source is the sunlight. For the release of this energy, chemical changes are involved which. require oxygen; as byproducts, carbon dioxid gas is given off and water is formed in the cells; this whole process is respiration. This process of respiration is similarin animals. All animals require oxygen and give off carbon dioxid. Likewise, all living parts of the plart must have a constant supply of oxygen.

188. In green plants, at night, carbon dioxid is given off into the air and oxygen is taken into the cells. In the daytime, respiration goes on, but the required oxygen is derived from the supply released in photosynthesis; and the carbon dioxid released in respiration supplies a part of the carbon dioxid used in photosynthesis. In the daytime, the plants tend to purify the air because they use carbon dioxid and give off oxygen. At night, like animals, they tend to make the air foul because they use oxygen and give off carbon dioxid. The carbon dioxid given off by a few plants at night, however, is so slight that it need not disturb one at all.

189. The oxygen that the plants need may come into the plant through the stomata, through pores in the stems or trunks of trees, or it may diffuse through the cell walls. All rapidly growing plants respire very freely. Germinating 
seeds especially give off a large quantity of carbon dioxid. In a wide-mouthed bottle place several hundred germinating pea seeds. Fill a small vial with a filtered concentrated solution of barium hydrate. Place the vial in the bottle with the seeds. Do not spill the solution. Tightly stopper the wide-mouthed bottle and after several hours note the heavy, white precipitate that forms in it. As a check, place a similar vial of barium hydrate solution is a similar bottle tightly stoppered. Does a heavy precipitate form? Using a piece of glass tubing, blow air into a bottle of barium hydrate. The exhaled air is rich in carbon dioxid. The water becomes turbid, due to the precipitate formed when carbon dioxid reacts with barium hydrate.

Review.-What are the sources of the raw material? What part of the dry matter is carbon? What percentage of the air is carbon dioxid? How does it enter the plant? What is chlorophyll? What is necessary for its formation? What is meant by photosynthesis? What gas is given off in photosynthesis? What conditions are necessary for photosynthesis? What is meant by digestion of starch? What is meant by assinilation? Respiration? When does it oceur? What gas is given off in the process? What gas is required in the process? Contrast the process of respiration in animals and plants. 


\section{CHAPTER XV}

\section{DEPENDENT PLANTS}

190. Dependent and Independent Plants.-Plants with roots and foliage usually depend on themselves. They collect the raw materials and make them over into assimilable food. They are independent. Plants without green foliage cannot make food: they must have it made for them

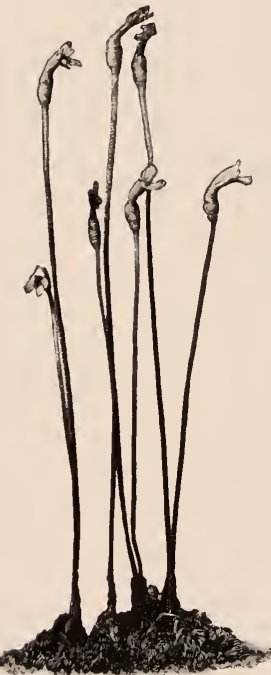

131. A parasite, growing in woods.-Aphyllon. It is in bloom. or they die. They are dependent. The potato sprout (Fig. 45) cannot collect and elaborate carbon dioxid. It lives on the food stored in the tuber.

191. All plants with naturally white or blanched parts are dependent. Their leaves do not develop. They live on organic matter-that which has been made by a plant or an animal. The Indian pipe, aphyllon (Fig. 131), beech-drop, coral-root (Fig. 132) among flower-producing plants, also mushrooms as well as bacteria and other fungi (Figs. 133, 134, 135) are common examples.

192. Saprophytes and Parasites.A plant that lives on dead or decaying matter is a saprophyte. Mushrooms are examples: they live on the decaying matter in the soil. Mould on bread and cheese is an example. Lay a piece of moist bread on a plate and invert a tumbler over it. In a few 
days it will be mouldy. The spores were in the air, or perhaps they had already fallen on the bread but had not had opportunity to grow.

193. Saprophytes break down or decompose organic

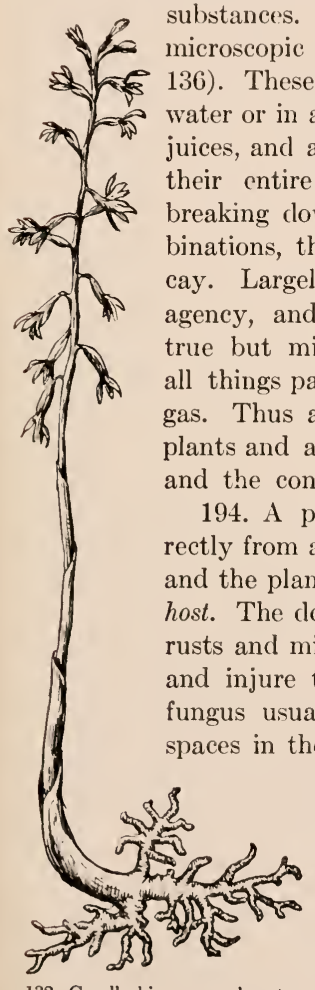

132. Corallorhiza or coral-root, showing the mycorhizas.

Chief of these saprophytes are the organisms known as bacteria (Fig. innumerable bodies are immersed in nimal and plant absorb food over surface. By organic comthey produce decay. Largely through their agency, and that of many true but microscopic fungi, all things pass into soil and

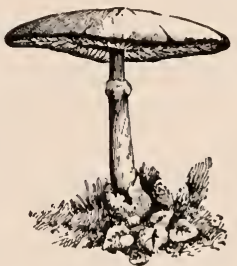
gas. Thus are the bodies of plants and animals removed

133. A mushroom, example of a saprophytic plant.

continuing round of life is maintained. plant that secures its nutrition difrom a living plant or animal is a parasite, and the plant or animal on which it lives is the e dodder is a true parasite. So are the mildews that attack leaves and shoots the them. The threads of the parasitic fungus usually creep through the intercellular spaces in the leaf or stem and send suckers (or haustoria) into the cells. (Fig. 137.) In some forms these threads (or hyphæ) penetrate the cells. The hyphæ clog the air-spaces of the leaf and often plug the stomata, and they aiso appropriate and disorganize the cell fluids: thus they injure or kill their host. The mass of hyphæ of a 
fungus is called mycelium. Some of the hyphæ finally grow out of the leaf and produce spores or reproductive cells

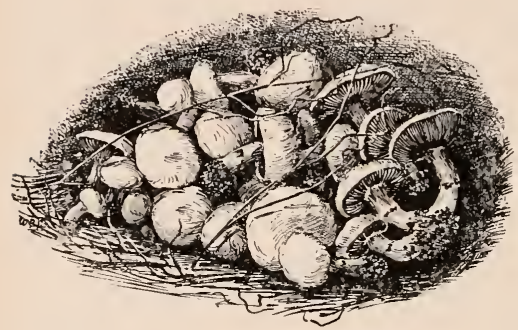

134. The cultivated mushroom, a saprophytic plant. which answer the purpose of seeds in distributing the plant (b, Fig. 137). 195. The abnormal condition produced in plants by fungous and bacterial parasites and by other agents is known as a disease. On some plants, the disease takes the form of a leaf-spot or a blight; in others swellings or galls are produced. Cankers on branches of trees and on stems of herbaceous plants are produced by fungi living in the affected tissue. The well-known fireblight and blight-canker of pears are caused by bacteria. The rots of fruits and vegetables are largely produced by fungi or bacteria.

196. Some parasites spring from the ground (Figs. 131, 132), as other plants do, but they are parasitic on the roots of their hosts. Some parasites may be

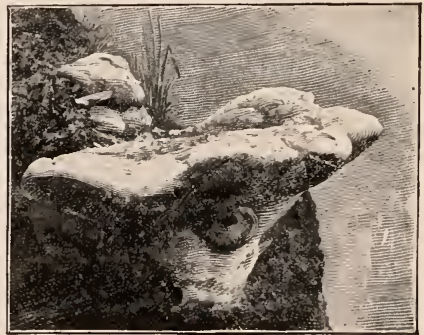

135. Saprophytic fungus. One of the shelf fungi (Polyporus) growing on dead trunks and logs. partially parasitic and partially saprophytic. Many (perhaps most) of these root-saprophytes are aided in securing their food by soil fungi, which spread their delicate threads over the root-like branches of the plant and act as intermediaries 
between the food and the saprophyte. The roots of the coral-root (Fig. 132) are covered with this fungus, and the roots have practically lost the power of absorbing nutrients direct. These fungus-covered roots are known as mycorhizas (meaning "fungus root"). Mycorhizas are

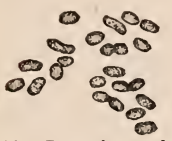

136. Bacteria, much magnified. not peculiar to saprophytes. They are found on many wholly independent plants as, for example, the heaths, oaks, apples and pines. It is probable that the fungusthreads perform some of the offices of roothairs to the host. On the other hand, the fungus obtains some nourishment from the bost. The association seems to be mutual.

197. Some parasites are green-leaved. Such is the mistletoe. They anchor themselves on the host and absorb its juices, but they also appropriate and use the carbon dioxid of the air. In some groups of bacteria the process of photosynthesis, or something equivalent to it, takes place.

198. Parasitism and saprophytism are usually regarded as degeneration, that is, as a loss of independence. The ancestors of these plants might have been independent. Thus, the whole class of fungi is looked upon as a degenerate evolution. The more a plant depends on other plants, the more it tends still further to lose its independence.

199. Epiphytes.-To be distinguished from the dependent plants are those that grow on other plants without taking food from them. These are green-leaved plants whose roots burrow in the bark of the host plant and perhaps derive some food

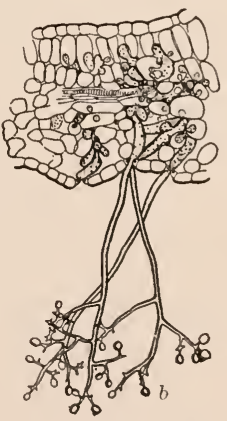

137. A parasitic fungus, magnified. The mycelium, or vegetative part, is shown by the dotted-shaded parto ramifying in the leaf tissue. The rounded haustoria projecting into the cells are also shown. The long fruiting parts of the fungus hang from the under surface of the leaf. 
from it, but which subsist chiefly on materials that they secure from air-dust, rain-water and the air. These plants are epiphytes (meaning "upon plants") or air-plants.

200. Epiphytes abound in the tropics. Orchids are amongst the best known examples. (Fig. 13.) The Spanish moss or tillandsia of the South is another. Mosses and lichens that grow on trees and fences may also be called epiphytes. In the struggle for existence, the plants probably have been driven to these special places in which to find opportunity to grow. Plants grow where they must, not where they will.

Review.-What is an independent plant? Dependent? Give examples. How are dependent plants distinguished from others in looks? Define saprophyte. Parasite. Give examples. What is a host? How does a parasitic fungus live on its host? What is meant by plant disease? What are hyphæ? What is mycelium? What are rootparasites? Give examples. What is a mycorhiza? What is the relation of the soil fungus to its host? What is the role or office of saprophytes in nature? Are parasites ever green? Explain. What has probably been the evolution of most parasites and saprophytes? What is an epiphyte? Give examples. How do epiphytes live? Why may they have become epiphytes?

Note.-Usually, the most available parasite is the dodder. It is common in swales from July until autumn, winding its coral-yellow stems about herbs and soft-growing bushes. It is a degraded member of the morning-glory family. It produces true flowers and seeds. These seeds germinate the following spring. The slender young vine grows from the ground for a time, but if it fails to find a host, it perishes. One of the dodders is a pest in alfalfa fields. From the Ohio River southward, the mistletoe is available. 


\section{CHAPTER XVI}

\section{LEAVES AND FOLIAGE}

201. Leaves may be studied from two points of view - with reference to their function, or what they do; and with reference to their form, or their shapes and kinds.

202. Function.-Leaves, as we have seen, make organic matter from carbon dioxid. Almost any part of the plant, however, may bear chlorophyll and perform the function of leaves. The general form and structure of leaves is intimately associated with their function: they are thin and much expanded bodies, thereby exposing the greatest possibje surface to light and air. The position of the leaves usually has relation to light, as we have seen (Chapter VIII). Leaves usually hang in such a way that one casts the least shade on the other; those that have the least favorable positions die and fall.

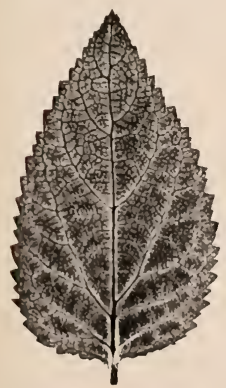

138. Simple leaf. One of the eupatoriums or bonesets.

203. Parts.-Leaves are simple or unbranched (Fig. 138), and compound or branched (Fig. 139). The method of compounding or branching follows the style of veining. The veining, or venation, is of two general kinds: in most plants the main veins diverge, and there is a conspicuous network of smaller veins: such leaves are netted-veined. In other plants the main veins are parallel, or nearly so, and there is no conspicuous network: these are parallel-veined leaves (Fig. 150). The venation of nettedveined leaves is pinnate or feather-like, 
when the veins arise from the side of a continuous midrib (Fig. 138); palmate or digitate (hand-like), when the veins

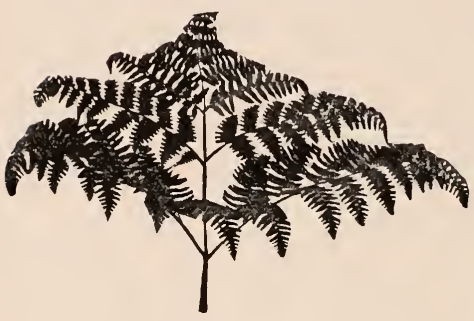

139. Compound or branched leaf of brake (which is a fern).

arise from the apex of the petiole (Fig. 140). If the leaf were divided between the main veins, it would be pinnately or digitately compound. 204. It is customary to speak of a leaf as compound only when the parts or branches are completely separate blades, as when the division extends to the midrib (Figs. 139, 141, 142). The parts or branches are known as leaflets. Sometimes the leaflets themselves are compound, and the whole leaf is then said to be bi-compound or twice-compound (Fig. 139). Some leaves are three-compound, fourcompound, or five-compound. Decompound is a general term to express any degree of compounding beyond twicecompound.

205. Leaves that are not divided to the midrib are said to be:

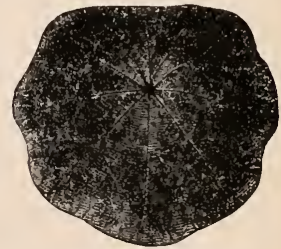

140. Digitate-veined peltate leaf of nasturtium.

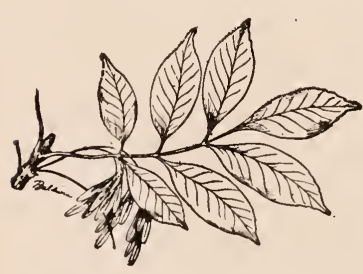

141. Pinnately compound leaf of ash.

lobed, openings or sinuses not more than half the depth of the blade (Fig. 143).

cleft, sinuses deeper than the middle.

parted, sinuses two-thirds or more to the midrib (Fig. 144). divided, sinuses nearly or quite to the midrib. 
The parts are called lobes, divisions, or segments, rather than leaflets. The leaf may be pinnately or digitately lobed, parted, cleft, or livided. A pinnately parted or cleft leaf is sometimes said to be pinnatifid.

206. Leaves may have one or all of three parts-blade or expanded part, petiole or stalk, stipules or appendages at the base of the petiole. All these parts are shown in Fig. 145. A leaf that has all three of these parts is said to be complete. The stipules

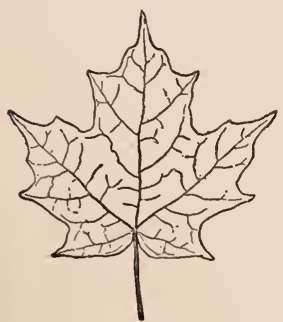

143. Lobed leaf of sugar maple.

are often green and leaf-like and perform the function of foliage, as in the pea and Japanese quince (the latter common in yards).

207. Leaves and leaflets that have no stalks are said to be sessile (Fig. 149), i.e., sitting. The same is said of flowers and fruits. The blade of a sessile leaf may partly or wholly surround the stem, when it is said to be clasping (Fig. 146). In some cases the leaf runs down the stem, forming a wing: such leaves are said to be decurrent (Fig. 147). When opposite sessile leaves are joined by their bases, they are said to be connate (Fig. 148).

208. Leaflets may have one or all of these three parts, but the stalks of leaflets are called petiolules and the stipules of leaflets are

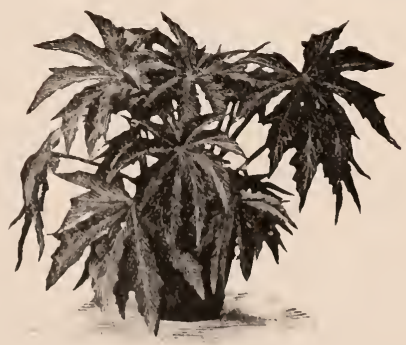

144. Digitately parted leaves of begonia. 
called stipels. The leaf of the garden bean has leaflets, petiolules, and stiples.

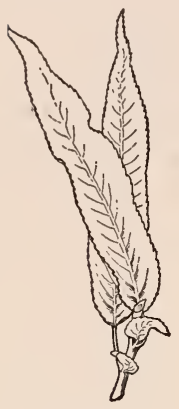

145. Complete leaves of willow.

209. The blade is usually attached to the petiole by its lower edge. In pinnate-veined leaves, the petiole seems to continue through the leaf as a midrib (Fig. 138). In some

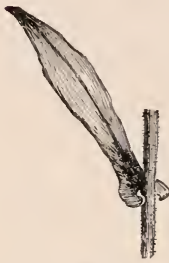

146. Clasping leaf of wild aster. plants, however, the petiole joins the blade inside or beyond the margin (Fig. 140). Such leaves are said to be peltate or shield-shaped. This mode of attachment is particularly common in floating leaves (e.g., the water-lilies). Peltate leaves are usually digitate-veined.

210. Shape.-Leaves and leaflets are infinitely variable in shape. Names have been given to some of the more definite or regular shapes. These names are a part of the language of botany. They represent ideal or typical shapes, but there are no two leaves alike and very few that perfectly conform to the definitions. The shapes are likened to those of familiar objects or of geometrical figures:

Linear, several times longer than broad, with the sides nearly or quite parallel. Spruces and most grasses are examples. (Fig. 150.) In linear leaves, the main veins are usually parallel to the midrib.

Oblong, twice or thrice as long as broad, with the sides parallel for most of their length. Fig. 149 shows the short-oblong leaves of the box, a plant which is much used for edgings in gardens.

Elliptic differs from the oblong in having the sides gradually tapering to either end from the middle. The European beech (Fig. 151) has elliptic leaves. (This tree is often planted.) 
Lanceolate, four to six times longer than broad, widest below the middle and tapering to each end. Some of the narrow-leaved willows are examples. Most of the willows and the peach have oblong-lanceolate leaves.

Spatulate, a narrow leaf that is broadest toward the apex.

The top is usually rounded. It is much like an oblong leaf.

Ovate, shaped somewhat like the longitudinal section of - an egg: twice as long as broad, tapering from near the base to the apex. This is one of the commonest leaf forms. (Fig. 152.)

Obovate, ovate inverted,- the wide part toward the apex. (1) Leaflets of horse-chestnut are obovate. This form is commonest in leaflets of digitate leaves.

Reniform, kidney-shaped. This form is sometimes seen in wild plants, particularly in root-leaves. Leaves of wild ginger are nearly reniform.

Orbicular, circular in general outline. Very few leaves are perfectly circular, but there are many kinds that are nearer circular than any other shape. (Fig. 153.)

The shape of many leaves is described in combinations of these terms, as ovate-lanceolate, lanceolate-oblong.

211. The shape of the base and . apex of the leaf or leaflet is often characteristic. The base may be rounded (Fig. 138), tapering (Fig. 127), cordate or heart-shaped (Fig. 152), truncate or squared as if cut

147.

Decurrent leaves of mullein. off. The apex may be blunt or obtuse, acute or sharp, acuminate or long-pointed, truncate (Fig. 154).

212. The shape of the margin is also characteristic of 
each kind of leaf. The margin is entire when it is not indented or cut in any way (Fig. 149). When not entire, it may be

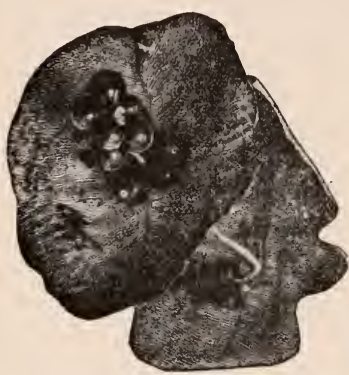

148. Two pairs of connate leaves of honeysuckle. undulate or wavy (Fig. 140), serrate or saw-toothed (Fig. 152), dentate or more coarsely notched (Fig. 138), crenate or round-toothed, lobed, and other forms.

213. Leaves often differ greatly in shape on the same plant. Observe the different shapes of leaves on the young growths of mulberries (Fig. 88) and

wild grapes; also on vigorous squash and pumpkin vines. In some cases there may be simple and compound leaves on the same plant. This is marked in the so-called Boston ivy or ampelopsis (Fig. 155),

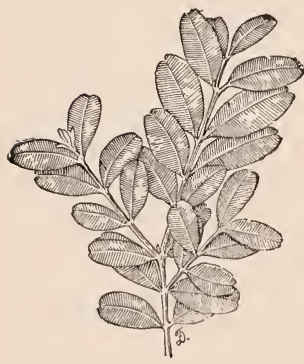

149.

a vine which is used to cover brick and stone buildings. Different degrees of compounding, even in the same leaf, may often be found in honey-locust and Kentucky coffee tree. Re- 150. Linearmarkable differences in acuminate forms are seen by comgrass. paring seed-leaves with mature leaves of any plant (Fig. 156).

214. The Leaf and Its EnvironShort-oblong leaves of box. ment.-The form and shape of the leaf often have direct relation to the place in which the leaf grows. Floating leaves are usually expanded and flat, and the petiole varies in length with the depth of the water. 
Submerged leaves are usually linear or thread-like, or are cut into very narrow divisions. Thereby is more surface exposed, and possibly the leaves are less injured by moving water.

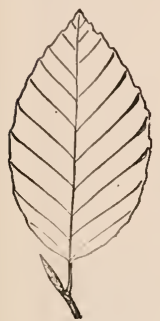

151. Elliptic leaf of purple beech.

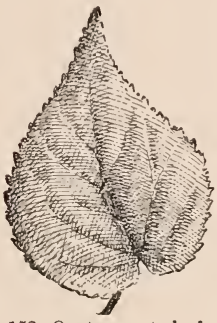

152. Ovate serrate leaf of hibiscus.

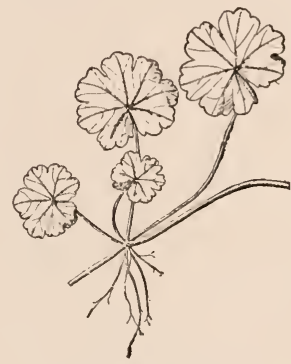

153. Orbicular lobed leaves.

215. The largest leaves on a sun-loving plant are usually those that are fully exposed to light. Compare the sizes of the leaves on the encls of branches with those at the base of the branches or in the interior of the tree-top (106). In dense foliage masses, the petioles of the lowermost or undermost leaves tend to elongate - to push the leaf to the light. (Fig. 157.)

216. On the approach of winter the leaf ceases to work, and often dies. It may drop, when it is said to be deciduous; or it may remain on the plant, when it is said to be persistent. If persistent leaves remain green during the winter, the plant is said to be evergreen. Most leaves fall by breaking off at the lower end of the petiole with a distinct joint or articulation.

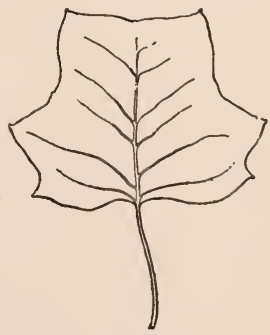

154. Truncate leaf of tulip-trce.

There are many leaves, however, that wither and hang on the plant until torn off by the wind: of such are the 
leaves of grasses, sedges, lilies, orchids, and other plants known as monocotyledons (Chapter XXV). Most leaves

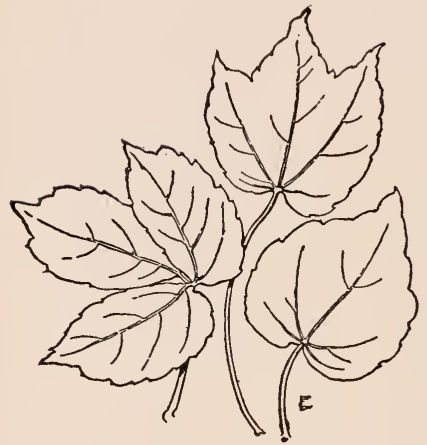

155. Different forms of leaves from one plant of ampelopsis. of this character are parallel-veined.

217. Leaves also die and fall from lack of light. Observe the yellow and weak leaves in a dense tree-top or in any thicket. Why do the lower leaves die on house-plants? Note the carpet of needles under the pines. All evergreens shed their leaves after a time. Counting back from the tip of a pine or spruce shoot, determine how many years the leaves persist. (Fig. 158.) In some spruces a few leaves may be found on branches ten or more years old.

218. Although the forms and positions of leaves often have direct relation to the places and conditions in which the leaves grow, it is not probable that all forms and shapes have been developed to adlapt the plant to its environment. It is probable that the toothing or lobing of the leaf-margins is due to the same causes that produce compounding or branching of leaves, but what these causes are is not known. It has been suggested that leaves have become compound in order to increase their surface and thereby to offer a greater

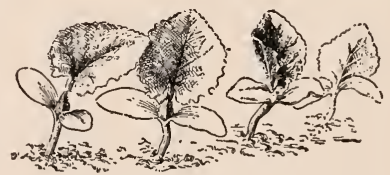

156. Muskmelon seedlings, with the unlike seed-leaves and true leaves. exposure to light in shady places, but very many sun-loving species have compound leaves, and many shade-loving species have simple and even small leaves. Again, it has 
been suggested that compound leaves shade underlying leaves less than simple leaves do.

219. How to Tell a Leaf.- It is often difficult to distinguish compound leaves from leafy branches, and leaflets

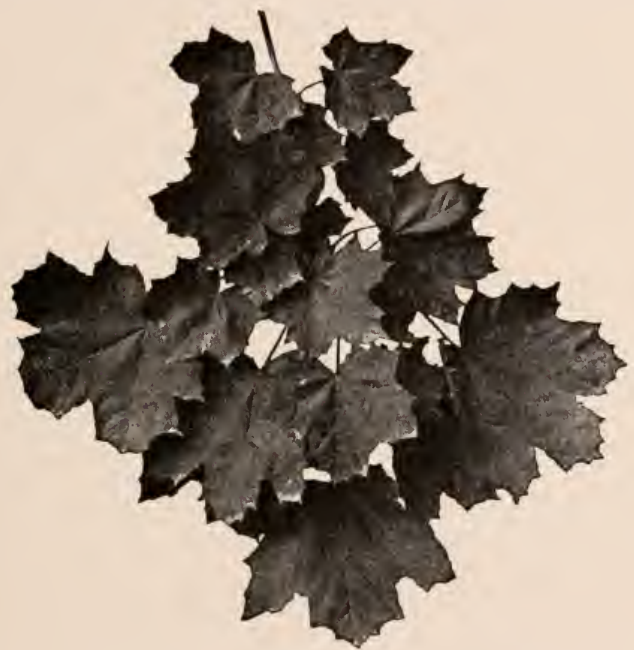

157. A leaf mosaic of Norway maple. Note the varying lengths of petioles.

from leaves. As a rule, leaves ean be told by the following tests: (1) Leaves are temporary structures, sooner or later falling. (2) Usually buds are borne in their axils. (3) Leaves are usually borne at joints or nodes. (4) They arise on wood of the current-year's growth. (5) They have a more or less definite arrangement. When leaves fall, the twig that bore them remains; when leaflets fall, the main petiole that bore them falls also.

Review.-How may leaves be studied? What is meant by function? What do leaves do? What other parts may perform the function 
of leaves? How is the form of leaves associated with their function? What are simple leaves? Compound? What is venation? What are the types or kinds of venation? What are the two types of compound leaves? What is a leaflet? Define bi-compound; decompound. What are lobed, cleft, parted, and divided leaves? Pinnatifid leaf? Complete leaf? Complete leaflet? What is a sessile leaf? How may the petiole join the blade? How are the shapes of leaves named or classified? Define the shapes described in 210. Describe common shapes of the base of the leaf. Of the apex. Of the margin. How are the forms and sizes of leaves ever related to the place in which they grow? Why do leaves fall? Define deciduous. Persistent. Evergreen. When do pine leaves fall? How can you distinguish leaves?

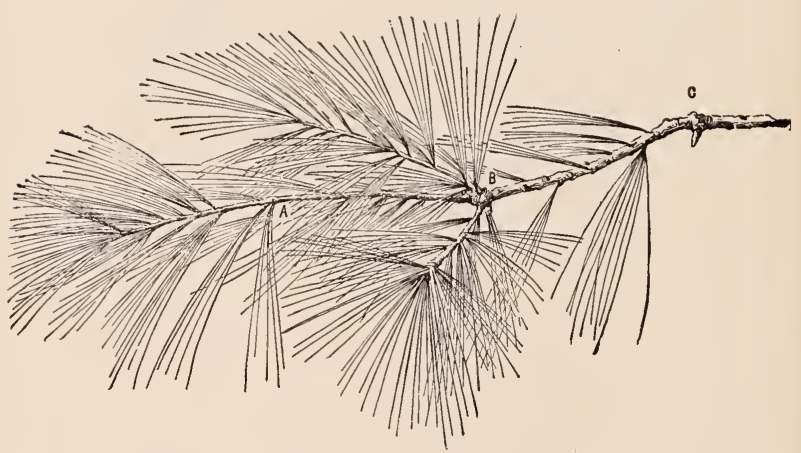

158. Shoot of the common white pine, one-third natural size.

The picture shows the falling of the leaves from the different years' growth. The part of the branch between the tip and $\mathrm{A}$ is the last season's growth; between $\mathrm{A}$ and $B$ it is two years old; the part between $B$ and $C$ is three years old; it has few leaves. The part that grew four seasons ago-beyond $\mathrm{C}$-has no leaves. 


\section{CHAPTER XVII}

\section{MORPHOLOGY, OR THE STUDY OF THE FORMS OF PLANT MEMBERS}

220. Botanists interpret all parts of the plant in terms of root, stem and leaf. That is, the various parts, as thorns, flowers, fruits, bud-scales, tendrils, and abnormal or unusual members, are supposed to represent or to stand in the place of roots, stems (branches) or leaves.

221. The forms of the parts of plants are interesting, therefore, in three ways: (1) merely as forms, which may be named and described; (2) their relation to function, or how they enable the part better to live and work; (3) their origin, as to how they came to be and whether they have been produced by the transformation or modification of other parts. The whole study of forms is known as morphology (literally, the "science of forms"). We may consider examples in the study of morphology.

222. It is customary to say that the various parts of plants are transformed or modified root, stem or leaf, but the words transformation and modification are not used in the literal sense. It is meant that the given part, as a tendril, may occupy the place of or represent a leaf. It was not first a leaf and then a tendril: the part develops into a tendril instead of into a leaf: it stands where a leaf normally might have stood: it is the historical descendant of the leaf.

223. It is better to say that parts which have similar origins, which arise from the same fundamental type, or which are of close genealogical relationship, are homologous. Thus the tendril, in the example assumed above, is homologous with a leaf. Parts that have similar func- 
tions or perform similar labor, without respect to origins, are analogous. Thus a leaf-tendril is analogous to a branchtendril, but the two are not homologous.

224. There are five tests by means of which we may hope to determine what a given part is: (1) by the appearance or looks of the part

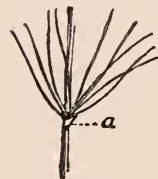

159. Leaf and cladophylla of asparagus.

(the least reliable test); (2) by the position of the part with relation to other parts-its place on the plant; (3) by comparison with similar parts on other plants (comparative morphology); (4) by study of intermediate or connecting parts; (5) by study of the develop-

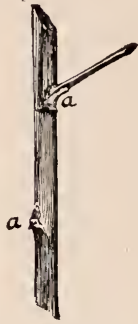

160. Leaves of asparagus.

ment of the part in the bud or as it originates by means of the microscope (embryology). The last test can be applied only by the trained investigator, but it often gives the most conclusive evidence. Even with the application of all these tests, it is sometimes impossible to arrive at a definite con-

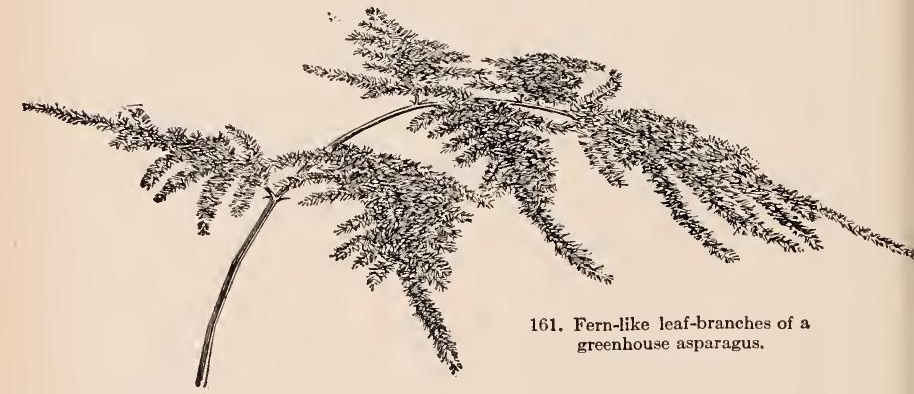

clusion as to the origin or morphology of a part. For example, it is not yet agreed whether most cactus spines represent leaves or branches, or are mere outgrowths of the epidermis (as hairs are). 
225. The foliage of asparagus is composed of modified branches. The true leaves of asparagus are minute whitish scales. ( $a$, Fig. 159.) The green foliage is produced in the axils of these scales. On the strong spring shoots of asparagus, which are edible, the true leaves appear as

large scales. ( $a, a$, Fig. 160.) These

large scales persist on the base of the asparagus plant, even in the

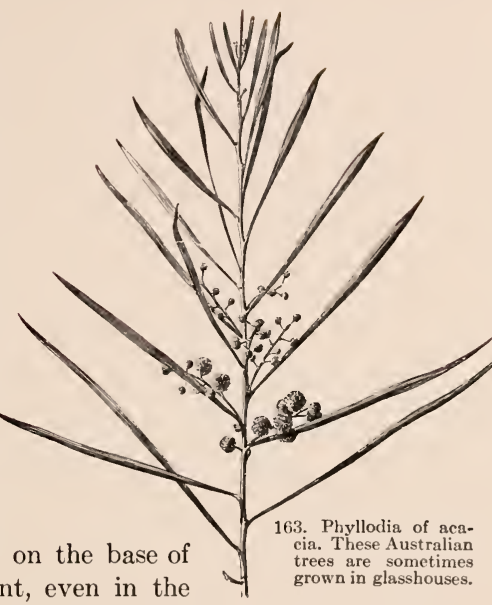
fall. In the species of greenhouse or ornamental
asparagus, the delicate foliage is also made up of green leaf-like branches. (Fig. 161.) In some cases the true leaves fall after a time, and there is little If evidence left. The strong new shoots usually show the true leaves plainly (as in Fig. 162). Branches I that simulate leaves are known as cladophylla (singular, cladophyllum). The broad flat leaves of florists' smilax (common in glasshouses) are cladophylla.

226. In the study of morphology, it is not enough, however, merely to determine whether a part represents root, stem or 162. Strong new shoot of Asparagus Sprengeri, showing the true leaves and the branches springing from the axils. leaf: one must determine what part or kind of root, stem or leaf it stands for. For example, the foliage in Fig. 163 represents green expanded petioles. These 
leaf-like members have buds (which produce branches) in their axils, and they have the arrangement or phyllotaxy of leaves;

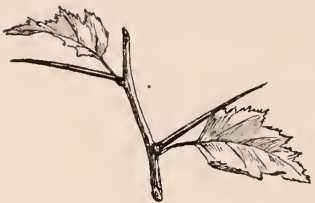

164. The thorns are in the axils of leaves. therefore they are considered to be true leaf parts. But they stand edgewise as if they might be petioles; sometimes they bear leafblades; other acacias have compound expanded leaves; there are intermediate forms or gradations between different acacias; young seedlings sometimes show intermediate forms. From all the evidence, it is now understood that the foliage of the simpleleaf acacias represents leaf-like petioles. Such petioles are known as phyllodia (singular, phyllodium).

227. Thorns and strong spines are usually branches. The spines of hawthorns or thorn-apples are examples: they are

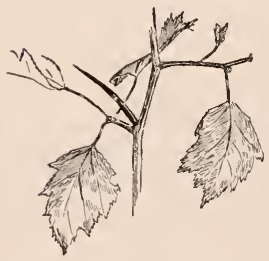

166. Some of the buds produce leafy branches. borne in the axils

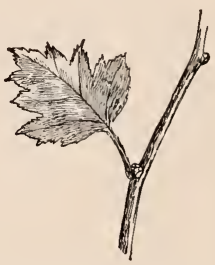

165. Two or more buds are borne in the axils. of leaves as branches are (Fig. 164); hawthorns usually bear two or more buds in each axil (Fig. 165), and one or two of these buds often grow the following year into normal leafy branches (Fig. 166); sometimes the thorn itself bears leaves. (Fig. 167.) The thorns of wilding pears, apples and plums are short, hardened branches. In well-cultivated trees there is sufficient vigor to push the main branch into longer and softer growth, so that the side buds do not have a chance to start. The thorns of osage-orange and honeylocust are also branches. Those of the honey-

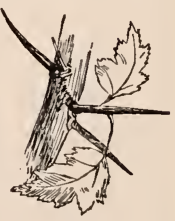

167. The thorn may bear leaves. 
locust usually arise from supernumerary buds that are borne somewhat above the axils.

228. Prickles, bristles and weak spines, which have a definite arrangement on the stem, are usually modified leaves or parts of leaves. The spines of thistles are hardened points of leaf-lobes. The spines of the barberry are reduced leaves; in their axils are borne short branches

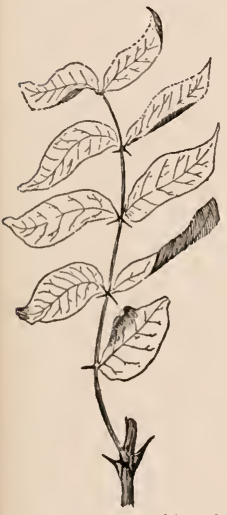

169. Small prickles of the prickly ash. or leaf-tufts (Fig. 168); in spring on young shoots may

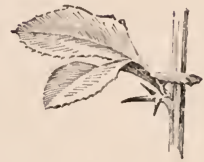

168. Leaf-spine of barberry. be found almost complete gradations from spiny leaves to spines. The prickly ash has prickles (Fig. 169) that simulate stipules and stipels, but the irregularity of position indicates that they are not homologous with stipules. The prickles of the common locust (robinia) are usually interpreted as stipules.

229. Prickles, bristles and hairs that are scattered or have no definite arrangement, are usually mere outgrowths of the epidermis. They commonly are removed with the bark. Of such are the prickles of squashes, briars (Fig. 170), and the roses.

230. The reason for the existence of spines is difficult to determine. In many or most cases they seem to have no distinct use or function. In some way they are associated with the evolution of the plant, and one cannot determine why they came without knowing much of the genealogy of the

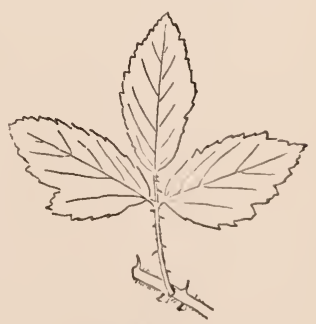

170. Prickles of dewberry. plant. In some cases they seem to be the result of the contraction of the plant-body, as in the cacti and other 
desert plants; and they may then serve a purpose in lessening transpiration. It is a common notion that spines and prickles exist for the purpose of keeping enemies away, and that hairs keep the plant warm, but these ideas usually lack scientific accuracy. Even if spines do keep away browsing animals in any plant, it is quite another question why the spines came to be. To determine what spines and hairs are for demands close scientific study of each particular case, as does any other problem.

231. Leaves are usually smaller as they approach the flowers. (Fig. 171.) They often become so much reduced

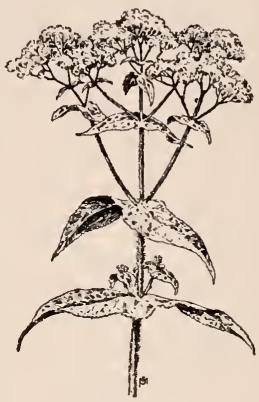

171. The diminishing leaves of boneset. as to be mere scales, losing their office as foliage. In their axils, however, the flower-branches may be borne. (Fig. 172.)

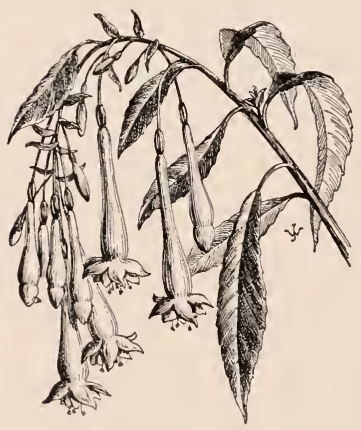

172. The uppermost flowers are borne in the axils of bracts.-Fuchsia. Much-reduced leaves, particularly those that are no longer green and working members, are called bracts. In some cases, large colored bracts are borne just beneath the flowers and look like petals: the flowering dogwood is an example; also the bougainvillea, which is common in glasshouses; also the scarlet sage of gardens, some of the euphorbias or spurges, and the flaming poinsettia of greenhouses. Sometimes a green leaf is borne close against a head or cluster of flowers, as in the clover (Fig. 173); but a separate bract or scale will be found for each flower in the head. 
232. The scales of buds are special kinds of bracts. In some eases each scale represents an entire leaf; in others, it represents a petiole or stipule. In the expanding pear, maple, lilac, hickory and horse-ehestnut buds, note the gradation from dry seales to green leaf-like bodies. When the winter scales fall by the pushing out of the young shoot, scars are left: these scars form "rings," which mark the annual growths. (See Chap. VII.) The seales of bulbs are also special kinds of leaves or bracts. In some eases they are merely protective bodies; in others they are storehouses. We have found (45) that the presenee of seales or bracts is one means of distinguishing underground stems from roots.

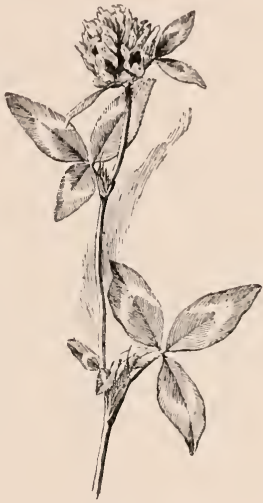

173. Red clover. Leaves 3 -foliolate.

REview.- What are considered to be the fundamental or type forms from which the parts of plants are derived? How do the forms of plants interest us? What is morphology? What is meant by transformation and modification as used by the morphologist? What is meant by homologous parts? Analogous parts? Tell how one may determine the morphology of any part. What is a cladophyllum? Phyllodium? Show a specimen of one or the other, or both (canned asparagus can always be had in the market). What is the morphology of most thorns? Explain the thorns of hawthorn. What are bristles, prickles and hairs? Why do spines and bristles exist? Explain what a bract is. A bud-scale. A bulb-scale. 


\section{CHAPTER XVIII}

\section{HOW PLANTS CLIMB}

233. We have seen that plants struggle or contend for a place in which to live. Some of them have become suited to grow in the forest shade, others to grow on other plants as epiphytes, others to climb to the light. Observe how woods grapes, and other forest climbers, spread their foliage on the very top of the forest tree, while their long flexile trunks may be bare. One who has seen a dense tropical forest has realized the struggle for light on the tops of the trees.

234. There are several ways by which plants climb, but most climbers may be classified into four groups: (1) scramblers, (2) root-climbers, (3) tendril-climbers, (4) twiners.

235. Scramblers. - Some plants rise to light and air by resting their long and weak stems on the tops of bushes and quick-growing herbs. Their stems are elevated by the

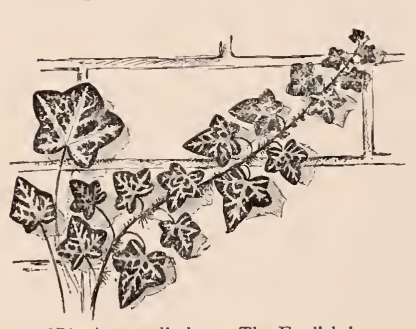

174. A root-climber.-The English ivy. growing twigs of the plants on which they recline. Such plants are scramblers. Usually they are provided with prickles or bristles. In most weedy swamp thickets, scrambling plants may be found. Briars, some roses, bed-straw or galium, bittersweet (Solanum Dulcamara, not the celastrus), the tearthumb polygonums, and other plants are familiar examples of scramblers.

236. Root-climbers.-Some plants climb by means of 
truc roots, as explained in paragraph 31 . These roots are of adventitious origin. They grow in a horizontal direction and enter the chinks of walls or the furrows in the bark of trees. Fig. 12, the trumpet ereeper, is a familiar example. The true or English ivy, which is often grown to cover buildings, is another example. (Fig. 174.) Still another

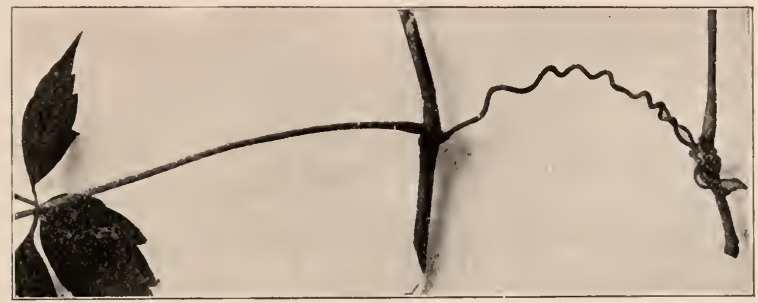

175. Tendril of Virginia creeper. The direction of the coil changes near the middle

is the poison ivy. Roots are distinguished from stem tendrils by their irregular or indefinite position as well as by their mode of growth.

237. Tendril-climbers.-A slender coiling part that serves to hold a climbing plant to a support is known as a tendril. The free end swings or curves until it strikes some object, when it attaches itself and then coils and draws the plant elose to the support. The spring of the coil also allows the plant to move in the wind, thereby enabling the plant to maintain its hold. Slowly pull a well-matured tendril from its support, and note how strongly it holds on. Wateh the tendrils in a storm. To test the movement of a free tendril, draw an ink line lengthwise of it, and note that the line is now on the concave side and now on the convex side. Of course this movement is slow, but often it is evident in an hour or so. Usually the tendril attaches to the support by coiling about it, but the Virginia creeper and Boston ivy attach to walls by means of disks on the ends of the tendrils. 
238. Since both ends of the tendril are fixed, when it finds a support, the coiling would tend to twist it in two. It will be found, however, that the tendril coils in different directions in different parts of its length. In Fig. 175 the change of direction in the coil occurs at the straight place beyond the middle. In long tendrils of cucumbers and melons there may be several changes of direction.

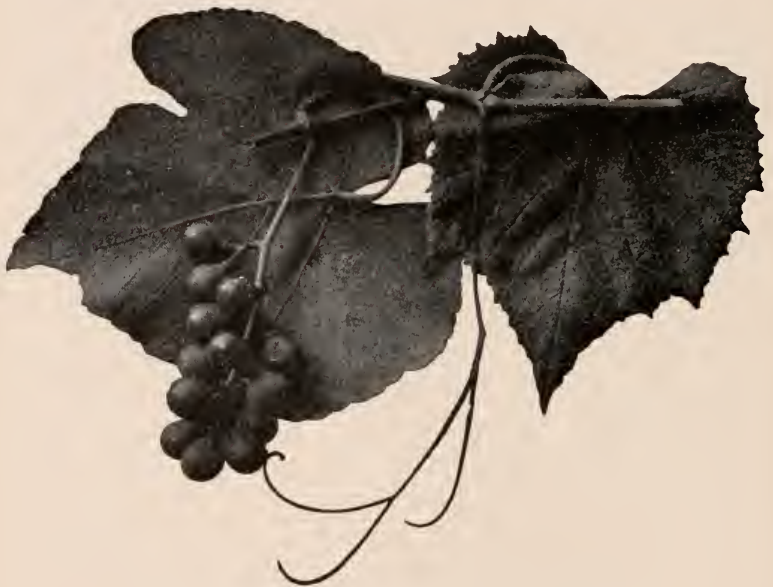

176. The fruit-cluster and tendril of grape are homologous.

239. Tendrils may be either branches or leaves. In the Virginia creeper and grape they are branches; they stand opposite the leaves in the position of fruit-clusters (Fig. 176), and sometimes one branch of a fruit-cluster is a tendril. These tendrils are therefore homologous with fruit-clusters, and fruit-clusters are branches.

240. In some plants tendrils are leaflets. Examples are the sweet pea (Fig. 177) and common garden pea. In Fig. 177, observe the leaf with its two stipules, petiole, 
two normal leaflets and two or three pairs of leaflet-tendrils and a terminal leaflet-tendril. The cobea, a common garden elimber, has a similar arrangement. In some cases tendrils are stipules, as probably in the greenbriers (smilax).

241. The petiole or midrib may act as a tendril, as in various kinds of clematis. In Fig. 178, two opposite leaves are attached at $a$. Each leaf is pinnately compound and

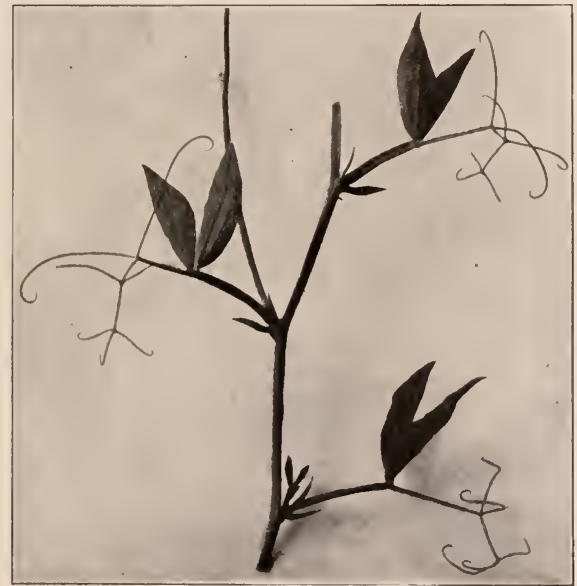

177. In the sweet pea (and garden pea) the leaflets are tendrils.

has two pairs of leaflets and a terminal leaflet. At $b$ and $c$ the midrib or rachis has wound about a support. The petiole and the petiolules may behave similarly. Examine the tall-growing nasturtiums in the garden.

242. Twiners.-The entire plant or shoot may wind about a support. Such a plant is a twiner. Examples are bean, hop, morning-glory, moon-flower, false bittersweet or wax-work (celastrus), some honeysuckles, wis- 
taria, Dutchman's pipe, dodder. The free tip of the twining branch sweeps about in curves, much as the tendril does, until it finds support or becomes old and rigid.

243. Each kind of plant usually coils in only one direction. Most plants coil against the sun, or from the observer's

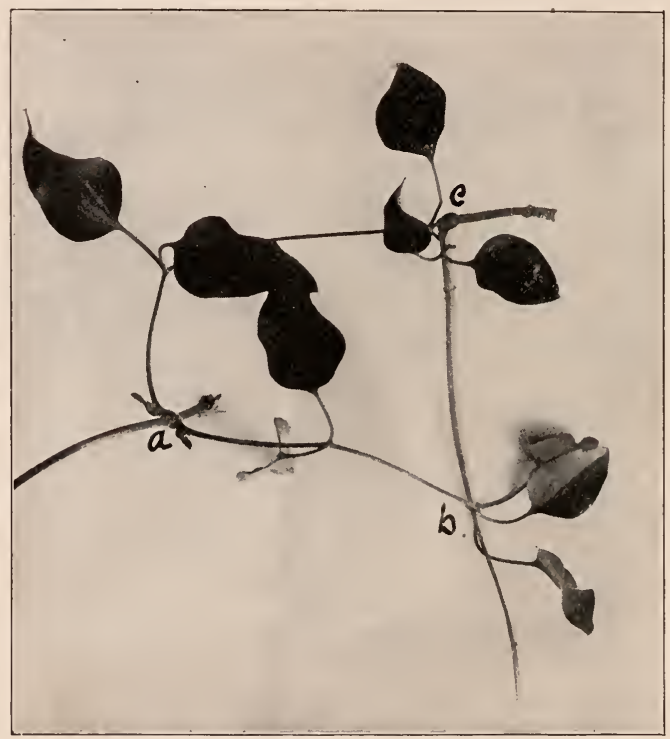

178. Clematis climbs by means of its leaf-stalks.

left across his front to his right as he faces the plant. Such plants are said to be antitropic, or to move against the sun from the position in which the observer stands. Examples are bean, morning-glory. The hop twines from the right to his left; such plants are eutropic (with the sun). Fig. 179 shows the two directions. 


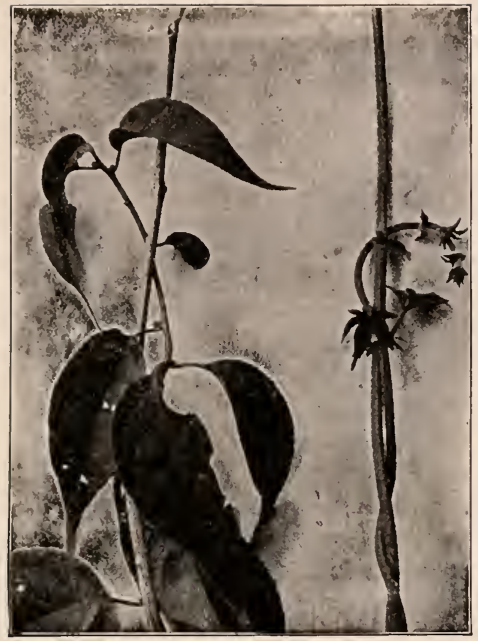

179. Antitropic and eutropic twiners.-False bitter-sweet and hop.

REview.-How do plants elimb? Explain what is meant by seramblers. By rootclimbers. What is a tendril? How does it find a support? How does it eoil? How does it grasp its support? What is the morphology of the tendril of Virginia creeper? Of the pea? Of the clematis? What is a twiner? How does it find a support? What is an antitropic twiner? Eutropic?

Note.-The pupil may not understand why the branch (as tendril and flower-cluster) stands oppo-c site the bud in the grape and Virginia creeper. Note that a grape-shoot ends in a tendril ( $a$, Fig. 180). The tendril represents the true axis of the shoot. On the side a leaf is borne, from the axil of which the branch grows to continue the shoot. This branch ends in a tendril, $b$. Another leaf has a branch in its axil, and this branch ends in the tendril $c$. The real apex of the shoot is successively turned aside until it appears to be lateral. That is, the morphologieally terminal points of the suecessive shoots are the tendrils, and the order of their appearing is $a, b, c$. The tendrils braneh: observe the minute scale representing a leaf at the base of each branch. This type of branching-the axial growth being eontinued by successive

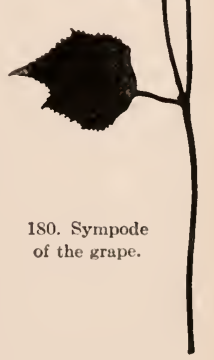
lateral buds-is sympodial, and the branch is a sympode. Continuous growth from the terminal bud is monopodial, and the branch is a monopode. 


\section{CHAPTER XIX}

\section{FLOWER-BRANCHES}

244. We have seen (87) that branches arise from the axils of leaves. Sometimes the leaves may be reduced to bracts and yet branches are borne in their axils (225). Some of the branches grow into long limbs; others become short spurs or thorns (227); others bear flowers.

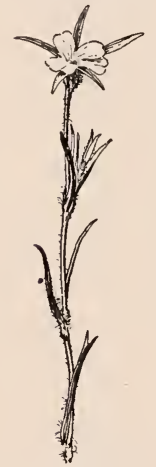

181. Solitary terminal flower of corn-cockle.

245. Flowers are usually borne near the top of the plant, since the plant must grow before it blooms. Often they are produced in great numbers. It results, therefore, that flower-branches usually stand close together, forming a cluster. The shape and arrangement of the flower-cluster differ with the kind of plant, since each plant has its own mode of branching.

246. Certain definite or well-marked types of flower-clusters have received names. Some of these names we shall discuss, but the flower-clusters that perfectly match the definitions are the exception rather than the rule. The determining of the kinds of flower-clusters is one of the most perplexing subjects in descriptive botany. We may classify the sub-

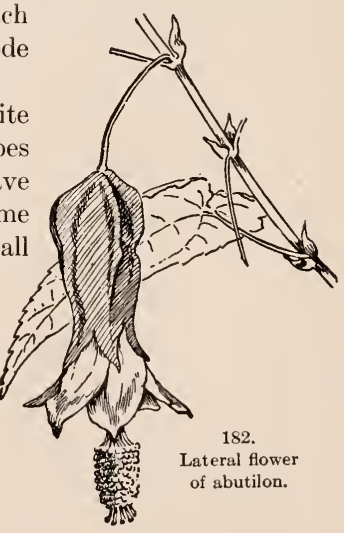


ject around three ideas: solitary flowers, corymbose clusters, cymose clusters.

\section{Solitary Flowers.-In} many cases flowers are borne singly. They are then said to be solitary. The solitary flower may be either at the end of the main shoot or axis (Fig. 181), when it is said to be terminal, or from the side of the shoot (Fig. 182), when it is said to be lateral.

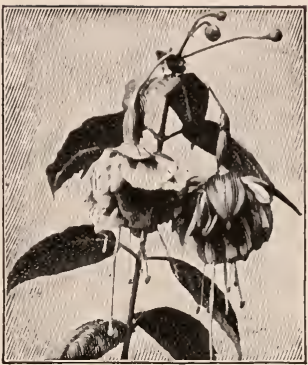

183. Leafy flower-cluster of fuchsia. The lateral flower is also said to be axillary.

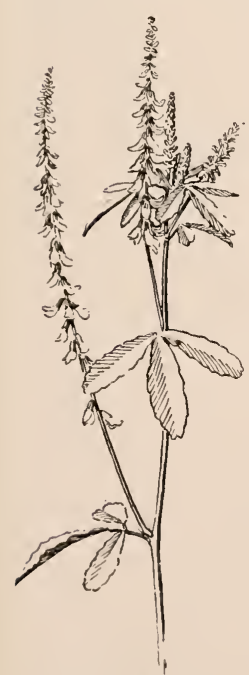

184. Racemes of sweet clover.

248. Corymbose Clusters. - If the flower-bearing axils were rather close together, an open or leafy flower-cluster might result, as in Fig. 183. The fuchsia continues to grow from the tip, and the older flowers are left farther and farther behind. If the cluster were so short as to be flat or convex on top, the outermost flowers would be the older. A flower-cluster in which the lower or outer flowers open first is said to be a corymbose eluster. It is sometimes said to be an indeterminate cluster, since it is the result of a type of growth which may go on more or less continuously from the apex.

249. The simplest form of a definite corymbose cluster is a raceme, which is an unbranched open cluster in which the flowers are borne on short stems and bloom from below (that is, from the older part of the shoot) upwards. The raceme may be terminal to the main branch, or it 
may be lateral to it, as in Fig. 184. Racemes often bear the flowers on one side of the stem, or in a single row.

250 . When a corymbose flower-cluster is long and dense and the flowers are sessile or nearly so, it is called a spike (Figs. 185, 186). Common examples of spikes are plantain, mignonette, mullein.

251. A very short

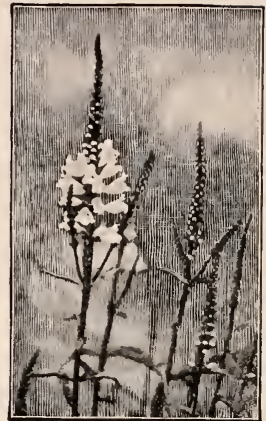

185. Loose spikes of false dragon's-head or physostegia.

and dense spike is a head. Clovers (Figs. 173, 187) are examples. The sunflower and related plants bear many small flowers in a very dense head. This special kind of head of the sunflower, thistle and aster tribes has been called an anthodium, but this word is little used. Note

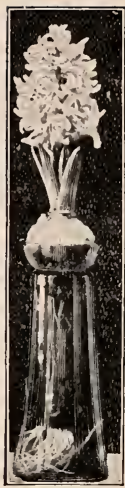

186. Spike of hya e in $t h$. Note, also, that the flowers and foliage are produced from the stored food in the bulb, only water being given.

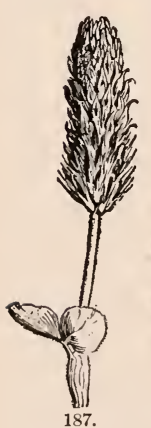

Head of crimson clover. that in the sunflower (Fig. 188) the outside or exterior flowers open first. Very often the anthodium terminates the main stem, as in Fig. 189.

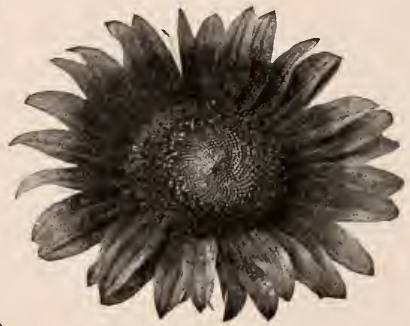

188. Head of sunflower.

252. Another special form of spike is the catkin, which usually has scaly bracts and the whole cluster is deciduous after flowering or fruiting, and the flowers (in typi- 
cal cases) have only one sex. Examples are the "pussies" of willows (Fig. 229) and flower-clusters of oaks (Fig. 228), hickories, poplars and walnut (Fig. 190).

253. When a loose, elongated corymbose flower-cluster branches, or is compound, it is called a panicle. Because of the earlier growth of the lower branches, the panicle is usually broadest at the base or conical in outline. The flowercluster of the oat is an example. (Fig. 191.) True panicles are not common.

254. When an indeterminate flower-cluster is short, so that the top is con-

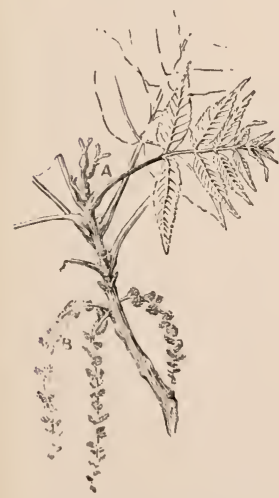

190. Catkins of black walnut, at $b$. Pistillate flowers at $a$. Paragraph 284.

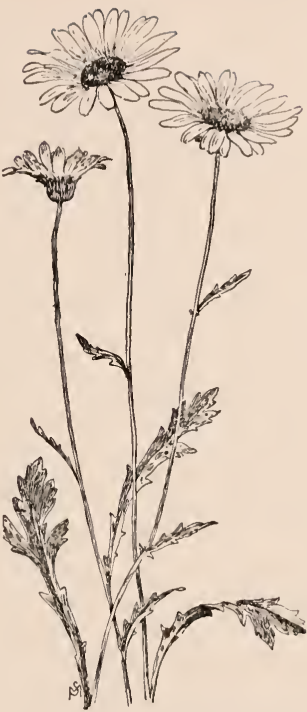

189. Terminal heads of the whiteweed (in some plaees erroneously called ox-eye daisy).

(Fig. 192.)

The outer-

most flowers open first. Fig. 193 shows many corymbs of the bridal wreath, one of the spireas.

255. When the branches of an indeterminate cluster arise from a common point, like the frame of an umbrella, the cluster is an umbel. (Fig. 194.) Typical umbels occur in carrot, parsinip, parsley and other plants of the parsley family: the family is known as the Umbellifera or umbel-bearing family. In $\mathrm{tl}$, 


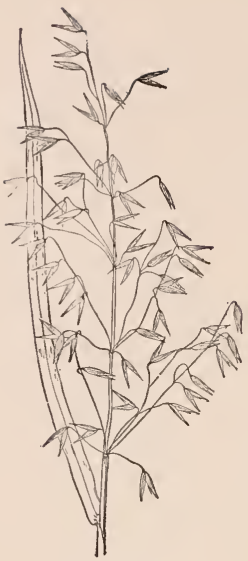

191. Panicle of oat.

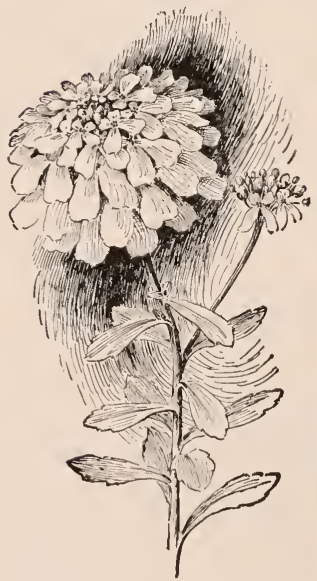

192. Corymb of candytuft. carrot and many other Umbelliferæ, there are small or secondary umbels, called umbellets, at the end of each of the main branches. (In the center of the wild carrot umbel one often finds a single, purplish, often aborted flower, comprising a 1-flowered umbellet).

256. Cymose Clusters.-When the terminal or central flower opens first, the cluster is said to be cymose. The growth of the shoot or cluster is determinate, since the length is definitely determined or stopped by the terminal flower. Fig. 195 shows a determinate or cymose mode of flower-bearing.

257. Dense cymose clusters are usually flattish on top because of the cessation of growth in the main or central axis, but cymes are

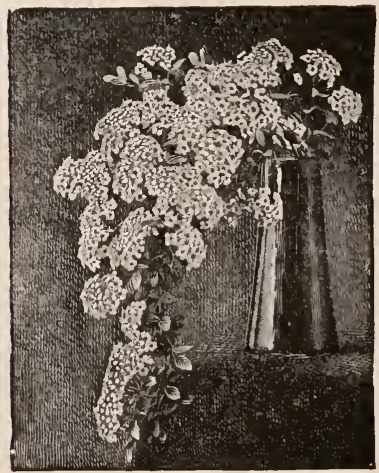

193. Corymbs of the bridal wreath (spirea). 
sometimes open and loose. These flower-clusters are known as cymes. Apples, pears (Fig. 196) and cherries bear flowers in cymes. Some cyme-forms are like umbels in general appearance. A head-like cymose cluster is a glomerule: it blooms

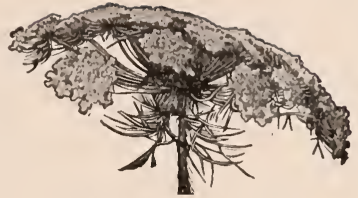

194. Compound umbel of wild earrot.

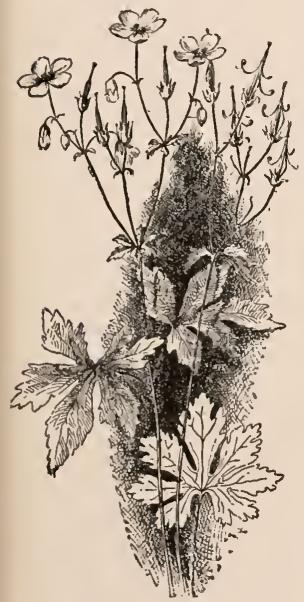

195. Determinate or cymose arrangement.-Wild geranium.

from the top downwards rather than from the base upwards.

\section{Centripetal and Centrifugal.-}

A cluster in which the outermost (or lowermost) flowers open first is corymbose or indeterminate, as we have learned; it is also said to be centripetal (meaning "toward the center"). A cluster in which the innermost or central flowers open first is cymose or determinate; it is also said to be centrifugal (meaning "away from the center"). These contrasts can best be understood by study of diagrams, since actual clusters so often vary from the assumed standard. Such diagrams are presented in Figs. 197, 198, 199.

259. Mixed Clusters.-Often the

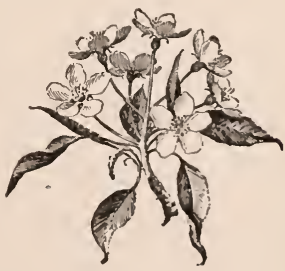

196. Cyme of pear. cluster is mixed, being determinate in one part and indeterminate in another part of the same cluster. This is the case in horse-chestnuts. The main cluster is indeterminate, but the branches are determinate. The cluster has the appear- 

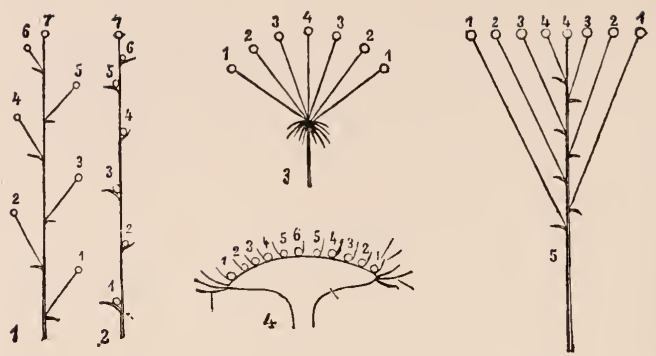

197. Forms of centripetal flower-clusters.

1 raceme; 2 , spike; 3 , umbel; 4 , head or anthodium; 5 , corymb.
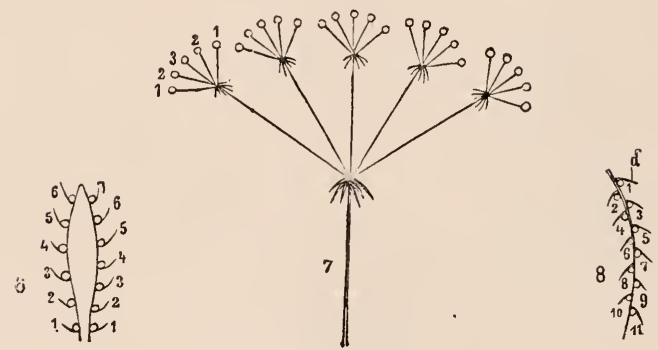

198. Centripetal inflorescence.

6 , spadix; 7 , compound umbel; 8 , catkin.
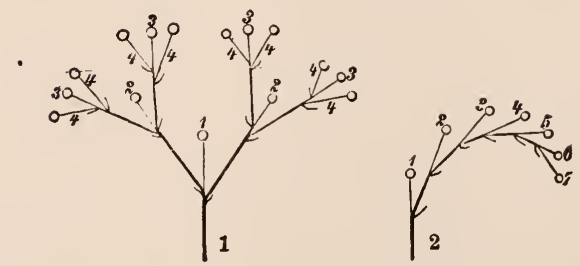

199. Centrifugal inflorescence

1, cyme; 2 , scirpioid eluster (or half cyme 
ance of a paniele, and is usually so called, but it is really a thyrse. Lilac is a familiar example of a thyrse. In some eases, the main cluster is determinate and the branches are indeterminate, as in hydrangea and elder. Such clusters also are mixed clusters.

260. Inflorescence.-The mode or method of flower arrangement is known as the inflorescence. That is, the inflorescence is cymose, corymbose, paniculate, spicate, solitary. By custom, however, the word inflorescence has come to be used for the flower-cluster itself in works on descriptive botany. Thus a eyme or a panicle may be called an inflorescence. It will be seen that even solitary flowers follow either indeterminate or determinate methods of branching.

261. The Flower-stem.-The stem of a solitary flower is known as a peduncle; also the general stem of a flower-cluster. The stem of the individual flower in a eluster is a pedicel.

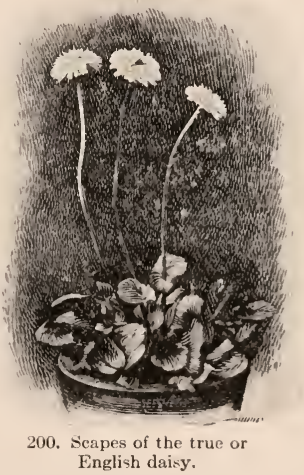

262. In the so-called stemless plants (37) the peduncle may arise directly from the ground, or crown of the plant, as in dandelion, hyacinth (Fig. 186), garden daisy (Fig. 200). This kind of a peduncle is ealled a scape. A scape may bear one or many flowers. It has no foliage leaves, but it may have bracts. In some cases, of course, the flowers are sessile, and in others very nearly sessile (207). In Fig. 201, the little fruits (following the flowers) are in close elusters in the axils of the leaves.

Review.-What is the homology of flower-branches? How is it that flowers are often borne in clusters? Explain what may be meant 
by a solitary flower. What are the two types of flower-clusters? What are corymbose clusters? Define raceme. Spike. Head and anthodium. Catkin. Panicle. Umbel. Umbellet. Corymb. What are cymose clusters? What is a cyme? Glomerule? Contrast indeterminate and determinate modes of branching. Centripetal and centrifugal. Explain mixed clusters. What is a thyrse? Define peduncle, pedicel and scape.

Note.-In the study of flower-clusters, it is well to choose first those that are fairly typical of the various classes discussed in the preceding paragraphs. As soon as the main types are well fixed in the mind, random clusters should be examined, for the pupil must never receive the impression that all flower-clusters follow the definitions in books. Clusters of some of the commonest plants are very puzzling, out the pupil should at least be able to discover whether the inflorescence is determinate or indeterminate.

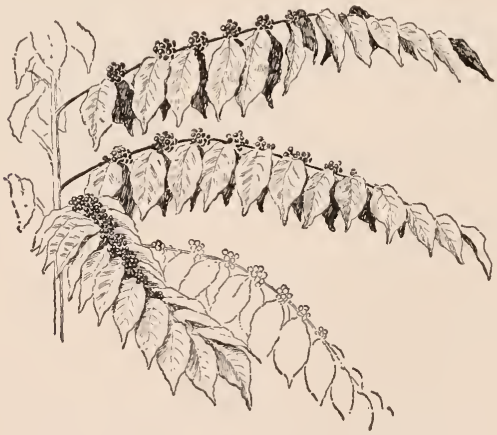

201. The practically sessile axillary clusters of coffee. 


\section{CHAPTER XX \\ THE PARTS OF THE FLOWER}

263. The flower exists for the purpose of producing seed. It is probable that all its varied forms and colors contribute to this supreme end. These forms and colors please the human fancy and make living the happier, but the flower exists for the good of the plant, not for the good of man.

264. The parts of the flower are of two general kindsthose that act as covering and protecting organs, and those that are direetly concerned in the production of seeds. The former parts are known as the floral envelopes; the latter as the essential organs.

265. Envelopes.-The floral envelopes usually bear a close resemblance to leaves. These envelopes are very commonly of two series or kinds - the outer and the inner. The outer series, known as the calyx, is usually smaller and green. It commonly comprises the outer eover of the flower-bud. The ealyx is the lowest

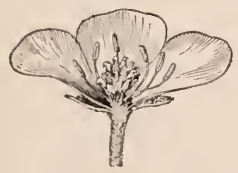

202. Flower of a buttercup in section. whorl in Fig. 202.

The inner series, known as the corolla, is usually colored and more special or irregular in shape than the

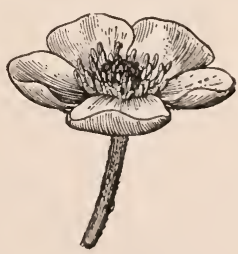

203. Flower of buttercup.

calyx. It is the showy part of the flower, as a rule. The corolla is the second or large whorl in Fig. 202. It is the large part in Fig. 203.

266. The ealyx may be composed of several leaves. Each 
leaf is a sepal. If it is of one piece, it may be lobed or divided, in which case the divisions are called calyx-lobes. In

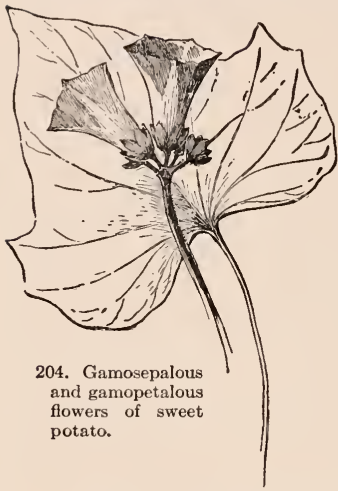

like manner, the corolla may be composed of petals, or it may be of one piece and variously lobed.

267. A calyx of one piece (as in Fig. 204), no matter how deeply lobed, is gamosepalous. A corolla of one piece is gamopetalous. When these series are of separate pieces (as in Fig. 202), the flower is said to be polysepalous and polypetalous. Sometimes both series are of separate parts, and sometimes only one of them is so formed. The floral envelopes are homologous with leaves.

268. Sepals and petals, at least when more than three or five, are each in more than one whorl, and one whorl stands below another so that the parts overlap. They are borne on the expanded or thickened end of the flower-stalk: this end is the torus. In Fig. 202 all the parts are seen as attached to the torus. This part is sometimes called a receptacle, but this word is a common-language term of several meanings, whereas torus is a technical word exclusively. Sometimes one part is attached to another part, as in the fuchsia (Fig. 205) in which the petals are borne on the calyx-tube.

269. Essential Organs. - The essential organs are borne within the floral envelopes (when envelopes

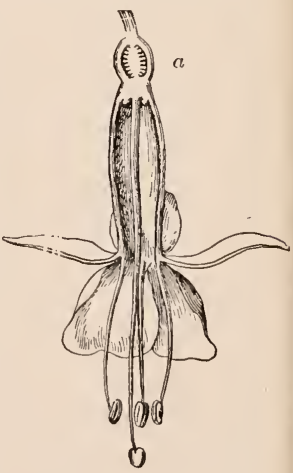

205. Flower of fuchsia in section. 
are present). They are of two series. The outer series is composed of the stamens. The inner series is composed of

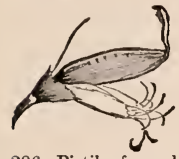

206. Pistil of garden pea, the stamens being pulled down in order to diselose it; also a section, showing the single compartment. the pistils. Stamens and pistils are homologous with leaves.
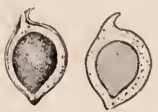

207. Simple pistils of buttercup, one in longitudinal section.

270. Stamens bear the pollen, which is made up of a large number of minute grains. The stamen is of two parts, as readily seen in Figs. 202, 203, 205, - the enlarged terminal part or anther, and the stalk or filament. The filament is often so short as to seem to be absent, and the anther is then said to be sessile. The anther bears the pollen grains. It is made up of two or four parts (known as sporangia or spore-cases), which burst and discharge the pollen. When the pollen is shed, the stamen dies.

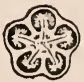

208. Compound pistil of a St. John's-wort. It has 5 carpels.

271. Pistils bear the ovules, which become seeds. The pistil may be of one part or eompartment, or of many parts. The different units or parts of which it is composed are carpels. Each carpel is homologous with a leaf. Each carpel bears one or more seeds. A pistil of one carpel is simple; of two or more carpels, compound. Usually the structure of the pistil may be determined by cutting across the lower or

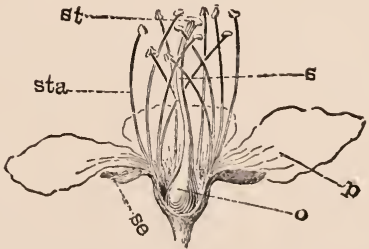

209. The structure of a plum blossom. se. sepals; $p$. petals; sta, stamens; $o$. ovary; s. style; st. stigma. The pistil consists of the ovary, style, and stigma. It contains the seed part. The stamens are tipped with anthers, in which the pollen is borne. The ovary, $o$, ripens into the fruit. seed-bearing part. Figs. 206, 207, 208 explain. A flower may contain one carpel (simple pistil) as the pea (Fig. 206); 


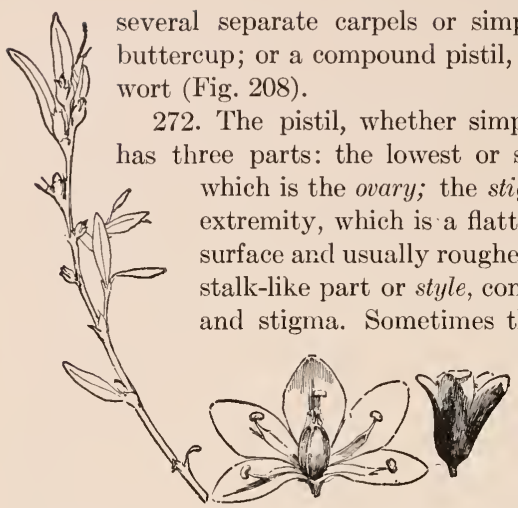

210. Knotweed, a very common but inconspicuous plant along hard walks and roads. Two flowers, enlarged, are shown at the right. These flowers are very small and borne in the axils of the leaves. ently wanting, and the stigma is said to be sessile on the ovary. These parts are shown in the fuchsia, Fig. 205. The ovary or seed vessel is at $a$. A long style, bearing a large stigma, projects from the flower. See, also, Figs. 207 and 209.

\section{Conformation of the Flower.-} A flower that has calyx, corolla, stamens and pistils is said to be complete; all others are incomplete. In some flowers both the floral envelopes are wanting: such are naked. When one of the floral envelope series is wanting, the remaining series is said to be calyx, and the flower is therefore apetalous (without petals). The knotweed (Fig. 210), smartweed, buckwheat, elm (Fig. 96), are examples.

274. Some flowers lack the pistils but have stamens: these are staminate, whether the envelopes are missing or

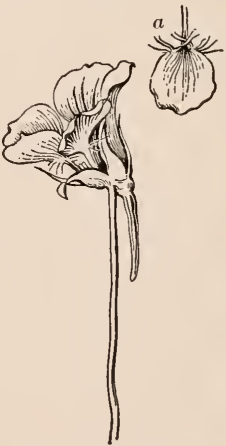

211. Flower of garden nasturtium. Separate petal at $a$. The calyx is prolonged into a spur. 
not. Others lack the stamens but have pistils: these are pistillate. Others have neither stamens nor pistils: these are
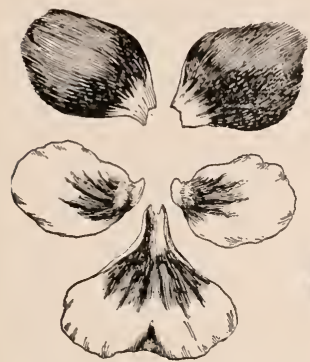

212. The five petals of the pansy, detached to show the form. sterile (snowball and hydrangea). Those that have both stamens and pistils are perfect, whether or not the envelopes are missing. Those that lack either stamens or pistils

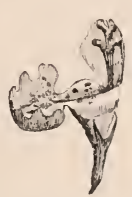

213. Flower of catnip.

are imperfect or diclinous. Staminate and pistillate flowers are imperfect or diclinous.

275. Flowers in which the parts of each series are alike are (as in Figs. 202, 203, 204, 205). Those in which some parts are unlike other parts of the same series are irregular. The irregularity may be in the calyx, as in nasturtium (Fig. 211); in the corolla (Figs. 212,213 ); in the stamens (compare nasturtium, catnip (Fig. 213) sage, or in the pistils. Irregularity is most frequent in the corolla.

Review.-What is the flower for? What are the two general kinds of organs in the flower? What is the homology of the flower-parts? What are floral envelopes? Calyx? Sepals? Calyx-lobes? Corolla? Petals? Corollalobes? Gamosepalous flowers? Gamopetalous? Polysepalous? Polypetalous? Define torus. What are the essential organs? Stamen? Filament? Anther? Pollen? Pistil? Style? Stigma? Ovary? Carpel? Define a complete flower. In what ways may flowers be incomplete? Explain perfeet and imperfect (or diclinous) flowers. Define regular flowers. In what ways may flowers be irregular? said to be regular
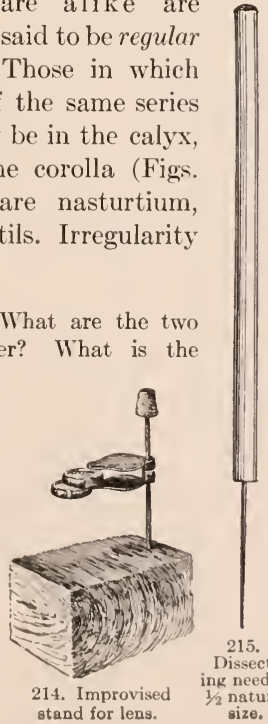

215.

Dissecting needle. $1 / 2$ natural size. 
Note.-One needs a lens for the examination of the flower. It is best to have the lens mounted on a frame, so that the pupil has both hands free for pulling the flower in pieces. An ordinary
pocket lens may be mounted on a wire in a block, as in
Fig. 214. A cork is slipped on the top of the wire to avoid
injury to the face. The pupil should be provided with two
dissecting needles (Fig. 215), made by securing an ordinary
needle in a pencil-like stick. Another convenient arrange-
ment is shown in Fig. 216. A small tin dish is used for the
base. Into this a stiff wire standard is
soldered. The dish is filled with solder,
to make it heavy and firm. Into a cork
slipped on the standard, a crosswire is
inserted, holding on the end a jeweler's
glass. The lens can be moved up and
down and sidewise. This outfit can be

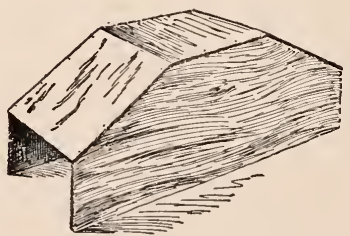

217. Dissecting stand. 


\section{CHAPTER XXI \\ FERTILIZATION AND POLLINATION}

276. Fertilization.-Seeds result from the union of two elements or parts. One of these elements, a nucleus of a plant-cell, is borne in the germinating pollen-grain. The other element, an egg-cell, is borne in the ovary. The pollengrain falls on the stigma. (Fig. 218.) It absorbs water or the juices exuded by the stigma and grows by sending out a tube. (Fig. 219.) This tube grows downward through the style, absorbing food as it goes, and finally reaches the eggcell in the interior of an ovule in the ovary, and fertilization by the union of the two nuclei takes place. The ovule then develops into a seed. The growth of the pollentube is often spoken of as germination of the pollen, but it is not germination in the sense in which the word is used when speaking of seeds.

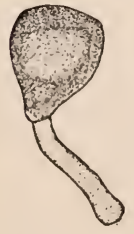

219.

Pollen - grain germinating. Magnified.
277. In order that the pollen may grow, the stigma must be ripe. At this stage, the stigma is usually moist and sometimes sticky. The pollen is held by the mucilaginous secretion on the stigma. The stigma may be barbed or feathery and hold the pollen by this means. Observe the stigma of some of the lilies. In corn the "silk" constitutes the style, and the stigma is feathery. A ripe stigma is said to be 
receptive. The stigma may remain receptive for several hours or even days, depending on the kind of plant, the weather, and how soon pollen is received. When fertilization takes place, the stigma dies. Note the dried

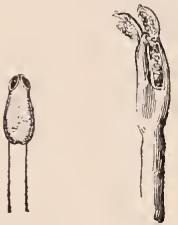

$$
220 .
$$

Anther of

a zalea,

opening

by termi-

nal pores.

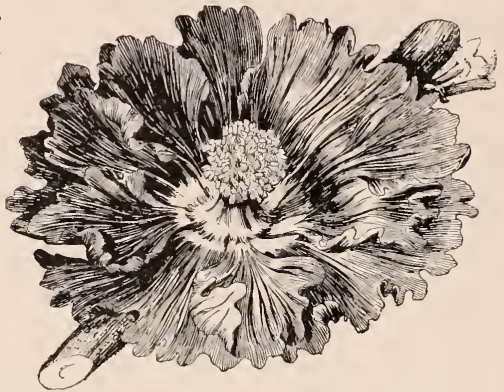

222. Flower of hollyhock; proterandrous. See Fig. 223.

end of the "silk" of corn. Observe, also, how soon the petals wither after the stigma has received pollen.

278. Pollination.-The transfer of the pollen from anther to stigma is known as pollination. The pollen may fall of its own weight on the adjacent stigma, or it may be carried from flower to flower by wind, insects or other agents. There may be self-pollination, close-pollination or cross-pollination.

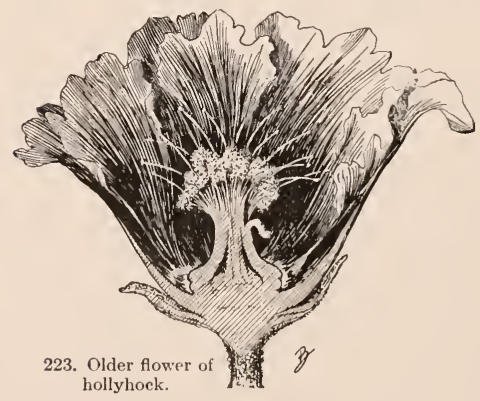

In self-pollination, the pollen that falls on the pistil is derived from the same flower. In closepollination, the pollen may be derived from different flowers on the same plant. In cross-pollination, the pollen is derived from flowers on differ- 
ent plants. Fertilization resulting from self- or close-pollination is close-fertilization. Fertilization resulting from crosspollination is cross-fertilization. In many cases cross-pollination is essential for good seed or fruit development. Corn, if close-pollinated, produces imperfect ears. Cultivated plants frequently exhibit decreased vigor by closepollination.

279. Usually the pollen is discharged by the

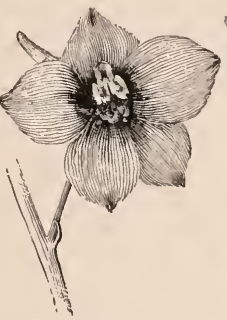

224. Flower of larkspur.
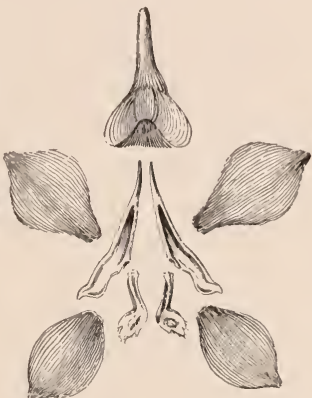

225. Envelopes of a larkspur. There are five wide sepals, the upper one being spurred. There are four small petals.

bursting of the anthers. The commonest method of discharge is through a slit on either side of the anther. (Fig. 218.) Sometimes it discharges through a pore at the apex, as in azalea (Fig. 220), rhododendron, huckleberry, wintergreen. In
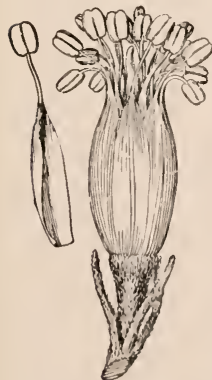

226. Stamens of larkspur, surrounding the pistils. some plants a part of the anther wall raises or falls as a licl, as in barberry (Fig. 221), blue cohosh, May apple. The opening of an anther (as also of a seed-pod) is known as dehiscence. When an anther or seed-pod opens it is said to dehisce.

280. Most flowers are so constructed as to increase the chances of cross-pollination. The commonest means of insuring crosspollination is the different times of maturing of stamens and pistils in the same fower. In most cases the stamens mature first: the flower is then proterandrous. When the pistils mature first the flower is 
proterogynous. (Aner, andr, is a Greek root often used, in combinations, for stamen, and gyne for pistil.) The difference in time of ripening may be an hour or two, or it may be a day. The ripening of the stamens and pistils at different times is known as dichogamy, and flowers of such

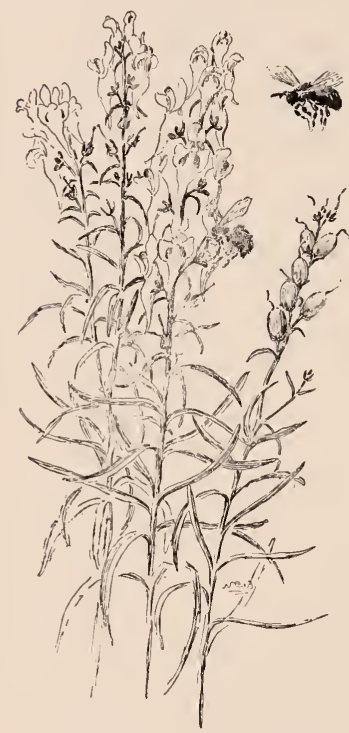

227. Toad-flax is an insect-pollinated flower. character are said to be dichogamous. There is little chance for dichogamous flowers to pollinate themselves. The hollyhock is proterandrous. Fig. 222 shows a flower recently expanded. The center is occupied by the column of stamens. In Fig. 223, showing an older flower, the long styles are conspicuous. Many flowers are imperfectly ${ }^{*}$ dichogamous-some of the anthers mature simultaneously with the pistils, so that there is chance for self-pollination in case foreign pollen does not arrive. Even when the stigma receives pollen from its own flower, cross-fertilization may result.

281. Some flowers have so developed as to prohibit selfpollination. Very irregular flowers are usually of this category. Regular flowers usually depend on dichogamy and on the impotency of pollen on the pistil of the same flower. Flowers that are very irregular and provided with strong perfume are usually pollinated by insects. Gaudy colors probably attract insects in many cases, but odor appears to be a greater attraction. The insect visits the flower for the 
nectar (for the making of honey) and may unknowingly carry the pollen. Spurs and sacs are commonly nectaries, but in spurless flowers the nectar is usually secreted in the bottom of the flower-cup. Fig. 224 shows a larkspur, and the envelopes are separated in Fig. 225. The long spur at once suggests insect pollination. The spur is sepal. Two hollow petals project into this spur, apparently serving to guide the bee's tongue, but probably of no sig-

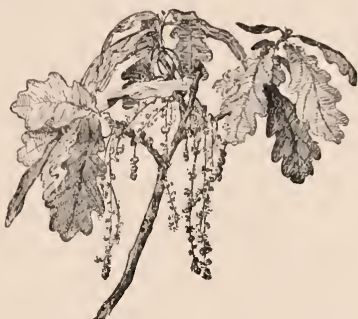

228. Staminate catkins of oak. The pistillate flowers are in the leaf axils, and not shown in this picture.

nificance. The two smaller petals, in front, are differently colored and seem to serve the bee in locating the nectary. The stamens ensheath the pistils. (Fig. 226.) As the insect stands on the flower and thrusts his head into its center, the envelopes are pushed downward and outward and the pistil

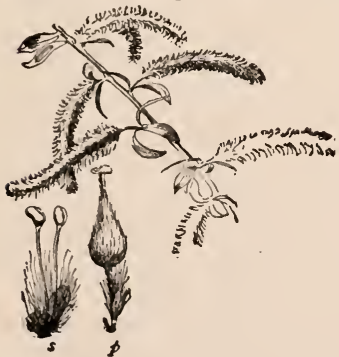

229. Catkins of a willow. A staminate flower is shown at $s$. and a pistillate flower at $p$. The staminate and pistillate are on different plants. and stamens come in contact with his abdomen. Since the flower is proterandrous, the pollen which the pistils receive from the bee's abdomen must come from another flower. Note a somewhat similar arrangement in the toad-flax or butterand-eggs. (Fig. 227.) Clover and alfalfa are pollinated by insects.

282. The bee is perhaps the most efficient of all insects in distributing pollen, for in addition to carrying away pollen accidentally in its seareh for nectar, it also deliberately gathers pollen from the flowers. 


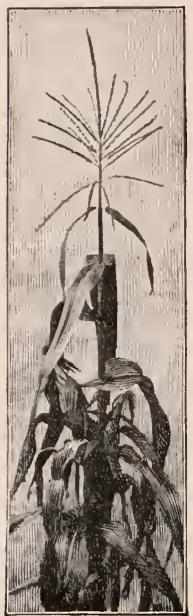

230. Indian corn, a monœeious plant, wit h staminate flowers borne in the tassel and pistillate flowers borne in the ear.

In certain seasons, moreover, it confines itself to a single species of plants. Bees are very useful to the fruit-grower, wholly aside from the honey that they make for him.

283. Many flowers are pollinated by the wind. Such flowers produce great quantities of pollen, for much of it is wasted. They usually have broad stigmas, which expose large surfaces to the wind. They are usually lacking in gaudy colors and in perfume. Grasses and pine trees are typical examples of wind-pollinated plants.

284. In many cases cross-pollination is insured by the stamens and pistils being in different flowers (diclinous, 274). When the staminate and pistillate flowers are on the same plant, e.g., oak (Fig. 228), beech, chestnut, hazel, walnut (Fig. 190), hickory, the plant is monacious ("in one house"). When they are on different plants (poplar and willow, Fig. 229), the plant is dicecious ("in two houses"). Monœcious and diœcious plants may be pollinated by wind or insects, or other agents. They are commonly windpollinated, although willows are often, if not mostly, insect-pollinated. Some plants, as rye, insure cross-pollination

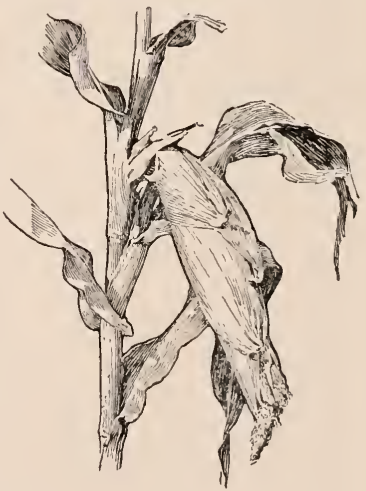

231. Ear of maize, product of the pistillate flowers fertilized by pollen borne in the tassel, the whole enclosed in a husk or sheath. 
because the pollen of one flower is impotent on the pistil of that flower. Buckwheat is another such plant.

285. The corn plants are monoecious, and therefore selfpollination is impossible. The staminate flowers of the Indian corn are in a terminal panicle or tassel. (Fig. 230.) The pistillate flowers are in a clense spike (ear), inclosed in a sheath or husk. (Fig. 231.) Each

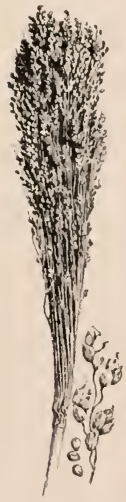

233. Head or brush of broom - eorn at seeding time. Broomeorn is a sorghum. Brooms are made from the stiff peduncles or rays. "silk" is a style. Each pistillate flower may produce a kernel of corn. Sometimes a few

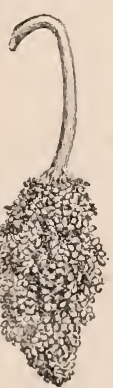

234. Head of one of the $\mathrm{kafirs}$ (or milo) in seed. Kiafirs are forms of sorghums. They are $\mathrm{much}$ grown in dry regions. pistil-

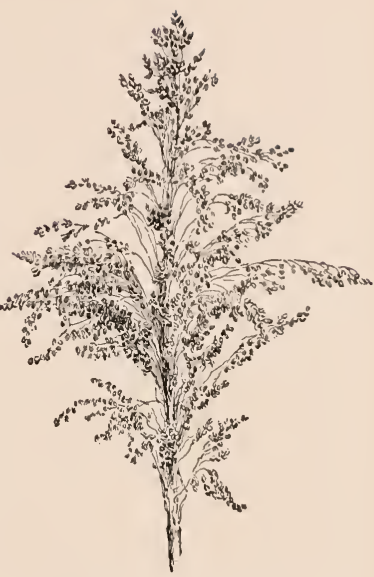

232. Paniele or tassel of a sorghum in blooming time.

late flowers are borne in the tassel and a few staminate flowers on the tip of the ear. In sorghums, broomcorn and kafirs (Figs. 232, 233, 234), the two kinds of flowers are in the same cluster or tassel.

286. Although most flowers are of such character as to insure or increase the chances of cross-pollination, there are some in which crossing is absolutely forbidden. These flowers are usually borne beneath or on the ground, and they lack showy colors and perfumes. They are known as cleistogamous flowers (meaning "hidden flowers"). The plant has normal 
showy flowers that may be insect-pollinated, and in addition is provided with these specialized flowers. Only a few plants bear cleistogamous flowers. Hog-peanut, common blue violet, fringed wintergreen, and dalibarda are the best subjects in the northern states. Fig. 235 shows a cleistogamous flower of the hog-peanut at $a$. Above the true roots, slender

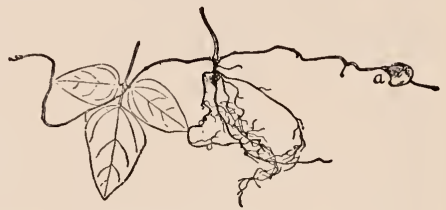

235. Hog-peanut, showing a leaf, and a cleistogamous flower at $a$.

rhizomes bear these flowers, which are provided with a calyx and a curving corolla that does not open. Inside are

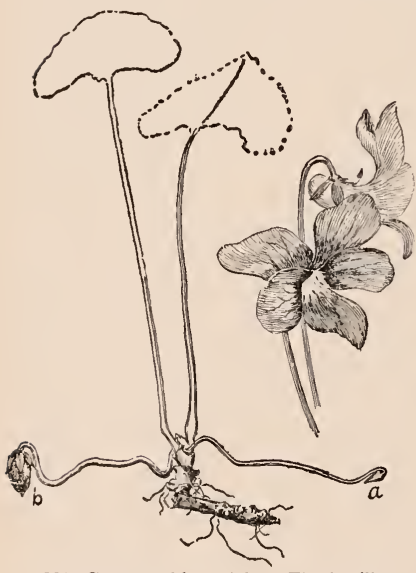

236. Common blue violet. The familiar flowers are shown, natural size. The corolla is spurred. Later in the season, cleistogamous flowers are often borne on the surface of the ground. A small one is shown at $a$. A nearly mature pod is shown at $b$. Both $a$ and $b$ are one-third natural size. the stamens and pistils. The pupil must not confound the nodules on the roots of the hog-peanut with the cleistogamous flowers: these nodules are concerned in the appropriation of food. Late in summer the cleistogamous flowers may be found just underneath the mold. They never rise above the ground. The following summer one may find a seedling plant with the remains of the old cleistogamous flower still adhering to the root. The hog-peanut is a common low twiner in woods. It also bears racemes of small pealike flowers. Cleistogamous flowers usually appear after the showy flowers have 
passed. They seem to insure a crop of seed by a method that expends little of the plant's energy. (Fig. 236.)

287. There is a special and peculiar structure in the peanut or goober. The flowers are of two kinds.

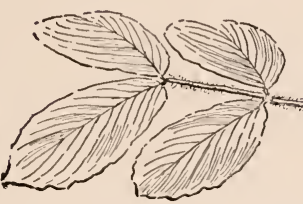

237. Peanut. Staminate showy flower above; young pod from pistillate flower below.

One is showy and staminate (shown uppermost in Fig. 237); and one is small and pistillate, and after fertilization is thrust downward into the earth by the elongation of the torus and flowerstem, and the pods ripen underground. (Fig. 238.)

288. Flowers may be cross-pollinated by hand.

One may carry the pollen of a given flower to the pistils of another flower, for the purpose of securing seeds that may combine some of the characteristics of the two parerits.

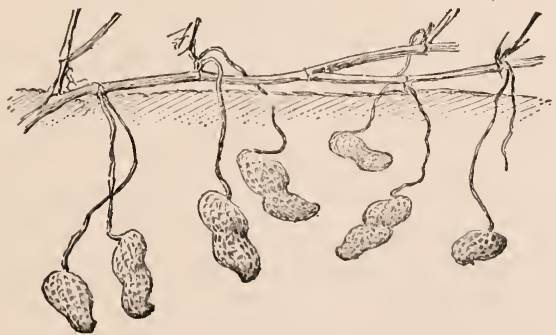

238. Peanut pods ripening underground.

In this case, the stamens are early removed from the flower to be pollinated so that all possibility of self-fertilization is averted; and after the other pollen is applied, the flower is 
protected by being securely covered with a paper bag. (Fig. 239.) In monœcious plants, if the staminate flowers are removed or covered close-fertilization is prevented.

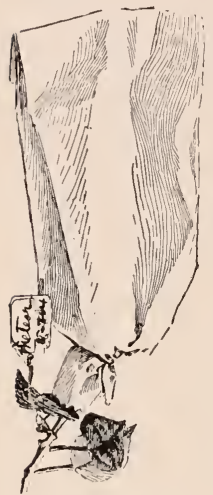

239. A bag covering a pollinated flower.

Review.-What is fertilization? Pollination? Pollen germination? What is a receptive stigma? How is pollen discharged? How is cross-pollination secured? Are plants benefited by cross-pollination? What is meant by impotent pollen? What do you understand by dichogamy? Its office? Is it frequent? What is the character of insectpollinated flowers? Why is the bee an effective insect in distributing pollen? What is the significance of irregularity in flowers? Where is the nectar borne? What are monœecious and diœcious flowers? Cleistogamous flowers? Why may flowers be hand-pollinated?

Note.-The means by which cross-pollination is insured are absorbing subjects of study. It is easy to give so much time and emphasis to the subject, however, that an inexperienced observer comes to feel that perfect mechanical adaptation of means to end is universal in plants, whereas it is not. One is likely to lose or to overlook the sense of proportions and to form wrong judgments.

In studying cross-pollination, one is likely to look first for devices that prohibit the stigma from receiving pollen from its own flower, but the better endeavor is to determine whether there is any means to insure the application of foreign pollen; for the stigma may receive both but utilize only the foreign pollen. Bear in mind that irregular and odd forms in flowers, strong perfume, bright colors, nectar, suggest insect visitors; that inconspicuous flowers with large, protruding stigmas and much dry powdery pollen suggest wind-transfer; that regular and simple flowers depend largely on dichogamy, whether wind- or insectpollinated. Most flowers are dichogamous. 


\section{CHAPTER XXII \\ PARTICULAR FORMS OF FLOWERS}

289. General Forms.-Flowers vary wonderfully in size, form, color, and in shapes of the different parts. These variations are characteristic of the species or kind of plant. The most variable part is the corolla. In many cases, the disguises of the parts are so great as to puzzle botanists. Some of the special forms, notably in the orchids, seem to have arisen as a means of adapting the flower to pollination by particular kinds of insects. A few well-marked forms are discussed below in order to illustrate how they may differ among themselves.

290. When in doubt as to the parts of any flower, look first for the pistils and stamens. Pistils may be distinguished by the ovary or young seedcase. Stamens may be distinguished by the pollen. If there is but one

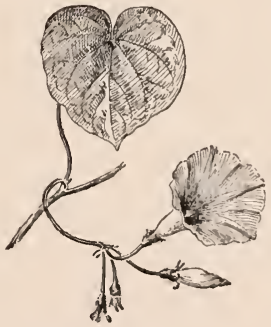

240. Funnel form flower of morning-glory. snries in the floral envelope, the flower is assumed to lack the

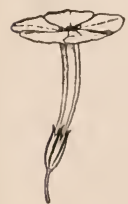

241.

Salver form flower of phlox. corolla: it is apetalous (273). The calyx, however, in such cases, may look like a corolla, e.g., buckwheat, elm, sassafras, smartweed, knotweed. (Fig. 210.)

291. The parts of a flower usually have a numerical relation to each other,-they are oftenest in 3's or 5's or in multiples of these numbers. The pistil is often an exception to this order, however, although its compartments or 


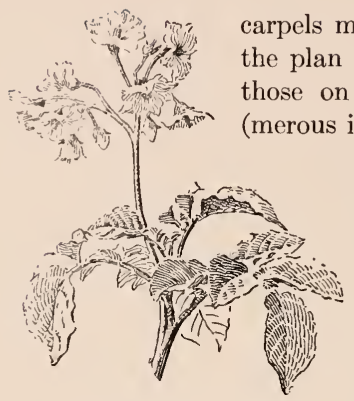

242. Rotate flowers of potato.

ber"). In descriptive botanies these words are often written 5-merous and 3-merous.

292. The corolla often assumes very definite or distinct forms when gamopetalous. It may have a long tube with a wide-flaring limb, when it is said to be funnelform, as in morning-glory (Fig. 240) and pumpkin. If the tube is very narrow and the limb stands at right angles to it, the corolla is salverform, as in phlox. (Fig. 241.) If the tube is very short and the limb wide-spreading and nearly circular in outline, the corolla is rotate or wheel-shaped, as in potato. (Fig. 242.)

293. A gamopetalous corolla or gamosepalous calyx is often cleft in such way as to make two prominent parts. Such parts are said to be lipped or labiate. Each of the lips or lobes may be notched or toothed. In 5merous flowers, the lower lip is usually 3-lobed and the upper one 2-lobed. Labiate flowers are characteristic of the mint family (Fig. 213), and the family therefore is called the Labiatæ. (Properly, labiate means merely lipped, without specifying the number of lips or lobes; but it is commonly used to designate 2-lipped flowers.) Strongly 2-parted polypetalous flowers may be said to be labiate; but the term is oftenest used for gamopetalous corollas.

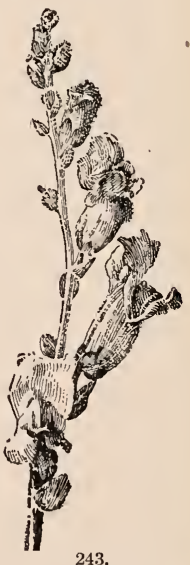

Personate flowers of snapdragon. 


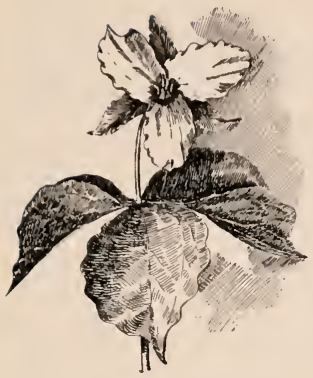

244. Flower of trillium.

294. Labiate gamopetalous flowers which are closed in the throat (or entrance to the tube) are said to be grinning or personate (personate means masked, or person-like). Snapdragon is a typical example (Fig. 243); also toad-flax or butter and eggs (Fig. 227), and many related plants. Personate flowers usually have definite relations to insect pollination. Observe how a bee forces his head into the closed throat of the toad-flax.

295. Lily Flowers.-In plants of the lily family (Liliaceæ) the flowers are typically 3-merous, having three sepals, three petals, six stamens and a 3-carpelled pistil. The parts in the different series are distinct from each other (excepting the carpels), and mostly free from other series. The sepals and petals are so much alike that they are distinguished chiefly by position, and for this reason the words calyx and corolla are not used, but the floral envelope is called the perianth and the parts are segments. Flowers of lilies and trilliums (Fig. 244) answer these details. Not all flowers in the lily family

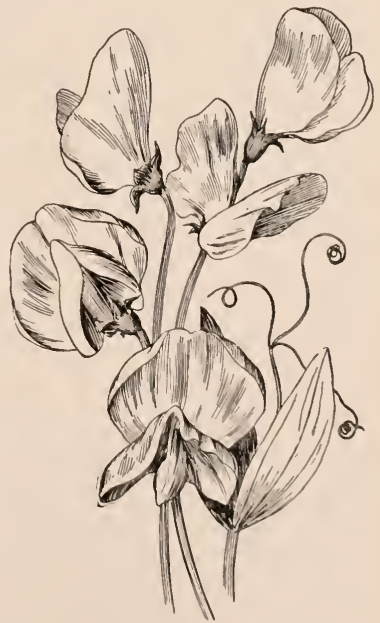

245. Papilionaceous flowers,Sweet pea. 
answer in all ways to this description. The term perianth is used in other plants than the Liliaceæ.

296. Papilionaceous Flowers.-In the pea and bean

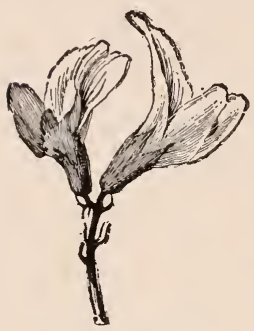

246. Flowers of alfalfa, enlarged. tribes the flower has a special form (Figs. 245, 246). The calyx is a shallow 5-toothed tube. The corolla is composed of four pieces,- - the large expanded part at the back,

1.2. known as the standard or banner; the two hooded side pieces, known as the wings; the single boat-shaped part 247.

Cassia flower, beneath the wings, known as

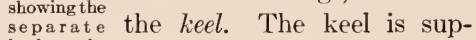
keel petals.

posed to represent two united petals, since the calyx and stamens are in 5's or multiples of 5 ; moreover, it is of two distinct parts in cassia (Fig. 247) and some other plants of the pea family. Flowers of the pea shape are papilionaceous (Latin papilio, a butterfly).

297. Flowers of the pea and its kind have a peculiar arrangement of stamens. The stamens are 10 , of which 9 are united into a tube which incloses the pistil. The tenth stamen lies on the upper edge of the pistil. The remains of these stamens are seen in Fig. 206. The stamens are said to be diadelphous ("in two brotherhoods") when united into two groups as in this case. Stamens in one group would be called monadelphous, and this arrangement occurs in some members of the Leguminosæ or pea family.

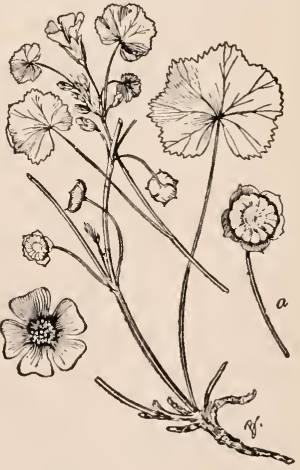

248. Common mallow, a trailing plant to which the circle of fruits, $a$, gives the names "cheeses" and "shirt button plant." 
Malvaceæ, or Mallow family, has flowers similar to those of the hollyhock. To this family belong marsh mallow, althea, okra, cotton (Fig. 249). Observe that even though the hollyhock is a great tall-growing showy plant and the "cheeses" is a weak trailing inconspicuous plant, they belong to the same family, as shown by the structure of the flowers.

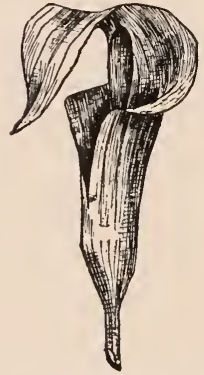

251. Jack-in-the-pulpit. "Jack" is the spadix; the "pulpit" is the spathe.

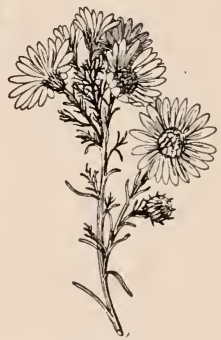

252. Wild aster, with six heads, each containing several florets.

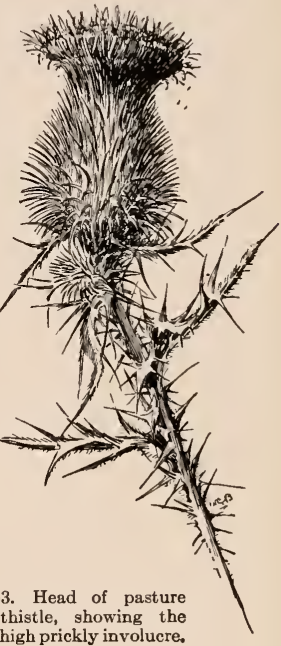

300. Orchid Flowers.-The flowers of orchids vary wonderfully in shape, size and color. Most of them are specially adapted to insect pollination. The distinguishing feature of the orchid flower, however, is the union of stamens and pistil in one body, known as the column. In Fig. 250 the stemless lady's-slipper is shown. The flower is 3-merous. One of the petals is developed into a great sac or "slipper," known as the lip. Over the opening of this sac the column hangs. The column is shown in detail: $a$ is the stigma; $d$ is an anther, and there is another similar one on the opposite side, but not shown in the picture; $b$ 
is a petal-like stamen, which does not produce pollen. In most other orchids there is one good anther.

301. In orchids the pollen is usually borne in adherent masses, one or two masses occupying each sporangium of the anther, whereas, in most plants the pollen is in separate grains. These pollen-masses are known technically as pollinia. Orchids from the tropics are much grown in choice greenhouses. Several species are common in woods and swamps in the northern states and Canada.

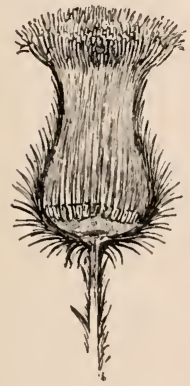

254. Longitudinal section of thistle head.

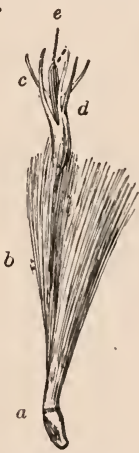

255. Floret of thistle.
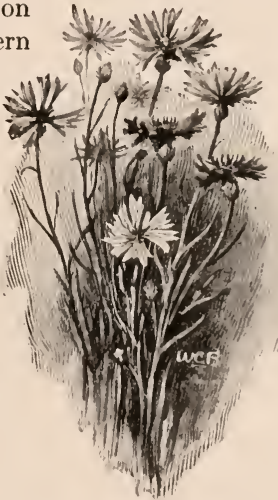

256. Cornflower or bachelor's button, in which the outer florets are large and showy.

302. Spathe Flowers.-In many plants, very simple (often naked) flowers are borne in dense, more or less fleshy spikes, and the spike is inclosed in or attended by a leaf, sometimes corolla-like, known as a spathe. The spike of flowers is technically known as a spadix. This type of flower is characteristic of the great Arum family, which is chiefly tropical. The commonest wild representatives in the North are Jack-in-the-pulpit or Indian turnip (Fig. 251) and skunk cabbage. In the former the flowers are all diclinous and naked. The pistillate flowers (comprising only a 1-loculed 
ovary) are borne at the base of the spadix, and the staminate flowers (each of a few anthers) are above them. The ovaries ripen into red berries. In the skunk cabbage all the flowers are perfect and have four sepals. The common calla of greenhouses is a good example of this type of inflorescence.

303. Compositous Flowers.-The head (anthodium) or so-called "flower" of sunflower and whiteweed and daisy (Figs. 188, 189, 200), thistle, aster (Fig. 252), dandelion, daisy, chrysanthemum, goldenrod, is composed of several or many little flowers, or florets. These florets are inclosed

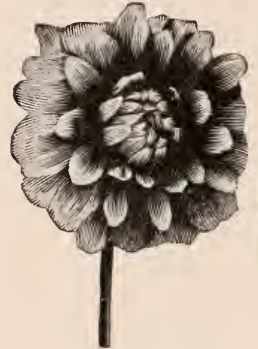

257, 258. Double dahlias. In one, the florets have developed flat rays. In the other, the florets appear as inrolled tubes.

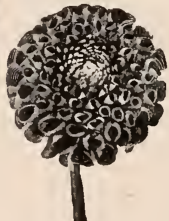
in a more or less dense and usually green involucre. In the thistle (Fig. 253) this involucre is prickly. A longitudinal section (Fig. 254) discloses the florets, all attached at bottom to a common torus, and densely packed in the involucre. The pink tips of these florets constitute the showy part of the head. 304. Each floret of the thistle (Fig. 255) is a complete flower. At $a$ is the ovary. At $b$ is a much-divided plumy calyx, known as the pappus. The corolla is longtubed, rising above the pappus, and is enlarged and 5 -lobed at the top, $c$. The style projects at $e$. The five anthers are united about the style in a ring at $d$. Such anthers are said to be syngenesious.

305. These are the various parts of the florets of the Compositæ, sometimes known as the Sunflower family. In some cases the pappus is in the form of barbs, bristles or scales, and sometimes it is wanting. The pappus, as we shall see later, assists in distributing the seed. Often the florets are not all alike. The corolla of those in the outer circles may be 
developed into a long, strap-like or tubular part and the corolla of those at the center may be but a short tube. The head then has the appearance of being one flower with a border of petals. Of such is the sunflower (Fig. 188), aster (Fig. 252), bachelor's button or cornflower (Fig. 256). These long corolla-limbs are called rays. In some cultivated composites, all the florets may develop rays, as in the dahlia (Figs. 257, 258) and chrysanthemum. In some species, as dandelion, all the florets naturally have rays. Syngenesious arrangement of anthers is the most characteristic single feature

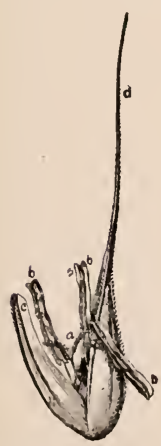

260. Flower of rye. $a$, stigma; $b, b, b$, stamens; $c$, palet; d, flowering glume. Enlarged.

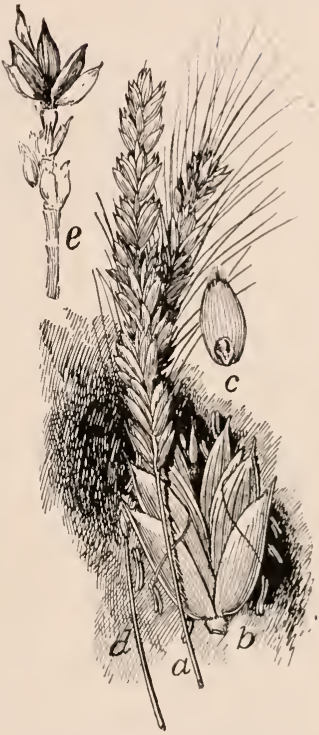

259. Spikes and flowers of wheat. $a$. beardless wheat; $d$, bearded wheat; $b$, spikelet in bloom; $c$, grain; $e$, single spikelet on a mature head. The benrds in $d$ are awns on the flowering glumes, derstand them he may begin with wheat or rye or barley, which are members of the Grass family. The "head" or spike of wheat is made up of flowers and bracts. The flowers are in little clusters or spikelets (often called "breasts" by farmers). One of the spikelets is shown at $b$, in Fig. 259. Each spikelet contains from 1 to 4 flowers or florets. The structure of the flower is similar to that 
of rye (Fig. 260) and other grasses. The pistil has 2 feathery protruded stigmas (wind-pollinated) shown at $a$, Fig. 260. There are 3 stamens, $b, b, b$. There are minute scales in the base of the flower (not shown in the cut) that probably represent true floral envelopes. These are lodicules. The larger parts, $c, d$, are bracts. The larger one, $d$, is the flowering glume, and the smaller, $c$, is a palet. The entire spikelet is

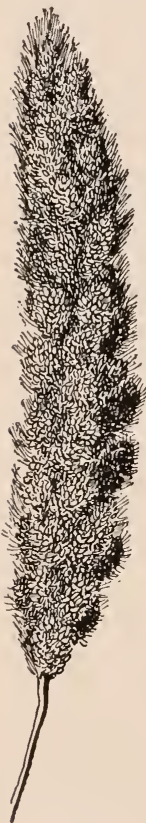

262. German millet. also subtended by two bracts or glumes; these are the two lowermost parts in $b$, Fig. 259. The glumes of the spikelet, and flowering glumes and palets of the flowers, constitute the chaff when wheat is threshed. Compare barley, Fig. 261. There are many grass plants with large florets that are adap-

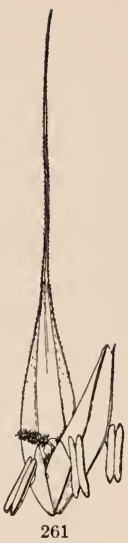

Barley flower. Enlarged. table to elementary class work, as millet (Fig. 262), sorghums (Figs. 232 to 234), rice, oats (Fig. 191), and a number of big lawn grasses Maize is one of the Grass family.

307. Attachment of the Flower Parts.-The parts of the flower may all be borne directly on the torus, or one part may be borne on another. With reference to the pistil or ovary, the stamens and envelopes may be attached in three ways: hypogynous, all free and attached under the ovary, when it is said to be superior, as in Fig. 202; perigynous, or attached to a more or less evident cup surrounding the ovary, as in Fig. 209; epigynous, some or all of them apparently borne on the ovary, when it is said to be inferior, as in Fig. 205.

308. Double Flowers.-Under the stimulus 
of eultivation and increased food-supply, flowers tend to become double. True doubling arises in two ways, morpho-

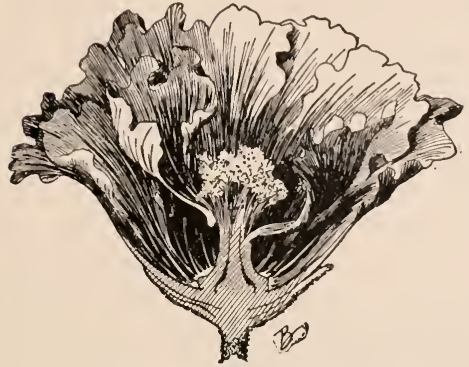

263. Petals arising from the staminal column of hollyhock; and accessory petals in the corolla-whorl.

logieally: (1) Petals may appear in place of stamens and pistils; (2) adventitious or aceessory petals may arise in the circle of petals. Both of these categories may be present in the same flower, as in Fig. 263. In the full-double hollyhock, the petals derived from the staminal eolumn are shorter and make a rosette in the eenter of the flower.

309. Other modifications of flowers are sometimes known as doubling. For example, double dahlias (Fig. 257), chrysanthemums and sunflowers are forms in which the disk flowers have developed rays. The snowball is another ease. In the wild plant (Fig. 264) the external flowers of the eluster are large and sterile. In the cultivated plant (Fig. 265) all the flowers have become large and sterile. Hydrangea is a similar example. Double flowers are likely to be sterile.

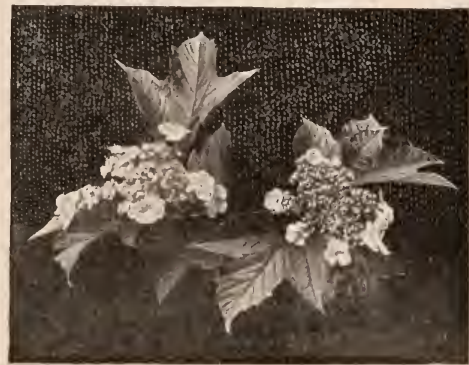

264. The wild or original form of the snowball.Outer flowers larger. 
Review.-How do flowers vary in form? How are the various parts determined in disguised flowers? What are 5-merous and 3-merous flowers? What are some of the common forms of gamopetalous corollas? Describe a labiate flower. Personate. Lily flower. Papilionaceous flower. What are monadelphous and diadelphous stamens? Describe a mallow flower. Orchid flower. Spathaceous flower. Compositous flower. If grass flowers are studied in class, describe one of them. What do you understand by the terms hypogynous, perigynous, epigynous? How do flowers become double? What is meant by doubling in compositous flowers? In snowball and hydrangea?

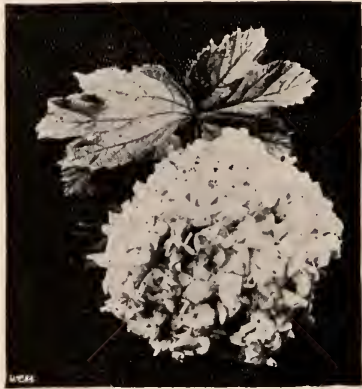

265. Cultivated snowball, in which all the flowers in the cluster have become large and showy. 


\section{CHAPTER XXIII}

\section{FRUITS}

310. The ripened ovary, with its attachments, is known as the fruit. It contains the seeds. If the pistil is simple, or of one carpel, the fruit also will have one compartment. If the pistil is compound, or of more than one carpel, the fruit usually has an equal number of compartments, although one or more of the compartments may be suppressed as the parts grow. The compartments in pistil and fruit are known as locules (from Latin locus, meaning "a place"), or cells.

311. The simplest kind of fruit is a ripened 1-loculed ovary. The first stage in complexity is a ripened 2- or manyloculed ovary. Very complex forms may arise by the attachment of other parts to the ovary. Sometimes the style persists and becomes a beak (mustard pods, dentaria, Fig. $266)$, or a tail as in clematis; or the calyx may be attached to the ovary; or the ovary may be imbedded in the receptacle, and ovary and receptacle together constitute the fruit; or an involucre may become a part of the fruit, as

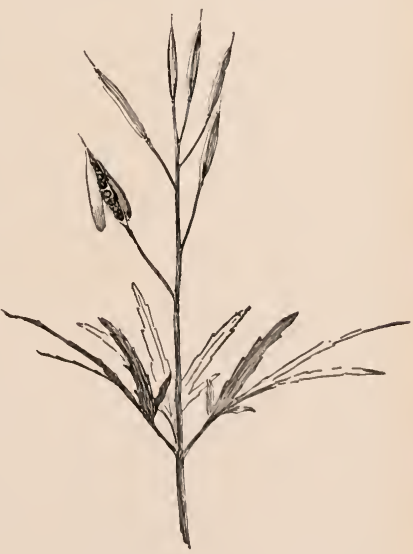

266. Dentaria, or toothwort, in fruit. possibly in the walnut and hickory, and cup of the acorn. The chestnut (Fig. 267) and the beech bear a prickly invo- 
lucre, but the nuts, or true fruits, are not grown fasi to it, and the involucre can scarcely be called a part of the fruit. A ripened ovary is a pericarp. A pericarp to which other

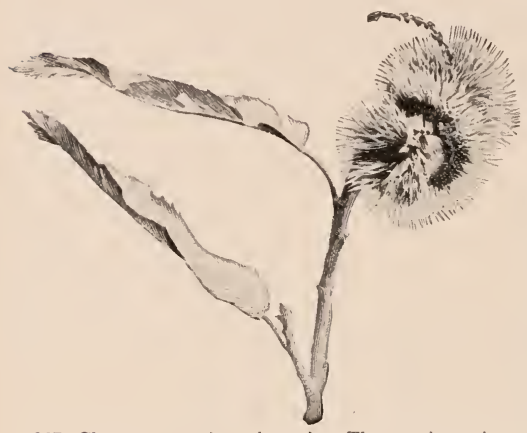

267. Chestnuts are ripened ovaries. They are borne in a prickly involucre. The remains of the catkin of staminate flowers is seen in the picture.

parts adhere has been called an accessory or reinforced fruit.

312. Some fruits are dehiscent, or split open at maturity (279) and liberate the seeds; others are indehiscent, or do not open. A dehiscent pericarp is called a pod. The parts into which such a pod breaks or splits are known as valves. In indehiscent fruits the seed is liberated by the decay of the envelope, or by the rupturing of the envelope by the germinating seed. Indehiscent winged pericarps are known as samaras or keyfruits (consult Chapter XXIV). Maple, elm (Fig. 97), and ash (Fig. 141) are examples.

313. Pericarps. - The simplest pericarp is a dry, oneseeded, indehiscent body. It is known as an achene. A head of achenes is shown in Fig. 268, and the structure is explained in Fig. 207. Achenes may be seen in buttercup, hepatica, anemone, smartweed, buckwheat.

314. A 1-loculed 268. Achenes pericarp that dehisces

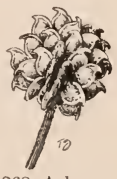
of buttereup.

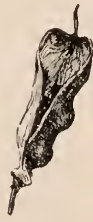

269.

Follicle of larkspur.

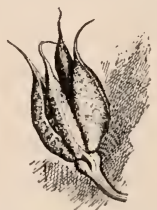

270. Young follicles of larkspur. Normally, the flower has 5 pistils, but some are lost in the struggle for existence. 


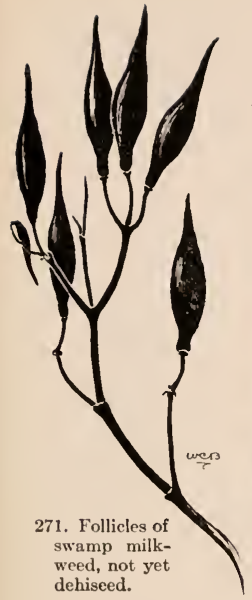

along the front edge (that is, the inner edge, next the center of the flower) is a follicle. The fruit of the larkspur (Fig. $269)$ is a follicle. There are usually five of these fruits (sometimes three or four)

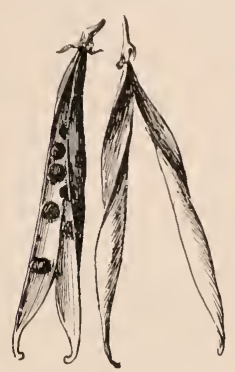

272. Legumes of perennial or everlasting pea. in each larkspur flower, each pistil ripening into a follicle. (Fig. 270.) If these pistils were united, a single eompound pistil would be formed. Columbine, peony, ninebark and milkweed (Fig. 271) also have follicles.

315. A 1-loculed pericarp that dehisces on both edges is a legume. Peas and beans are typical examples (Figs. $272,273,274)$ : in fact, this character gives name to the pea-f a mily,-Leguminosæ. Often the valves of the legume twist forcibly and expel the seeds, throwing them some distance. Sometimes (as in peanut) the legume does not dehisee of itself, even though it has all the essential structure of a true pod. The word pod is sometimes restricted to legumes, but it is better to use it generically (as in 312) for all dehiseent pericarps.

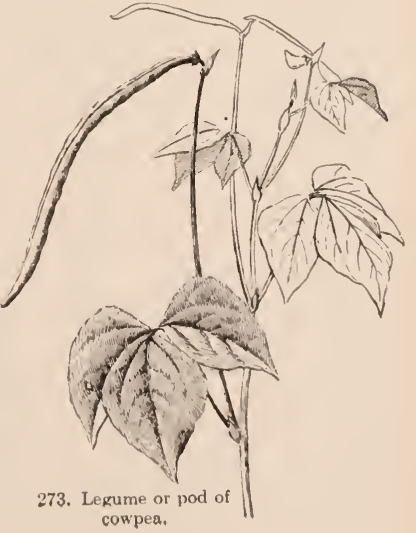



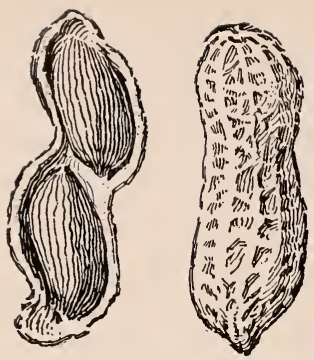

274. Peanuts. Compare Figs. 237, 238.

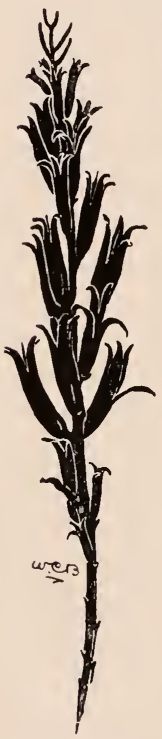

276. Capsules of evening primrose. Leculicidal.

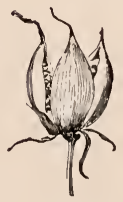

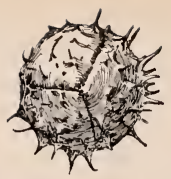

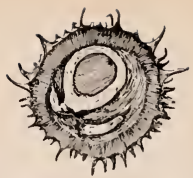

277. Three-carpelled fruit of horse-chestnut Two locules are closing by abortion of the ovules.

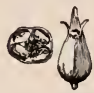

282. Apical dehiscence in capsule of Bouncing Bet. Four columns of seeds are attached to a central shaft.
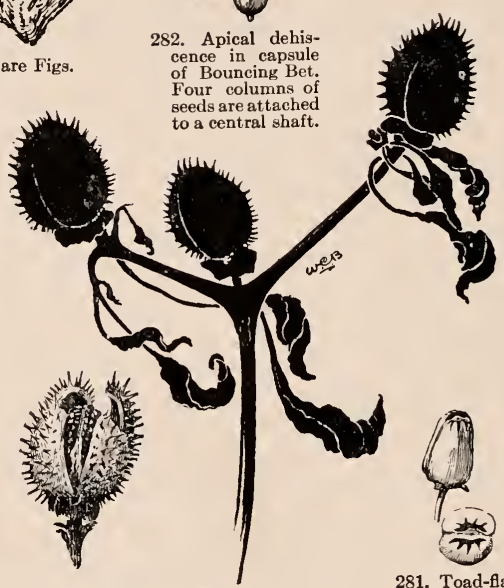

275. Capsules of datura or jimson weed. Septicidal and loculicidal.

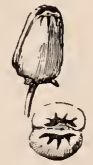

281. Toad-flax capsule.
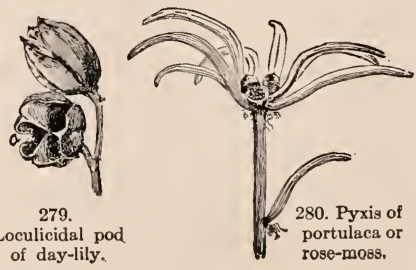
316. A compound pod-dehiscing pericarp of two or more carpels - is a capsule. (Figs. 275, 276.) There are some capsules of one locule, but they may have been com-

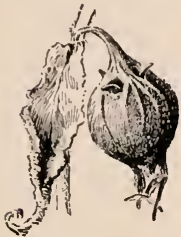

283. pound when young (in the ovary stage) and the partitions may have vanished. Sometimes one or more of the carpels are uniformly crowded out by the exclusive growth of other carpels. (Fig. 277.) The seeds or parts that are crowded out are said to be aborted.

317. There are several ways in which Basal dehiscence of campanula capsule. capsules dehisce or open. When they break along the partitions (or septa), the mode is known as septicidal dehiscence; Fig. 278 shows it. In septicidal dehiscence, the fruit separates into parts representing the original carpels. These carpels may still be entire, and they then dehisce individually, usually along the inner edge as if they were follicles. When the compartments split in the middle, between the partitions, the mode is loculicidal dehiscence. (Fig. 279.) In some eases the dehiscence is at the top, when it is said to be apical (although several modes of dehiscence are here included). When the whole top comes off, as in purslane and garden portulaca (Fig. 280), the pod is known as a pyxis. In some cases apical dehiscence is by means of a hole or clefts. (Fig. 281.) In pinks and their allies the dehiscence does not extend much below the apex. (Fig. 282.)

284. Two-valved pods of catalpa. 
Dehiscence may be basal. (Fig. 283.) Two-loculed capsules that resemble legumes in external appearance are those of catalpa and trumpet-creeper. (Figs. 284, 285.)

318. The peculiar capsule of the mustard family, or Cruciferæ, is known as a silique when it is distinctly longer than broad (Fig. 266), and a silicle when its breadth nearly equals or exceeds its length. (Fig. 286.) A cruciferous capsule is 2-carpelled, usually with a thin partition, each locule containing seeds in one or two rows. The two valves detach from below upwards. Cabbage, mustard, cress, shepherd's purse, sweet alyssum, wallflower, honesty, are examples.

319. The pericarp may be fleshy and

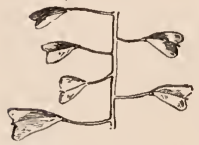

286. Shepherd's purse. Silicle. indehiscent. A pulpy pericarp with several or many seeds is a berry. (Fig. 287.) To the horticulturist a berry is a small, soft, edible fruit, without particular reference to its structure. The botanical and horticultural conceptions of a

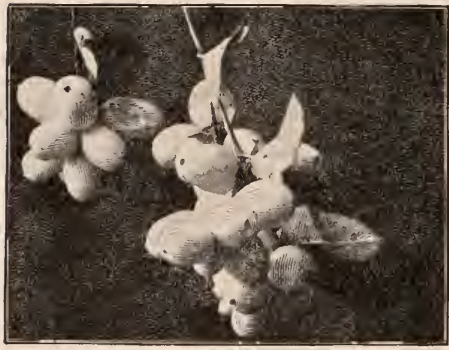

287. Berries of the snowberry. berry are, therefore, unlike. In the botanical sense, gooseberries, currants, grapes, tomatoes, potatoballs and even eggplant fruits (Fig. 288) are berries; strawberries, raspberries, blackberries are not. 320. A fleshy pericarp containing one 
relatively large seed or stone is a drupe. Examples are plum (Fig. 289), peach, cherry, apricot, olive. The walls of the pit in the plum, peach and cherry are formed from the inner coats of the ovary, and the flesh from the outer coats. Drupes are also known as stone-fruits.

321. Fruits that are formed by the subsequent union of separate pistils are aggregate fruits. The carpels in aggregate fruits are usually more or less fleshy. In

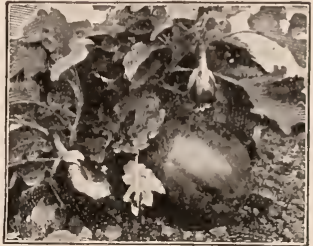

288. Eggplant fruits. Examples of large berries. the raspberry and blackberry flower, the pistils are essentially distinct, but as the pistils ripen they cohere and form

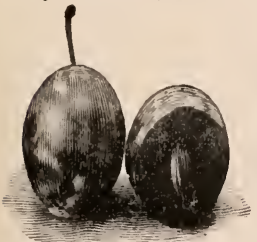

289. Plum. Example of a drupe.

one body. (Fig. 290.) Each of the carpels or pistils in the raspberry and blackberry is a little drupe, or drupelet. In the raspberry the entire fruit separates from the torus, leaving the torus on the plant. In the blackberry and dewberry the fruit adheres to the torus, and the two are removed together when the fruit is pieked.

322. Accessory Fruits.-When the periearp and some other part grow together, the fruit is said to be accessory or reinforced (311). An example is the strawberry. (Fig. 291.) The edible part is a greatly enlarged torus, and the pericarps are achenes imbedded in it. These achenes are commonly ealled seeds.

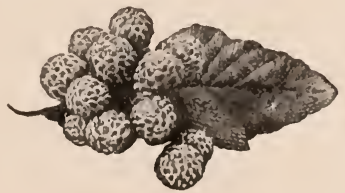

290. Aggregate fruits of raspberry.

323. Various kinds of reinforced fruits have received special names. One of these is the hip, characteristic of roses. (Fig. 292.) In this ease, the torus is deep and hollow, like an 
urn, and the separate achenes are borne inside it. The mouth of the receptacle may close, and the walls sometimes become fleshy: the fruit may then be mistaken for a berry.

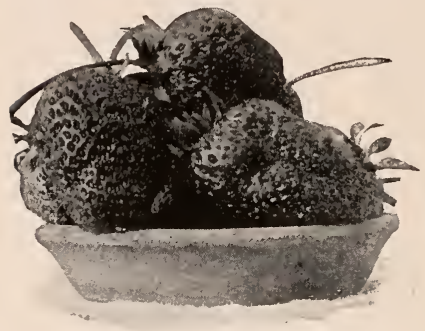

291. Strawberries. The edible part is torus.

324. The reinforced fruit of the pear, apple, and quince is known as a pome. In this case the five united carpels are completely buried in the hollow torus, and the torus makes most of the edible part of the ripe fruit, while the pistils are represented by the core. (Fig. 293.)

Fig. 294 shows the apple in bloom; Fig. 295 shows young fruits, only one having formed in each cluster. In the lower left-hand flower of Fig. 294, note that the sepals do not fall. Observe the sepals on the top of the torus (apex of the fruit) in Fig. 295. In the plum flower (Fig. 209), note that the pistil sits free in the hollow torus: imagine the pistil and torus grown together, and something like a pome might result.

325. The reinforced fruit of pumpkin, squash (Fig. 296), melon and cucumber is a pepo. The outer wall is torus, but the sepals do not persist, and the fruit is normally 3-loculed (although the partitions may disappear as the fruit ripens). The maypop, one of the passion flowers growing wild in the southern states, has a similar structure.

326. Gymnospermous Fruits.- 292. Hip of rose.

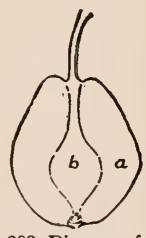

293. Diagram of a pear. The receptacle is $a$, and the pericarp $b$.

In pines, spruces and their kin, there is no fruit in the sense in which the word is used in the preceding pages, because there is no ovary. The ovules are naked or uncov- 


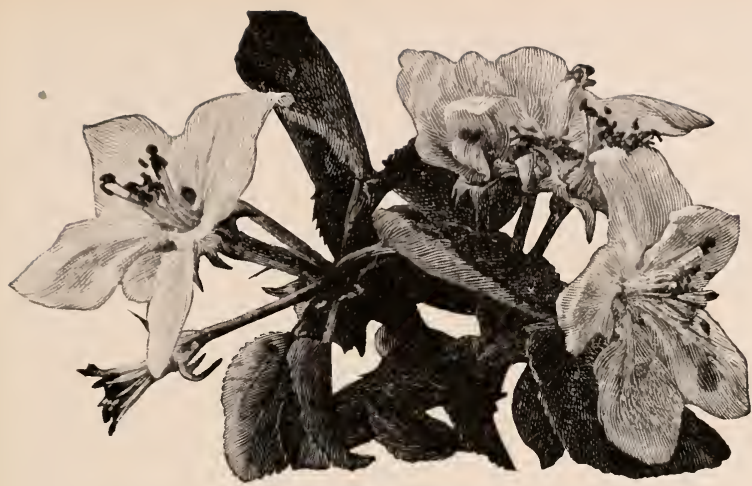

294. Apple flowers.

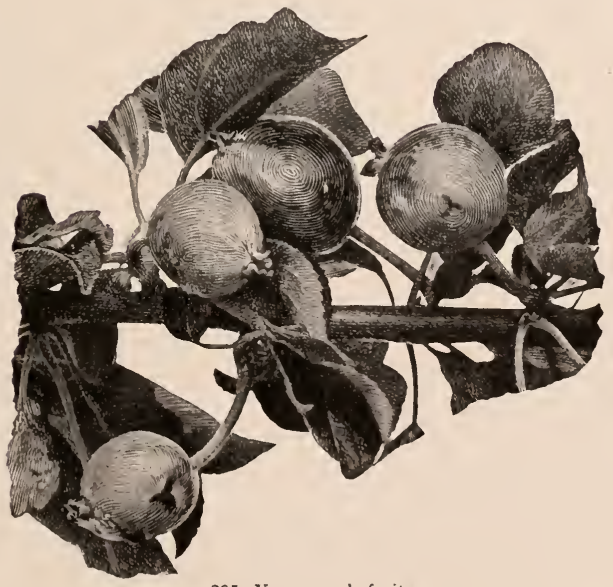

295. Young apple fruits. 
ered, in the axils of the scales of the young cone, and they have neither style nor stigma. The pollen falls directly on

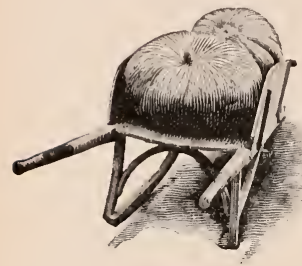

296. Pepo or squash. the mouth of the ovule. The ovule ripens into a seed (Fig. 297) which is usually winged. Because the ovule is not borne in a sac or ovary, these plants are called gymnosperms (Greek for "naked seeds"). All the true cone-bearing plants are of this class; also certain other plants as red cedar, juniper,

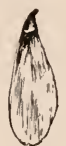

297. Winged seed of Norway spruce.

yew. The plants aire monœcious or sometimes diœcious. The staminate flowers are mere naked stamens borne beneath scales, in small yellow catkins which soon fall. The pistillate flowers are naked ovules beneath scales on cones which persist. (Figs. 298, 299.)

Review. - What is a fruit, as understood by the botanist? What is a locule? What are simple, compound and accessory or reinforced fruits? Define pericarp. Pod. What are dehiscent and indehiscent

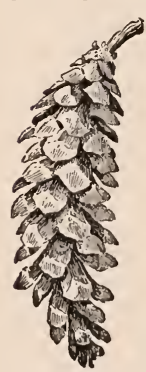

299. Pistillate cone of white pine. fruits? What is a samara or key-fruit? Define achene. Follicle. Legume. Capsule. Explain septicidal and loculicidal dehiscence. Apical dehiscenc. Basal dehiscence. What is a pyxis? Silique? Silicle? Berry? Drupe? Drupelet? Explain an aggregate fruit. Explain the fruit of strawberry, rose, apple, squash. What is the fruit of pines and spruces?

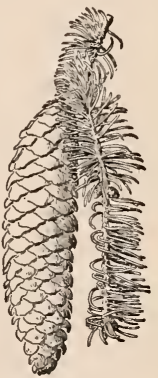

298. Pistillate cone of Norway spruce. This tree is one of the commonest of planted evergreens.

Nоте.-Fully mature fruits are best for study, particularly if it is desired to see dehiscence. For comparison, pistils and partially grown fruits should be had at the same time. If the fruits are not ripe enough to dehisce, they may be placed in the sun to dry. 
In the school it is well to have a collection of fruits for study. The specimens may be kept in glass jars.

The following diagram will aid the pupil to remember some of the fruits to which particular names have been given. He must be warned, however, that the diagram does not express the order of evolution of the various kinds. He should also remember that there are many common fruits that answer to no definition, and these should be studied and compared with the forms that have received definite names:

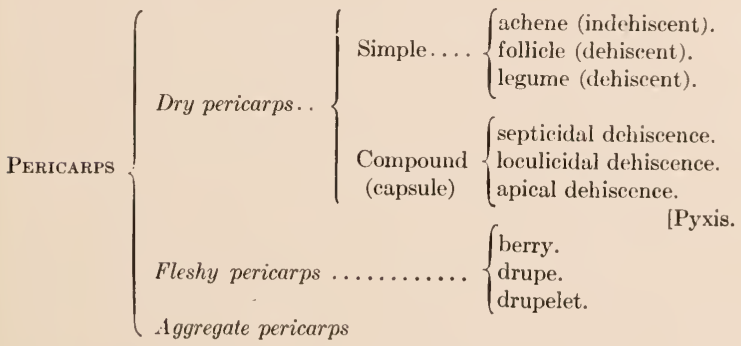

Accessory Frutts $\ldots \ldots \ldots \ldots \ldots \ldots \ldots,\left\{\begin{array}{l}\text { strawberry. } \\ \text { hip. } \\ \text { pome. } \\ \text { pepo. }\end{array}\right.$

Gymospermous or Cone Fruits. 


\section{CHAPTER XXIV \\ DISPERSAL OF SEEDS}

327. It is to the advantage of the plant to have its seeds distributed as widely as possible. It has a better chance of

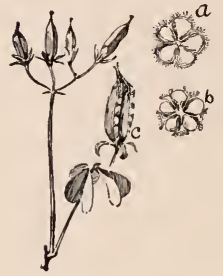

300. Explosive fruits of oxalis. An exploding pod is shown at $c$. The dehiscence is shown at $b$. The structure of the pod is seen at $a$. surviving in the struggle for existence. It gets away from competition. Many seeds and fruits are of such character as to increase their chances of wide dispersal. The commonest means of dissemination may be classed under four heads: explosive fruits; transportation by wind; transportation by birds; transportation as burs.

\section{Explosive Fruits.-}

Some pods open with explosive force and scatter the seeds. Even beans and everlasting peas

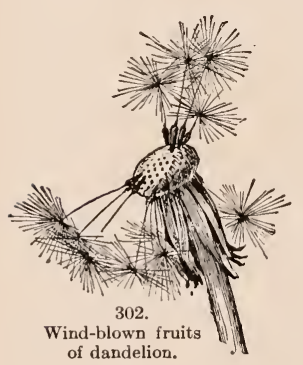
(Fig. 272) do this. More marked examples are the locust, witch hazel, garden balsam, wild jewelweed or impatiens (known also as "touch-

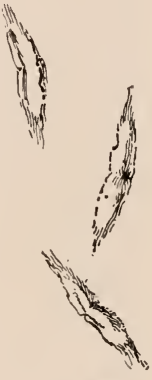

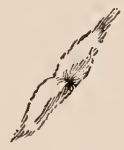

301.

Winged seeds of eatalpa. me-not"), violet, and the oxalis. (Fig. 300.) The oxalis is common in several species in the wild and in cultivation. One of them is known as wood sorrel. Fig. 300 shows the common yellow 


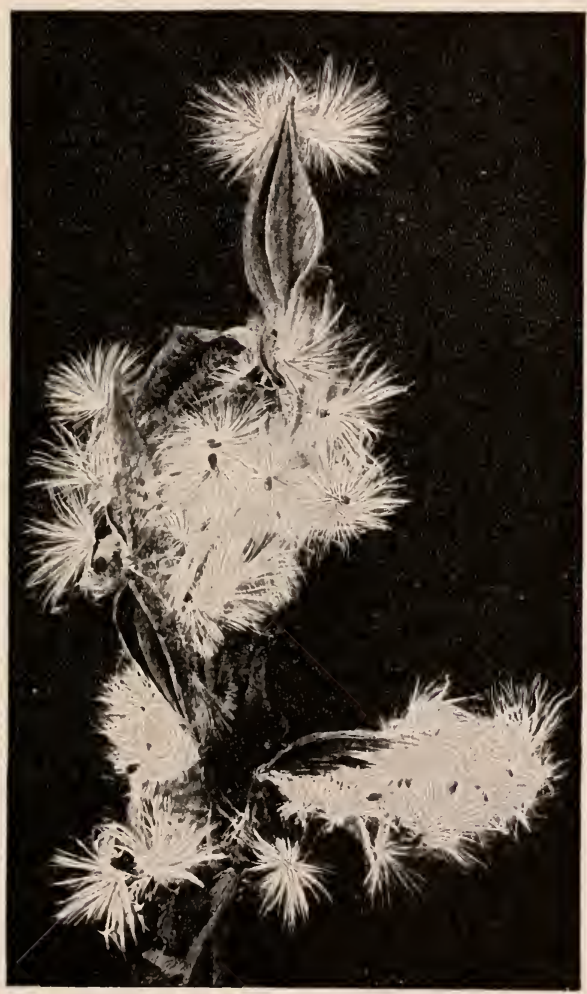

303. The expanding balloons of the milkweed.

oxalis. The pod opens loculicidally. The elastic tissue suddenly contracts when dehiscence takes place, and the seeds are thrown violently. The fruit of the squirting cucumber discharges the seeds with great force, throwing them many 
feet. This plant is easily grown in a garden (procure seeds of seedsmen).

329. Wind - travelers. - W in d - transported seeds are of two general kindsthose that are provided with wings, as the flat seeds of catalpa (Fig. 301) and conebearing trees (Fig. 297) and the samaras of ash, elm, tulip-tree, ailanthus and maple; those that have feathery buoys or parachutes to enable them to float in the air. Of the latter kind are the fruits of many composites, in which the pappus is copious and soft. Dandelion (Fig. 302) and thistle (Fig. 256) are examples. The

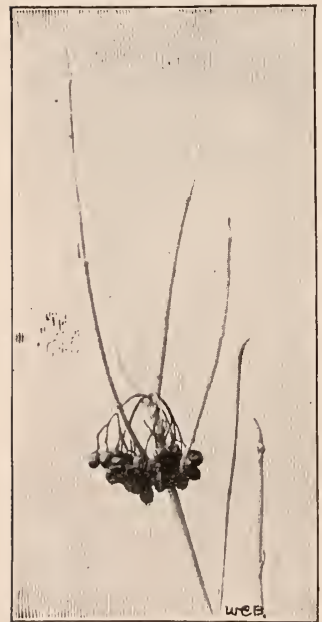

305. Drupes of the black haw, loved of robins in winter. silk of the milkweed (Fig.

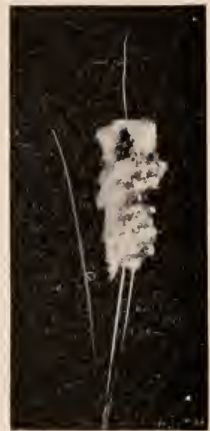

304. Head of cat-tail in late fall. The fruits are carried in the late autumn winds.

303) has a similar office, and also the wool of the cat-tail. (Fig. 304.) Recall the cottony seeds of the willow and poplar.

330. Dispersal by Birds.Seeds of berries and of other small fleshy fruits are carried far and wide by birds. The pulp is digested, but the seeds are not injured. Note how the cherries, raspberries, blackberries and Juneberries spring up in the fence-rows, where the birds rest. Some berries and drupes persist far into winter, when they supply food to cedar-birds, robins and the winter birds. (Fig. 305.) Red cedar is distributed by birds. Many of the pulpy fruits are 
agreeable as human food, and some of them have been greatly enlarged or "improved" by the arts of the cultivator.

331. Burs.-Many seeds and fruits bear spines, hooks, and hairs that adhere to the coats of animals (Fig. 306) and to clothing. The burdock has an involucre with hooked scales, containing the fruits inside. The clotbur is also an involucre. Both are compositous plants, allied to thistles, but the whole head, rather than the separate fruits, is transported. In some compositous fruits the pappus takes the form of hooks and spines, as in the "Spanish bayonets" and "pitchforks." Fruits of various kinds are known as "sticktights," as of the agrimony and

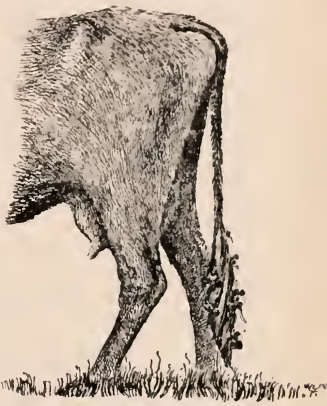

306. The cow is carrying burdocks. hound's tongue. Those who walk in the woods in late summer and fall are aware that plants have means of disseminating themselves. (Fig. 307.) If it is impossible to identify the burs which one finds on clothing, the seed may be planted and specimens of the plant may then be

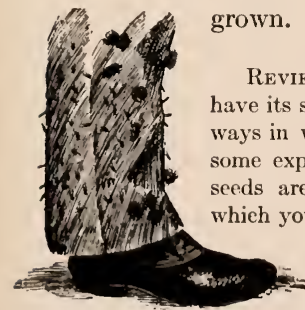

307. Stealing a ride.

Review.-What advantage is it to the plant to have its seeds widely dispersed? What are the leading ways in which fruits and seeds are dispersed? Name some explosive fruits. Describe wind-travelers. What seeds are earried by birds? Deseribe any bur with which you are familiar.

Note.-This lesson will suggest other ways in which seeds are transported. Nuts are buried by squirrels for food, but if they are not eaten they may grow. The seeds of many plants are blown on the snow. The old stalks of weeds, standing through the winter, may serve to disseminate the plant. Seeds are carried by water down the streams and along shores. About woollen 
mills strange plants often spring up from seeds brought in the fleeces. Sometimes the entire plant is rolled for miles before the winds. Such plants are "tumble-weeds." Examples are Russian thistle (Fig. 113), hair-grass or tumblegrass (Panicum capillare), cyclone plant (Cycloloma platyphyllum), and white amaranth. About seaports strange plants are often found, having been introduced with the earth that is used in ships for ballast. These plants are usually known as "ballast plants." Most of them do not persist long.

In some way, the seeds of every plant are dispersed, some far and some near: discover these ways for any plant that you know. 


\section{CHAPTER XXV}

\section{GERMINATION}

332. The Seed.-We have found (276) that as a result of fertilization a seed is formed. The seed contains a miniature plant or embryo. The embryo usually has three parts that have received names: the little stemlet or caulicle; the seed-leaf or cotyledon (usually 1 or 2); the bud or plumule lying between or above the cotyledons. These parts are well seen in the common bean (Fig. 308), particularly when the seed has been soaked for a few hours. One of the large cotyledons-comprising half of the bean-is shown at $r$. The caulicle is at $c$. The plumule is at $a$. The cotyledons are attached to the caulicle at $f$ : this point is the first node, and the plumule is at the second node.

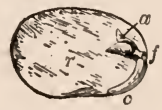

308. Parts of the bean. $r$, cotyledon; $c$, caulicle; $a$, plumule; $f$, first node.

333. Every seed is provided with food, to support the germinating plant. Commonly this food is starch. The food may be stored in the cotyledons, as in bean, pea, squash; or outside the cotyledons, as in castor bean, pine, Indian corn. When the food is around the embryo, it is usually called endosperm.

334. The embryo and endosperm are inclosed within a covering made of two or more layers and known as the seedcoats. Over the point of the caulicle is a minute hole or a thin place in the coats known as the micropyle. This is the point at which the pollen-tube entered the forming ovule and through which the caulicle breaks in germination. The micropyle is shown at $m$ in Fig. 309. The scar where the seed broke from its funiculus or stalk is the hilum. It 
occupies a third of the length of the bean in Fig. 309. The hilum and micropyle are always present in seeds, but they are not always close together. In many cases it is difficult to identify the micropyle in the dormant seed, but its location $\bar{m}^{n}$ is at once shown by the protruding caulicle as germination begins. Opposite the micropyle in the bean (at the other end of the hilum) is 309.

External parts of bean. an elevation known as the raphe. This is formed by a union of the funiculus or seedstalk with the seed-coats, and through it food was transferred for the development of the seed, but it is now functionless.

335. Seeds differ wonderfully in size, shape, color and other characteristics. They also vary in longevity. These characteristies are peculiar to the species or kind. Some seeds maintain life only a few weeks or even days, whereas others will "keep" for ten or twenty years. In special cases, seeds have retained vitality longer than this limit, but the stories that living seeds, several thousand years old, have been taken from mummies are unfounded. Oats do not retain their vitality for more than a year or two. Seed of alfalfa may retain its vitality for eight years or more. The condition of storage of the seed is an important factor in the retention of seed vitality. Moisture is especially deleterious; a dry atmosphere of the storage room is necessary for maintaining the vigor of the seed.

336. Germination.-The embryo is not dead; it is only dormant. When supplied with moisture, warmth, and oxygen (air), it awakes and grows: this growth is germination. The embryo lives for a time on the stored food, but gradually the plantlet secures a foothold in the soil. The roots absorb and the leaves elaborate food and the seedling is independent with respect to its food supply. When the plantlet is finally able to shift for itself, germination is complete.

337. The germinating seed first absorbs water, and swells. The starch and other stored foods are transformed 
into soluble products. They are digested, so to speak, and made available for assimilation by the protoplasm. Germinate barley. Note how sweet it is to the taste. Compare it with the ungerminated barley. Do likewise with corn and wheat. What is the source of the sugar? The seed-coats are ruptured, the caulicle and plumule emerge. In this process, the seed respires freely, giving off earbon dioxid $\left(\mathrm{CO}_{2}\right)$. Fill a tin box or large-neeked

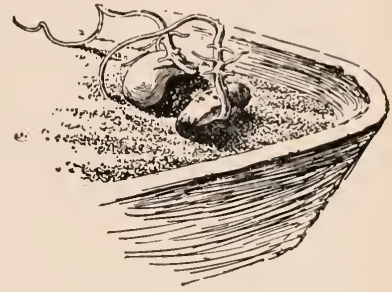

310. The young roots are not able to gain a foothold.

bottle with dry beans or peas, then add water; note how much they swell. Secure two fruit-jars. Fill one of them

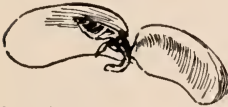

311. Cotyledons of germinating bean spread apart to show elongating caulicle and plumule.

a third full of beans and keep them moist. Allow the other to remain empty.

In a day or two insert a lighted splinter or taper into each. In the empty jar the taper burns: it contains oxygen. In the seed-jar the taper goes out: the air has been replaced by carbon dioxid. Usually there is a perceptible rise in temperature in a mass of germinating seeds.

338. The caulicle usually elongates, and from its lower end roots are produced. The elongating caulicle is known as the hypocotyl ("below the cotyledons"). That is, the hypocotyl is that part of the stem of the plantlet lying between the roots and the cotyledon. The

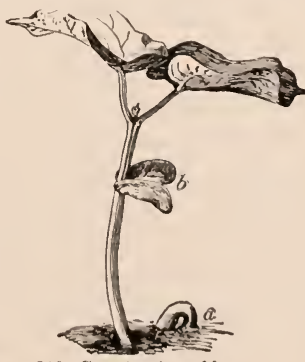

312. Germination of bean. general direction of the young hypocotyl or emerging caulicle is downwards. As soon as roots form, it becomes 
fixed, and its subsequent growth tends to raise the cotyledons above the ground, as in the bean.

339. When cotyledons rise into the air, germination is said to be epigeal ("above the earth"). Bean and pumpkin are examples. When the hypocotyl does not elongate greatly and the coty-

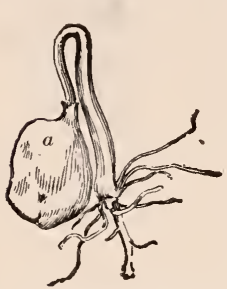
ledons remain under

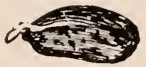
ground, the germination is hypogeal ("beneath the earth"). Pea and scarlet runner bean are examples. When the germinating seed lies on a hard surface, as on closely compacted soil, the hypocotyl and rootlets may not be able to secure a foothold and they assume grotesque forms. (Fig. 310.) Try this with peas

314. Germination of castor bean. Endosperm at $a$. and beans.

340. The first internode above the cotyledons - between the cotyledons and the plumule-is the epicotyl. It elevates the plumule into the air, and the plumule-leaves expand into the first true leaves of the plant. These first true leaves, however, may be very unlike the later leaves.

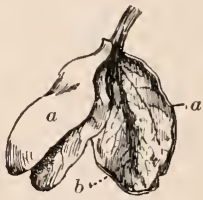

315. Castor bean. Endosperm at $a, a$; cotyledons at $b$.

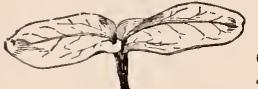

341. Germination of Bean.-The common bean, as we have seen (Fig. 308), has cotyledons that occupy all the space inside the seed-coats. When the hypocotyl or elongating caulicle emerges, the plumule-leaves have begun to enlarge and to unfold. (Fig. 311.) The hypocotyl elongates rapidly. One end of it is held by the roots. The other is held by the seed-coats in the soil. It, therefore, takes the form of a loop, and 
its central part "comes up" first. (a, Fig. 312.) Presently it draws the cotyledons out of the seed-coats, and then it straightens and the cotyledons expand. These cotyledons, or "halves of the bean," persist for some time. (b, Fig. 312.) They often become green and

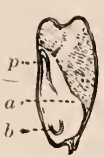

317. Sprout- 318. Kernel of ing Indian Indian corn. corn. $\mathrm{Hi}-$ Caulicle at lum at $h ; \quad b$; cotyledon micropyle $a$; plumule at $d$. probably perform some function of foliage. Because of its large size, Lima bean shows all these parts well.

342. Germination of Castor Bean. - In the castor bean the hilum and micropyle are at the smaller end. (Fig. 313.) The bean "comes up" with a loop, which indicates that the hypocotyl greatly elongates. On examining a germinating seed, however, it will be found that the cotyledons are contained inside a fleshy body or sac. (a, Fig. 314.) This sac is the endosperm. To its inner surface the thin, veiny cotyledons are very closely appressed, absorbing its substance. (Fig. 315.) The cotyledons

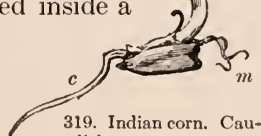

319. Indian corn. Caulicle at $c$; roots emerging at $m$; plumule at $p$. increase in size as they reach the air (Fig. 316), and become functional leaves.

343. Germination of Indian Corn.-Soak kernels of corn. Note that the micropyle and hilum are at the

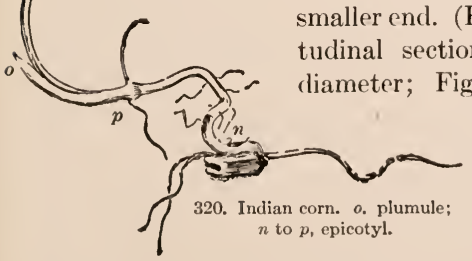
smaller end. (Fig. 317.) Make a longitudinal section through the narrow diameter; Fig. 318 shows it. The single cotyledon is at $a$, the caulicle at $b$, the plumule at $p$. The cotyledon remains in the seed. The food is stored both in the cotyledon and as endosperm, chiefly the latter. The emerging shogt is the plumule, with a sheathing 
leaf. ( $p$, Fig. 319.) The root is produced from the tip of the caulicle, $c$. The caulicle is held in a sheath (formed mostly from the seed-coats), and some of the roots escape through the upper end of this sheath. ( $m$, Fig. 319.) The epicotyl

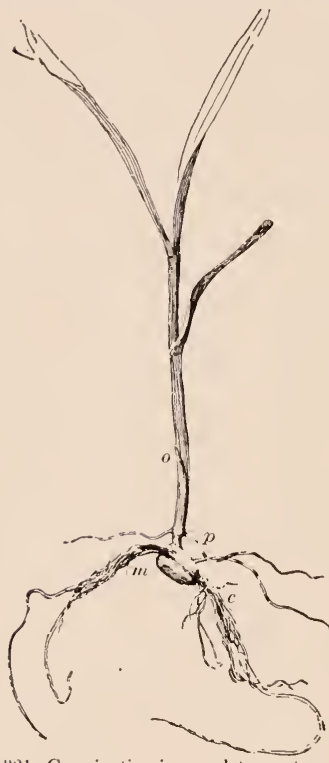

321. Germination is complete. $p$, top of epicotyl; $o$, plumule-leaf; $m$, roots; $c$, lower roots. elongates, particularly if the seed is planted deep or if it is kept for some time confined. In Fig. 320 the epicotyl has elongated from $n$ to $p$. The true plumule-leaf is at $o$, but other leaves grow from its sheath. In Fig. 321 the roots are seen emerging from the two ends of the caulicle-sheath, $c, m$; the epicotyl has grown to $p$; the first plumule-leaf is at $o$.

Review.-What does a seed contain? What do you understand by the embryo? What are its parts? Where is the food in the seed? What are the seed-coats? What is the micropyle? Hilum? How may the position of the micropyle be determined? How do seeds differ? With what are these differences associated? What is germination? Under what conditions does a seed germinate? What is meant by seed vitality? What are the best conditions for storage of seed? When is germination complete? What is the first phenomenon of germination? Explain the relation to $\mathrm{O}$ and $\mathrm{CO}_{2}$. Define hypocotyl. Epicotyl. Hypogeal and epigeal germination. What becomes of the plumule? Explain germination in a seed which you have studied.

NoтE.-Few subjects connected with the study of plant-life are so useful in schoolroom demonstrations as germination. The pupil should prepare the soil, plant the seeds, water them and care for the 


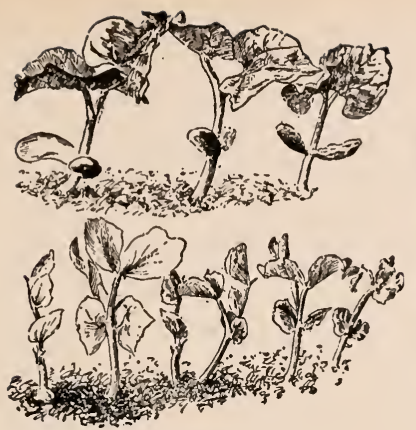

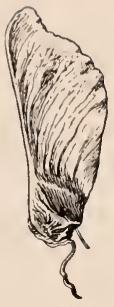

324.

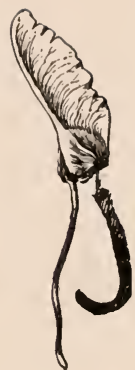

The beginning. 325. A later stage.

322. Germination of beans and peas.

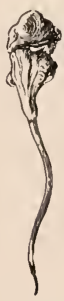

328.

Casting the seedcoats.

323. Natural planting of the fruits of Norway maple.

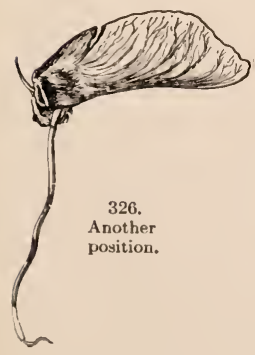

L

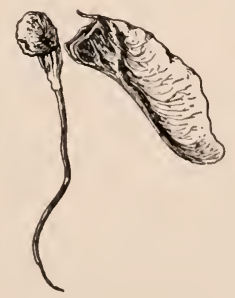

327. The wing cast off; the seed -coats still adhering.

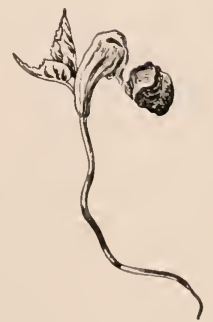

329. Free from the seed-coats. 
plants. Plant in pots or shallow boxes. Cigar-boxes are excellent. The depth of planting should be two to three times the diameter of the seeds. It is well to begin the planting of seeds at least ten days in advance of the lesson, and to make four or five different plantings

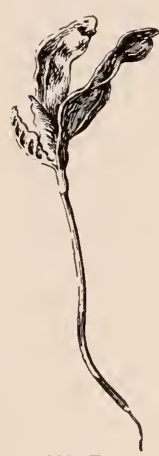
at intervals. A day or two before the study is taken up, put seeds to soak in moss or cloth. The pupil then has a series from swollen seeds to complete germination, and all the steps can be made out. Dry seeds should be had for comparison.

Good seeds for study are those detailed in the lesson,- - bean, castor bean, corn. Pea is a good plant to contrast with bean. (Fig. 322.) Make drawings and notes of all the events in the germination. Note the effects of unusual conditions, as planting too deep and too shallow and different sides up. For hypogeal germination, use the garden pea, scarlet runner or Dutch case-knife bean, acorn, horse-chestnut. Squash seeds are excellent for germination studies, because the cotyledons become green and leafy and germination is rapid. Its germination, as also that of the scarlet runner bean, is explained in "Lessons with Plants." Onion is excellent, except that it germinates too slowly. In order to study the root development of germinating plantlets, it is well to provide a deep box with a glass side against which the seeds are planted.

Observe the germination of any seed that is common about the premises. Where elms and maples are abundant, the germination of their seeds may be studied in lawns and along fences. Figs. 323 to 330 suggest observations on the Norway maple, which is a common ornamental tree. 


\section{CHAPTER XXVI \\ PHENOGAMS AND CRYPTOGAMS}

344. The plants thus far studied produce flowers; and the flowers produce seeds by means of which the plant is propagated. There are other plants, however, that produce no seeds, and these plants are probably more numerous than the seed-bearing plants. These plants propagate by means of spores, which are generative cells, usually simple, containing no embryo. These spores are very small, and sometimes are not visible to the naked eye.

345 . Prominent amongst the spore-propagated plants are ferns. The common Christmas fern (so called because it remains green during winter) is shown in Fig. 331. The plant has no trunk. The leaves spring directly from the underground stem. The leaves of ferns are called fronds. They vary in shape, as other leaves do. Compare Fig. 139 and the pictures in this ehapter. Some of the fronds are seen to be narrower at the top. If these are examined more closely (Fig. 332) it will be seen that the leaflets are contracted and are densely covered beneath with brown bodies. These bodies are collections of sporangia or sporecases (singular, sporangium).

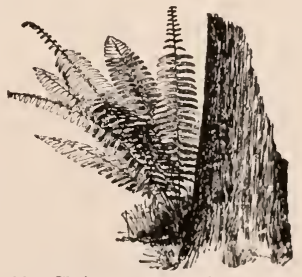

331. Christmas fern.-Dryopteris acrostichoides; known also as Aspidium.

346. The sporangia are collected into little groups, known as sori (singular, sorus) or fruit-dots. Each sorus is covered with a thin scale or shield, known as an indusium. This indusium separates from the frond at its edges, and the 
sporangia are exposed. Not all ferns have indusia. The polypode (Figs. 333, 334) does not: the sori are naked. In the brake (Fig. 335) and maidenhair (Fig. 336) the edge of the frond turns over and forms an indusium. In some ferns (Fig. 337) an entire frond becomes contracted to cover the sporangia. In other cases the indusium is a sac-like covering, which splits. (Fig. 338.)

347. The sporangium or sporecase of a fern is a more or less globular body and usually with a stalk. (Fig. 334.) It contains the spores. When ripe, it bursts and the spores are set free. Lay a mature fruiting

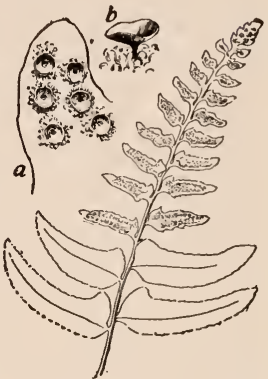

332. Fruiting frond of Christmas fern. Sori at $a$. One sorus with its indusium, at $b$. frond of any fern on white paper, top side up, and allow it to remain in a dry, warm place. The spores will discharge on the paper.

348. In a moist, warm place the spores germinate. They produce a small, flat, thin, green, more or less heart-shaped membrane. (Fig. 339.) This is the prothallus. Sometimes

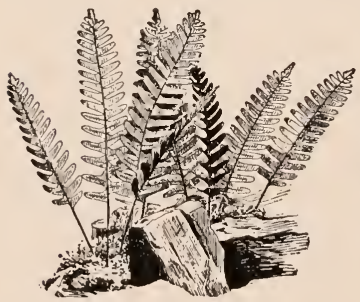

333. Common polypode fern.Polypodium vulgare. the prothallus is an inch or more across, but oftener it is less than one-fourth this

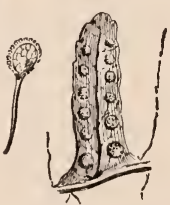

334. Sori and sporangium of polypode. size. It is commonly unknown except to botanists. Prothalli may often be found in greenhouses where ferns are grown. Look on the moist stone or brick walls, or on the firm soil of undisturbed pots and beds. 
349. On the under side of the prothallus two kinds of organs are borne. These are the archegonium and the antheridium. These organs are minute specialized parts of the prothallus. Their positions on a particular prothallus are

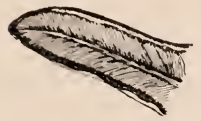

335. The brake fruits underneath the revolute edges of the leaf. shown at $a$ and $b$ in Fig. 339, but in some ferns they are on separate prothalli (plant diœecious). The sperm-cells escape from the antheridium and in the water which collects on the prothallus are carried to the archegonium, where fertilization takes place. From a fertilized archegonium a plant grows, and this plant becomes the "fern." In most cases the prothallus dies soon after the fern plant begins to grow.

350. The fern plant, arising from the fertilized egg in the archegonium, becomes a perennial plant, each year producing spores from its fronds, as we have seen; but these spores-which are merely detached special kinds of cellsproduce the prothallic phase of the fern plant, from which new individuals arise. A fern is fertilized but once in its life-time. The prothallium here is the gametophyte; the "fern" is the sporophyte (phyton is Greek for "plant").

351. This succession of generations runs all through the vegetable kingdom, although there are some groups of plants in which it is very obscure or apparently wanting. It is very marked in ferns and mosses. In algx (including the sea-

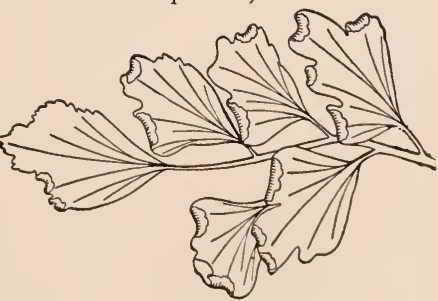

336. Reflexed margins of a maidenhair frond. weeds) the gametophyte constitutes the "plant," as the nonbotanist knows it. There is a general tendency, in the evolution of the vegetable kingdom, for the gametophyte to lose its relative importance and for the sporophyte to become 
larger and more highly developed. In the seed-bearing plants the sporophyte generation is the only one seen by the

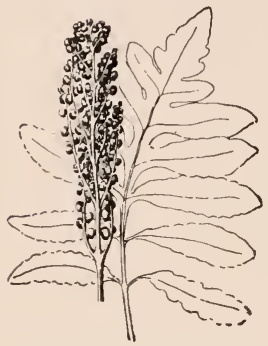

337. Fertile and sterile fronds of the sensitive fern. non-botanist. The gametophyte stage is of short duration and the parts are small: it is confined to the time of fertilization.

352. The sporophyte of the seedplants, or the plant, as we know it, produces spores which, however, are not visible to the naked eye. The spores are of two kinds: microspores borne in tissues called sporangia which forms part of the anther; and macrospores which are present in the pistil. The microspore developes into the pollen-grain. The macrospore develops in the ovule into an embryo-sac, which contains the egg nucleus. The germinated pollen-grain constitutes the completely developed sterile gametophyte.

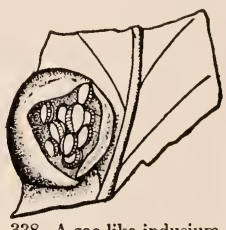

338. A sac-like indusium. The fully developed embryo-sac constitutes the fertile gametophyte. Fertilization occurs, and the sporophyte is again

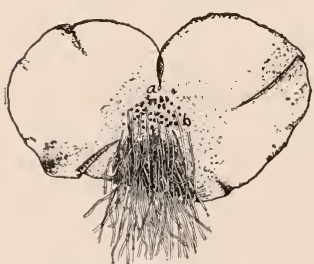

339. Prothallus of a fern. Enlarged. Archegonia at $a$; antheridia at $b$. produced. This new sporophyte develops farther and we have the embryo plant formed in the seed. This may remain dormant for a time, and when germination occurs the visible sporophyte plant is produced. This in turn produces microspores and macrospores, and the cycle is again complete. The alternation of these phases in the plant's life history is known technically as alternation of generations. 
353. It happens that the spores of seed-bearing plants are borne amongst a mass of specially developed leaves known as flowers: therefore, these plants have been known as the flowering plants. Some of the leaves are developed as envelopes (calyx, corolla), and others as spore-bearing parts, or sporophylls (stamens, pistils). But the spores of the lower plants, as of ferns and mosses, may also be borne in specially developed foliage, so that the line of demareation between flowering plants and flowerless plants is not so definite as was once supposed. The one definite distinction between these two classes of plants is the fact that one class produces seeds and the other does not. The seedplants are now often called spermaphytes, but there is no single coördinate term to set off those which do not bear seeds. It is quite as well, for popular purposes, to use the old terms, phenogams for the seed-bearing plants and cryptogams for the others. These terms have been objected to in recent years because their etymology does not express literal facts (phenogam refers to the fact that the flowers are showy, and cryptogam to the fact that the parts are hidden), but the terms represent distinct ideas in classification. Nearly every word in the language has grown away from its etymology. The eryptogams include three great series of plants - the Thallophytes or algæ, lichens and fungi; the Bryophytes or moss-like plants; the Pteridophytes or fernlike plants. In each of these series there are many families. See the following Chapter.

Review.-What is a spore? Describe the appearance of some fern plant that you have studied. What are the spores and sporangia? What is a sorus? Indusium? What grows from the spore? How does the new "fern" plant arise? What is meant by the ph ase "alternation of generations?" Define gametophyte and sporophyte. Deseribe the alternation in flowering plants. Explain the flower from this point of view. What is the significance of the word spermaphyte? Contrast phenogam and cryptogam.

Note,-All the details of fertilization and of the development of 
the generations are omitted from this book, because they are subjects for specialists and demand more training in research methods than the high-school pupil can properly give to plant-study. Cryptogams are as widespread as phenogams, and for this reason it has been urged that they are most proper subjects for study in the school. This position is untenable, however, for the best plant subjects for youth are those which mean most to his life. It is said, also, that cryptogams are best for the beginner because their life-processes are relatively simple in many cases; but the initial study of plants should be undertaken for the purpose of quickening the pupil's perception of common and familiar forms and problems, rather than for the purpose of developing a technical knowledge of a given science. 


\section{CHAPTER XXVII \\ STUDIES IN CRYPTOGAMS}

The special advanced pupil who has acquired skill in the use of the compound microscope may desire to make more extended excursions into the cryptogamous orders. The following plants, selected as examples in various groups, will serve as a beginning.

\section{ALGE}

The algæ comprise most of the green floating "scum" which covers the surface of ponds and other quiet waters. The masses of plants are often called "frog spittle." Others are attached to stones, pieces of wood and other objects submerged in streams and lakes, and many are found on moist ground and on dripping rocks. Aside from these, all the plants commonly known as seawceds belong to this category. They are inhabitants of salt water.

The simplest forms of algæ consist of a single spherical cell, which multiplies by repeated division or fission. specimens of these may be found growing on damp rock and the shady side of trees. Most of the forms found in fresh water are filamentous, i.e., the plant-body consists of long threads, either simple or branched. Such a plantbody is termed a thallus. This term applies to the vegetative body of all plants which are not differentiated into stem and leaves. Such plants are known as thallophytes (353). All algæ contain chlorophyll, and are able to assimilate carbon dioxid from the air. This distinguishes them from the fungi.

Spirogyra.-One of the most common forms of the green algæ is spirogyra. (Fig. 340.) This plant frequently forms the greater part of the floating green mass on ponds. The filamentous character of the thallus can be seen with

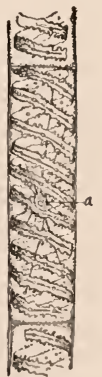

540. Strand of spirogyra, showing the chlorophyll bands. There is a nucleus at $a$. the naked eye or with a hand lens, but to study it carefully a microscope magnifying two hundred diameters or more should (185) 
be used. The thread is divided into long cells by cross-walls which, according to the species, are either straight or curiously folded. (Fig. 341.) The chlorophyll is arranged in beautiful spiral bands near the wall of each cell. From the character of these bands the plant takes

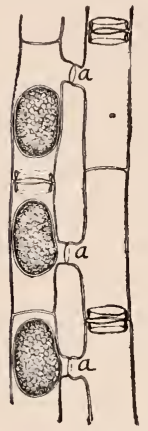

341. Conjugation of spirogyra. Ripe zy gospores on the left; connecting $a$, tubes. its name. Each cell is provided with a nucleus and other protoplasm. The nucleus is suspended near the center of the cell, $a$, Fig. 340 , by delicate strands of protoplasm radiating toward the wall and terminating at certain points in the chlorophyll band. The remainder of the protoplasm forms a thin layer lining the wall. The interior of the cell is filled with cell-sap. The protoplasm and nucleus cannot be easily seen, but if the plant is stained with a dilute alcoholic solution of eosin (153) they become clear.

Spirogyra is propagated vegetatively by the breaking off of parts of the threads, which continue to grow as new plants. Resting-spores, which may remain dormant for a time, are formed by a process known as conjugation. Two threads lying side by side send out short projections, usually from all the cells of a long series. (Fig. 341.) The projections or processes from opposite cells grow toward each other, meet and fuse, forming a connecting tube between the cells. The protoplasm, nucleus and chlorophyll band of one cell now pass through this tube, and unite with the contents of the other cell. The entire mass then becomes surrounded by a thick cellulose wall, thus completing the resting-spore, or zygospore. (Fig. 341, z.)

Vaucheria is another alga common in shallow water and on damp soil. The thallus is much branched, but the threads are not divided by cross-walls as in spirogyra. The plants are attached by means of colorless root-like organs which are much like the root-hairs of the higher plants: these are rhizoids. The chlorophyll is in the form of grains seattered through the thread.

Vaucheria has a special mode of vegetative reproduction by means of swimming spores or swarm-spores. These are formed singly in a short, enlarged lateral branch known as the sporangium. When the sporangium bursts the entire contents escape, forming a single large swarm-spore, which swims about by means of numerous lashes or cilia on its surface. The swarm-spores are so large that they ean be seen with the naked eye. After swimming about for some time they come to rest and germinate, producing a new plant. 
The formation of resting-spores of vaucheria is accomplished by means of special organs, oögonia Fig. 342. o, and antheridia. (Fig. $342, a$.) Both of these are specially developed branches from the thallus. The antheridia are nearly cylindrical, and curved toward the oögonia. The upper part of an antheridium is eut off by a cross-wall, and within it numerous eiliated sperm-cells are formed. These eseape by the ruptured apex of the antherid-

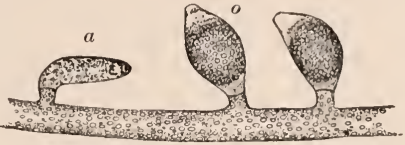

342. Thread of vaucheria with oögonia and antheridia.

ium. The oögonia are more enlarged than the antheridia and have a beak-like projection turned a little to one side of the apex. They are separated from the thallus-thread by a cross-wall, and contain a single large green cell, the eggcell. The apex of the oögonium is dissolved, and through the opening the sperm-cells enter. Fertilization is thus accomplished. After fertilization, the egg-cell becomes invested with a thick wall and is thus converted into a resting-spore, the oöspore. (Fig. 343.)

\section{FUNGI}

Some forms of fungi are familiar to every one. Mushrooms and toadstools, with their varicd forms and colors, are common in ficlds, woods and pastures. In every household the common moulds are familiar intruders, appearing on old bread, vegetables and even within tightly sealed fruit jars, where they form a felt-like layer dusted over with blue, yellow or black powder (192). The strange oecurrence of these plants long mystified people, who thought they were productions of the deal matter upon which they grew, but now we know that a mould, like any other plant, eannot originate spontancously; it must start from something which is analogous to a seed. The "seed" in this case is a spore. The term spore is applied to the minute reproductive bodies of all flowerless plants. A spore is a very simple structure, usually of only one plant-eell, whose special function is to reproduce the plant. A spore may

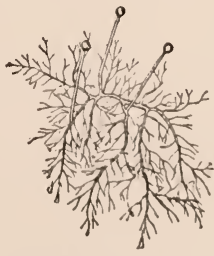

34.4. Mueor mucedo, showing habit.

be produced by a vegetative process (growing out from the ordinary plant tissues), or it may be the result of a fertilization process (344). 
Mould.-One of these moulds, Mucor mucedo, which is very common on all decaying fruits and vegetables, is shown in Fig. 344, somewhat magnified. When fruiting, this mould appears as a dense mass of long white hairs, often over an inch high, standing erect from the fruit or vegetable upon which it is growing.

The life of this mucor begins with a minute rounded spore ( $a$, Fig. 345 ), which lodges on the decaying material. When the spore germinates, it sends out a delicate thread which grows rapidly in length and forms very many branches which soon permeate every part of the substance on which the

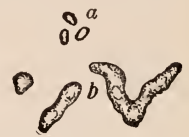

345. Spores of mucor; some germinating. plant grows. ( $b$, Fig. 345.) One of these threads is termed a hypha. All the threads together from the mycelium of the fungus (194). The mycelium disorganizes the material in which it grows, and thus nourishes the mucor plant. (Fig. 344.) It corresponds physiologically to the roots and stems of other plants.

When the mycelium is about two days old, it begins to form the long fruiting stalks which we first noticed. To study them, use a compound microscope magnifying about two hundred diameters. One of the stalks, magnified, is shown in Fig. 346, $a$. It consists of a rounded head, the sporangium, $s p$, supported on a long, delicate stalk, the sporangiophore, st. The stalk is separated from the sporangium by a wall which is formed at the base of the sporangium. This wall, how-

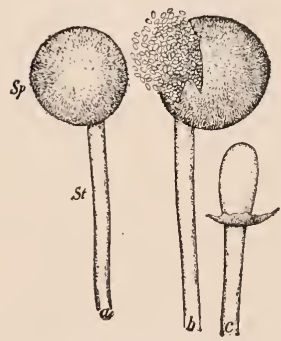

346. Mucor. $a$, sporangium; $b$, sporangium bursting; $c$, columella. ever, does not extend straight across the thread, but it arches up into the sporangium like an inverted pear. It is known as the columella, $c$. When the sporangium is placed in water, the wall immediately ruptures and allows hundred of spores, which were formed in the cavity within the sporangium, to escape, $b$. All that is left of the fruit is the stalk, with the pear-shaped columella at its summit, $c$. The spores which have been set free by the breaking of the sporangium wall are now scattered by the wind and other agents. Those which lodge in favorable places begin to grow immediately and reproduce the fungus. The others soon perish.

The mucor may continue to reproduce itself in this way indefinitely, but these spores are very delicate and usually die if they do not fall on favorable ground, so that the fungus is provided with another means of carrying itself over unfavorable seasons, as winter. This is 
accomplished by means of curious thick-walled resting-spores or zygospores. The zygospores are formed on the mycelium buried within the substance on which the plant grows. They originate as follows: The threads of two sexually different plants that lie near together send out short branches, which grow toward each other and finally meet. (Fig. 347.) The walls at the ends, $a$, then disappear, allowing the contents to flow together. At the same time, however, two other walls are formed at points farther back, $b, b$, separating the short section, $c$, from the remainder of the thread. This section now increases in size and becomes covered with a thick, dark brown wall ornamented with thickened tubercles. The zygospore is now mature and, after a period of rest, it germinates, either producing a sporangium directly or growing out as mycelium.

The zygospores of the mucors form one of the most interesting and instructive objects among the lower plants. They are, however, very difficult to obtain. One of the mucors, Sporodinia grandis, may be frequently found in summer growing on toadstools. This plant usually produces zygospores, which are formed on the aërial mycelium. The

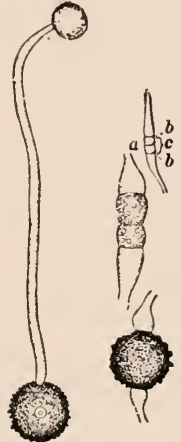

347. Mucor showing formation of zygospore on the right; germinating zygospore on the left. zygospores are large enough to be recognized with a hand lens. The material may be dricd and kept for winter study, or the zygospores may be prepared for permanent mieroscopic mounts in the ordinary way.

Willow mildew.-Most of the molds are saprophytes (192). There are many other fungi which are parasitic on living plants and animals. Some of them have interesting and complicated life-histories, undergoing many changes before the original spore is again produced. The

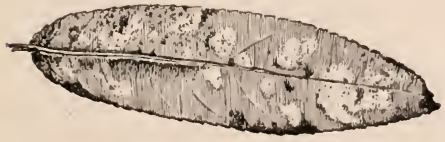

348. Colonies of willow mildew.

willow mildew and the common rust of wheat will serve to illustrate the habits of parasitic fungi.

The willow mildew (Uncinula salicis) forms white downy patches on the leaves of willows. (Fig. 348.) These patches consist of numerous interwoven threads which may be recognized as the mycelium of the fungus. The mycelium in this case lives on the surface of the leaf and nourishes itself by sending short branches into the cells of the leaf to absorb food-materials from them. 
Numerous summer-spores are formed on short erect branches all over the white surface. One of these branches is shown in Fig. 349. When it has grown to a certain length, the upper part begins to segment or divide into spores which fall and are scattered by the wind. Those

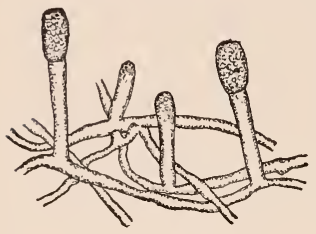

349. Summer-spores of willow mildew. falling on other willows reproduce the fungus there.

This process continues all summer, but in the later part of the season provision is made to maintain the mildew through the winter. If some of the white patches are closely examined in July or August, a number of little black bodies will be seen among the threads. These little bodies, called perithecia, are shown in

Fig. 350. To the naked eye they appear as minute specks, but when seen under a magnification of 200 diameters they present a very interesting appearance. They are hollow spherical bodies decorated around the outside with a fringe of crook-like hairs. The resting-spores of the willow mildew are produced in sacs or asci inclosed within the leathery perithecia. Fig. 351 shows a cross-section of a perithecium with the asci arising from the bottom. The spores remain securely packed in the perithecia. They do not ripen in the autumn but fall to the ground with the leaf and there remain securely protected among the dead foliage. The following spring they mature and are liberated by the decay of the peri-

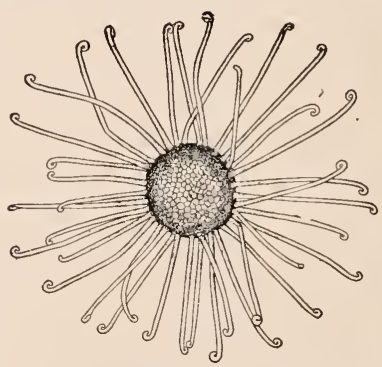

350. Perithecium of willow mildew. thecia. They are then ready to attack the unfolding leaves of the

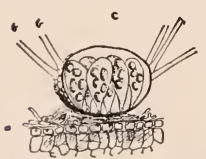

351. Section through perithecium of willow mildew, willow and repeat the work of the summer before.

Wheat rust.-The development of some of the rusts, like the common wheat rust (Puccinia graminis), is even more interesting and complicated than that of the mildews. Wheat rust is also a true parasite, affecting wheat and a few other grasses. The mycelium here cannot be seen by the unaided eye $_{1}$ for it consists of threads which are present 
within the host-plant, mostly in the intercellular spaces. These threads also send short branches, or haustoria (194), into the neighbor-

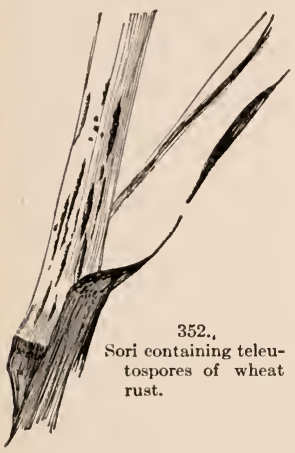
ing cells to absorb nutriment.

The resting-spores of wheat rust are produced in late summer, when they may be found in black lines breaking through the epidermis of the wheat-stalk. They are formed in masses, called sori (Fig. 352), from the ends of numcrous crowded mycelial strands just beneath the epidermis of the host. The individual spores are very small and can be well studied only with high powers of the microscope ( $\times$ about 400 ). They are brown two-eelled bodies with a thick wall. (Fig. 353.) Since they are the resting- or winter-spores, they are termed teleutospores ("completed spores"). They usually do not fall, but remain in the sori during winter. The following spring each cell of the teleutospore puts forth a rather stout thread, which does not grow more than several times the length of the spore and terminates in a blunt extremity. (Fig. 354.) This germ-tube, promycelium, now becomes divided into four cells by cross-walls, which are formed from the top downwards. Each cell gives rise to a short, pointed branch which, in the course of a few hours, forms a single small spore at its summit. In Fig. 354 a germinating spore is drawn to show the basidium, $b$, divided into four cells, each producing a short branch with a little sporidium, $s$.

A most remarkable circumstance in the life-history of the wheat rust is the fact that the mycelium produced by the tcleutospore can live only in barberry leaves, and it follows that if no barberry bushes are in the neighborhood the sporidia finally perish. Those whieh happen to lodge on a barberry bush germinate immediately, producing a mycelium which enters the barberry leaf and grows within its tissues. Very soon the fungus produces a new kind of spores on the barberry leaves. These are called acidio-

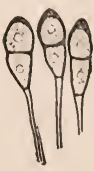

353.

Teuleutospore of wheat rust.

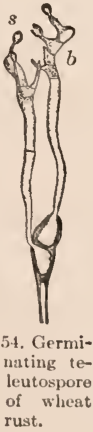
spores. They are formed in long chains in little fringed eups, or xcidia, which appear in groups on the lower side of the leaf. (Fig. 355.) These orange or yellow wcidia are termed cluster-cups. In Fig. 356 is shown 
a cross-section of one of the cups, outlining the long chains of spores, and the mycelium in the tissues.

The æcidiospores are formed in the spring, and after they have been set free some of them lodge on wheat or other grasses, where they germi-

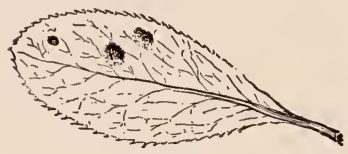

355. Leaf of barberry with cluster-cups. nate immediately. The germ-tube enters the leaf through a stomate, whence it spreads among the cells of the wheat plant. The recidiospores are not able to infect the barberry leaf. During summer one-celled uredospores ("blight spores") are produced in a manner similar to the teleutospores. The sori bearing them are red, due to the color of the spores of the mass. These are capable of germinating immediately and serve to disseminate the fungus during the summer on other wheat plants or grasses. (Fig. 357.) Late in the season, teleutospores are again produced, completing the life cycle of the plant.

Many rusts besides Puccinia graminis produce different spore-forms on different plants. The phenomenon is called heterocism, and was first shown to exist in the wheat rust. Curiously enough, the peasants of Europe had observed and asserted that barberry bushes cause wheat to blight long before science explained the relation between the cluster-cups on barberry and the rust on wheat. The true relation was actually demonstrated, as has since been done for many other rusts on their respective hosts, by sowing the rcidiospores

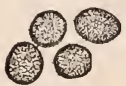

357.

Uredospores of wheat rust.

on healthy wheat plants and thus producing the rust. The cedar apple is another

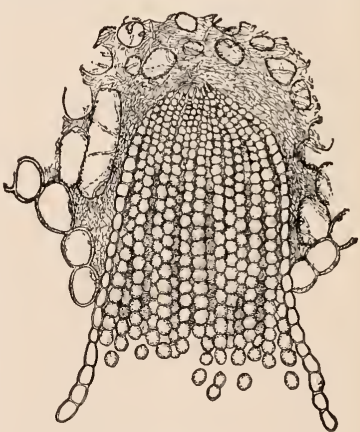

356. Section through a cluster-cup on barberry leaf. rust, the fungus producing the curious swellings often found on the branches of red cedar trees. In the spring the teleutospores ooze out from the "apple" in brownish yellow masses. It has been found that these attack various pomaceous fruit trees producing æcidia on their leaves. Cedar tiees about orchards may be a menace unless carefully watched. 


\section{LICHENS}

Liehens are so common everywhere that the attention of the student is sure to be drawn to them. They grow on rocks (Fig. 373), trunks of trees, old fences and on the earth. They are too diffieult for beginners, but a few words of explanation may be useful.

Lichens were formerly supposed to be a distinet or separate division of plants. They are now known to be organisms, each species of which is a constant association of a fungus and an alga. The thallus is ordinarily made up of fungous mycelium or tissue, within which the imprisoned alga is definitely distributed. This association of alga and fungus is usually spoken of as symbiosis, or mutually helpful growth, both together being able to accomplish work which neither could do independently. By others this union is considered to be a mild form of parasitism, in which the fungus profits at the expense of the alga. Each component may be able to grow independently, and under such conditions the algal cells seem to thrive better than when imprisoned by the fungus.

Lichens propagate by means of soredia, which are tiny parts separated from the body of the thallus, and consisting of one or more algal cells overgrown with fungous threads. These are readily observed in many liehens. They also produce spores, usually aseospores, which are always the product of the fungous element, and which reproduce the lichen by germinating in the presence of algal cells, to which the hyphæ immediately eling.

Lichens are found in the most inhospitable places and, by means of acids which they seerete, they attack and slowly disintegrate even the hardest rocks. By making thin seetions of the thallus with a sharp razor and examining under the compound mieroseope, it is easy to distinguish the two components in many lichens.

\section{LIVERIVORTS}

The liverworts are peeuliar, flat, green plants usually found growing on wet eliffs and in other moist, shady places. They frequently oceur in greenhouses where the soil is kept constantly wet. One of the eommonest liverworts is Marehantia polymorpha, two plants of which are shown in Figs. 358, 359. The plant consists of a flat ribbonlike thallus which spreads over the soil, beeoming repeatedly forked as it grows. The end of each branch is always eonspieuously notehed. There is a prominent midrib extending along the eenter of each branch 
of the thallus. On the under side of the thallus, especially along the midrib, there are numerous rhizoids which serve the purpose of roots, absorbing nourishment from the earth and holding the plant in its place. The upper surface of the thallus is divided into minute rhombic areas which ean be seen with the naked eye. Each of these areas is perforated by a small breathing pore or stomate which leads into a

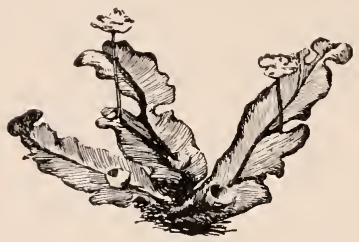

358.

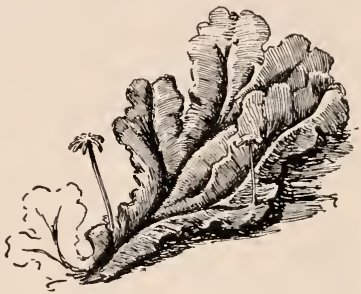

359.

Plants of marchantia.

cavity just beneath the epidermis. This space is surrounded by chlorophyll-bearing cells, some of which stand in rows from the bottom of the cavity. (Fig. 360.) The delicate assimilating tissue is thus brought in close communication with the outer air through the pore in the thick protecting epidermis.

At various points on the midrib are little cups which contain small green bodies. These bodies are buds or gemme which are outgrowths from the cells at the bottom of the cup. They become loosened and are then dispersed by the rain to other places where they take root and

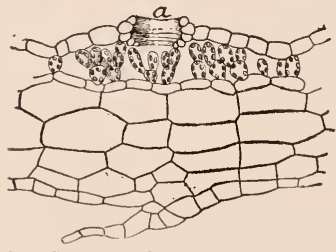

360 . Section of thallus of marchantia. Stomate at $a$.

scope magnifying from 100 to guide the pupil.

The antheridiophores are fleshy lobed disks borne on short stalks. grow into new plants.

The most striking organs on the thallus of marchantia are the peculiar stalked bodies shown in Figs. 358, 359. These are termed archegoniophore and antheridiophores or receptacles, each produced on separate plants. Their structure and function are very interesting, but their parts are so minute that they can be studied only with the aid of a micro400 times. Enlarged drawings will 
(Fig. 358.) The upper surface of the disk shows openings searcely visible to the naked eye. However, a section of the disk, such as is drawn in Fig. 361, shows that the pores lead into oblong cavities in the receptacle. From the base of each eavity there arises a thick club-shaped body, the antheridium. Within the antheridium are

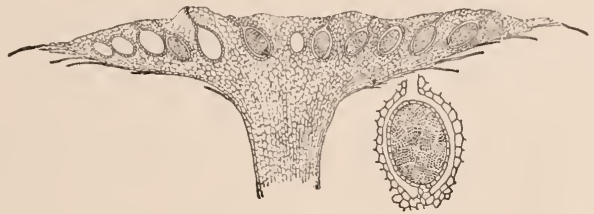

361. Section through antheridiophore of marchantia, showing antheridia. One antheridium more magnified.

formed many sperm-cells which are eapable of swimming about in water by means of long lashes or eilia attached to them. When the antheridium is mature, its wall ruptures and allows the ciliated spermcells to eseape.

The archegoniophores are also elevated on stalks. (Fig. 359.) Instead of a simple disk, the receptacle consists of nine or more fingerlike rays. Along the under side of the rays, between delieately fringed curtains, peculiar flask-like bodies, or arehegonia, are situated. The arehegonia are not visible to the naked eye. They can be studied only with the mieroseope ( $x$ about 400 ). One of them much magnified is represented in Fig. 362. Its prineipal parts are the long neck, $a$, and the rounded center, $b$, inclosing a large free cell-the egg-cell.

We have seen that the antheridium at maturity discharges its

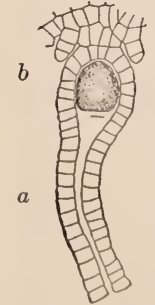

362. Archego. nium of marchantia. sperm-eells. These swim about in the water provided by the dew and rain. Some of them finally find their way to the archegonia and egg-cells, which are thus fertilized, as pollen fertilizes the ovules of higher plants.

After fertilization the egg-cell deve'ops into the spore-capsule or sporogonium. The mature sporecapsules may be seen in Fig. 363. They consist of an oval spore-case on a short stalk, the base of which is imbedded in the tissue of the receptacle from which it derives the necessary nourishment for the development of the sporogonium. At

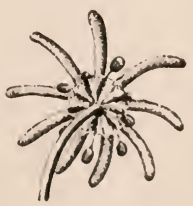

363. Archegoniophore with sporogonia of marchsntis. 


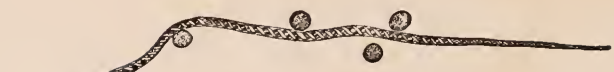

364. Spores and elaters of marchantia.

maturity the sporogonium is ruptured at the apex, setting free the spherical spores together with numerous filaments having spirally thickened walls. (Fig. 364.) These filaments are called elaters. When drying, they exhibit rapid movements by means of which the spores are scattered. The spores germinate and again produce the thallus of marchantia.

\section{MOSSES}

If we have followed carefully the development of marchantia, the study of one of the mosses will be comparatively easy. The mosses are more familiar plants than the liverworts. They grow on trees, stones, and on the soil both in wet and dry places. One of the common larger mosses, known as Polytrichum commune, may serve as an example. This plant grows on rather dry knolls, mostly in the borders of open woods, where it forms large beds. In dry weather these beds have a reddish brown appearance, but when moist they form beautiful green cushions. This color is due, in the first instance, to the color of the old stems and leaves and, in the second instance, to the peculiar

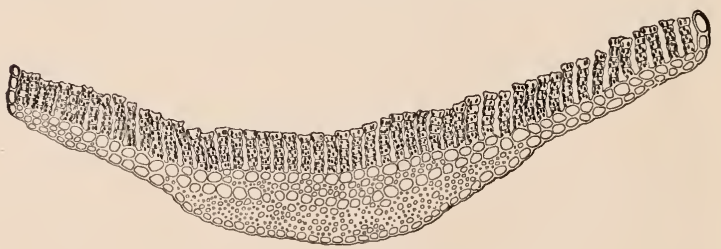

365. Section of leaf of Polytrichum commune.

action of the green living leaves under the influence of changing moisture-conditions. The inner surface of the leaf is covered with thin, longitudinal ridges of delicate cells which contain chlorophyll. These are shown in cross-section in Fig. 365. All the other tissue of the leaf consists of thick-walled, corky cells which do not allow moisture to penetrate. When the air is moist the green leaves spread out, 
exposing the chlorophyll cells to the air, but in dry weather the margins of the leaves roll inward, and the leaves fold closely against the stem, thus protecting the delicate assimilating tissue.

The antheridia and arehegonia of polytrichum are borne in groups

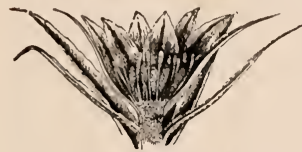

366 . Section through a receptacle of Polytricbum commune, showing paraphyses and antheridia. at the ends of the branches on different plants (many mosses bear both organs on the same branch). They are surrounded by involueres of eharaeteristie leaves termed perichatia or perichatal leaves. Multicellular hairs known as paraphyses are seattered among the archegonia and antheridia. The involucres with the organs borne within them are ealled receptacles or, less appropriately, "moss flowers." As in marchantia, the organs are very minute and must be highly magnified to be studied.

The antheridia are borne in broad eup-like receptaeles on the antheridial plants. (Fig. 366.) They are much like the antheridia of marchantia, but they stand free among the paraphyses and are not sunk in eavities. At maturity they burst and allow the sperm-cells or spermatozoids to escape. In polytrichum when the receptacles have fulfilled their function the stem continues to grow from the center of the cup. (Fig. 367, m.) The archegonia are borne in other receptacles on different plants. They are like the archegonia of marehantia exeept that they stand erect on the end of the branch.

The sporogonium which develops from the fertilized egg is shown in Fig. $367, a, b$. It consists of a long, brown stalk bearing the spore-case at its summit. The base of the stalk is embedded in the end of the moss stem by which it is nour-

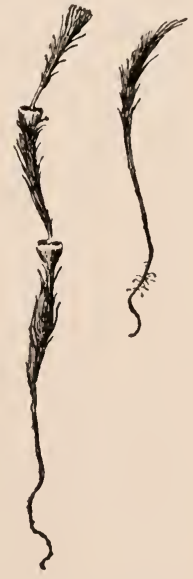

367. Polytrichum commune; $f, f$, fertile plants, one on the left in fruit; $m$, antheridial plant. ished. The capsule is entirely inclosed by a hairy cap, the calyptra, $b$. The calyptra is really the remnant of the archegonium, which for a time 
increases in size to accommodate and protect the young growing capsule. It is finally torn loose and carried up on the spore-case. The mouth of the capsule is closed by a circular lid, the operculum, having a conical projection at the center. The operculum soon drops, or it may be removed, displaying a fringe of sixty-four teeth guarding the mouth of the capsule.

This ring of teeth is known as the peristome. In most mosses the teeth exhibit peculiar hygroscopic movements, i.e., when moist they bend outwards and upon drying curve in toward the mouth of the capsule. This motion, it will be seen, serves to disperse the spores gradually over a long period of time.

Not the entire capsule is filled with spores. There are no elaters, but the center of the capsule is occupied by a columnar strand of tis-

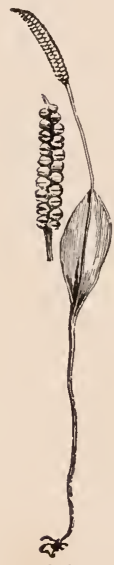

368 . sue, the columella, which expands at the mouth into a thin, membranous disk, closing the entire mouth of the capsule except the narrow annular chink guarded by the teeth. In this moss the points of the teeth are attached to the margin of the membrane, allowing the spores to sift out through the spaces between them.

When the spores germinate, they form a green, branched thread, the protonema. This gives rise directly to moss plants, which appear as little buds on the thread. When the moss plants have sent their little rhizoids into the earth, the protonema dies, for it is no longer necessary for the support of the little plants.

\section{FERNS}

The adder's tongue fern, Ophioglossum vulgatum, shown in Fig. 368, is one of a peculiar type of ferns belonging to the family Ophioglossacex. This plant has a short, subterranean stem from which a single frond unfolds each year. The roots arise near the bases of the leaves. The leaves are curiously divided into a sterile and a Ophioglossum fertile part, the latter being a sporophyll. The sterile part vulgatum.

has a tongue-shaped blade which is narrowed to a petiole.

The young leaves are inclosed by the sheathing base of the petiole. The growth is very slow, so that it takes several years for each leaf to develop before it is ready to unfold. During its development each leaf is sheathed by the one preceding it.

The sporophyll is elevated on a stalk arising near the base of the sterile part of the frond. The upper part consists of a spike bearing 
two rows of large spore-cases or sporangia sunk in the tissue. At maturity the sporangia open by transverse slits and discharge the inclosed spores.

When the spores germinate they produce subterranean tuberous prothallia which, however, are rarely found, and of whose history little is known. They develop archegonia and antheridia beneath the surface of the ground, and the fertilized egg produces the young fern plant.

The generations of the true ferns are explained in Chapter XXVI.

\section{EQUISETUMS, OR HORSETAILS}

There are about twenty-five species of equisetum, eonstituting the only genus of the unique family Equisetaceæ. Among these E. arvense is common on elayey and sandy soils.

In this species the work of nutrition and that of spore-production are performed by separate shoots from an underground rhizome. The fertile branches appear early in spring. The stem, which is 3 to 6 inches high, consists of a number of cylindrical furrowed internodes each sheathed at the base by a eircle of seale-leaves. The shoots are of a pale yellow color. They eontain no ehlorophyll, and are nourished by the food stored in the rhizome. (Fig. 369.)

The spores are formed on specially developed fertile leaves or sporophylls which are collected into a spike or cone at the end of the stalk (Fig. 369, $a$ ). A single sporophyll is shown at $b$. It consists of a short stalk expanded into a broad, mushroom-like head. Several large sporangia are borne on its under side.

The spores formed in the sporangia are very interesting and beautiful objects when examined under the microscope ( $X$ about 200). They are spherical, green bodies each surrounded by two spiral bands attached to the spore at their intersection, $s$. These bands exhibit hygroseopic movements by means of which the spores become entangled, and are held together. This is of advantage to the plant, as we shall see.

All the spores are alike, but some of the prothallia are better nourished and grow to a greater size than the others. The large prothallia produce only archegonia while the smaller ones produce antheridia. Both of these organs are much like those of the ferns, and fertilization is accomplished in the same way. Since the prothallia are usually diccious, the special advantage of the spiral bands holding the spores together, so that both kinds of prothallia may be in elose proximity, will be easily understood. As in the fern, the fertilized egg-cell develops into an equisetum plant. 
The sterile shoots, Fig. 369, st, appear much later in the season. They give rise to repeated whorls of angular or furrowed branches. The leaves are very much reduced scales, situated at the internodes. The stems are provided with chlorophyll and act as assimilating tissue, nourishing the rhizome and the fertile shoots. Nutriment is also stored in special tubers developed on the rhizome.
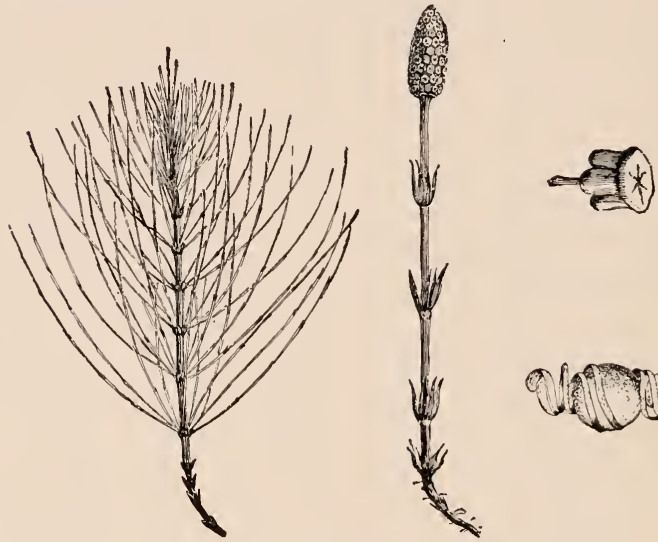

369. Equisetum arvense; $s t$, sterile shoot; $f$, fertile shoot showing the spike at $a ; b$, sporophyll, with sporangia; $s$, spore.

Other species of equisetum have only one kind of shoot-a tall, hard, leafless, green shoot with the spike at its summit. Equisetum stems are impregnated with silica and they are sometimes used for scouring floors and utensils: hence the common name "scouring rush."

\section{ISOت̈TES}

Isoëtes or quillworts are usually found in water or damp soil on the edges of ponds and lakes. The general habit of a plant is seen in Fig. $370, a$. It consists of a short, perennial stem bearing numerous erect, quill-like leaves with broad sheathing bases. The plants are commonly mistaken for young grasses.

Isoëtes bears two kinds of spores, large roughened ones, the macrospores, and small ones or microspores. Both kinds are formed in spo- 
rangia borne in an excavation in the expanded base of the leaf. The macrospores are formed on the outer, and the microspores on the inner leaves. A sporangium in the base of a leaf is shown at $b$. It is partially eovered by a thin membrane, the relum. The minute triangular appendage at

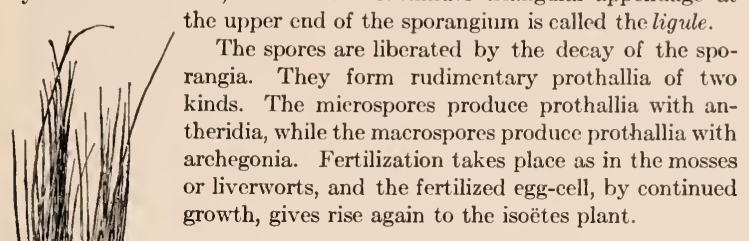

\section{ALTERNATION OF GENERATIONS}

In Chapter XXVI, the alternations of generations and the terms gametophtye and sporophyte were explained. In many of the plants just studied, this alternation is more clearly and beautifully marked than in any other groups of plants.

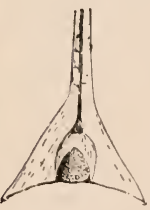

370. Isoëtes showing habit of plant at $a ; b$, base of leaf showing sporangium, velum, and ligule.

In each generation, the reproductive body (egg or spore) gives rise to a new plantform or generation different from the parent generation. In the liverworts the thallus produces the egg. The fertilized egg-cell is the beginning of a new plant, but this new plant is not like the thallus which produced the egg, nor does it lead an independent existence. It is the sporogonium, whieh, although it is attached to the thallus, is not a morphological part thereof. The sporogonium produces spores. It is the sporophyte generation of the plant, and not until the spores germinate is the thallus again produced. The same is true in the mosses. The "moss plant" produces the egg-cells. It is the gametophyte. The fertilized egg-cell develops into the sporophyte - the spore-ease and its stem. We can pull the stem of the capsule out of the moss plant and thus separate the sporophyte from the gametophyte.

The fungi and alga are omitted from these remarks. In the former there is nothing analogous to the sporophyte and the gametophyte. In algæ like spirogyra, evidently the whole plant is a gametophyte, 
and, since the zygospore germinates directly into a new gametophyte, there is probably no sporophyte. In some other algx traces of a sporophyte have been found, but the discussion of these would lead too far for the present purpose.

In the ferns the egg-cells are developed on the prothallus. This then is the gametophyte. It corresponds to the thallus of marchantia and to the "moss plant," but it has become much reduced. The plant developing from the fertilized egg-cell is the large and beautiful "fern plant" differentiated into stems and leaves. Since the fern plant produces the spores directly, it is the sporophyte and corresponds to the shaft and capsule of the mosses. Both sporophyte and gametophyte lead an independent existence.

As we pass on to equisetum and oscetes, the sporophyte is still more conspicuous in comparison with the gametophyte. In isoëtes the prothallus (gametophyte) is very rudimentary, consisting only of a few cells remaining within the spore, which merely bursts to expose the archegonia or to allow the sperm-cells to escape. Moreover, the spores have become differentiated into micro- and macrospores corresponding to the pollen and embryo-sac of higher plants.

This gradual increase of the sporophyte and reduction of the gametophyte can be traced on through the flowering plants in which "the plant" is the sporophyte, and the gametophyte is represented simply by a few cells in the germinating pollen grain, and in the embryo-sac. 


\section{PART II-}

\section{THE PLANT IN RELATION TO ITS}

ENVIRONMENT AND TO MAN 



\section{CHAPTER XXVIII}

\section{WHERE PLANTS GROW}

354. Environment.-The circumstances and surroundings in which an organism lives constitute its environment. The environment comprises effects of soil, moisture, temperature, altitude, sunlight, competition with animals and other plants, and the like. An organism is greatly influenced by the environment or conditions in which it lives. Not only must a plant live and grow and multiply its kind, but it must be capable of withstanding diverse environments.

355. The particular place in which a plant grows is known as its habitat (i.e., its "habitation"). The habitat of a given plant may be a swamp, hill, rock, sand plain, forest, shore. The plant inhabitants of any region are known collectively as its flora. Thus we speak of the flora of a meadow or a hill or a swamp, or of a country. The word is also used for a book describing the plants of a region (as in Part IV).

356. Plants Grow Where They Must.-The plant is not able to choose its environment. It has no volition. Its seeds are scattered, and only a few of them fall in favorable places. The seeds make an effort to grow even though the places are not favorable; and so it happens that plants are often found in places that are little adapted to them. See the fern growing on a brick in Fig. 74. Plants must grow in unoccupied places.

357. Not only do the seeds fall in unfavorable places, but most places are already occupied. So it comes that plants grow where they must, not always where the conditions are the most favorable. There are, of course, certain limits beyond which plants cannot grow, Water-lilies can thrive 


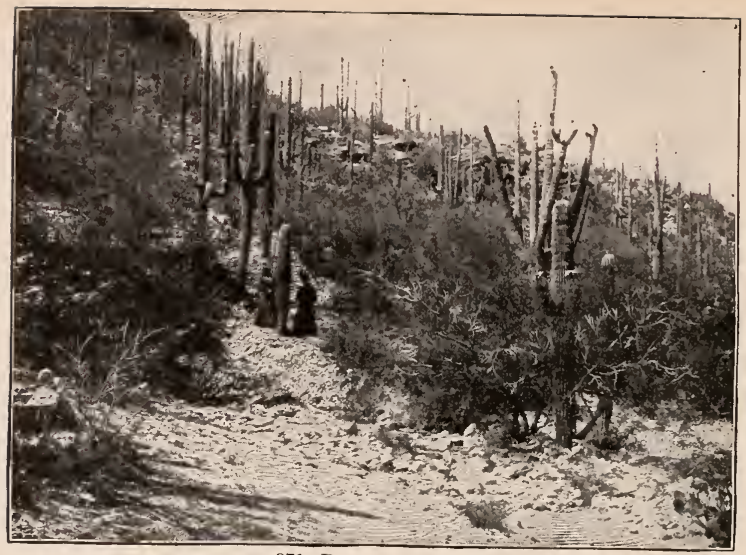

371. Desert vegetation.

The tree cacti grow only in special regions. Arizona.

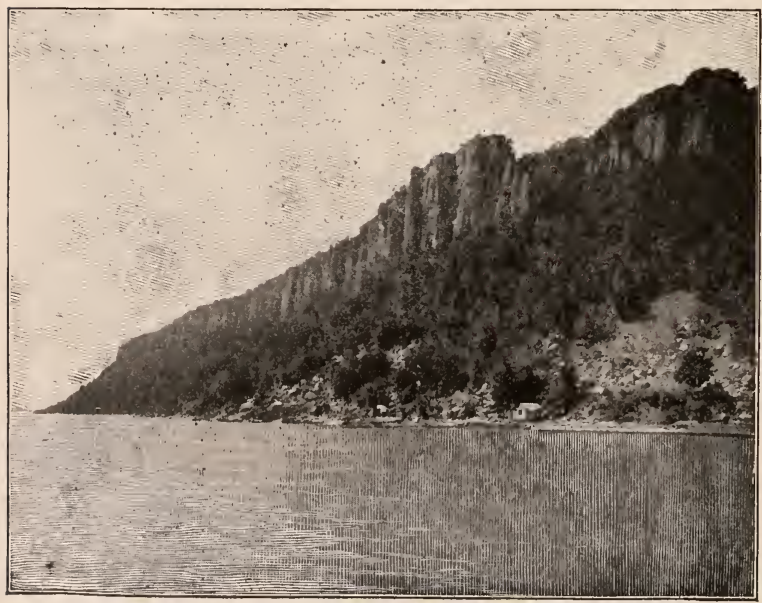

372. Plants seize the first opportunity to grow. Palisades of the Hudson.

(206) 
only in water, and white oaks only on dry land, but it is seldom that either the water-lily or the oak finds the most congenial place in which to grow. Fine large plants of the lily and strong giant trees of the oak are so infrequent, as compared with the whole number, that we stop to admire them.

358. Originally, plants probably were aquatic, as animals were. Much of the earth was sea. Many plants are now aquatic, and the larger number of these-as algæ and their kin-belong to the lower or older forms of plant life. Many plants of higher organization, however, as the water-lilies, have taken to aquatic life. True aquatic plants are those that always live in water, and that die when the water dries up. They are to be distinguished from those that live on shores or in swamps. Aquatic plants may be wholly immersed or under water, or partly emersed or standing above the water. Most flowering aquatic plants come to the surface to expand their flowers or to ripen their fruits. Some aquatic plants are free-swimming, or not attached to the bottom. Of this kind are some utricularias or bladder-worts. In some waters, particularly in the ocean, there are enormous quantities of free-swimming microscopic life, both animal and vegetable, which is carried about by currents: this is known under the general name of plankton (Greek for "wandering" or "roaming").

359. The general tendency has been for plants to become terrestrial, or land-inhabiting. Terrestrial plants often grow in wet places, but never

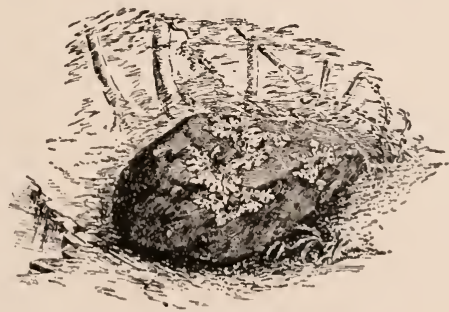

373. The lichen grows on the hard rock. in water throughout their entire life; of such are swamp, bog and marsh plants. Some plants have the ability to grow 
in standing water when young and to become terrestrial as the water dries up. Such are amphibious. Some buttercups are examples; mermaid-weed (Proserpinaca) is another.

360. Some plants grow in very special soils or special localities, and consequently are infrequent or are confined to certain well-marked geographical regions. (Fig. 371.)

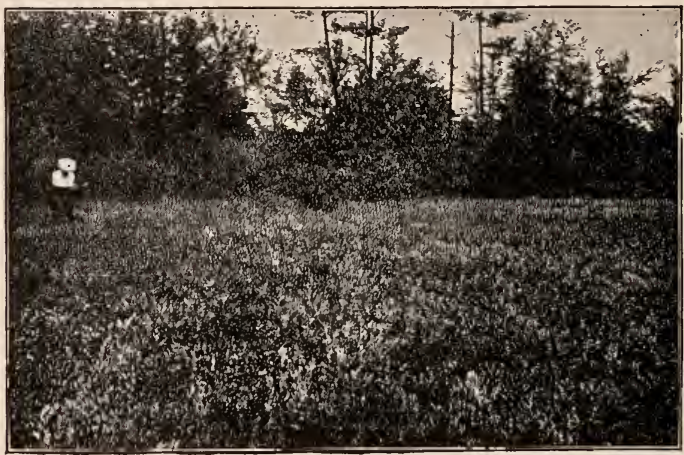

374. Sphagnum bog, green and living on top, but dead and dying underneath. Sphagnum moss is used by nurserymen and florists as packing material for plants.

Common plants are those that are able to accommodate themselves to widely different environments. Weeds are examples. Many plants have become so specialized in habitat as to be parasitic, saprophytic or epiphytic. (Chap. XV.)

361. Common plants often grow in most unusual and difficult places. Note that some weeds grow not only in fields, but often gain a foothold in chinks in logs, on rotting posts, in crotches of trees, on old straw stacks, in clefts and crannies of rocks. In moist climates, as in England, plants often grow on thatched roofs.

362. Plants may be said to be seeking new places in 
which to grow. Whenever ground is eleared of vegetation, plants again spring up. The farmer plows the meadow or pasture, and immediately a horde of weeds appears.

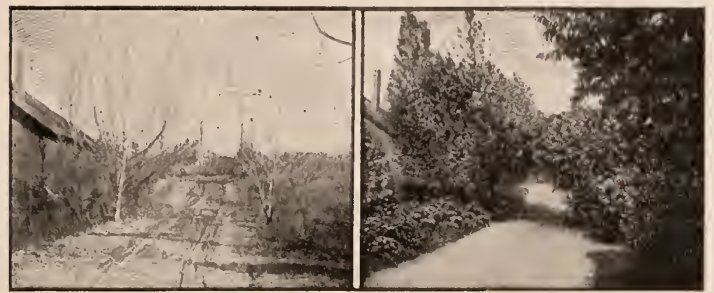

375. The same landscape in winter and in summer.

Any breach or break in the earth's surface makes room for a new group of plants. Note how the railway embankments and the newly graded roadsides take on a covering of vegetation. Observe the ragweed. Whenever soil is formed at the base of a eliff, plants at once secure a foothold. (Fig. 372.)

363. Plants Aid in the Formation of Soil.-This they do in two ways: by breaking down the rock; by passing into earth when they decay. Even on the hardest rocks, lichens and mosses may grow. (Fig. 373.) The rhizoids eat away the rock. A little soil is formed. Ferns and other plants gain a foothold. The erevices are entered and widened. Slowly the root acids corrode the stone. Leaves and stems collect on the rock and decay. Water and frost lend their aid. As the centuries pass, the rock is eaten away and pulverized. Note the soil that eollects on level rocks in woods where wind and rain do not remove the aceumulations.

364. In bogs and marshes and on prairies, the remains of plants form a deep black soil. In bogs the vegetable matter is partially preserved by the water, and it slowly becomes solidified into a partially decayed mass known as 
peat. When dug out and dried, peat may be used as fuel. Finally it may decay and make a vegetable soil known as muck. When thoroughly decayed, plants become vegetable mold or humus. New plants grow on peat or muck, and the accumulations year by year tend to raise the level of the bog, and the surface finally becomes so high as to support plants of the high lands. An important agent in the formation of peat bogs is sphagnum moss. New moss grows on the old, and the bog becomes higher as time goes on. (Fig. 374.)

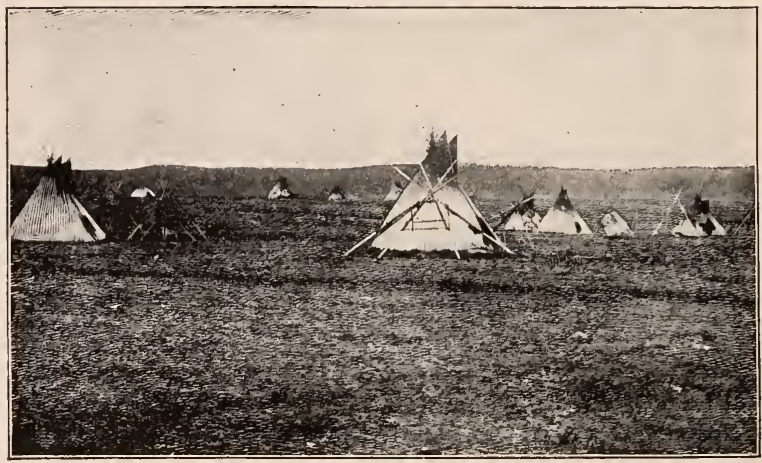

376. A landseape devoid of vegetation. Western United States.

365. Plants Contribute to Scenery.-Aside from sky and air, natural scenery depends chiefly on two things: the physical contour of the earth; the character of the vegetation. Contrast the aspect of winter and summer scenes as expressed in vegetation. (Fig. 375.) Imagine any landscape with which you are familiar to be devoid of plants. Compare Figs. 376 and 377.

Review.-What is meant by environment? By habitat? Flora? What determines where plants shall grow? What is an aquatic plant? 
Explain immersed, emersed, free-swimming. What is plankton? Explain terrestrial. Amphibious. Why are some plants rare or local? Why are some plants common? Name some unusual places in which you have seen plants growing. Give examples of how plants occupy the new places. How do plants aid in the formation of soil? Explain what is meant by peat, muck, humus. How are peat bogs formed? What relation have plants to scenery?

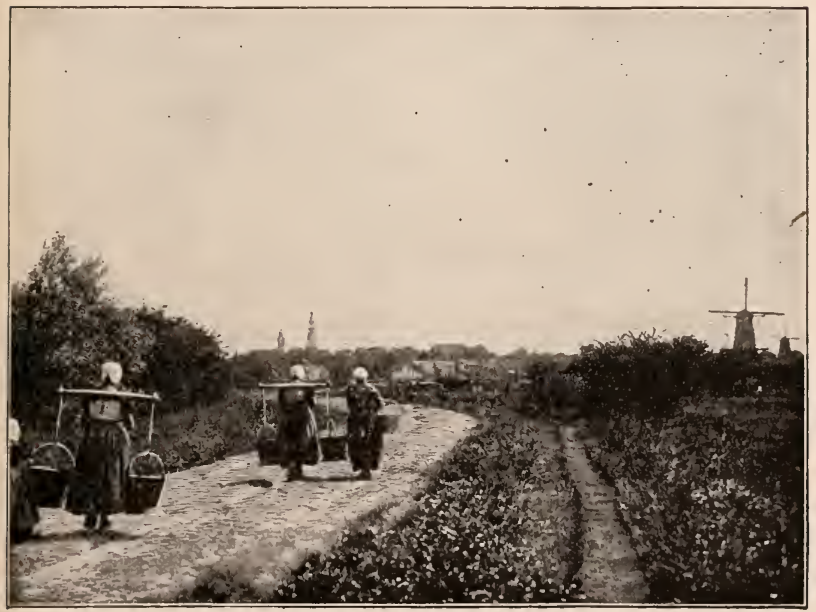

377. A landscape with vegetation. Holland. 


\section{CHAPTER XXIX}

\section{CONTENTION WITH PHYSICAL ENVIRONMENT}

366. The Physical Environment.-We have seen (354) that the environment in which a plant grows is made up of two sets of factors-the physical environment of climate and soil, and the organic environment of competing animals and plants.

367. Modifications to Climate in General.-Every particular climate induces particular modifications in its plants. There are two general ways, however, in which plants are modified by climate: modification in the length of the period of growth; modification in stature. Any modification of the plant, visible or invisible, that enables it to grow in a climate at first injurious to it, is acclimatization.

368. In short-season climates, plants hasten their growth. They mature quickly. Indian corn may require five or six months in which to mature in warm countries, but only

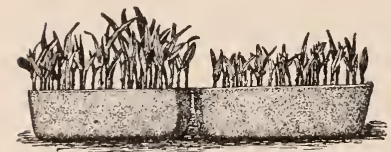

378. Germination of corn grown in New York (on the left) and in Alabama. three months in very cold countries. Garden vegetables probably mature quicker from the time of planting in the North than in the South when they are raised from seeds grown in their respective localities. Some seedsmen think this to be true and they like to raise seeds of early varieties in the North, for such seeds usually give "early" plants. Many plants that are perennials in warm countries become annuals or plurannuals in cold countries (14).

369. Plants are usually dwarf or smaller in stature in 
short-season climates. Indian corn is a conspicuous example. As one ascends high mountains or travels in high latitudes, he finds the trees becoming smaller and smaller, until finally he passes beyond the regions in which the trees can grow. Many of the Esquimaux doubt the statements of travelers that there are plants as high as a man. In these high altitudes and high latitudes, plants tend also to become prostrate.

\section{Plants} are Influenced by Wind.-In regions of strong prevailing winds, as on lake and sea shores and on hills and mountains, treetops develop unsymmetrically and are heaviest on the leeward side. (Figs. 379, 380.) Observe this fact in orchards in windy regions, and note

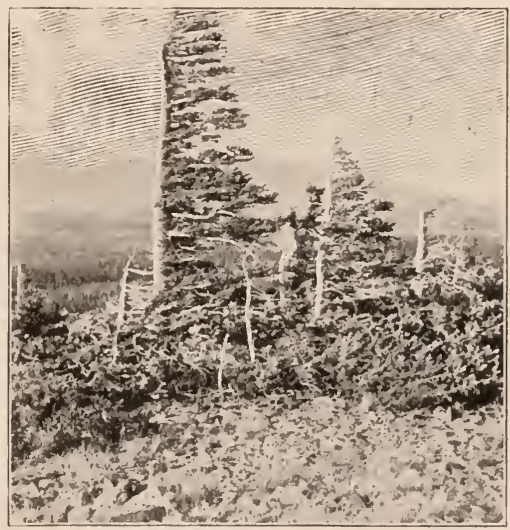

379. Evergreen trees on wind-swept heights of the Roeky Mountains.

that the most unsymmetrical trees are those on the exposed side of the plantation.

371. Trees often lean away from the prevailing winds. The tips of the branches of exposed trees usually indicate whether there are strong prevailing winds. (Fig. 381.) Observe trees in pastures and along roadsides, particularly in high places and within a few miles of exposed shores. Note the tip-top spray of hemlock trees.

372. Plants are Profoundly Influenced by Soil.-The 
nutrient supply varies with the kind of soil; and the supply determines to a large extent the character of the individual plant. On poor soils plants are small; on rich soils they are large. The difference between poor and good yields of wheat, or any other crop, is largely a question of soil-fertility. The farmer reinforces his poor soils by the addition of fertilizers, in order to make his plants vary into larger or more productive individuals.

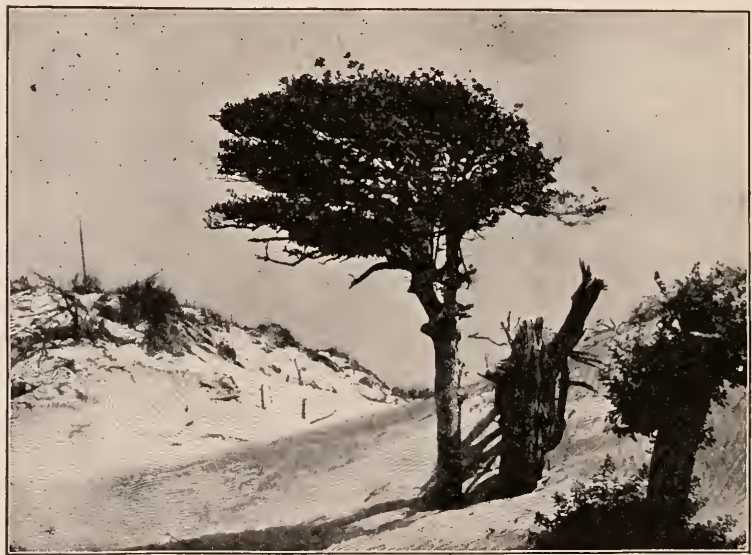

380. One-sided holly tree growing near the ocean. New Jersey.

373. The moisture-content of the soil exerts a marked influence on plants. We have found (157) that a large part of the plant-substance is water. The water is not only itself food for plants, but it carries nutrients into the plant and transports them from tissue to tissue. However rich a soil may be in mineral nutrients, it is inert if it contains no moisture. The character of the plant is often determined more by the moisture in the soil than by all the other soil 
materials. Note how rank the plants are in low places. Observe how the weeds grow about the barn where the soil is not only rich but where moisture is distributed from the eaves. Contrast with these instances the puny plants that grow in dry places. In dry countries irrigation is employed to make plants grow vigorously; or the moisture may be stored in the soil by means of deep preparation and frequent surface tillage and other dry-farming methods. In moist and rich soil plants may grow so fast and so tall as not to be able to withstand the wind, as in Fig. 382.

374. Plants are Influenced by the Exposure of the Place In Which They Grow.-The particular site or outlook is known as the exposure or aspect. The exposure, for example, may be southward,

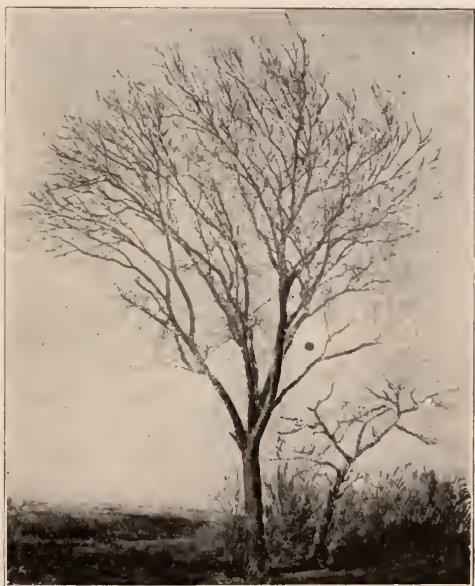

381. A tree that shows which way the wind blows. Oklahoma. eastward, bleak, warm, cold. A favorable exposure for any plant is one that supplies the requisite warmth, room, sunlight, moisture and nutrients, and immunity from severe winds and other destructive agencies. Against the edge of a forest (Fig. 383) or at the base of a cliff, certain plants thrive unusually well. Note the plants of any kind growing in different exposures: observe that they vary in stature, 


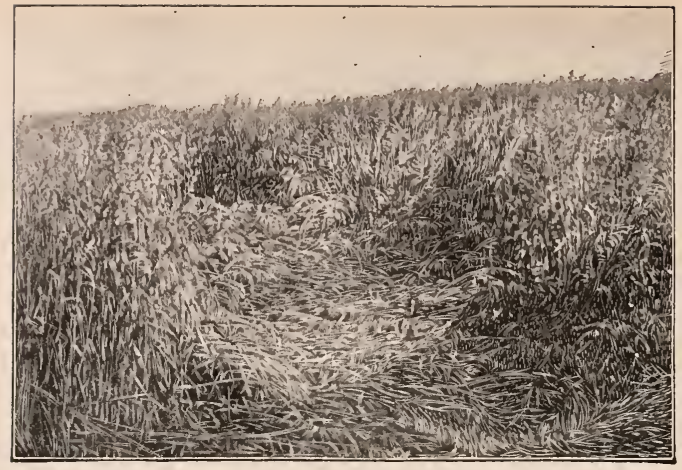

382. "Lodged" oats. On rich ground the grain is often broken by wind and rain, the plants having grown so heavy as to be unable to support themselves.

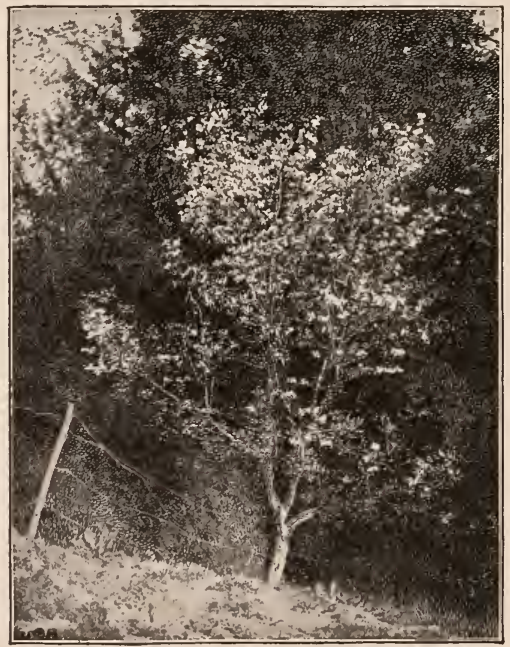

383. The flowering dogwood is seen at its best along the margins of the wood and in partially open places. 
time of maturity, color of foliage and flowers, productiveness, size of leaves and flowers, longevity.

Review.-Contrast physical and organic environments. How are plants modified by climate? 1)efine acclimatization. Explain how time of maturity is influenced by climate. Explain how climate influences stature. How do winds affect plants? How are plants influenced by soil? By soil moisture? Exposure?

Observe two or three plants of any one kind on your way to school, and note how they differ from each other in size, form, branching, color, earliness or lateness, productiveness and other characters: are you able to correlate these differences with the conditions in which the plants grow? 


\section{CHAPTER XXX \\ COMPETITION WITH FELLOWS}

375. The Fact of Struggle for Existence.-We have seen (Chapter IX) that branches contend amongst themselves for opportunity to live and grow. Similarly, separate plants contend with each other. We shall observe that this is true; and we are compelled to believe it by considering the efforts that all plants make to propagate themselves. The earth is filled with plants. It is chiefly when plants die or are killed that places are made for others. Every one of these plants puts forth its utmost effort to prepetuate its kind. It produces seeds by the score or even by the thousand. In some cases it propagates also by means of vegetative parts. If the earth is full and if every plant endeavors to multiply its kind, there must be struggle for existence.

376. The effects of struggle for existence are of three general categories: (1) the seed or spore may find no opportunity to grow; (2) sooner or later the plant may be killed; (3) the plant may vary, or take on new characters, in response to the conditions in which it grows. Consicler the crop of seeds that any plant produces: how many germinate? How many of the young plants reach maturity? Note the profusion of seedlings under the maples and elms, and then consider how few maple and elm trees there are. Count the seeds on any plant and imagine that each one makes a plant: where will all these new plants find a place in which to grow?

377. What Struggle for Existence Is.-Struggle for existence with fellows is competition for room or space, for nutrients and moisture in the soil, for light. We may consider examples in each of these three categories. 


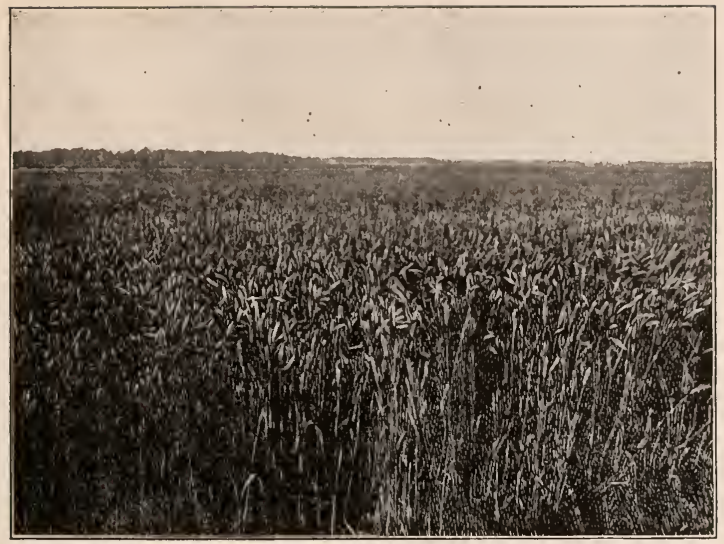

384. There is no opportunity for weeds in a good field of wheat.

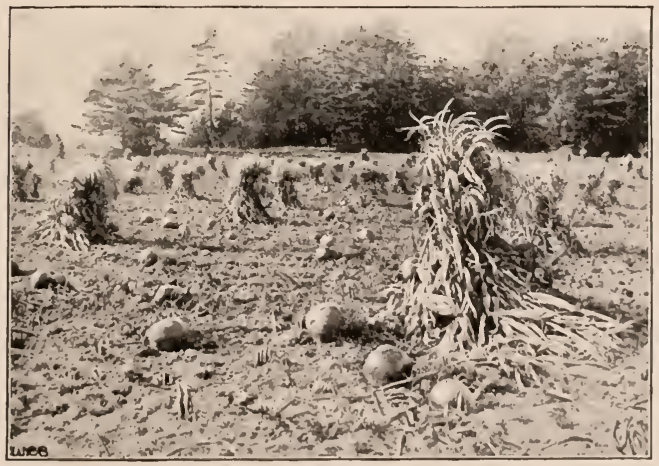

385. Divergence of character in a cornfield. 


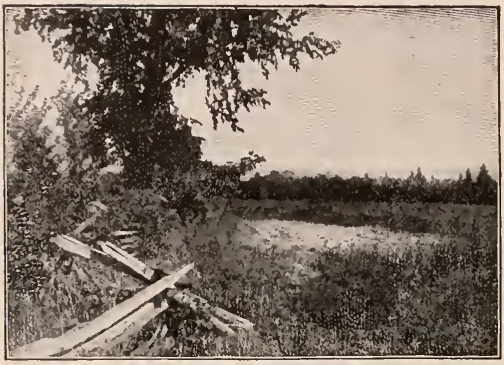
that a large area remains bare of vegetation.
386. The tree has appropriated the food and moisture, so

378. If the earth is filled with plants, there must be sharp competition for every inch of its surface. If any good soil is not populated with plants, it is usually because it has recently been moved. If the farmer does not move or till his soil frequently, various plants get a foothold, and these plants he calls weeds. Determine how much room an apple tree, or other plant, occupies: then calculate how much space would be required for all the seedlings of that tree or plant. The greater the population of any area, the less chance

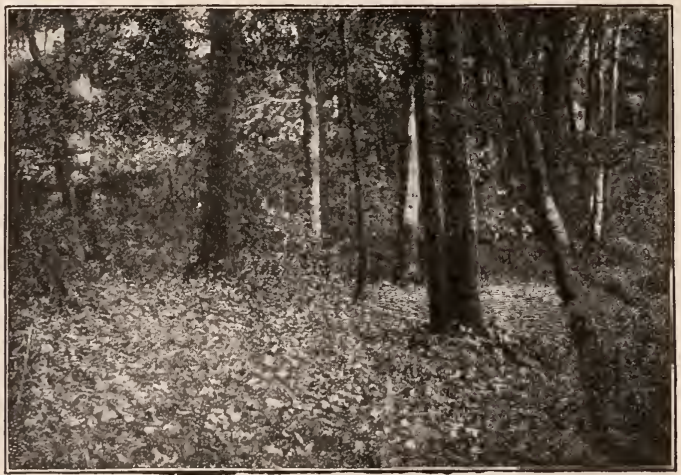

387. Low shade-loving plants on the forest floor. 
have other plants to gain a foothold. When the wheat completely covers the ground, as in Fig. 384, there are no weeds to be seen.

379. Plants of different form and habit may grow together, and thereby the area may support more plants than would be possible if only one kind were growing on it. This principle has been called by Darwin the divergence

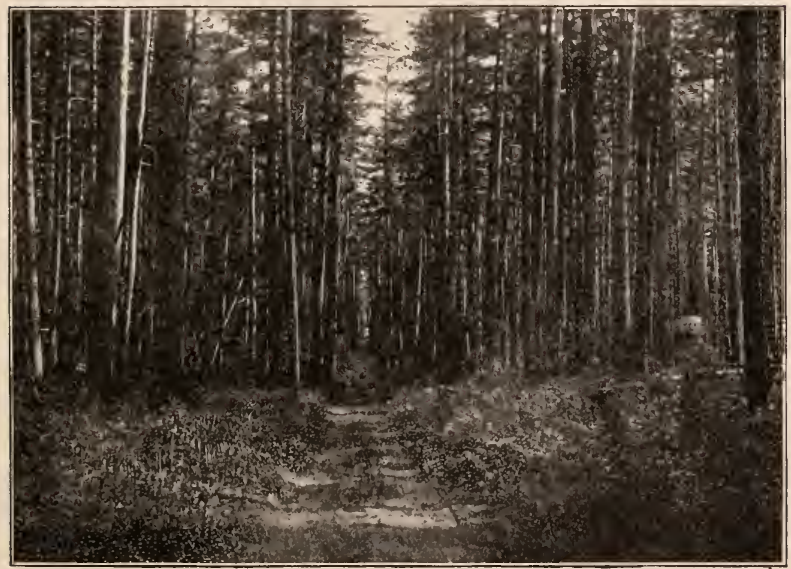

388. A primeval pine forest.

Along the roadway foreign vegetation has come in. Michigan.

of character. When an area is occupied by one kind of plant, another kind may grow between or beneath. Only rarely do plants of close botanical relationship grow together in compact communities. A field that is full of corn may grow pumpkins between. (Fig. 385.) A full meadow may grow white clover in the bottom. Herbs may grow on the forest floor. When an orchard can support no more trees, weeds may grow bencath. 
380. We have learned that the plant may possess an extensive root-system $(25,26)$. The plant that is first established appropriates the nutrients to itself, and newcomers find difficulty in gaining a foothold. Note the bare area near

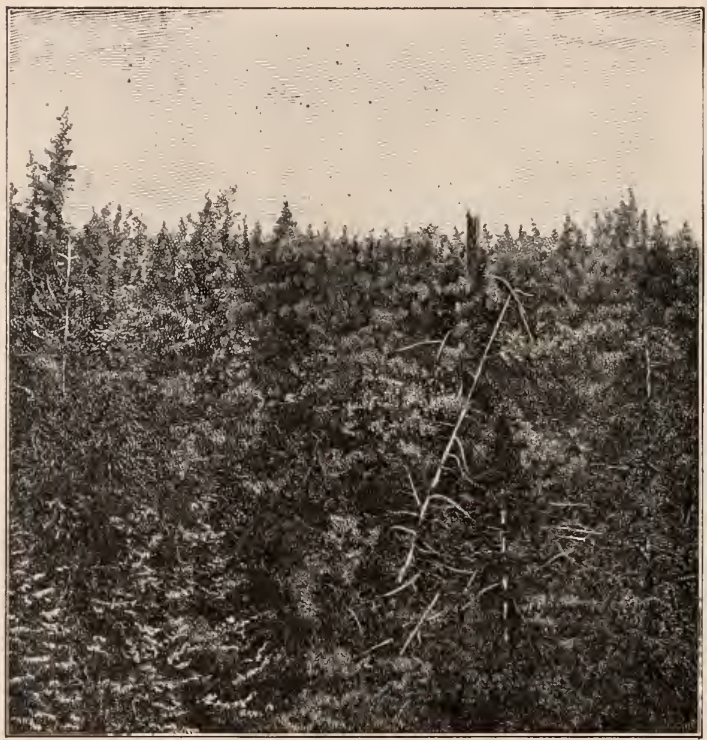

389. On the top of an evergreen forest.

the large tree in Fig. 386. Recall how difficult it is to make plants grow when planted under trees. This is partly due to the intercepting of the rain by the tree-top, partly to shade, and partly to lack of available food and moisture in the soil, and perhaps partly to unknown factors. The farmer knows that he cannot hope to secure good crops near large trees, 
even beyond the point at which the trees intercept the rain and light. It is difficult to establish new trees in the vacancies in an old orchard.

381. In Chapter VIII we studied the relation of the plant and its parts to sunlight. Plants also compete with each other for light. Plants climb to get to the light (Chapter XVIII). (Fig. 77.) Some plants have become so modified as to

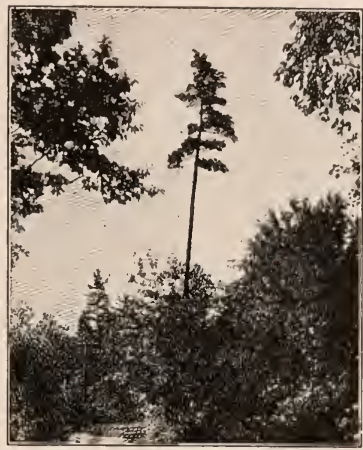

390. The tell-tale pine. grow in subdued or transmitted light, but no green plants can grow in darkness. The low plants in forests are shadelovers. (Fig. 387.) Note the plants that seem to be shadelovers and those that prefer full sunlight. Some plants

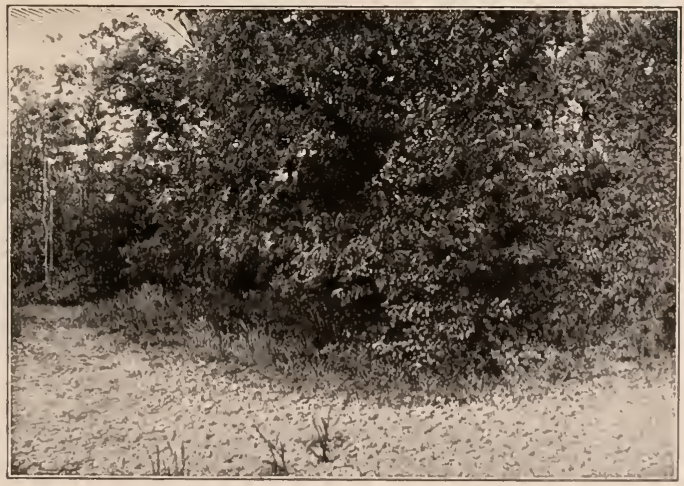

391. The forest rim. Looking toward the woods. 


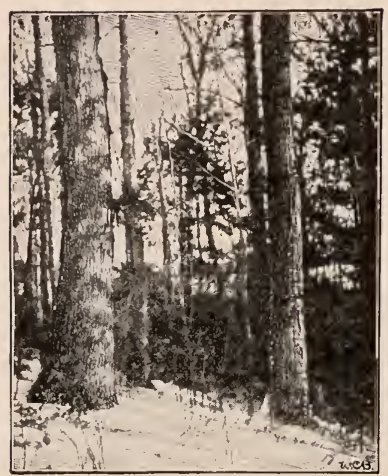

392. The forest center. Looking from the woods, with the forest rim shown in Fig. 391 seen in the distance.

are so constituted as to grow well in both sun and shade. Most ferns are shade-lovers.

382. In the midst of dense plant populations, each individual grows upwards for sunlight. Thus are forests made: the competing trees become long slender boles with a mantle of foliage at the top. The side branches do not develop or they die for lack of light and food, and they fall from decay or are broken by storm; the wounds are healed, and the bole becomes symmetrical and trim. Fig. 388 shows the interior of a primeval pine forest. Note the

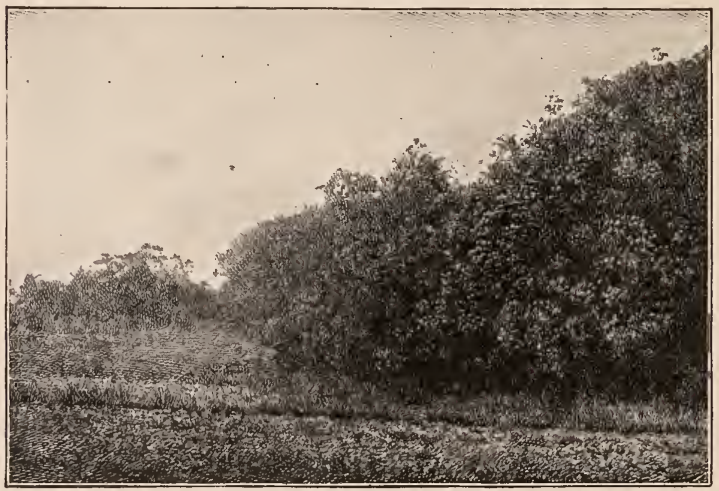

393. The foliage bank of a tangle. 
bare trunks and the sparse vegetation on the dim forest floor. Fig. 389 is the top of a great forest. With these pietures compare Figs. 79 and 80. Fig. 384 shows a deep wheat forest. A lone survivor of a primeval forest is shown in Fig. 390. In dense plantations, plants tend to grow to a single stem. When these same plants are grown in open or cultivated grounds, they often become bushy or develop

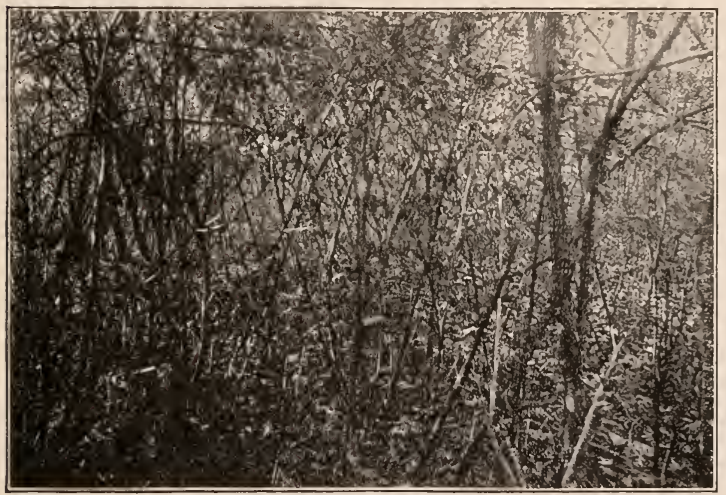

394. View just inside the tangle.

more than one trunk. In what places have you seen trees with more than one trunk?

383. On the margins of dense populations, each individual grows outwards for sunlight. Note the dense forest rim: then plunge through it, and stand by the tall bare trunks. Figs. 391, 392, show these two views of the same forest. Note the kinds of trees and other plants that grow in areas similar to those depicted in these illustrations. Note the dense wall of foliage in Fig. 393, and the thin brushy area just behind it in Fig. 394. Observe the denser and greener foliage on the outside rows in thick orchards. Consider how 


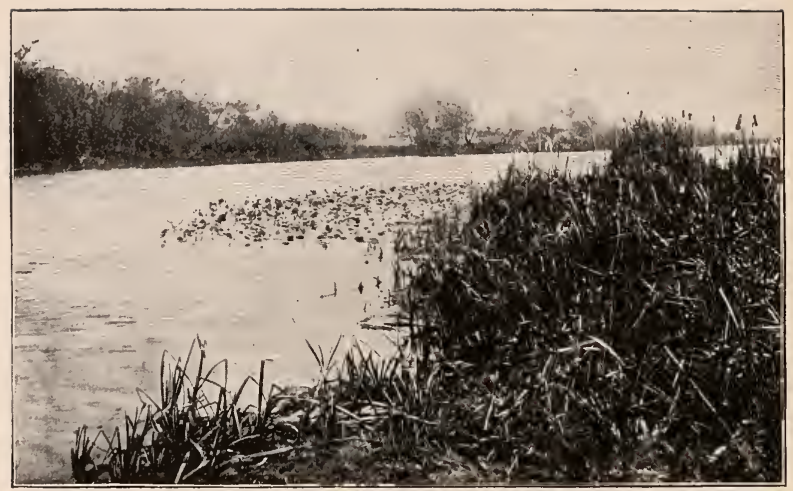

395. A hydrophytic society. New York.

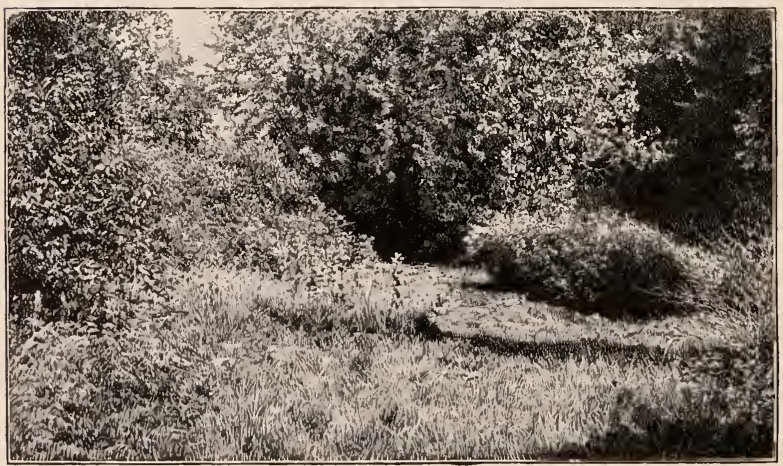

396. A mesophytic society. Michigan. 
the plants extend over the borders in dense flower-beds. Note where the best-foliaged plants are in the greenhouse. Notice the foliage on the outer rows in a very thick cornfield. Observe how plants nearest to buildings reach outward for the light and room.

REview.-Why is there struggle for existence? How does it affect plants? Tell what it is. How do plants compete for space? What is meant by the phrase "divergence of character?" Give examples. How do plants compete for nutrients and water from the soil? In what respects have plants become modified to the light relation? How do plants grow in dense plantations? On the margins of these plantations? You know some tree or other plant: describe how it is constituted to compete with its fellows. 


\section{CHAPTER XXXI}

\section{PLANT SOCIETIES}

384. What Plant Societies Are.-In the long course of evolution, in which plants have been accommodating themselves to the varying conditions in which they are obliged to grow, they have become modified to every different environment. Certain plants, therefore, may live together or near each other, all enjoying the same conditions and surroundings. These aggregations of plants adapted to similar conditions are known as plant societies.

385. Moisture and temperature are the leading factors in determining plant societies. The great geographical societies or aggregations of the plant world are for convenience associated chiefly with the moisture-supply. These are: (1) hydrophytic or wet-region societies, comprising aquatic and bog vegetation (Fig. 395); (2) xerophytic or arid-region societies, comprising desert and much sand-region vegetation (Fig. 371); (3) mesophytic or mid-region societies, comprising the vegetation in intermediate conditions (Fig. 396). Mesophytic vegetation is characteristic of most regions that are fitted for agriculture. The halophytic or salt-loving societies are also distinguished, comprising the seashore and salt-area vegetation. Much of the characteristic scenery of any place is due to its plant societies (365). Xerophytic plants usually have small and hard leaves, apparently to prevent too rapid transpiration. Usually, also, they are characterized by stiff growth, hairy covering, spines, or a much-contracted plant-body, and often by large underground parts for the storage of water. Halophytic plants are often fleshy. 
386. Plant societies may also be distinguished with reference to latitude and temperature. There are tropical societies, temperate-region societies, boreal or cold-region societies. With reference to altitude, societies might be classified as

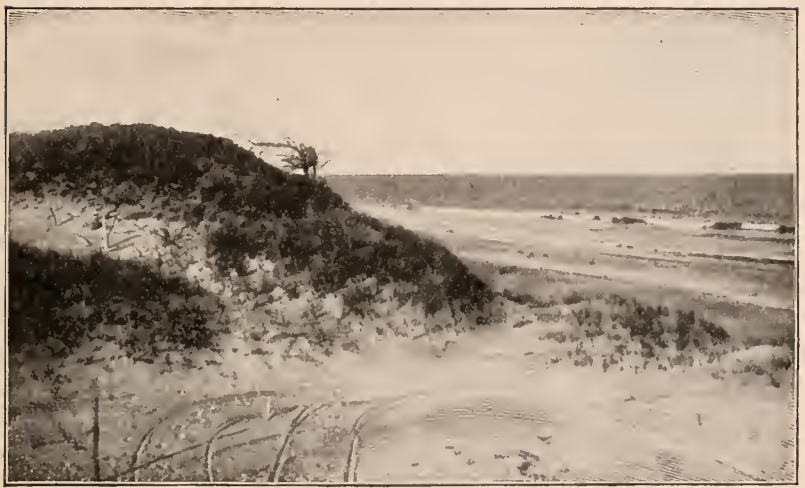

397. A society of sand-dune plants. New Jersey.

lowland (which are chiefly hydrophytic), intermediate (chiefly mesophytic), subalpine or mid-mountain (which are chiefly boreal), alpine or high-mountain.

387. The above classifications have reference chiefly to great geographical floras or societies. But there are societies within societies. There are small societies coming within the experience of every person who has ever seen plants growing in natural conditions. There are roadside, fencerow, lawn, thicket, pasture, dune (Fig. 397), woods, eliff, barn-yard, corn-field societies. Every different place has its characteristic vegetation. Note the smaller societies in Figs. 395 and 396 . In the former is a water-ily society and a cat-tail society. In the latter there are grass and bush and woods societies. 
388. Some Details of Plant Societies.-Societies may be composed of scattered and intermingled plants, or of dense clumps or groups of plants. Dense clumps or groups are usually made up of one kind of plant, and they are then called colonies. Colonies of most plants are transient: after a short time other plants gain a foothold amongst them, and an intermingled society is the outcome. Marked exceptions to this are grass colonies and forest colonies, in which one kind of plant may hold its own for years and centuries.

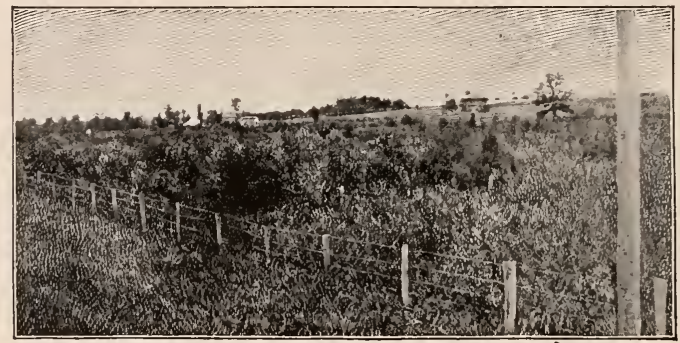

398. The return to forest. Bushes and trees now begin to crowd.

389. In a large newly cleared area, plants usually first establish themselves in dense colonies. Note the great patches of nettles, jewel-weeds, smart-weeds, clot-burs, and others in recently cleared but neglected swales, also the fire-weeds in recently burned areas, the rank weeds in the neglected garden, and the ragweeds and May-weeds along the recently worked highway. The competition amongst themselves and with their neighbors finally breaks up the colonies, and a mixed and intermingled flora is generally the result.

390. In many parts of the world the general tendency of neglected areas is to run into forest. A large number of different plants begin growth in a eleared area. Here and there bushes gain a foothold. Young trees come up: in time 
these shade the bushes and gain the mastery. Sometimes the area grows to poplars or birches, and people wonder why the original forest trees do not return; but these forest trees may be growing unobserved here and there in the tangle, and in the slow processes of time the poplars perish-for they are short-lived-and the original forest may be replaced. Whether one kind of forest or another returns will depend largely on the kinds that are most seedful in that vicinity and which therefore, have sown themselves most profusely. Much depends, also, on the kind of undergrowth that first springs up, for some young trees can endure more or less shade than others. Fig. 398 shows an early stage in the return to forest.

391. Pasturing and mowing tend to keep an area in grass. This is because the grass will thrive when the tops are repeatedly taken off, whereas trees will not. Note that the wild herbs and bushes and trees persist along the fences and about old buildings, where animals and mowing machines do not take them off. A sod society means grazing or mowing. Consider Figs. 110, 399, 400. The farmer keeps his wild pastures "clean" by turning in sheep: the sheep are fond of browsing.

392. Some plants associate. They grow together. This is possible largely because they diverge or differ in character (379). Plants associate in two ways: by growing side by side; by growing above or beneath. In sparsely populated societies (as in Fig. 401)

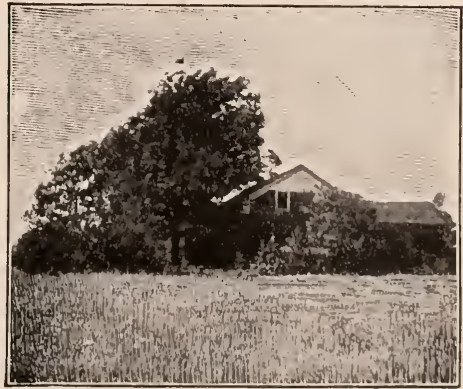

399. Sod and tree societies. About the building the trees find refuge from the mowing machine. 


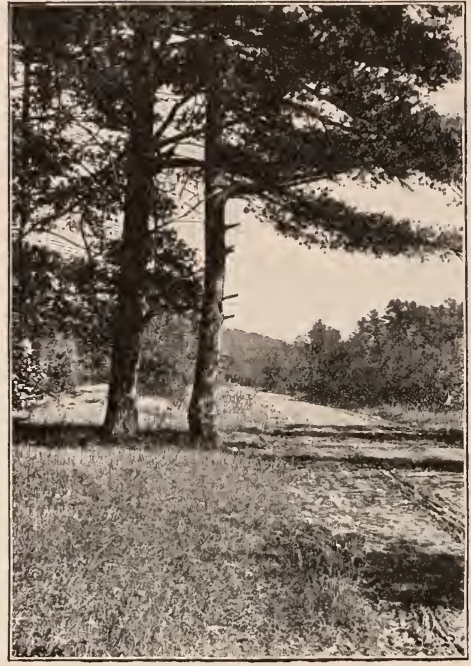

400. The farmer mows part of his roadside.

plants may grow along side each other. In most cases, however, there is overgrowth and undergrowth: one kind grows beneath another. Plants that endure shade (381) are usually undergrowths. In a cattail swamp, grasses and other narrowleaved plants grow in the bottom, but they are usually unseen by the casual observer. Search the surface of the ground in any swale or meadow. Note the undergrowth in woods or under trees. (Fig. 402.) Observe that in pine and spruce forests there is almost no undergrowth, because conditions are not favorable. (Fig. 388.)

393. On the same area the societies may differ at different times of the year. There are spring, summer and fall societies. The knoll that is cool with grass and strawberries in June may be aglow with other plants in September.

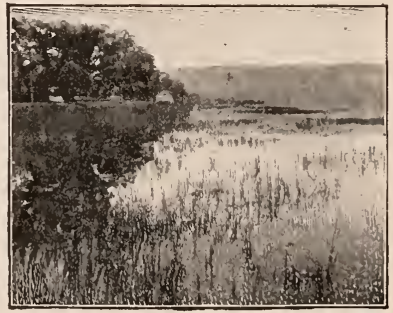

401. An aquatic society in which several kinds of plants grow side by side. 
If the bank is examined in May, look for the young plants that are to cover it in July and October; if in September, find the dead stalks of the flora of May. What succeeds the skunk cablage, hepaticas, trilliums, phlox, violets, buttercups of spring? What precedes the wild sunflowers, ragweed, asters, and goldenrod in fall?

394. In lands that gradually rise from wet to dry, the societies may take the form of belts or zones. Starting at a shore, walk back into the high

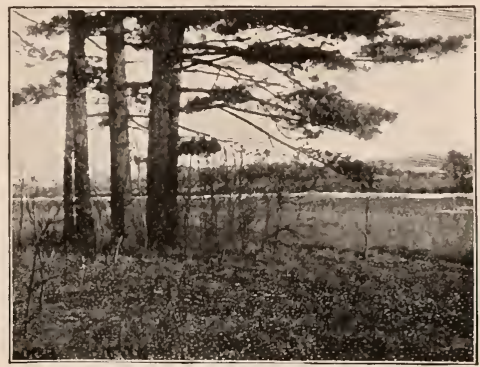

402. Overgrowth and undergrowth in three series, -trees, bushes, grass. land; note the changes in the flora. Three zones are shown in Fig. 403.

395. To a large extent, the color of the landscape is determined by the character of the plant societies. Evergreen societies remain green, but the shade of green varies from season to season; it is bright and soft in spring, becomes dull in midsummer and fall, and often assumes a dull yellow-green in winter. Deciduous societies vary remarkably in color-from the dull browns and grays of winter to the brown-greens and olive-greens of spring, the staid greens of summer, and the brilliant colors of autumn.

396. The autumn colors are due to intermingled shades of green, yellow and red. The eoloration varies with the kind of plant, the special location and the season. Even in the same species or kind, individual plants differ in color; and this individuality usually distinguishes the plant year by year. That is, an oak that is maroon-red this autumn 
is likely to exhibit that color every year. The autumn color is associated with the natural maturity and death of the leaf, but it is most brilliant in long and open falls-largely because the foliage ripens more gradually and persists longer in such seasons. It is probable that the autumn tints are

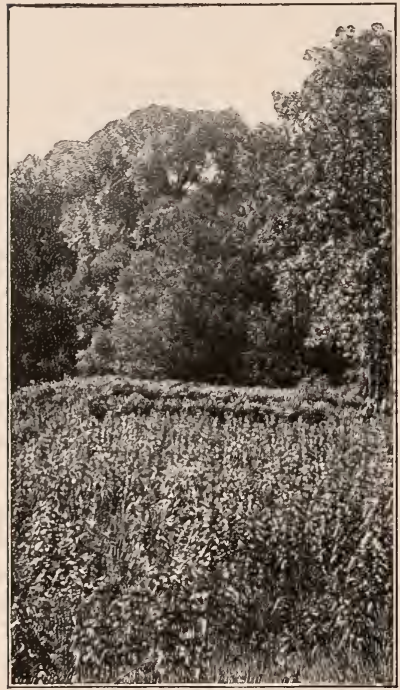

403. Three society zones-bog, forest rim, forest.

of no utility to the plant. The yellows seem to be due in part to the breaking down and disorganization of the chlorophyll. Some of the intermediate shades are probably due to the unmasking or liberating of normal cell colorbodies which are covered with chlorophyll or obscured by it in the growing season. The reds are due to changes in the color of the cell-sap, or to the unmasking of the red by the disintegration of the chlorophyll. Autumn colors are not caused by frost. Because of the long, dry falls and the great variety of plants, the autumnal color of the

American landscape is phenomenal.

397. Ecology.-The study of the relationships of plants and animals to each other and to seasons and environments is known as ecology (still written œecology in some dictionaries). All the discussions in Part II of this book are really different phases of this subject. It considers the habits, habitats and modes of life of living things- 
the places in which they grow, how they migrate or are disseminated, means of collecting food, their times and seasons of flowering, reproduction, and the like.

Review.-What is a plant society? Why do plants grow in societies? Name societies that are determined chiefly by moisture. What societies are most abundant where you live? Name those determined by latitude and altitude. Name some small or local societies. What are colonies? Where are they most marked? Why do they tend finally to break up? How are societies composed when colonies are not present? How do forests arise on cleared areas? What effect have pasturing and mowing? How do plants associate? What is undergrowth and overgrowth? Explain how societies may differ at different times of the year. What are zonal or belt societies? Discuss autumn colors. What is ecology?

Note.-One of the best of all subjects for school instruction in botany is the study of plant societies. It adds definiteness and zest to excursions. Let one excursion be confined to one or two societies. Visit one day a swamp, another day a forest, another a pasture or meadow, another a roadside, another a weedy field, another a cliff or ravine. Visit shores whenever possible. Each pupil should be assigned a bit of ground-say 10 or 20 feet square-for special study. He should make a list showing (1) how many kinds of plants it contains, (2) the relative abundance of each. The lists secured in different regions should be compared. It does not matter if the pupil does not know all the plants. He may count the kinds without knowing the names. It is a good plan for the pupil to make a dried specimen of each kind for reference. The pupil should endeavor to discover why the plants grow as they do. Challenge every plant society. 


\section{CHAPTER XXXII \\ VARIATION AND ITS RESULTS}

398. The Fact of Variation.-No two plants are alike (16). In size, form, color, weight, vigor, productiveness, season or other characters, they differ. The most usual form of any plant is considered to be its type, that is, its representative form. Any marked departure from this type is a variation, that is, a difference.

399. The Kinds of Variations.-Variations are of many degrees. The differences, in any case, may be so slight as to pass unnoticed, or they may be so marked as to challenge even the casual observer. If a red-flowered plant were to produce flowers in different shades of red, the variation might not attract attention; but if it were to produce white flowers, the variation would be marked. Whenever the variation is so marked and so constant as to

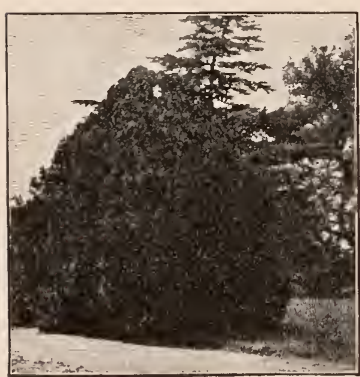

404. An arborvitæ tree, from which seeds were taken one day. be worth naming and describing, it is called a variety in descriptive botany. If the variation is of such character as to have value for cultivation, it is called an agricultural or horticultural variety. There is no natural line of demarcation between those variations that chance to be named and described as varieties and those that do not. Varieties are only named variations. 
400. Variations may arise in three ways: (1) directly from seeds; (2) directly from buds; (3) by a slow change. or a lack of development in the entire plant after it has begun to grow.

401. Variations arising from seeds are seed-variations; those that chanee to be named and described are seedvarieties. Never does a seed exactly reproduce its parent; if it did, there would be two plants alike. Neither do any two seeds, even from the same fruit, ever produce plants exactly alike. Even though the seedlings resemble each other so elosely that people say they are the same, never-

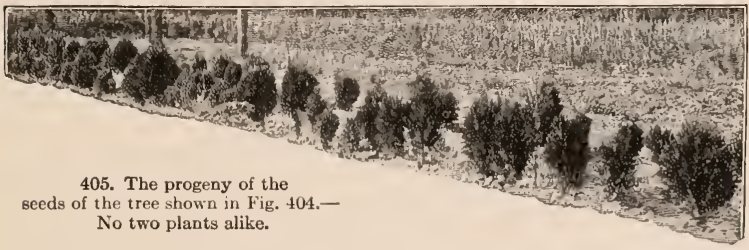

theless they will be found to vary in size, number of leaves, shape, or other features. Study Figs. 404 and 405.

402. Variations arising directly from buds, rather than from seeds, are bud-variations, and the most marked of them may be deseribed and named as bud-varieties. We have learned in Chapter $\mathrm{V}$ how the horticulturist propagates plants by means. of buds: not one of these buds will reproduce exactly the plant from which it was taken. We have already discovered $(17,119)$ that no two branches are alike, and every branch springs from a bud. Bud-variation is usually less marked than seed-variation, however; yet now and then one branch on a plant may be so unlike every other branch that the horticulturist seleets buds from it and endeavors to propagate it. "Weeping" or pendent branches sometimes appear on upright trees; neetarines sometimes are borne on one or more branches of a peach tree, and 
peaches may be borne on nectarine trees; russet apples are sometimes borne on Greening apple trees; white roses are sometimes found on red-flowered plants.

403. Frequently a plant begins a new kind of variation long after germination, even after it has become well

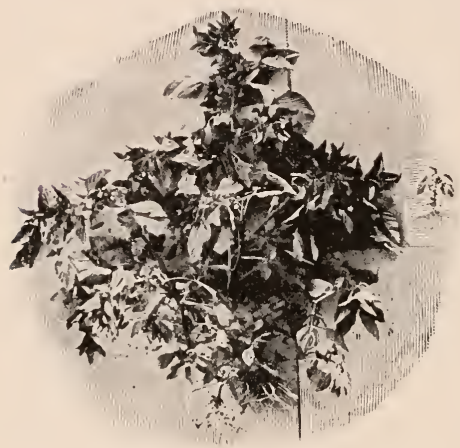

406. Variation.-Big and little redroot pigweeds of the same kind. established. It is on this fact that successful agriculture depends, for the farmer makes his plants better by giving them better nutrition and care: and betterment (like deterioration) is only a variation as compared with the average plant. Plants that start to all appearances equal may end unequal: some may be tall and vigorous, others may be weak, others may be dwarf: some will be worth harvesting and some will not.

404. The Causes of Variations.-Variations are induced by several, and perhaps many, causes. One class of origin lies in the environment, and another lies in the tendencies derived from parents. Of the environmental causes of variation, the chief is probably food-supply. Good agriculture consists largely in increasing the food-supply for plants-by giving each plant abundant room, keeping out competing plants, tilling the soil, adding fertilizers. (Fig. 406.) Another strong environmental factor is climate (Chapter XXIX). It is very difficult to determine the exact reasons for any variation. There is much difference of opinion respecting the causes of variation in general, The extent of variation 
apparently due to food-supply is illustrated in Fig. 406. The two weeds grew five feet apart, one in hard soil by a walk, the other near a compost pile. They were of similar age. One weighed $\frac{1}{2} \mathrm{oz}$; t the other $4 \frac{1}{4} \mathrm{lbs}$., or 136 times as much.

405. Heredity.-Marked variations tend to be perpetuated. That is, immediate offspring are likely to retain some of the peculiarities of their parents. This passing over of characteristics from parent to offspring is heredity. By "selecting the best" for seed the farmer maintains and improves his crops. It is said that "like produces like." This is true of the general or average features, but we have seen that the reproduction is not exact. It is truer to say that similar produces similar. Fig. 407 represents a marked

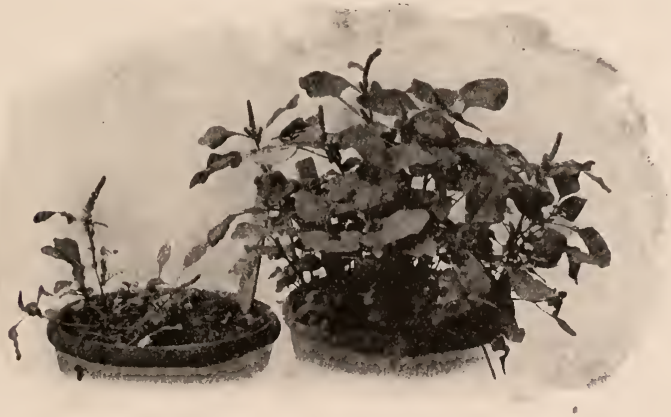

407. The progeny of little and big plants.

case of heredity of special characters. The plants on the right grew from a parent $24 \mathrm{in}$. high and $30 \mathrm{in}$. broad. Those on the left grew from one $12 \mathrm{in.} \mathrm{high} \mathrm{and} 9 \mathrm{in}$. broad. (For a history of these parents see "Survival of the Unlike," p. 261.)

406. Selection.-There is intense struggle for existence: there is universal variation: those variations or kinds live that are best fitted to live under the particular conditions. 
This persistence of the best-fitted and loss of the leastfitted is the process designated by Darwin's phrase "natural selection" and by Spencer's "survival of the fittest." Natural selection is also known as Darwinism.

407. By a similar process, the cultivator modifies his plants. He chooses the variations that please him, and from their offspring constantly selects for seed-bearing those that he considers to be the best. In time he has a new variety. Plant-breeding consists chiefly of two factors or processes; producing a variation in the desired direction; selecting, until the desired variety is secured.

408. Evolution.-Variation, heredity, natural selection and other agencies bring about a gradual change in the plant kingdom; this change is evolution. The hypothesis that one form may give rise to another is now universally accepted amongst investigators; but whether the vegetable kingdom has all arisen from one starting point is unknown. Only a few of the general lines of the unfolding of the vegetable kingdom, with numberless details here and there, have been worked out. Not every form or kind of plant can be expected ever to vary into another kind. Some kinds have nearly run their course, and are undergoing the age-long process of extinction. It is thought, however, that every kind of plant now living has been derived from some other kind. Evolution is still in progress. Variation and heredity are two of the most important facts in organic nature.

Review.-What is a variation? A variety? Agricultural variety? How many variations arise? Explain each of the three categories. What are some of the apparent causes of variation? What is heredity? Selection? What are essentials in plant-breeding? What is evolution? 


\section{CHAPTER XXXIII}

\section{WEEDS}

409. Plants compete with each other. It happens that some of the competitors are speeially useful to man, and he endeavors to protect them; and in protecting them he destroys the plants that tend to erowd them out. Certain plants have the habit of oecupying places that are desired for other uses, A weed is a plant that is not wanted.

410. Weeds, therefore, are of two general elasses: those that interfere with plants that man cultivates; those that inhabit unoccupied and waste places. Certain kinds of plants are specially adapted to hold their own in such competition or to invade open places; and these plants are particularly known as weeds. But any plant may be a weed, if it is out of place or is not wanted. June-grass is a weed in a cornfield, but not in a pasture or lawn. Dandelion and purslane are commonly regarded as real weeds, yet they are sometimes cultivated for "greens," and they then become a crop. When any crop is too thick, the weaker and useless plants interfere with the others and become weeds. Thus some of the corn plants may be weeds in a cornfield. If one were growing a forest of maples, other trees might be weed trees.

411. The plants commonly known as weeds have the power to distribute themselves and to persist, otherwise they

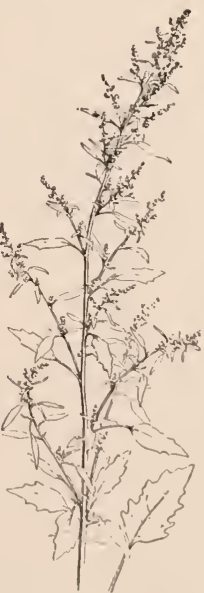

408. Common white pigweed. $-\mathrm{Ch}$ e nopodium album. 
would not be successful competitors or vagrants. Usually they are (1) suited to a wide range of conditions; (2) strongly tenacious of life; (3) have effective means of dissemination; (4) and they often have a life-cycle similar to that of some cultivated plant, and they therefore take the fortunes of that plant. As examples of these categories, we may recall the wide range of such plants as pigweeds (Fig. 408) and docks; the tenacity and endurance of Canada thistles (Fig. 409) and quack-grass (Fig. 27); the way in which the burdock spreads its seeds; the fact that cockle (Fig. 181) ripens with the wheat, and the seeds pass through the separator with the grain.

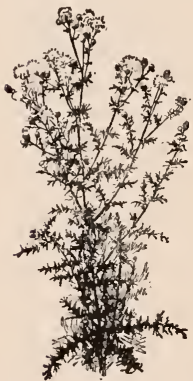

409. Canada thistle.

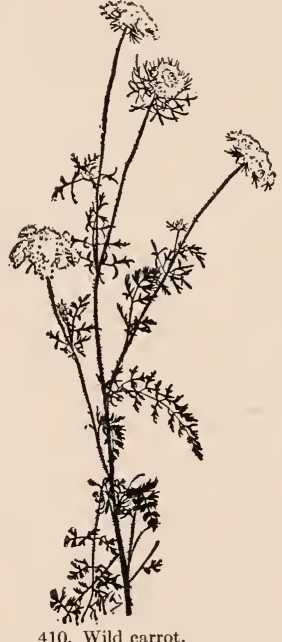

410. Wild carrot.

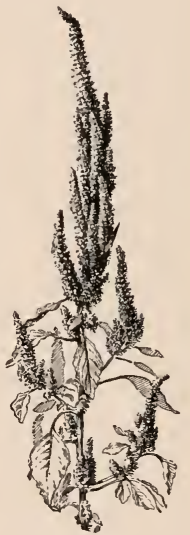

411. Redroot pigweed. -Amarantus.

412. Certain kinds of weeds follow certain crops or certain systems of farming. Dandelion (Figs. 8, 302), wild carrot (Figs. 194, 410) and whiteweed or daisy (Fig. 189) are essentially weeds of grass lands; purslane, pigweed, chickweed, redroot (Figs. 406, 407, 411), shepherd's purse, are pests of gardens and tilled grounds; cockle, chess (Fig. 
412), kinghead (an ambrosia), mustard or charlock (Fig. 413) are weeds of grain crops; dock, plantain, hound's-tongue, burdock and catnip (Fig. 414) are weeds of back yards and by-ways; sorrel, mullein, evening primrose (Figs. 276, 415) are denizens of old fields; ragweed (Fig. 416), mayweed (417), stick-tight (Fig. 418), prickly lettuce (Fig. 86), sweet clover (Fig. 184) and Russian thistle (Fig. 113) are suited to roadsides and waste places.

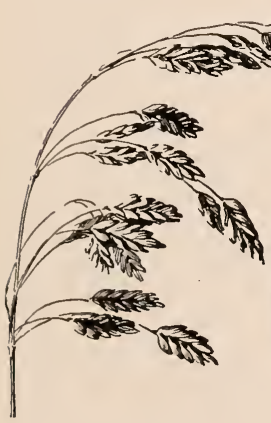

412. Chess or cheat.

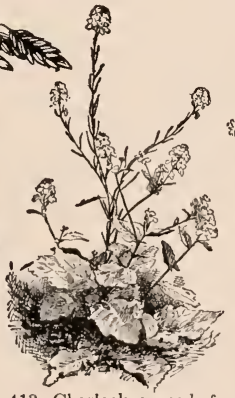

413. Charlcck, a weed of grain fields and open places.

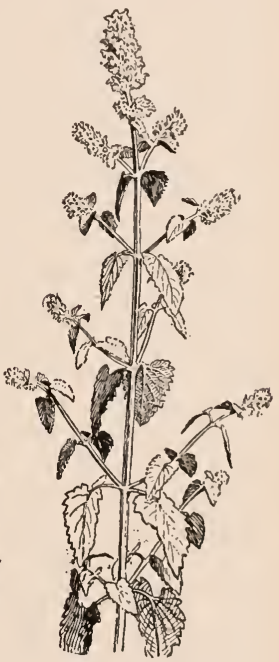

414. Catnip, often a weed about old places.

413. Some weeds come and go year by year; these are mostly weeds of tilled and raw ground, and usually annuals, as pigweeds of several kinds, pepper-grass, purslane, ragweed, pigeon-grass, jimson weed (Fig. 275). Such weeds are avoided by the use of clean seed, preventing the weeds from ripening seeds, and taking care not to spread them in manure.

414. Some weeds have a two-year cycle, making a tuft or getting a foothold one year and ripening seed the following year. These are biennials, as mullein, burdock, bull thistle (Fig. 254), evening primrose, wild carrot, creeping 
mallow or "cheeses" (Figs. 153, 149), teasel. These weeds may be mown when coming into bloom, or the plant may be spudded or cut off below the crown in fall, and care should be taken not to spread the seeds.

415. Some weeds persist for a longer period, sometimes for many years. These are perennials, as docks and daisy. Many of them propagate by underground parts as well as by seeds, such as quack-grass, toadflax (Fig. 227), Canada thistle, Johnsongrass, nut-grass or coco-grass, bindweed, hawkweed or paint-brush. In lawns and gardens, the roots may be dug out, or the plant cut below the ground with a spud; small patches or clumps may be smothered out by covering deeply with leaves or straw, or sometimes crowded out by securing a dense sod on the area. Thorough and clean cultiva-

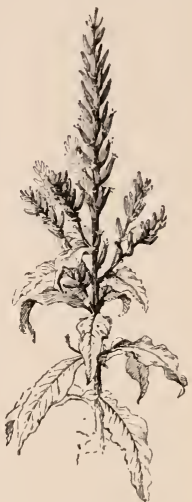

415. Evening primrose in fruit.

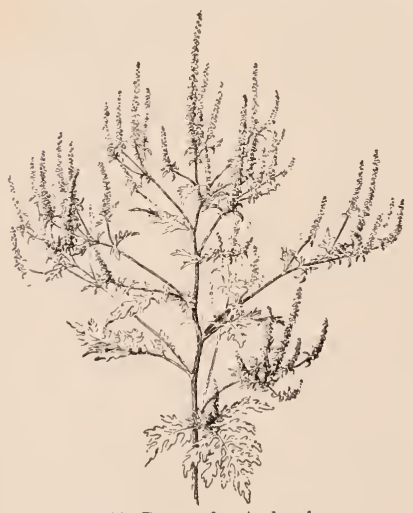

416. Ragweed.-Ambrosia.

tion will destroy most kinds, but care should be taken not to carry the rootstocks to fresh ground on the plow or cultivator. Meadow and pasture seeds are liable to be carried with grass seed and with grain.

416. The best treatment for weeds is to prevent or change the conditions under which they thrive. A good rotation of crops, cleaning up of waste places and putting them into crops or sod or tim- 


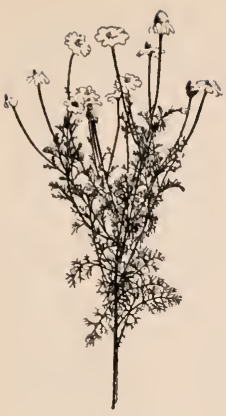

417. Mayweed.Anthemis.

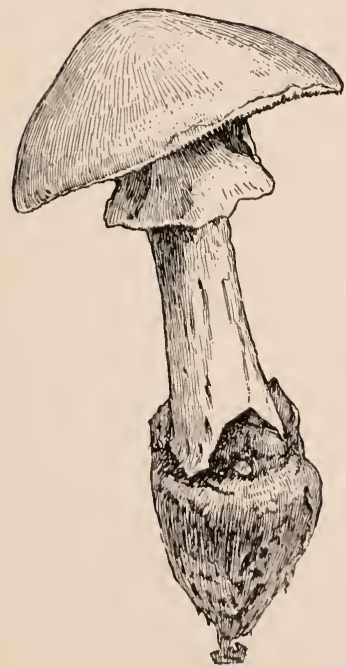

419. Poisonous mushroom.

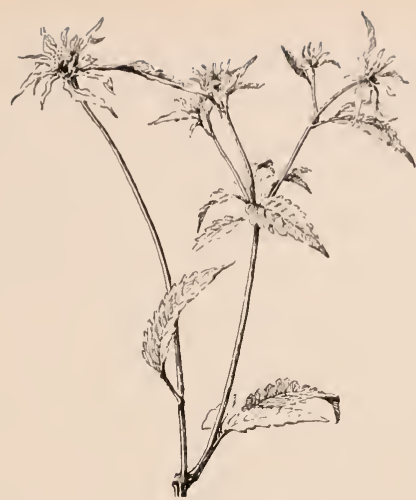

418. Stick-tight.-Bidens.

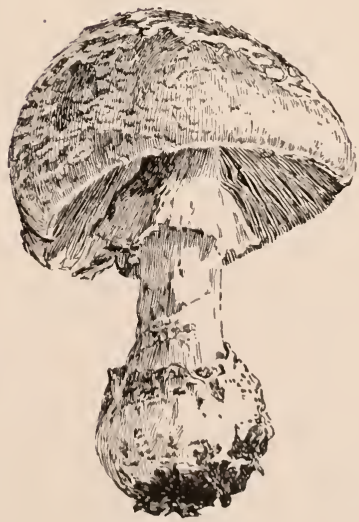

420. Poisonous mushroom 
ber, clean tillage, are essential to a clean, weedless farm. To these efforts should be added care to secure clean seed, and manure that is not weed-infested; and the farmer or gardener should be alert to recognize new weeds as soon as they invade the neighborhood and be prepared to meet them.

417. On lawns, weeds may be lessened by the use of the cleanest grass seed, and of chemical fertilizers or only wellrotted or other clean manure. The grass seed should be sown

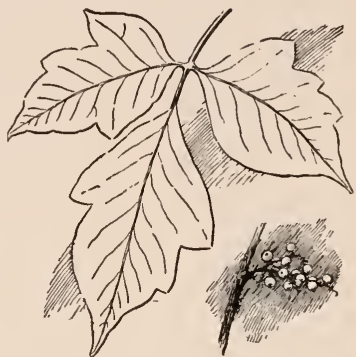

421. Poison ivy.-Rhus Toxicodendron. very thick ( 3 to 5 bus. of blue grass to the acre) both to secure a soft dense lawn and to crowd out,weeds. Frequent

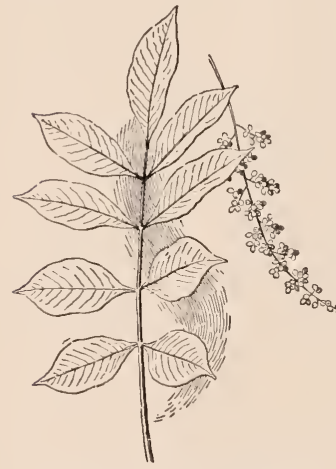

422. Poison sumac, poison elder, a bush of swamps and low places. -Rhus venenata or R. Vernix.

mowing will destroy most annual weeds, and these weeds are usually most troublesome when the lawn is newly made. Dandelions and other perennials may be taken out with a spud or long, strong knife. In badly infested places, the area may need to be dug over, and a new seeding made with clean seed and chemical fertilizer.

418. Some weeds may be killed by poisons or herbicides. Sulfuric acid is sometimes poured on the crowns of plants in lawns. Salt is often used to kill grass and weeds in gutters and walks; carbolic acid and arsenical poisons are sometimes used for the same purpose. Recipes are to be found 
in books and government publications, and periodicals. Sprays of copper sulfate or iron sulfate are sometimes used

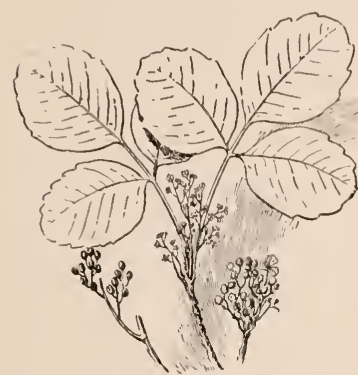

423. Poison oak, a trailing or climbing plant of the Pacific Coast.-Rhus diversiloba.

for mustard and other field weeds. A 3 per cent solution of copper sulfate (about $10 \mathrm{lb}$. to 40 gal. water) at the rate of 40 to 50 gallons an acre destroys wild mustard without injuring peas or cereals with which the weed may be growing. There are special herbicides about which information can be secured from the experiment stations. These herbicides are poisonous, and must be used with eaution and only by those who are reliable and who understand them.

419. Poisonous Plants.-Many plants produce ill effects on live stock and human beings when eaten; and some are injurious to the touch. Some plants produce such marked results, leading even to death, that they are known as poisonous plants. Some of the mushrooms are examples, two of which are shown in the illustrations (Figs. 419, 420), (wild mushrooms should never be eaten except on the advice of someone who knows the different species). Many plants of the parsley family (U'mbelliferæ) are poison-

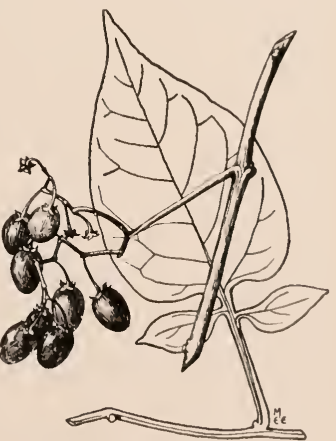

424. Solanum Dulcamara. ous; the poison hemlock and the water hemlock or musquash-root are deadly when eaten. The poison ivy is shown 
in Fig. 421, poison sumac in Fig. 422, and poison oak of the Pacific coast in Fig. 423; these are poisonous to the touch.

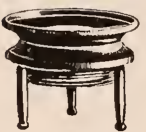

425. Magnifier. The handsome red berries of the bittersweet (Solanum Dulcamara, Fig. 424) are poisonous if eaten; and it has poisonous relatives.

REviEw.-Explain your understanding of a weed. How may we classify weeds? What are the commonest kinds of weeds in your locality? What enables a plant to be an habitual weed? Name some of the weed groups or associations. Name the ways in which weeds may be controlled or eradicated on farms. On lawns. What would you recommend to be done with weedy roadsides? Are there laws in your state for the control of weeds? Are there village or city ordinances on the subject where you live? What is an herbicide? Name the poisonous plants that you know, or of which you have heard.

NoтE.-Every class studying plants should learn the usual weeds of the neighborhood, and should make herbarium specimens of them. Discussions should be had of the weeds infesting the local crops, and the reasons for them. The school should have a collection of weed seeds in bottles, and it should study commercial samples of grain and grass seeds. The U. S. Department of Agriculture and perhaps the State Experiment Station may have bulletins to aid in such examination. If the school is to indentify weed seeds in such samples, it should also have a collection in bottles of the leading grains, grass seeds and field seeds. A small lens or magnifier is needed for this examination, as shown in Fig. 425, or in Figs. 214, 216.

Many plants are poisonous to a greater or less degree. No one should eat of any plant or fruit or root that he does not know to be safe. Some plant families are known for poisonous qualities: as Solanaceæ, of which the common black nightshade (Solanum nigrum) and others are examples; Umbelliferæ, with the hemlock herbs, water parsnip, and others; Ranuneulacex, with the aconites or monkshoods; and other families. Fatalities are frequently reported from eating the thick roots of certain Umbelliferæ. There are useful government publications on poisonous plants. 


\section{CHAPTER XXNIV}

\section{CROPS}

420. Plants that are grown by man for his uses constitute a crop. The term is commonly used for the product of a field, but is just as applieable to the produet of a planted or managed forest or of a garden or a greenhouse. Thus we may speak of a crop of wheat, of rye, of hemp, of pine timber, of celery, of roses or violets, of mushrooms.

421. Crops may be distinguished into four groups: (1) those grown for human food or medicine or condiments, as rice, potatoes, strawberries; (2) those grown to provide materials for shelter and clothing, and for use in the manufacturing arts, as timber, eotton,

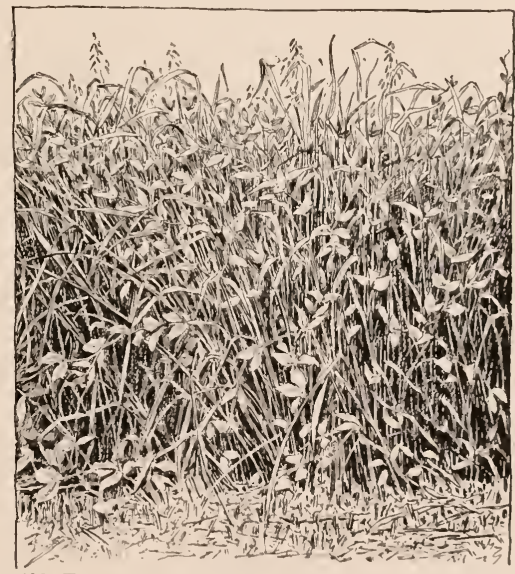

426. Two crops growing together-oats and peas for forage. flax, rubber; (3) those grown to satisfy the artistic impulses, as roses; (4) those grown for food of domestic animals, as grass and elover. Another division, and one followed in a grneral way in colleges of agriculture, is into field crops and horti- 
cultural crops; and the horticultural crops include fruit crops (pomology), vegetable-gardening crops (vegetable-gardening or olericulture), flower- and ornament-crops (floriculture).

422. We may group crops also as follows into more particular divisions: forage and fodder crops; cereal grains; root-crops; fiber-crops; sugar plants; oil plants; dye-stuff

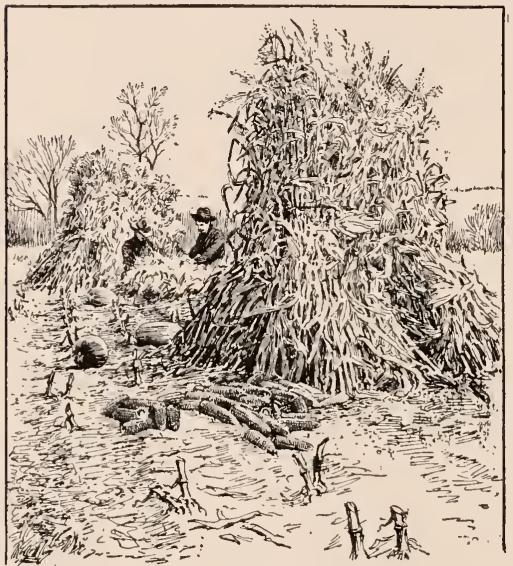

427. A crop of Indian Corn. plants; beverage-p roducing plants; stimulants; aromatic and medicinal plants; perfumery plants; fruit crops; vegetablegarden crops; timber crops; manuring crops. Some crops fall under more than one division, depending on the purposes for which they are grown, as oats, beets, peas, sorghum, maize or Indian corn, flax: explain why. Sometimes two plants are grown together purposely, as shown in Fig. 426, and also in Fig. 427.

423. Many of the crops may be assembled, on the basis of their botanical affinities, into the families to which they belong: Grass-family crops, all cereal grains as well as the meadow and pasture grasses, as wheat (Fig. 384), rye, barley, oats (Fig. 382), rice, maize (Fig. 427), sorghum (Fig. 20), kafir, broom-corn (Fig. 429), millets of several kinds, sugar-cane (Fig. 428); leguminous or pulse crops, beans and peas of all 
kinds, cowpea, peanut or goober, alfalfa, clovers, sweet clover, lespedeza, vetch; cruciferous or mustard-family crops, mustard, cabbage, kale, rape, turnip, rutabaga, kohlrabi ; rosefamily crops, rose, apple, pear, plum, peach, almond, apricot, cherry, quince, strawberry, blackberry, raspberry medlar, loquat; cucurbitous crops, pumpkin, squash, melon, watermelon, cucumber, gherkin, gourds; solanaceous crops, potato, tomato, tobacco. Some of the important crops belong to families that do not yield other leading cultivated species, as buckwheat to the knotweed family, cotton to the mallow family, flax to the flax family, hemp and hops to the nettle family, sugar-beet and other beets to the goosefoot family.

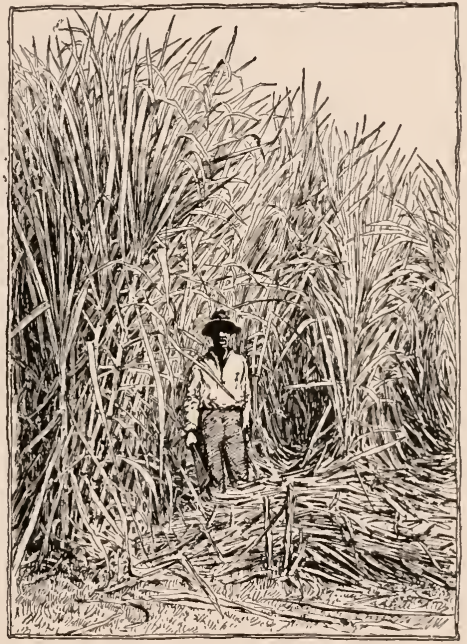

428. A crop of sugar-cane.

424. How to Study a Crop.-Every botany class should know the leading crops of its vicinity and region, including the grasses, the grains, the most important fruits and vegetables, and any special crops that may be grown in the locality. This knowledge may be derived from the experience of the members of the class, from inquiries made of farmers and from census figures. Having learned the kinds of crops and their relative importance in the region, the class should 
try to determine why they are important there, and should then gather information as to their importance in other regions and where they are grown with the greatest success. Then may follow such details as the rotation or farm-plan in which these crops find a place, the times and methods of sowing, the fertilizers used, the methods of tilling, harvesting and marketing; and then inquire as to any special difficulties in the way of insects or plant diseases. The cost

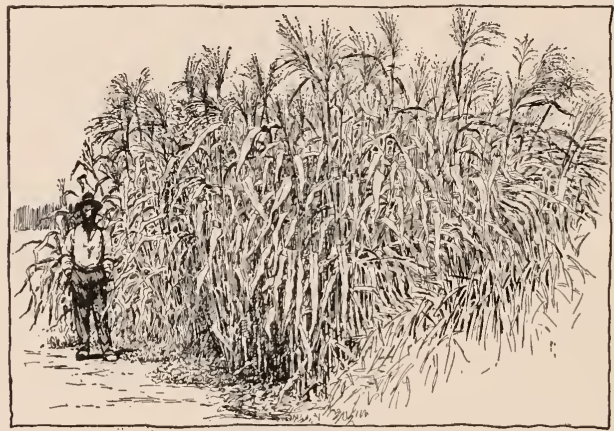

429. A crop of broom-corn.

of growing the crop, the usual prices and the yields should always be determined as nearly as possible.

425. How to Study a Crop Plant.-We have been directed in this book to some of the important things to look for in a plant, from root to fruit; and our attention has been called to some of the relations of plants when they live together. These observations may be made on cultivated plants with as much interest as on wild plants. The cultivator of plants should develop the habit of careful observation on individual plants that he cultivates; this observation should aid him in discovering the reasons for failure or success in the growing of plants. The student should go directly to the 
plant. Examine the plant where it stands,-height, spread, color, mode of branching and any special peculiarities: make

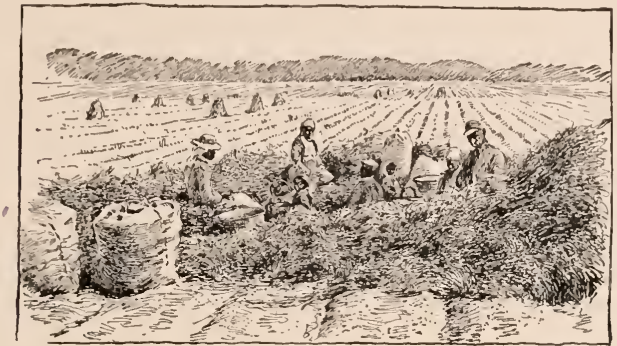

430. Harvesting a peanut crop.

a sketch. Collect the plant, root and all,-character of root as to depth and spread, mode of branching, nodules (if a legume), and other features: make sketch. The specimen may now be taken to the schoolroom or other laboratory, and studied as to direction and size of stem, features of nodes, character of bark or rind, position of branches and leaves and flowers, characters of leaves and flowers and fruits, how pollinated, yield, whether it bears any evidence of disease or insect injury or lack of normal vigor, whether it has suffered in contest with its fellows or with other plants: make notes and sketches.

426. Plants or plant products are sometimes judged by comparing them with an assuned or ideal standard of perfection. These standards may be printed in form for ready use, and they are theu known as

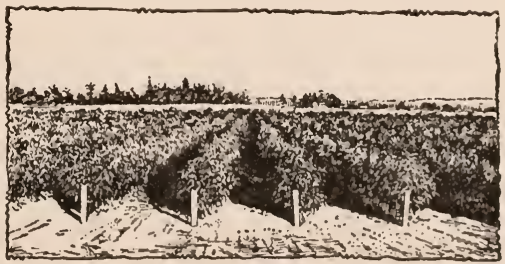

431. A crop' of nursery trees. Year-old peach trees. 
score-cards. A few useful score-cards of common cultivated plants are as follows:

Plum. Points

Form ............. 10

Size................. 25

Color.............. 15

Uniformity of fruits ..... 25

Freedom from blemish.... 25

100

Apple.

Size................. 10

Color. ............... 20

Good shape or form....... 10

Uniformity............ 15

Freedom from blemish. . . . 20

Texture and flavor....... 25

Sweet Pea.

Length of stem.........25

Color................ 20

Size................ 25

Substance............ 15

Number of flowers on stem. 15

Wheat (grain).

Trueness to variety....... 10

Uniformity in size and shape of kernel............. 10

Color of grain.......... 10

Freedom from mixture.... 15

Size of kernel. . . . . . . 10

Percentage and nature of impurities (weed seed, dirt). 15

Percentage of damaged, smutty or musty kernels . 5

Weight of grain per bus.... 10

Germination test........ 15

Potato. Points

Uniformity of sample.... 20

Symmetry of tubers....... 15

Trueness to type........ 20

Freedom from disease and insects............. 15

Commercial value....... 30

100

Corn.

Adaptability to purpose.... 25

Seed condition, as to whether fresh, well kept, etc..... 15

Shape of kernel......... 15

Uniformity and trueness to type............. 15

Weight of ear.......... 10

Length and proportion of ear................ 10

Color of grain and cob.... 5

Butts and tips covered.... 5

100

Determine in advance what weight and proportion of ear is to be assumed for the variety under examination.

Carnation.

Color................ 25

Size................ 20

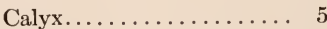

Stem............... 20

Substance or texture of flower............. 10

Form............ 15

Fragrance........... 5 
The "points" in the score-card represent the mark of perfection: if the size of the carnation flower is normal for the variety under examination, the particular specimen will be marked 20; if it should receive a rating of only 75 per cent perfect, it receives 15 points. In any large bunch of carnations, one plant may be taken to represent perfection in one feature and another plant for another feature; or, better, if an expert carnation-grower is available he may set the ideal of perfection. The pupil may make up his own ideal as to what the perfect plant or product should be.

427. The Vegetation Environment.-The botany class should take part in a harvest festival, in which the plant products of the community are exhibited, together with the wild plants in the form of leaves, flowers, nuts and other interesting parts. Members of the class should explain what the products and the plants mean.

428. The class should also know the most important vegetation of the vicinity, and should arrange excursions for the school or classroom to close-by places in order to explain the vegetation setting of the school; and if possible a crop excursion for the entire school should be undertaken.

Review.-What is a crop? Name the six most important crops of your neighborhood. How may crops be classified or grouped? Give two examples in each group. What natural families contribute very important crops in temperate regions? Outline a study blank for the general study of the most important crop in the locality. Make a similar outline for a study of the plant itself. What is a score-card and how it is used? What may an exhibition teach? An excursion?

Note.-Various texts and bulletins now set forth the standards of perfection in many of the leading crop products, and give the student definite statements of what is considered to be the product that should score 100. 


\section{CHAPTER XXXV}

\section{THE FOREST}

429. An area of trees growing close together and having its own features and its own life is a forest. An avenue of trees, or a grove of shade trees, is not a forest. The science and the practice of growing and utilizing forests is forestry. A forest is a great plant society.

430. Forest trees constitute a crop. The chief product is timber; other products are stove-wood, bark, resin, tur-

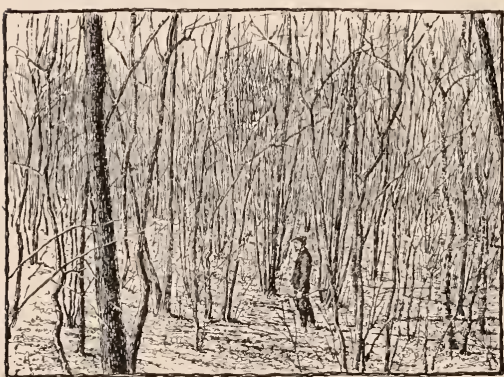

432. A stand of young timber in need of thinning. pentine, rubber, paper pulp. The crop is regularly harvested, in some cases by removing the entire forest and planting anew, but often, in planted and managed forests, by removing the mature or ripe trees and allowing the forest to continue.

431. The value of the forest crop depends on the kinds of trees, how they are mixed or associated in the forest, and the distance at which they stand apart, as well as on location and soil and climate, freedom from insects and timber diseases, and other factors. A natural forest may not be the most productive forest, any more than a natural or wild meadow may be a perfect meadow. There are likely to be 
open and poor spots, and many of the trees may be weed trees of no value in themselves and interfering with the growth of useful trees. Some natural forests (as that shown in Fig. 388) present a uniform and continuous stand of timber of one kind; others (as in Fig. 387) are mixed forests. Both kinds may be useful and desirable.

432. Trees standing alone or on the edge of a forest do not produce good timber because they branch too low and are likely to be too much exposed to wind. They produce short and knotty logs. (Fig. 400.) It is essential that the forest be thickly and continuously planted.

433. Forests may be planted anew; or natural forests may be perpetuated by removal of ripe and undesirable trees and the in-planting or saving of other trees. The

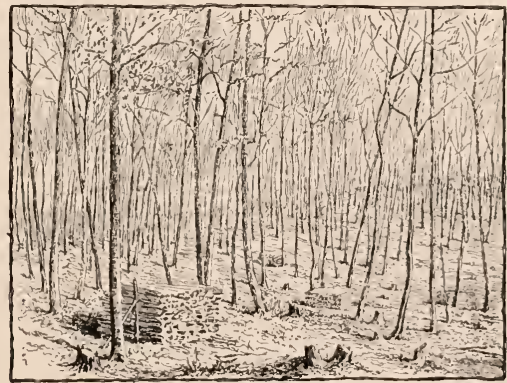

433. A stand of young timber after moderate thinning. planting and rearing of trees in forests is silviculture. The planting and rearing of trees in general is arboriculture, and this may have no direet relation to forestry, beeause the planting may be of lawn trees, park trees, roadside trees or fruit trees. Silviculture is one part of forestry; other parts or divisions are forest management, harvesting, marketing, timber teehnology. The safeguarding and utilization of the forests, both on public and private lands, is one of the great public questions, and demands the attention of persons of special training and skill.

434. Forestry is an important farming question, for the 
forest crop may be as important as other crops on the farm. In hilly regions, practically all farms have forests, yielding timber, posts, firewood and other supplies, and protecting lands from washing, affording windbreaks, and providing good use for lands that cannot be profitably devoted to other crops. There are many planted woodlots in the West. The management of these small forests is called farm forestry. Every good general farmer should be skillful in the growing of forest crops as in the growing of grain crops or fruit crops. The principles of good plantgrowing may be applied to the forest, the trees being planted,

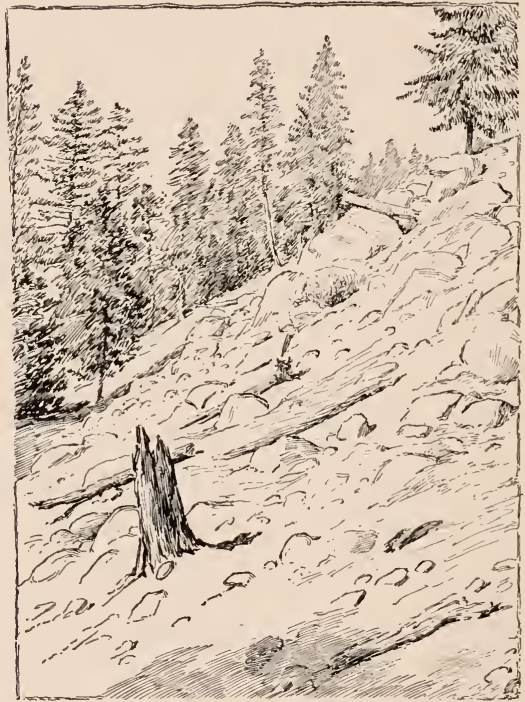

434. Absolute forest land,- - unadaptable to other uses. cared for, the forest thinned if too thick (Figs. 432, 433) or filled if too thin, fire kept out, and the trees properly harvested.

435. What small forests contribute to the farm, the larger public forests contribute to the nation or to all the people: profitable utilization of remote, rocky and less fertile areas; the holding back of the rainfall so that floods and serious erosions 
are prevented and the flow of navigable streams regulated; protection of wild life; tempering of physical conditions by regulation of water-flow in streams and lakes and elsewhere and by checking the sweep of winds; providing an attractive cover for large areas of the surface of the earth, in which the people may find recreation and help. Areas that

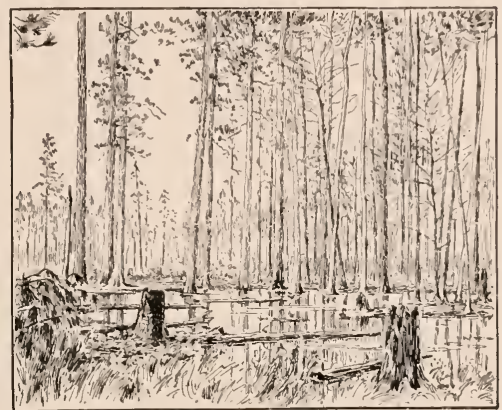

435. Absolute forest land,-a cypress swamp. can be utilized for no other crop than forest are said to be absolute forest land (Figs. 434, 435); and much land that is available to some extent for pasture or other croppage may still be most profitable in forests. (Fig. 436.) Very

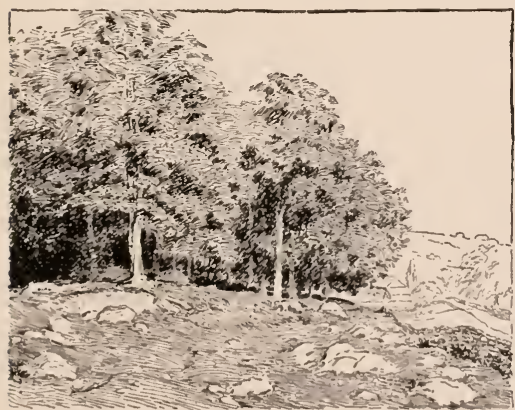

436. Land that may be profitably used for forestry purposes, special forests (Fig. 437) may be grown on arable lands. In the general scheme or plan of a farm, a forest or woodlot may be an essential part; and likewise, in a national domain large forest areas are 
essential. Even with the greater use of cement, the demand for timber will increase.

Review.-What is a forest? Forestry? In what sense is a forest a crop? On what general factors does the value of a forest crop depend? Name some of the forest products. How may man produce a more profitable forest than nature often does? What do you say about the timber value of trees standing alone? What is aboriculture? Silviculture? Farm forestry? What are some of the large values or benefits of forests? What is the nature of the forests in your neighborhood? What kinds of trees dominate them?

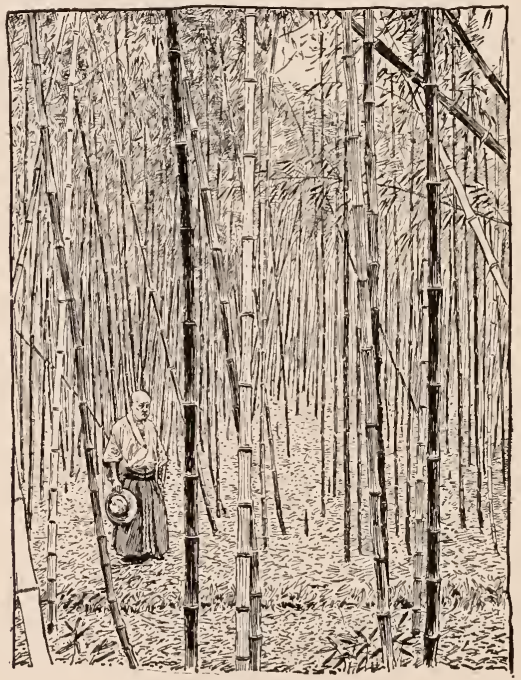

437. A forest of paper bamboo. 


\section{PART III \\ HISTOLOGY, OR THE MINUTE STRUCTURE OF PLANTS}





\section{CHAPTER XXXVI}

\section{THE CELL}

436. Plants Composed of Cells.-All the higher plants are made up of a large number of small structures termed cells. They are so minute that, in most cases, they are invisible to the naked eye. These cells are box-like structures. They are of many forms. Many of the lower forms of plants, as bacteria, yeasts, spores of fungi, and many of the algæ, are composed of but a single cell.

437. Cells are of Many Forms.-In general, plant cells may be assigned to some one of the following forms:

Spherical, as in protococcus (a minute alga to be found on damp walls and rocks), and apple flesh;

polyhedral, or many-sided, as in pith of elder;

tabular, or flat, as in epidermis of leaves;

cylindrical, as in vaucheria, spirogyra (fresh water algæ); fibrous, as cotton fibers;

vascular, as the ducts of wood;

stellate, as in the interior of leaves of lathyrus (sweet pea) and other plants.

438. Parts of a Cell.-The typical cell is composed of living and dead matter. The living matter of the cell is the protoplasm. The protoplasm is differentiated into a nucleus, cytoplasm and plastids.

439. The nucleus is usually a round or elliptical body, denser than the remainder of the protoplasm, in which it may be imbedded or from which it may be suspended by strands of protoplasm called cytoplasm. The cytoplasm lines the wall of every living cell, and commonly in old cells the nucleus is in this layer of cytoplasm. In the cell may be aggregates 
of protoplasm forming definite structures, usually scattered in the layer of cytoplasm. They are the plastids. The ones most familiar are the chloroplasts, in which the green pigment chlorophyll is imbedded. They are found in cells of leaves and stems exposed to the light. Plastids are not found in all cells. The dead part of the cell is the cell-wall, the cellsap stored in chambers or pockets in the protoplasm called vacuoles (Fig. 438), and various inclusions. The cell-sap contains mineral nutrients in solution or suspension, as well

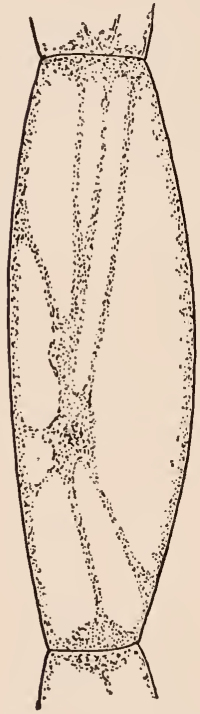

438. Circulation of protoplasm in a cell of a stamen hair of tradescantia or spiderwort. Magnified 600 times. as organic foods, as sugar and other substances. Imbedded in the cytoplasm or in the plastids may be starch grains, oil droplets and other substances. In the nucleus is a densely granular body called the nucleolus.

440. Study of Cell.-Examine with the aid of the microscope the cells in the stamen hair of tradescantia or spider-wort. (Fig. 438.) If the flowers of this plant are not available, use the young bristle hairs of squash plants; a plant a few weeks old will supply sufficient hairs. Note the shape of the cell and the contents. The nucleus will probably be located near the middle of the cell, and to it run the strands of cytoplasm. The protoplasm is not entirely homogeneous. It is composed of a viscous, colorless fluid in which are imbedded many minute granules. In a young cell the protoplasm fills almost the entire cell. In an old cell the vacuoles are of increased size. Compare old and young cells in the stamen hairs of tradescantia or in squash hairs for their protoplasmic content. Examine the cells of the epidermis of the onion. Note 
the large volume of the cell occupied by the vacuoles. The protoplasm in this case will consist probably only of the lining layer of cytoplasm in which the nucleus is imbedded. Examine the leaf of the water plant elodea or the thin leaves of some of the mosses. Note the character of chloroplasts in the cells (Fig. 439). These chloroplasts may be observed in the cells of the leaf of higher plants if a eross-seetion of the leaf is cut and a microscopical examination made. Study should be made of cells of the soft pulp of a celery stem; of hairs scraped from the surface of a begonia leaf; of threads of spirogyra; soft, white cells of apple; the

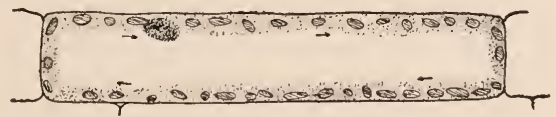

439. Rotation of protoplasm in Elodea canadensis (often known as Anacharis). Common in ponds.

cells of the potato tuber (observe the starch grains). Examine the lower epidermal cells of eyelamen, irises, or coleus and note that the cell-sap is colored by a red pigment. The beet also has cells with red pigmented cell-sap.

441. Nature of Protoplasm.-The living substance is protoplasm. It is proteid. Its chemical composition is not known. It is semi-liquid, of hyaline color, and colloidal in nature. It may be killed by heating to a high temperature or by various chemical reagents. The whole principle of antiseptics is based on these facts and processes.

4ł2. Within the cell-wall, at times the protoplasm shows a tendency to move from place to place. This movement is chiefly of two kinds: (1) Circulation, or movement not only along the walls but also aeross the cell-body, as seen in the long, thin-walled cells of celandine; in the staminal hairs of tradescantia (Fig. 438); in the bristles of squash vines; in the stinging hairs of nettle; in stellate hairs of hollyhock. (2) Rotation, or movement along the walls only, well 
seen in the cells of many water plants, as elodea (Fig. 439), chara, and nitella.

443. Besides these and other movements of protoplasm within the cell-wall, there are also movements of naked protoplasm, of two main types: (1) Amaboid or creeping movements, such as may be seen in a plasmodium of myxomycetes, or in an amoba. (2) Swimming by means of cilia or flagella, illustrated in the swarm-spores of water fungi, and of some algæ. By the latter type of movement the unicellular bodies (swarm-spores) are often moved very rapidly. To see movement in protoplasm, carefully mount in water a few hairs from the stamens of tradescantia (spider-wort). The water should not be too cold. Examine with a power high enough to see the granules of protoplasm. Make a sketch of several cells and their contents. It may be necessary to make several trials before success is attained in this experiment. If the microscope is cold, heat the stage gently with an alcohol lamp, or by other means; or warm the room. See Fig. 438.

444. Nature of Cell-wall.-The cell-wall of very young cells is a delicate film or membrane. As a cell grows in size the wall remains thin and does not begin to thicken until the cell has ceased to enlarge. The fundamental substance of cell-walls is a carbohydrate known as cellulose.

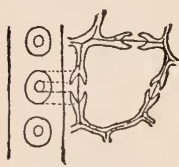

440. Bordered pits in pine wood. The cellulose usually stains blue with hematoxylin. Often by incrustations or deposits of one kind or another, the cellulose reaction is lost or obscured. Two of the most common additions are lignin, forming wood, and suberin, forming cork. The walls then are said to be lignified or suberized.

445. In all the cells studied in the above experiments, the walls are thin and soft. In general, those cells that have thin walls are called parenchymatous cells. Some cells, as those of nuts and the grit of pear fruit, have very 
thick walls, and are called sclerenchymatous cells. In many cases the cell-walls are intermediate between these extremes.

446. Cell-walls often thicken by additions to their inner surface. This increase in thickness seldom takes place uniformly in all parts. Many times the wall remains thin at certain places, while the most of the wall becomes very thick. Again the walls may thicken very much in angles or along certain lines, while most of the wall remains thin. As a result of this uneven thickening, the walls of cells take on certain definite markings. Some of the names applied to these markings are:

Pitted, with little holes or depressions, forming very thin places, as

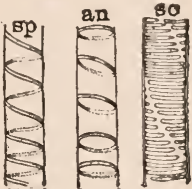

441. Markings in cellwalls. $s p$, spiral; $a n$, annular; sc, scalariform.

seen in seeds of sunflower, and in the large vessels in the stem of the cucumber.

Bordered pits, when the pits are inclosed in the cell-wall, as in wood of pines and other conifers. (Fig. 440.)

Spiral, with the thickening in a spiral band, as in the primary wood of most woody plants and in the veins of leaves. (Fig. 441.)

Annular, with thickening in the form of rings; seen
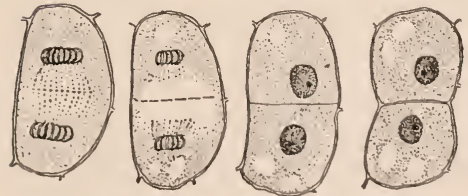

442. Four steps in process of cell-division. Mother cell at left, fat advanced in division; daughter cells at right.

in the small vessels of the bundles in stem of Indian corn. (Fig. 441.)

Scalariform, with elongated thin places in the wall, alternating with the thick ridges which appear like the rounds of a ladder. (Fig. 441.) These are well shown in a longitudinal section of the root of the brake fern (Pteris). 
447. While a true cell must have cytoplasm and a nucleus, the word cell is applied to the unit structures that make up the plant body. Many of these cells are dead. The wood of trees consists largely of dead wood. The pith of stems also may consist largely of dead cells. The cells of bark are largely dead cells.

448. Multiplication of Cells.-Every cell owes its origin to some previous cell, and all go back eventually to the germ-
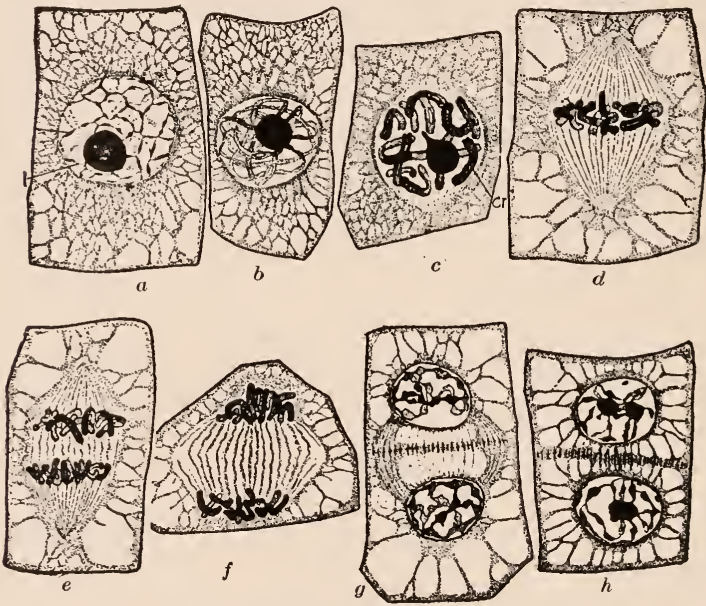

443. Nuclear and cell division in the root of corn: cell with prominent resting nucleus $(a)$ : prophases of nuclear division, spirem $(b)$ and chromosome $(c)$ stages; bipolar spindle $(d)$; early $(e)$ and late $(f)$ anaphases; telophases $(g)$ and first evidence of cell-plate; location of cell-wall clearly defined $(h)$. (After Curtis.)

cells. The method whereby cells are produced is complex. The process is at first internal, and consists in the formation of definite aggregates of protoplasm derived from the nucleus, called chromosomes. In the course of the formation of these chromosomes, intricate changes occur in the cell nucleus 
and cytoplasm. In the division of the cell, equal numbers of these chromosomes are found at its equator. Half of these chromosomes then go to the opposite poles of the cell and unite again to form at each pole a nucleus. A cell-wall is then laid down at the equator, and we have two cells in the place of one. Enlargement and further changes may go on in these two cells. The method of cell division by this complex means is known as mitosis or karyokinesis. It is exceedingly complex and too difficult for the beginner to follow or to comprehend. Some of the stages are given in Fig. 442. A more detailed representation of these changes is shown in Fig. 443.

REview.-Of what is the plant composed? What is the general nature of cells? Forms of cells? What part of the cell is dead matter? Living matter? Compare different cells studied. State your conception of protoplasm. State the divisions in the protoplasm. Name two kinds of movement of protoplasm. What is the nature of the cell-wall? Its modifications? How do cells multiply? 


\section{CHAPTER XXXVII \\ CONTENTS AND PRODUCTS OF CELLS}

449. The Living Cell is a Laboratory.-In nearly all cells are found one or more non-protoplasmic substances. produced by the plant. Some of these are very useful to the plant, and others seem to be waste or by-products. There is considerable division of labor among the cells of higher plants, one cell or group of cells producing one product, and another group of cells producing another product and functioning in a different way. We know that there is also division of labor among the different organs of a plant.

450. Chlorophyll.-Cells may contain chlorophyll bodies if they are exposed to the sunlight. Chlorophyll is a green substance infiltrated in a protoplasmic ground-mass. It imparts color to all the green parts of the plant. Its presence is absolutely necessary in all plants that secure their nourishment wholly or in part from the air and from mineral matter of soil. Review Chapter XIV. Most parasites and saprophytes do not bear chlorophyll, but live on organic matter (Chapter XV). The oval bodies in the cell of Figs. $468,470,471$, are chloroplasts.

451. The Cell Contents.-The products formed in plants are of varied character and exceedingly large in number. Of the more common and most abundant products are the following:
Grape (glucose or dextrose, with the chem- ical formula $\mathrm{C}_{6} \mathrm{H}_{12} \mathrm{O}_{6}$ ).
Sugars $\quad$ Fruit (fructose or levulose $\mathrm{C}_{6} \mathrm{H}_{12} \mathrm{O}_{6}$ ).
Cane (saccharose $\mathrm{C}_{12} \mathrm{H}_{22} \mathrm{O}_{11}$ ).
Malt (Maltose $\mathrm{C}_{12} \mathrm{H}_{22} \mathrm{O}_{11}$ ). 
Amyloses $\left\{\begin{array}{l}\text { starch, found in most plants. } \\ \mathrm{C}_{6} \mathrm{H}_{10} \mathrm{O}_{5} \\ \text { dextrin in various seeds. } \\ \text { cellulose in date seed. } \\ \text { inulin in dahlia tubers. }\end{array}\right.$

Fats and oils, as in flax seed, castor bean, cotton seed, corn and other seeds.

Muscus and mucilage, as in orehid roots, onions, quince seed, and other plants.

Tannins, as in oak and hemlock bark, persimmon, and, in general, in all plants that are astringent to the taste. Glucosides. Complex products which on digestion yield glucose sugar as one of the products. Amygdalin of almond and peach nut, and indican of the indigo plant, which yields the indigo dye, are examples.

452. Some of the cell contents are alkaloids, complex nitrogenous products, of which the following may be mentioned:

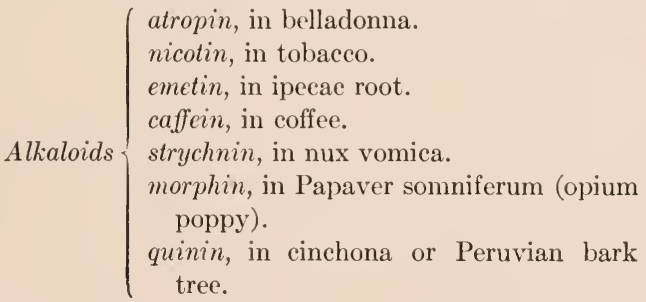

Resins, as in Coniferæ.

Gum-resins, Caoutchouc, as in India-rubber plant.

Vegetable acids

formic, as in stinging nettles. acctic, as in fermented cider. oxalic, mostly in form of calcium oxalate. malic, as in apple. citric, as in lemon. And many others. 
453. Other cell contents are the proteids. There is a large number of different proteids. They are very complex organic products composed of carbon, oxygen, hydrogen, nitrogen, and in addition sometimes phosphorus and sulfur. The white of egg is a proteid. The protoplasm itself is a proteid.

454. Of the various sugars in the cell, glucose or grapesugar, so named because it is so abundant in grapes, is perhaps the most common in plants (179). It is probably the first carbohydrate formed in the plant, and the one from which all others are derived. It is also a product of the digestion of maltose, which in turn is derived from the conversion of starch in the plant. It is also one of the sugars formed from the digestion of cane sugar. It is very soluble and therefore is in a convenient form for transportation from one part of the plant to another. Corn syrup is glucose derived from starch of the corn kernel.

455. To test for glucose: Make a thick section of a bit of the edible part of a pear and place it in a bath of Fehling's solution. After a few moments, boil the liquid containing the section for one or two minutes. It will turn to an orange color, showing a deposit of an oxid of copper and perhaps a little copper in the metallic form. A thin section treated in like manner may be examined under the microscope, and the fine particles, precipitated from the solution by the sugar of the pear, may be clearly seen. Fructose and maltose, as well as other organic substances, give a similar reaction with Fehling's solution. In the case of fruits and other common products, it may be assumed that precipitation of the oxid of copper is due to glucose or fructose. With barley malt, the precipitation of the copper oxid is due to maltose. Test various fruits by boiling them in water in a test-tube, and then determine whether sugar is present by adding Fehling's solution to the extract and again heating.-Fehling's solution is made by taking one part each of these three solutions and two parts of water: (1) Copper sulfate, 9

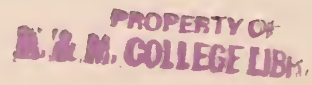


grams in 250 c.c. water; (2) sodium hydroxid, 30 grams in 250 c.c. water; (3) Rochelle salts (sodium potassium tartrate), 43 grams in 250 c.c.

456. Cane-sugar is stored as a reserve food in many plants. In the maple tree, sugar-beet, sorghum, and sugarcane, cane-sugar is abundant. Test the sugar-beet for glucose with Fehling's solution. None is found. Boil a piece of sugar-beet in a little water in a test-tube. To the water first add a drop of hydrochloric acid. When cool add a pinch of sodium carbonate and Fehling's solution, and again heat. A precipitate of oxid of copper is obtained. Canesugar heated in the presence of hydrochloric acid is converted into glucose and fructose. This is one test for canesugar. Another test is as follows: (1) Make a thin section of sugar-beet and let it stand a few minutes in a strong solution of copper sulfate. Then carefully rinse off all the salt. (2) Heat in a very strong solution of potassium hydroxid. There will be seen a blue coloration in the section, gradually washing out into the liquid.

457. To test for the oil content of the cell: Mount a thin section of the endosperm of castor-bean seed in water and examine with high power. Small drops of oil will be abundant. Treat the mount with alcanin (henna root in alcohol). Half an hour or more may be required. The drops of oil will stain red. This is a standard test for fats and oils.

458. To examine gum-resin: Mount a little of the milky juice of the leaf-stem of the garden poinsettia (Euphorbia pulcherrima). It is of a creamy consistency. Examination under the microscope shows that it is not white, as it seems to the naked eye. The particles are yellowish or colorless and insoluble. These particles are gum-resin. They have been emulsified by the plant, making the juice appear white.

459. Starch is the most abundant of the solid products of the cell. Starch grains have a definite form for each group of plants; and these groups can be determined by the form 
of their starch grains. Detection of adulteration of various products containing starch is accomplished by the aid of the microscope. This method is now particularly important in determining adulteration of stock foods. In potato starch the grains are ovate, with a "nucleus" near one end, as shown in Fig. 444. In poinsettia they are dumb-bell shaped, with two nuclei. (Fig. 444.) In corn they have equal diameters, with radial fissures. In Egyptian lotus they are forked or branched. So far as known, all starch grains are marked with rings, giving a striated appearance, due to the differ-

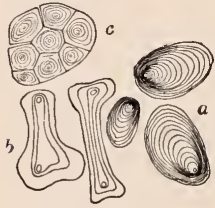

444. Starch grains. $a$, potato; $b$, poinsettia; $c$, rice. ence in density of the layers: When all water is driven out of the starch, the rings disappear. The layers are more or less concentric, and are formed about a starch nucleus.

460. Starch grains may be simple, as found in potato, wheat, arrow-root, corn, and many others; or they may be in groups called compound grains, as in oats, rice (Fig. 444), and many of the grasses.

461. Starch may be found in all parts of the plant. It is first formed in presence of chlorophyll in daytime, mostly in the leaves, and at night it is converted into sugar and then it is carried to some other part of the plant, as to the roots or tubers, to be stored or to be used. When found in the presence of chlorophyll, it is called transitory starch, because it is soon converted into sugar to be transported to other parts of the plant. When deposited for future use, as in twigs and tubers, it is stored starch.

462. The composition of starch is represented by $\mathrm{C}_{6} \mathrm{H}_{10} \mathrm{O}_{5}$. The grains are insoluble in cold water, but by saliva they are changed to sugars, which are soluble. Great heat converts them into dextrine, which is soluble in water. Starch turns blue with iodin (76). The color may be destroyed by heat, but will return as the temperature lowers. 
463. To test for starch: Make pastes with wheat flour, potato starch, and corn starch. Treat a little of each with a solution of rather dilute iodin. Try grains from crushed rice with the same solution. Are they the same color? Cut a thin section from a potato, treat with iodin and examine under the microscope. To study starch grains: Mount in cold water a few grains of starch from each of the following: potato, wheat, arrow-root (buy at drug store), rice, oats, corn, euphorbia. Study the sizes, forms, layers, fissures, and location of nuclei, and make a drawing of a few grains of each.

464. Amylo-dextrine is a solid product of the cell much resembling starch in structure, appearance, and use. With the iodin-test the grains change to a wine-red color. Seeds of rice, sorghum, wild rice, and other plants contain amylodextrine. Amylo-dextrine is a half-way stage in the conversion of starch into maltose and dextrine. These latter substances do not react with iodin.

465. Proteid or nitrogenous matter is stored largely in the form of aleurone grains, and is most abundant in seeds of various kinds. It is present also in solution or in amorphous compounds. The grains are very small, colorless or yellowish in most plants, rarely red or green. In the common cereals they occupy the outer layer of cells of the endosperm. (Fig. 445.) In many other cases they are distributed throughout the seed. The grains vary in size and form in different species, but are rather constant within each group. They are entirely soluble in water unless certain hard parts or bodies, known as inclusions, are present, and these may remain undissolved. The inclusions may be $(a)$ crystaloids, as

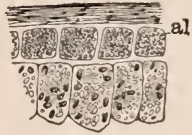

445. Aleurone grains (al) in kernel of wheat. in potato, castor-oil seed; $(b)$ globoids, as in peach, mustard;

(c) calcium oxalate crystals, as in grape seed.

466. To study aleurone grains and their inclusions: Cut 
a thin cross-section of the peripheral cells of a grain of wheat and mount in alcohol. Stain with an alcoholic solution of iodin to color the grains yellow, and examine with the highest power. Make a sketch of a few layers of cells, just beneath the epidermis. Make a sketch of a few of the grains removed from the cells. While looking at the mount, run a little water under the cover-glass and watch the result. Make a similar mount and study of the endosperm of castor-oil seed, or of grape seed. In the castor-oil seed, look for inclusions of large crystaloids and small globoids. In the grape seed, globoids should be found with erystals of calcium oxalate within them. This experiment will require the power of one-sixth or one-fifth inch objective.

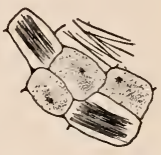

446. Raphides of rhizome of skunk cabbage.

467. Cells may contain crystals. Besides the crystals found as inclusions of aleurone grains, many others occur. In onion skin they are prisms; in nightshade they are in the form of crystal flour; in the petioles of the peach they are roundish, with many projecting angles; in the root-stock of skunk cabbage, in the bulbs of hyacinth, and leaves of tradescantia they are needle-shaped and are called raphides. (Fig. 446.) In the leaf of the India-rubber plant (common in greenhouses) are found compound clusters resembling

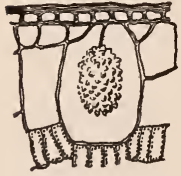

447. Cystolith in leaf of rubber plant.Ficus elastica. bunches of grapes, which are called cystoliths. (Fig. 447.) These are concretions and not true crystals. In saxifrage, mineral matter appears as incrustations on the surface of the plant. Toward autumn, crystals of calcium oxalate become very abundant in the leaves of many deciduous trees; examine cross-sections of peach petiole in June and again in October.

468. To study crystals and cystoliths: Section the rootstock of skunk cabbage or Jack-in-the-pulpit, the leaf 
of Ficus elastica, the leaf of ivy (Hedera helix); make a separate mount of each in water, and examine with the high power. When the erystals are found, draw them, with a view of the adjacent cells. Make a similar study of a bit of thin onion skin.

Review. - Name ten classes of contents or products of the cell. Where found? Of what use? What is chlorophyll? What is its use? What is assimilation (185)? Give outline of the products of cells found dissolved in cell-sap. What are the uses of sugar to plants? Name some kinds of sugar found in plants. Deseribe an experiment to test for glucose. Same for eane-sugar. How may we find the oil in plants? Deseribe an experiment for the study of gum-resin. Why does the juice containing it appear white? Deseribe stareh grains of potato. Tell how starch grains of other plants studied differ from those of potato. What are the uses of starch to the plant? Where is the plant's starch factory? Describe an experiment to test for starch. Name some plants in which one may find amylo-dextrine. How does its test differ from that for starch? What are aleurone grains? In what cells are they found in kernels of wheat? Name some of the forms in which we find true erystals in plant cells.

NOTE.-The digestion of starch is produced by means of enzyms (183) or unorganized ferments (i.e., ferments that are not bacterial or fungal, but are chemical substances). These ferments, as diastase, are present in seeds and other living tissues containing stareh. During dormant periods the enzyms either are not present, or their action is prohibited by the presence of other substances. There are various specific enzyms, each producing definite chemical changes.

Grape-sugar and its associate, fruit-sugar, appear to be the forms most generally useful to plants. Cane-sugar is readily inverted into these sugars. 


\section{CHAPTER XXXVIII}

\section{TISSUES}

469. The lowest plants are unicellular or composed of only one cell. Of such are bacteria. (Fig. 136.) All the higher plants are composed of collections or aggregations of innumerable cells: they are multicellular. If we examine the cells of the stem, the leaves, and the roots of any common garden plant we find that they differ very widely from each other in shape, size, and texture.

470. Any group of similar cells is called a tissue. Each of the different tissues of a plant has its own type of cells, although the cells in a tissue may differ from each other in various minor ways.

471. Parenchymatous Tissue.-Thin-walled cells are known as parenchyma cells. When they unite they form parenchymatous tissue. These may or may not be elongated in form, and they usually contain protoplasm. Parenchymatous tissue is found at the growing point of a shoot or root (Fig. 448); in the mesophyll (soft pulpy part) of the leaves (Fig. 468); around the vascular bundles of stems and roots (Fig. 455f), and in a few other places, as pith, medullary rays, etc. The cells of this tissue may be meristematic - in a state of active division and growth; or they may be permanent, no longer able to divide.

472. One important use of this tissue is to form other tissues, as in growing points. Near the end of any young root or shoot the cells are found to differ from each other more or less, according to the distance from the ponit. This differentiation takes place in the region just back of the growing point. In the mesophyll (or middle soft part) of 
lcaves the elaboration of plant-food takes place. Intercellular spaces filled with air and other gases are common in this tissue of leaves, as well as in parenchyma of other parts of the plant.

473. To study growing points use the hypocotyl of Indian corn. Prepared slides may be secured having stained longitudinal sections of the hypocotyl. The median section should be studied with the high power. Note these points (Fig. 448): (a) Root-cap beyond the growing point. (b) The shape of the end of the root proper and the shape of the cells found there. (c) The group of cells in the middle of the first layers beenath the root-cap. This group is the growing point. (d) Study the slight differences in the tissues a short distance back of the growing point. There are four regions: the plerome, several rows of cells in the center; the endodermis, composed of a single layer on each side; the periblem, of several layers outside the endodermis; the dermatogen, on the outcr edges. Make a drawing of the section. If a series of the cross-sections of the hypocotyl should be made

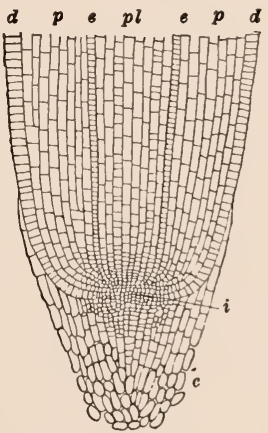

448. Growing point of root of Indian corn: $d, d$, dermatogen; $p, p$, periblem; $e, e$, endodermis; $p l$, puerome; $i$, initial group of cells, or growing point proper; $c$, root-cap. and studied, beginning near the growing point and running back some distance, it would be found that these four tissues become more distinctly marked. The central eylinder of plerome will contain the ducts and vessels; the endodermis remains as endodermis; periblem becomes the cortex of parenchyma; the dermatogen becomes the epidermis of the root.

474. Epidermal Tissue is a special modification of parenchyma, comprising the thin layers on the exterior of 
leaves and stems. The cells are often tabular or plate-like in form, as in the epidermis of leaves (Fig. 137); and their outer surface bears a layer of cuticle, a protective substance which is insoluble even in sulfuric acid. They do not: bear chloroplasts and often contain only cell-sap, with a little protoplasm. Their walls are much thickened in some cases, as in Figs. 447 and 471. Hairs and bristles are considered to be modified epidermal tissue.

475. Collenchymatous Tissue.-Tissue composed of cells thickened at the angles, not much elongated and not lapping

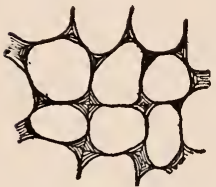

449. Collenchyma in wild jewel-weed or touchme-not (impatiens). at the ends, is known as collenchyma. (Fig. 449.) It is strengthening tissue. Good examples are found in such vines as pumpkin, cucumber and gourd. The tissue is slightly elastic and allows of some stretching. Cut a few thin cross-sections of large stems of jewel-weed, and mount in water. Study with high power.

476. Soft Bast or Sieve Tissue.-In the higher plants is a tissue known as soft bast or sieve tissue (this also forms part of the bundle; 476). It is composed of two types of cells which almost always accompany each other. These are sieve tubes and companion cells. (Fig. 450.) Both are elongated, thin-walled and blunt at the ends. The sieve tubes are so called because of the sieve-like areas that they bear in various parts. These areas, called sieve plates, are commonly at the ends (as partitions) but may be in the lateral walls. (Fig. 450.) They serve to connect the cellcavities with each other, and through them the protoplasm strands extend, as shown in the figure.

47.7. Prosenchymatous Tissue.--Several elongated and strong tissues, that greatly strengthen the stems in which they are found, are collectively known as prosenchyma. The cells of these tissues become much thickened by the addition of layers to the inner surface, and finally lose their protoplasm. 
At times they may serve as store-rooms for starch and other products, and take an important part in the transfer of the plant juices.

478. There are four main varieties of tissues that may be included under prosenchyma. (1) Fibrous tissue, composed of very thickwalled cells with very small central cavities. (F, Fig. 454.) They are very long and tapering at the ends, which lap. Such tissue is found in many plants where it often wholly or in part surrounds the fibro-vascular bundles. It is more often but not always found near the soft bast: hence the cells are sometimes called bast fibers or hard bast. Wood tissue, or wood fibers. This is composed of cells much like the preceding in strueture, but with thimner walls and the central cavity not so nearly closed. In some cases

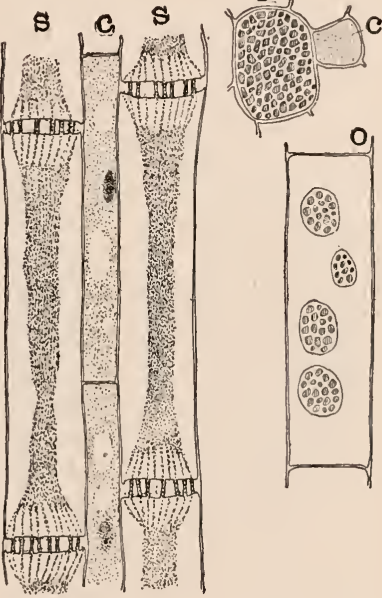

450. Bast-tissue. $s, s$, sieve tubes; $c$, companion cell; $p$, shows a top view of a sicre plate, with a companion cell, $c$, at the side $o$, shows sieve plates in the side of the cel. In $s, s$, the protoplasm is shrunken from $t 1.3$ walls by reagents.

such fibers have transverse walls. Wood cells constitute a large part of the wood of some plants and in other cases are scattered only among the other prosenchyma. (3) Tracheids. Cells of this tissue differ from ordinary cells in being supplied with numerous bordered pits or other characteristic markings. They constitute almost all of the wood of the pines and other gymnosperms. (Fig. 
451.) (4) Vascular tissue, composed of large cells which become confluent end to end, forming long tubes or ducts. ('T'', Fig. 454.) From the thickened markings which these cells bear they are named spiral, annular, pitted, scalariform, etc. (Fig. 441.) These vessels are often of considerable length, but are never continuous through the entire plant. Cut a grape-vine stem 2 or 3 feet long. Place one cut end in a glass of water and with the other end in the mouth,

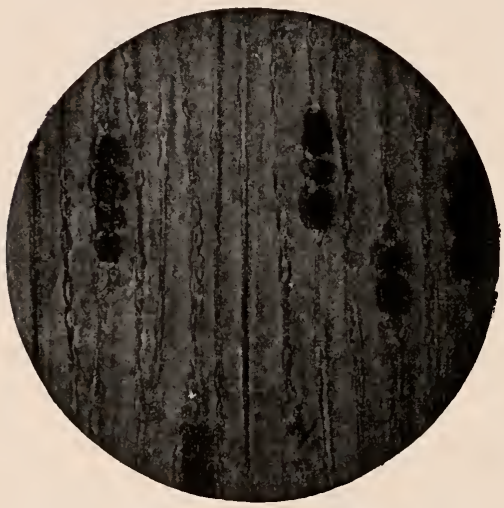

451. Longitudinal tangential section of Scoteh pine wood, highly magnified. It shows tracheids with bordered pits. The dark cells are cut ends of medullary rays. try to force air through the stem. If not successful, shorten the stem a little.

479. Sclerenchymatous or Sclerotic Tissue. - Sclerenchyma cells are hard, not elongated, of ten somewhat spherical, and their thickened walls are provided with simple or branching canals. The cells of this tissue are illustrated by the common grit cells of the pear and some other fruits. They are also found in the coats of many seeds, in nut shells, in the pith of some plants. Hold a large gritty part of a pear between two pieces of smooth elder pith or cork and make free-hand sections. Mount in water. Make a drawing of a single cell showing thickness of wall, size of central cavity, wall markings. Note the general shape of the cells.

480. Laticiferous Tissue.-That tissue found in many 
plants which contain a milky liquid is called laticiferous tissue. There is no fixed type for the vessels that carry this fluid, as they vary greatly in different plants, being simple in the asclepias (milk-weed), and complex in the danclelion.

481. Tissue Systems.-The parts of complex plants may be conveniently grouped into three tissue systems: (1) Fibro-vascular tissue system. This is composed of fibro-vascular bundles. The fibrous framework of roots, stems, and leaves is made of fibro-vascular bundles. ("Fibrovascular" means fibrous or long and slender, and having long openings or shannels.) Each bundle is composed of two fundamental parts: phloem and xylem. The bast fibers may or may not be present. Phloem is another name for the soft bast or sieve tissue, while xylem is the name of the lignified or woody part, and is composed chiefly of the wood cells, tracheids, and ducts. In stems of dicotyledons (exogens), these two parts of the bundle are separated by cambium, a meristematic layer giving rise to xylem on one side and to phloem on the other. For types of bundles, see next chapter. (2) Fundamental tissue system. This is composed of the parenchymatous tissue already described. The fibrovascular system may be said to be imbedded in the fundamental tissue. (3) Epidermal tissue system. This is the covering of the other systems, and is composed of epidermal tissue, already described. It should be borne in mind that the types of cells and tissues as defined in this chapter are not all that may be found in plants. There are many intermediate forms, e.g., tracheids and ducts blend the one into the other; and the same is true of wood cells and tracheids.

482. Summary of tissues studied:

1. Parenchymatous tissue.

a. meristematic.

$b$. permanent.

2. Epidermal tissue. 
3. Collenchymatous tissue.

4. Soft bast or phloem (sieve tissue).

5. Prosenchymatous tissue.

a. Fibrous tissue or bast fibers.

$b$. Wood tissue or wood fibers.

c. Tracheids.

d. Vascular tissue or ducts.

6. Sclerenchymatous or sclerotic tissue.

7. Laticiferous tissue.

8. Tissue systems.

Review.-What is a tissue? How may two tissues differ? What is parenchymatous tissue? Name three places where this is found. Distinguish between meristematic and permanent tissue. Name two uses of parenchymatous tissue. Of what utility are the intercellular spaces of leaves? Describe the parts studied in the section of root tip. What part of this tip will become vascular? Describe epidermal tissue. Collenchyma. Sieve tissue. Of what use are the sieve areas? What are the chief uses of prosenchyma? Describe fibrous tissue, wood cells or wood fibers; tracheids; ducts. What does your experiment in blowing air through a grape-vine stem indicate? Describe cells of sclerotic tissue. Laticiferous tissue. Name three tissue systems. What are fibro-vascular bundles? What two classes of tissue are found in each bundle? Of what is phloem composed? Xylem? 


\section{CHAPTER XXXIX \\ STRUCTURE OF STEMS AND ROOTS}

483. There are two main types of stem structure in flowering plants, which have their differences based upon the arrangement of the fibro-vascular bundles. These types are endogenous and exogenous.

484. Endogenous Stems.-In endogenous stems, the vascular bundles are irregularly scattered through the fundamental tissue of the stem (Fig. 452), and are not arranged in eircles about a common center. These plants are monocotyledons. The bundles are not parallel with each other, and are not of the same size throughout their length. Fig. 453 shows the direction often taken by the bundles in the stem. On the exterior there is either an epidermis or a false rind. The only trees that have this kind of stem are natives of the tropies or of warm countries. The palm is one of them, and these stems are sometimes ealled the palm type. In our climate are many examples, such as greenbrier, Indian corn, asparagus, grasses, orehids, iris, and eat-tail.

485. To study arrangement of bundles in corn: Cut thin sections of a small corn stem that has been

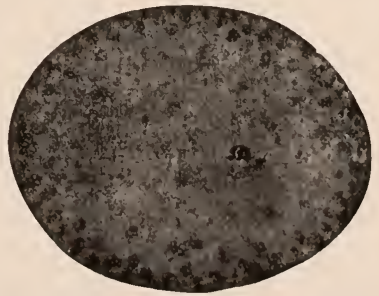

452. Cross-section of corn-stalk, showing the scattered fibro-vascular bundles. Slightly enlarged. preserved in aleohol. Stain with hematoxylin; or the sections may be examined first without staining. Examine with the 
low power, and make a sketch showing the arrangement of the bundles. The sections, if mounted in a permanent way, as in balsam, may be kept for further study of the bundles. Compare with Fig. 454.

486. Exogenous Stems.-The fibro-vascular bundles in exogenous (or dicotyledonous) stems are arranged in a circle around the center, which is usually filled with pith. Outside the ring of bundles is a cortex of fundamental tissue. Around this is either a layer of cork or an epidermis. Layers of parenchyma cells, called medullary rays, are found between the

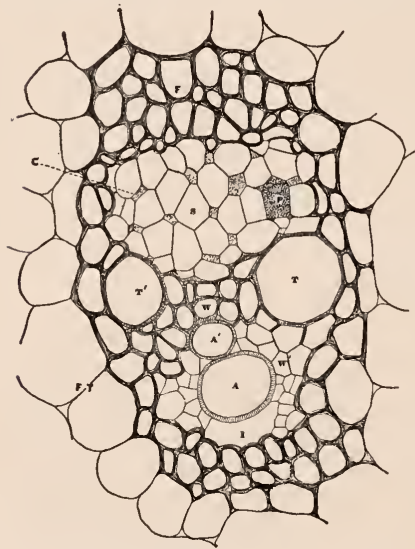

454. Fibro-vascular bundles of Indian corn, much magnified. A, annular vessel; $\mathbf{A}^{\prime}$, annular or spiral vessel; $\mathbf{T T}^{\prime}$, thick-walled vessels; w, tracheids or woody tissue; $F$, sheath of fibrous tissue surrounding the bundle; FT, fundamental tissue or pith; s, sieve tissue; $\mathbf{P}$, sieve plate; $c$, companion cell; $\mathbf{I}$, intercellular space, formed by tearing down of adjacent cells; w', wood parenchyma. bund les and often extending

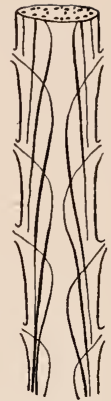
from the central pith to the outer cortex. These usually are prominent in young stems of woody plants and in vines. (Fig. 457.) All trees and nearly all other woody plants of the temperate regions, as well as many herbaceous plants, show this plan of stem. The medullary rays are very prominent in oak wood. These rays are lignified in the xylem part of the bundle and non-lignified in the phloem part.

487. To study arrangement of bundles in ex- 
ogens: Prepare thin cross-sections of the stems of menispermum (moonseed), one year old, of geranium or of tomato

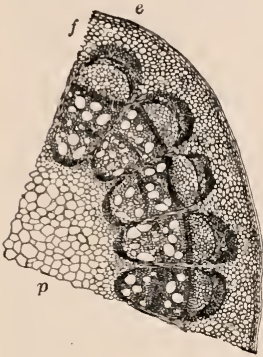

455. Arrangement of tissues in 2-year-old stem of moonseed. $p$, pith; $f$, fundamental tissue; $e$, epidermis. The fibrovascular bundles are very prominent.

plant. Other greenhouse or garden plants may be employed. Stain with hematoxylin. Make a permanent mount. Study with low power, and make a sketch showing the shape and location of the fibro-vascular bundles. (Fig. 455.) Save the mount for further study. If menispermum stems are not easily obtained, ivy (Hedera helix), clematis, geranium, coleus, tomato or other plants may be substituted. In woody stems the compression is such that the student is usually puzzled to understand the bundle structure. The subject will be simplified if he compares (on cross-section) the bundles in such a plant as the cucumber with that part of the vascular ring that lies between any two medullary rays in one-year-old stems of peach, elm, oak.

488. Other Stems.-Besides the two types of stems studied above, which are prevalent among phenogams, there are other kinds of structures of stems among the cryptogams. A com-

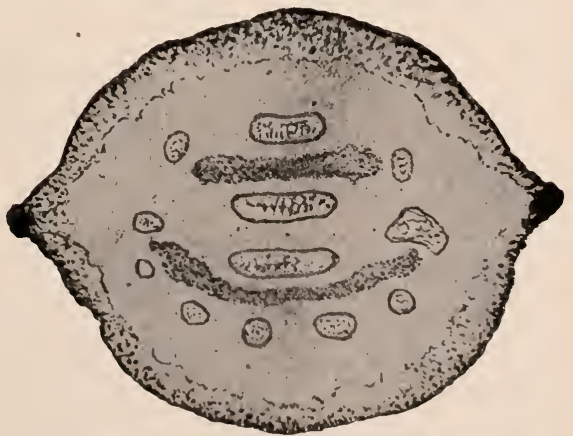

456. Cross-8ection of root of brake (Pteris aquilina), showing twelve concentric fibro-vascular bundles. The two long dark strands are composed of fibrous tissue. 


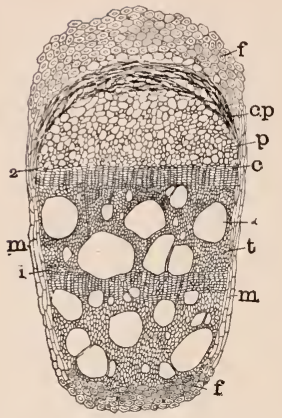

457. Cross-section of fibro-vascular bundle of moonseed (see Fig. 455). $f$, $f$, crescent-shaped sheaths of bast fiber; $p$, phloem; $c p$, erushed phloem; $c$, cambium; $d$, xylem ducts; $t$, xylem tracheids; $m$, medullary rays of fundamental tissue; from $c$ to $f$ (at bottom), xylem; 1 , end of first year's growth; 2 , end of second year's growth of wood.

bundles are based. These plans are collateral, bi-collateral and concentric.

490. In collateral bundles, the phloem and xylem are placed side by side, the xylem being nearer the center of the stem and the phloem outside or nearer the circumference of the stem. This plan occurs in the stems of phenogams. The collateral bundles may be either open or closed. Open bundles are those that continue to increase in size during life

mon arrangement of the bundles is in the form of a circle some distance from the center, with a few other bundles within the circle. Within the circle also are sometimes large areas of fibrous tissue. (Fig. 456.) There are, however, wide variations from this structure, but this mode of arrangement is often called the fern type of stem.

489. Three Types of Bundles.It has already been said (481) that every fibro-vascular bundle is made up of two parts: (1) phloem or soft bast; (2) xylem or wood. The relative position of these two strands of tissue is very important. There are three plans of arrangement, on which three types of

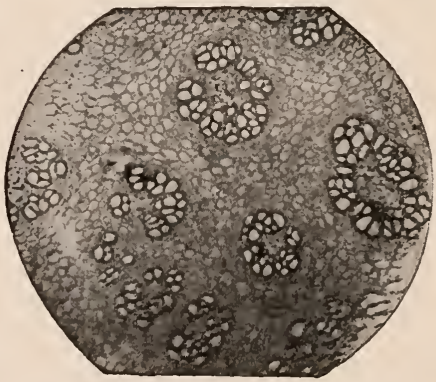

458. Part of cross-section of root-stock of asparagus, showing a few fibro-vascular bundles. 
by the presence of a growing layer at the line of union of the phloem and xylem. This layer of growing cells is called cambium. Dicotyledonous stems have open collateral bundles. (Fig. 455.) Closed bundles are those that cease growing very early and have no cambium or growing layer. They are called closed, perhaps from the fact that there is no means by which they may become larger. Stems of monocotyledons have bundles of the closed collateral type. Examine with high power cross-sections of menispermum stems and corn stems (see Figs. 454, 455, 457), that have been stained with hematoxylin. Study the tissues found in a single bundle of each, with the aid of the illustrations.

491. In concentric bundles, the xylem is centrally placed in the bundle and the

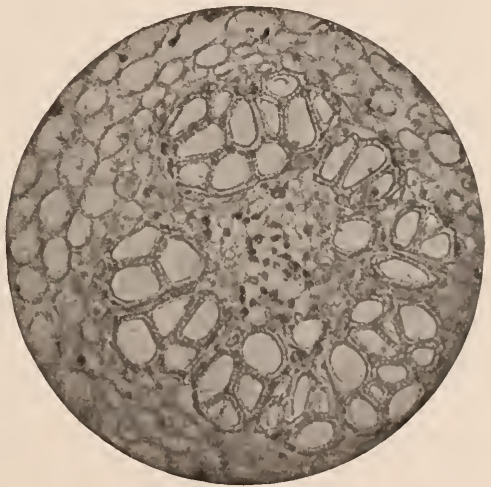

459. Enlargement of a single concentric bundle from Fig. 458. phloem is all around it, as in club mosses and ferns (Fig. $456)$; or the phloem is in the center of the bundle and the xylem surrounds it, as in the underground stems of some monocotyledons, as asparagus. (Figs. 458, 459.)

492. To see concentric bundles: Prepare cross-sections of the stem of pteris or aspidium. They should be cut very thin and stained with hematoxylin. Make a sketch showing the arrangement of bundles. Bicollateral bundles differ from the collateral in having additional phloem on the inner side of the xylem strand; as in pumpkins and squashes. 
493. In roots, the phloem and xylem are not definitely arranged in bundles, but in alternating radial strands or plates. This plan is typical in young roots and rootlets, but is more or less obscured in older ones as seen in Fig. 467.

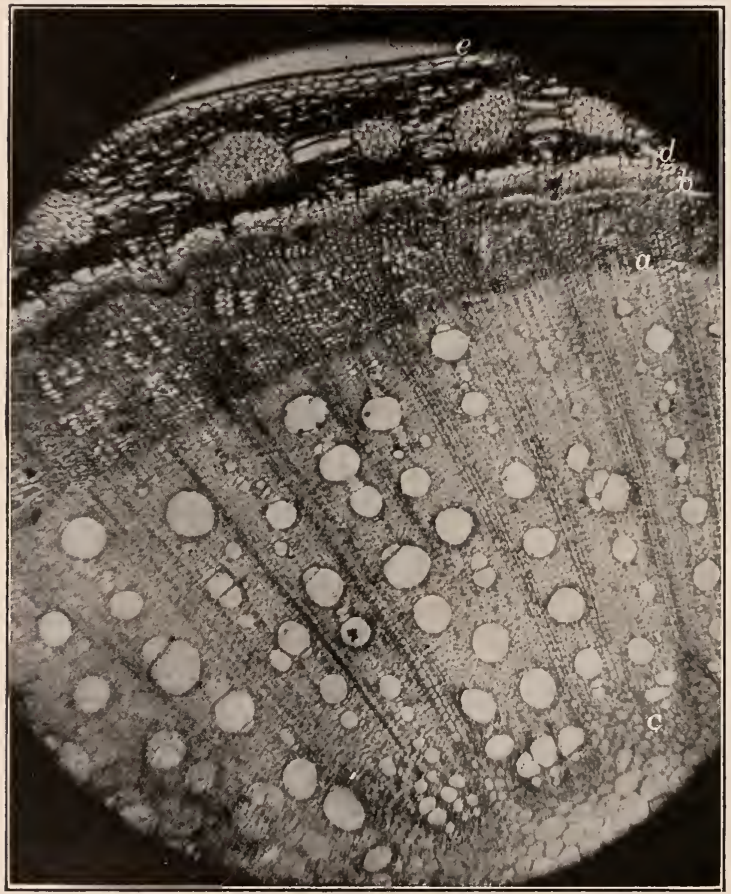

460. Microphotograph of cross-section of grape cane of a single season's growth; a cambium; $a-b$, phloem; $a-c$, xylem; $b-d$, periderm layer, derived from phellogen, which cuts off the cortex, $d-e$, with its primary bast bundles. Note large medullary rays, $m$, and the large ducts for water conduction. Compare with structure of pine wood, Fig. 461. 
494. Secondary Thickening of Stems.-Dicotyledonous (or exogenous) stems with open collateral bundles may increase in diameter each year. If they are perennial, they may add a ring of growth each spring. (Fig. 461.) These rings may be counted on the smooth cross-cut surface of a tree, and the age of the tree usually can be very closely determined. All

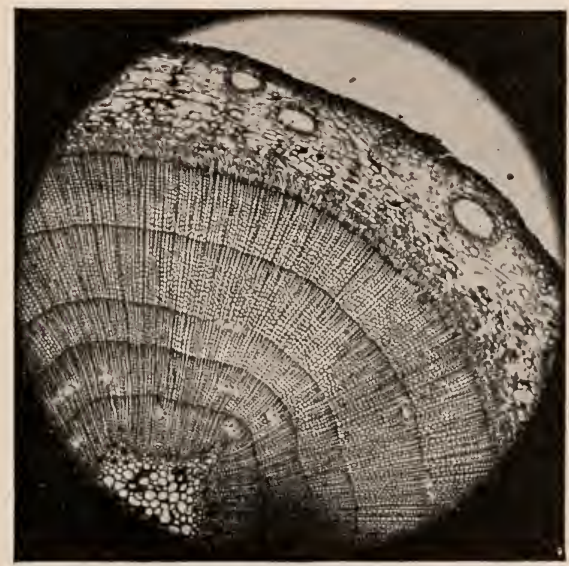

461. White pine stem five years old. The outermost layer is bark.

growth in thickness due to the formation of new cells outside of the primary wood is called secondary thickening.

495. As we have seen (490), there is a cambium or growing layer in every open collateral bundle just between the xylem and phloem. Each spring the cells of this layer divide many times and form new cells both inside and outside the cambium ring. (Figs. 462, 463.) Those formed inside become thick-walled and are xylem. Those formed to the outside of the ring are gradually changed into phloem. The crowding of the cells within the cambium ring causes the 
ring itself to enlarge its circumference and to move outward by this growth.

496. To study secondary thickening: Cut thin crosssections of basswood stems of different ages (one to three years old). Stain and mount. Examine with low power and
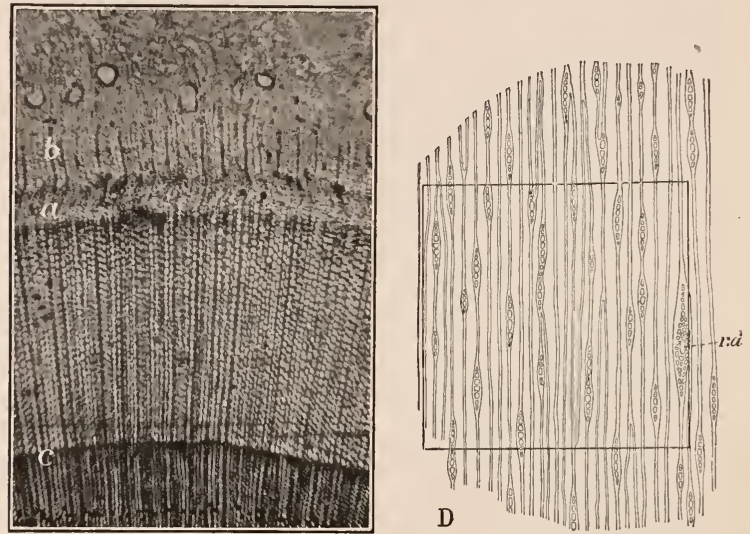

462. Microphotograph of cross-section showing secondary growth in larch, June $13 ; a$, cambium; $a-b$, new phloem; $a-c$, new wood. D. Tagential section of wood of pine, showing transverse section of medullary rays; $r d$, transverse resin-duct.

sketch the arrangement of bundles in the oldest and youngest. Note the effect of growth on the medullary rays. Test them with iodin for starch. Now with the high power study the peculiar character of the bast tissue. Note the abundance of fibrous tissue all through it. Draw a single bundle from the stem one year old, carefully showing the location of the cambium and the different tissues in the xylem and phloem strands. (Fig. 464). It may be thought best to precede this experiment with a similar study of two-year-old stem of moonseed, ivy or other vines. 
497. Bark.-In most woody plants, that part of the stem which is outside the cambium ring is called bark. At first it contains the epidermis or outer layer of cells, the phloem and the cortex lying between the epidermis and the phloem. The gradual growth of the stem causes the outer dead layers of bark to crack more or less irregularly and finally

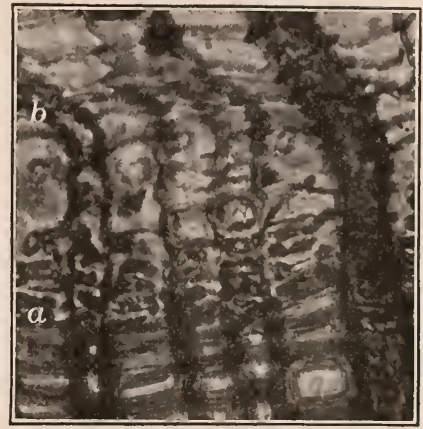

463. Cambium tissue $a-b$, in larch, May 20. Lower quarter, cells of old xylem. Upper quarter, cells of old phloem. Diameter increase just about to begin. Medullary rays are shown. Magnification 500 times. to split off. Examples of this can be seen on the trunks of any large trees. Before the tree is many years old, the cortical cells of the bark become much crushed and are lost to view. The epidermis is shed rather early in

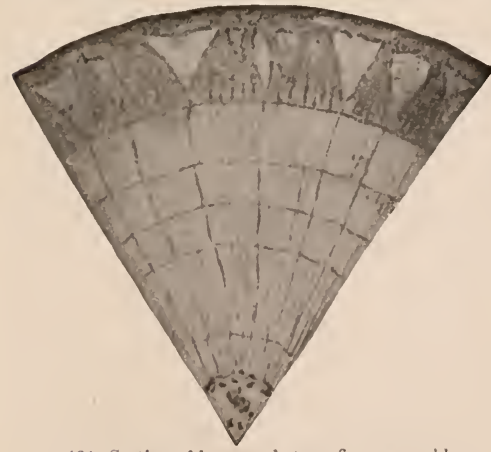

464. Section of basswood stem, five years old.

The cone-shaped growths of phloem are plainly seen. the life of the tree. 498. Usually very early in the life of the stem a corky layer of bark is produced. This is the product of an active layer of cells called phellogen. This layer is first found at those places where the stomates were located. The epidermis is first crowded 
off at these places, and the rough corky spots are called lenticels. Phellogen is very active in the cork oak of Spain,

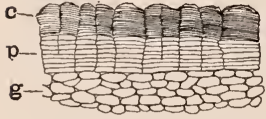

465. Cross-section of red currant twig. showing bark. $c$, corky tissue; $p$, phellogen; $g$, parenchyma or cortex but it occurs in nearly all woody plants. In such plants as buttonwood (sycamore), in which the bark peels off in thin, flat layers, the phellogen layer is nearly uniformly active in all parts, while in many other cases there is very little uniformity. In wahoo (burning-bush) it is in four bands, giving rise to four corner wings. In the section of menispermum already studied, it is found only under the lenticel spots where the stomates have been located. Fig. 465 shows structure of the outer bark as it occurs in the whole circumference of the three-year-old stem of red currant.

499. To study phellogen and corky tissue: Cut thin cross-

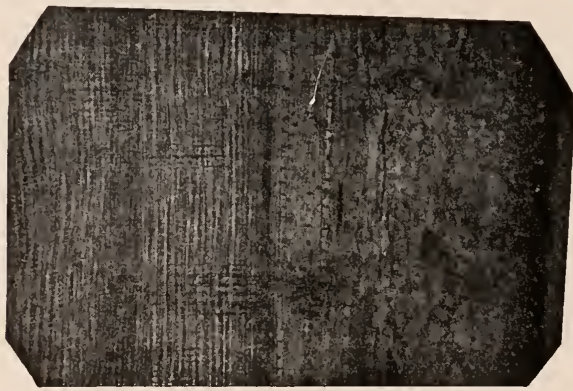

466. White pine stem in radial longitudinal section.

Tracheids on the left with medullary rays crossing them. Next to the wood is the phloem, then fundamental tissue, then the dark bark.

sections of red currant from stems two or three years old that have been kept in alcohol at least several hours. The sections should be stained. With the highest power make a careful study of the phellogen and the corky tissue outside 


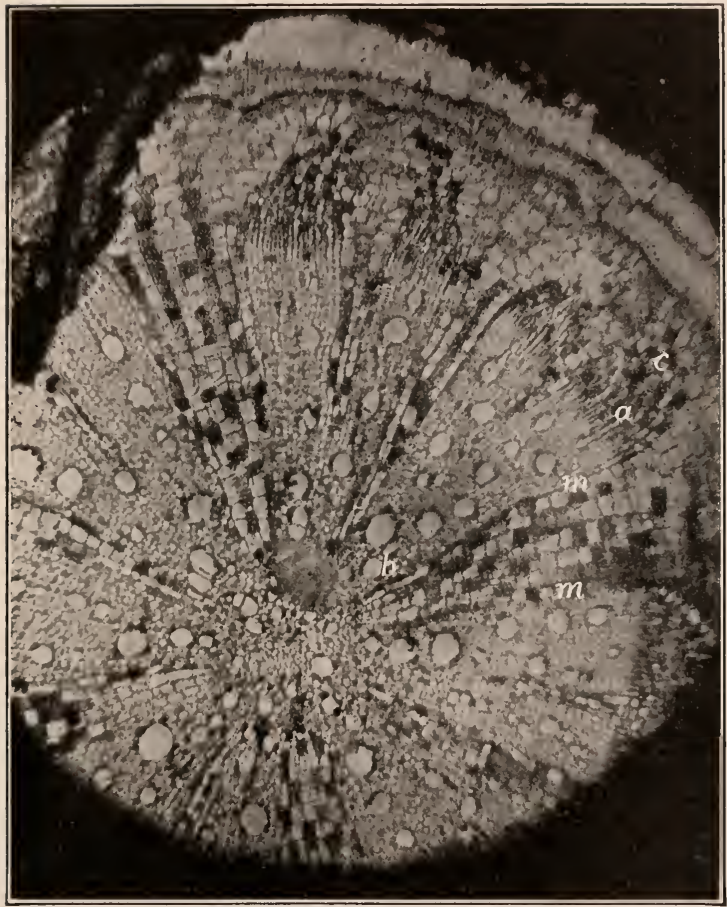

467. Microphotograph of cross-section of root of grape one season old; $m$, medullary rays; $a$, cambium; $a, c$, phloem; $a, b$, xylem.

of it. Draw. The relation of bark to woody tissue in pine is shown in Fig. 461. Cork tissue may be studied to advantage in the skin of the potato.

500. Structure of Roots.-At the growing point, the root has a cap (of small compact eells) that protects the delicate tissues from injury. (Fig. 448.) Such a protection 
does not occur in growing points (buds) of stems. In their internal structure roots differ from stems, especially when very young. In older roots the differentiation is not so marked. (Fig. 467.) Young roots have the radial arrangement of phloem and xylem (490). The number of xylem strands radiating from the center differs with the plant. In roots also there is almost uniformly a true endodermis. This layer is just within the cortex and is composed of rather thick-walled cells. However, many rhizomes and stems have a true endodermis.

501. To study pea roots: From the roots of the pea a few weeks old cut thin cross-sections; stain and mount. With the aid of the low power make a sketch showing the , arrangement of the strands of wood and bast, and also the amount of fundamental tissue. Use the highest power and draw a portion including one strand of wood and two of bast. In this part, draw the tissues from the center out beyond the endodermis. Sections may also be made of the roots of germinating pumpkins or squashes.

REvaEw.-Name two types of stems occurring in flowering plants. Describe each and give examples to illustrate them. Give the plan of arrangement of bundles in fern stems. How many types of bundles are there? Upon what do their differences depend? Describe and give examples of collateral bundles. What difference is there between open and closed collateral bundles? Give examples of each. Describe and give examples of concentric bundles. Radial arrangement. What is secondary thickening? What plants show it? What is the layer called that forms the new cells in a bundle? When is this layer most active? Describe the work of this layer. What part of each bundle of a dicotyledon is found in the bark? What are lenticels? What is phellogen? Describe the work of phellogen in any plant you have studierl. Where is the root cap? What is its use? Describe fully the structure of roots, telling how they differ from stems. 


\section{CHAPTER XL}

\section{STRUCTURE OF LEAVES}

502. Besides the framework or system of veins found in blades of all leaves, there is a soft tissue (468) called mesophyll or leaf-parenchyma, and an epidermis that covers the entire outside part.

503. Mesophyll.-The mesophyll is not all alike or homogeneous. The upper layer of it is composed of elongated cells placed perpendicular to the surface of the leaf. These are called palisade cells. The chlorophyll grains are most abundant in them, because they are on the side of the leaf most directly exposed to the sunlight. Below the palisade cells is the spongy parenchyma, composed of cells more or less spherical in shape, irregularly arranged, and provided with many intercellular air cavities. (Fig. 468; also Fig. 137.) In leaves of some plants exposed to strong light there may be more than one layer of palisade cells, as in the Indiarubber plant and oleander. Ivy, when grown in bright light, will develop two such layers of cells, but in shaded places it may be found as in Fig. 468. Such plants as iris and compass plant,

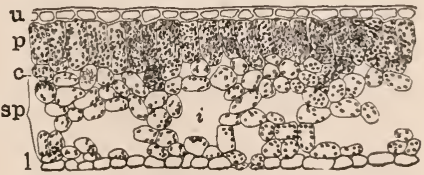

468. Cross-section of ivy leaf, which grew in shade and has only one layer of palisade cells. $u$, upper epidermis; $p$, palisade cells; $c$, a crystal; $s p$, spongy parenehyma; $i$, intereellular space; $l$, lower epidermis. The plant here intended is the true or English ivy, Hedera helix.

which have both surfaces of the leaf equally exposed to sunlight, usually have a palisade layer beneath each epidermis. 504. Epidermis. - The outer or epidermal cells of leaves 
do not bear chlorophyll, but are usually so transparent that the green mesophyll can be seen through them. They often become very thick-walled, and are in most plants devoid of all protoplasm except a thin layer lining the walls, the cavities being filled with cell-sap. This sap is sometimes colored, as in the under surface of begonia leaves. It is not common to find more than one layer of epidermal cells on each surface of a leaf. The epidermis serves to retain moisture in the leaf. In desert plants the epidermis as a rule is very thick and has a dense cuticle.

505. There are various outgrowths of the epidermis. Hairs are the chief of these. They may be (1) simple, as on primula, geranium, nægelia; (2) once branched, as on wallflower; (3) compound, as on verbascum or mullein; (4) disk-like, as on shepherdia (Fig. 469); (5) stellate, or star-

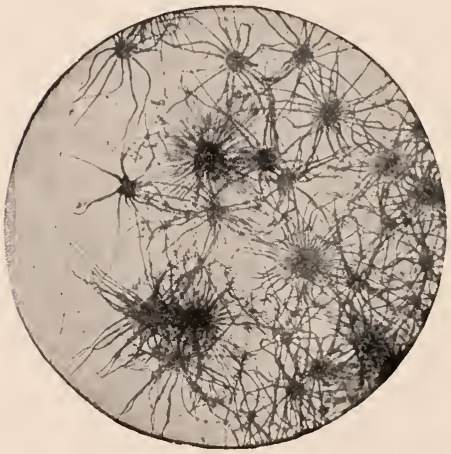

469. Disk-like or radial hairs of shepherdia. shaped, as in certain crucifers. In some cases the hairs are glandular, as in Primula sinensis and certain hairs of pumpkin flowers.

506. To study epidermal hairs: For this study use the leaves of the plants mentioned above or others that may be substituted. Cross-sections may be so made as to bring hairs on the edge of the sections. Or, in some cases, the hairs may be peeled or scraped from the epidermis and placed in water on a slide. Make sketch of the different kinds of hairs. 507. Stomates are small openings or pores in the epi- 
dermis of leaves and soft stems, allowing the passage of air and other gases and vapors. They are placed near the large intercellular spaces of the mesophyll. Fig. 470 shows the usual structure. There are two guard-

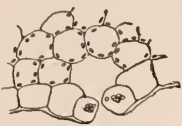
cells at the mouth of each stomate, which may in most cases open or close the passage. It is commonly thought that the opening and closing of the guard-cells is in response

470. Stomate of geranium leaf, showing the guard-cells. to different moisture conditions of the atmosphere. When the air is dry it is assumed that the stomates close and thus retard water loss from the plant, and vice versa. The stomates have generally been thought to regulate transpiration. This is not true. In Fig. 471 is shown a case in which there are compound guard-cells, that of ivy.

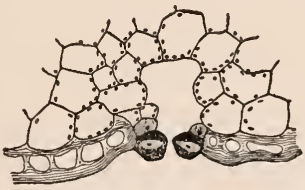

471. Stomate of ivy, showing compound guard-cells. On the margins of certain leaves, as of fuchsia, impatiens, and cabbage, are modified stomates known as water-pores.

508. Stomates are very numerous, as will be seen from the numbers giving the pores to each square inch of leaf surface:

$\begin{array}{rr}\text { Lower } & \begin{array}{c}\text { Upper } \\ \text { surface }\end{array} \\ 13,790 & \text { None } \\ 63,600 & \text { None } \\ 160,000 & \text { None } \\ 200 & 200 \\ 2,000 & 2,000 \\ 11,572 & 11,572\end{array}$

The arrangement of stomates on the leaf differs with each kind of plant. Figs. 472 and 473 show stomates on two plants, and also the outlines of contiguous epidermal cells. The guard-cells contain chloroplasts.

509. Fall of the Leaf.-In most common deciduous plants, when the season's work for the leaf is ended some of the 
nutrients are withdrawn into the stem, and a layer of corky cells is completed over the surface of the stem where the leaf is attached. The leaf soon falls. It often falls even before killed by frost. Deciduous leaves begin to show the surface line of articulation in the early growing season. This articulation may be observed at any time during the summer. The area of the twig once covered by the petioles is called the leaf-scar after the leaf has fallen. Figs. 57, 87, 91 show a number of leaf-scars. Fig. 474 shows the leafscar in the form of a ring surrounding the bud, for in the plane-tree the bud is covered by the hollowed end of the petiole; sumac is a similar case. Examine with a handlens leaf-scars of several woody plants. Note the number of bundle-scars in each leaf-scar. Sections may be cut through a leaf-scar and examined with the microscope. Note the character of cells that cover the leaf-scar surface. Compare 216.

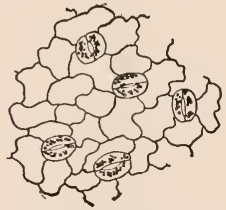

472. Stomates of geranium leaf.

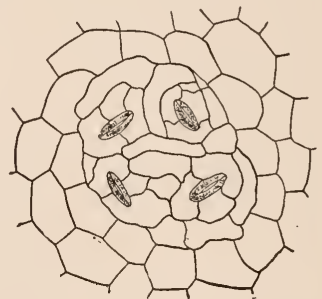

473. Grouped stomates on a begonia leaf.

REview.-Name three tissues found in leaves. On the board, draw a sketch showing the structure of a leaf as seen in cross-section. What cells of leaves bear protoplasm and chlorophyll? Why do some leaves have palisade cells near both surfaces? Describe epidermal cells. Why are their walls much more thickened in some plants than in others? What is the purpose of epidermis? What are stomates? Draw on the board a section through a stomate showing epidermis and mesophyll. Give some idea of number of stomates in various plants. Name several types of epidermal hairs. What utility could be suggested for the dense coat of hairs on leaves of shepherdia? (Fig. 469.)

Note.-To study leaf tissues: A number of leaves can be com- 
pared by making free-hand cross-sections of leaves held between two pieces of pith or cork, and mounting the material in water. Study such leaves as ivy (Hedera helix), begonia, cycas, geranium, and corn. Note the number of layers of palisade cells, the spongy parenchyma, the epidermal layers. Which cells bear chlorophyll? Write a brief description of the tissues of each leaf, and make a drawing of the geranium.

To study stomates in cross-section: In the cross-sections of leaves of geranium, corn, ivy, lily, or spider-lily prepared for the above experiment, look for the stomates and make a careful drawing from the one you can see best.

Study of stomates in surface view: From the under surface of leaves of geranium and impatiens, peel bits of epidermis by tearing the leaf. Mount these in water and examine under low power. Are the stomates scattered or in groups? With the aid of a higher power, draw a few stomates showing their guard-cells and the surrounding epidermal cells. Make

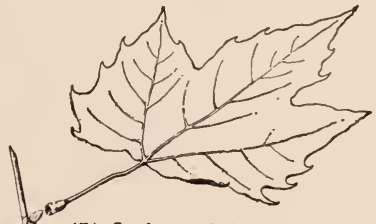

474. Leaf-scar of the plane-tree or sycamore. The scar surrounds the bud, which was covered by the hollow base of the petiole.

a similar study and sketch of the epidermis torn from the under surface of a Begonia sanguinea leaf.

The openings or pores are known as stomata, singular stoma; also as stomates, singular stomate.

Note on Scope, Apparatus, and Methods.-The work outlined in Part III is sufficient, if well done, to occupy one period of the pupil's time each school day for six weeks. These chapters are intended only as laboratory guides. The pupil should work out each structure or part for himself before taking up the succeeding subject. The work in this Part deals with only the elements of the subject, but it is as much as the pupil can hope to take up with profit in an outline course.

Apparatus.-The apparatus necessary for the work outlined in these chapters on histology may be secured from dealers in microscopes and laboratory supplies at a low figure. Schools should obtain catalogues from the following and other reliable dealers:

Bausch \& Lomb Optical Co., Rochester, N. Y.

Eimer \& Amend, New York.

The Franklin Educational Co., Boston.

Ward's Natural Science Establishment, Rochester.

Richards \& Co., Chicago and New York. 
Spencer Lens Co., Buffalo.

Williams, Brown \& Earle, Philadelphia.

Geneva Optical Co., Chicago.

Whitall, Tatum \& Co., New York.

Chas. Lentz \& Sons, Philadelphia.

Kny-Scheerer Co., New York.

Cambridge Botanical Supply Co., Cambridge, Mass.

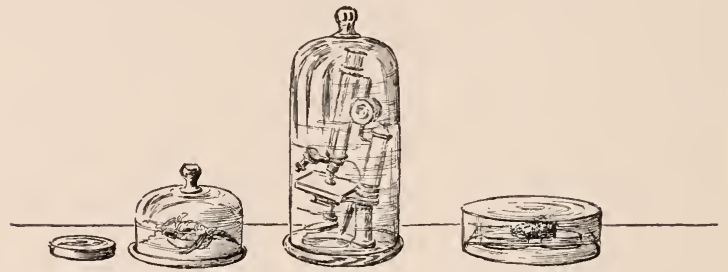

475. All material and apparatus should be kept under cover when not in use.

The microscope should have a 1-inch and perhaps a 2-inch eyepiece, and two objectives of say $2 / 3$ and $1 / 6$ focal lengths. By arranging the laboratory study of the pupils at different times, each microscope may be used by three, four, or even more pupils.

There should be a microtome or section-cutter for use by the class.

If possible, each pupil should have his own individual tools and bottles of reagents, as follows:

1 good razor (hollow-ground on one side only).

1 small scalpel.

1 pair forceps.

2 sharp needles mounted in handles (as penholders). (Fig. 215).

1 medicine dropper.

1 small camel's-hair brush.

A number of slides and cover-glasses.

Of reagents, stains, and other chemicals, there should be the following:

Glycerine.

95 per cent alcohol.

Canada balsam.

Xylol.

Copper sulfate solution.

Iodin dissolved in water.
Iodin dissolved in alcohol.

Potassium hydroxide solution.

Fehling's solution.

Alcanna (henna root in alcohol).

Formalin.

Preparing and keeping laboratory material.-In preparing material for the experiments outlined in Part III, the pupil or teacher will find 
it best to secure much of the material during the growing season and preserve it until the time for use. Material collected can be prepared by placing it immediately in 95 per cent alcohol and then transferring it after twelve hours into 70 per cent alcohol, in which it may be stored for future use. Material may also be prepared in a 2 or $21 / 2$ per cent solution of formalin. Formalin burns the skin.

Free-hand cutting and mounting.-To cut sections, the material may often be held between pieces of pith or smooth cork by the fingers. The material and sections should be kept wet with alcohol during the time of cutting.

The sections when cut should be wet in water, then stained with Delafield's hematoxylin for a few minutes; drain off the hematoxylin and rinse with water; then use 95 per cent followed by absolute aleohol, to extract all the water from the sections; then pour on xylol for a few minutes. If the section is too heavily stained, some of the stain may be removed by repeated rinsing with water. Mount the section on the slide in a drop of balsam and cover with the thin coverglass. Mounts so male are permanent.

Hematoxylin does not mix readily with alcohol, and balsam does not mix with water nor with alcohol. Sections mounted before they are freed from water become cloudy and worthless.

All materials should be kept covered when not in actual use, and always in order. (Figs. 475, 476.) A good work-table may be made on the side of the school-room. (Fig. 477.)

Microtome sectioning.-The sectioning may be improved by the use of a hand microtome, that may be purchased of a dealer at small cost. A more complicated microtome may be employed, but in this case the material must first be imbedded in a matrix like collodion, paraffine or other substance. This imbedding is a complex process; the material must first be treated with various reagents. The method will not be considered here. The reader should refer to Chamberlain's "Methods in Plant Histology" or to Stevens' "Plant Anatomy" for the methods necessary and for directions for staining.

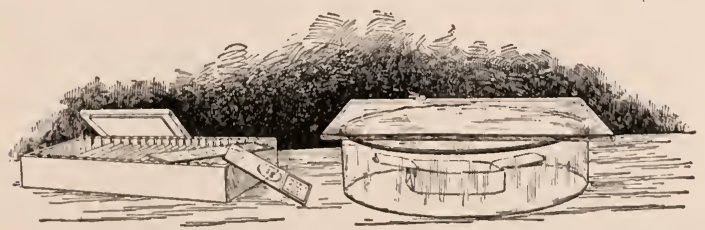

476. Box of microscope slides, and a packet of collodion drying in a glass vessel. 


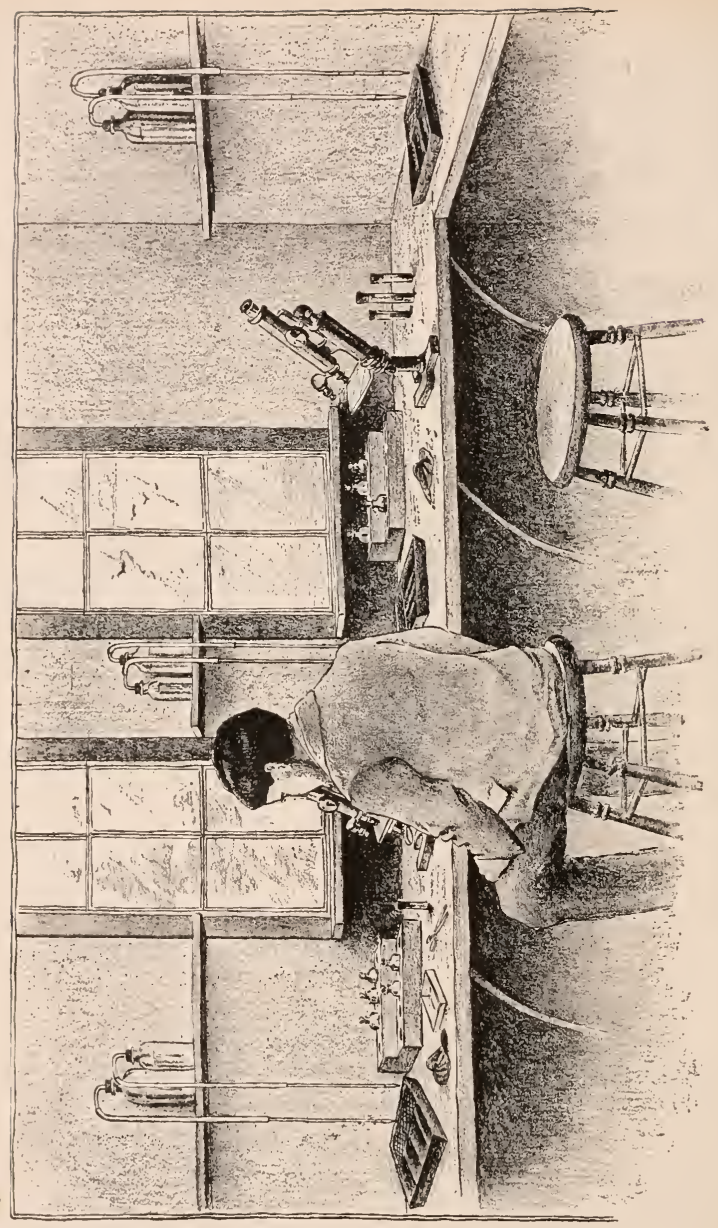

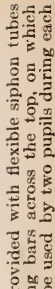

ह่

\&

ठ \&

प⿺

ता है

पें 를

\% क्ष

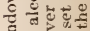

5 :

ङ 대요

范范总。

\& का

ष्य

है

5 F

c

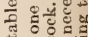

c.

IU

풍ㅎ․ㄹ

- 들

의

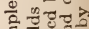

है

$<$ 品

$\therefore$ 过

Is

है.

을

is

흔을

c $\frac{1}{3}$

$\&$ \%

ह.ㄷำ

8 क

․ㅗㅇ

का

등 들

舟的

है: 




\section{PART IV}

\section{THE KINDS OF PLANTS}

Number of Plants.-Above 120,000 distinct kinds or species of seed-bearing plants are known and described. Probably little more than one-half of the total number now existing on the earth is known. Even in the older countries and regions, seed-bearing plants heretofore unknown to science are discovered now and then. Outlying regions are relatively little known botanically. Large parts of Africa, South America, Central America, China, Central Asia, and the tropical islands are only imperfectly explored for plants. Cryptogamous plants are very numerous in kinds, and many kinds - as, for example, various bacteria - are almost infinite in numbers of individuals. In the lower ranges of cryptogamous plants, as in fungi and bacteria, new kinds are being described even in countries in which they have been carefully studied.

Species.-Each kind of plant is called a species. There is no absolute mark or characteristic of a species. Between many kinds there are intermediate forms, and some kinds vary immensely under different conditions. What one botanist considers as a distinct species another botanist may regard as only a variety or form of another species. No two botanists agree as to the number of species in any region. Species are not things in themselves. In practice, any kind of plant that is distinct enough to be recognized by a description, and that is fairly constant over a considerable territory, is called a species. We make species merely to enable us to talk and to write about plants: we must have names to call them by. The different kinds of 
plants are the results of evolution. Probably none of them was created in the beginning as we now find it.

Names of Species.-For more than one hundred and fifty years (since Linnæus published "Species Plantarum" in 1753), species have been known by two names, the generic and the specific. The generic name is the name of the genus or group to which the plant belongs: it corresponds to a surname. The specific name belongs only to the particular species or kind: it corresponds to a given or Christian name. Both names are necessary, however, to designate the species. Thus Quercus is the generic name of all the oaks. Quercus alba is one of the oaks (the white oak), Q. virginiana (the live-oak) another. All maples belong to the genus Acer, and all elders to Sambucus. The same specific name may be used in any genus, as the same Christian name may be used in any family. Thus, there is a Quercus nigra, Cyperus niger, Acer nigrum, the word "niger" meaning black.

By common consent, the oldest proper name of any species must stand. If a species happens to have been named and described twice, for example, the first name, if in the proper genus, must hold; the later name becomes a synonym. It sometimes happens that the same specific name has been given to different plants of the same genus. Of course this name can be allowed to stand for only one species, and the other species must receive another name. In order to avoid confusion of this and other kinds, it is customary to write the author's name with the speciesname that he makes. Thus, if Gray describes a new Anemone, his name is written after the plant-name: Anemone cylindrica, Gray. The author's name thus becomes an index to the history of the species-name.

Plant-names are thrown into the forms of the Latin language. When plants first were studied seriously, knowledge was preserved in Latin, and Latin names were used 
for plants. The Latin form is now a part of the technical system of plant and animal nomenclature, and is accepted in all countries; and the Latin language is as good as any other. In the Latin language all plant-names have gender, and the termination of the word usually differs in each gender. The species-name must agree with the genus-name in gender. Acer is neuter: so are A. rubrum and A. nigrum. Cyperus is masculine; so is $C$. niger. Quercus is feminine, although masculine in form, but trees and shrubs are feminine in Latin: so we write $Q$. nigra. Masculine, feminine, and neuter endings are seen in Rubus sativus, Pastinaca sativa, Pisum sativum. "Sati-vus" means cultivated.

The name of a species not only identifies the species, but classifies it. Thus, if a plant is named in the genus Acer, it belongs to the maples; if it is named in Fragaria, it belongs to the strawberries; if it is named in Pyrus, it is allied to apples and pears; if it is Helianthus, it is one of the sunflowers.

Use of Knowing Plant-names.-The name is an introduction to the plant, as it is to a person. It is an index to its history and literature. It enables us to think and to speak about the plant with directness and precision. It brings us nearer to the plant and increases our interest in it.

The name is a means, not an end. Merely to know the name is of little use or satisfaction. Knowing the name should be only one step in knowing the plant. Of late years, the determining of the names of plants has been discouraged as a school-exercise. This is because all inquiry stopped when the name was secured. A name was a stone wall when it should have been a gate.

How to Find Out the Names of Plants.-There can be no short-cut to the names of plants, for names cannot be known accurately until the plant is known. The name and the plant should be indissolubly associated in the mind. Study first the plant. If one does not know the plant, there is no occasion for knowing its name. 
Learn first to classify plants: names will follow. Look for resemblances, and group the plants around some wellknown kind. Look for sunflower-like, lily-like, rose-like, mint-like, mustard-like, pea-like, carrot-like plants. These great groups are families. The families of plants are better recognized by studying a few representative plants than by memorizing technical descriptions. Go to the botany and use the keys in these families, in order to run the plant down to its genus and species. If the family is not recognized, use the key to find the family. Use the keys at first: gradually discard them. When one looks for relationships, the vegetable kingdom comes to have continuity and meaning. Merely to know names of plants here and there is of little use.

It is unwise for the beginner to try first to find the name of any plant. Let him first examine familiar plants or those which seem to be related to other plants that he knows. Let him get in mind the bold characteristics of the families which are most dominant in his locality. After a time, in case of each new plant, he should be able to give a shrewd guess as to its family; then he may go to the book to verify the guess.

In the following Flora, about fifty well-marked families are chosen for study. Some of them are not the most characteristic of American vegetation, but they are such as afford easily accessible species, either in the wild or in cultivation, and which are not too difficult for the beginner. The pupil should begin with plants of which he knows the common names or with which he is familiar. Several plants should be studied in each family, that he may grasp the characteristics of the family and thereby be led to compare plant-groups and to clarify his perception and widen his horizon. When these families, or the larger part of them, are understood, if the pupil desires further knowledge of species, he may go to the regular manuals in 
which species are grouped or classified according to their natural affinities. It is well to study more than one plant in a genus whenever possible, for then close comparisons can be made.

Making a Collection.-The making of a collection of plants foeuses one's attention, defines one's ideas, and affords material for study at any season. The collecting and preserving of plants should be encouraged. Not until one searches for himself, and collects with his own hands, can he know plants. The collection should not be an end, however. It should be only a means of knowing plants as they live and grow. Too often the pupil thinks it sufficient merely to have made a collection, but the collection of itself is scarcely worth the while.

Plants are preserved by drying them under pressure. The collection, when properly arranged and labeled, is an herbarium. Each species should be represented by sufficient specimens to display the stems, foliage, flowers, fruits. If the plant is an herb, its roots should be shown. There should be several or many specimens of each species, to show the different forms that it assumes. It is less important to have an herbarium of many species than to have one showing the life-phases of a few species. First make specimens of the common species: later one may include the rare ones if he choose, although an herbarium that selects plants merely because they are rare is of little account except as a collection of curiosities. The commonest plants are usually the least represented in herbaria.

Dry the plants between blotters that are 12 inches wide and 18 inches long. These blotters are called "driers." They may be purchased of dealers in botanical supplies, or they can be cut from felt "carpet paper." It is well to place the specimen in a folded sheet of newspaper, and then lay the newspaper between the driers. If the specimens are large or sueculent, three or four driers should be laid 
between them. The sheets may be piled one above another, until the pile becomes so high (10-16 inches) that it tends to tip cver. On the top place a board of the dimensions of the drier, and apply twenty to thirty pounds of stones or other weight. Change the driers-but not the newspapers-once a day at first, laying the moist driers in the sun for a time. In a dry warm place, most plants will dry in a week or ten days. When thoroughly dried, they retain no soft, sappy, fresh-green areas, and they usually break if bent sharply. They will be perfectly flat.

The use of corrugated paste-board has proved very satisfactory in drying specimens. The board should be of the same size as the driers. Place one of the corrugated boards upon a table; over it lay a drier; then the sheet containing the specimen; over this a drier; then another corrugated board, a drier, a sheet containing specimens, and so on. The corrugations of the board provide air passages for the removal of moisture absorbed from the specimens by the driers; and, unless very succulent plants are being pressed, it is not necessary to change driers at any time while the specimens are drying. The pile should be weighted as described above.

The specimen may now be secured to strong white paper, known as "mounting paper." The regulation size of the sheets is $11 \frac{1}{2} \times 161 / 4$ inches. It is the quality of heaviest ledger paper. By the ream, it can be bought for one cent or less a sheet. The specimen should be large enough nearly or quite to cover the sheet, unless the entire plant is smaller than this. It may be glued down tight, as one pastes pictures in a scrap-book, or it may be held in place by strips of gummed paper. The former is the better way, because the plants are not so easily broken. Only one species should go on a sheet. In one corner, glue the label. This label should give the place and date of collecting, name of collector, and any information as to height, color, nature of soil, and the like. Sooner or later, the label should 
contain the name of the plant; but the name need not be determined until after the plant is mounted. (Fig. 478.)

The sheets of one genus are laid together in a folded sheet of strong straw-colored paper. This folded sheet is

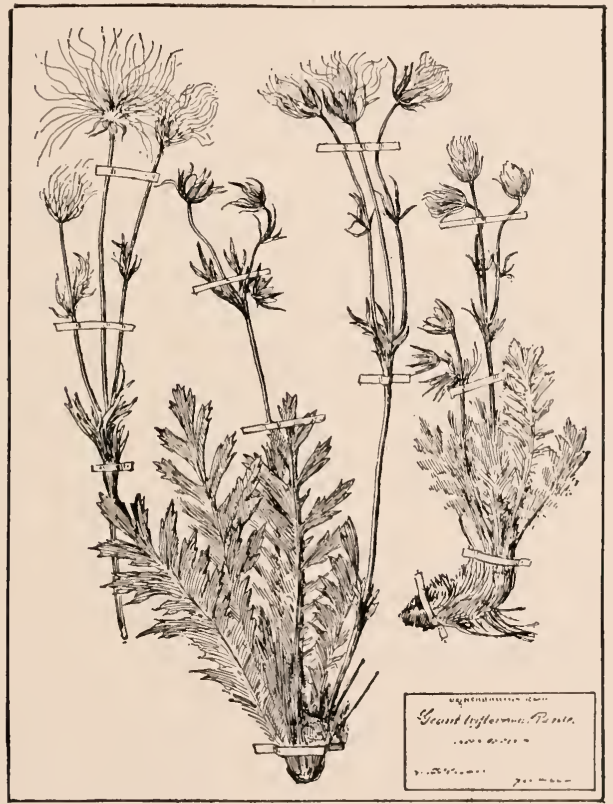

478. An herbarium sheet. In this case, the specimens are held in place by atrips of glued paper.

the "genus cover." Its size when folded is $11^{3} \frac{1}{4} \times 16^{1 / 2}$ inches. On the lower left-hand corner the name of the genus is written. If one has many sheets in one genus - say more than 20 -it may be necessary to have more than 
one cover for them. The covers are laid in cupboards flatwise, one on the other, and the sheets then retain their shape and are always ready for use.

Explanation of the Flora.-The following Flora contains 625 species of plants in 294 genera and 51 families. These species are selected from common and representative plants, in the hope that 50 to 100 of them may be secured by any pupil. The pupil should collect his own specimens as far as possible, and he should press and preserve them after he has studied the structure. Familiarity with 100 plants will give the pupil a good grasp of plant forms, provided he does not stop with merely acquiring the names and pressing the specimens. He should know how the plants look, where they grow, how they associate with other plants, how long they live, and the like.

Avoid the use of keys as much as possible: learn to see the plant as a whole: go directly to the family, if possible. But it may be necessary to use keys at first. In this book coördinate parts of the key are marked by the same letter: e.g., F, FF, FFF, are three coördinate entries. Coördinate entries are also introduced by the same catch-word, as "flowers," "leaves," "fruit." Using a key is a process of elimination. First try the plant in $\mathrm{A}$; if it does not belong there, go to AA. Then repeat the search in D, DD, etc., until the family is found.

Synonyms are placed in parentheses immediately following the accepted name. Thus "Impatiens biflora, Walt. (I. fulva, Nutt.)" means that the accepted name is Walter's I. biflora, but that the plant is also known by Nuttall's name, I. fulva.

Proper pronunciation is suggested by the accent, which indicates both the emphatic syllable and the length of the vowel. The grave accent (") indicates a long vowel; the acute ('), a short vowel. Terminal vowels are pronounced in Latin words. The word officinale is pronounced offici- 
nìy-ly; aurea with au as in Laura; virginiana with the $a$ as in hay; ilba, with $a$ as in had; acutíloba with $i$ as in hill; minor with $i$ as in mine; halimifolia with $o$ as in hole; japónica with $o$ as in con; rimex with $u$ as in tune; fúnkia with $u$ as in run.

Key to the families as represented in the following pages

A. CRYPTOGAMS: no true flowers or seeds: propagating by means of spores. . . . . . . . . 321

AA. PHENOGAMS: bearing flowers and seeds.

B. Gymosperus: seeds naked (not enelosed in ovaries), borne in cones or berries: no conspicuous flowers: lvs. needleshaped or scale-like: plants usually evergreen..... Coniferæ, p. 324

BB. Angiosperus: seeds borne in ovaries: flowers usually showy: leaves very various, mostly deciduous.

c. Monocotyledons: cotyledon 1: leaves mostly parallelveined, not falling with distinet articulation: stem with seattered fibro-vascular bundles (endogenous) and no separable bark: flowers mostly 3-merous.

D. Flowers without true perianth, except sometimes small scales, or bracts, or bristles, but inclosed by green alternate glumes, or chaffy braets: arranged in spikes or spikelets: grass-like plants.

E. Glumes in pairs, of 2 sorts (glumes and palets): culms round, hollow: leaf-sheaths usually split on one side opposite blade ......................

Graminex, or Grass Family, not treated here.

EE. Glume or seale single, with flower in axil: perianth none or replaeed by bristles: culm triangular, solid; sheath entire or elosed ...................

Cyperaceæ, or Sedge Family, not treated here.

(For grass-like plants having flowers with 6 similar, green or chaffy bracts [glumaceous segments], culms solid, See Juncacex, or Rush Family, not ineluded here.)

DD. Flowers without glumes, borne on spadix, small, inconspicuous, usually attended ly spathe..........Aracex, p. 327

DDD. Flowers not on spadices, mostly conspicuous.

E. Perianth free from ovary.

F. The perianth with all parts similarly colored.

G. Parts of perianth 6, similar, green or chaffy (bract-like) or glume-like (glumaceous segments).

Juncaceæ.

GG. Parts of nerianth 6, regular, eolored .... Litiaeeæ, p. 328 FF. The perianth with parts differently eolored.

G. Leaves in a whorl: stipmas 3 . Trillium in Litiacex, 1), 332 GG. Leaves alternate: stigma $1 \ldots \ldots$ Commelinacex, 1). 334 
EE. Perianth-tube adherent to ovary wholly or partly: flowers perfect.

F. Anthers $3 \ldots \ldots \ldots \ldots \ldots \ldots \ldots \ldots$. $\ldots \ldots$ ridaceæ, p. 337

FF. Anthers $6 \ldots \ldots \ldots \ldots \ldots \ldots \ldots$ Amaryllidace $x$, p. 335

FFF. Anthers 1 or 2 , united with pistil, gynandrous......

Orchidaceæ, p. 339

cc. Dicotyledons: cotyledons 2 or more: leaves mostly nettedveined, usually falling with a distinct joint or articulation: stem with concentric layers of wood when more than one year old (exogenous), and a distinct separable bark: flowers mostly 5-merous or 4-merous (comprising the remainder of this key).

D. Choripetalæ: petals distinct or wanting (i. e., flowers polypetalous, apetalous or naked, in distinction from gamopetalous, pD, p. 319).

E. Flowers characteristically apetalous; mostly small and often greenish, inconspicuous.

F. Plants woody.

G. The flowers monœcious or diœeious, one or both sorts in catkins.

н. Fertile flowers in short catkins or heads: calyx regular in the pistillate flower, becoming fleshy or juicy in the fruit (juice milky)......

Urticacex, p. 345

нн. Fertile flowers $1-3$ in a cup-like involucre: or 2 or 3 at each seale of the pistillate catkin: fruit dry, often winged, or a 1-seeded nut: sterile fls. in elongated catkins..... Cupuliferæ, p. 342 GG. The flowers not in eatkins.

H. Calyx-tube adherent to ovary: climbing........

Aristolochiacex, p. 348

нн. Calyx-tube hypogynous.

I. Leaves opposite.

J. Fruit a double samara, 2-winged.........

Sapindaceæ, p. 343

JJ. Fruit a single-winged samara or 1-seeded drupe: stamens $2 \ldots \ldots \ldots \ldots$. . . Oleaceæ, p. 388 JJJ. Fruit not winged: 3 -seeded: stamens $4 \ldots \ldots$.

Euphorbiaceæ, p. 351

II. Leaves alternate.

J. Styles or stigmas 2 or 2-cleft; stamens equal the calyx-lobes and opposite to them.................. Urticaceæ, p. 345

JJ. Styles or stigmas 3, each 2-cleft: pod 3celled and 3-seeded: flowers 3-parted: fruit a dry capsule: stamens 8 to many... 
FF. Plants herbaceous: flowers not in eatkins or aments.

G. Ovary inferior, 6-celled: stamens 6 or $12 \ldots \ldots \ldots$.

GG. Ovary superior, 1-celled.

Aristolochiacex, p. 348

H. Stamens indefinite

Ranunculaceæ, p. 355

нн. Stamens few (4-12).

I. Styles 2-3: stipules sheathing stem at nodes of the alternate leaves..........Polygonacex, p. 349

II. Style single: stipules not sheathing stem.......

Urticaceæ, p. 345

GGG. Ovary superior, 3-celled.......... Euphorbiaceæ, p. 351

EE. Flowers characteristically polypetalous, generally showy.

F. Plants woody.

G. The stamens numerous (more than 10).

н. Leaves alternate.

I. Ovary 1, simple or compound, or ovaries numerous; fruit a drupe or fleshy: stamens distinct, inserted on the eup-shaped receptacle.....................Rosacex, p. 385

II. Ovaries many or numerous: stamens many, monodelphous..............Malvaccæ, p. 372

нн. Leaves opposite: ovary single, 2-5-celled: fruit a dry eapsule. . . . . . . . . . . Saxifragaceæ, p. 393

GG. The stamens 10 , or less than 10 .

H. Stamens 2 (rarely or aecidentally 3 or 4 ): fruit a drupe, or 2-celled berry or 2-celled pod.......

Olcacex, p. 420

нн. Stamens 5, alternate with petals: fruit a berry.

Saxifragaceæ, p. 393

ннн. Stamens 5 or 10 united at base, some sterile: leaves simple: fruit 5 -lobed, carpels separating from central axis when ripe.....Gcraniacex, p. 373

нннн. Stamens 5-10: leaves compound: fruit a leathery 1-3-valved pod and flower irregular: or, fruit a 3-celled inflated (bladdery) pod and flowers regular...................... Sapindacex, p. 375

ннннн. Stamens usually 10, monadelphous, diadelphous, or distinet: fruit a legume.........

FF. Plants herbaceous.

Leguminosæ, p. 379

G. The stamens 10 or more.

H. Ovary 1, simple: fruit a 1-2-seeded berry .....

нн. Ovaries several, simple.

Bcrbcridaccæ, p. 360

I. Stamens indefinite, hypogynous

Ranunculaceæ, p. 355 
II. Stanens indefinite, inserted on cup-like receptacle...................Rosacex, p. 385

ннн. Ovary compound.

1. Water plants: leaves flat and floating, or heart-shaped and erect........Nymphæaceæ, p. 361

II. Land plants.

J. Ovary compound and 1-celled.

K. With central placentæ, many-ovuled:

plants juicy (watery).....Portulacacex, p. 371

KK. With 2 or more parietal placentæ: colored or milky juice..........Papavcracex, p. 362

ккк. With 3 or more parietal placentæ: leaves opposite: juice not milky: flowers yellow, cymose.........Hypericaceæ, p. 370

Js. Ovary compound, several-celled: stamens monadelphous.............Malvaccæ, p. 372

GG. The stamens 10 or less in number.

н. Ovary single, 1-celled, simple or compound.

1. Corolla regular or nearly so.

J. Sepals and petals $4-5$ each.

к. Leaves alternate.

L. Stigma $1 \ldots \ldots \ldots \ldots \ldots$. Leguminosæ, p. 379

LL. Stigmas 4 . . . . . . . . . Saxifragaceæ, p. 393

кK. Leaves opposite, punctate: flowers yellow.

Hypericaceæ, p. 370

ккк. Leaves opposite, not punctate: flowers pink, red, white........Caryophyllacex, p. 353

JJ. Sepals 2: petals 4-5.......Portulacaccæ, p. 371

JJJ. Sepals 6: stamens hypogynous, opposite

to the petals............. Berbcridacc $x$, p. 360

II. Corolla irregular.

J. Fruit a legume.............Leguminosæ, p. 379

JJ. Fruit a capsule.

K. Petals 5: stamens 5: pod 1-celled, 3-valved.

Violaceæ, p. 369

KK. Petals 4: stamens 6, diadelphous: fruit 2-valved (globular) 1-seeded, indehiscent in Fumaria..........Fumariaccæ, p. 363

Hн. Ovary 2-5-celled: fruit dry.

1. Fruit of 2 dry seed-like carpels: flowers small, umbelled or in heads: stamens 5. .Umbclliferæx, p. 397

II. Fruit a 2-celled pod, silique or silicle, or sometimes loment, or indehiscent and nut-like: flowers not truly umbelled, but solitary or in racemes.

J. Stamens 6 : sepals 4 : petals ( 0 or) $4 \ldots \ldots \ldots$ 
JJ. Stamens 4-8, distinet or monadelphous; fls. very irregular: sepals 5 , unequal and some of them colored: petals 3 (or 5 , with 2 scale-like): pods 2-seeded.....Polygalacex, p. 378

11I. Fruit (or ovary) a 4-eelled capsule: stamens 2,

4 or 8 : petals 0,2 or $4 \ldots \ldots$ Onagracex, p. 396

IIII. Fruit (or ovary) a 5-celled capsule.

J. Leaves simple, evergreen: seeds minute, innumerable: plants white, or yellowish, parasitic or saprophytie about the roots of trees................ Ericacex, p. 423

JJ. Leaves simple, more or less lobed or divided, capsule 5-10-seeded: or stem succulent and translucent: pod walls elastic, each cell several-seeded...........Geraniaceæ, p. 373

JJs. Leaves compound, palmately 3 -foliolate. . . .

Oxalis in Geraniaceæ, p. 373

1111. Fruit of 2 follieles, sceds hairy tufted: juice milky................Asclepiadaceæ, p. 417

DD. Gamopetale: corolla in one piece, at least toward the base (as if the petals were more or less united): ealyx and corolla both present.

E. Stamens more numerous than corolla-lobes.

F. Ovary 1-celled, 1 parietal placenta: fruit a legume...

Leguminosæ, p. 379

FF. Ovary 3, several-celled.

G. The stamens nearly or quite free from corolla: style $1 \ldots \ldots \ldots \ldots \ldots \ldots \ldots \ldots$. . . . . . . . . . 423

GG. The stamens free from corolla: styles $5 \ldots \ldots \ldots \ldots$

Oxalis in Geraniacrx, p. 373

GGG. The stamens on base of corolla-tube: filaments monadelphous...............Malvacex, p. 372

EE. Stamens as many in number as the lobes of the corolla and inserted opposite to the loles: ovary 1-eelled: style and stigma 1: pod several to many-seefled.....

Primulaccæ, p. 422

EEE. Stamens equal in number to lobes of corolla and alternate with them, or fewer in number.

F. Ovary inferior.

G. The stamens distinet, inserted on corolla, 4 or 5: ovary 2-5-celled.

H. Leaves whorled or opposite with stipules.......

Rubiaceæ, p. 426

нн. Leaves opposite, without true stipules........

Caprifoliaccx, p. 427

GG. The stamens inserted on corolla and united by anthers. 
н. Flowers in a head with involucre subtending....

Compositæ, p. 431

нн. Flowers not in involucrate heads, but separate: corolla irregular..............Lobeliacer, p. 431

GGG. The stamens not inserted on corolla and not united to each other: no stipules: juice milky....

Campanulaceæ, p. 430

FF. Ovary superior.

G. Corolla irregular: stamens 4 , in 2 pairs: or 2 stamens: the ovary deeply 4-lobed around the style: fruits 4 dry nutlets: stem square..Labiatæ, p. 400

GG. Corolla somewhat irregular: stamens 5 , inserted on corolla.

H. The ovary deeply 4-lobed about the style......

Echium in Borraginacex, p. 412

нн. The ovary not lobed: pod many-seeded: filaments all or some woolly..............

Verbascum in Scrophulariaceæ, p. 405

GGG. Corolla regular: stamens equal in number to the lobes of the corolla.

H. Ovaries 2, distinct: lvs. opposite: juice milky: styles or stigmas united into 1.

I. Stamens separate, inserted on corolla: corolla bell-shaped, funnel- or salver-formed: pollen granular, as usual.......Apocynacex, p. 418

II. Stamens monadelphous, anthers attached to stigma: a erown of hood-like appendages each containing an incurved horn, borne on the stamen-tube: pollen cohering in masses (waxy or granular).............Asclepiadaceæ, p. 417

нн. Ovary 1, deeply 4-lobed around style (2-lobed in Heliotropium).

I. Leaves alternate: plants usually rough-hairy... Borraginaceæ, p. 412

11. Leaves opposite: stems square...........

Mentha in Labiatæ, p. 400

ннн. Ovary 1, not deeply lobed, 1-celled: ovules parietal, or 2 parietal placentæ.

I. Leaves simple, entire, opposite, exstipulate...

Gentianaceæ, p. 417

II. Leaves toothed, lobed or pinnately compound, mostly alternate..........Hydrophyllaceæ, p. 415

нннн. Ovary not deeply lobed, 2-10-celled.

I. Leaves none: parasites, twining...........

Cuscuta in Convolvulacex, p. 411

II. Leaves opposite, without stipules. 
J. Stamens free from corolla but inserted with it: style $1 \ldots \ldots \ldots \ldots \ldots \ldots$. . . . . . . . . . 423

JJ. Stamens inserted on tube of corolla.

K. Number of stamens 4 in 2 sets: ovary 2-4-celled (eells 1-seeded)... Verbenaceæ, p. 403

кк. Number of stamens 5 or (rarely) more.

L. Fruit 2 or 4 nutlets.... Borraginacex, p. 412

LL. Fruit a pod, few-seeded.

м. Calyx 5-lobed: styles 3-cleft.........

Polemoniaceæ, p. 416

MM. Calyx 5-lobed: style 1 or 2, or 2-eleft: ovary 2-celled (rarely 3-celled): seeds good-sized, 1 or 2 per cell: generally twining herbs..........

Convolvulacex, p. 411

LLL. Fruit a pod, many-seeded, or a berry: style 1 ................ Solanaceæ, p. 408

GGGG. Corolla regular or irregular: stamens fewer than the corolla-lobes.

н. Stamens 2: ovary 4-lobed: corolla nearly equally 4 -lobed......... Lyeopus in Labiatæ, p. 400

нн. Stamens 2 (rarely 3): ovary 2-celled.

I. Woody plants, shrubs or trees: corolla regular,

4-cleft...................... Oleacex, p. 420

II. Herbs: corolla wheel-shaped or salver-shaped, with a 4-parted (rarely 5-parted) border, or somewhat irregular.................

Veronica in Scrophulariacex, p. 408

\section{A. CRYPTOGAMS.}

\section{FILICES. Ferns.}

Herbaceous and leafy plants, ours without stems or trunks above ground, but producing perennial rootstocks: plants flowerless and seedless, but bearing spores in sporangia, the latter collected into sori which are usually borne on the under side or margins of the fronds and which are sometimes covered with an indusium.-Most abundant in warm countries, of about 4,000 species, of which about 165 are native to the United States. The leaflets of fern-fronds are pinnx; the secondary leaflets are pinnules.

A. Fruit borne in eontracted panicles or on specially contracted parts of the frond, these parts being devoid of resemblance to green leaves. 
B. Sporangia large and globose, without a ring of special cells running around their margin............ Osmunda

BB. Sporangia with a ring of prominent elastic cells running around the margin, and which are concerned

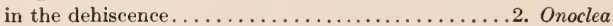

AA. Fruit borne on the back of green fronds (the fruiting pinnæ sometimes narrowed but still leaf-like), sporangia with a ring of elastic cells.

B. Sori naked (no indusium) 3. Polypodium

Bв. Sori borne under the reflexed margins of the frond.

c. Pinnæ entire on the lower edge, somewhat triangular in outline....................... Adiantum

cc. Pinnæ toothed on both margins, oblong in outline...5. Pteris ввв. Sori covered with a distinct scale-like indusium.

c. Shape of sori oblong...................... Asplenium cc. Shape eircular.

D. Indusium circular-peltate, without a sinus.......7. Polystichum DD. Indusium reniform, or if circular with a narrow

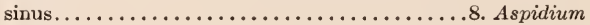

\section{OSMÚNda. Flowering Fern.}

Strong ferns from stout creeping rootstocks, with large, pinnate fronds: sporangia covered with interwoven ridges, but wanting the elastic ring of most ferns. Inhabitants of bogs and wet woods.

O. regàlis, Linn. Royal fern. Top of the frond contracted into a fruit-

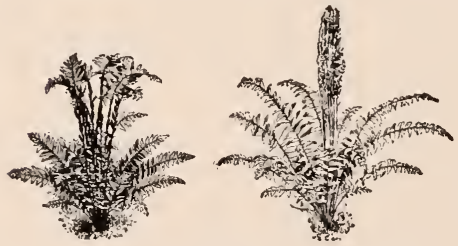

479. Osmunda Claytoniana (left). Osmunda cinnamomea. ing panicle: frond 2-pinnate, the pinnæe oblong, obtuse, and nearly entire.

O. Claytoniàna, Linn. Fig. 479. Two to four pairs of pinnæ near the middle of the frond contracted into fruit-bearing parts: pinnse linear-lanceolate and acute, deeply lobed.

O. cinnamòmea, Linn. Cinnamon fern. Fig. 479. Some fronds entirely contracted into fruiting parts, and these cinnamon colored (whence the vernacular name): sterile form with the fronds much like those of $O$. Claytoniana in shape except more acute at top.

\section{ONOClèa. Sensitive Fern.}

Mostly rather strong ferns, with broad sterile fronds and with the fertile fronds rolled into hard contracted fruiting bodies, which remain after the sterile leafy fronds have perished: sporangia with an elastic marginal ring of cells. Bogs and old springy fields. 
O. sensíbilis, Linn. Sensitive fern. Brake. Fig. 337. Sterile frond triangular-ovate, the pinnæ not extending quite to the midrib and toothed: fertile frond usually lower than the other $(1-2 \mathrm{ft}$. high), with a few pinnæ. Common in old pastures.

O. Struthiopteris, Hoffm. Ostrich fern. Very tall $(2-5 \mathrm{ft}$.$) , the$ sterile fronds narrow, once-pinnate, with long-lanceolate acute-lobed pinnæ: fertile fronds much shorter, blackish, with many pinnæ.

\section{POLYPÒDIUM. Polypony.}

Small ferns, with simple or once-pinnate fronds from slender creeping rootstocks: sori round, borne at the ends of little veins. On dry cliffs.

P. vulgàre, Linn. Common polypody or polypode. Figs, 333, 334. Fronds a foot or less tall, narrow-oblong in outline, pinnatifid, the lobes nearly or quite entire: fertile pinnæ not contracted.

4. adiántum. Mainenhair Fern. Fig. 336.

Small ferns with compound forking fronds and wedge-shaped or somewhat triangular pinnæ, shining stipes or petioles, and sori borne at the ends of the veins under the reflexed margins of the pinnæ.

A. pedàtum, Linn. Common maidenhair. Plant $2 \mathrm{ft}$. or less high, the leaves forking into several or many long pinnæ which bear broad pinnules notched on the upper margin. Cool, shady woods. Very graceful.

5. PTÊRIS. BRAKE.

Coarse ferns of mostly dryish places, with long pinnæ: sporangia borne beneath the reflexed margin of the pinnules, on small, transverse veins.

P. aquilina, Linn. Common brake. Figs. 139, 335. Fronds broadly triangular, twice- or thrice-pinnate, the pinnules long-laneeolate, acuminate, and lobed. Common in sunny places: perhaps our commonest fern. Two to $3 \mathrm{ft}$. high, growing in patches, particularly in burned areas.

\section{ASPLENIUM. SPLEENWORT.}

Middle-sized ferns, mostly with pinnate leaves: sori oblong or linear, borne on the upper side of a veinlet, or back to back on opposite sides of the veinlet, these veinlets not interwoven.

A. Filix-fómina, Linn. Lady-fern. Large, the fronds $2-3 \mathrm{ft}$. tall, growing many together, twice-pinnate, the pinnules oblong-pointed and sharp-toothed: sori short and close together, at maturity becoming more or less continuous. A very common fern in moist woods and copses.

\section{POLYSTichum. Christmas Fern.}

Much like the last in general appearance, but the sori circular and covered with peltate indusia.

P. acrostichoìdes, Kuntze (Aspidium acrostichoides, Swartz). Christmas fern. Figs. 331, 332. Fronds $2 \mathrm{ft}$. or less tall, narrow, once-pinnate, the pinne serrate and bearing a larger tooth on the upper side near the base, the terminal part of the frond somewhat contracted in fruit. Common in woods. Nearly or quite evergreen. 


\section{ASPIDIUM. Shield Fern.}

Resembles Polystichum but with reniform indusia or, if circular-peltate,

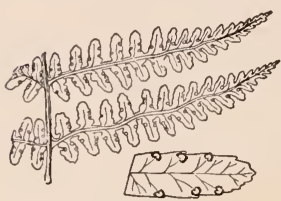

480. Aspidium marginale. having a distinct sinus along one side.

A. Thelýpteris, Swartz (Dryopteris Thelypteris, Gray). Marsh shield fern. Fronds standing $2 \mathrm{ft}$. high, long-pointed, once-pinnate, the pinnæ many-lobed, the margins of the fertile fronds revolute.

A. marginàle, Swartz (Dryopteris marginalis, Gray). Fig. 480. Large, handsome fern growing in woods and ravines, $2 \mathrm{ft}$. high: fronds once-pinnate, the pinnæ pinnatifid and lance-acuminate: sori large and close to the margin of the frond: petiole chaffy.

\section{AA. PHENOGAMS: B. GYMNOSPERMS.}

\section{Coníferat. Cone-bearing or Pine Family.}

Woody plants, mostly trees, with resinous sap and stiff needleshaped or scale-like, mostly evergreen leaves: plants bearing no ovaries, the ovules lying naked and receiving the pollen directly: flowers diclinous (usually monœecious), generally in scaly catkins, those catkins bearing the pistillate flowers maturing into cones but sometimes becoming berry-like (as in junipers). Above 300 species, one-third of which inhabit North America: particularly abundant in elevated and mountainous regions.

A. Cone dry, with overlapping scales.

B. Scales many and cones 1 in. or more long.

c. Leaves long and needle-like, in sheaths or bundles of

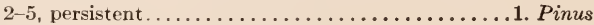

cc. Leaves short, scattered, persistent.

D. In cross-section, lvs. 4-sided: sessile............2. Picea

DD. In cross-section, lvs. flat: short-petioled.......... Tsuga

ccc. Leaves short but very slender, in clusters, deciduous.4. Larix BB. Scales few (3-12), the cones about $1 / 2$ in. long ........5. Thuja AA. Cone modified into a fleshy, berry-like body .........6. Juniperus

1. Pìnus. Pine.

Trees with long, persistent, needle-shaped, angled leaves, in bundles of 2-5, and with scale-like deciduous leaves on the young branchlets: sterile catkins usually borne at the base of the new shoot: fertile cones maturing the second year, often hanging on the tree for years: cotyledons several.

P. Stròbus, Linn. White pine. Figs. 158, 299. Large forest tree, much 
used for lumber: leaves long and soft, light green, in 5's: cones long and symmetrical, with thin-edged scales, terminal on the shoots and falling after shedding the seeds. Grows as far south as Georgia.

P. palústris, Mill. Long-lcaved pine. Very tall tree, with nearly smooth bark: leaves very long and slender (usually a foot or more), clusters at the ends of the branches, in 3 's: cones 6 in. or more long, the scales tipped with a short eurved spine. Lumber tree. Virginia, south.

P. rígida, Mill. Pitch pine. Fig. 481. Medium-sized or small tree with rough dark bark: leaves short and stiff, usually in 3's: cone 2-3 in. long, conical, the scales with a short spine. Grows as far

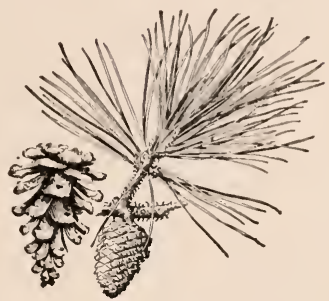

481. Pinus rigida.

Old open cone at the left. south as Virginia; common in pine barrens of the north Atlantic coast. An eastern species.

P. sylvéstris, Linn. Scotch pine. Fig. 482. Medium-sized tree, with glaucous green leaves in 2's: cone short, the scales tipped with a priekle or point.
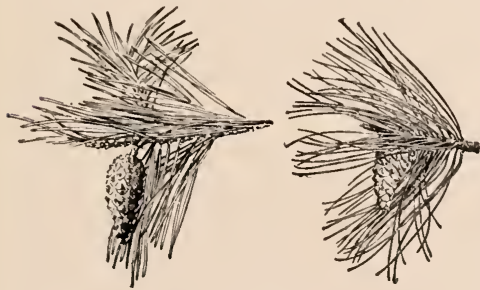

482. Pinus sylvestris (left). Pinus austriaca.
Europe; very commonly planted.

P. austrìaca, Höss. Austrian pine. Fig. $4 \$ 2$. Large tree with rough bark, and long, dark green stiff leaves (about 6 in. long) in 2's: cone about 3 in. long, "the scales not prickly. Europe, commonly planted; a coarser tree than the seoteh pine.

\section{PİCEA. Spruce.}

Trees of medium or large size, with short, scattered leaves: cones maturing the first year, hanging at maturity, their scales thin.

P. Ȧbies, Karst. (P. exeelsa, Link). Norway spruce. Figs. 297, 298. Becoming a tall tree: cones 5-7 in. long, the large seales very thin-edged. Europe, but the commonest of planted evergreens. Until 25-40 years old, the trees are symmetrical cone-shaped speeimens, holding their lower branehes.

P. mariàna, B.S.P. ( $P$. nigra, Link). Black spruce. Fig. 483. Bceom-

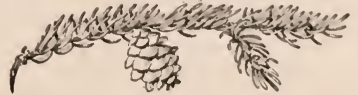

483. Picea mariana. 
ing a middle-sized tree, with dull, dark foliage; cones $1 \frac{1}{2} \mathrm{in}$. or less long, usually hanging for several years, the edges of the scales often irregular. Cold woods, as far south as North Carolina in the mountains.

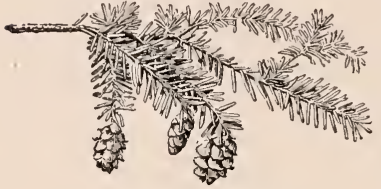

484. Tsuga canadensis.

\section{TSÙga. Hemlock Spruce.}

Differs from Picea in having flat 2-ranked petioled leaves: cones hanging on the end of last year's branches.

T. canadénsis, Carr. Hemlock. Fig. 484. Large forest tree, with deep-furrowed, dark bark and coarse wood: leaves whitish beneath: cones not an inch long, compact. Common lumber tree. Bark much used in tanning.

\section{LÀrIX. LARCH.}

Trees of medium size: leaves soft, short, in fascicles or clusters on short branchlets, falling in autumn: cones much like those of Picea, but standing erect at maturity.

L. decídua, Mill. (L. europaa, DC.). European larch. Leaves 1 in. long: cones of many scales, about 1 in. long. Planted for ornament and timber.

L. laricina, Koch (L. americana, Michx.). Tamarack. Hackmatack. Leaves shorter and pale in color: cones of few scales, $1 / 2$ in. or less long. Swamps.

\section{THÙ JA. Arborvita.}

Trees, becoming large: leaves opposite, closely appressed to the branchlets, the latter frond-like: cones small, oblong or globular, of few scales. Leaves awl-like on new growths and scale-like on the older growths.

T. occidentàlis, Linn. Arborvita. White cedar of some places. Fig. 485. Cones $1 / 2$ in. or less long, bearing 2 -winged seeds. Swamps and cold woods, as far south as North Carolina in the mountains. Very commonly planted as a hedge evergreen and as single specimens, but in the wild becoming very large trees and much used for telegraph poles.

\section{JUNÍPERUS. JUNIPER.}

Small trees or shrubs, with opposite or whorled awl-like leaves (often of two kinds): fertile catkin of 3-6 fleshy scales

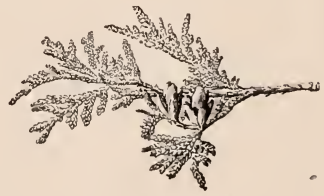

485. Thuja occidentalis. which cohere and form a berry-like fruit containing 1-3 hard seeds.

J. commùnis, Linn. Common juniper. Shrub, erect or usually spreading and lying close to the ground, with leaves in whorls of 3 and all alike (awllike): berries large and smooth. Banks and sterile ground. 
J. virginiàna, Linn. Red cedar. Savin. Small tree or large shrub, usually narrow pyramidal in growth, with leaves of two kinds (seale-like and awl-like, the former small and lying close to the braneh): berry glaueous: heart-wood red and highly scented. Common on banks and in old fields.

\section{BB. ANGIOSPERMS: C. MONOCOTYLEDONS.}

\section{ARÃCEe. Arum Family.}

Perennial herbs, with rhizomes or eorm-like tubers and acrid juice: flowers minute, often diclinous and naked, borne on a spadix and surrounded or attended by a spathe: fruit usually a berry, the entire spadix usually enlarging and bearing the coherent berries in a large head or spike. Leaves often netted-veined. Mostly tropieal plants, and some of temperate regions, many of them odd and grotesque. Genera about 100; speeies about 1,000. Representative plants are skunk cabbage, jack-in-the-pulpit, calla, caladium, anthurium.

A. Leaves compound........................ Arisæma

AA. Leaves simple.

B. Spathe hooded or roofed at the top............. Symplocarpus

вв. Spathe open or spreading at the top............. Richardia

ввв. Spathe open and spreading for its whole length....4. Calla

вввв. Spathe separated from spadix, appearing lateral....5. Acorus

\section{ARIS'Ama. Indian TuRnip. Jack-IN-The-Pulpit.}

Stem arising from a corm-like tuber, and bearing 1 or 2 compound leaves with sheathing petioles: flowers naked and diclinous, the pistillate at the base of the spadix and the staminate above them (or the plant diøeious), the top of the spadix not flower-bearing: staminate flowers of a few sessile anthers, and the pistillate with 1 sessile ovary, which ripens into a red fewseeded berry. Plants of spring or early summer, in rich woods. Tuber very pungent, often used in domestic medicine.

A. triphyllum, Schott. Jack-in-the-pulpit. Common Indian turnip. Fig. 251. Leaves usually 2 , each bearing 3 oblong elliptic pointed leaflets: spathe purple-striped, curving over the spadix.

A. Dracóntium, Schott. Dragon-root. Leaf usually 1, with 7-11 narrow oblong leaflets: spathe greenish, shorter than the spadix.

\section{SYMPLOCÂRPUS. SKUNK CABBAGE.}

Leaves and flowers arising from a strong rootstock, the lvs. very large and appearing after the spathes: fls. perfect, eaeh with 4 sepals, 4 stamens and single ovary which is sunk in the fleshy spadix: fruit made up of the fleshy spadix with imbedded fleshy seeds: spathe pointed and arehing, inclosing the spadix. Common in wet meadows in the northeastern states. 
S. fótidus, Nutt. Spathes purple, arising in the earliest spring: leaves very large (often $2 \mathrm{ft}$. long), simple and entire, ovate, in tufts. The tufted leaves and fetid odor give the plant the name of skunk cabbage.

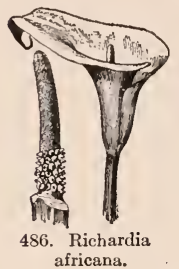

\section{Richárdia. Calla lily.}

Leaves several from each short rootstock, their petioles sheathing the flower-scape: flowers naked and diclinous, the stamens above and the 3 -loculed ovaries below on the spadix: spathe large and showy, the top flaring and the base rolling about the spadix. Several species are cultivated, but the following is the only common one.

R. africàna, Kunth. Calla or Calla lily of gardens. Fig. 486. Leaf-blades broadly arrow-shaped, simple and entire, cross-veined, glossy: spathe white and wax-like.

Cape of Good Hope.

\section{4. câlla. Water Arum.}

Differs from the above in having a spathe which does not inclose the spadix, and mostly perfect flowers (the upper ones sometimes staminate), each of 6 stamens and 1 ovary: fruit a red berry. One species.

C. palústris, Linn. True calla. Fig. 487 . Leaves about $1 \mathrm{ft}$. high, the blades arrow-shaped: spathe about 2 in. long, white on the upper face. In cold bogs, north.

\section{5. ÂCORUS. Sweet Flag. Calamus.}

Erect, having long, horizontal, branching root-stocks, thick and aromatic: leaves sword-shaped, rising from the rootstocks: scapes 3-angled, bearing each a eylindric spadix, but much prolonged and leaf-like, causing the spadix to appear as if borne on the side of the leaf-like scape: flowers on a very dense spadix: ovary oblong, 2-4-celled, with $2-8$ ovules in each cell.

A. Cálamus, Linn. Sweet flag. Calamus-root. Along the margins of streams, in swamps and wet soils. Leaves 2-3 ft.: flowers greenish-yellow, very small. May to July. The rootstocks supply "sweet flag roots" of the druggists.

\section{LILIÂCEÆE. Lily Family.}

Herbs, with bulbs, corms, or large rootstocks: fls. mostly regular and showy, the perianth of 6

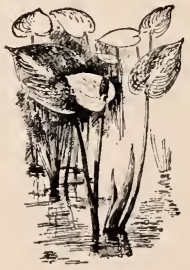

487. Calla palustris. separate or coherent parts, the stamens usually 6 and standing in front of the parts of the perianth: ovary superior, usually 3-loculed, ripening into a capsule or berry. About 200 genera, including more than 
2,000 widely distributed species. Charaeteristic plants are lily, lily-ofthe-valley, onion, Solomon's seal, tulip, trillium, hyacinth, asparagus, yucea.

A. Fruit a loculicidal capsule.

B. Style 1, undivided.

c. Plant bulbous: root-leaves not in large clumps.

D. Stem tall and leafy.................. 1. Lilium

DD. Stem short, with only $2-6$ leaves.

E. Flower ereet.................... 2. Tulipa

EE. Flower nodding................... Erythronium

DDD. Stem naked, bearing many flowers.

E. Perianth tubular.

F. Flowers funnelform, throat open: lobes spreading or recurved, as long as the tube....................... Hyacinthus

FF. Flowers urn-shaped, constricted at throat; lobes much shorter than tube......... 5. Muscari

EE. Perianth parted nearly to base......... 6. Ornithogalum

cc. Plant with a rootstock, and large elumps of leaves.

D. Flowers yellow and paniculate on a somewhat branching scape.................. Hemerocallis

DD. Flowers white or blue, mostly in a simple raceme....................... 8. Funkia

Bв. Style 1 at base, but 3-eleft or 3-parted: flowers bell-like, drooping, yellow.............. 9. Uvularia

AA. Fruit an angled berry: styles or stigmas 3: leaves broad and netted-veined ................. Trillium

AAA. Fruit a globular berry: style 1: fls. small white, or greenish.

B. Foliage made up of cladophylls, the true leaves being mere scales: stamens borne on the base of the small corolla..................... Asparagus

Bв. Foliage of ordinary leaves: stamens borne on the corolla-tube.

c. Perianth of 6 parts, separate.............. Smilacina

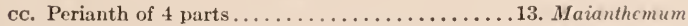

ccc. Perianth gamosepalous, with 6 lobes.

D. Flowers racemose on a seape.............14. Comvallaria

DD. Flowers hanging from the axils of the leaves..15. Polygonatum

\section{Lílium. Lily.}

Strong-growing bulbous herbs, with leafy stems usually bearing severa! or many flowers: perianth bell-shaped or funnelform, the 6 divisions nearly or quite separate and spreading or recurving and having a honey-hearing groove at the base: anthers attached by the middle (versatile). 


\section{a. Flowers white.}

L. longiflòrum. Thunb. Easter lily. One to $4 \mathrm{ft}$., with scattered longlanceolate pointed leaves: flowers $5-8$ in. long, horizontal, scarcely widened from the base to the middle, fragrant. Japan and China, now

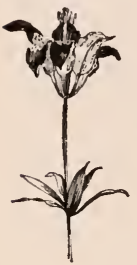

488. Lilium philadelphicum. much cultivated under glass. Many of the bulbs are grown in the Bermuda Islands, whence the name "Bermuda lily."

L. cándidum, Linn. Common white lily. Leaves broadlanceolate, scattered: flowers numerous, 5 in. or less long, widening gradually from the base. Europe. Common in gardens.

aa. Flowers in shades of yellow or orange.

L. philadélphicum, Linn. Fig. 488. Flowers 1-3, erect, 2-3 in. long, orange-red and spotted, the divisions separate: leaves whorled. Dry soil.

L. canadénse, Linn. Wild orange-red lily. Wood lily. Two to $5 \mathrm{ft}$., with leaves in whorls and bulbs producing rhizomes or runners: fls. several or many, erect or horizontal on long stalks, the divisions spreading above the middle, orange or red and spotted. Meadows and swales.

L. supérbum, Linn. Turk's-cap lily. Fig. 489. Very tall, bearing several or many nodding red-orange spotted flowers in a panicle, the segments all pointing backward. Meadows and low grounds.

L. tigrìnum, Ker. Tiger lily. Fig. 31. Four to $5 \mathrm{ft}$., bearing a loose cottony covering on the stems: leaves sessile, scattered, lanceolate: flowers many, nodding in a panicle, orange-red and black-spotted, the divisions about $4 \mathrm{in}$. long and rolled back. China and Japan; old gardens.

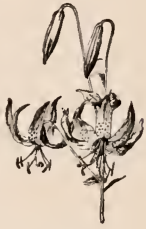

489. Lilium superbum.

\section{TÜLIPA. TULIP.}

Low bulbous plants with a few leaves near the ground on the 1-flowered stem: flower large, erect, the 6 divisions erect or flaring: capsule triangular.

T. Gesneriàna. Linn. Common tulip. Leaves 3-6, broad: peduncle

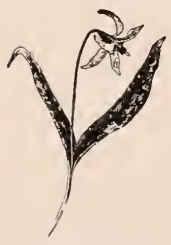

490. Erythronium smericanum. glabrous: divisions of the flower broad at the end, with a very short point in the center: late-blooming tulips, originally from Asia Minor.

T. suavèolens, Roth. Duc Van Thol tulip. Early and dwarf, with fewer leaves, downy peduncle, and acuminate segments. Caspian Sea; common in cultivation.

\section{ERYTHRÒNIUM. DOG'S-TOOTH VIOLET.}

Low herbs with deep-seated conical bulbs, and scape with 2 leaves near the ground: flower nodding, the 6 divisions wide-spreading or recurved, the style long and clubshaped. Blooming in earliest spring. 
E. americànum, Smith. Common dog's-tooth violct, or adder's-tongue. Fig. 490. Leaves thickish, oblong-lanceolate, mottled with purple; flower light yellow, nodding on a stem 3-6 in. tall. Low grounds.

E. albidum, Nutt. White adder's-tongue. Leaves searcely mottled: flowers whitish. Low grounds.

\section{HYACÍNTHUS. HYaCinth.}

Low plants, with large bulbs, producing many flowers in spikes or dense racemes on a short seape, the leaves arising directly from the bulb: flowers bell-shaped or funnelform, the 6 lobes spreading or eurling back.

H. orientàlis. Linn. Common hyacinth. Fig. 186. Early spring, the flowers of many colors and sometimes double, the perianth-tube swollen, the oblong-spatulate lobes as long as the tube. Greece to Asia Minor.

Var. álbulus, Baker. Roman hyacinth. Flowers fewer and usually smaller, white or nearly so, the perianth-tube scarcely swollen and the lobes shorter. France. Much eultivated.

\section{Múscàri. Grape Hyacinth.}

Low herbs, with very narrow, somewhat fleshy leaves and small flowers in a raceme: perianth deep blue or white, the tube ventricose or urn-shaped, with 6 short blunt tecth.

M. botryoides. Mill. Grape hyacinth. Flowers faintly odorous, nodding, deep blue: scape 4-10 in.: leaves linear, obtuse, erect, becoming longer than scapes. In grass about gardens and lawns in very early spring; also escaped in some places to meadows and along roadsides. Asia.

\section{6. oRnithógalum. Star of Bethlehem.}

Stemless low herbs, with narrow linear, fleshy, channelled leaves: flowers in terminal clusters, usually with conspicuous bracts: perianth of 6 parts, white, spreading, veined: stamens 6, hypogynous: filaments flattened, subulate: ovary sessile, 3-celled: capsule roundish, 3-angled: seeds few, black.

O. umbellàtum. Linn. Scape 4-10 in.; flowers 5-8, on long spreading pediccls: sepals white, each with green band outside. Common about gardens. Introduced from Europe. Early spring.

\section{HEMEROCÁLLIS. DAY-LILY.}

Strong-growing plants from tuberous roots, producing clumps of long sword-shaped leaves: flowers yellow or orange, erect, large and lily-like, in clusters or panicles on a tall, branching scape, the divisions widely spreading at the top. Old World, but conımon in gardens.

H. fúlva, Linn. Orange day-lily. Flowers tawny orange, produced in early summer, the inner perianth divisions nearly or quite obtuse. The commonest species, and often escaped along roadsides.

H. flàva, Linn. Yellow day-lily. Plant somewhat smaller, earlyblooming: flowers fragrant, pure lemon-yellow, inner divisions acute. 


\section{FÚNKia. White and Blue Day-lily.}

Medium-sized plants, producing dense clumps of broad-bladed leaves from rootstocks: flowers blue or white, in racemes on scapes, each flower sheathed at the base by 1 or 2 bracts, the perianth-tube long and the limb

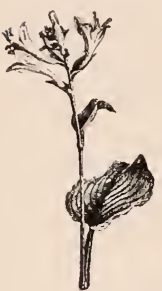

491. Funkia subcordata. sometimes irregular. China and Japan; planted by houses and along walks.

F. subcordàta, Spreng. White day-lily. Fig. 491. Leaves broadly cordate-ovate: flowers large and white, in a short raceme, not drooping.

F. ovàta, Spreng. (F. cærùlea, Sweet). Blue day-lily. Fig. 492. Leaves broadly ovate: flowers deep blue, in a long raceme, nodding.

\section{UVulària. Bellwort. "Wild Oats."}

Low, erect plants, with short rootstocks: stems with leaves alternate above, sessile or perfoliate, parallel-veined: flowers yellow, drooping, solitary at the end of the forking stems, the perianth elongated, bell-shaped, of 6 similar, distinct, narrow sepals, each bearing a nectar gland at inside base. Spring-flowering wood plants.

U. grandiflòra, Smith. Large-flowered Bellwort. Commonly 1-2 ft. tall: leaves oblong, whitish-pubescent beneath, and perfoliate: perianth smooth on inner surfaces. Common in rich woods. Blooms a little earlier than $U$. perfoliata.

U. perfoliàta, Linn. Smaller than the preceding: glaucous, leaves perfoliate: perianth segments twisted, covered on inner surface with shining grains (papillose): flowers somewhat fragrant, pale yellow. Common in moist woods.

U. sessilifòlia, Linn. (Oakesia sessilifolia). Straw lily. Leaves sessile, lance-oval, thin, smooth, pale beneath: stem angled, slender and zigzag: flower greenish-yellow, about 1 in. long. Woods.

\section{TRÍLLIUM. WAKE-ROBIN.}

Low herbs from deep-seated corm-like tubers: leaves 3 in a whorl, broad and netted-veined: flower single, of 3 -colored petals and 3 green sepals, the latter persistent until the angled, many-seeded berry

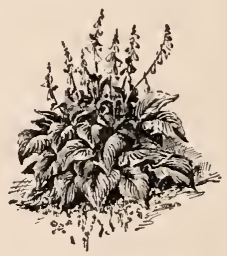

492. Funkia ovata. ripens; stigmas 3 , often sessile. Plants of earliest spring, growing in rich woods.

\section{a. Flower sessile in the leaf-whorl.}

T. séssile, Linn. Flowers dull purple, the parts narrow, pointed, and nearly erect: leaves sessile, ovate, often blotched with purple. Pennsylvania, west and south. 


\section{aa. Flower stalked in the leaf-whorl.}

T. grandiflòrum, Salisb. Common wake-robin, or birthroot. Fig. 244. Flowers large and white, the peduncle standing erect or nearly so, the petals broadest above the middle (obovate) and $2-21 / 2$ in. long: leaves broadovate, sessile or nearly so. Flowers become rose-pink with age.

T. eréctum, Linn. Flowers smaller, ill-scented, varying from white to pink and purple, the peduncle erect or declined, the petals ovate or lanceolate and spreading: leaves broad-ovate. Frequent North, and south to Tennessee.

T. cérnuum, Linn. Flowers not large, white, the peduncle declined under the broad leaves; petals ovate-lanceolate, rolled back. Range of the last.

T. undulàtum, Willd. Painted wake-robin. Flowers on peduncles ereet, or partly declined; segments ovate, or ovate-lanceolate, margined, thin, widely spreading, white, penciled with purple stripes at base; sepals half as long as petals: leaves ovate, taper-pointed, distinctly petioled, obtuse or rounded at the base. Cool damp woods, from New Brunswick to Georgia, and west.

\section{ASPÁRAgUS. Asparagus.}

Mostly tall, often climbing plants with cladophylla and very small scale-like true leaves: flowers white or greenish, small, bell-shaped, scattered or in groups of 2 or 3 : fruit a 3-loculed and 1-6-seeded small berry.

A. officinàlis, Linn. Common asparagus. Figs. 159, 160. Erect and branchy, the strong young shoots thick and edible: berries red. Europe.

A. plumòsus, Baker. Fig. 161. Twining, with dark, frond-like foliage, small white flowers and black berries. South Africa; greenhouses.

A. medeoloides, Thunb. Smilax of florists (but not of botanists). Fig. 493. Twining: foliage broad

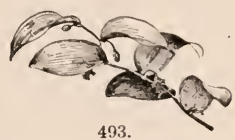

Asparagus medeoloides. and leaf-like: flowers solitary and fragrant: berries dark green. South Africa; much grown by florists.

\section{Smilacìna. False Solomon's Seal.}

Low, erect plants with many small white flowers in racemes or panicles: perianth 6-parced: fruit a 3 -loculed berry: rootstock creeping.

S. racemòsa, Desf. False spikenard. About $2 \mathrm{ft}$. tall, somewhat downy, with many oblong or oval leaves: flowers in a panicle: berries pale red, speckled. Spring and early summer. Rich woods.

S. stellàta, Desf. Nearly or quite smooth: leaves narrower: flowers in a simple raceme. Forms patehes in low ground.

\section{3. maiánthemum. Two-leaved Solomon's Seal.}

Neat little herbs, with slender rootstocks: stems unbranched, fewlcaved: flowers small, in an open raceme, with usually 2 or 3 pedicels together; perianth of 4 ovate, obtuse, spreading segments, united at hase: fruit a globular 1-2-seeded berry. One species in eastern North America. 
M. canadénse, Desf. Slender stem, 3-6 in. high, terminated by the many-flowered raceme: flowers white: leaves ovate, cordate at base, shortstalked. Common in moist woods and on shaded banks, making mats or patches. May to July.

\section{CONVALLÀRIA. LILY-OF-THE-VALLEx.}

Low, spring-flowering herbs from branching rootstocks: flowers gamopetalous, white and waxy, nodding in a 1 -sided raceme, the 6 short lobes recurving: fruit a red berry.

C. majàlis. Linn. Leaves oblong, numerous from the rootstocks, forming mats, and about 2 with each seape: flowers very fragrant: One of the best-known garden flowers. Europe. The only species.

\section{POlygónatum. Solomon's Seal.}

Mostly strong plants from long running rootstocks on which the scars of preceding stalks are very evident (whence the common name): stems leafy, bearing nodding gamosepalous flowers in the axils: fruit a globular, dark-colored berry. Rich woods, spring.

P. commutàtum, Dietr. Three to $5 \mathrm{ft}$. tall: leaves ovate, somewhat clasping: peduncles in each axil, 2-8-flowered: filaments not roughened.

P. biflòrum, Ell. One to $3 \mathrm{ft}$.: leaves oblong, nearly sessile, somewhat glaucous, hairy: peduncles usually 2 -flowered: filaments roughened.

\section{COMMELiNĀCEÆ. Spiderwort Family.}

Herbs, annual or perennial, with flat, narrow leaves, sheathing at base: roots fibrous, sometimes thickened: flowers regular or irregular, perfect, usually showy, in terminal cymes, usually borne above a leafy or spathe-like bract; sepals 3 : petals 3 , soon decaying or falling; stamens 6, hypogynous, some of them often deformed or abortive: ovary 2-3-celled, style single, stigma entire or somewhat lobed: juice slimy or mucilaginous. More than 300 species, mainly belonging to tropical regions.

A. Flowers irregular, inclosed in cordate spathe-like floral leaf; perfect stamens 3 (rarely 2)........... Commelina

AA. Flowers regular, or nearly so; bracts leaf-like; stamens $6 \ldots \ldots \ldots \ldots \ldots \ldots \ldots \ldots \ldots \ldots \ldots \ldots \ldots \ldots \ldots \ldots$ Tradescantia

AAA. Flowers somewhat irregular, tubular, usually in pairs: trailing habit, easily rooting at nodes............. Zebrina

\section{COMMElìna. Day Flower.}

Plants erect or partly procumbent and rooting at joints, succulent, branching: leaves petioled or sessile, the floral leaf or spathe cordate: flowers recurved on their pedicels and hooded by the floral leaf before and after flowering, open for a short time only. 
C. virgínica, Linn. Stem glabrous or somewhat downy, aseending 1-2 $\mathrm{ft}$.: leaves lanceolate to linear, acuminate: flowers $1 \mathrm{in}$. wide, the odd petal very small. In moist soil.

\section{TRADESCÁNTIA. SPIDERWORT.}

Mucilaginous herbs, with stout, succulent stems, simple or branched: leaves elongated, narrow, keeled, sometimes purple-veined: flowers in terminal and axillary umbelled clusters, with leaf-like bracts, not tubular; filaments glabrous or bearded.

T. virginiàna, Linn. Plant green, ereet, with linear leaves: flowerclusters showy, terminal; corolla over $1 \mathrm{in}$. broad, the 3 petals decp blue (rarely white), longer than sepals; filaments blue, and clothed with hairs. Cultivated and wild; mostly in rich soil. Very variable. Flowers quickly fading by beeoming mueilaginous, but produced all summer.

T. pilòsa, Lehm. Stout, more or less zigzag, stems soft-hairy or nearly smooth: leaves laneeolate, tapering at apex, narrowed at base, hairy on both sides: cymes terminal and axillary, or on short axillary branches: flowers $34^{-1}$ in. wide. In rich moist soil, woods and thickets, or in shaded places.

T. fluminénsis, Vell. One of the greenhouse plants known as Wandering Jew (sce Zebrina), but leaves usually green and flowers white. South Ameriea.

\section{ZEBRİNA. WANDERING JEW.}

Low, trailing or partially climbing, rooting readily at the nodes, and branching: leaves often striped with purple, green, white, thick and ovate: flowers small, more or less irregular, tubular, usually in pairs.

Z. péndula, Sehnitzl. Stems trailing, perennial: corolla 3-parted, roseate: calyx with short tube, 3-parted: ovary 3-celled, 3-6 ovuled: leaves ovate or oblong, heavy or succulent, green and silver stripes above, purple beneath. Much used for vases and baskets. A native of Mexico.

\section{AMARYLlidĀCEæ. Amaryllis Family.}

Differs from Liliacea ehiefly in having an apparently inferior ovary and in bearing its flowers more unifornly on seapes. More than 600 species in nearly 70 genera, widely dispersed. Rejesentative plants are narcissus, daffodil, snowdrop, tuberose, amaryllis. Plants of the first three genera may be grown from bulbs in the school-room.

A. Plants from coated lullis; stem a leafless scape.

B. Perianth with a crown or cup in its center.......... Narcissus

BB. Perianth with no eup.

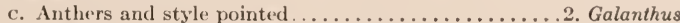

cc. Anthers and style blunt.................... Leucoium

AA. Plants from tuberous rootstocks or corms.

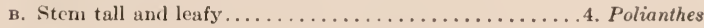

BB. Stem a low, leafless seape.................. Hypoxis 


\section{NARCÍSSUS. NARCISSUS. DAFFODIL.}

Low plants producing from 1 to many 6-parted flowers on a scape which arises from a tunicated bulb: perianth with a long tube and bearing a cup

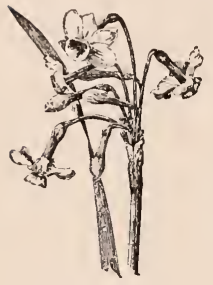

494.

Narcissus Tazetta. or crown in its center. Old World, but frequently cultivated.

\section{a. Crown as long as, or longer than, the divisions of the perianth.}

N. Pseùdo-Narcíssus, Linn. Trumpet narcissus. Common daffodil. Scape 1-flowered, the flower large and yellow with a relatively short tube and a wavyedged crown. Leaves flat and glaucous. Double forms are common in gardens.

aa. Crown half or more as long as the divisions of the perianth.

N. incomparábilis, Curt. Scape 1-flowered, the flower about 2 in. or more across, yellow, the cylindrical tube $1 \mathrm{in}$. long, the crown plaited and usually a deeper yellow: leaves flat and glaucous.

\section{aaa. Crown less than half the length of the division.}

N. Tazétta, Linn. Polyanthus narcissus. Chinese sacred lily. Fig. 494. Flowers several to many in an umbel, yellow or white, small, the crown usually darker colored and usually somewhat scalloped: leaves flat and somewhat glaucous. One of the commonest kinds. The narcissus known to florists as "Paper-white" is a white-flowered form of this species.

N. poéticus, Linn. Poet's narcissus. Scape rather slender, usually 1-flowered, the flower white with the thick rim of the very short crown margined with red: leaves flat, glaucous.

N. Jonquilla, Linn. Jonquil. Scape 2-5-flowered, the flowers small and yellow, the tube slender and the segments wide-spreading: leaves linear, somewhat cylindrical.

\section{GALÁNTHUS. SNOWDROP.}

Small, spring-blooming plants, with a single white flower nodding from the top of the scape, followed by grass-like leaves: perianth divisions 6 , oblong and more or less concave, the three inner ones shorter, some of them usually green-blotched at the tip; anthers and style pointed.

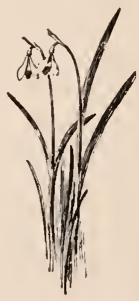

495. Galanthus nivalis.

G. nivallis, Linn. Snowdrop. Fig. 495. One of the earliest of spring flowers, appearing as soon as the snow is gone, the flower and leaves arising from a small bulb: scape 6 in. or less high: inner divisions of the bell-shaped flower tipped with green. Europe. 
3. LeUcòium. SNowflake.

Flowers often more than 1: divisions of the perianth all alike: anthers and style blunt: otherwise very like Galanthus.

L. ver rnum, Linn. Snowflake. Taller than the snowdrop (about $1 \mathrm{ft}$.), the scape usually 1-flowered, blooming later, the flowers larger. Europe.

\section{POLIÁnthes. Tuberose.}

Leafy-stemmed lily-like plants, with a thick, tuberous rootstock (whence the name tuber-ose not tube-rose), bearing an ereet spike of white flowers; perianth with a short slightly eurved tube and 6 spreading nearly equal divisions: stamens included in the tube (not projecting).

P. tuberòsa, Linn. Tuberose. Two to $3 \mathrm{ft}$., bearing long-linear, channelled, many-ranked leaves: flowers very fragrant, sometimes tinted with rose. A popular garden 'plant from Mexico, blooming in the open in late summer and autumn; some forms are double.

\section{HYPÓXIS. STAR-GRAss.}

Stemless, with grass-like, hairy leaves, growing from a corm-like rootstock: flowers yellow on filiform seapes; perianth 6-parted.

H. hirsùta, Coville. Scape $3-8$ in.. not so long as the grassy leaves, softhairy: flowers $1-4$, yellow, greenish without, about $1 / 2$ in. in diameter. Common in dry soils.

\section{IRIDĀCEÆ. Iris Family.}

Differs from Amaryllidaceæ and Liliaceæ in its inferior ovary, 3 stamens which are opposite the outer parts of the perianth, and 2-ranked equitant (bases overlapping) leaves: stigmas sometimes large and petal-like. About 60 genera and 700 species. Representative plants are iris or blue flag, crocus, gladiolus, freesia. Crocuses and freesias are easily grown in window-boxes for winter and spring bloom.

A. Lobes of the style expanded and colored, looking like

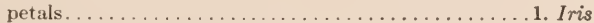

AA. Lobes of the style thread-like.

в. Plant stemless: flowers borne on scapes.

c. From corms: spathe 1-flowered: flower large, and perianth-tube long and slender............ Crocus

cc. From mostly fibrous roots: perianth-tube scareely perceptible, if at all: flowers small: spathe 2or more flowered ...................... Sisyrinchium

BB. Plants with a leaf-bearing and flower-bearing stem.

c. Flowers in a short 1-sided cluster: plant small....4. Freesia

cc. Hlowers in a terminal spike: plant large..........5. Gladiolus 


\section{IRİS. Fleur-DE-LIS. FlaG.}

Mostly strong plants, with rhizomes or tubers: flowers mostly large and showy, the 3 outer segments recurving and the 3 inner ones usually smaller and more erect or sometimes incurving; the 3 long divisions of the style petal-like and often more or less hairy, covering the stamens; stigma on

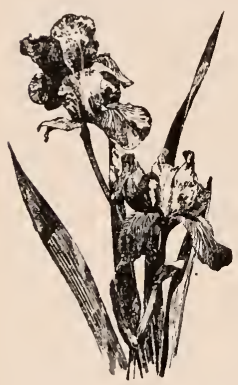

496. Iris germanica. the under side of the style: leaves long and swordshaped. Several wild and many cultivated species. The following species have rhizomes:

\section{a. Flowers yellow.}

I. Pseudácorus, Linn. Common yellow flag. One to $3 \mathrm{ft}$., with several-flowered, often branching stems; outer divisions of the perianth with no hairs or crests; flowers bright yellow. Europe.

aa. Flowers in shades of blue (sometimes varying to white).

I. versícolor, Linn. Common wild blue flag. Two to $3 \mathrm{ft}$., stout: leaves $3 / 4 \mathrm{in}$. wide, flat: flowers about 3 in. long, short-stalked violet-blue, the tube shorter than the ovary, the inner petals small and the outer ones with no hairs. Swamps.

I. lævigàta, Fisch. \& Mey. (I. Kaempferi, Sieb.). Japanese iris. Two to 3 feet, the stem much overtopping the thin, broad leaves: flowers large (sometimes several inches across), flat, the inner lobes spreading, the outer ones very large and rounded, with no hairs or crests: color mostly in shades of blue and purple. Japan; now one of the choicest of garden irises.

I. germánica, Linn. Common blue flag of gardens (sometimes runs wild). Fig. 496. Two to $3 \mathrm{ft}$, with long sword-shaped leaves: flowers few or several to each stem, about $3-4$ in. across, the drooping outer segments with yellow hairs, the inner segments erect and arching inward. Europe.

\section{CRÒcus. Crocus.}

Small, stemless plants, the long-tubed flowers and the grass-like leaves arising directly from the coated corm: flowers with the 6 obovate divisions all alike and erectspreading or the inner ones a little the smaller, opening only in sunshine. The following, from Europe, blooms in earliest spring:

C. vérnus, Linn. Common crocus. Fig. 497. Leaves $2-4$ to each flower, glaucous on the under side: flower

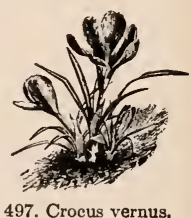
rising little above the ground; color in shades of lilac and variously striped, sometimes white.

\section{SiSYRÍNCHIUM. BlUE-EYEd GRAsS.}

Low, slender, perennial herbs with grass-like, linear, or lanceolate leaves and fibrous roots: scapes or stems erect, compressed, 2-edged or 
winged, often branched: flowers small, usually blue or bluish, soon withering, in terminal 2-5-flowered umbels in a 2-leaved spathe; perianth segments spreading, bristle-pointed: stamens 3 , monadelphous; style 1 long; stigmas very slender; ovary 3 -celled.

S. angustifölium, Mill. Grassy plants in tufts or clumps: scape 4-12 in., spathe single, sessile: flowers blue to purple, rarely white; petals notched and mucronate. In moist meadows, among grass. Summer. Common.

\section{FREEsia. Freesia.}

Small, cormous plants with flat leaves: flowers white or yellowish, tubular, with a somewhat spreading limb, the tube generally curved: stem about $1 \mathrm{ft}$. high, bearing several erect flowers on a sidewise cluster. Popular florists' plants of easy culture and quick growth.

F. refrácta, Klatt. Fig. 498. Leaves narrow:

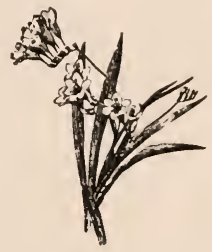

498. Freesia refracta. flower usually somewhat 2-lipped or irregular, white in the most popular forms but yellowish in some, often with blotches of yellow; fragrant. Cape of Good Hope.

\section{Gladiolus. Gladiolus.}

Tall, erect plants, with flat, strong-veined leaves, the stem arising from

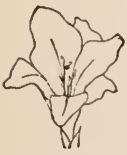

499. Gladiolus gandavensis. a corm (Fig. 54): flowers in a more or less 1-sided terminal spike, short-tubed, the limb flaring and somewhat unequal: stamens separate (united in some related genera): style long, with 3 large stigmas.

G. gandavénsis, Van Houtte. Fig. 499. Upper segments of the perianth nearly horizontal: colors various and bright: spikes long. Hybrid of two or more species from the Cape of Good Hope. Summer and fall. The common gladioli of gardens are greatly hybridized.

\section{ORCHIDĀCEA. ORChid FAMILy.}

Perennial herbs, distinguished by singular and extremely irregular perfect flowers, among the most ornamental and interesting of native and exotic plants, curiously adapted, in most cases, to insect pollination; many air-plants (epiphytes) of the tropies and warmer regions also belong to this family. Leaves usually alternate, simple, entire, sheathing: perianth in 6 divisions, adnate to the 1-celled ovary: sepals 3 , the outer segments of the perianth usually colored and similar or nearly so, appearing petal-like, the 2 lateral petals generally alike; third petal, the lip (the upper petal and, morphologieally, next to axis, but apparently next to bract, by a peeuliar twisting of the ovary), 
very unlike the others, usually larger and frequently lobed, spurred, or saccate: stamens 1 or 2 fertile, variously coherent with the style or with a thick, fleshy stigma, all together forming the column: pollen in waxy or powdery masses: ovary inferior. About 5,000 species and over 400 genera, of wide distribution but most abundant in the tropies; species rather difficult to determine, and therefore not described here in detail. Ours usually found in cool, damp woods, bogs, and meadows. Some of the rarest of greenhouse plants, and of ten very difficult to grow, are members of this family.

A. Lip sac-like or inflated, larger than the other parts.

B. Anthers 2, one on each side of the style: a spreading sterile stamen over the summit of the style: flowers generally large and drooping.......... Cypripedium AA. Lip not saccate, but spurred, and sometimes fringed: flowers in a terminal spike.

B. Sepals more or less spreading................ Habenaria

Bв. Sepals and petals somewhat arching together........ Orchis

AAA. Lip not noticeably saccate or spurred.

B. Flowers in spikes, appearing more or less twisted about the spike, in 1 or several rows: flowers small.

c. Leaves not variegated.................... Spiranthes

cc. Leaves variegated with white veins.........5. Epipactis

вв. Flowers 1 to several, in a spike-like loose raceme: or terminal on a leaf-bearing stem.

A. Stem (scape) from one grass-like leaf: lip crested with colored hairs....................6. Calopogon cc. Stem 1-3-leaved...................... Pogonia

\section{CYPRIPÈDIUM. Lady's Slipper. Moccasin Flower.}

Distinguished by having 2 fertile anthers: pollen sticky, as though varnished on surface, powdery beneath: lip a large, inflated, spurless sac, toward which the column bends: leaves large, broad, many-nerved: flowers large, showy. Fig. 250.

C. hirsùtum, Mill. Stem leafy, 1-2 ft., or more: flower solitary or 2 or 3 together; lip a globular sac, white, colored with purplish-pink, 11/2-2 in. long. In swamps, bogs and woods, North, and South in mountains. June to September. One of our rare and beautiful wild flowers.

C. acaùle, Ait. Scape $1 \mathrm{ft}$. tall, with two leaves at base, 1-flowered: sepals greenish purple, spreading; lip pink, veined with rose-purple, about 2 in. long, fragrant, split down the front, but edges closed. Woods and bogs. May to June. Fig. 250.

C. pubéscens, Willd. Stem slender, leafy, 1-2 ft., usually clustered, 1- to several-flowered: flowers yellow, lip much inflated, with purplish stripes or spots, $1 \frac{1}{2}-2$ in. long. Low woods, meadows. May to July.

C. parvifiòrum, Salisb. Stem 1-2 ft. high, leafy, 1- to several-flowered: 
flowers yellow, fragrant; lip usually more marked with purplish spots or lines than preceding and smaller, about $1 \mathrm{in.} \mathrm{long.} \mathrm{Low} \mathrm{woods} \mathrm{and} \mathrm{thickets.}$ May to July.

C. cândidum, Muhl. Lip white, with purple veins and stripes, not 1 in. long. A very rare species, found in bogs and wet meadows, New York and New Jersey to Minnesota, Missouri, Kentucky.

C. arietinum, R. Br. Slender, less than $1 \mathrm{ft}$., leafy stemmed: flower 1, drooping, the 3 sepals separate and very narrow and greenish, the lip somewhat shorter than sepals $1 / 2$ in. long, red with lighter veins. Cold woods, North.

\section{2. habenària. Fringed or Ragged Orchids.}

Flowers several or numerous, in open terminal spikes, each flower in the axil of a foliaceous bract: corolla white, purplish or yellow, with lip variously fringed or 3-parted and cut-toothed, spur longer than lip: 1 anther: pollen-mass stalked, cohering. Growing, for most part, in wet places, borders of ponds, etc., through eastern United Statcs. Several species, rather too critical for the beginner and therefore not described here. By some, the genus is broken up into several genera.

\section{3. ÓRCHIS.}

Very similar to Habenaria, differing in having the glands attached to the pollen masses, and inclosed in a kind of pocket: the petals are arched and somewhat connivent over the column.

O. spectábilis, Linn. Stem short, from 2 large and glossy root-leaves, and carrying 1 or 2 lanceolate bracts, with several flowers above, in a raceme: lip white, spurred at base: other petals purplish pink, arching up over the flower. Woods.

\section{SPIRÂNTHES. LADIES' TrESSES.}

Generally characterized by small flowers, whitish, yellowish or greenish white, bent horizontally and arranged in 1-3 rows spirally in a spike, appearing as if twisted: stem usually bearing leaves below, or at the base: lip of the little flowers not saceate but erect, oblong, recurved, channelled, the base cmbracing the column and bearing 2 callous protuberances; anther 1-2-celled: 1 powdery pollen mass in each cell. Several species.

S. cérnua, Richard. Six to $20 \mathrm{in}$. high, having leafy bracts with the flowers; spike dense, with flowers in 3 rows, inflorescence appearing but slightly twisted: leaves lance-linear. Common in moist meadows and swamps. Late summer and early autumn.

S. grácilis, Beck. Spike and scape slender, with flowers in one straight or spiral row: leaves all radical, ovate to oblong, commonly withering away at or before flowering. Common in dry or sandy fields, qpen or hilly woods. July to October.

\section{EPIPÁctis. Rattlesnake Plantain.}

In spike and perianth similar to spiranthes, but without the 2 lateral callous protuberances on the lip: leaves basal, tufted, thickish, petioled, 
dark green, usually blotched or veined with white. A few species widely distributed, but not common, with handsome leaves. The genus is also known as Peramium and as Goodyera.

\section{CAlopògon. Grass Pink.}

Scapes from round solid bulbs bearing several flowers in loose terminal spikes or racemes; leaf 1 , grass-like. Distinguished by having the lip on the upper side (ovary or stalk not twisting) bearded.

C. pulchéllus, R. Br. Scape $1 \mathrm{ft}$. high, 2-6-flowered: flowers 1 in. across, pink-purple; the lip triangular at apex, crested with colored hairs (yellow, orange, purple), club-shaped: anther lid-like: pollen-masses 4, powdery. Wet meadows and bogs. Very pretty.

\section{POGÒNIA.}

Low, with solitary, terminal, odd flowers; alternate leaves: lip spurless, crested or hooded or 3-lobed; column not attached: calyx spreading; fertile anther lid-like; 2 pollen-masses, granular.

P. ophioglossoìdes, Ker. Stem 6-9 in. from a fibrous root; leaf sessile, oval near middle of stem: lip erect, bearded and fringed; flower 1 in. long, sweet-scented, pale rose color, slightly nodding, with a leafy bract. Marshes or swampy places. Eastern United States. June to July.

\section{BB. PHENOGAMS: ANGIOSPERMS: DICOTYLEDONS. \\ D. CHORIPETALAE.}

\section{CUPUlífERA. OAK Family.}

Monœcious trees and shrubs with staminate flowers in catkins and the pistillate in eatkins or solitary: leaves alternate, with stipules early deciduous (mostly scale-like), and the side-veins straight or nearly so: stamens 2 to many: fruit a 1-seeded nut, sometimes inclosed in an involucre. Ten or a dozen genera and upwards of 450 species. Representative plants are oak, chestnut, beech, birch, hazel, ironwood.

A. Sterile flowers in a hanging head: fruits 2 three-cornered nuts in a small, spiny involucre or bur............. Fagus AA. Sterile flowers in cylindrical catkins.

в. Fruit 1-4 rounded or flat-sided nuts in a large, sharpspiny involucre or bur....................... Castanea

вв. Fruit an acorn-a nut sitting in a scaly or spiny cup.....3. Quercus ввв. Fruit flat and often winged, thin and seed-like, borne under scales in a cone.

c. Fertile flowers naked: mature cone-scales thin........ Betula

cc. Fertile flowers with a calyx: cone-scales thick.......5. Alnus 


\section{FÀGUS. ВEECH.}

Tall forest trees with light bark, and prominent parallel side-veins in the leaves: sterile flowers in a small, pendulous head, with 5-7-cleft calyx and 8-16 stamens: fertile flowers 2 , in a close involucre, ripening into 2 three-cornered "beech nuts" in a 4-valved bur.

F. grandifòlia, Ehrh. American beech. Close-grained, hard-wood tree, with light colored bark: leaves ovate-oblong and acuminate, coarsely serrate, usually with 9 or more pairs of nerves: nuts ripening in the fall, and much sought by boys and squirrels. A common forest tree.

F. sylvática, Linn. European beech. Fig. 151. Often planted, particularly in the form of the purple-leaved and weeping beech: foliage differs in being mostly smaller, ovate or elliptic, small-toothed, with 9 or less pairs of nerves.

2. CAstànea. Chestnut.

Forest trees, with rough, furrowed bark: Sterile flowers with 4-7-lobed calyx and 8-20 stamens in very long, erect or spreading catkins, which appear in clusters in midsummer: fertile flowers about 3 in an involucre, producing "chestnuts" in a spiny bur.

C. dentàta, Borkh. American chestnut. Fig. 267. Tall, straightgrained tree, with large, broad and thin, oblong-lanceolate leaves, which are taper-pointed, and have large teeth with spreading spines: nuts usually 1 in. or less across, sweet. Grows as far west as Michigan, and south to Mississippi.

C. satìva, Mill. European chestnut. Less tall: leaves smaller and narrower, more pubescent when young, not long-acuminate, the teeth smaller and their spines more incurved: nuts $1 \mathrm{in.}$ or more across, not so sweet as those of the American chestnut. Europe. Very commonly planted.

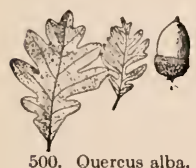

500. Quercus alba.

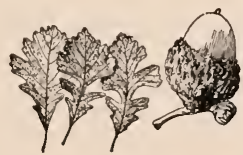

501. Quercus macrocarpa.

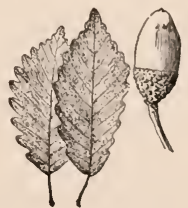

502. Quercus Prinus.

3. QUÉRCUS. OAK.

Strong, close-grained trees, with mostly laterally-lobed leaves: sterile flowers in elustered hanging eatkins, with a 4-7-lobed calyx, and 3-12 stamens: fertile one in a shallow involucre which becomes the cup of the acorn, the stigma 3-lobed: fruit an acorn. See Fig. 228, which represents a form of the English oak ( $Q$. Robur) often planted in choice grounds.

a. White oak group, distinguished by its light gray scaly bark, rounded lobes or teeth of the leaves, and the acorns maturing the first year. (Q. virens has nearly or quite entire leaves.)

Q. álba, Linn. White oak. Fig. 500. Leaves obovate, 5 or 6 in. long. the lobes usually 7 and at equal distances apart, and the sinuses 
deep or shallow: acorn small, with a rather shallow and not fringed cup. The commonest species.

Q. macrocárpa, Michx. Bur oak. Fig. 501. Leaves obovate, downy or pale on the lower surface, toothed towards the tips and irregularly and often deeply lobed toward the base: acorn cups heavily fringed on the margins: young branches corky. More common West.

Q. Prìnus, Linn. Chestnut oak. Fig. 502. Leaves rather long-obovate,

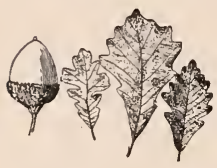

503. Quercus bicolor.

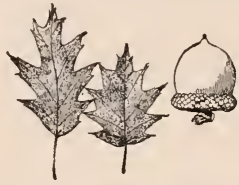

504. Quercus rubra.

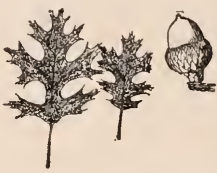

505. Quercus coccinea.

toothed, with rounded teeth and yellow-ribbed: acorn long and the cup hard-scaled: bark dark with broad, deep furrows. Eastern.

Q. bícolor, Willd. Swamp white oak. Fig. 503. Leaves obovate. whitedowny on their lower surface, toothed with squarish teeth, the bases wedgeshaped: acorn small, with the margin of the cup finely fringed. Common in low grounds and along ravines.

Q, virginiàna, Mill. Live-oak. Leaves small, oblong, entire or sometimes spiny-toothed, thick and evergreen: acorn oblong, the nut about one-third covered with its scaly cup. Virginia, south.

aa. Black oak group, distinguished by its dark furrowed bark, pointed lobes of the leaves, and the acorns maturing the second year.

Q. rùbra, Linn. Red oak. Fig. 504. Leaves obovate or sometimes shorter, the 7-9 lobes triangular and pointing toward the tips: acorn large,

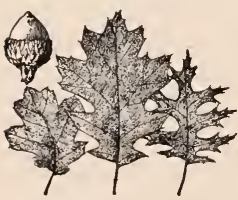

506. Quercus velutina. flat-cupped. Common.

Q. coccínea, Moench. Scarlet oak. Fig. 505. Leaves obovate, bright scarlet in autumn, thin, smooth on the lower surface, the sinuses deep, wide and rounded: margin of the acorn cup rounding inwards and the scales close: inner bark reddish. Common.

Q. velùtina, Lam. Black oak. Fig. 506. Leaves obovate, coarser, downy on the lower surface until midsummer or later, wider toward the tip, the sinuses shallow (or sometimes as in the scarlet oak): margin of the acorn cup not rounding inwards and the scales looser: inner bark orange. Common.

\section{BÉTULA. BirCh.}

Small to medium-sized trees, with sterile flowers in drooping, cylindrical catkins, 3 flowers with 4 short stamens being borne under each bract: fertile 
flowers in short, mostly ereet cat kins which become eones at maturity, 2 or 3 naked flowers being borne under each 3-lobed bract: fruit winged and seedlike: leaves simple, toothed or scrrate; bark often aromatic.

\section{a. Brown-barked birches: leaves ovate.}

B. lênta, Linn. Cherry birch. Swcet birch. Tall tree, the bark tight (not peeling in layers), the twigs very aromatic: leaves oblong-ovate, somewhat cordate at base, doubly serrate, becoming glossy above: bracts of the oblong-cylindric fruiting eatkins with wide-spreading lobes. Rich woods.

B. lùtea, Michx. Yellow or gray birch. Bark grayer or silvery, peeling in layers: leaves scarcely cordate, dull, more downy: bracts of the short-oblong fruiting eatkins with scarcely spreading scalcs: tree less aromatic than the other. Same range.

\section{aa. White-barked birches: leaves triangular or broad-ovate.}

B. papyrifera, Marsh. Paper birch. Canoe birch. Tree of medium to rather large size, with the bark peeling in very large plates or layers: leaves broad-ovate and often somewhat cordate, dull green. Pennsylvania, north.

B. populifòlia, Ait. American white birch. Small and slender tree with rather tight, glistening, white bark: leaves triangular-acuminate, toothed, dangling, and moving incessantly in the wind. Northeastern states.

B. âlba, Linn. European white birch. A larger tree, with triangularovate leaves which are pointed but not long-acuminate. Europe. The common cultivated white birch. There are weeping forms (Fig. 6).

\section{5. ÁLNUS. ALDER.}

Much like Betula, but smaller trees or bushes: flowers with a 3-5parted calyx, and the small, short, fertile catkins composed of thickened, woody scales. In the following, the flowers appear before the leaves in earliest spring, from catkins formed the previous year and remaining partly developed during winter. Common along streams.

A. incàna, Moench. Speckled alder. Shrub or small tree, with pubeseent branches: leaves oval to oblong-ovate, acute, doubly serrate, glaucous and downy underneath: cones about $1 / 2$ in. long, mostly sessile.

A. rugòsa, Spreng. (A. serrulàta, Willd.). Smooth alder. Leaves elliptic or obovate, acute or rounded at the apex, finely serrate, the under side of the leaves smooth or pubescent only on the veins: eones short-stalked.

A. vulgàris, Hill. Black alder. Leaves orbicular or very broadly obovate, not aeute, irregularly serrate, dull and nearly smooth beneath: cones peduneled. Europe. Planted, some varieties with divided leaves.

\section{UrticìceA. Nettle Family.}

Trees and herbs, with small apetalous flowers in small clusters or solitary: leaves mostly straight-veined, with stipules: plants dicecious or monceious, or flowers perfect in the elms: stamens usually as many 
as the lobes of the calyx and opposite them: ovary superior, ripening into a 1-seeded indehiscent, often winged fruit. A very polymorphous association, by some botanists divided into two or three coördinate families. More than 100 genera and 1,500 species. Representatives are elm, hackberry, mulberry, osage orange, nettle, hop, hemp.

A. Trees.

B. Fruit a samara............................... Ulmus

вв. Fruit a small drupe $\ldots \ldots \ldots \ldots \ldots \ldots \ldots \ldots \ldots \ldots \ldots \ldots \ldots \ldots \ldots \ldots \ldots \ldots$ Celtis

ввв. Fruit as large as an orange, formed of the whole mass of

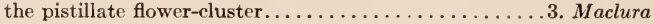

вввв. Fruit resembling a blackberry, formed of the pistillate flower-eluster................................ Morus

AA. Herbs.

B. Leaves digitately lobed or divided.

c. Plant standing erect............................ Cannabis

cc. Plant twining............................ Humulus

BB. Leaves not lobed: plant with stinging hairs........... Urtica

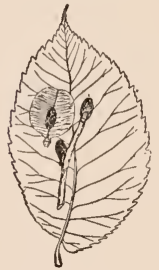

507. Ulmus fulva.

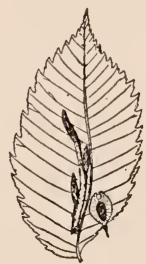

508. Ulmus americana.

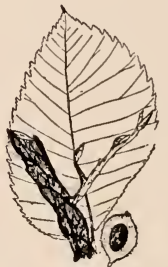

509. Ulmus racemosa.

\section{1. ÚlMuS. Elm.}

Trees, mostly large and valuable for timber, with rough-furrowed bark: leaves alternate (2-ranked), ovate and straight-veined, dentate: flowers small and not showy, appearing in earliest spring, sometimes diclinous, the calyx 4-9-parted, the anthers 4-9 on long filaments: ovary generally 2-loculed, ripening into a 1 -seeded wing-fruit.

\section{a. Leaves large, rough on the upper surface: fruit large, nearly orbicular.}

U. fúlva, Michx. Slippery elm. Fig. 507. Middle-sized or small tree with inner bark mucilaginous or "slippery" in spring: leaves 6-8 in. long and half or more as broad, ovate-elliptic and unequal-sided, doubly serrate, very rough above and softer beneath: samara $1 / 2-3 / 4$ in. long, orbicular or nearly so, with the seed in the center: flowers in dense clusters. Common. 
aa. Leaves not very rough above: fruit oval, dceply notched at the apex.

U. americàna, Linn. Common or white elm. Figs. 96-100,508. Tall and graceful tree: leaves elliptic-oval, serrate: samara small, more or less hairy on the thin wing, the notch in the apex extending nearly to the seed: flowers hanging on slender stalks. One of the finest of American trees.

U. racemòsa, Thomas. Cork elm. Fig. 509. Smaller tree than the last, with corky-winged branches: leaves with straighter veins: samara with sharp incurved points at the apex: flowers in racemes. Less common.

U. alàta, Michx. Wahoo elm. Small tree, with wide, corky ridges on the branches: leaves small and rather thick, almost sessile, ovate to nearly lanceolate and acute: samara downy, at least when young. Virginia, south and west.

\section{Céltis. Nettle-tree. Hackberry.}

Elm-like in looks, but the fruit a 1-seeded, berry-like drupe: flowers greenish, in the leaf axils, mostly diclinous; calyx 5-6-parted; stamens 5 or 6: stigmas 2 , very long.

C. occidentàlis, Linn. Common hackberry. Middle-sized tree with rough-furrowed bark: leaves ovate-pointed, oblique at base, serrate: fruit purplish, as large as a pea, edible in the fall when ripe. Low grounds.

\section{3. maclüra. Osage Orange.}

Small tree, with diccious flowers in catkins, and alternate, simple leaves: sterile flowers in raceme-like, deciduous catkins: fertile flowers densely crowded in a head, with 4 sepals and 2 stigmas, the ovary ripening into an achene, the

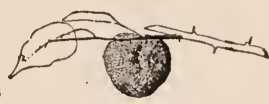

510. Maclura pomifera. whole flower-eluster becoming fleshy and ripening into an orange-like mass.

M. pomifera, Schneid. (Toxylon pomiferum, Raf.). Osage orange. Fig. 510. Spiny, low tree, much used for hedges, but not hardy in the northernmost states: leaves narrow-ovate and entire, glossy: flowers in spring after the leaves appear, the fruit ripening in autumn. Missouri and Kansas south.

\section{MÒrUS. MULbERrY.}

Small to middle-sized trees, with broad, alternate toothed or lohed leaves and monocious flowers, with 4-parted calyx: stamens 4, with filaments at first bent inward, the staminate catkins soon falling: fertile flowers ripening a single achene, but the entire catkin becomes fleshy and blackberrylike, and prized for eating. Leaves very variable, often lobed and not lobed on the same branch.

M. rùbra, Linn. Common wild mulberry. Often a large tree in the South: leaves ovate-acuminate, oblique at the base, rough and dull on the upper surface and softer beneath, dentate: fruit $1 / 2-1$ in. long, black-red, sweet. Wood yellow. Most abundant South, but growing as far north as Massachusetts. 
M. álba, Linn. White mulberry. Fig. 511. Leaves light green and usually glossy above, the veins prominent and whitish beneath, the teeth usually rounded or obtuse: fruit of variable size, often $11 / 2 \mathrm{in}$. long, whitish, violet, or purple. China; planted for ornament and for its fruit, also for feeding silkworms. The much-planted Russian muloerry is a form of it.

\section{CÁNNABís. Hemp.}

Tall, strong, diœcious herbs with 5-7 leaflets: fertile flowers in clusters, with 1 sepal surrounding the ovary, and 2 long, hairy stigmas: sterile flowers in racemes or panicles, with 5 sepals and 5 drooping stamens.

C. sativa, Linn. Hemp. Six to $10 \mathrm{ft}$., strong-smelling, blooming all summer: leaflets lanceolate, large toothed. Old World; cultivated for fiber and sometimes escaped in waste places.

6. HÙMULUS. Hop.

Twining diøecious herbs of tall growth, with 5 sepals in the sterile

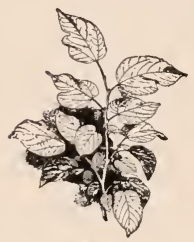

511. Morus alba. flowers, the stamens erect: fertile flowers with 1 sepal, 2 flowers under each scale of a short, thin catkin which becomes a kind of cone or "hop."

H. Lùpulus, Linn. Common hop. Perennial, roughhairy: leaves broad-ovate, deeply 3-lobed (only rarely 5-7-lobed): sterile flowers in panicles 2-6 in. long: pistillate eatkin enlarging into a "hop" often 2 in. or more long. A native plant, cultivated for hops and sometimes for ornament.

H. japónicus, Sieb. \& Zucc. Japanese hop. Fig. 179. Annual: leaves not less than 5-lobed: fertile catkin not enlarging into a hop. Japan; much cultivated for ornament.

\section{7. ÚRTica. NetTle.}

Erect herbs with opposite simple leaves and stinging hairs, and monœcious or diœcious flowers in racemes or dense clusters. the calyx of 4 separate sepals: stamens 4 : stigma sessile: fruit an ovate flat achene. The following are perennials with flowers in panicled spikes:

U. grácilis, Ait. Common nettle. Two to $6 \mathrm{ft}$.: leaves ovate-lanceolate, serrate, on long petioles. Common in low grounds.

U. dioica, Linn. Not so tall: leaves ovate-cordate and deeply serrate, on rather short petioles, downy underneath. Weed from Europe, very stinging.

\section{ARISTOLOCHIĀCEA.}

\section{Birthwort Family. Dutchman's Pipe Family.}

Low acaulescent herbs, or tall twining vines: leaves basal or alternate, without stipules, petiolate, roundish or kidney-shaped: flowers regular or irregular, perfect: perianth-tube brown or dull, valvate in 
bud, adherent to ovary: stamens 6-12, epigynous, and adherent to base of the styles: ovary 6-celled, pistil 1. A small family of about 200 species, sparingly represented in this country. Many of the members have aromatic or bitter-tonic properties.

A. Low stemless herbs.......................... Asarum

AA. Leafy-stemmed herbs, or woody elimbers...........2. Aristolochia

\section{1. ÀsArum. Wild Ginger.}

Perennial spreading herbs: leaves large, kidney-shaped, pubesent: flower brown, inconspicuous, borne on a short peduncle arising from between the petioles: rootstocks creeping, elongated, very aromatic.

A. canadénse, Linn. Leaves in pairs, large, reniform, but more or less pointed at tip, soft-hairy with a silky finish: flower greenish outside, purplebrown within, consisting of a 3-lobed calyx, adnate to ovary: stamens 12 , the filaments longer than the anthers. Common in rich woods. April, May.

\section{ARISTOlòchia. Dutchman's Pipe.}

Herbs or tall vines, with alternate, petiolate leaves, cordate, entire and palmately nerved: flowers irregular, the calyx tubular, the tube oddly inflated above ovary and contracted at throat, shaped like a much-bent pipe, the margin reflexed or spreading, 3-6-lobed or appendaged: stamens 6 .

A. macrophýlla, Lam. (A. Sipho, L'Her.). Calyx-tube about 1-11/2 in. long, curved to resemble a Dutch pipe, the margin spreading, brownishpurple: leaves large, smooth, dark green, round kidney-shaped. Wild in rich woods; May; often cultivated.

\section{POLYGONĀCEAE. Buckwheat Family.}

Herbs, mostly with enlarged joints or nodes and sheaths (representing stipules) above them: leaves simple and usually entire, alternate: flowers small, apetalous, usually perfect and generally borne in spikes or dense clusters: stamens 4-12, attached to the very base of the 3-5-merous calyx: ovary 1-loculed, ripening into a 3-4-angled achene. Thirty or more genera and about 600 widely dispersed species. Characteristic plants are buckwheat, rhubarb, dock, sorrel, smartweed.

A. Root-leaves $1 \mathrm{ft}$. or more across, rounded........... Rheum AA. Root-leaves narrow or not prominent.

B. Calyx of 6 sepals, often of two kinds............. Rumex

вв. Calyx of 5 (rarely 4 ) sepals, all alike.

c. Flowers white and fragrant................. Fagnpyrum

cc. Flowers greenish or pinkish, uot distinctly fragrant...4. Polygonum 


\section{RHEUM. RHUBARB.}

Very large-leaved perennials, sending up stout hollow flower-stalks in early summer which bear smaller leaves with sheathing bases: sepals 6 , all alike, withering rather than falling, and persisting beneath the 3 -winged

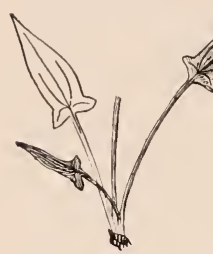

512. Rumex Acetosella. achenes: stamens 9: styles 3. Old World.

R. Rhapónticum, Linn. Rhubarb. Pieplant. Figs. 81, 82. Leaves $1 \mathrm{ft}$. or more across, the thick petioles edible: fls. white, in elevated panicles.

2. RÜMEX. Dock. Sorrel.

Perennial often deep-rooted plants with herbage bitter or sour: sepals 6 , the 3 outer large and spreading, the 3 inner (known as "valves") enlarging after flowering and one or more of them often bearing a grain-like tubercle on the back; stamens 6 , styles 3 ; flowers in panicles or interrupted spikes.

a. Docks: herbage bitter: valves often grain-bearing: flowers mostly perfect: leaves not arrow-shaped.

R. obtusifòlius. Linn. Bitter dock. Lower leaves oblong-cordate and obtuse, not wavy: one valve usually grain-bearing. Weed from Europe.

R. críspus, Linn. Curly doek. Leaves lanceolate, wavy or curled: all valves usually grain-bearing. Weed from Europe.

aa. Sorrels: herbage sour: valves not grain-bearing: flowers diceious: leaves arrow-shaped.

R. Acetosélla, Linn. Common or sheep sorrel. Fig. 512. Low (1 ft. or less): lvs, mostly arrowshaped at base: flowers brownish, small, in a terminal panicle. Common in sterile fields. Europe.

\section{FAGOPỲRUM. BUCKWHEAT.}

Fast-growing annuals, with somewhat triangular leaves, and fragrant flowers in flattish, panicle-like clusters: calyx of 5 parts: stamens 8: fruit a triangular achene. Old World.

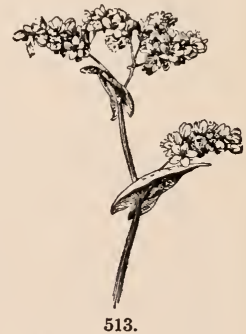

F. esculéntum, Moench. Common buckwheat. Fagopyrum esculentum. petioled: flowers white, in a compound cluster: achene with regular angles. Flour is made from the grain.

F. tatáricum, Gaertn. India wheat. Slenderer, the leaves smaller and more arrow-shaped and short-petioled: flowers greenish or yellowish, in simple racemes: achene notched on the angles. Somewhat cultivated. 


\section{Polygondm. Knotweed. Smartweed.}

Low weedy plants, or some exotic ones tall and eultivated, blooming in summer and fall, the small pinkish or greenish flowers mostly in racemes or spikes (in the Knotweeds in the leaf-axils): calyx usually 5-parted: stamens 4-9: stigmas 2 or 3: black achene lenticular or triangular.

a. Knotweeds: flowers sessile in the axils of the leaves, greenish and very small.

P. aviculàre, Linn. Common knotweed. Doorweed. Fig. 210. Prostrate or creeping, bluish green wiry plant, growing along the hard edges of walks and in yards, and commonly mistaken for sod: leaves small, mostly oblong, entire: sepals very small, green with a broad white margin: stamens 5 or more: stigmas usually 3 . Annual.

P. eréctum, Linn. Taller knotweed. One ft. or more high: leaves three or four times larger, oblong or oval and obtuse. Common annual.

aa. Smartweeds: flowers in terminal spikes, mostly pinkish.

b. Sheaths of leaves (surrounding stem) hairy on the edge, or the margin with a spreading border.

P. orientàle, Linn. Prince's feather. Several feet tall, softhairy: flowers in long cylindrical nodding spikes: leaves ovate: stamens 7. India; cultivated. Annual.

P. Persicària, Linn. Smartweed. Lady's thumb (from the dark bloteh near the center of the leaf). Fig. 514. About 1 ft.: leaves lanceolate: spikes oblong, dense and erect: stamens usually 6 : stigmas 2 . Weed from Europe.

P. Hydropìper, Linn. Smartweed. Herbage very pungent or "smarty:" leaves oblong-lanceolate: spikes short and nodding, the flowers greenish: stamens 6: stigmas 3 . Low grounds. Annual.

P. hydropiperoides, Michx. Smartweed. Herbage not pungent: spikes slender and erect, the flowers whitish: stamens 8: stigmas 3 . In very wet places. Perennial.

P. àcre, HBK. Smartweed. Herbage pungent: leaves

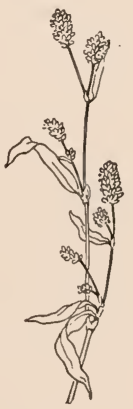

514.

Polygonum Persicaria. linear or lanceolate, long-pointed: spikes slender and erect: flowers white or blush: stamens 8: stigmas 3 . Low grounds. Perennial.

bb. Sheaths of leaves not hairy, nor the margin bordered.

P. pennsylvánicum, Linn. Smartweed. Pungent: plant with conspicuous glandular hairs above: leaves lanceolate: spikes short-oblong and erect, the flowers purplish: stamens 8: stigmas 2. Low ground. Annual.

\section{EUPHORBIĀCEÆ. Spurge Family.}

Trees, shrubs or herbs, often with milky, pungent juice, sometimes poisonous: flowers monocious or dicecious, mostly apetalous, usually small and inconspicuous. The family is large, in warmer parts 
of the world. The determination of the genera and species is difficult. Euphorbia and Ricinus will sufficiently explain the flower structure for the beginner.

A. Flowers in a cup-like involucre, which imitates a perianth:

flowers diceious, without calyx or corolla............. Euphorbia

AA. Flowers, not in an involucre, but in a terminal panicle:

flowers diceious, calyx present, but no corolla ........2. Ricinus

\section{EUPHÓRBIA. SPURGE.}

Flowers monœeious inclosed in an involucre, which is 4-5-lobed and often showy, resembling a perianth: staminate flowers each consisting of a stamen jointed to filament-like pedicel, subtended by a minute bract, attached on the inner surface of the involucre: the solitary pistillate flower, standing at the bottom of the involucre, is at length protruded on a stalk: capsule 3-lobed and 3-celled: styles 3, each 2-cleft: stigmas 6. Many of the species are cultivated for ornamental purposes, as $E$. splendens, Crown of Thorns; E. Cyparissias, Cypress spurge, common in old yards and about cemeteries, where it has run wild.

E. corollàta, Linn. Flowering spurge. Perennial, 2-3 ft., slenderbranched: leaves mostly alternate, or the uppermost ones, or those on the branches opposite, whorled, oval, rather thick, usually pale beneath: flowering branches much forked: involucres terminal, or on peduncles, from the forks of the branches, the lobes snowy white, appearing like petals with oblong yellowish green glands at base of each. In dry or sandy soil, common. July to October.

E. maculàta, Linn. Small plant, prostrate or spreading, the branches slender and radiating, dark green, often dark red: leaves oblong-linear, usually with red-brown spots in center: involucre minute, the corolla-like appendages narrow, white or red. A common inconspicuous weed throughout North America, except the extreme north.

E. pulchérrima, Willd. Poinsettia. Floral leaves brilliant red and appearing like flaming blossoms: flowers in a greenish involucre, with a large yellow gland on summit. A Mexican species, well known as an ornamental greenhouse plant.

\section{Rícinus. Castor-oil Plant. Figs. 313-316.}

Tall stately, perennial herb (annual North), with large, alternate, palmately cleft leaves: flowers monœcious, apetalous, greenish, in terminal racemes or panicled clusters, the pistillate flowers above the others; styles large, reddish.

R. commùnis, Linn. Castor bean. Palma Christi. Stem erect from 3-12 ft., somewhat branched: leaves very large, peltate, lobes acute, pointed, toothed: seeds smooth, black, mottled or variegated with gray and brown. Grown for medicinal and ornamental purposes. Tropical. There are many forms in cultivation. 


\section{CARYOPHYLlà́CEA. Pink Family.}

Herbs, with opposite, mostly narrow, entire leaves without conspicuous veins: flowers 4-5-merous, sometimes apctalous, with stamens twice or less the number of sepals or petals, and 2-5 styles which may be wholly scparate or partially united: pod usually a 1-loeuled capsule commonly inclosed in the calyx, mostly splitting from the top, the seeds usually attached to a central column. Genera between 30 and 40 , species about 1,000. Representative plants are pink, earnation, bouncing Bet, eatchfly, chickweed, corn-cockle, lychnis, spurry.

A. Flowers polypetalous, with sepals united into a tube.

B. Bracts at the base of the calyx................. Dianthus

BB. No bracts at base of calyx.

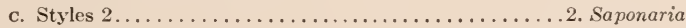

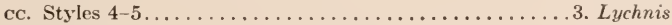

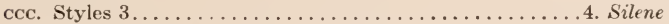

AA. Flowers often apetalous, the sepals nearly or quite distinct.

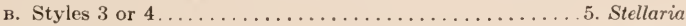

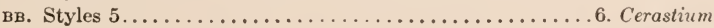

\section{DiÁNTHUS. Pink.}

Showy-flowered small herbs, with striate, many-furrowed calyx and sepal-like bracts at its base: petals with slender claws or bases, the limb usually toothed or fringed: styles 2 .

\section{a. Flowers singlc on ends of branches.}

D. chinénsis, Linn. China or florists' pink. Leaves short-lanceolate, not grass-like: caly $\mathrm{x}$-bracts linear-acute and as long as the calyx: petals in white and shades of red, very showy. China. Perennial, but grown as an annual (mostly under the florists' name D. Heddewigi).

D. plumàrius, Linn. Grass or Scotch pink. Common pink of old gardens, from Europe. Low, growing in mats, glau-

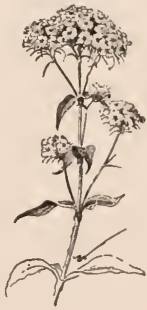

515. Dianthus barbatus. cous-blue: leaves grass-like: flowers very fragrant, deep-fringed, white or pink. Perennial.

D. Caryophýllus, Linn. Carnation. Two ft. or more, with wiry stems, glaucous-blue: leaves grass-like: ealyx-bracts short and broad: petals more or less toothed but not fringed: flowers fragrant. Europe.

\section{aa. Flowers in compact clusters.}

D. barbàtus, Linn. Sweet William. Fig. 515. One ft. or more, erect, green: flowers small, in dense clusters in red and white. Old World; common in old gardens. 


\section{SAPONÀRIA. SOAPWORT.}

Calyx cylindrical or angled, 5-toothed, with no bracts at its base: stamens 10: styles 2: pod 4-toothed at top (Fig. 282).

S. officinàlis, Linn. Bouncing Bet. Perennial, forming colonies in old yards and along roads, 1-2 ft. high, glabrous, with ovate or oval leaves: flowers 1 in. across, white or rose, in dense clusters, often double, the petals with a crown. Europe. Common.

\section{LYCHNIS. Lychnis. Cockle.}

Annual or perennial, with styles usually 5 , and pod opening by 5 or more teeth: calyx 5-toothed and 10-or more-nerved, naked at the base: stamens 10 .

L. Githàgo, Scop. (or Agrostemma Githago, Linn.). Fig. 181. Corn cockle, because it is a common weed in wheat fields (wheat is known as corn in Europe), its seeds not being readily separated from wheat because of their similar size and its seasons corresponding with those of wheat: annual, 2-3 ft., hairy: flowers purple-red and showy, on very long stalks, the petals crowned and the calyx-lobes long and leafy: leaves very narrow. Europe.

L. Coronària, Desv. Dusty Miller. Mullein pink. Biennial or perennial, white-woolly all over: leaves oblong: flowers rose-crimson, showy. Europe. Old gardens and along roads.

\section{Silène. Campion. Catchfly.}

Annual or perennial herbs, with white, pink, or red flowers, solitary or in cymes: calyx often inflated, 5-toothed, 10- to many-nerved, with no bracts at base; petals 5 , clawed, sometimes with erown or scale at base of blade; stamens 10; styles 3 (rarely 4 or 5); ovary 1-celled (or incompletely 2-4-celled): fruit a capsule, or pod, 1-celled or 3-celled at base, dehiscent by 3 or 6 teeth at apex, many-seeded. A viscid secretion covers the calyx and stems of certain species, by which creeping insects are caught, whence the name "catehfly."

S. stellàta, Ait. Starry campion. Perennial, 2-3 ft. high: leaves ovatelanceolate, acuminate, in whorls of 4 (at least the upper ones): flowers in panicled cymes; calyx bell-shaped, loose and inflated; petals fringed, crownless, white. July. Open woods.

S. latifòlia, Britten \& Rendle. Bladder campion. Perennial, 1-2 ft.: leaves ovate-lanceolate, acute, opposite: flowers in panicles, inclined or drooping: calyx globular, thin and much inflated, conspicuously veined; petals 2-cleft, white. Roadsides, fields and waste places. Common eastward. Naturalized from Europe.

S. pennsylvánica Michx. Wild pink. Perennial, viscid-pubescent above, 4-10 in.: basal leaves spatulate or cuneate, narrowed into petioles; stemleaves lanceolate, sessile, opposite: flowers in terminal, few-flowered cymes; calyx narrow; petals wedge-shaped, slightly emarginate (or eroded) on edge, pink-red, crowned. In dry soil in eastern states.

S. virgínica, Linn. Fire pink. Perennial, 1-8 ft.: lower leaves thin, spatulate, the cauline oblong or lanceolate, sessile: flowers few in a loose 
cyme, peduncled, showy, 11/2-2 in. broad; ealyx bell-like, enlarged as pod matures: petals 2-cleft, crowned, bright crimson: stem viscid-pubescent. Open, dry woods. May to September.

S. noctiflòra, Linu. Night-flowering catchfly. Annual: lower leaves spatulate or obovate, the upper linear: flowers large, few, pedicelled, in loose panicle, opening at dusk for the night: very fragrant: ealyx-tube elongated, noticcably veined, with awl-like teeth: petals 2-cleft; white, crowned. Weed introduced from Europe. July to September.

\section{STELlària. Chickweed.}

Small, weak herbs with sepals 4-5, petals of equal number and deeply eleft or sometimes wanting; stamens 10 or less; styles usually 3: pod opening by twice as many valves as there are styles.

S. mèdia, Cyrill. Common chickweed. Fig. 457. Little prostrate annual, making a mat in cultivated grounds, with ovate or oblong leaves mostly on hairy petioles: flowers solitary, minute, white, the 2-parted

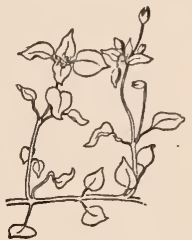

516. Stellaria media. petals shorter than the calyx, the peduncle elongating in fruit. Europe; very common. Blooms in cold weather.

\section{Cerástium. Mouse-ear Chick weed.}

Differs from Stellaria chiefly in having 5 styles and pod splitting into twice as many valves. The two following gray herbs grow in lawns. From Europe.

C. viscòsum, Linn. Annual, about 6 in. high: leaves ovate to spatulate: flowers small, in close clusters, the petals shorter than the calyx, and the pedicels not longer than the acute sepals.

C. vulgàtum, Linn. Perennial and larger, elammy-hairy: leaves oblong: pedicels longer than the obtuse sepals, the flowers larger.

\section{RANUNCUlĀCEA. Crowfoot or Buttercup Family.}

Mostly herbs, with various habits and foliage: parts of the flower typically all present, free and distinct, but there are some apetalous and diccious species: stamens many; pistils many or few, in the former case becoming aehenes and in the latter usually becoming follicles. Upwards of 30 genera and 1,000-1,200 speeies. Characteristic plants are buttereup, anemone, meadow-rue, marsh-marigold or cowslip, adonis, elematis, larkspur, aconite, columbine, baneberry, peony. Known from Rosacex by the hypogynous flowers.

A. Plants not climbing: herbs.

в. Fruits achenes, several or many from each flower. 
c. True petals none, but the sepals petal-like (and involucre often simulating a calyx).

D. Flowers in small umbels, or peduncles 1-fld.

E. Involucre of 2 or more lvs. some distance below the flower................... Anemone

EE. Involucre of 3 sepal-like leaves close to the flower 2. Hepatica

EEE. Involucre of 3 compound lvs., sessile at base of umbel: pistils fewer than in Anemone..... 3. Anemonella

DD. Flowers in panicles or corymbs........... 4. Thalictrum

cc. True petals present: yellow............... 5. Ranunculus Bв. Fruits, follicles.

c. Flowers regular.

D. Petals each spurred................... 6. Aquilegia

DD. Petals none: sepals petal-like, yellow......... 7. Caltha

DDD. Petals many: fls. very large and of shades of red: plant bushy...................... 8. Pronia

cc. Flowers irregular; upper sepal spurred; 2 petals spurred........................... 9. Delphinium BвB. Fruits, berries, red or white.

c. Flowers with petals and 3-5 petal-like sepals: fls. small, white, in a short raceme.............. Actxa

AA. Plants climbing by the leaf-stalks: stem woody.......11. Clematis

1. ANEMÒnE. ANemony. Windflower.

Low perennial herbs with mostly showy apetalous flowers and an involucre of 2 or more mostly divided leaves standing some distance below the flower: pistils ripening into a head of achenes.

\section{a. Achenes woolly or silky.}

A. japónica, Sieb. \& Zucc. Japanese anemony. Three ft., blooming in fall, with pink or white flowers $2-3$ in. across: leaves with 3 cordate-ovate notched leaflets. Much planted.

A. virginiàna, Linn. Two $\mathrm{ft}$., with involucre of three 3-parted leaves: flowers on long stalks arising in succession from succeeding nodes: sepals 5 , acute, greenish white: head of fruit oblong, $1 / 2 \mathrm{in}$. long. Woods.

aa. Achenes not woolly or silky.

A. quinquefölia, Linn. (A. nemorosa of some). Common windflower. Low, about 6 in., blooming in rich woods in early spring: involucral leaves 3 , each with 3 or 5 long leaflets: flowers white, purplish outside, pretty.

2. hepática. Liverleaf. Mayflower of some places.

Differs from Anemone chiefly in having 3 simple sepal-like bracts beneath the flower (but they are sometimes a half-inch removed from it): flowers in earliest spring, white, blush, or blue, on simple hairy scapes: leaves broad, 3 -lobed. Woods.

H. tríloba, Chaix. Leaves with rounded lobes.

H. acutíloba, DC. Leaves with acute lobes. 


\section{3. anemonélla. Rue Anemone.}

Attractive slender perennial herb, resembling Anemone: basal leaves 2 or 3 times compound: involucre of 3 compound leaves at base of the umbel: leaflets petioled: flowers in a terminal umbel, on slender pedicels; petals wanting; sepals $5-10$, white or pinkish, $1 \mathrm{in}$. broad, petal-like; pistils 4-15; stigma broad, sessile on carpels, glabrous and deeply grooved.

A. thalictroides, Spach. Rue anemone. Stem slender, 6-10 in., appearing in earliest spring before the $2-3$ ternately compound basal leaves, rising from a cluster of tuberous roots: sepals 5-10, bright, quite lasting. A comnon spring flower of the woodland, appearing with the Wood Anemone or Windflower and easily confused with it.

\section{THalíctrum. Meadow RUe.}

Mostly smooth perennial herbs, erect, sometimes several feet high: panieled flowers small, greenish and inconspicuous, often dicecious, or polygamous: foliage light, graeeful, the alternate leaves being 2-4 ternately compound, with the leaflets and divisions stalked: calyx of 4-5 petal-like greenish sepals, soon falling; stamens many; ovaries 4-15, 1-seeded.

T. dioicum, Linn. Early meadow rue. Flowers diœeious, green or purplish, in loose panicles: leaflets thin and delicate, 3-7-lobed, pale beneath, somewhat drooping on the petiolules: anthers yellow, drooping on threadlike filaments: achenes about 8 , sessile or nearly so: 1-2 ft. high. Common in woodlands. April and May.

T. polýgamum, Muhl. Tall meadow rue. Coarser, ranker and later than $T$. dioicum, 4- $8 \mathrm{ft}$. high: filaments of stamens broad, spatulate: achenes stalked: flowers polygamous, sepals white.

T. dasycárpum, Fisch. \& Lall. Purplish meadow rue. Stem 2-5 ft. high, usually purplish: stem-leaves almost sessile: leaflets thick, dark green above, pale and waxy or downy beneath, margins slightly rolled or thickened: flowers polygamous or dicecious, greenish and purplish: anthers drooping on filiform filaments. June to August.

5. Ranúnculus. Crowfoot. Buttercup. Figs. 202, 203, 207, 268.

Perennials or annuals, with mostly yellow flowers; sepals 5 ; petals 5 and bearing a little pit or scale at the base inside: leaves alternate: aehenes many in a head.

R. àcris, Linn. Tall buttercup. Two to $3 \mathrm{ft}$., from a fibrous root: leaves 3-parted, all the divisions sessile and again 3-cleft: flowers bright yellow. Europe, but now a common weed. Summer.

R. bulbòsus, Linn. Earlier and only half as tall, from a bulbous base: leaves 3-parted, the lateral divisions sessile and the terninal one stalked: peduncles furrowed: flowers bright yellow. Europe; common eastward.

R. septentrionàlis, Poir. Stems more or less prostrate at base, often forming long runners: leaves 3-divided, divisions all stalked and 3-lobed or -parted: petals obovate, yellow. Wet places.

R. abortivus, Linn. Glabrous, biennial herb; 6 in. to $2 \mathrm{ft}$., hranehing: basal leaves heart-shaped or kidney-form, erenate (sometimes lobed), on 
long stalks: later leaves, often 3-5-lobed or -parted, and sessile or nearly so: petals small, yellow, not equal to the sepals: styles very short, curved. Shady woods and along stream-sides. April to June.

R. micránthus, Nutt. Pubescent, smaller than preceding and basal leaves ovate, but not heart-shaped, some 3-parted: fairly common.

R. recurvàtus, Poir. Usually pubescent, erect, branching, 1-2 ft.: leaves all petioled and similarly 3-parted: sepals longer than the pale yellow petals and recurved: beaks of achenes strongly hooked. Common. Spring.

\section{Aquilègia. Columbine.}

Upright herbs, with compound leaves which have petioles expanded at the base: sepals 5 , somewhat petal-like; petals 5 , each one produced into a long nectary spur; pistils 5 : fruit a several-seeded follicle. Delphinium

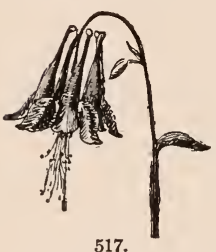

517. or larkspur is an allied genus.

\section{a. Spurs straight.}

A. canadénsis, Linn. Common wild columbine. Often incorrectly called honeysuckle. Fig. 517. About $2 \mathrm{ft}$.: leaflets rounded or obovate, toothed at top: flowers about $2 \mathrm{in}$. long, drooping, scarlet and orange or nearly yellow, the stamens projecting. Common on rocks.

A. chrysantha, Gray. Yellow columbine. Flowers bright yellow, often tinged, erect or becoming so. New Aquilegia canadensis. Mexico and Arizona, but frequent in gardens.

aa. Spurs hooked at the end.

A. vulgàris, Linn. Blue columbine. A European species, common in gardens, and often full double: flowers varying from blue and purple to white, with rather short and thick hooked spurs.

\section{Cáltha. Marsh Marigold. Cowslip (in America)}

Low tufted herbs with undivided leaves, and clusters of yellow buttercup-like flowers: sepals 5-9, petal-like; petals none; pistils 5-10, ripening into several-seeded follicles.

C. palústris, Linn. About $1 \mathrm{ft}$. high: leaves rounded or kidney-shaped, crenate or nearly entire. Wet places, in early spring. Used for "greens."

\section{Pæònia. Peony. Piney.}

Stems shrubby and perennial or, as in the commoner garden forms, herbaceous, from thick, fleshy roots: leaves ternately and pinnately compound: flowers large, terminal, solitary; sepals 5 , unequal, leafy, persistent; petals 5 to indefinite in number; ovaries $3-5$, surrounded by a disk: fruit, manyseeded follicles. Oriental.

P. officinàlis, Linn. Common garden peony. Large flowers, double, red, pink, flesh-colored to white; carpels 2, pubescent, forming 2 erect, many-seeded follicles. June. 


\section{DELPhíNiUm. Larkspur. Figs. 224, 225, 269, 270.}

Stems erect, simple or branching, with alternate leaves, petioled, palmately-divided or -lobed: flowers in a terminal raceme or paniele, white, blue, purple and showy, with irregular sepals and petals; sepals 5 , colored, the upper spurred behind; petals 4 (rarely 2), the upper pair spurred, and inclosed in the spur of the sepal; carpels 1-5, sessile, forming many-secded follicles. Several wild and cultivated species.

D. Ajàcis, Linn. Annual, 1-2 ft.: flowers purple, roseate or whitc, sometimes double, many in crowded racemes; pistil 1: follicle pubescent, with short, stout beak. Cultivated and a showy garden plant; sometimes escaped from gardens.

D. tricórne, Michx. Perennial, 6 in. to 1 or $2 \mathrm{ft}$.: flowers blue or white, in few-flowered racemes (6-12): leaves 5-parted, the divisions 3-5-cleft: pistils 3: follicles widely diverging, short-beaked. In rich soil, west of Alleghanies. April to June.

\section{ACT ÆेA. BANEBERRY.}

Ereet, perennial plants, in rich woods, 2-3 ft., with conspicuous red or white berries: stems mostly simple, bearing large, ternately compound leaves, the leaflets ovate but sharply cut-lobed or toothed: flowers small, white, in thick terminal racemes; sepals $3-5$, soon falling; petals $4-10$, longclawed, flat, spatulate; stamens many, filaments white and slender; ovary 1 , with a broad, sessile, 2-lobed stigma, many-ovuled.

A. álba, Mill. White baneberry. Raceme oblong: petals truncate, pedicels thickened, and usually red: berries white, ellipsoid. Common in woods. April to June.

A. rùbra, Willd. Red baneberry. Raceme ovate or hemispherical; petals acute; pedicels slender: berries cherry-red (sometimes white), oval or ellipsoid. Common in woods, especially northward. In bloom, April, May.

\section{CLÉMATIS. Virgin's Bower. Figs. 77, 178.}

Herbs, or somewhat woody, generally climbing by clasping petioles: leaves opposite, simple or compound: flowers apetalous, or petals very small; sepals 4 (rarely more) and colored; stamens many, a number of them (sometimes all) usually sterile; pistils many in a head, bearing the persistent, plumose or silky styles. Many large-flowered cultivated forms.

C. verticillàris, DC. A woody climber, nearly smooth: leaves in whorls of 4's, each 3-foliate: large, purple flowers 2-3 in. across, at each node. Not common, belonging mainly to the North and to mountainous districts. May, June

C. Viórna, Linn. Leaves mostly pinnately compound, with 3-7 leaflets, entire, or 3-lobed: flowers solitary and usually nodding on long peduneles, bell-shaped, having peculiarly thick sepals, with their points recurved; purplish-red color: the long akenes plumose. Climbing. Peonsylvania, west. May to August.

C. virginiàna, Linn. Common virgin's bower. Old-man vine (from 
the heads of hairy styles). A common climbing plant, along fences, streams and in low woodlands: leaves compound, glabrous, with 3 leaflets cut or lobed and nearly heart-shaped at base: flowers small, in leafy panicles, polygamo-diceious; petals none, but sepals whitish, thın, spreading: styles long-plumed in fruit, making a feathery cluster. July, August.

\section{BERBERIDĀCEÆ. BARBERry Family.}

Herbs and shrubs with alternate or radical leaves, sometimes with stipules: flowers regular, perfect (except 1 genus), hypogynous, solitary or racemed; sepals and petals usually in several rows of 3 each, and calyx colored; stamens as many as petals (rarely more) and one opposite to each petal: anthers opening at the top by 2 valves or lids (except in Podophyllum): pistil 1: fruit a berry or pod. About 20 genera and 100 species.

A. Shrubs: flowers yellow: berries red or orange, remaining

on branches into the winter...................... Berberis

AA. Herbs.

B. Flowers on leafless scapes: leaves radical, each 2parted: fruit a pod, opening at the top by a lid.....2. Jeffersonia

вв. Flower on short pedicel, in fork between 2 large

leaves: fruit a large, oval, edible berry............ Podophyllum

\section{BÉRBERIS. BARBERRY. Figs. 168, 221.}

Shrubs, often spiny: flowers yellow, in drooping racemes; sepals 6-9, colored, bracted; petals 6 , each with 2 basal glandular spots; stamens 6 , irritable, bending inward when touched; pistil 1; stigma circular, sessile: berries sour, 1-few-seeded: leaves simple or compound, bases dilated and jointed on short petioles, usually spiny-toothed, sometimes reduced to eleft spines.

B. vulgàris, Linn. Common barberry. Leaves with repandly-toothed margins, teeth spinous-pointed or represented by branched (3-pronged) spines: berries oblong, scarlet, acid. Europe; but cultivated and naturalized in eastern and middle states.

B. canadénsis, Mill. Shrub 1-3 ft., native to southern mountains, with oval berries and few-flowered racemes.

B. Thúnbergii, DC. Cultivated, low shrub with small entire leaves and handsome horizontal sprays: flowers solitary or in pairs, on slender pedicels, from leaf-axils: berries bright red, remaining on the twigs into the winter: leaves $1 / 2^{-1} \mathrm{in}$. long, also red in fall. Japan.

\section{JeFFERSÒnIA. Twin-Leaf. Rheumatism Root.}

Perennial glabrous herb, from roots of matted, blackish fibers, with ample 2-parted leaves, rising on long petioles from the roots: scape bearing 1 terminal large white flower; sepals 4 , soon falling; petals usually 8 , oblong; 
stamens 8 , with linear anthers on slim filaments; stigma peltate, with many ovules on lateral placentæ: pod green, leathery, becoming pear-shaped and dehisees by a lid, opening half-way round the upper part, from which the many, rounded seeds, arilled on one side, spill forth.

J. diphýlla, Pers. Seape erect to 8 or 12 in.: leaves divided longitudinally into 2 parts, with usually entire margins. Very interesting little plant in rich woods, spring: sometimes cultivated.

\section{3. podophyllum. May Apple. Mandrake.}

Smooth perennials from ereeping horizontal rootstoeks, and thick, fibrous roots: stems smooth, simple, carrying large, peltate, glossy-green leaves and a solitary white flower: sepals 6 , petal-like, soon falling; petals 6-9, eoneave, broad and large; stamens as many or twice as many as petals; pistil 1, with sessite, large, thick, stigma: fruit a large, fleshy, oval, 1-celled berry, filled by many seeds, each seed inclosed in a pulpy aril, edible.

P. peltàtum, Linn. Leaves 2, large, orbicular, peltate, deeply 5-9-lobed and few-toothed: flowers fragrant, solitary from the eommon axil of the 2 stem leaves, borne on a short, recurved peduncle: petals, large, white, waxlike: common in rich, shady, woodland, often in large patches. May, June.

\section{NYMPHÆĀCEÆ. WATER-LILY FAMILY.}

Aquatic, perennial herbs, with very large rootstocks under water: leaves large, peltate or heart-shaped, often floating: flowers solitary, on axillary peduncles; sepals $3-5$ or 6 ; petals 5 to many; stamens 5 to many, with large, erect anthers; carpels 3 to many, distinct, or united in a circle or with the reeptacle: fruit indehiseent, or group of distinet carpels. Eight gencra, of wide distribution in fresh water. The great Victoria Regia of the Amazon, and of ten cultivated, belongs here.

A. Flowers white: sepals $4 \ldots \ldots \ldots \ldots \ldots \ldots \ldots \ldots \ldots$. Castalia AA. Flowers yellow: sepals 5 or more.................. Nymphxa

\section{CASTÀlia. Water-LiLy.}

Herbs with floating leaves and beautiful, large, many-petaled flowers: sepals 4, white, green without; petals large, wax-like, gradually becoming smaller, and passing into the yellow stamens which are adherent to the many-celled ovary; stigmas radiate (as in a poppy head) from a eenter: fruit ripens under water.

C. odoràta, Woodville \& Wood. White water-lily. Flower 2-6 in. aeross, very sweet-scented: petals oftenest white, sometimes tinged with pinkish. Common.

\section{NYMPH ȦA. YELLOW POND-LILY.}

Distinguished from the water-lily by the leaves, which are more or less heart-shaped, floating or erect: also by the flowers, which are $2-3$ in. in 
diameter, with small, linear, yellow or purplish petals, becoming stamen-like toward center: fruit ripens above water. The name Nymphæa is sometimes applied to the genus Castalia.

N. ádvena, Ait. Spatterdock. Leaves oval, thick, 6 in. to $1 \mathrm{ft}$. long, floating or erect: flowers yellow, sepals 6 or more, not equal; petals thick, truncate, resembling stamens.

\section{PAPAVERÃCEA. PoPPY FAMILY.}

Herbs with milky or colored juice (acrid and narcotic), alternate or radical exstipulate leaves, the upper rarely opposite: flowers mostly single, regular or irregular, perfect; sepals 2 (rarely 3 or 4), falling as the flower opens; petals 4-6 (or more), imbricated, often crumpled in the bud, and early falling; stamens usually many; ovary 1- to manyovuled, 1-celled: fruit a dry pod or capsule, 1-celled or, in Poppy, imperfectly many-celled, generally dehiscing by a pore or by valves. Small family of mostly small but usually showy herbs.

A. Plants with white (milky) juice................ Papaver

AA. Plants with colorless juice (watery) .............. Eschscholtzia AAA. Plants with red or orange juice.

в. Flower-bud erect: flowers white, in earliest spring....3. Sanguinaria вв. Flower-buds generally nodding; flowers yellow.

c. Stigma 3-4-lobed, on a short style. Capsule ovoid.4. Stylophorum cc. Stigma 2-lobed, about sessile: capsule long.......5. Chelidonium

\section{PAPÀVER. Poppy.}

Herbs with white juice: stems smooth or hairy, erect, and the terminal buds nodding, but erect in flower and fruit: sepals 2 (or 3 ) soon falling; petals 4-6; sessile stigmas united to form a rayed disk.

P. somniferum, Linn. Opium poppy. Annual, erect to $1 \frac{1}{2}-2 \mathrm{ft}$., branching, glaucous, with large, white or purplish-centered flowers on long peduncles: leaves sessile, clasping, variously incised: capsule smooth. Cultivated for opium and for ornament.

P. Rhœ̀as, Linn. Corn poppy. Shirley poppy. Annual, bristly, hairy, the leaves deeply lobed: flowers mostly red or scarlet with a dark center, varying in cultivation: pod small.

P. orientàle, Linn. Stem rough-hairy, 1-flowered: flowers very large, brilliant, scarlet: leaves scabrous, deep green, about pinnate. A favorite perennial in gardens.

P. nudicaùle, Linn. Iceland poppy. Rather delicate, hairy, with leaves radical, pale green, and pinnately incised: flowers single, on slender, hairy scapes, orange or white. Gardens.

\section{ESCHSCHÓLTZIA.}

Annual or perennial herbs: leaves glaucous, finely pinnatifid: sepals 2, cohering as a pointed cap, falling as flower opens; petals 4 , yellow or orange 
or eream-colored; stamens many, adherent to petals; stigmas 2-6, sessile: pods long, eylindrie, grooved, many-seeded.

E. califórnica, Cham. California poppy. Cultivated in flower-gardens: stem branehing, leafy: flowers showy and large, reeeptaele funnelform, with a broadly dilated rim: pod long and slender. California.

\section{SANGUIN ÀRIA. BLOONROOT.}

Low, acauleseent perennial, from thick, horizontal, pointed and searred rootstocks, with juice red and aerid: in very early spring a naked seape, earrying 1 terminal white flower, enfolded at first by long-petioled kidneyshaped or cordate, glaucous, palmately veined leaf; sepals 2 , soon falling; petals 8-12, unequal, in 2 rows, not lasting; stamens many: fruit a capsule, oblong, swollen, 1-eelled, many-seeded, 2-valved, dehiscent at base.

S. canadénsis. Linn. Flower large, white, fragile, on a seape about 6 in. tall: glabrous and glaueous: leaves with rounded lobes and sinuses. Common in rich, open woods and on sunny banks; early spring.

\section{Stylóphorum. Celandine Poppy.}

Hairy herbs with yellow juice, and pinnately divided leaves: flowers large, yellow: style 1: stigma 3-4-lobed.

S. diphýllum, Nutt. Low perennial, usually with two opposite, pinnately parted leaves on the stem; leaves often marked with white, 5-7-lobed: flowers few, in umbels, large, $1 \frac{1}{2}-2$ in. aeross, elear yellow. Frequent in rieh woods in eentral states. May.

\section{Chelidònium. Celandine.}

Rather weak, branehing herbs; perennial: leaves alternate, pinnatifid: juice deep yellow: flowers yellow, small, the bud nodding; sepals 2; petals 4 ; stamens many.

C. màjus, Linn. Along roadsides, about fenees, as a weed, growing 1-4 ft. high: leaves thin, onee or twice pinnatifid: flowers in loose umbels, soon perishing, about $1 / 2-3 / 4$ in. in diameter.

\section{FUMARIĀCEA.}

Smooth, succulent herbs with noticeably delicate, finely dissected, or lace-like leaves, alternate or radieal, exstipulate: flowers small, irregular, raeemose; 2 very small sepals, scale-like; petals 4 , small, partially united: 6 diadelphous stamens ( 2 sets of 3 each); ovaries 1-celled: fruit a pod, 1-eelled, 1-seeded and indehiscent, or severalseeded with 2 parietal placentx.

A. Corolla 2-spurred at base, or heart-shaped: fls. pendent...1. Dicentra A. Corolla with 1 spur at base.

B. Pod slender, several-seeded: seeds arilled, or erested....2. Corydalis

вв. Pod globular, 1-seeded, indehiseent................ Fumaria 


\section{DICÉNTRA.}

Low, acaulescent perennials, among the earliest and most delicate of spring flowers: leaves compound in 3's, finely dissected (lace-like), on tender pinkish petioles from the roots: the racemose, nodding flowers borne on leafless, flesh-colored scapes; pedicels 2-bracted; corolla peculiarly irregular-4 petals in 2 pairs, the 2 outer spurred at base, somewhat united to form a 2-spurred corolla, the inner pair of petals spoon-shaped, crested, meeting over the pistil and stamens; stamens 6 , in two sets, opposite the outer petals.

D. Cucullària, Bernh. Dutchman's breeches. Leaves from a cluster of little pinkish tubers, forming a bulb: flowers with straight spurs, longer than pedicel, and diverging, mostly creamy with yellow tips to petals, not fragrant.

D. canadénsis, Walp. Squirrel corn. Similar to the preceding, hut leaves usually glaucous: root-tubers yellow, resembling grains of Indian corn: flowers differing in shape from $D$. Cucullaria in being more elongated, spurs short and rounded, and the erests of the inner 2 petals prominent: fragrant. Blooms a little later than preceding, but found in same situations.

D. spectábilis, DC. Bleeding-heart. A smooth, leafy-stemmed plant of many gardens; stems much branching; leaves large, twice ternately compound: flowers many and showy in long racemes drooping from the curving stems, heart-shaped, bright rose or pink; no sepals when in full flower. Siberia.

\section{CORYDALIS.}

Biennial or perennial herbs with leafy stems, pale or glaucous: leaves much divided or decompound: flowers small, in racemes; corolla 4-petaled, irregular; one of the outer pair of petals spurred at the base, all erect and somewhat united.

C. sempérvirens, Pers. Stem slender, erect, 6 in. to $2 \mathrm{ft}$.: leaves small, sessile above, all finely dissected: flowers horizontal in terminal racemes; spurs short and blunt; corolla rosy, yellow-tipped; outer petals sharp-pointed: pods erect, slender. May to June.

C. a ùrea, Willd. Low, diffuse or spreading: flowers yellow, $1 / 2$ in. long; outer petals keeled, not crested; spur shorter than pedicel ( $1 / 4 \mathrm{in}$.), decurved: pods hanging or spreading, knotty. March to May.

\section{FUMÀria. FUMitory.}

Annuals, branched and leafy-stemmed: leaves compound, finely dissected: flowers small, in dense racemes or spikes; petals 4, unequal, 1-spurred at base; stamens 6, diadelphous: fruit small, globular, 1-seeded, indehiscent, the style falling.

F. officinàlis, Linn. Low, much branched, erect to $1 \mathrm{ft}$., glabrous: flowers purple-tipped, pinkish, minute, in loose spikes; sepals acute, sharply toothed, shorter than corolla. Waste places. Summer. Introduced. 


\section{CRUCÍfERA. Mustard Family.}

Herbs, mostly of small stature, with alternate mostly simple leaves: flowers 4-merous as to envelopes, the 4 petals usually standing 90 degrees apart and thereby forming a eross (whence the name Crueiferæ, or "cross-bearing"); stamens usually 6,2 of them shorter: fruit a silique or silicle. A very natural or well-marked family, with about 180 genera and nearly 2,000 species. Familiar plants are mustard, shepherd's purse, honesty, eress, pepper-grass, wallflower, stock, cabbage, turnip, radish, horse-radish.

A. Fruit a silique (mueh longer than broad).

B. Silique tipped with a long point or beak, extending

beyond the valves, the latter more than 1-nerved.. 1. Brassisa

Bв. Silique not prominently beaked beyond the valves.

c. Flowers yellow ...................... 2. Barbarea

cc. Flowers white or purple.

D. Valves with a midrib, or seeds in 2 rows.

E. Stigma deeply 2-lobed: flowers large........ 3. Matthiola

EE. Stigma but slightly, if at all 2-lobed........ 4. Arabis

DD. Valves without midrib.

E. Seeds in 1 row.

F. Stems leafless below, with 2 or 3 leaves near middle: rootstock sealy........... 5. Dentaria

FF. Stems leafy: roots more fibrous ......... 6. Cardamine

EE. Seeds in 2 rows in each eell. (Water plants.

See Radicula.)

AA. Fruit a silicle (short and broad).

в. Partition in the pod parallel to the sides.

c. Fruit not mueh compressed: seeds minute, in 2 rows in each cell.................... 7. Radicula

cc. Fruit quite flattened, 2-8-seeded............ . Alyssum

BB. Partition erosswise the pod.

c. Pod obeordate, many-seeded ................ 9. Capsella

cc. Pod orbicular, 2-seeded: corolla regular.........10. Le pidium

ccc. Pod rounded or ovate: eorolla irregular with unequal petals.......................... Iberis

AAA. Fruit fleshy, indehiseent, constrieted between the

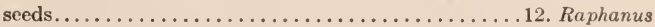

\section{BRÁSSICA. Mustard.}

Ereet branchy herbs, mostly annual, with more or less lyrate lower leaves, and small yellow flowers in racemes or panieles: petals elawed or narrowed below, the limbs spreading horizontally: silique narrow, eylindrieal or 4-angled, the valves 1-5-nerved and the seeds in 1 row in each locule. Cabbage, eauliflower, and turnip also belong to this genus. The three following are eommon weeds introduced from Europe: 
B. nìgra, Koch. Black mustard. Fig. 518. Leaves pinnatifid, somewhat hairy: pod short, strongly 4-angled, not hairy. Mustard (flour) comes largely from this species.

B. álba, Boiss. White mustard. Leaves pinnatifid, and rough-hairy: pods rather slender, hairy, but only the lower part seed-bearing.

B. arvénsis. Kuntze. Charlock. Leaves strongly toothed: pod knotty, hairy or smooth, the upper third indehiscent and 2edged. Fig. 413.

\section{Barbarea. Winter Cress.}

Low herbs, blooming in early spring, with many small light yellow flowers, and lyrate leaves with the terminal division much the largest: pod cylindrical or somewhat 4-angled, the valves having a strong midvein: seeds a single row.

B. vulgàris, R. Br. Common winter cress. Yellow rockct. Biennial, about $1 \mathrm{ft}$. high, with smooth foliage and flowers in elongating clusters: lower leaves lyrate, upper ones cut or merely toothed. Low grounds.

518.

Brassica nigra.

3. Matthìla. Stock. Gilliflower.

Cultivated garden or house plants from Europe: stems and leaves hoary-pubescent: flowers showy, single or double, of many colors, fragrant, in terminal racemes; stigma deeply 2-lobed: silique nearly cylindrical, with prominent midrib on each of the 2 valves; seeds winged.

M. incàna, R. Br. Biennial or perennial with stout, rather woody stem: leaves lanceolate, entire: flowers white, varied shades of red, purple, etc. Much grown in gardens and greenhouses.

\section{4. Árabis. Rock Cress.}

Mostly very small herbs with purple or white flowers: stems leafy: radical leaves spatulate, the stem-leaves sessile: siliques very narrow, elongated, flat, the valves smooth, keeled or one-nerved in the middle, or veined lengthwise; seeds in 1 or 2 rows in each cell, flattened, usually margined or winged.

A. canadénsis, Linn. Sickle-pod. Biennial with stems erect, 1-3 ft.: leaves lanceolate, pointed at both ends, simple, toothed or entire, sessile, pubescent: flowers small, white, petals twice as long as sepals: pods long, flat, sickle-shaped, pendent on hairy pedicels; seeds broadly winged. Common in woods and rocky ravines.

A. glàbra, Bernh. Biennial tall, 2-4 ft., glaucous above, but pubescent at base, with many stem-leaves, ovate-lanceolate, sessile, sagittate-clasping at base; petals yellowish white, scarcely longer than the calyx: pods narrow, erect: seeds in 2 rows, marginless. Fields and rocky places.

\section{DENTÀRIA. TOOTHWORT.}

Low herbs, perennial, found in damp woodland, blooming with the early spring flowers, bearing flowers in corymbs, white, roseate or purplish, larger than the similar flowers of Cardamine: rootstocks long, horizontal, 
scaly or toothed, aromatic or with cress-like taste: stems erect, unbrancherl, leafless below, with 2 or 3 palmately divided or compound leaves on petioles; near the middle: fruit a linear silique, flattened, valves not nerved, with 1 row of seeds in each cell; seeds not winged.

D. diphýlla, Michx. Crinkle-root. Pepper-root. Stem erect, from a toothed rootstuck: leaves usually 2: leaflets 3-parted, wide-ovate, with margins dentate: flowers white.

D. laciniàta, Muhl. Fig. 266. Rootstóck deep, short, tuberous, constricted in several places (necklace-like): stem-leaves 3, nearly verticillate, deeply 3-parted into lanceolate, linear or oblong leaflets, which are lobed or toothed, and some 2-cleft: flowers white or pinkish, smaller than preceding.

\section{CARDAMìne. Bitter-Cress.}

Very similar to Dentaria, the chief difference being in the stem, which is leafy, and the leaves simple, usually more or less lobed, alternate on stem. Glabrous perennials, growing in wet places and along waterways, from fibrous roots or tubers (not sealy rootstocks), the flowers white or purple in terminal racemes.

C. bulbòsa, BSP. Stem simple, erect, 9-18 in., from a tuber: leaves simple, petioled below, ovate or rhombic-oblong in shape: petals white, small, mueh longer than calyx. A variety purpurea, not so tall (4-6 in.), with rose-colored flowers, appears even earlier than the type.

\section{Radícula. Water-Cress. Horse-radish.}

Low, mostly aquatic or marsh plants, with pinnate or pinnatifid leaves (sometimes simple); flowers small, white or yellow, with spreading sepals; stamens 1-6: fruits various, short and broad (silicle) or short-cylindrical: valves convex, nerveless or 1-nerved. Formerly called Nasturtium.

R. Nastúrtium-aquáticum, Britten \& Rendle. Water-cress. Glabrous, growing in or about water: stems spreading, rooting at the nodes: leaves pinnately lobed, with 3-11 lobes, the terminal segment largest: flowers small in racemes, which elongate as the fruits mature: petals white and twice as long as the sepals. A favorite plant for saladis.

R. palústris, Moench. Marsh-cress. Annual or biennial, with simple, fibrous roots: stem erect, 1-2 ft., glabrous or slightly pubescent: pinnately lobed leaves, the upper sessile: flowers small, yellow: pods oblong or ovoid, turgid, little if any longer than the pedicels. Weed in marshy places.

R. Armoràcia, Robinson. Horse-radish. Cultivated, but sometimes eseaped into waste grounds: perennial, the roots long and thick: root-leaves large, coarse, glabrous, oblong, crenate, rarely pinnatifid, on thick petioles, the stem leaves sessile, lanceolate: flowers small, petals white, longer than calyx.

\section{ALYSSUM. AlYssum.}

Small plants, mostly trailing, with entire and small leaves: pod small, orbicular, 1 or 2 seeds in each locule: flowers in elongating racemes. 
A. maritimum, Linn. Sweet alyssum of the gardens (from Europe). Fig. 519. Annual, producing a profusion of small white, fragrant flowers. There are many cultivated forms.

9. Capsélla. Shepherd's PUrse.

Low short-lived annuals, with very small white flowers in racemes:

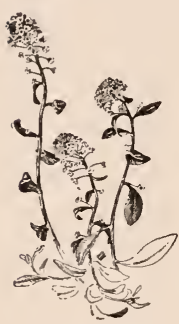
pod obcordate or inversely triangular, the partition running across the narrow diameter, containing several seeds.

C. Búrsa-pastòris, Medic. Common shepherd's purse. Fig. 286. One of the commonest little weeds: root-leaves pinnatifid or strong-toothed, in a rosette, the stem-leaves arrow-shaped. Europe.

\section{LEPÍdiUM. Pepper-grass.}

Small stiffish annuals (or biennials), which shed their leaves late in the season: flowers very small, white or greenish, in elongating racemes: pod small and roundish, the partition running across the narrow diameter. Plant peppery to the taste.

519. Alyssum maritimum.

L. virgínicum, Linn. Common pepper-grass. About $1 \mathrm{ft}$. high, much branched, glabrous: leaves linear to lanceolate, tapering to the base, the lower mostly pinnatifid. Common weed; often fed to canary birds.

\section{IBÊRIS. CANDYTUFt. Fig. 192.}

Herbs with white, or purple flowers in flat or elongated clusters; 2 outer petals larger than 2 inner: silicles flattened, truncate, cells 1 -seeded. Cultivated.

I. umbellàta, Linn. Annual, $1 \mathrm{ft}$. or more: lower leaves lanceolate, the upper linear and entire: flowers mostly purple or lilac in flat clusters: silicles acutely 2-lobed. June and July.

I. a màra, Linn. Annual: leaves lanceolate, toothed toward apex: flowers white. The common white-flowered candytuft, in many forms (including the garden $I$. coronaria).

\section{RÁPHANUS. RADISH.}

Annual or biennial herbs, with lyrate, pinnately-lobed root-leaves: flowers rather showy in long racemes; calyx erect; petals clawed; style long and slender: pod linear, indehiscent, constricted between the seeds, pithy; seeds spherical. Europe.

R. Raphanistrum, Linn. White charlock. A weed, common in the East: tap-root slender: petals yellow, fading to white or purplish: pod 4- to 10-seeded, long-beaked, constricted between seeds when dry.

R. sativus, Linn. Garden radish. Flowers pink or white: root fleshy, spindle- or turnip-shaped, red or white: silique 2-3-seeded, short and pointed, with fleshy partitions between seeds: seeds round and blackish. 


\section{ViOlĀCEAE. Violet Family.}

Ours herbs with or without stems, and simple, entire or cleft leaves, radical or alternate, with stipules: flowers showy, irregular, solitary on peduneles; sepals persistent; petals unequal, the lower one larger or spurred at base; stamens with filaments short, broad, continued beyond the anthers, usually coherent, joining over and around the pistil; ovary simple, 1-celled, 3 parietal placentæ: fruit a 3-valved capsule, loculicidal, and, after dehiscence, edges strongly inrolled in drying, thus dispersing the seeds. One genus is well known.

víola. Violets. Heart's-ease. Johnny-Jump-up. Fig. 236.

Early flowers conspicuous and petaliferous, but frequently sterile; sometimes later flowers eleistogamous, concealed under the leaves, apetalous and self-fertilized, usually developing seeds; sepals eared at base; petals unequal, the lower spurred or saceate at base; stamens 5, 2 with spurs which project into the corolla spur.

a. Stemless: leaves basal: flowers on peduncles from rootstocks.

b. Flowers blue or violet: side petals beardless.

V. pedàta, Linn. Bird's-foot violet. Not stoloniferons, rootstock short, stout, nearly smooth: leaves orbicular in outline, but palmately 3- or 5-11lobed or divided, segments linear not lanceolate: flowers large, 1 in. broad, pale violet or deep purple (varying to white); stigma large, not beaked. Sandy soil. Var. bicolor has 2 upper petals deep velvety violet, 3 lower pale blue.

bb. Flowers blue or violet: side petals bearded.

V. palmàta, Linn. Common, or early blue violet. Pubescent to nearly glabrous: rootstock stout and scaly: early leaves rounded, cordate or kidneyshaped, margin crenate, the later leaves various, palmately or pedately lobed or parted, on long stalks: flowers deep or pale bluc; spur short, saccate; stigma beaked.

V. cucullàta, Ait. Common blue violet. A common form, variable and grading into $V$. palmata: leaves not lobed or toothed at base, merely erenate or dentate, kidney-form to broadly ovate: nearly or quite glabrous.

V. sagittàta, Ait. Leaves sagittatc-lanceolate, or often cordate, toothed near base: scapes bearing the flowers shorter than the leaves, 3-5 in.; sometimes all petals bearded; stigma beaked; flowers usually large.

V. odoràta, Linn. Sweet violet. English violet. Hardy, cultivated species from Europe: stoloniferous by creeping runners: leaves downy or glabrous, rounded or heart-shaped or broadly ovate: flowers fragrant, single or double, sometimes white.

\section{bbb. Flowers white.}

V. lanceolàta, Linn. Rootstock smooth, creeping: stoloniferous: leaves lanceolate to linear, erect, the blade decurrent on the long petioles: flower 
small, white, the lower and side petals purplish-veined: petals beardless cleistogamous flowers on erect pedicels, frequently from stolons. Wet places.

V. blánda, Willd. Sweet white violet. Stoloniferous from slender rootstock: flowers fragrant: petals beardless or nearly so, white veined with purple: leaves cordate or rounded: few cleistogamous flowers on curved stalks. Wet places. Plant small.

\section{bbbb. Flowers yellow.}

V. rotundifòlia, Michx. Stoloniferous: leaves rounded to cordate, margin somewhat erenate, finally growing large, glossy and lying flat on the ground: flowers small: lateral petals bearded, and with brown lines; sepals blunt-pointed. Cool woodlands.

aa. Stems evident, leafy: flowers showy on axillary stalks.

b. Flowers blue or violet.

V. rostràta, Pursh. Plant 3-8 in.: leaves rounded heart-shaped, serrate, the upper acuminate: stipules fringe-toothed, lanceolate: flowers pale violet, darker-veined: petals beardless: spur slender, longer than corolla. Moist woodland and shaded hillsides.

V. arenària, DC. Stems weak, 6-8 in., glabrous: leaves heart-shaped or kidney-form, margin crenate: stipules lanceolate, somewhat fringetoothed: spur slender, half as long as corolla. Swamps and wet places. Pale purple. American forms differ from the European.

bb. Flowers white, tinged with pink or violet.

V. canadénsis, Linn. Upright, 6 in. to $2 \mathrm{ft}$.: stems leafy, stipules broadlanceolate, entire: leaves large, heart-shaped, serrate: petals white inside, pinkish or violet beneath, spurred petal yellow at base: lateral petals bearded. Common. Rich woods. All summer.

bbb. Flowers yellow.

V. pubéscens, Ait. Downy yellow violet. Pubescent: stems erect, 5-20 in., leafy: leaves broadly heart-shaped, toothed: stipules large, entire: rootleaves soon wither up: lower petals veined, more or less obscurely, with purple; spur short; stigma beakless: pod downy. Dry woods.

bbbb. Flowers of various colors: cultivated

v. trícolor, Linn. Garden pansy. Stems angular, branching, leafy: leaves roundish to cordate: stipules leaflike, incised: flowers widely varied in colors. Europe. Var. arvensis, in fields, is slender, and petals scarcely exceeding sepals.

\section{HYPERICACEA. St. John's-wort FAMiLY.}

Herbs or shrubs (in our species), with leaves chiefly sessile, simple, opposite, some with translucent or black dots: flowers regular, usually in terminal eymes, and yellow; sepals and petals 4 or 5 ; sta- 
mens few to many, often in clusters of 3 or 5, hypogynous: pod 1- to 7-celled.

HYPERICUM. ST. JoHN's-woRT. Figs. 208, 278.

Mostly branching plants with yellow flowers in cymes: leaves sessile, usually dotted: sepals and petals 5; stamens many, mostly in 3-5 groups.

H. perforàtum, Linn. A common introduced speeies: stems upright, 1-3 ft., branching, 2-edged: leaves linear to oblong, dotted, sessile: flowers about 1 in. in diameter, the petals dotted with black and much exceeding the lanceolate sepals; stamens grouped in 3 sets: capsule 3-cellod. Spreads by running shoots from base.

H. punctàtum, Lam. Much like preceding, but leaves more broadlyoblong, sepals more ovate, and the petals often lined, as well as dotted, with black.

\section{PORTUlaCÃCEÆ. Purslane Family.}

Herbs succulent or fleshy, with entire leaves, alternate or opposite, and dry stipules: flowers regular but not symmetrical; sepals 2; petals $4-5$ or none; stamens equal to number of petals and opposite, or fewer, or more; ovaries free, each 1-celled; style 2-3-eleft, or divided, stigmatic on inner surfaces: fruit a 1-celled pod, opening loculicidally, or a pyxis, opening by a lid; seeds small, kidney-shaped, few or many.

A. Stamens more numerous than petals: flowers opening once

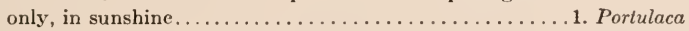
A1. Stamens 5: flowers open for some time............... Claytonia

1. PORtuláca. Purslane. Fig. 280.

Low, fleshy annuals, diffuse or ascending: terminal flowers, which open once only, in sunshine; sepals 2, joined at base and partially adherent to ovary; petals 4-6 on calyx, not lasting; stamens 7 to many, on calyx; style 3-8-parted.

P. oleràcea, Linn. Common purslane. Pusley. A very common weed. Smooth, fleshy, prostrate: stems cylindrieal, reddish: leaves obovate or wedge-form, thick, nearly sessile: flowers small, yellow, sessile, open in morning sunshine. Sometimes used for greens.

P. grandiflòra, Lindl. Rose-moss. Stems ereet, 3-6 in., fleshy, smooth or hairy: leaves alternate, cylindrical, $1 / 2-1$ in. long: flowers open in morning; very gay colors, white, yellow, reds, 1-2 in. wide. South America. Gardens.

\section{Claytònia. Spring Beauty.}

Low, glabrous, perennial herbs, from small tubers: flowers iasting some time; sepals 2; petals 5 , distinct or slightly united; stamens 5,1 on base of each petal; style 3-lobed; ovary 1-celled: capsule 3-valved, few-seeded: 
stem erect, usually bearing 2 leaves and terminating in a raceme. Among the first spring flowers in open woods.

C. virgínica, Linn. Leaves thickish, linear-lanceolate, 3-6 in. long, nearly sessile: stem about 3 in. from tuberous root, bearing 2 (3 or 4 occasionally) leaves: petals white or pink with darker veins, emarginate $1 / 4-3 / 8$ in. long; sepals and petals obtuse.

C. caroliniàna, Michx. Leaves 1-2 in. long, oblong or oval to spatulate, short-petioled: flowers fewer than in preceding, white or pinkish, veined.

\section{MALVĀCEæ. MaLlow Family.}

Herbs or shrubs (trees in the tropics) with alternate, mostly simple leaves which have stipules: flowers perfect and regular, 5-merous, often subtended by a calyx-like involucre, the petals 5; stamens many, united in a column which closely surrounds the several styles; ovaries several, connivent into a ring or sometimes united into a compound pistil, in fruit making 1-seeded 1-loculed more or less indehiscent carpels or a several-loculed capsule. About 60 genera and 700 species. Representative plants are mallow, hollyhock, abutilon, hibiscus, althea, okra, cotton.

A. Anthers borne only at the top of the stamen-tube.

B. Fruits 1-seeded, forming a ring at the base of the styles.

c. Involucre of 3 bracts....................... Malva .

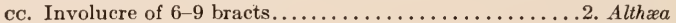

Bв. Fruit of several-seeded carpels................ Abutilon

AA. Anthers borne all along the side of the stamen-tube.......4. Hibiscus

1. Málva. Mallow.

Herbs, with a 3-leaved involucre like an extra calyx; petals obcordate; carpels many in a ring, separating at maturity, 1-seeded and indehiscent: leaves usually nearly orbicular in general outline.

M. rotundifòlia, Linn. Common mallow. Cheeses. Fig. 248. Trailing biennial or perennial, rooting; leaves orbicular, indistinctly lobed, toothed: flowers small, white or pinkish, clustered in the axils. Yards and roadsides; from Europe. A common weed.

2. althè丶a. Marsh Mallow.

Differs from Malva chiefly in having a 6-9-cleft involucre.

A. ròsea, Cav. Hollyhock. Figs. 222, 223, 263. Tall perennial, with angled or 5-7-lobed cordate leaves, and large flowers in many colors. China.

3. ABÙtilon. Indian Mallow. Fig. 182.

Mostly shrubs, often with maple-like leaves, and no involucre to the flower: ovaries and fruits several-seeded. Contains conservatory plants. Fig. 520 . 
A. striàtum var. Thómpsonii, Veiteh. Spotted flowering maple. Shrub: leaves 3-5-lobed but more typically 5-7-lobed, green: flowers drooping, on long solitary axillary peduncles, bell-shaped, veiny-orange or red. A conservatory and house plant. Several forms are in cultivation, probably cultural variations from the tropical American type.

A. Theophrásti, Medic. Velvet leaf. Indian mallow. Stout annual, 3 or $4 \mathrm{ft}$., densely pubescent: flowers yellow, erect, on peduncles shorter than the long petioles: leaves large, roundish heart-shaped, taper-pointed, and velvety: ealyx 5-cleft; earpels 12-15, united, pubescent, beaked, 2-valved, with 3-9 sceds in. each cell. August to October. Weed, from Asia.

4. Hibíscus. Rose Mallow.

Herbs or shrubs, with an involuere of many narrow bracts: stamen-column anther-bearing most of its length:

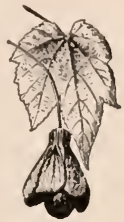

520. Garden abutilon. styles, 5, united: pod 5-loculed, loculicidal: flowers large and showy.

H. syriacus, Linn. Althea of cultivated grounds. Rose of Sharon. Shrub $10 \mathrm{ft}$.: leaves wedge-ovate and 3-lobed: flowers showy, in various colors, in the leaf-axils in summer and fall, often double. Asia.

\section{GERANiācez. Geranium Family.}

Herbs, chiefly with simple leaves: flowers perfect, in most genera nearly regular (but sometimes very irregular), 5-merous; stamens as many or twice as many as the sepals, hypogynous; ovary single, the locules usually as many as the sepals: fruit capsular. A most diverse family, often divided into several. There are about 20 genera and 700 species. Common examples are geranium, pelargonium, nasturtium, balsam, jewel-weed or touch-me-not, oxalis.

A. Flowers regular or very nearly so.

B. Leaves simple (often deeply lobed).

c. Anther-bearing stamens $10 \ldots \ldots \ldots \ldots \ldots \ldots$. Geranium

cc. Anther-bearing stamens about $7 \ldots \ldots \ldots \ldots \ldots \ldots$. Pelargonium

Bв. Leaves compound................................

AA. Flowers very irregular.

B. Flower with one very long spur............... Tropæolum

BB. Flower hanging by its middle, with a short hooked spur.5. Impatiens

\section{Gerànium. Cranesbill.}

Small herbs with forking stems and 1-3-flowered peduneles: sepals and petals 5 ; glands on the torus 5 , alternating with the petals; stamens 10 , usually all of them with perfect anthers: fruit 5 1-seeded earpels separating from the axis from the base upwards and curling outwards.

G. maculàtum, Linn. Common wild cranesbill. Fig. 195. Perennial, 1-2 ft., hairy erect: leaves orbicular, deeply 5-7-parted: petals entire, hairy on the elaw: flower rose-purple, 1 in. across. Common; spring. 
G. Robertiànum, Linn. Herb Robert. Annual or biennial, 1 ft. or sometimes less, somewhat hairy, spreading: leaves 3- or 5-divided into pinnatifid divisions: fls. $1 / 2$ in. or less across, pink-red. Moist places; common.

\section{PElargòniUm. Geranium of gardens.}

Somewhat fleshy, strong-scented plants, differing from Geranium in having a somewhat 2-lipped corolla, and stamens with anthers less than 10 .

P. hortòrum, Bailey. Garden geranium. Fish geranium. Fig. 39. Stem somewhat succulent and hairy: leaves orbicular or reniform, crenate-lobed, often with bands of different colors: flowers in umbel-like clusters, deflexed in bud of many colors, often double. South Africa, but of hybrid origin.

P. peltàtum, Ait. Ivy-leaved geranium. Trailing: filaments 10, some being sterile: petals pink or white, nearly equal: leaves more or less peltate, nearly or quite smooth, 5-angled or -lobed.

P. fràgrans, Willd. Nutmeg geranium. Stems somewhat shrubby, and the branches straggling, thick, and softly hairy: leaves small, rounded, very downy, fragrant: flowers small, white.

P. gravèolens, Ait. Rose geranium. Somewhat shrubby: filaments 10 , some sterile: leaves divided palmately, the 5 or 7 lobes more or less toothed, revolute and rough-edged: petals not equal, but 2 upper larger: flowers umbelled, small, pinkish-lavender, veined with darker: plant very fragrant.

\section{3. ÓXALIS. OXalis. WOOD-SORREL.}

Low often tuberous herbs with small flowers which have no glands on the torus-disk: leaves digitate, of 3 or more leaflets, usually mostly radical: flowers (opening in sun) with 5 sepals and petals and 10 somewhat monadelphous stamens, the alternate ones shorter: pod 5-loculed, often opening elastically. The following have 3 obcordate leaflets, closing at night.

O. strícta, Sav. Common yellow oxalis. Fig. 300 . Stem leafy and branching: peduncles bearing 2-6 small yellow flowers. Common in fields.

O. Acetosélla, Linn. Wood-sorrel. Scape $2-5$ in. high, from a ereeping rootstock: flowers white and pink-veined. Deep woods.

O. violàcea, Linn. Scape 5-10 in. high with an umbel of several bright violet flowers, from a sealy bulb. Woods South, and a common windowgarden plant.

\section{TROPAÒLUM. NASTURTIUM of gardens.}

Tender, mostly climbing herbs (by means of leafstalks), with one of the 5 petals extended into a long, nectar-bearing yellow spur: petals usually 5 , with narrow claws, often bearded; stamens 8 , of different shapes; carpels 3 , indehiscent in fruit. The following (from Peru) have peltate orbicular leaves (Fig. 140).

T. màjus, Linn. Climbing nasturtium. Tall-climbing: flowers yellow, red, cream-white, and other colors; petals not pointed.

T. minus, Linn. Dwarf nasturtium. Fig. 211. Not climbing: petals with a sharp point. 


\section{IMPÃTIENS. TOঠCH-ME-NOT. JEWEL-WEED.}

Soft or succulent tender herbs with simple alternate or opposite leaves and very irregular flowers: sepals 3 to 5 , usually 4 , one of them produced into a large curving spur; petals apparently 2 , but each consisting of a united pair; stamens 5: fruit 5-valved, elastieally diseharging the seeds (whence the names "Impatiens" and "touch-me-not").

I. Balsámina, Linn. Garden balsam. Erect and stout, 1-21/2 ft.: leaves lanceolate, toothed: flowers in the axils, of many colors, often full double.

I. biflòra, Walt. (I. fulva, Nutt.). Orange jewel-weed. Fig. 521. Tall branching plant $(2-4 \mathrm{ft}$.) with alternate

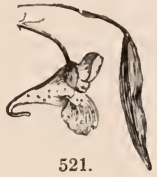

Impatiens biflora. oval or long-oval blunt-toothed long-stalked leaves: flowers $3 / 4 \mathrm{in}$. long, horizontal and hanging, orange-yellow with a red-spotted lower lip, the upper lip less spotted and of one piece, the 2 green sepals at the apex of the pedicel closely appressed to the tube, the tail of the spur curled under

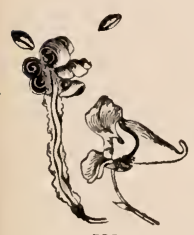

522. the spur: pod opening elastically when ripe, throwing the seeds (the 5 valves quiekly eurling from above downwards). Common in swales.

I. pállida, Nutt. (I. aùrea, Muhl.). Yellow jewel-weed. Fig. 522. Leaves usually stronger-toothed, the teeth usually ending in sharp points: flowers $1 \mathrm{in.} \mathrm{long} \mathrm{and} \mathrm{much}$ broader than those of 1 . biflora, clear yellow, the upper lip of two parts, the lower also of 2 parts and nearly horizontal, the 2 sepals at apex of pedicel large and not elosely appressed, tail shorter: pods as in the other. Less common Impatiens pallida. than the other, but often growing with it.

\section{SAPINDĀCEA. SoAPBERry or MAPLE.}

Trees or shrubs, of various habit: flowers polypetalous or apetalous, often inconspicuous, 4- or 5-merous: stamens 10 or less, borne on a fleshy ring or disk surrounding the single 2-3-loculed pistil: fruit a pod or samara. A various family, largely tropical. Genera about 75 and species about 600-700. Maple, box-elder, buckeye, horse-chestnut, bladder-nut, are familiar examples.

A. Herb: climbing by hook-like tendrils among the

flowers in the cluster: fruit an inflated pod........ Cardiospermum

AA. Trees and shrubs.

B. Stature of trees (or tall shrubs).

c. Leaves simple (more or less palmately lobed) or (in 1 speeies) 3-5 pinnately compound: fruit a samara (with 2-winged seeds)......... Acer cc. Leaves digitately eompound, 5-9 leaflets........ . Esculus

вB. Stature of shrubs: leaves pinnately $3-7$ compound: fruit a large bladdery pod.............. Sta phylea 


\section{CARdiospérmum. Balloon-vine. Heart-seed.}

Vines climbing by axillary, hook-like tendrils among flower-clusters: leaves alternate, biternate, leaflets toothed: flowers diøeious, or some perfect; sepals 4, 2 of them smaller; petals 4 , irregular, each with an appendage

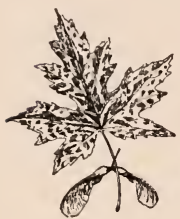

523.

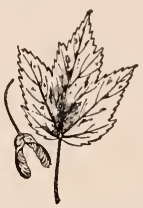

524. at inner base; stamens 8 , filaments unequal; style short, 3-cleft; ovary triangular, 3 -celled, 1 ovule to each cavity: capsule membranous, much inflated.

C. Halicấcabum, Linn. Climbing or spreading herb, delicate and slender: leaflets ovate-lanceolate, acute, cut and toothed: flowers small, white: fruit large, balloon-like, decorative; seeds black with white scar, hard, round. Cultivated.

Acer saccharinum. Acer rubrum. Summer.

\section{2. ÀCer. MAPLE. BoX-elder.}

Trees or shrubs, with opposite lobed or parted leaves (pinnate in boxelder): flowers small and greenish or reddish, in early spring and often from winter buds, in box-elder diöecious, in true maples perfect (or imperfectly diclinous); calyx about 5-cleft; petals 5 or none; stamens usually $3-8$ : fruit a samara with 2 seeds and 2 wings. Two shrubby woods maples are common in some parts of the country.

\section{a. Maples: leaves simple, palmately lobed.}

b. Flowers from lateral winter buds, preceding the leaves: fruit maturing very early.

A. saccharìnum, Linn. (A. dasycárpum, Ehrh.). White or silver maple. Fig. 523. Flowers greenish, with no petals: leaves very deeply 5-lobed, silvery white beneath, the narrow divisions lobed and toothed: fruit with large spreading wings, downy when young. Common along streams and in low grounds; much planted. There is a cut-leaved form known as Wier's maple, popular as a lawn tree. Wood white. Linnæus thought it to be the sugar maple, hence his name "saccharinum."

A. rùbrum, Linn. Red, soft, or swamp maple. Fig. 524. Tree usually of only medium size: flowers red, with narrowoblong petals: leaves rather small, not deeply 3-5-lobed, whitish beneath, the lobes serrate and toothed: fruit with'nearly parallel or slightly spreading wings, not downy. Low grounds.

bb. Flowers in clusters, with the lcaves, some or all on shoots of the season.

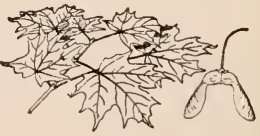

525. Acer saccharum.

A. sáccharum, Marsh. (A. saccharinum of some). Sugar, hard, or rock maple. Figs. 143, 525. Flowers greenish, drooping, on long pedicels, the petals none and the calyx hairy at the top: leaves bright green, firm, cordateorbicular in outline, 3-lobed and the side lobes again lobed, all lobes and 
teeth ending in points, the basal sinus broad and open: wings of fruit somewhat spreading. Commonest of maples East.

A. nìgrum, Michx. Black sugar maple. Fig. 526. Foliage dark and limp, the lobes broad and shallow, little toothed and with only blunt points, the basal sinus nearly or quite closed: wings of fruit nearly parallel, large. Eastern Central States; by some regarded as a form of A. saccharum.

A. plantanoìdes, Linn. Norway maple. Figs. 79, 80, 157, 323-330. Flowers late, in umbel-like clusters, yellowish green, large, with both sepals and petals: leaves large and heavy, 3-5-lobed and mueh toothed, all parts ending in points: fruit with wide-spreading wings. Europe. Commonly planted: has milky juice.

A. Pseùdo-plátanus, Linn. Sycamore maple. Tree from Europe, and many varieties cultivated: leaves broad, 3-7-lobed, glabrous above, whitish and downy below; lobes acute, unequally toothed: racemes terminal, drooping; flowers yellowish-green; ovaries woolly: fruit downy, the wings rather spreading.

bbb. Flowers appearing after the leaves, in racemes: large bushes or bushlike small trees in cool woods and ravines.

A. pennsylvánicum, Linn. Striped maple. Moose-wood. Bark smoothish, light green, striped: flowers greenish, in terminal drooping loose racemes: leaves simple, thin, 3-lobed near apex, the lobes acuminate, with finely toothed margin all around: fruit greenish, smooth, with large, widely diverging wings. Small tree.

A. spicàtum, Lam. Mountain maple. Shrub, 5-10 ft., usually forming clumps: bark green,

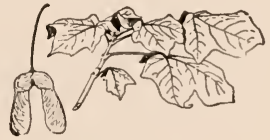

526. Acer nigrum. not striped: flowers appearing after leaves, in dense racemes, upright, compound, small, greenish: leaves slightly 3-5-lobed, coarsely serrate: fruit with narrow, somewhat divergent wings.

\section{aa. Box-elder: leaves pinnate.}

A. Negúndo, Linn. (Negundo aceroides, Moench). Box-elder. Tree with green glaucous twigs and leaf-bases covering the buds: flowers in long racemes, diœeious, with 4-5-eleft ealyx and no corolla, and 4-5 stamens, the sterile flowers on long, slender pedicels: leaves pinnate, with $3-5$ ovatepointed toothed leaflets: fruit with somewhat incurving wings. Common; much planted in cold and dry regions west.

\section{3. asculus. Horse-chestnut. Buckeye.}

Trees: leaves opposite, on long petioles, palmately compound, 5-7-foliolate: flowers irregular, in a terminal panicle, some often imperfeet, most of them with some imperfect pistils and stamens; calyx 5-toothed; corolla irregular, with 4 or 5 clawed petals; stamens $5-8$, usually 7 : fruit a leathery capsule, smooth or spiny, 2-3-valved, each valve containing, usually, 1 seed only; seed large, with shiny brown coat and a large, round, pale scar; not edible. 
Æ. Hippocástanum, Linn. Common horse-chestnut. Fig. 277. Buds noticeably large and resinous: leaf-scars large, horseshoe-shaped: leaves large, palmately compound, usually with 7 leaflets; leaflets obovate, abruptly pointed at tip: corolla of 5 petals, white, spotted with purple and yellow; stamens long, exserted: fruit prickly. Blooms June to July.

E. rubicúnda, Loisel. Red horse-chestnut. Small, round-headed tree, cultivated: leaflets $5-7$ : petals 4 , broad, on slender claws, rose-red; stamens usually 8 .

E. glàbra, Willd. Ohio buckeye. Tall tree, native in woods and along river banks, west of Alleghanies: bark rough and ill-scented when peeled or bruised: leaflets 5, oval or oblong, acuminate: flowers small, in short panicle; petals 4, narrow, on claws, nearly equal, erect, pale yellow; stamens longer than petals: fruit prickly at first. April, May.

E. octándra, Marsh. Sweet buckeye. Large tree, rarely shrubby: bark dark brown, scaly: leaflets usually 5 , sometimes 7 : flowers yellow; calyx oblong; petals 4, very unequal, long-clawed, connivent, longer than stamens: fruit glabrous. Rich woods West and South. April and May.

E. Pàvia, Linn. Red buckeye. Shrub or small tree, 3-10 ft., found in fertile soil West and South: flowers red; calyx tubular; petals 4, unequal, longer than the stamens: fruit nearly smooth.

\section{STAPHYLÈ. BladDER-NUT.}

Upright shrubs with opposite leaves, pinnately compound, with 3-7 leaflets, stipulate: flowers small, white, in drooping clusters; sepals, petals and stamens 5; styles 2-3: capsule a large bladdery pod, 2-3-lobed, 2-3-celled, each cell several-seeded.

S. trifòlia, Linn. Shrub 6-10 ft., in thickets, in moist soil: leaflets 3 , ovate, acuminate, serrate, stipules deciduous: flowers bell-like, white, in clusters at ends of branchlets.

\section{POLYGALÃCEæ. MiLKwort FÁmily.}

Herbs or shrubs, with leaves mostly simple, entire, without stipules, and flowers irregular and perfect. Represented by the genus

\section{POLYGala. Milkwort.}

Mostly herbs, with bitter juice: flowers very irregular, some often cleistogamous; sepals 5, unequal, 2 of them winged and colored (petal-like); petals 3 , usually united into a tube, the middle petal hooded or crested, or otherwise appendaged; stamens 6 or 8 , the filaments usually monadelphous, but the sheath split, more or less connate, within or hidden in the middle petal; ovary 2-celled. The irregularity of the flowers makes some of the species conspicuous, but others have very minute flowers, difficult to examine.

P. paucifòlia, Willd. Fringed polygala. Flowering wintergreen. The most striking of the common milkworts, the flower being large (about 1 in. long) and showy, rose-purple, with a fine, fringed crest on the central corolla 
lobe: plant low, 3-4 in. high, branching, from a creeping rootstock, with oval petiolate leaves clustered near the tips of the stems, the lower leaves scale-like: there are small, whitish and fertile (eleistogamous) flowers on the rootstock. In moist, rich woodland. East and North.

P. Sénega, Linn. Seneca snakeroot. Flowers small in terminal, slender, spike-like racemes: stem erect, $8-15$ in., simple and leafy: leaves laneeolate, alternate: flowers white or greenish, on very short pedicels; eorolla with small crest. Perennial.

\section{XXViII. Leguminósa. Pulse, or Pea Family.}

Herbs, shrubs, or trees, mostly with pinnately compound alternate leaves: flower papilionaceous in the species described below: fruit typically a legume. A vast family and widely dispersed, with many tropical species. Genera about 400, and species about 6,500. By some authors, the species with papilionaceous flowers are separated into the family Papilionacere, and those of the acacia tribes, with regular flowers, as the Mimosaceæ. Familiar leguminous plants are pea, bean, lupine, clover, alfalfa, vetch, wistaria, locust, red-bud.

A. Shrubs, twining.

1. Wisteria

AA. Trees, or ereet shrubs.

B. Leaves once or twice pinnately compound: flowers in racemes: often large trees.

c. Flowers truly papilionaceous, rather large and showy, usually fragrant: leaves with sharp spines or prickles often in place of stipules..... 2. Robinia

cc. Flowers small, greenish and inconspicuous, not truly papilionaceous: tree usually armed with large pronged thorns ................... Gleditsia

вв. Leaves simple, entire: corolla not truly papilionaceous: fls. in umbel-like clusters, before the leaves....... 4. Cercis

aAd. Herbs.

B. Plant elimbing by tendrils.

c. Calyx leafy-lobed.................... 5. Pisum

cc. Calyx not leafy-lobed.

D. Style flattened, bearded down 1 side........ 6. Lathyrus

DD. Style slender, with a tuft of hairs at apex only, or about the upper part ................ 7. Vicia

Bв. Plant not tendril-bearing: leaves compound.

D. The leaves 3 -foliolate (sometimes simple in No. 9).

E. Leaves digitately compound.

F. Stamens diadelphous (9 and 10), and the flowers in heads, or spikes............. 8. Trifolium FF. Stamens 10, distinet: flowers in racemes.... 9. Baptisia 
EE. Leaves pinnately compound (terminal 1stalked, and the stalk jointed), 3 leaflets.

F. Flowers small, in a long raceme.

G. Pod straight, exceeding calyx: flowers small, in very slender racemes.........10. Melilotus

GG. Pods curved or coiled: flowers. small to medium, in heads or short spikes......11. Medicago

FF. Flowers medium to large, clustered at the ends of the raceme.

G. Keel of the corolla coiled into a spiral....12. Phaseolus

GG. Keel curved but not coiled.......... Vigna

DD. The leaves more than 3-foliolate, or digitately compound.

E. Digitately compound, 5-7 leaflets.........14. Lupinus

EE. Pinnately compound.

F. Even-pinnately compound: many leaflets:

flowers yellow .................... Cassia.

FF. Odd-pinnate (sometimes 3 leaflets) of 5-7

leaflets: flowers purplish or lavender......16. A pios

\section{WISTERIA.}

Tall shrubby twiner, producing long, dense racemes of showy flowers: leaves pinnate, with several or many leaflets: 2 upper calyx-teeth shorter: standard large and roundish: pod knotty, several-seeded.

W. chinénsis, DC. Wistaria. Popular climber for porches, from China, with large drooping racemes of bright blue (sometimes white) pea-like flowers in spring and summer.

\section{ROBÍNIA. Locust.}

Trees or large shrubs with compound, odd-pinnate leaves, with stipules or stipular spines, the base of the leaf-stalk covering the next year's bud: flowers showy, pea-like, hanging in axillary racemes; calyx 5-cleft; standard of the corolla large, turned back, inclosing side petals in bud.

R. Pseùdo-Acàcia, Linn. Common black locust. Tree, native West and South, everywhere introduced and valuable for timber. Bark nearly black, very rough: stiff spines at base of each leaf: leaflets 9-19, ovate or oval, somewhat mucronate at tip, on short stalks: racemes $3-5$ in. long, from axils, pendulous, slender and loose, the flowers white, very fragrant: pod smooth, 4-7-seeded.

R. viscòsa, Vent. Small tree, native to southern states: cultivated: leafstalks, branchlets and pods glandular-viscid (clammy): prickles short: flowers roseate, in dense, erect racemes. April to June.

R. híspida, Linn. Rose acacia. A straggling shrub, to $10 \mathrm{ft}$.: branches, stalks, and pods bristly with flexible red spines: flowers pink, handsome, in loose pendulous racemes. Native of southern mountains. Cultivated. May to June. 


\section{Gleditsia. Honey Locust.}

Trees, thorny with stout branching spines on branches and usually on trunk: leaves abruptly pinnate, frequently bi-pinnate, and all gradations often on same leaf: flowers in axillary, spicate racemes, greenish, ineonspicuous, some imperfect, not papilionaceous; calyx-tube short, $3-5$ cleft; petals 3-5, nearly equal, inserted on calyx-tube; stamens 3-10, distinst, inserted on petals: fruit a large, leathery, flat pod, clongated, containing 1 to many sceds.

G. triacánthos, Linn. Large tree with hard and heavy wood: pods 6-18 in. long, an ineh or so wide, twisted or hoop-like, filled with sweetish pulp between the several to many smooth, shiny seeds.

\section{CÉRCIS. REDBŨ.}

Small trees with simple, rounded, heart-shaped leaves and tiny stipules soon falling: flowers roseate-purple, in numerous small clusters along branches, even on trunk, before leaves, thus giving the tree a striking appearance; calyx 5-toothed, campanulate; corolla irregular, not papilionaceous; petals 5 and standard inelosed by wings; stamens 10, distinct: legume oblong, flat, many-seeded, margined on one edge.

C. canadénsis, Linn. Redbud. Judas tree. Native small tree of mididle and southern states, $10-30 \mathrm{ft}$. high, irregularly branching: bark smooth and dark. Cultivated as ornamental tree, April, May.

\section{PISUM. PEa.}

Slender herbs, climbing by tendrils which are homologous with leaflets: leaves pinnate, with 1-3 pairs of foliar leaflets, and very large, leafy stipules: lobes of calyx leafy; flowers large, white, or pink, on axillary peduncles: pod a typical legume, several-seeded.

P. sativum, Linn. Garden pea. Figs. 206, 310. Smooth and glaucous: leaflets usually 2 pairs, broad-oval: peduncles 2- or more-flowered. Old World.

\section{LÁTHYRUS. VEITCHLING.}

Much like Pisum, differing chiefly in very technical characters, but best told in general by the narrow leaflets and pods, and not leafy calyx.

L. odoràtus, Linn. Sweet pea. Figs. 177, 245. Annual, the stem hairy: leaflets one pair, narrow-oval or oblong: flowers 2 or 3 on a long peduncle, very fragrant, in many colors. Southern Europe.

L. latifòlius, Linn. Everlasting pea. Fig. 272. Perennial of long duration, smooth, the stems winged: leaflets one pair, long-oval: flowers many in a deuse cluster on long peduncles, rose-purple and white. Europe.

7. vícia. Vetch. Tare.

Herbs, mostly trailing or climbing by tendrils from the ends of pinnately compound leaves: leaflets usually many, entire or emarginate: stipules half-sagittate: flowers in axillary racemes or pairs; calyx somewhat oblique, 5-toothed; wings adhering to keel; style slender, bent, hairy or with hairy ring beneath stigma: pods flat, 2-valved, 2- to several-seeded. 
V. americàna, Muhl. Perennial, smooth: leaflets 10-14, oblong, blunt: peduncles 4-8-flowered: flowers purplish-blue, $1 / 2^{-2 / 3}$ in. long. Moist soil.

V. Crácca, Linn. Perennial, more or less pubescent, with weak stems: leaflets 12-24, oblong to linear, mucronate: racemes many-flowered, 1-sided, spike-like, on axillary peduncles; flowers blue to purple, $1 / 3-1 / 2 \mathrm{in}$. long. Dryish soil.

V. sativa, Linn. Spring vctch. Annual, rather pubescent, not climbing: leaflets, 5-7 pairs, oblong or obovate, to linear, obtuse or retuse or mucronate: flowers in pairs, from axils, nearly sessile, violet-purple, $3 / 4-1 \mathrm{in}$. long: pod smooth, linear, 5-10-seeded. Cultivated or wild; from Europe.

V. villòsa, Roth. Hairy or winter vctch. Diffuse, very hairy: flowers showy in long axillary racemes, deep purple: seeds small and black. Cultivated and eseaped. Europe. Annual and biennial, perhaps sometimes perennial.

\section{TRIFÒlium. Clover.}

Annual or perennial herbs with digitate leaves of 3 leaflets (all 3 leaflets joined directly to top of petiole): flowers small, with bristle-form ealyxteeth, in dense heads: fruit a 1- to few-seeded little pod which does not

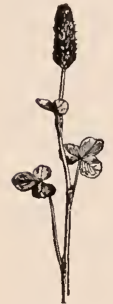

527.

Trifolium incarnatum. exceed the calyx.

\section{a. Flowers sessile in the dense heads.}

T. praténse, Linn. Common red clover Figs. 85, 173. Erect, 1-2 ft., with oval or obovate leaflets, which have a pale spot or band near the eenter and usually a notch at the end: flowers rose-red, honey-sweet, the heads closely surrounded by leaves. Europe, but common everywhere in the North.

T. mèdium, Linn. Medium red clover. Larger, the stem less straight, the leaflets oblong, entire and with a spot: head stalked above the uppermost leaves. Otherwise like the last.

T. arvénse, Linn. Rabbit-foot clover. Annual; 5-10 in., erect: flowers sessile in dense, cylindrical heads, which become very soft and grayish fur-like, from the silky plumose calyxteeth; corolla insignificant, whitish. Dry, sandy soils; introduced from Europe.

\section{aa. Flowers short-stalked in the heads.}

T. hỳbridum, Linn. Alsike clover. Slender, from a prostrate base, 1-3 ft.: leaflets obcordate: head small and globular, light rose-colored. Europe.

T. rèpens, Linn. White clover. Small, the stems long-creeping and sending up flowering stems 3-12 in. high: leaflets obcordate: heads small, white. Common; native, also European.

T. incarnàtum, Linn. Crimson clover. Fig. 527. Stout, hairy, erect plant, 1-21/2 ft., with obovate-oblong leaflets and brilliant crimson flowers in a long-stalked head. Europe; now frequently cultivated.

T. refléxum, Linn. Buffalo clover. Annual or biennial, pubescent, ascending 8-18 in.: standard purple, keel and wings whitish: leaflets oval or obovate, finely toothed. Most common in central states, from western New York. 
T. procúmbens, Linn. Low hop clover. Annual, slender, proeumbent or upright to 6 or 12 in.: flowers yellow, turning brown and dry when old, finally reflexing; standard striate; heads small, rounded, 20 40-flowered: leaflets wedge-shaped and notehed at end, terminal one stalked, stipules ovate. June. Dry soil, introdueed.

T. agràrium, Linn. Hop clover. Larger: leaflets ovateoblong, the terminal one not stalked, and stipules narrow and joined for half their length to the petiole. Introduced.

\section{BAPtísia. False Indigo.}

Perennial herbs: leaves palmately 3 -foliolate, with stipules (or, simple, sessile, exstipulate, perfoliate leaves): flowers raeemed; ealyx 4-5-toothed; standard ereet, rounded, the sides rolling baek; keel and wings oblong, nearly straight; stamens 10, distinet: pod stalked in a persistent calyx, pointed, inflated, many-seeded. Plants usually blackened in drying.

B. tinctòria, R. Br. Bushy, erect to $2 \mathrm{ft}$., sonewhat glaeuous: leaves sessile or nearly so, with tiny deciduous stipules; leaflets small, entire, wedged-ovate: racemes many, terminal, loosely few-flowered; flowers yellow, about $1 / 2$ in. long, papilionaceous. Dry soil in woods.

\section{Melilòtus. Sweet Clover.}

Tall, ereet annuals or biennials, with sweet-scented herbage and small white or yellow flowers in numerous

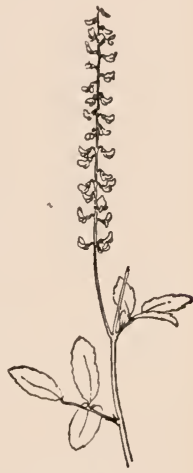

528. Melilotus officinalis. open raeemes: leaflets, 3 , oblong: pod ovoid, somewhat exceeding the calyx, 1-2-seeded.

M. álba, Desr. White sweet clover. Bokhara clover. Fig. 184. Two to $5 \mathrm{ft}$. tall, smooth: leaflets truncate: flowers white, the standard longer than other petals. Europe; common on roadsides.

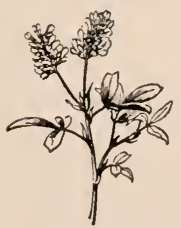

529. Medicago sativa.

M. officinàlis, Lam. Yellow sweet clover. Fig. 528. Leaflets obtuse: flowers yellow. Less common than the other.

\section{MEDICÀGO. MEDICK.}

Clover-like plants with small flowers in heads or short spikes and toothed leaflets: particularly distinguished by the eurved or coiled pod.

M. sativa, Linn. Alfalfa. Lucerne. Figs. 21, 246, 529. Erect perennial, with ovate-olblong leaflets and short spikes or dense racemes of blue-purple flowers. Europe. Grown extensively for forage, being made into hay and also ground into "alfalfa meal."

M. lupulina, Linn. Black medick. Trailing elover-like plant, with obovate leaflets and yellow flowers in heads or very short spikes: pod black when ripe. Europe; common weed East. 


\section{PHASÈOlUS. Bean.}

Tender herbs, often twining, the flowers never yellow, and the pinnate leaves of 3 leaflets: flowers usually in clusters on the joints of the raceme or at the end of the peduncle, the keel (inclosing the essential organs) coiling into a spiral: fruit a true legume.

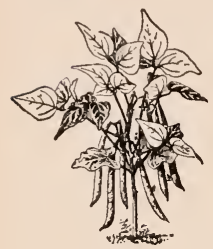

530.

P. vulgàris, Linn. Common bean. Figs. 1, 308, 309, $311,312,322,530$. Annual: twining (the twining habit bred out in the "bush beans"): leaflets ovate, the lateral ones unequal-sided: flowers white or purplish, the racemes shorter than the leaves: pods narrow and nearly straight. Probably from tropical America.

P. lunàtus, Linn. Lima bean. Fig. 531. Annual: talltwining (also dwarf forms): leaflets large: flowers whitish, in racemes shorter than the leaves: pods flat and curved, with a few large flat seeds. South America.

P. multifiòrus, Willd. Scarlet runner bean. Perennial Phaseolus vulgaris. in warm countries from a tuberous root, tall-twining: leaflets ovate: flowers bright scarlet (white in the "White Dutch Runner bean") and showy, the racemes exceeding the leaves: pod long and broad but not flat. Tropical America; cultivated for ornament and for food.

\section{VIGNA. Cowpea.}

Differs from Phaseolus chiefly in technical characters, one of which is the curved rather than coiled keel of the flower.

V. sinénsis, Endl. Cowpea. Black pea. Stock pea. Figs. 273, 532. Long-trailing or twining, tender annual: leaflets narrow-ovate; flowers white or pale, 2 or 3 on the apex of a very long peduncle, the standard rounded; pod slender and long, cylindrical: seed (really a bean rather than pea)

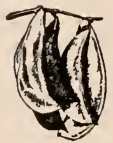

531. Phaseolus lunatus. small, short-oblong. China, Japan; much grown South for forage, and used also as cover-crop.

\section{LUPINUS. LUPINE.}

Low herbs: leaves palmately compound, 5-15 foliolate, rarely simple: flowers showy, in terminal spikes or racemes: calyx

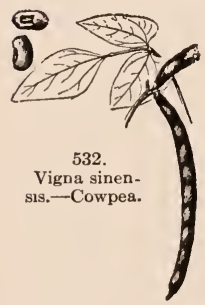
decidedly 2-lipped: standard round, sides rolled backward: keel incurved, sickle-like: wings lightly united above keel: stamens monadelphous, with 3 alternate anthers, different in size and shape from others: pod oblong, flattened, often knotty.

L. perénnis, Linn. Perennial, somewhat downy: stem erect to 1 or $11 / 2 \mathrm{ft}$.: leaflets $7-11$, large, radiating, nearly sessile, oblanceolate, mucronate; stipules small: flowers blue or whitish, in loose racemes: pod linear-oblong, hairy, 5-6-seeded. Sandy soil. May to June. 
15. CÁssia. Senna. Fig. 247.

Our herbs with odel-pinnate, compound leaves and yellow flowers: sepals 5 , nearly equal; corolla not papilionaceous, nearly regular; petals 5 , stamens 5-10, some anthers usually imperfect: pod often curved, many-seeded.

C. marilándica, Linn. Smooth perennial, 3-4 ft.: leaflets 6-9 pairs, laneeolate-oblong, mueronate, with a gland at or near base of petiole: stipules deciduous: stamens 10, 3 imperfeet, with deformed anthers, the anthers black: flowers showy yellow, short, axillary racemes. Summer.

\section{6. ÀPIOS. Groundnut.}

Perennial, twining herb, with edible underground tubers: leaves pinnately 3-7-foliate: flowers in short, dense, often branching axillary racemes: ealyx rather 2-lipped: standard broad and reflexed: keel strongly ineurved, pushing into the standard, and finally coiled or twisted.

A. tuberòsa, Moeneh. Flowers brownish purple, sweet-seented, in dense racemes about 1-3 in. long: no tendrils: juice milky. Summer. In low, moist ground and shady woods.

\section{ROSĀCEA. Rose FAmily.}

Herbs, shrubs and trees, much like the Saxifragaceæ: leaves alternate, mostly with stipules (whieh are often deciduous): flowers mostly perfeet and polypetalous, the stamens usually perigynous, mostly numerous (more than 20); pistils 1 to many: fruit an aehene, follicle, berry, drupe, or aceessory. A very mixed or polymorphous family, largely of temperate regions, of about 75 genera and 1,200 speeies. By some writers, divided into three or four families. Common rosaeeous plants are rose, strawberry, apple, pear, plum, peach, cherry, blackberry, raspberry, spirea, cinquefoil.

A. Herbs.

B. Torus not enlarging.

c. Carpels many, in a head.

D. Style deeiduous................... 1. Potentilla

DD. Style persistent on achene, usually jointed and plumose........................ 2. Geum

cc. Carpels 2: ealyx prickly and lobes elosing over the fruit: 1 or 2 achenes..................... Agrimonia

вв. Torus becoming fleshy: flowers directly from the crown or root....................... Fragaria

AA. Shrubs or trees.

B. The ovary 1 , superior: fruit a drupe.......... 5. Prunus

Bв. The ovaries more than 1 .

c. Fruit 1-seeded drupes aggregated, or achenes. 
D. Ovaries many, free from calyx and torus, becoming drupelets................. 6. Rubus

DD. Ovaries 5-8: shrubs not prickly: leaves simple:

flowers yellow: fruit achenes............ 7. Kerra

cc. Fruit achenes inside a hollow torus........... 8. Rosa

ccc. Fruit a pome: ovaries usually 5 , immersed in the torus.

D. Petals oblong-spatulate: carpels $3-5$-celled, but appearing about 10 -celled............. 9. Amelanchier

DD. Petals rounded: ovaries 5 .

E. Pome with 2-seeded carpels............. Pyrus

EE. Pome with many-seeded carpels .........11. Cydonia

EEE. Pome with 1-5 stony kernels.......... Cratægus

cccc. Fruit 2-8 dry follicles, each several-seeded... . . . 13. Spiræa

\section{Potentílla. Five-finger. Cinquefoil.}

Herbs (sometimes shrubby) with flat deeply 5-cleft calyx and 5 bracts beneath it, and 5 obtuse, mostly yellow or white petals; stamens many: fruit an achene, of which there are many in a little head on the small, dry torus: leaves compound.

P. norvégica, Linn. An erect (1-2 ft. tall) very hairy and coarse annual, with 3 obovate, or oblong serrate leaflets and small flowers in which the yellow corolla is usually not so large as the calyx. Common weed.

P. canadénsis, Linn. Common five-finger. Trailing, strawberry-like with 5 narrow leaflets, but the lateral ones deeply lobed: flowers solitary, on axillary peduncles, bright yellow. Fields; common.

P. argéntea, Linn. Perennial, with stem prostrate, branching above, white-woolly: leaflets 5 , wedge-oblong, green above, white-pubescent beneath, with a few large, incised teeth, and margins revolute: flowers small, cymose, yellow; stamens about 20. June to September, in dry soil.

P. fruticòsa, Linn. Stem erect (1-2 ft.), shrubby, diffusely branched: leaves pinnate, with 5-7 sessile leaflets, margins entire, revolute: flowers axillary; petals yellow, orbicular, and longer than calyx, 1 in. broad. Marshy and wet ground. June to September.

\section{GÈUM. Avens.}

Perennial, erect herbs, with odd-pinnate or lyrate leaves, with stipules: flowers resembling those of Potentilla; calyx 5-cleft with 5 alternate bracts; stamens, many: achenes numerous, aggregated on a conical receptacle, with long persistent styles jointed, or bent, or plumose.

G. rivàle, Linn. Stems erect, 1-2 ft., several-flowered: root-leaves lyrate, and irregularly pinnate, petioled: stem-leaves few, usually of 3 leaflets, or 3-lobed: flowers few, large, nodding, the calyx purplish, the petals clawed, erect, yellowish purple; styles purplish, jointed and bent in middle, stigmas plumose: fruit stalked in the calyx. May to July. Bogs.

G. canadênse, Jacq. From 2-3 ft., with stem erect, branching, smooth or downy: root-leaves of 3-5 leaflets, or simple with smaller leaflets at base: 
stem-leaves few, simple, lobed, or 3-divided or toothed and short-petioled: flowers whitish, the petals not longer than sepals: head of fruits sessile in the calyx: styles jointed and bent near middle, the lower part hooked: torus bristly. Late spring and summer.

G. virginiànum, Linn. Differs from preceding in being hirsute: rootleaves various, but pinnate, with a very large rounded terminal leaflet; the upper leaves mostly 3-parted: flowers white or pale yellow: reeptacle not bristly; heads of fruits on short, stout, hairy stalks. Low ground. Summer.

\section{Agrimònia. Agrimony.}

Perennial, erect herbs, with alternate odd-pinnately compound leaves, and slender, spike-like racemes, with yellow flowers: leaves with small segments interposed, and large dentate stipules: calyx-

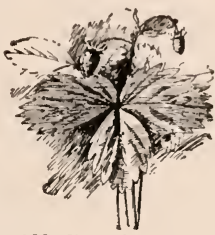

533. Fragaria vesca. tube contracted at the throat with a 5 -eleft limb, and bristly on upper part; petals 5 ; stamens slender, 5-15, carpels 2 , styles terminal: fruit dry, ineluded in the prickly calyx-tube.

A. gryposépala, Wallr. Spicate raceme terminating the stem $(6$ in. to $2 \mathrm{ft}$. high), petals yellow and twice longer than the ealyx. Dryish soils. Summer.

\section{FragÀria. Strawberry.}

Low perennials with 3 broad-toothed leaflets and a few flowers on radieal peduneles: torus enlarging in fruit, usually becoming fleshy.

F. vésca, Linn. Fig. 533. Small, very sparsely hairy, the leaves thin and rather light green, very sharply toothed: flower-clusters overtopping the foliage, small and erect, forking: fruit slender and pointed, light colored (sometimes white), the achenes not sunk in the flesh. Cool woods; common North.

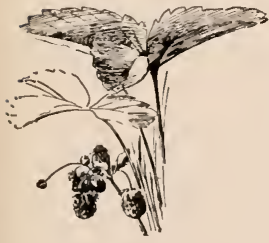

534. Fragaria virginiana.

F. virginiàna, Duch. Common field strawberry. Fig. 534. Stronger, darker green, loose-hairy, the leaves with more sunken veins and larger and firmer: flower-cluster slender but not overtopping the leaves, in fruit with drooping pedicels: fruit globular or broad-conical, with achenes sunk in the flesh; light colored. Very common.

F. chiloênsis, Duch. Garden strawberry. Fig. 291. Low and spreading but stout, the thick leaves somewhat glossy above and bluish white beneath, rather blunt-toothed: flower-clusters short, forking, the pedicels strong and long: fruit large and firm, dark colored, with sunken achenes. Chile.

\section{Prùnus. Peach. Pldm. Cherry.}

Trees and shrubs, mostly flowering in early spring: sepals, petals and stamens borne on the rim of a saucer-shaped torus, the calyx with 5 green 
spreading lobes and the petals 5 and obovate; pistil 1 , sitting in the bottom of the flower, the ovary ripening into a drupe: leaves alternate.

a. Peach and apricot: flowers solitary from lateral winter-buds, usually appearing before the leaves.

P. Pérsica, Stokes. Peach. Fig. 535. Small tree, with oblong-lanceolate pointed serrate leaves and solitary fuzzy fruits on

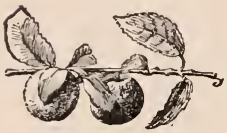

535. Prunus persica. last year's wood. China. The nectarine is a smooth-fruited form.

P. armeniaca, Linn. A pricot. Figs. 69, 536. Leaves ovate to round-ovate, serrate: fruits solitary, on last year's shoots or on spurs, smooth or nearly so. China.

aa. Plums: flowers in umbel-like clusters: fruit large and smooth, usually with a distinct suture (or "crease") on one side and covered with a "bloom," the stalk short.

P. doméstica, Linn. Common plum. Figs. 209, 289. Small tree, usually with young shoots downy: leaves thick and relatively large, dull dark green, ovate, oval or obovate, very rugose or veiny, somewhat pubescent beneath, coarsely and unevenly serrate: flowers large: fruits various, usually thickmeated and with heavy "bloom." Europe, Asia.

P. americàna, Marsh. Wild plum of the North. Fig. 537. Twiggy small tree, often thorny, the young shoots usually not downy: leaves obovate, dull green, abruptly pointed, coarsely toothed or jagged, not pubescent beneath: fruit small, red or yellow, tough-skinned and glau-

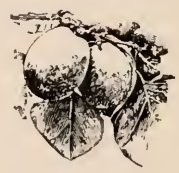

536. Prunus armeniaca. cous, the pit large and flattened. Common in thickets; improved forms are in cultivation. Including $P$. nigra, perhaps distinct.

P. angustifòlia, Marsh. Chickasaw plum. Mountain cherry. Fig. 538. Smaller, the young growth smooth and zigzag and usually reddish: leaves lanceolate to oblong-lanceolate, often trough-shaped, shining, finely serrate, cherry-like: fruit a small thin-fleshed shining plum on a long pedicel.

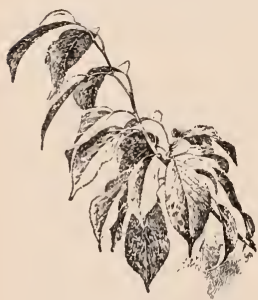

537. Prunus americana. Delaware, south; also in cultivation.

aaa. Cherries: flowers in umbel-like clusters: fruit small and nearly globular, early-ripening, usually without a prominent suture and "bloom," the stalk slender.

P. Cérasus, Linn. Sour cherry. Round-headed tree, with flowers in small clusters from lateral buds: leaves hard and stiffish, short-ovate or obovate, grayish green, serrate: fruit small, sour. Europe.

P. Avium, Linn. Sweet cherry. Fig. 539. Straight grower, the "leader" prominent in young trees, with flowers in dense clusters from lateral spurs: leaves 
oblong-ovate, dull and soft, on the young growth hanging: fruit usually rather large, sweet. Europe.

aaaa. Wild cherries, with small, scarcely edible fruits: flowers umbellate or racemed.

P. pennsylvánica, Linn. Wild red eherry. Pin or bird cherry. Small tree, 20-30 ft. high, with red-brown, peeling bark: flowers small, white, on long pedicels in umbel-like clusters, from lateral scaly buds, in early spring, before or with the leaves: fruit very small, globose, red, smooth, with thin, sour flesh.

P. virginiàna, Linn. Choke cherry. Small tree or shrub, 5-20 ft., with grayish spotted bark: leaves thin, oval or obovate, abruptly acute at tip, sharp-serrate: flowers white, in short

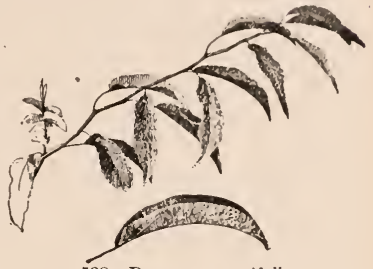

538. Prunus angustifolia. racemes, terminating leafy branches, appearing after leaves in late spring: fruit small, globose, red changing to dark crimson (nearly black), very astringent: usually found along banks and in thickets.

P. serôtina, Ehrh. Wild black eherry. Tree, 50-80 ft., with black, rough bark and reddish brown branches: leaves thickish, oblong or oblong-lanceolate, acute or tapering at tip, serrate with incurving or bluntish teeth: flowers later than preceding, white, in elongated, drooping or spreading, termi nal racemes: fruit deep purple or black (1/4 in. in diameter) with a sweetish, bitter taste.

\section{RÙBUS. Bramble.}

Shrubs, usually thorny, the canes or shoots dying after fruiting, with alternate digitately compound leaves: flowers white, in clusters, with 5-parted calyx and 5 petals: ovaries many, ripening into coherent drupelets.

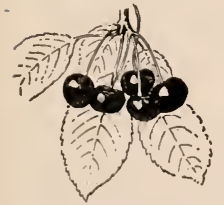

539. Prunus Avium.

a. Raspberries: drupelets or berry separating from thc torus.

R. occidentàlis, Linn. Black raspberry. Figs. 142, 290. Canes long and thorny, glaucous, rooting at the tips late in the season: leaves of mostly 3 ovate doubly-toothed leaflets: flowers in close, umbel-like clusters: fruits firm, black (sometimes amber-color). Woods, and common in cultivation.

R. aculeatíssimus, C. A. Meyer. Red raspberry. Canes erect and weak-prickly, more or less glaucous, not rooting at tips, leaflets oblong-ovate: flowers in racemes: fruits soft, red. Woods, and cultivated.

R. odoràtus, Linn. Flowering raspberry. Flowering "mulberry." Shrubby and erect, branching, 3-5 ft., not prickly, but rather bristly and stickyhairy: leaves large, 3-5-lobed: flowers large, I-2 in. broad, in terminal 
corymbs, the petals orbicular and purplish rose (rarely whitish): fruit red, ripe in August, flattened, sweetish but scarcely edible. Common in woods.

aa. Blackberries: drupelets adhering to the torus (the torus forming the "core" of the berry).

R. allegheniénsis, Porter ( $R$. villòsus of some). Common blackberry. Tall, very thorny: leaflets 3 or 5 , ovate and pointed, toothed, hairy beneath: flowers large, in open racemes: fruit cylindrical and firm, black when ripe. Woods, and cultivated.

R. villòsus, Ait. (R. canadénsis of some). Northern dewberry. Trailing and rooting at tips, prickly: leaflets 3-7, ovate-acuminate or oblong-ovate, toothed: flowers $1-3$, on erect, short peduncles, large: fruit like a small and shining blackberry. Sterile fields, and in cultivation.

R. triviàlis, Michx. Southern dewberry. Fig. 170. Long-trailing, very thorny and bristly: leaves 3-5, more or less evergreen, mostly lance-oblong and small, strong-toothed: flowers 1-3: fruit black. Sands, Virginia, south; also in cultivation.

\section{KÉRRIA. Globe Flower. "Japan Rose,"}

Shrubby plants with calyx of 5 acuminate, nearly distinct sepals; petals 5 (or flowers double); ovaries 5-8, smooth, globose: leaves simple, ovate, acuminate, doubly serrate, with stipules: flowers terminal on branches, solitary or a few together.

K. japónica, DC. Bush 3-8 ft. with green winter twigs: flowers orangeyellow, usually double: leaves sometimes variegated. Late May and June. Cultivated.

\section{RÒSA. ROSE.}

More or less thorny erect or climbing shrubs with pinnate wing-petioled leaves, and flowers with 5 calyx-lobes and 5 large, rounded petals: pistils many, becoming more or less hairy achenes which are inclosed in a hollow torus (fruit becoming a hip, Fig. 292). Most of the garden roses are too difficult for the beginner: they are much modified by the plant-breeder.

R. carolina, Linn. Swamp rose. Tall, often as high as a man, the few spines usually somewhat hooked: stipules (petiole wings) long and narrow: leaflets 5-9, narrow-oblong and acute, finely serrate: flowers rather large, rose-color. Swamps.

R. virginiàna, Mill. Usually low, with stout hooked spines: stipules rather broad; leaflets about 7 , smooth and mostly shining above: flowers large, rose-color. Moist places.

R. hùmilis, Marsh. Three feet or less tall, with straight, slender spines: stipules narrow; foliage usually less shining. Dry soils.

R. rubiginòsa, Linn. Sweet briar. Eglantine. Erect, 4-8 ft., curving, armed with stout recurved prickles, with weaker ones intermixed: leaflets $5-9$, ovate or oval, coarsely and doubly serrate and resinous or glandular, pubescent beneath, very aromatic: flowers small, pink or white, solitary, single or double. Naturalized from Europe and in cultivation. 


\section{9. amelánchier. Service Berry. June Berry.}

Small trees or shrubs, with smooth, grayish bark: leaves simple, petioled, serrate: flowers white, in racemes, or rarely solitary; calyx-tube 5cleft; petals 5 ; stamens many, short, inserted on ealyx-throat; ovary inferior, apparently 10-celled, with 1 ovule in each cavity; styles 5 , united below: fruit a berry-like pome, 4-10-celled.

A. canadénsis, Medic. Shadbush. Small tree or bush 5-50 ft. high, with snowy white flowers in very early spring before the foliage: leaves ovate to oblong, sharply serrate, acute at apex, base cordate, soon smooth; stipules long and silky-hairy: fruit red or purple pomes, on slender pedicels, sweet and edible. Woods, common.

\section{PỲrus. Pear. Apple.}

Small trees or shrubs with alternate leaves, and flowers in clusters in spring; flowers 5-merous: ovaries usually 5, immersed in the torus, the styles free.

\section{a. Leaves simple: pear and apple.}

P. commùnis, Linn. Pear. Figs. 61, 62, 65, 66, 67, 118, 119, 196, 293. Leaves ovate, firm and shining, smooth, close-toothed: fruit tapering to the pedicel. Europe.

P. Màlus, Linn. Apple. Figs. 294-295. Leaves ovate, soft-hairy beneath, serrate: fruit hollowed at the base when ripe. Europe.

P. coronària, Linn. Wild crab. Bushy tree to about $20 \mathrm{ft}$., somewhat thorny: leaves ovate-triangular to heart-shaped, cut-serrate, or somewhat lobed, soon smoothish: flowers large, strikingly fragrant, rose-colored, few in a corymb or cluster: pome flattened at the ends, long-stemmed, indented at the attachment to stalk, green, becoming yellowish, fragrant but sour. Open glades, from New York, west and south.

P. ioénsis, Bailey. Prairie crab. Pubescent: leaves oblong or ovate, notched or parted along the sides, the petioles short: pome globular or oblong, short-stemmed, with light dots. Mostly west of Great Lakes.

\section{aa. Leaves compound: mountain-ashes. (Sorbus.)}

P. americàna, DC. American mountain-ash. Tree or large shrub, native to mountain woods in the East, but sometimes cultivated: leaves odd-pinnately compound, with 13-15 leaflets that are lanceolate, taper-pointed, serrate, bright-green above: flowers numerous, small, white, in compound, flat cymes; styles 3-5: berry-like pomes globose, bright red, or orange, about the size of peas.

P. Aucupària, Ehrh. English mountain-ash. Rowan. Leaves pubescent on both sides when young, the leaflets blunt: fruit larger than that of preceding, about $1 / 2$ in. in diameter.

\section{CYDÒNIA. QUINCE.}

Small trees or shruhs: flowers and leaves much as in Pyrus: ovary 5celled, with many seeds in each: fruit a pome, usually hollowed at top end, globose, or pyriform. 
C. vulgàris, Pers. Quince. Six to $15 \mathrm{ft}$. high, with crooked branches; flower solitary, large, pale pink or roseate, on shoots of the season: leaves oblong-ovate, acute at apex, with obtuse base, entire. A small tree grown for its large yellow fruits.

C. japónica, Pers. Japan quince. Shrub, 3-6 ft., cultivated for hedges and flowers: branches armed with short, straight spines: leaves glebrous and shining, acute at the end, serrulate, the stipules conspicuously reniform: flowers in axillary clusters, nearly sessile, crimson or scarlet. Fruit globose, fragrant.

\section{CRAT $æ$ Æ̇GUS. HawthorN. Figs. 164-167.}

Large bushes or small trees, much branched, the wood tough and hard, usually very thorny: flowers white or pink, in dense umbel-like clusters; petals 5, entire; stamens 5-10 to many: fruit a small red or yellow drupe containing large bony stones: leaves simple, mostly toothed or lobed. Many species wild in North America, and some cultivated; too difficult of determination for the beginner. The wild hawthorns are amongst the most decorative plants in the American landscape.

\section{SPIR Æ̇A. SPIREA, Fig. 193.}

Hardy perennial herbs and many ornamental shrubs: leaves alternate: flowers white or roseate, usually small but many; calyx 5-cleft, short and open; petals 5 ; stamens many: fruit of about 5 follicles, not inflated. A large and very interesting group of flowering plants, mostly with white bloom. Following are small shrubs:

S. salicifòlia, Linn. Meadow-sweet. Glabrous or nearly so, erect to 3 or $4 \mathrm{ft}$., stem often purplish: leaves simple, oblong-ovate to lanceolate, serrate, with stipules deciduous: flowers in terminal erect panicles, white or pinkish-tinged, small, with pods (follicles) 5, smooth, many-seeded. Moist or swampy ground. Summer.

S. tomentòsa, Linn. Hardhack. Erect, 2-4 ft. high, with pubescent stems, rusty or hairy: leaves simple, oblong or ovate, serrate, woolly on lower surface, without stipules: flowers in terminal thyrse-like dense panicles, pink or purple (rarely white), the follicles 5, pubescent or woolly: pastures and low grounds. Late summer.

S. trilobàta, Linn. Bridal wreath. Large bush with long recurving branches and bearing a profusion of showy flowers in flat-topped clusters: leaves round-ovate, crenately cut and 3-lobed. $S$. Van Houttei is an improved form. The forms of this species-group are the most popular cultivated spireas.

S. hypericifòlia, St. Peter's wreath. From 3-6 ft., leaves obovateoblong or wedge-shaped, obscurely toothed or lobed: flowers white, in many small iateral sessile clusters, on short branches. Cultivated.

S. Thúnbérgii, Sieb. Compact bush with very narrow leaves, sharply serrate and very light green: flowers umbellate, small, white. Handsome species from Japan. 


\section{SAXIFRAGĀCEA. Saxifrage Family.}

Herbs or shrubs of various habit, with opposite or alternate leaves that usually do not have stipules: flowers with ovary mostly inferior, 5 -merous, the stamens usually 10 or less (in a few cases as many as 40); pistils 10 or less, either separate or the earpels united, the frut a folliele, eapsule or berry. A polymorphous family comprising some 600 speeies in about 75 genera. Comprises saxifrage, mitre-wort, hydrangea, mock orange, currant and gooseberry.

A. Herbs.

B. Stamens twice as many as petals.

c. Petals entire: stamens usually 10.

D. Flowers in cymes or panicles (rarely solitary): capsule 2-beaked: ovary usually 2-eelled.......1. Saxifraga

DD. Flowers in racemes: ovary 1-celled: eapsule 2-beaked. with 1 beak the longer and larger....2. Tiarella

cc. Petals with edges fringed or eleft............. Mitella

BB. Stamens (fertile) 5, or equal in number to the petals: elusters of sterile stamens opposite each petal.....4. Parnassia

AA. Shrubs.

B. Leaves opposite.

c. Stamens 8 or 10 .

D. Flowers all alike: sepals $5 \ldots \ldots \ldots \ldots \ldots \ldots \ldots$. Deutzia

DD. Flowers usually of 2 kinds: the marginal ones enlarged and neutral, apetalous............. Hydrangea

cc. Stamens many: petals 4 or 6 , large, white........ 7. Philadelphus вв. Leaves alternate.................... Ribes

\section{SAXÍfRAGA. SAXifrage.}

Herbs, with root-leaves in rosette: flowers perfect, small, whitish, in cymes or panieles, on leafy stems or leafless scapes; sepals 5 , more or less united; petals 5 , entire inserted on ealyx-tube; stamens mostly 10; styles 2 and capsule 2-beaked, or of nearly separate divergent pods.

S. virginiénsis, Michx. Little perennial herb with spatulate or obovate, petioled, erenate, thick leaves: seape 3-12 in., ereet, viseid-pubeseent, bearing many small, white flowers in a loose cyme, the petals exceding the calyx. In early spring, on moist banks and rocks.

2. tiarélla. False Mitrewort.

Perennials, with small white flowers in racemes: calyx white, campanulate, 5-lobed; petals 5, entire on claws; stamens 10 , with long filaments from the ealyx-tule; ovary 1-eclled, nearly superior; styles 2, long and slender: eapsule with two very unequal beaks.

T. cordifolia, Linn. Seape slender, pubeseent, leafless or with 1 or 2 leaves: stoloniferous from rootstoeks: leaves cordate, lobed or toothed, petioled, slightly hairy or downy beneath: flowers white, in short raecme. Spring. Handsome. 


\section{3. mitélla. Mitrewort. Bishop's Cap.}

Delicate little perennials, with small, white flowers in a raceme or spike, the basal leaves heart-shaped or reniform: scape with 2 opposite leaves, or 1 or none: calyx short, 5 -cleft, adherent to base of ovary; petals 5 , white edges daintily fringed, inserted on calyx; stamens $5-10$, with short filaments, on petals; styles 2, short.

M. diphýlla, Linn. About $1 \mathrm{ft}$. tall: root-leaves in a cluster, cordate, ovate, somewhat $3-5$-lobed, toothed, hairy: scape rather hairy, with 2 opposite nearly sessile leaves near middle: flowers tiny, many, white. May to early June, in rich woods.

M. nùda, Linn. Very delicate and slender: scape usually leafless: basal leaves reniform, crenate: flowers few, greenish, very small, pedicelled; not common. Damp, cold woods, northward. Late spring and early summer.

\section{Parnássia. Grass of Parnassus.}

Low, glabrous perennials, belonging mostly to marshy or wet situations: root-leaves in rosettes, rounded, entire; stem-leaves 1 or few, alternate: flowers solitary, terminal, on a scape-like stem, white or greenish; calyx 5-lobed to near base; fertile stamens 5, alternating with the 5 whitish petals, a cluster of sterile filaments at base of each petal; ovary superior 1-celled, with 4 parietal placentæ, and usually 4 stigmas.

P. caroliniàna, Michx. One flower with sessile petals, white, with greenish veins, $1-1 \frac{1}{2}$ in. broad: root-leaf thickish, ovate or cordate, 1 leaf usually near base of scape: 6-15 in. high. Wet places. Summer.

\section{DEÙTZIA.}

Shrubs, having opposite, simple, exstipulate leaves: flowers panicled or racemed, numerous, white or pinkish: calyx-lobes 5 ; petals 5 to many; stamens 10, 5 long and 5 short, the filaments flat, commonly with 3 prongs, the middle prong antheriferous; ovary inferior, styles $3-5$.

D. grácilis, Sieb. \& Zucc. Grows to 2 or $3 \mathrm{ft}$.: flowers many, white, single or double: leaves oblong-lanceolate, sharply serrate, green and smooth. June. Cultivated from Japan.

D. scàbra, Thunb. Tall, pubescent: leaves ovate or oblong-ovate, finely crenate or serrate: flowers pinkish. Later-blooming than preceding, and much larger. China and Japan.

\section{HYDRÁNGEA.}

Shrubs, with opposite, stalked exstipulate leaves, and flowers of two kinds in terminal corymbs or cymes, the outer ones usually sterile, often apetalous, consisting merely of a showy, flat or spreading 5-lobed calyx, the fertile flowers small, with calyx-tube 4-5-toothed; petals 4 or 5 : stamens $8-$ 10, filaments slender; ovary inferior, 2-celled (rarely 3- or 4-celled); styles 2-4.

H. arboréscens, Linn. Leaves ovate, obtuse or cordate at base, acuminate, serrate, green on both surfaces, nearly or quite smooth: flowers in flat cymes, often all fertile, but sometimes with many large, white, sterile flowers. Along streams. June to July. 
H. Horténsia, DC. Smooth, with large, toothed, bright green oval leaves and flowers nearly all neutral, pink, blue or whitish, in great roundish clusters. China and Japan. Cultivated in greenhouses.

H. paniculàta, Sieb. Somewhat pubescent, with oblong-ovate, longpointed, dull, sharp-toothed leaves, and whitish flowers in great elongated panieles. Japan. The common hydrangea of lawns.

7. Philadelphus. Mock Orange (from the flowers). Syringa.

Shrubs with showy corymbose or paniculate white flowers and opposite simple leaves: petals 4 or 5 ; stamens 20 or more; ovary $3-5$-loculed, becoming a capsule.

P. coronàrius, Linn. Tall shrub with erect branches: leaves oblongovate and smooth: flowers eream-white, fragrant, in close clusters, in late spring. Europe.

P. grandiflòrus, Willd. Tall, with long recurving branehes: leaves ovatepointed and somewhat downy beneath: flowers pure white, scentless, in loose elusters. Virginia, south, and planted.

\section{Rìbes. Gooseberry and Currant.}

Low shrubs, often prickly, with alternate digitately lobed leaves: flowers small; sepals 5 and petal-like, on the ovary; petals and stamens 5 , borne on the calyx: fruit a small globular berry.

\section{a. Gooseberries: flowers 1-3: usually spines below the leaves.}

R. oxyacanthoìdes, Linn. Small bush, with long, graceful branches and very short thorns or none: leaves thin, orbicular-ovate, about 3 -lobed, the edges thin and round-toothed: flowers on very short peduncles, the calyx-lobes longer than the calyx-tube, the ovary and berry smooth, the fruit reddish or green. Swamps North; probable parent of Houghton and Downing gooseberries.

R. Grossulària, Linn. English gooseberry. Stiffer and denser bush, with firm and thickish more shining leaves, which have revolute margins: ovary downy and the large fruit pubescent or bristly. Europe; parent of the largefruited gooseberries.

R. Cynôsbati, Linn. Tall, open prickly bush, with thickish bluntly 3-lobed downy leaves and long peduncles bearing 3 or more flowers with calyx-lobes shorter than the tube: leaves rounded and 3-lobed: fruit dull purple, either prickly or smooth. Common in dry places.

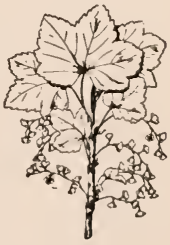

540. Ribes,vulgare.

aa. Currants: flowers in long racemes: no spines.

R. vulgàre, Lam. Red and white currant. Fig. 540. Erect bush, with broad-cordate 3-5-lobed leaves with roundish lobes end not strong-smelling: racemes drooping, the flowers greenish and nearly flat open: berries (currants) red or white. Europe.

R. nigrum, Linn. Black currant. Stronger bush, with strong-scented 
leaves and larger oblong or bell-shaped flowers with bracts much shorter than the pedicels: berries black and strong-smelling. Europe.

R. flóridum, L'Her. (R. americanum, Marsh.). Wild black currant. Fig. 541. Straggling bush, with heart-shaped 3-5-lobed doubly serrate somewhat scented leaves: flowers in long racemes, whitish, with bracts longer than the pedicels: fruit black, scented. Woods.

R. aùreum, Pursh. Golden, buffalo, or flowering currant. Fig. 542.

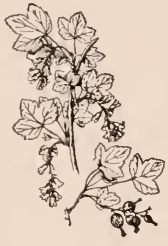

541. Ribes floridum. Large bush, with racemes of long-tubular yellow very fragrant flowers: fruit blackish. Missouri, west, but common in gardens for its flowers.

\section{ONAGRĀCEæ. Evening Primrose Family.}

Mostly herbs: leaves various, alternate or opposite, without stipules: flowers perfect, usually 4-parted, with calyx-tube joined to ovary and often prolonged, the margin 4-lobed, lobes valvate in the bud, usually reflexed in flower: petals 4 (2-9), on throat of calyxtube: stamens as many or twice as many as petals: style 1 , slender, the stigma 4-lobed (sometimes 2-lobed); ovary 2-4-celled. More than 300 species and 40 genera, of wide distribution.

A. Calyx-tube much prolonged beyond the ovary.

B. Lobes generally reflexed: fruit a dry capsule, dehiscent..1. Enothera

вв. Lobes large and spreading: calyx-tube highly colored:

fruit a.4-celled berry: flowers drooping............ Fuchsia

A A. Calyx-tube not much prolonged.

B. Stamens 8 ; petals $4 \ldots \ldots \ldots \ldots \ldots \ldots \ldots \ldots \ldots \ldots$ Epilobium

Bв. Stamens 2 ; petals $2 \ldots \ldots \ldots \ldots \ldots \ldots \ldots \ldots \ldots \ldots$. Circáa

\section{ENOTHERA. Evening Primrose.}

Herbs, stems usually erect: leaves alternate: flowers brightly colored, regular, axillary or in terminal spikes; calyx-tube proionged beyond ovary,

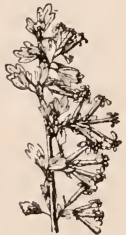

542. Ribes sureum. the 4 lobes usually reflexed, sometimes soon falling; petals 4 ; stamens 8; stigma 4-lobed; capsule usually narrow and long, 4-celled, many-seeded.

⿷. biénnis, Linn. Common evening primrose. Figs, 276, 415. Stem erect, 2-5 ft., hairy and leafy: leaves lance-oblong, somewhat repandly-toothed; flowers pure yellow, fragrant, in terminal, leafy spikes, not remaining open in broad sunshine: calyx-tube 2 to 3 times longer than ovary and lobes reflexed; petals obcordate: pod oblong, bluntly 4-angled. A very common biennial of roadside and pasture, opening quickly at nightfall.

E. fruticòsa, Linn. Sundrops. Biennial or perennial: stem 
erect, 1-3 ft., leafy, more or less hairy: flowers yellow, 1-2 in. in diameter, in eorymbed racenes, open in daytime: pod decidedly 4-angled and 4ribbed, rather downy, shortly stalked. Dry soil.

E. pùmila, Linn. Resembles preceding, but smaller, 5-12 inches high: corolla yellow, about $1 / 2$ in. across: pod smooth, 4 -angled, sessile or shortstalked. Dry soil.

2. FÙCHSIA. Figs. $172,183,205$.

Herbs or shrubby plants (some trees): leaves opposite, or 3 in a whorl: flowers drooping, axillary; ealyx-tube colored, extended beyond ovary; margin 4-lobed, spreading; petals 4 on throat of calyx; stamens 8 , projecting; style long: fruit a 4 -celled berry. $\Lambda$ number of species of these ornamental plants in cultivation. Mainly native to South America.

F. magellánica, Lam. Smooth and tender: leaves simple, toothed, slender-petioled: flowers hanging on long peduneles from leaf axils; calyx red, lobes long, exceeding the tube and the petals; petals blue or purple or red, obovate, notehed, convolute about the bases of the long filaments and style. The common window-garden fuchsias ( $F$. speciosa) have descended from this species, more or less hybridized with others.

\section{EPILÒBIUM. WILLOW-HERB.}

Mostly perennials, with leaves nearly sessile, alternate or opposite: flowers white or purple, spicate, racemed, or solitary; calyx-tube little if any longer than ovary, limb 4-eleft; petals 4; stamens 8; stigma 4-lobed: fruit linear, 4 -sided, dehiseent by 4 loeulieidal valves, many-seeded: seeds with tuft of long, silky hair attached to tip.

E. angustifolium, Linn. Purple fireweed. Stem simple, erect, 4-7 ft.: lower leaves alternate, lanceolate, nearly entire: racemes long, terminal, showy; flowers large, about 1 in. across, reddish purple. Common in woods.

\section{CiRC EA. Enchanter's Nightshade.}

Low, delieate, and insignificant perennial herbs, with creeping rootstocks: leaves opposite, very thin, petioled: flowers very small, in terminal and lateral racemes; calyx-tube slightly prolonged beyond ovary; parts of the flower in 2's. Damp, shady places. Summer.

C. Lutetiàna, Linn. Stem erect, 1-2 ft. tall, pubeseent: leaves ovate, slightly repand-toothed: flowers white or pink, about $1 / 8 \mathrm{in}$. in diameter, on slender pedicels, bractless: fruit small, round, 2-celled, bristly. The common species in damp, shady places in summer.

\section{UMBELlífere. Parsley Fammy.}

Herbs, mostly strong-scented and with compound alternate leaves with petioles expanded or sheathing at the base: flowers small, mostly perfeet, 5-merous, epigynous, in umbels or umbel-like clusters; stamens 5: fruit consisting of 2 carpels, which are dry and secd-like and 
indehiscent. Oil-tubes, in the form of stripes, 1 or several in the intervals of the ribs on the fruits, also sometimes under the ribs and on both faces of the fruit, are characteristic features of the Umbelliferæ. A well-marked natural family of about 1,500 species in about 160 genera. Some of the species are poisonous. Here belong parsley, parsnip, carrot, celery, caraway, sweet cicely. Rather difficult for the beginner.

A. Fruits bristly....................................

AA. Fruits not bristly.

B. The fruits winged.

c. Wing single, surrounding the margin: flowers yellow ............................. Pastinaca

Cc. Wing double on margin: flowers white........... Angelica

Bв. The fruits wingless.

c. Fruit long and slender, tapering at base: no apparent oil-tubes: flowers white............... Osmorrhiza

cc. Fruit ovate or orbicular.

D. Plant low and delicate: blooms in earliest spring: stem with 1 or 2 leaves, if any ........... Erigenia

nD. Plant tall: stems leafy.

E. Axis not splitting in two when the carpels fall from it........................ Apium

EE. Axis splitting in two when the carpels or "seeds" fall. Leaf-segments filiform, flowers white...7. Carum

\section{DAÛCUS. Carrot.}

Annuals or biennials, bristly, slender and branching, with small white flowers in compound umbels, the rays of which become inflexed in fruit: the fruit oblong, ribbed and bristly.

D. Caròta, Linn. Carrot. Figs. 194, 410. Leaves pinnately decompound, the ultimate segments lanceolate: outer flowers with larger petals. Europe; cultivated for the root, and extensively run wild.

2. PASTIN ÀCA. PARSNip.

Tall, smooth biennials of strict habit and with pinnately compound leaves: flowers yellow, in compound umbels with scarcely any involucres: fruit oval, very thin, wing-margined.

P. sativa, Linn. Parsnip. Flowering stem 2-4 ft. tall, grooved, hollow: leaflets ovate or oblong, sharp-toothed. Europe; cultivated for its roots and also run wild.

\section{ANGELICA.}

Strong, tall, perennial weeds, with great compound leaves and large umbels of small white flowers, with involucre and involucels none, or only a few small bracts: fruit ovate or oval, flattened, with rather broad, marginal wings: oil-tubes many, 
A. atropurpùrea, Linn. A great weed, 3-8 ft. tall, in moist, rieh soil or swampy ground, with stem stout, smooth, strong-seented, often purple: leaves large, 3-compound, on petioles with broad, inflated bases: umbels large, flowers greenish white.

\section{OSMORRHİZA. SWEet CiCEly.}

Herbs, 1-2 ft. or more, perennial, glabrous or pubeseent, from thickclustered, aromatie roots: leaves 2 or 3 times pinnately compound; leaflets variously toothed,-the whole leaf fern-like: flowers many, small, white, in eompound, rayed umbels: fruit linear to linear-oblong, attenuate at base, short-beaked, eompressed, with 5 bristly ribs: no oil-tubes.

O. Clàytònii, Clarke. Stout, downy, 1-2 or $3 \mathrm{ft}$.: style eonieal, shorter than the ovary.

O. longistylis, DC. Glabrous or nearly so, otherwise much like the preceding: style slender and about as long as the ovary: root aromatic.

\section{ERIGENİA.}

Little, glabrous perennial, early flowering: simple stem, springing from a rounded tuber: leaves finely compound: flowers in small elusters, in leafy braeted umbels, small, white; ealyx-teeth wanting; petals obovate or spatulate: fruit nearly orbieular, eompressed on sides, glabrous, notched at both ends.

E. bulbòsa, Nutt. Harbinger of spring. A delicate and pretty but inconspieuous plant, 4-10 in. high, springing from the ground in earliest spring, on sunny slopes of woodlands. The little white petals and brown or purplish anthers give a "pepper-and-salt" appearance.

\section{6. ÀPIUM. Celery.}

Annuals or biennials, with large pinnate leaves: flowers white, in small umbels: fruit small, usually as broad as long, each carpel 5-ribbed: axis, from which the earpels fall, not splitting in two.

A. gravèolens, Linn. Celery. Biennial, smooth: leaflets 3-7, wedgeshaped or obovate, the lower ones about 3-divided, round-toothed, Europe: eultivated for its petioles, which have become greatly enlarged. Many cultivated forms.

\section{CÀrUM. Caraway.}

Slender and ereet, smooth annual and biennial herbs with pinnate leaves: flowers white, in compound umbels provided with involueres: axis bearing the earpels, splitting in two at maturity.

C. Cárui, Linn. Caraway. Sten furrowed, 1-2 ft.: leaves cut into thread-like divisions: flowers white. Europe. Cultivated for its fruits, known as "Caraway seed," and also run wild.

C. horténse, Hoffm. (C. Petroselinum, Benth. Petroselinum hortense, Hoffm.). Parsley. One to $3 \mathrm{ft}$.: leaflets ovate and 3-eleft, of ten much eut or "eurled" in the garden kinds: flowers yellowish. Europe. Grown for its foliage, used for garnishing and flavoring. 


\section{GAMOPETALA.}

\section{LABIÀTA. Mint FAMILY.}

Herbs, usually of aromatic scent, with 4-cornered stems and opposite usually simple leaves: flowers typically 2-lipped; stamens 4 in 2 pairs, or only 2 ; ovary deeply 4-lobed, forming 4 indehiscent nutlets in fruit. A well-marked family of some 2,700 species, distributed in about 150 genera, of both temperate and tropical regions. To this family belongs the various mints, as peppermint, spearmint, catnip, hyssop, thyme, pennyroyal, savory, rosemary, sage, horehound, balm, basil. Flowers mostly in whorls in the axils of leaves or bracts, sometimes forming interrupted spikes.

A. Stamens 2 .

B. Calyx nearly equally toothed.

C. Lobes 5 : throat hairy.................. 1. Monarda

cc. Lobes 4-5: throat naked................ 2. Lycopus

вв. Calyx 2-lipped.

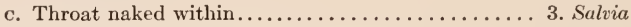

cc. Throat hairy: plants very pungent-scented....... 4. Hedeoma

AA. Stamens 4 .

B. Corolla scarcely 2-lipped: lobes nearly equal.

c. Border of corolla 4-lobed: upper lobe broadest and emarginate.......................... Mentha

cc. Border of corolla 4-lobed, with a deep fissure between the 2 upper lobes.................6. Teucrium

Bв. Corolla strongly 2 -lipped.

C. Calyx 2-lipped.

D. Lips of calyx toothed: flowers in dense terminal spikes or heads...................... 7. Prunella

DD. Lips of calyx entire, the upper humped, or appendaged: flowers axillary in bracts or leaf axils, solitary or racemed ............... 8. Scutellaria

cc. Calyx nearly or quite regular.

D. Upper pair of the stamens the longer......... 9. Nepeta

DD. Upper pair of the stamens the shorter.

E. Stamens short, included in the tube of the corolla...........................10. Marrubium

EE. Stamens long, projecting from the corolla-tube. 11. Leonurus

1. MONÁRdA. HoRse-MINT.

Rather stout, mostly perennials, with fiowers in close terminal heads: calyx tubular, 15-nerved, hairy in the throat, the teeth nearly equal: corolla strongly 2-lipped, the upper lip erect, the lower spreading and 3-lobed.

M. fistulòsa, Linn. Two to $5 \mathrm{ft}$., in clumps: leaves ovate-lanceolate: 
flowers in a clover-like flattish head: ealyx slightly curved: corolla about $1 \mathrm{in.}$ long, purple. Common in dry places.

M. dídyma, Linn. Oswego tea. Bee balm. Stem 4-angled and branehing: leaves petioled, shortly ovate to lanceolate, those ahout the terminal head tinged with red: not very eommon wild, but cultivated.

\section{LYCopus. Water Hoarhound.}

Low perennials, with stolons or suckers, much like the mints (Mentha) and growing in similar moist or shady places: not aromatic: flowers small, white clustered in leaf axils: calyx bell-shaped, 4- to 5-toothed: corolla campanulate, with 4 nearly equal lobes: fertile stamens 2 , the other 2 rudimentary or wanting: flowers small, white or purplish, bracted and whorled in axillary elusters.

L. virgínicus, Linn. Stem 6 in. to $2 \mathrm{ft}$, obtusely 4 -angled, green or often purplish: stoloniferous: leaves oblong or ovate-lanceolate, serrate, except at base, short-petioled or nearly sessile. In moist places. Summer.

\section{SÁlVIA. SAge.}

Annuals or perennials, mostly with large and showy flowers: calyx and corolla 2-lipped: upper lip of corolla large and usually arehed, entire or nearly so, the lower lip spreading and 3-lobed: stamens 2, short, the anther locules separated by a transverse bar.

S. officinàlis, Linn. Common sage. Erect low perennial, with gray pubescent foliage: leaves oblong-lanceolate, crenulate, very veiny: flowers blue, in spiked whorls. Europe; used for seasoning.

S. spléndens, Sell. (S. coccínea of gardens). Scarlet sage. Tender perennial from Brazil, but much eultivated for its bright scarlet floral leaves, calyx, and corolla: leaves ovate-pointed.

\section{4. hedeòma. Mock Pennyroyal.}

Low, aromatic-fragrant herbs, with small bluish flowers in loose axillary clusters, often forming terminal racemes or spikes: calyx tubular, 13-nerved, swollen on lower side, hairy in throat, 2-lipped; corolla 2-lipped, upper lip ereet, flat, emarginate, the lower spreading and 3-eleft, 2 perfect stamens; 2 shorter sterile stameus sometimes present.

H. pulegioides, Pers. Sniall annuals of pungent fragrance and taste, with slender stem 6-12 in. tall, ereet, branching, pubescent: leaves ovate to oblong, about $1 \mathrm{in}$. long, few-toothed, petiolate: whorls few-flowered, the corolla bluish, pubescent. In dry fields and woods. Summer.

\section{MÉNTHA. Mint.}

Low perennials: calyx with 5 similar teeth: corolla nearly or quite regular, 4-cleft: stamens 4, equal: flowers in heads or interrupted spikes, pur-. plish or white.

M. piperita, Linn. Peppermint. Straggling, $1-3 \mathrm{ft}$. tall, the plant dark colored (stems purphsh): leaves ovate, oblong, or narrower, acute, sharply serrate: flowers light purple, in thick spikes 1-3 in. long. Europe. 
M. spicàta, Linn. (M. viridis, Linn.). Spearmint. Fig. 543. Erect and smooth, 1-2 ft., green: leaves lanceolate and sharply serrate: flowers whitish or tinted, in long, interrupted spikes. Europe. Along roadsides, and cultivated.

M. canadénsis, Linn. Wild mint. One to $2 \mathrm{ft}$., pubescent: leaves lanceolate: flowers tinted, in whorls in the axils of the leaves. Low grounds.

\section{TEÙCRIUM. Germander.}

Perennial herbs (or shrubs) with small, pinkish, rather irregular flowers, in terminal bracted spikes (or heads) or verticillate in the upper axils of the stem-leaves: calyx 5-toothed, 10-nerved: corolla 5-lobed, with 4 upper lobes oblong, somewhat equal, and turned forward, the lowest lobe large, rounded: stamens 4 , in 2 pairs, projecting from a deep fissure between the 2 upper

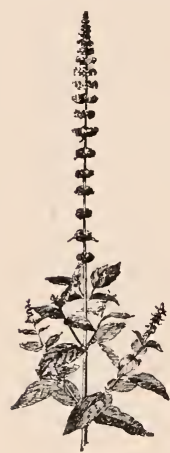

543.

Mentha spicata. lobes of the corolla.

T. canadénse, Linn. Erect, pubescent, 1-3 ft.: leaves ovate-lanceolate, irregularly serrate, short-petioled: bracts under the flowers linear-lanceolate, about as long as calyx: spike long and slender, the few odd-looking purplish or pinkish flowers in crowded verticels. Damp ground. Late summer.

\section{PRUNélla. Self-heal.}

Low, usually unbranched perennials without aromatic odor: calyx about 10-nerved, 2-lipped: corolla 2-lipped, the upper lip arched and entire, the lower one 3-lobed: stamens 4 , in pairs, ascending under the upper lip.

P. vulgàris, Linn. Self-heal. Three to 10 in. tall, with ovate or oblong, usually slightly toothed leaves: flowers small, violet (rarcly white), in a dense, oblong, clover-like head or spike. Common in grassy places; often a weed ir. lawns.

\section{SCUTELLÀria. SKULlCAP.}

Perennials, bitter, not aromatic: flowers solitary or in pairs, axillary or in bracted spike-like racemes; calyx bell-shaped, 2-lipped, the lips closed in fruit, the upper one appendaged on the back (at maturity the calyx splits to the bottom, the upper lip usually falling off); corollatube elongated, curved and ascending, swollen above the throat, 2-lipped, the upper lip arched and notched: stamens 4, ascending in pairs under the upper lip, the upper pair shorter.

S. laterifòlia, Linn. Mad-dog skulleap. Smooth, 1-2 ft. high: stem nearly or quite erert, much branched, slender, leafy: leaves thin, ovatelanceolate, pointed, serrate, petioled: flowers blue (rarely white), small, $1 / 4-1 / 3$ in. long, in axillary, 1 -sided racemes (some terminal). Wet, shaded places. Summer. Several related species grow in bogs and along slow streams, but most of them will not be likely to attract the attention of the beginner, although all are odd or interesting. 


\section{NÉPETA. Catmint.}

Perennials, mostly sweet-seented: calyx nearly equally 5-toothed; corolla 2-lipped, the upper lip ereet and somewhat coneave, the lower 3-lobed: stamens 4 , in pairs under the upper lip, the outer pair the shorter.

N. Catària, Linn. Common catmint or catnip. Figs. 213, 414. Ereet, 2-3 ft., pubesent: leaves eordate-ovate, erenate, grayish: corolla tinted: flowers in interrupted spikes. Introduced from Europe.

N. hederàcea, Trev. (N. Glechoma, Benth.). Ground ivy. Gill-over-theground. A weed from Europe, but familiar almost everywhere: ereeping, with rounded, crenately margined, petioled leaves: flowers bluish purple, small.

\section{MARRÙBIUM. HOREHOUND.}

Erect perennials, with white-woolly aspect: calyx nearly equally 5-10toothed, the teeth very sharp: corolla 2-lipped, the upper lip erect and notched, the lower one spreading and 3-lobed: stamens 4 , included in the corolla-tube. There are a number of Old World speeies, but only the following seems to have run wild in this country:،

M. vulgàre, Linn. Common horehound. Leaves broad-ovate and crenate: flowers small, white, in dense whorls. Europe, but common.

\section{LEONÜRUS. MOTHERWORT.}

Ereet perennials with green aspeet: calyx about equally 5-toothed, the teeth becoming spine-like; corolla 2-lipped, the upper lip somewhat arched and entire, the lower spreading and 3-lobed: stamens 4, aseending under the upper lip: nutlets 3-angled.

L. Cardiaca, Linn. Common motherwort. Tall: leaves rounded and lobed: corolla purple, the upper lip bearded; flowers in axillary whorls. Introduced from Europe. Common. Other introduced species may now and then be found.

\section{VERBENĀCEA. Vervain Family.}

Herbs, shrubs or trees: leaves opposite or whorled (in our species), exstipulate: flowers monopetalous, often irregular, in bracted cymes or panicles; calyx free trom the ovary, 4-5-cleft; corolla sometimes regular, bui often more or less 2-lipped: stamens 4 (rarcly 2 ), in unequal pairs, inserted on corolla, alternate with lobes; style 1; ovary mostly 2- to 4-celled (not lobed), with style from summit: . fruit dry or drupe-like. About 1,200 species, mostly tropical.

\section{VERBENA. VERVAIN.}

Herbs with simple, opposite, serrate or pinnately-lobed leaves: flowers usually sessile, bracted, in terminal spikes: corolla salver- or funnel-form, with border somewhat unevenly 5-cleft. 
V. urticæfolia, Linn. Perennial, common coarse weed in waste ground: 4-6 ft. tall: leaves oval, coarsely serrate, stalked: flowers minute, white, in slender spikes.

V. angustifòlia, Michx. A perennial, roughish weed, with stems 6 in. to $2 \mathrm{ft}$., mostly simple, leafy: leaves sessile, narrow-lanceolate, tapering to sessile base: flowers small, in spikes; corolla purple: fruits overlapping on spike. Dry fields.

V. strícta, Vent. Perennial, hoary-hairy: stem 1-3 ft., very leafy: leaves obovate or oblong, serrate and nearly sessile: spikes thick and densely flowered; flowers blue-purple, rather larger than in other common Vervains, $1 / 3$ in. across, but few open at one time. Westward.

V. hastàta, Linn. A common, rather pubescent weed of the waysides: stem 2-6 ft. tall, branching, with many slender spikes of the small, bracted, blue-purple flowers, few flowers in bloom at one time: leaves lanceolate, acuminate, petioled.

V. canadénsis, Brit. One of the species from which the garden Verbenas have come: stems rather prostrate and creeping: flowers in a corymb or peduncled spike and showy, of various colors and considerable size: leaves on petioles, ovate in outline, but pinnately cut or 3-parted. Wild from Indiana west.

\section{SCROPHULARIÃCEA. Figwort Family.}

Herbs (trees in warm countries), of various habit: flowers perfect, irregular, usually imperfectly 5-merous: corolla usually 2-lipped and personate: stamens 4 in 2 pairs, inseried on the corolla, with sometimes a rudiment of a fifth: ovary single, 2-loculed, ripening into a several- or many-seeded capsule. About 160 genera and 2,000 species. Representative plants are figwort, snapdragon, toad-flax, foxglove, mullein, pentstemon, monkey-flower or musk-plant.

A. Corolla very shallow and nearly regular........... 1. Verbascum AA. Corolla very irregular, often personate.

B. Flowers with long spur............... Linaria

BB. Flower spurless, but saccate or swollen at the base.. 3. Antirrhinum BBB. Flowers not spurred, saccate, or much swollen.

c. Stamens 5, but the fifth sterile, often a scale only.

D. Sterile filament a little scale on the upper side of the corolla: flowers small and dull-colored... 4. Scrophularia

DD. Sterile filament elongated: corolla 2-lipped.

E. Filament shorter than the others: the 2 lips of the corolla but slightly open: seeds winged ................. Chelone

EE. Filament about the same length as the others: corolla lip open: seeds wingless........6. Pentstemon 
DDD. Sterile filament, not conspicuous: corolla almost 2-parted, the middle lobe of the lower lip keeled, inclosing the 4 stamens ........... 7. Collinsia cc. Stamens plainly 4 .

D. Corolla 2-lipped: calyx 5-angled: flowers not drooping......................... Mimulus

DD. Corolla slightly 2-lipped, irregularly 5-lobed flowers drooping .................. 9. Digitalis

DDD. Corolla with upper lip narrow and ereet, much longer than the lower, and keeled: anthersacs are not alike: floral leaves colored like petals............................ Castilleja

ccc. Stamens 2 (or 2 others rudimentary or wanting).

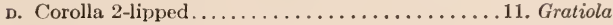

DD. Corolla rotate, lobes unequal............. Veronica

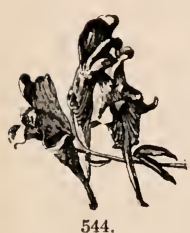

Linaria vulgaris.

\section{VERBÁSCUM. MULLEIN.}

Tall biennials, with alternate decurrent leaves: calyx and corolla 5-parted, the latter shallow and nearly or quite rotate; stamęns 5, some or all of the filaments woolly.

V. Thápsus, Linn. Common mullein. Fig. 147. Two to $5 \mathrm{ft}$., stout and usually unbranched, white-woolly: leaves oblong and acute felt-like: flowers yellow in a very dense spike. Weed from Europe.

V. Blattària, Linn. Moth mullein. Slender and branching, green and nearly smooth: leaves oblong, serrate, often laterally lobed, somewhat clasping: flowers yellow or cream-colored, in a loose raceme. Weed from Europe.

\section{LINÀRIA. TOAD-FLAX.}

Low herbs, of various habit: corolla personate, the throat nearly or entirely closed, spurred from the lower side: stamens 4: capsule opening by apical pores.

L. vulgàris, Mill. Toad-flax. Butter-and-eggs. Figs. $227,281,544$. Common perennial weed (from Europe), 1$2 \mathrm{ft}$., with linear leaves and yellow flowers in racemes.

L. Cymbalària, Mill. Kenilworth ivy. Fig. 545. Trailing: leaves orbicular, 5-7-lobed: flowers solitary on long peduncles, lilac-blue. Europe; very common in greenhouses and sometimes runs wild.

L. canadénsis, Dumont. Common annual or biennial in dry or sandy soil: flowering stems slender and erect, generally simple and fewleaved: also prostrate shoots, more leafy: leaves narrow, flat, entire, sessile, opposite or whorled: flowers small, blue, in a terminal, loose, slender raceme.

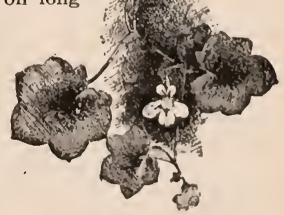

545. Linaria Cyubalaria. 


\section{ANTIRRHINNUM. SNAPDRAGON.}

From Linaria differs chiefly in having no spur, but only a swelling at the base of the corolla.

A. màjus, Linn. Snapdragon. Fig. 243. Erect biennial or perennial: leaves oblong, smooth, entire: flowers erect or ascending, 2 in. long, purple or white, in a raceme with downy axis. Europe.

\section{SCROPHULÀRIA. FigWORT.}

Herbs perennial, rank and generally ill-smelling, with opposite leaves, and very odd-looking small, greenish-purple flowers, in simple or compound loose terminal cymes: calyx deeply 5-parted: corolla irregular, with a globular tube, the limb 5-lobed, 4 upper lobes erect, but the lower one horizontal or reflexed: stamens 5,4 fertile, in two pairs, the fifth sterile and a mere rudiment at the top of the corolla-tube.

S. marilándica, Gray. Smooth, 3-6 ft., much branching, in thickets and damp woods, blooming in late summer and early fall; stems 4-angled: leaves ovate, oblong or lanceolate, coarsely toothed, 3-9 in. long, on slender petioles: flowers small, dull-colored.

\section{Chelòne. Turtlehead. Snakehead.}

Smooth, erect perennials, with opposite, serrate and stalked leaves: flowers large, sessile, white or rose-tinged, of curious shape, in the upper leaf axils, forming a terminal spike: calyx 5-parted, segments acute, bracted at base: corolla irregular, with inflated and elongated tube concave underneath, the limb 2-lipped, but lips only slightly open, the upper lip broad, usually emarginate, lower lip 3-lobed, bearded within: stamens 5 , the fifth sterile and smaller, the filaments woolly.

C. glàbra, Linn. Two to $4 \mathrm{ft}$. high, in swamps and by brooks or in wet places. Late summer.

\section{PENTSTEMMON. BEARD-TONGUE.}

Perennial herbs, with opposite leaves, the upper sessile or clasping: flowers showy: calyx 5-parted: corolla irregular, with tube more or less inflated and 2-lipped, the lower lip 3-lobed: stamens 5, 4 in 2 pairs each bearing an anther, the fifth filament conspicuous but sterile, sometimes longer than the others and bearded: fruit a globose capsule with many wingless seeds.

P. hirsùtus, Willd. (P. pubéscens, Ait.). Stems hairy, rather viscid above, 1-2 ft.: leaves narrow-oblong to lanceolate, minutely toothed or entire; panicle open: corolla about $1 \mathrm{in}$. long, 2-lipped, with a bearded palate in the throat, dull bluish violet or purplish. Dry situations. May to July.

\section{Collínsia. InNocence. Blue-eyed Mary.}

Pretty little annuals or biennials, branching and diffuse with opposite or verticillate leaves, and irregular flowers, blue and white, on pedicels, whorled or solitary in the axils of the upper leaves: corolla 2-lipped with the upper lip 2-cleft, the lower lip 3-cleft, with the middle lobe keeled and 
saccate, inclosing the 4 stamens and the style: a fifth stamen reduced to a mere rudiment.

C. vérna, Nutt. Stem \&-16 in., branching: leaves small, various, the lower ovate, the upper more lanceolate and elasping, margins erenate or toothed: flowers on long peduncles, in whorls of $4-6$ : corolla $1 / 2-2 / 3$ in., twice longer than ealyx: 3 lower petals sky-blue or pink, upper 2 petals, white. An extremely attractive plant in woods, blooming April to June.

\section{Mímulus. MONKEY-FLOWER.}

Small herbs with opposite leaves, with usually showy solitary flowers on axillary peduncles: ealyx 5-angled and 5-toothed: corolla tubular, the 2lobed upper lip ereet or spreading; stamens 4; stigma 2-łobed.

M. ríngens, Linn. Wild monkey-flower. Ereet perennial, with square stem and oblong or lanceolate clasping serrate leaves: flowers blue or light purple, somewhat personate. Wet places.

M. lùteus, Linn. Monkey-flower. Tiger-flower. Fig. 546. Annual, with ovate serrate leaves: flowers large, yellow, blotehed with briek-red or brown. Western America, and commonly cultivated. To gardeners often known as $\boldsymbol{M}$. tigridioides.

\section{Digitàlis. Foxglove.}

Stem simple and strict: leaves alternate: flowers with a long expanding tube and a very short indistinctly lobed limb, the throat wholly open: stamens 4.

D. purpùrea, Linn. Common foxglove. Usually biennial, tall and stout $(2-4 \mathrm{ft}$.): leaves oblong,

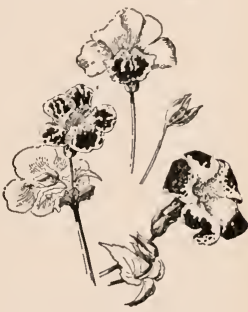

546. Mimulus luteus, nearly or quite entire, rough and downy: flowers many, drooping, in a long, erect raceme, $2 \mathrm{in}$. long, white to purple and spotted inside. Old garden plant from Europe.

\section{Castillèja. Painted Cup.}

Herbs, at least partially parasitie on roots of other plants: flowers sessile in leafy, often brilliantly colored, bracts; ealyx tubular, 2-4-cleft; corolla very irregular, tubular, the tube ineluded in the ealyx, the upper lip very long, arehed and keeled, enfolding 2 pairs of stamens; lower lip short, 3-lobed. Late spring and summer. Four or 5 speeies in our territory.

C. coccínea, Spreng. Annual or biennial, 8-12 in., with very striking infloreseence of scarlet or yellow 3-cleft bracts surrounding the flowers. Damp meadows or thickets, not eommon but conspicuous.

\section{GRatiola. Hedge Hyssop.}

Low, mostly perennial herbs, found in damp situations: leaves opposite: peduncles axillary, 1-flowered each; calyx 5-parted, segments scarcely equal; corolla 2-lipped, upper lip emarginate or 2-eleft, lower 3-lobed: fertile stamens 2 . 
G. virginiàna, Linn. Stems branching, or creeping at base, more or less viscid, 4-6 in. tall: leaves oblong or lanceolate, few-toothed, sessile: flowers with yellowish corolla, $1 / 3-1 / 2$ in. long: sterile filaments not present. Wet places. All summer.

\section{VERÓNICA. SPEEDWELL.}

Ours herbs with leaves mostly opposite or whorled, blue or white flowers solitary or in racemes from the lcaf-axils, or terminal; corolla wheel-shaped, the border irregularly 4-lobed; stamens 2, inserted on corolla-tube, with slender long filaments: ovary 2-celled, style slender: capsule flattened, notched at apex, 2-celled, few- to numerous-seeded.

V. americàna, Schw. Perennial, weak and decumbent at base, rooting at nodes, finally erect: leaves opposite at base, mostly petioled, thickish. oblong to lance-ovate, serrate racemes axillary, opposite, 2-3 in. long: flowers small, pale blue, on slender pedicels: capsule swollen, many-seeded. Common in and about brooks and swampy ground. June through summer.

V. officinàlis, Linn. Little pubescent prostrate perennial, $6 \mathrm{in}$. to $1 \mathrm{ft}$., in dry fields and woods: leaves wedge-oblong, or obovate, short-petioled, serrate: racemes spike-like, longer than leaves; flowers pale blue. July.

V. peregrìna, Linn. Annual, glabrous, erect, 4-9 in., branched: lower leaves thick, oval, toothed, petioled; others sessile, entire: flowers very small, whitish, axillary and solitary: capsule orbicular, slightly notched. A common weed. April to June.

V. serpyllifòlia, Linn. Perennial, creeping; leaves small, rounded, almost entire: flowering stems smooth, simple, ascending 2-6 in.; flowers very small, in terminal racemes; corolla pale blue or whitish with purple stripes, exceeding calyx. Common in lawns and grassy fields. May, through summer.

\section{SOLANĀCEÆ. Nightshade Family.}

Herbs or shrubs, with alternate often compound leaves: flowers perfect and regular, 5-merous, mostly rotate or open-bell-shaped in form and plaited in the bud; stamens 5, often connivent around the single 2-loculed pistil, borne on the corolla: fruit a berry or capsule (the latter sometimes 4-loculed by a false partition), the seeds borne on a central column. Some 70 genera and 1,500 species. Common representatives are nightshade, potato, tomato, husk tomato, cobacco, jimson-weed, petunia.

A. Fruit a fleshy berry.

в. Fruiting calyx bladdery-inflated and wholly inclosing the fruit; anthers not connected, opening lengthwise............................... Physalis

Bв. Fruiting calyx not inflated. 
c. Stamens with anthers equaling or exeeeding the filaments.

D. Anthers separate or barely eonnected, opening

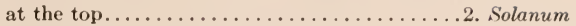

DD. Anthers united, opening lengthwise......... Lycopersicum cc. Stamens with anthers much shorter than filaments.4. Capsicum As. Fruit a eapsule.

B. Calyx 5-parted to near base................ Petunia

вв. Calyx toothed, not deep-parted.

c. Pod usually prickly, large............... Datura

cc. Pods not priekly, small................ Nicotiana

\section{PhÝsalis. Ground Cherry.}

Herbs, flowering through the summer: flowers solitary, nodding on axillary peduncles: leaves alternate or often somewhat paired, margins entire or sinuate: calyx enlarging after flowering, and finally inelosing the pulpy berry as a much-inflated papery sac; corolla yellowish or white, often with dark eenter, wheel-shaped, with short tube, the border obseurely 5-lobed, plaited in bud.

P. virginiàna, Mill. Perennial by rootstoeks, viseid: fruiting ealyx pyramidal, elosed, more or less 5-angled and indented at base: berry reddish yellow, edible, not filling the loosely inflated ealyx: corolla yellow, nearly an inch in diameter, with brown eenter, and edge 5- to 10-angled: anthers yellow. Open places, in rich soil. Summer.

P. pubéscens, Linn. Low annual, more or less pubescent and clammy: stem generally diffuse in branching, 9-18 in. tall, often somewhat swollen at nodes: corolla small, about $1 / 2$ in. across, yellow or greenish, with a dark, spotted center; anthers purple: the green or yellow berry does not fill the closed, 5-angled ealyx. In low or damp places.

\section{SOlĀNUM. Nightshade.}

Perennials or annuals: calyx and corolla 5-parted, the latter rotate; stamens 5 , exserted, the anthers separate and opening by a pore in the top: berry 2-loculed.

\section{a. Plants not prickly.}

S. tuberòsum, Linn. Potato. Figs. 24, 45, 242. Low, diffuse-growing perennial, producing stem-tubers on slender underground rootstocks: leaves pinnate, the leaflets differing in size and ovate: flowers bluish: berries globular, yellowish green. Warm temperate elevations of tropical Ameriea. The "Irish," "white" or "round" potato.

S. nigrum, Linn. Common nightshade. Branchy annual, 1-2 ft., nearly smooth: leaves ovate, wavy-margined: flowers small, white: berries small, black. Waste plaees.

S. Dulcamàra, Linn. Bittersweet. Fig. 424. Tall, loosely climbing: leaves cordate-ovate, sometimes 3-lobed, often with 2 or 4 small leaflets at the base: flowers small, violet-purple: berries oval, red. Perennial. Common. 


\section{aa. Plants prickly.}

S. Melóngena, Linn. Eggplant. Guinea squash. Fig. 288. Stout annual with large, ovate, somewhat angled pubescent leaves: flower large, purplish, the caiyx prickly: fruit a very large purple or white berry (often weighing

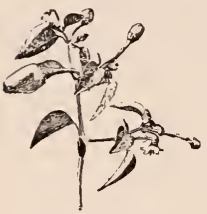
several pounds). India.

\section{LYCOPÉRSICUM. TOMATO.}

Differs from Solanum chiefly in having the anthers united at their tips by a membrane and opening by lengthwise slits.

L. esculéntum, Mill. Common tomato plant. Tall, hairy, strong-smelling herb, with pinnate leaves, the 547. Capsicum annuum. leaflets ovate and unequal-sided and of different sizes: flowers small, yellow, in short forked racemes: fruit a large red or yellow berry. South America.

\section{CÀpsicum. Red Pepper.}

Erect, branchy, smooth herbs: stamens with slender filaments which are much longer than the separate authers, the latter opening by lengthwise slits: fruit globular, long or irregular, firm.

C. ánnuum, Linn. Common red pepper. Fig. 547. Annual or biennial, with ovate entire leaves: flowers white, with very short-toothed or truncate calyx: fruit very various in the cultivated varieties. Tropical America.

\section{Petùnia. Petunia.}

Clammy-hairy diffuse herbs: calyx-lobes leaf-

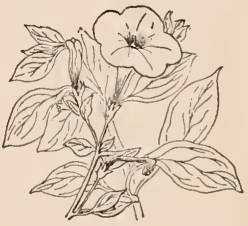

548. Petunia nyctagıniflora. like and much longer than the tube; corolla funnelform, showy, the stamens not projecting: fruit 2-loculed, capsular. South America.

F. nyctaginiflòra, Juss. White petunia. Fig. 548. Corolla white, very long-

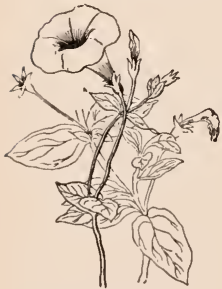

549. Petunia.

Very near the original

$P$, violacea. tubed: leaves oval-oblong, narrowed into a petiole.

P. violàcea. Lindl. Fig. 549. Weaker and more diffuse: corolla purple or rose, the tube short and broad: leaves ovate or oval, nearly or quitc sessile. The garden petunias are mostly hybrids of the 2 species.

6. DATÙRA. JAMESTOWN-WEed or Jimson-WEed.

Very strong bushy herbs, with large, long-tubular, short-lived flowers from the forks of the branches: stigma 2-parted: fruit a globular usually prickly capsule, opening by 4 valves.

D. Stramònium, Linn. Fig. 275. Annual, 3-5 ft., the stem green: leaves ovate, sinuate or angled: corolla white. Tropics; common weed.

D. Tátula, Linn. Stem and corolla purple. 


\section{NICOTIÀNA. TOBACCo.}

Tall herbs, with large usually pubescent leaves: corolla funnelform or salverform, the tube usually long: stigma not lobed: pod 2-4-valved, not very large, contained within the persistent ealyx.

N. Tabácum, Linn. Tobacco. Robust annual, 4-6 ft., with very large ovate deeurrent entire leaves and rose-purple panicled flowers. Tropical Ameriea.

N. alàta, Link \& Otto (N. affinis of gardens). Fig. 550. Slender but tall $(2-4 \mathrm{ft}$.) plant with elammypubescent herbage: leaves lanceolate or obovate, entire: flowers white, with very slender tube 5-6 in. long, the limb unequal. Brazil; common in gardens.

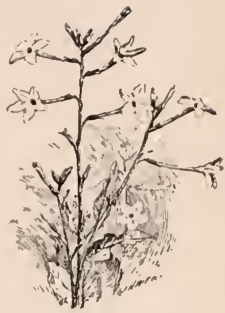

550. Nicotiana alata.

\section{CONVOlvulàCEA. Convolvulus Family}

Herbs, mostly twining, with alternate chiefly simple leaves: flowers regular, 5-merous, the tubular or trumpet-shaped corolla mostly twisted in the bud, the stamens 5 and borne on the corolla; ovary commonly $1-$, mostly 2 -loculed, with 2 ovules in each locule, becoming a globular capsule in truit. (which is sometimes 4-loculed by the insertion of a false partition). The family contains between 30 and 40 genera, and nearly 1,000 species. Common convolvulaceous plants are morning-glory, cypress vine, sweet potato, bindweed, dodder.

A. Plants with normal foliage.

B. Stigma 2-3-lobed, knobbed: calyx not bracted........ Ipomøa

вв. Stigmas 2, thread-form: ealyx sometimes inclosed by 2

leafy bracts............................ Convolvulus

As. Plants leafless, parasitic...................... Cuscuta

1. IPOM MEA. MORNING-GLORY.

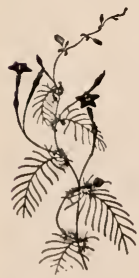

551. Ipomca Quamoclit.

Mostly twining, with showy flowers on axillary peduneles: eorolla with a long tube and a flaring limb; pistil 1 , with one style, and the stigma 2-3-lobed: fruit a eapsule, with 1-seeded locules.

\section{a. Leaves compound, with thread-like divisions.}

I. Quámoclit, Linn. Cypress vine. Fig. 551. Leaves pinnate: flowers solitary, red, small, narrow-limbed, with projecting style and stamens. Tropical America, but run wild South; also eultivated. Annual.

\section{aa. Leaves simple or decply lobed, broad.}

I. Bòna-Nóx, Linn. White moonflower. Fig. 552. Tall: leaves heart-shaped, or angled or lobed: flowers 1 to few, 
white, opening once at night, with a slender tube and a large limb 4-6 in. across. Tropical America. Perennial.

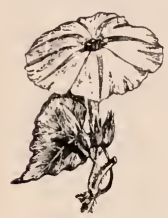

552. Ipomœa

Bona-Nox.

I. purpùrea, Roth. Morning-glory. Fig. 240. Leaves broadly cordate-ovate, entire: flowers $2-4$, large and funnel-shaped, $2-3$ in. long, purple to streaked and white. Tropical America. Annual.

I. hederàcea, Jacq. Leaves heart-shaped, 3-5-lobed: flowers 1-3, rather smaller than those of $I$. purpurea. Tropical America. Annual.

I. Batàtas, Poir. Sweet potato. Fig. 204. Creeping: leaves heart-shaped to triangular, usually lobed: flowers (seldom seen) 3 or 4 , light purple, funnel-form, $11 / 2$ in. long. Tropies; grown for its large edible root-tubers.

\section{CONVÓlvulus. BindweEd.}

Herbs (or shrubs) twining or erect: flowers large, on axillary peduncles; sepals 5; corolla funnelform or bell-form, limb entire, 5-angled or 5-lobed; stamens inserted on corolla-tube, included; style 1; stigmas 2, long; ovary and pod 2-celled, 4-seeded.

C. sèpium, Linn. Rutland beauty. Perennial: twining or trailing stem: leaves heart-shaped or arrow-shaped, auricles often toothed: flowers axillary and solitary on a peduncle; calyx with 2 large bracts at base, inclosing it; corolla morning-glory-like, white or pink, $1 / 2-2$ in. long, margin quite entire. Wild in low grounds. Summer.

C. arvênsis, Linn. Bindweed. Perennial, nearly glabrous, prostrate or climbing: leaves entire arrow-shaped, with basal ears acute-lobed, but variable: calyx not bracted at base; corolla pink, nearly white, small, not over 1 in. long. Europe. Bad weed. May to September.

\section{CÚSCUTA. Dodder.}

Parasitic twiners without foliage (leaves reduced to scales): flowers in clusters, the calyx and corolla with 4-5 lobes: fruit 2loculed, 4-seeded.

C. Gronòvii, Willd. (Fig. 553), is the commonest species, twining its slender coral-yellow stems over coarse herbs in swales: corolla bell-shaped, the tube longer than the blunt and spreading lobes.

\section{BORRAGINĀCEÆ. Borage Family.}

Generally rough herbs, with round stems, leaves usually alternate and hairy, exstipulate: inflorescence commonly 1-sided, in coiled terminal racemes, straightening as flowers open; lobes of calyx 5 : lobes of corolla 5 , usually regular; stamens 5 , on corolla-

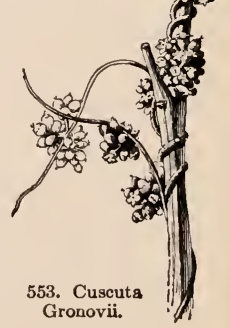


tube; ovary deeply 4-lobed, with style in eenter; stigmas 1 or 2: fruit usually 4 separate 1 -seeded nutlets at bottom of persistent calyx. About 1,500 species and 80 genera.

A. Ovary entire, style terminal : fruit dry nutlets (2 or 4$)$.1. Heliotropium

AA. Ovary deeply 4-parted, or 4-divided, the style rising from the center.

B. Corolla and stamiens regular.

c. Fruits (nutlets) bur-like, prickly or spiny.

D. Nutlets oblique, fixed by apex, or laterally, to style, covered all over by hooked prickles.2. Cynoglossum

DD. Nutlets erect, fixed by base or side to the central column: prickles in 1 or more rows on the surface..................... Lappula

cc. Fruits (nutlets) not armed with prickles.

D. Nutlets attached laterally to the receptacle: flowers rather large .................4. Mertensia

DD. Nutlets attached by bases to receptacle.

E. Flowers not bracted, in racemes ........5. Myosotis

EE. Flowers bracted, in racemes..........6. Lithospermum

вв. Corolla irregular: stamens unequal...........7. Echium

\section{1. heliotròpium. Heliotrope.}

Perennial or annual herbs (or shrubs) with white or purplish, small flowers in 1-sided spikes: flowers alternate, usually entire; stamens short, anthers nearly sessile; style short, with conical stigma; ovary 4-celled: fruit, 4 nutlets or two 2-celled nutlets.

H. peruviànum, Linn. Common garden heliotrope. Pubescent or rough, often rather shrubby: leaves lance-ovate to oblong, short-petioled, veiny and wrinkled: flowers very fragrant, white to lilac.

\section{CYNOGlósSum. Hound's Tongde. Stick-tight.}

Tall, coarse, usually rough and unpleasantly scented hairy weeds, with large entire alternate leaves: flowers small, inconspicuous, in racemes or forked cymes, some bracted; corolla short, nearly whecl form, with 5 converging, blunt scales closing the throat; ovary deeply 4-parted, with style from center: fruit of bur-like nutlets, covered with hooked prickles.

C. officinàle, Linn. A coarse, pubescent, troublesome dock-like weed from Europe, dull green, smelling like mice, grows to 1 or $2 \mathrm{ft}$., leafy to the top: leaves softly pubescent, lance-oblong, mostly sessile: corolla dull reddish purple, not $1 / 2$ in. across: nutlets margined. Biennial.

C. virginiànum, Linn. Stem stout, 2-3 ft. tall, bristly hairy, leafless above: leaves oblong oval with clasping bases: flowers pale blue, bractless, on short pedicels in terminal short spikes: nutlets not margined. Perennial.

3. LÁPPUla (Echinospérmum). Stick-SEed. BUR-seed.

Annual or biennial weeds in dry soils, grayish with hairs: leaves alternate, narrow, entire: flowers small, blue or white, in terminal, leafy-bracted 
racemes: corolla with 5 scales in throat: nutlets erect, bearing 1-3 rows of stout prickles, and fixed by side to the central column.

L. virginiàna, Lehm. A troublesome biennial or annual weed of thickets and open woods, 2-4 ft., slender and branching: leaves thin, oblong-ovate, tapering at both ends: flowers small, whitish or bluish, on pedicels, in racemes 1-3 in. long, reflexing in fruit: nutlets small, globose, covered with barbed prickles.

\section{MERTÉNSIA. LUNGWORT.}

Perennial, usually glabrous herbs, with leaves entire, pale green and often dotted, the radical ones many-veined and the stem-leaves sessile: flowers in terminal racemes; calyx short, 5-cleft; corolla funnelform or trumpet-shape, often with 5 small folds in throat, and stamens inserted between; style long and slender: nutlets erect, smooth, finely wrinkled.

M. virgínica, DC. Leaves entire, obovate, sessile on stem: flowers large, trumpet-shaped, 1 in. long, spreading or hanging on slender pedicels, light blue or pinkish; corolla-throat not crested, limb entire. Perennial. Rich soil. May, June.

\section{MYOSÒTIS. FORGET-ME-NOT.}

Low, usually villous herbs, with stems erect or reclining, branching: leaves small, alternate, entire: flowers small in bractless racemes; corolla salver-form, 5-lobed, lobes spreading, rounded with appendages at base: nutlets smooth or hard, fixed by base. Several species.

M. scorpioìdes, Linn. (M. palustris, With.). True forget-me-not. A favorite garden perennial introduced from Europe, but also escaped to field and moist spots: racemes 1-sided: leaves lance-oblong, obtuse: calyx open in fruit, the lobes shorter than the tube: corolla light-blue, with yellow center.

M. láxa, Lehm. Flowers smaller, paler, on long pedicels: calyx-lobes long: habit lax. Swamps.

M. arvénsis, Hoffm. Hairy: leaves lance-oblong, acute: calyx closing in fruit and beset with minutely hooked bristles. Fields, native.

\section{Lithospérmum. Gromwell. Puccoon.}

Hairy herbs with roots usually red: leaves alternate, entire: flowers in leafy-bracted racemes or spikes; calyx-segments 5, narrow; corolla funnelor salver-form, 5-lobed, sometimes crested in throat; stamens 5, with short filaments, included on corolla-throat; stigma 2-lobed: nutlets 4, smooth or wrinkled, usually stony.

L. arvénse, Linn. Rough weed from Europe, 8-12 in.: leaves small, lanceolate to linear: flowers insignificant: corolla white, hardly as long as calyx, without appendages in throat: nutlets roughly wrinkled, dull gray.

L. Gmélinii, Hitchc. (L. hirtum, Lehm.). A rough, native perennial, with simple stem, 8 in. to $2 \mathrm{ft}$., on dry, sterile ground: leaves lanceolate or linear, hairy: flowers densely crowded in short terminal leafy racemes: corolla bright orange-yellow, showy, longer than calyx, with little appendages in throat, and woolly. June. 
L. canéscens, Lehm. Puccoon. Not so rough as preeeding, but hoary, 6-18 in. high: flowers yellow axillary smaller and corolla-throat appendaged, liut not bearded. Grows in open woodlands and fields, Canada to Alabama and West.

\section{7. ÉCHIUM. Viper's Bugloss.}

Stout and coarse herbs: leaves alternate, entire: flowers rather large, usually blue or purplish, in spicate or panicled racemes; ealyx-segments 5 , narrow; corolla irregular, with 5 unequal lobes, short-tubed, and throat not bearded; stamens 5 , unequal, and long-exserted; stigmas 2 or 2-lobed: nutlets 4 , erect, rough-wrinkled.

E. vulgàre, Linn. Stems 1-3 ft. erect, leafy, very bristly hairy: leaves lanceolate, sessile on stem, 4-8 in. long: flowers bright purplish, changing to bright blue in 1-sided spikes. Biennial; early summer. Naturalized from Europe, and becoming a showy but troublesome weed in places.

\section{HYDROPHYLLĀCEA. WATERLEAF FAMily.}

Mostly hirsute or seabrous herbs, with good-sized mostly alternate, simple or compound leaves: flowers regular, 5-parted, in 1-sided cymes, spikes or racemes; ovary superior, 1-eelled, with 2 parietal placentæ, or apparently 2-celled; styles 2 or 2-cleft: capsule usually loculicidally 2-valved. Nearly 200 speeies, but only 1 genus frequent in northeastern states.

\section{HYDROPHÝLLUM. WATERLEAF.}

Perennial, usually found in rich, low woods: leaves large, petioled: cymes more or less eoiled: ealyx often with small appendages at the notehes of the lobes; eorolla bell-shape, 5-cleft, usually convoluted in bud and bearing 5 folds or seales inside the tube; style and stamens (with hairy filaments) projecting. In shady places, these interesting plants make heavy masses of foliage.

H. macrophýllum, Nutt. A hoary-hairy plant, about $1 \mathrm{ft}$. tall, branching: leaves pinnately cut: flower-eluster on long stout peduncle: corolla white or bluish, about 1 in. across: sepals not appendaged at base: stameus longer than corolla.

H. appendiculàtum, Michx. Hairy, 1-11/2 ft. tall: leaves large, mostly 5-lobed or angled, some of the lower ones pinnately parted: flower elusters loose; corolla blue; sepals appendaged at bases, bristly hairy; stamens not much if any longer than corolla.

H. canadènse, Linn. A bout $1 \mathrm{ft}$. high, smoothish: leaves all rounded, with 5-9 shallow lobes, and heart-shaped bases, or with small leaflets on the petioles: corolla white or purplish. $\boldsymbol{H}$. virginicum, Linn., is closely allied, but has pinnately divided leaves. 


\section{POLEMONiÃCEA. Phlox Family.}

Herbs, mostly annuals or perennials: flowers regular, in terminal clusters, 5-parted, with corolla monopetalous; stamens on corollatube, alternate with lobes; ovary 3-celled; style simple and 3-lobed: capsule 3-celled, with 3, mostly loculicidal, valves. About 200 species in several genera. Phlox is the leading genus.

A. Leaves entire, mostly opposite: stamens unequally inserted on tube of the corolla ............... Phlox

AA. Leaves pinnately compound, alternate: stamens equally inserted on the corolla-tube .................... Polemonium

\section{PHLOX. Fig. 241.}

Erect or diffuse herbs, stems leafy: leaves without stipules, entire, mostly sessile, opposite, or alternate above: flowers of different colors, in terminal clusters; corolla salver-form, tube long; stamens 5, unequal, included in tube. P. Drummondii is annual; the others perennial.

P. paniculàta. Linn. Stems $2-4 \mathrm{ft}$. high, usually stout and in clumps: leaves ovate-lanceolate, or oblong: flowers on short pedicels in many-flowered panicled cymes, terminal, white to various pinks and reds; calyx-teeth sharp-pointed; lobes of corolla rounded and entire.

P. maculàta, Linn. One to $2 \mathrm{ft}$. high: stem spotted with purple: lower leaves the heavier, lanceolate-linear; upper taper-pointed with a heartshaped sessile base: panicle elongated, pyramidal, of many pink-purple flowers; calyx-teeth less pointed than in preceding: corolla-lobes entire. All summer. This and the preceding species are the originals of the common perennial phloxes of gardens.

P. divaricàta, Linn. Ascending or diffuse to $1 \mathrm{ft}$., or more, terminating in loose corymb, rather sticky-pubescent: leaves ovate-oblong or broad-lanceolate, rounded at base, acute at tip, sessile, pubescent: corolla large, grayish blue or lilac, the lobes notched; calyx-teeth slender and longer than tube. Moist woods. Spring.

P. subulàta, Linn. Ground or moss pink. Stems creeping, tufted, much branched and leafy, forming a moss-like carpet over the ground: leaves about $1 / 2$ in. long, rigid, linear to awl-shaped, spreading in clustcrs: flowers 3-6 in depressed clusters, white to pinkish-purple; lobes of corolla shorter than tube. Spring.

P. Drúmmóndii, Hook. From Texas, now the common annual phlox in gardens: stems branching, spreading, about $1 \mathrm{ft}$. high, rather downy-clammy: flowers showy, in corymbs; various colors and patterns on the corolla and lobes variously notched.

\section{POLEMÒNIUM.}

Perennial herbs, with alternate pinnately compound leaves: calyx companulate, segments erect over fruit; corolla bell-form or rotate; stamens 
slende:, declined, hairy at base, inserted on eorolla base. The following native perennials are often cultivated.

P. réptans, Linn. Greek valerian. Stems rather weak, diffusely branching (not creeping), 6 in. to $11 / 2 \mathrm{ft}$.: leaves smooth, of $7-13$ leaflets, occasionally a simple one: leaflets lanee-ovate or oblong, about $1 \mathrm{in}$. long, with entire margins: flowers nodding, light blue eorolla 3 times as long as calyx, not over $1 / 2$ in. broad.

P. Van Brúntiæ, Brit. Jacob's ladder. Tall, ereet to $1-3 \mathrm{ft}$., smooth or hairy: leaflets 9-17, laneeolate, crowded: flowers bright blue, in erect long panicles; stamens and style longer than corolla-lobes; corolla 1 in. broad.

\section{Xli. GentianäCE. Gentian Family.}

Generally smooth herbs, with bitter, colorless juice (tonic properties): entire leaves mostly opposite, sessile and without stipules: flowers regular, solitary or in elusters; calyx persistent; corolla monopetalous, with 4-8-lobed margin, and with 4-8 stamens, inserted on tube: capsule 2-valved, many-seeded. Some 600 species, many very showy.

\section{Gentiàna. Gentian.}

Herbs in low woods and damp grounds, flowering mostly in autumn: flowers solitary or in elusters and showy, usually blue; corolla tubular, lobes 4-7, open or closed, some having a membranous fold in each of the notehes of the limb; stamens 4-7: style short or wanting.

G. crinita, Froel. Fringed gentian. Annual, in moist soil, blooming in September and Octoher: distinguished by the beautiful flowers, solitary and terminal on ereet stems (stems about $1 \mathrm{ft}$. tall), pure blue, $11 / 2-2 \mathrm{in}$. long, funnelform, with 4 spreading lobes, having the margins eut into a fringe all around: leaves clear green, lanceolate, acute, sessile.

G. prócera, Holm. Similar to the preceding, but smaller and corolla less fringed: leaves linear.

G. Andréwsii, Griseb. Closed gentian. Perennial: stems simple, smooth, to about $11 / 2-2 \mathrm{ft}$.: leaves ovate to lanceolate, with narrow base: flowers in terminal, sessile elusters: eorolla blue with notehed folds or appendages on the margin, never opening.

\section{ASClEPIADACEA. Milkweed Famly.}

Perennial herbs or shrubs, often vines, with milky juice: leaves opposite or sometimes whorled, exstipulate: flowers generally in umbels, regular and 5-parted, but very peeuliar in the structure and connection of stamens, stigma and pollen: hood-like appendages are borne behind the anthers, forming a corona about the stigma; stamens 5 with 
very short filaments, and mostly monadelphous; the anthers press against the fleshy 5-angled stigma, and the pollen coheres in waxy or granular masses, 1 or 2 to each anther-sac: fruit of 1 or 2 follicles: seeds bearing long silk (Fig. 303). About 2,000 species and 200 genera.

\section{asclèpias. Milkweed. Silkweed.}

Erect perennial herbs, with mostly opposite, thick simple leaves and flowers in simple umbels: ealyx and corolla each with 5 lobes, bent downward, leaving the erown of 5 hood-like appendages, each bearing a horn, conspicuously surrounding the stamens; filaments generally united, and the anthers adherent to the fleshy stigma; anther 2-celled and each cell containing a firm, waxy, elongated mass of pollen; adjacent pairs of the pollenmasses are connected and suspended from one of 5 glands resembling a pair of saddle-bags. The flower is peculiarly adapted to insect-pollination, the pollen-masses being carried on the feet of insects.

A. tuberòsa, Linn. Butterfly weed. Pleurisy root. About $2 \mathrm{ft}$., with most conspicuous erect clusters of brilliant orange flowers: leaves irregularly scattered on stems, or alternate, linear or lance-oblong, hairy, sessile: pods nearly erect, finely pubescent. Dry fields and hillsides. Summer.

A. incarnàta, Linn. Swamp milkweed. Fig. 271. A handsome milkweed of wet grounds: stems leafy, $2-5 \mathrm{ft}$.: leaves lanceolate or lance-oblong, acuminate, rather smooth, opposite: flowers rose-colored to white, sweetscented, in somewhat paniculate umbels: follicles erect, smooth.

A. syrìaca, Linn. (A. Cornùti, Decne.). Common milkweed. Fig. 303. Stems 3-4 ft. high, stout, very milky, usually simple, leafy: leaves large, oblong, downy beneath, stiff, 4-8 in. long, opposite, short-petioled: flowers $1 / 2$ in. long, greenish-lavender to lavender, with strong, sweet, but unpleasant odor: pods rough or warty.

A. purpuráscens, Linn. Purple milkweed. Stems erect, 1-3 ft., leafy, simple or branching: leaves oblong or ovate-oblong to elliptical, pointed, short-petioled, 3-6 in. long: flowers large ( $1 / 2$ in.), dull purple: pods smooth.

A. variegàta, Linn. Stems simple, smooth, leafy: leaves oval to lanceoval, opposite or whorled, petioled, pale beneath, umbels on downy peduncles: corolla white, hoods roundish, sometimes purplish. Dry woods.

A. quadrifòlia, Jacq. Stem 1-2 ft., nearly smooth, and leafy below: 1 or 2 whorls of 4-ovate, taper-pointed, petioled leaves near middle and above or below a pair of smaller ones: umbels few, loose-flowered; flowers small, crown white; corolla white, tinged with pink. Slender.

\section{XliII. APOCYNĀCEÆ. Dogbane Family.}

Herbs and woody plants, some of the commoner ones resembling milkweeds, in having milky, acrid juice, and seeds crested with silky hairs, but filaments distinct, pollen granular, and corolla twisted (rather than volvate) in the bud: hairs: leaves chiefly opposite, entire, 
simple, without stipules: flowers regular and monopetalous, solitary or in cymes, 5-parted; ovary of 2 free carpels; stigmas united. About 1,000 species and 120 genera.

A. Herbs ereet: flowers in terminal eymes or corymbs......1. A pocynum

AA. Half shrubby, trailing or ereet plants: flowers solitary in

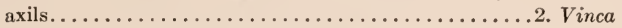

AAs. Cultivated house and garden shrubs: erect: leaves opposite, or whorled in 3 's........................ Nerium

\section{APóCynum. Dogbane.}

Upright branching herbs, with reddish, fibrous bark: flowers small, white or pink, in terminal corymbs: leaves opposite, entire, acuminate: corolla bell-shaped, 5-lobed, with 5 small, triangular scale-appendages within the tube, each alternating with one of the 5 stamens attached at base of tube; ovaries 2, distinet; stigma 2-lobed: pods long, slender and full of seeds which are tufted with silky hairs at one end.

A. androsæmifòlium, Linn. Smooth plants, $2-4$ or $5 \mathrm{ft}$. tall, with branches widely spreading; stems usually purplish: leaves $2-4$ in. long, ovate-acute, short-petioled: corolla small, $1 / 4 \mathrm{in}$. long, bell-form, with lobes spreading or recurving, the tube exceeding the ealyx. A very common weed along hedge-rows, in light woodlands and clearings.

A. cannabinum, Linn. Indian hemp. More erect: leaves oblong or oblong-ovate: flowers erect, with the corolla-lobes searcely spreading, the tube about the length of the calyx. Banks and shores.

\section{Vínca. Periwinkle.}

Herbs, creeping or ereet, and more or less woody: leaves mostly evergreen and opposite: flowers solitary, axillary, 5-parted; style 1; follieles 2, erect, slender.

V. mìnor, Linn. Periwinkle. Myrtle (improperly). A familiar trailing plant of the garden, lawns and cemeteries, growing in shady places, and spreading by creeping stems: leaves evergreen, oblong-ovate, shiny: flowers solitary in axils, blue (rarely white), the corolla salver-form, about $1 \mathrm{in}$. across. Spring and early summer.

V. ròsea, Linn. Erect, often $20-30$ in. high, rather woody at base: leaves ovate, obtuse, on long petioles: flowers large, on slender axillary pedicels, white, white with rose eye, or plain rose-color; blooming all season when grown in the house or conservatory, or all summer in the garden. Tropies.

\section{NÈriUm. Oleander.}

Shrubs from warm climates, much cultivated in windows and greenhouses: leaves laneeolate, leathery and stiff: flowers in terminal eymes, white or pink, single or double; corolla large, 1-2 in., salver-form, the throat bearing 5 fringed or toothed scales; ovary of 2 carpels; stamens 5 , the anthers tipped with awn-like bristles. 
N. Oleánder, Linn. Common oleander. Leaves lanceolate: flowers large, rose-color or white, not fragrant, with crown segments not fringed.

N. odòrum, Soland. Sweet oleander. Flower fragrant, and bearing crown segments which are more fringed, and long anther appendages.

\section{Xliv. OLEĀCEA: Olive Family.}

Trees or shrubs: leaves simple or pinnately compound, opposite: flowers various, but regular; calyx free from ovary, usually small and 4-lobed, or none; corolla regular, 4-parted, or of 4 distinct petals, or none; stamens 2 , with separate filaments inserted on petals, or hypogynous: ovary 2-celled; style 1 , if any.

A. Shrubs or very small trees: leaves simple: flowers perfect.

B. Flowers yellow ................. Forsythia

BB. Flowers white or lilac.

c. Fruit a dry pod, loculicidal................ Syringa

cc. Fruit berry-like.

D. Flowers practically polypetalous; petals long, narrow; flowers drooping................. Chionanthus

DD. Flowers gamopetalous; corolla-tube funnelform, 4-lobed; flowers ercet............. Ligustrum

AA. Large forest trees: leaves pinnately compound: flowers

imperfect, mostly diœeious: fruit a samara......... Fraxinus

\section{FORSYTHIA.}

Ornamental shrubs from the Orient, with opposite simple or trifoliolate leaves: flowers perfect, the deciduous calyx and the bell-shaped corolla in 4 parts; stamens 2 on base of corolla; style short: pod 2-celled, many-seeded.

F. viridissima, Lindl. Strong hardy shrub, with green branches covered with showy yellow flowers, separate on pedicels in early spring before leaves appear: leaves simple, lance-oblong: corolla-lobes narrow-oblong and spreading; style twice as long as stamens.

F. suspénsa, Vahl. Branches slender and drooping: corolla-lobes larger and more spreading and style shorter than in preceding: leaves simple, broadly-ovate, also frequently trifoliolate on same bush.

\section{SYRÍNGA. LiLAC.}

Common ornamental shrubs, usually tall, with leaves simple, entire, opposite: many small fragrant flowers in close terminal panicles or thyrses; calyx 4-toothed; corolla salver-form, tube long; limb 4-lobed; stamens 2, on summit of corolla-tube: fruit a 4-seeded flattened pod, 2-valved; seeds flattened, somewhat winged or margined. No native species. The name Syringa is sometimes popularly applied to Philadelphus.

S. vulgàris, Linn. Common lilac. Fig. 72. Well-known bushy shrụb from 
eastern Europe: flowers purple, lilac to white, in dense upright thyrses, very fragrant: leaves heart-shaped, entire, smooth.

S. pérsica, Linn. Persian lilac. Less bushy, and more slender than the common lilae: leaves lance-ovate, the bases tapering: and pale lilac or white flowers in loose elusters appearing later.

\section{CHIONÂNTHUS. Fringe-TrEe.}

Shrub or small tree with opposite, simple, entire, petioled leaves: flowers in large loose axillary rather drooping panieles; ealyx small, persistent; corolla white, with 4 long, narrow petals, scareely united at base; stamens $2-4$, but searcely adherent to corolla base: drupe usually 1-seeded. A handsome bush.

C. virgínica, Linn. Native to moist southern woods, but eultivated for oruament: leaves oval to oblong, 3-5 in. long: panieles with some leafy bracts; flowers conspicuous, in spring, appearing with leaves; petals 1 in. long.

\section{4. ligùstrum. Privet. Prim.}

Stiff shrubs or very small trees: leaves simple, entire, firm and thickish, short-petioled, opposite: flowers small, white, in terminal thyrses or panicles: ealyx small, minutely toothed or truncate; corolla funnelform, 4-lobed, spreading; stamens 2, inserted on corolla-tube; ovary 2-celled: fruit a 1-4-seeded, black berry.

L. vulgàre, Linn. Leaves thick, elliptic-lanceolate, abundant, persistent, but deeiduous: flowers $1 / 4$ in. wide and white; ealyx smooth: berries black. Eastern Europe. Used mostly for hedges.

\section{FRÁXINUS. AsH. Figs. 92, 141.}

Deciduous tree, some of them valuable for timber: leaves odd-pinnate, petiolate: flowers small, insignifieant, diøecious (polygamous in some speeies), racemed or panieled-the Ameriean species apetalous, appearing before or with the leaves; ealyx 4-toothed, small, seldom wanting; stigma 2-cleft: fruit a flat 1- (or 2-) eelled key, winged. Several species are native in North America.

F. americàna, Linn. White ash. Forest tree, 40-80 ft., with rough, blackish bark, and gray, smooth branches: leaflets 5-9, ovate or lanee-oblong and acuminate, entire or sparingly serrate, pale or downy beneath, smooth above, the lateral leaflets stalked: flowers mostly dicecious, apetalous; ealyx present in fertile flowers, and persistent: fruit with lanceolate wing at apex, base nearly eylindrieal, the key $11 / 2-2$ in. long.

F. pennsylvánica, Marsh. Red ash. A smaller tree than the white ash: young shoots and leaf petioles and lower leaf surfaces velvety-pubescent: calyx persistent on fertile flowers: fruit narrow, fluttened at base, the edges dilated into the oblanceolate wing.

F. excélsior, Linn. European ash, often planted: leaflets 9-13, ovatelanceolate or oblong, acute, serrate: fruit oblong, of ten notehed at end. 


\section{Xlv. PRIMUlàCEA. Primrose Family.}

Low herbs with leaves radical or opposite: flowers perfect, regular, 5-parted, monopetalous; stamens 5, inserted in corolla-tube, each opposite a lobe; style and stigma 1; ovary 1-celled, superior, with 3 central placentæ. About 300 species in some 25 genera.

A. Plants with all leaves basal: flowers on a scape.

B. Corolla-lobes spreading.

1. Primula

Bв. Corolla-lobes reflexed.

c. Several flowers on the scape; stamens protruding...2. Dodecatheon

cc. One flower on the seape; stamens included........... Cyclamen

AA. Plants with leafy stems $\ldots \ldots \ldots \ldots \ldots \ldots \ldots \ldots \ldots . \ldots \ldots$. Lysimachia

\section{Prímula. Primrose. Cowslip (of England). Auricula.}

Low perennials herbs, with radical leaves: flowers in an involucrate umbel in most species, terminal on a scape; calyx 5-cleft; corolla salvershaped, with 5 spreading lobes, entire or notched; stamens 5 , with short filaments included in corolla-tube, often of different lengths: capsules ovoid, opening by valves or teeth at the top. Native species rare, but a number of exotic primroses are much cultivated.

P. sinénsis, Sabine. Downy greenhouse plant: flowers in umbels, large and showy, of different colors, single or double; calyx large and inflated: leaves cordate, 7-9-lobed, on long petioles. China.

P. obcónica, Hance. Leaves ovate-cordate: scapes a foot high, bearing pink, purplish or whitish flowers in large clusters, the petals obconical and notched at the end; tube twice longer than the shallow-spreading calyx. The hairs on this plant are poisonous to some persons. Greenhouses. China.

P. Fórbesi, Franch. Baby primrose. Scapes many and very slender, 6-12 in., loosely hairy, bearing small lilac or rose flowers in successive whorls on slender pedicels: leaves small and crowded at the crown, oblong, somewhat sinuate-toothed. Greenhouses. China.

P. Polyantha, Hort. Polyanthus. Hardy primulas, grown in borders for the early spring bloom, of hybrid origin: leaves upright, oblong, tapering into a winged petiole, shallowly toothed, rugose beneath: flowers not much overtopping the leaves, tubular, with spreading limb, in shades of yellow and red.

\section{DODECÀTHEON.}

Smooth perennial herbs: leaves radical, simple, oblong or spatulate: flowers nodding in a terminal umbel on erect, unbranching, leafless scapes, with involucres of small bracts; calyx 5-cleft, lobes reflexed; corolla-tube very short, 5-parted, and the segments strongly reflexed; stamens 5 , with short filaments, united at base, the anthers long, acute and uniting at tip, forming a cone; style exserted.

D. Meàdia, Linn. Shooting star. Wild in open woodland in central states and South and West; also cultivated; resembles Cyclamen in the flowers, which are white or rose-purple, nodding on slender pedicels; scape 6 in. to $2 \mathrm{ft}$. high. 


\section{CÝCLAMEN.}

Glabrous plants from fleshy corm: leaves all basal, rounded, cordate or ovate: scapes bearing (each) one nodding flower; corolla-limb 5-parted, lobes turning back; antbers 5, sessile, not exserted. Cultivated as house plants, flowering in winter.

C. latifòlium, Sibth. \& Sm. (C. pérsicum). Leaves ovate, crenate-dentate, thick, often marked with white: flowers large, white, rose or purple, sometimes spotted, oblong. The florists' cyclamen.

\section{LYSIM ÃCHIA. Loosestrife.}

Perennials with leaves opposite or whorled, entire, often glandulardotted: flowers yellow, solitary in axils, or panieled; calyx 5-7-parted; corolla wheel-form; petals 5-7, nearly distinet; stamens 5-7, the filaments somewhat connate at base. Wild in low grounds.

L. vulgàris, Linn. Ereet, 2-3 ft., downy: leaves 3 or 4 in a whorl: flowers in terminal leafy panicles; corolla-lobes glabrous. Europe. Cultivated and escaped.

L. quadrifôlia, Linn. Erect, 1-2 ft., hairy: leaves lanceolate-ovate, sessile, dotted, commonly 4 in a whorl: flowers yellow, with dark lines, on slender pedicels, solitary from axils of upper leaves. Damp soil.

L. nummulària, Linn. Moneywort. Trailing glabrous perennial: leaves round, opposite, on short petioles: flowers pure yellow, axillary solitary, on short peduneles; stamen filaments glandular, connate at base. Running wild in moist places, often a weed in lawns.

\section{XlVi. ERICĀCEæ. Heath Family.}

Plants of various kinds, many of them shrubs or shrubby herbs, some trees, perennial herbs, and parasites: leaves simple and often evergreen, or scale-like: flowers most perfect; corolla usually monopetalous and 4- or 5-cleft; stamens hypogynous, as many or twice as many as petals, anthers usually opening by terminal pores; style 1 ; ovary generally as many celled as corolla has lobes. A large family, represented by heaths, cranberry, azaleas, arbutus, laurel.

A. Shrubs, or creeping shrubby plants.

B. Ovary inferior: fruit a berry.

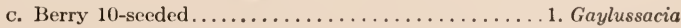

cc. Berry many-seeded...................... Vaccinium

BB. Ovary superior.

c. Low ereeping or proeumbent.

D. Fruit berry-like: leaves aromatic ............. Gaultheria

DD. Fruit dry ......................... Epigxa

cc. Shrubs, erect.

E. Corolla broadly open, with 10 little pouches holding the anthers.................. Kalmia 
EE. Corolla bell-shaped, no pockets: flowers from terminal, scaly buds.................... Azalea

AA. Parasitic herbs, destitute of green foliage, about the roots of trees........................................

\section{GAYLUSSÀCIA. LOW-BUSH HUCKLEBERRY.}

Shrubs, low and branching, leaves and branches sometimes with resinous dots: leaves alternate, entire or serrate: flowers in lateral racemes, small, white or pink, nodding on bracted pedicels, in late spring; corolla bell-like or ovoid, with 5 lobes erect or reflexing; stamens 10, usually included; ovary 10-celled: fruit berry-like, containing 10 little stones, blue or black, sweet and edible, ripe in late summer.

G. baccàta, C. Koch. High-land huckleberry. Shrub, 1-3 ft., with stiff branches and deciduous entire oval leaves, sprinkled with resinous dots: flowers, in 1-sided racemes; corolla white, tinged with pink, cylindrical or somewhat 5-angled, and contracted at margin: berry black, not glaucous.

G. frondosa, Torr. \& Gray. Tangle-berry. Shrub, 1-3 ft., with stiff spreading branches: leaves oblong to obovate, thin, smooth and pale below, resinous-dotted; corolla white, tinged with pink, short: berry large, dark blue, with a bloom.

\section{Vaccínium. Blueberry. Cranberry. Bilberry. High-bush HUCKLEBERRY.}

Shrubs much resembling Gaylussacia, but the ovary only 4-5-celled, although appearing to have twice as many cells by false partitions: fruit a many-seeded berry, generally edible. Fruit ripe in summer and autumn.

V. pennsylvánicum, Lam. Dwarf early blueberry. Shrub, 6-20 in., with smooth green warty branches: leaves deciduous, lance-oblong, smooth and glossy, but edges serrated and tipped with little bristly spines: flowers in clusters, with corolla cylindrical, white or pink-tinged, 5-toothed; anthers 10, included: berry many-seeded, blue-black with a bloom, edible.

V. corymbòsum, Linn. High-bush, or swamp, huekleberry. Blueberry. Tall bush, with oblong or elliptical leaves: berries blue, sweet, usually with a thick bloom.

v. macrocárpon, Ait. Cranberry. Creeping, slender, scarcely woody: leaves small, about $1 / 2$ in. long, evergreen, oval or oblong and margins rolled: flowers solitary, on slender erect pedicels, pale pinkish, deeper colored within, with 4 narrow reflexed segments.

\section{GaUlthèria. Wintergreen. Checkerberry.}

Stems procumbent, with leafy branches erect: leaves alternate, evergreen and tasting spicy and aromatic: flowers white or pink, nodding on axillary pedicels; corolla oblong or short-cylindrical with 5 short lobes; anthers 10 , awned at top: fruit berry-like, with capsule inside the thickened calyx.

G. procúmbens, Linn. Fig. 22. Leaves oval or obovate, much sought for their spicy flavor, as well as the edible red, mealy berries, which last all winter. In low and evergreen woods, 6 in. or less tall. 


\section{4. epig Áca. Trailing Arbutus. Mayflower.}

Trailing close to the ground, with rusty-hairy stems, and alternate evergreen rounded leathery leaves: flowers dimorphous, in clusters at ends of branches, bracted, sessile; sepals 5 , persistent but scale-like; co:olla salverform, with 5 lobes; stamens 10; ovary 5 -lobed.

E. rèpens, Linn. A favorite flower of very early spring, white to pink, $1 / 2$ in. broad, spicy-seented and wax-like, in small clusters from axils of the rusty leaves. Mostly North.

\section{KÁlmia. American Laurel.}

Shrubs, native (belonging to East and South), with entire evergreen leaves: flowers in umbels; corolla open, saucer-like, 5-angled with 10 little pits in which the anthers of the 10 stamens are caught until mature or disturbed by inseets, when the curved filaments spring upward, discharging the pollen; style long and slender.

K. latifòlia, Linn. Common mountain laurel. Stout shrub, 4-20 ft., often forming great patches on wild or rocky hillsides; also cultivated: flowers about 1 in. aeross, rosy, or white and red-spotted, in terminal compound corymbs: leaves mostly alternate, thick, acute, green on both sides, lanee-ovate: blooms in early summer. East and North.

K. angustifòlia, Linn. Sheep laurel. Lambkill. Low shrub with flowers about $1 / 2$ in. across, crimson or purplish, in lateral corymbs: leaves narrow, obtuse, short-petioled, opposite or in 3's, pale beneath. Hillsides.

\section{AZÀLEA. Fig. 220.}

Shrubs, with deciduous leaves: flowers showy, in terminal, umbel-like clusters; ealyx minute, 5-parted; corolla cylindrieal-tubed; stamens usually 5 ; style long, slender, exserted. Rhododendron is elosely allied, having evergreen leaves, stamens usually 10 , stamens and style usually not exserted.

A. viscòsa, Linn. Swamp honeysuckle. Stems 4-10 ft., branching: leaves obovate, short-petioled, mostly smooth above and downy on under veins: flowers in summer after the leaves, fragrant, white, 1-2 in. long, with slender tubes rather sticky-coated, the tube longer than the lobes. A swamp plant.

A. nudiflòra, Linn. Pinxter flower. Shrub, 3-6 ft., in swamps: flowers before or with leaves, rose-pink or white, fragrant, 1-2 in. across, the tube about the length of the lobes.

Rhodòra canadénse, Linn., or Rhododéndron Rhodòra, Don, of New England, is a low shrub, 2-3 ft., with fine large (1 in. wide) rose-colored flowers appearing before leaves.

\section{MONÓtropa. Indian Pipe. Pine-sap.}

Low herbs, parasitic on roots or saprophytic, no green about them, but stem bearing small scales: flowers solitary or in racemes; sepals 2 , bract-like; petals 4 or 5 , erect or spreading, wedge-shaped; stamens 8-10, hypogynous; anthers kidney-shaped; ovary 4-5-celled, stigma radiate or disk-like.

M. uniflòra, Linn. Indian pipe. Corpse plant. Odd fleshy waxy- 
white little plants, turning black when drying: stem, 3-6 in. high, bent over at the top with one nodding terminal flower.

M. Hypòpitys, Linn. Pine-sap. In oak and pine woods: stems scaly, white or tawny red, 4-8 in. high, single or in groups: flowers several, small, rather fragrant, in a scaly raceme.

\section{XLViI. RUBiàcEæ. Madder Family.}

A large and important family of herbs, shrubs, trees (including cinchona or Peruvian bark, and coffee): leaves opposite, or in 3's with stipules between, or apparently whorled without stipules: flowers perfect, sometimes dimorphous (of 2 sorts) or trimorphous; calyx-tube adherent to ovary, margin 3-6-toothed; corolla regular, inserted on calyx-tube, and of same number of lobes; stamens of equal number as corolla-lobes and alternate with them; ovary 1-10celled: fruit a capsule, berry or drupe. A large family (some 5,000 species), largely tropical.

A. Leaves $4-8$ in a whorl: no apparent stipules: fruit 2 nutlets, bur-like, or sometimes berry-like........... Galium

As. Leaves opposite (or whorled), with stipules.

B. Flowers in pairs, axillary: fruit a double berry: creeping................................ Mitchella

Bв. Flowers solitary, or in terminal clusters: not creeping.3. Houstonia ввB. Flowers in round heads...................... Cephalanthus

\section{Gàlium. Cleavers. Benstraw.}

Frail herbs, with square stems, often prickly or rough on angles and edges of leaves, usually diffusely branching: leaves apparently whorled and without stipules: flowers small or minute, sometimes diœcious, in cymes or panicles, axillary or terminal; calyx minutely 4-lobed; corolla 3-4-lobed: stamens 3-4; ovary 2-celled: fruit small, double, dry or fleshy, berry-like, indehiscent, or sometimes with only 1 carpel ripening. Many species.

G. aspréllum, Michx. Weak, reclining, or nearly erect branching perennial, the angles of stems with backward-pointing prickles: leaves small, not 1 in. long, whorled in 4's or 5's on branches, usually 6 on stem; edges and mid-ribs rough with prickles: flowers tiny, white, numerous, loosely clustered at end of branches: fruit small, smooth.

G. circaèzans, Michx. Wild licorice. Perennial, branching, ascending stems with leaves in 4's, not prickly: leaves oval to oblong, obtuse, more or less pubescent, an inch or more long: flowers dull greenish or brownish, on very short pedicels in branched cymes; fruit on reflexed pedicels, bristly: root and leaves with sweetish taste. Dry woods. Common.

G. Aparine, Linn. Cleavers. Goose-grass. Annual, stems weak, prostrate, scrambling, and diffuse, with backward-pointing barbs on angles: 
small lanceolate leaves, $6-8$ in a whorl, about 1 in. long, rough on edges and midrib: peduneles axillary, 1-3-flowered; flowers tiny, white or greenish: fruit a dry little bur, eovered with hooked prickles, on erect pedieels. Low ground or thickety woodland.

\section{2. mitchélla. Partridge-berry. Squaw-vine.}

Trailing, evergreen-leaved herbs: leaves opposite, round-ovate, dark green, smooth and glossy, entire, on short petioles: flowers small, dimorphous, in pairs, on a double ovary ( 2 ovaries united) from leaf-axils; eorolla funnelform, 4-parted, bearded within, white with pink tips to lobes; stamens and stigmas 4 : fruit a double scarlet berry, with 4 seeds or stones.

M. rèpens, Linn. A pretty little creeper of woods in the North: flowers fragrant and delieate, in June, the double searlet berries found all winter.

\section{3. houstònia. Bluets.}

Low, delicate little herbs, with stems ereet, simple or branehing: leaves opposite, entire; stipules entire and short, or a mere line eonneeting bases of the opposite leaves: flowers generally dimorphous in respeet to anthers and stigmas, small, solitary or elustered; ealyx 4-toothed; eorolla tubular, rotate, 4-lobed; stamens 4 on eorolla: fruit a short pod, 2-celled, manyseeded, opening at the top, upper part free from ealyx.

H. cær ùlea, Linn. Perennial, 3-6 in., the stems erect, very slender, in tufts, from slender rootstoeks: leaves sessile, oblong or spatulate, $1 / 4-1 / 3$ in. long, often hairy: flowers blue to white, with yellow eenters, solitary on peduncle. Early spring to summer; very floriferous.

\section{Cephalánthus. Button-Bush.}

Shrubs (or small trees): leaves entire, opposite or vertieillate: flowers small and many, white or yellow, in elose round heads, on peduncles; ealy $x$ 4-toothed; corolla tubular, with 4 short lobes; stamens 4 on eorolla throat; style long and exserted: fruit small, dry, inversely pyramidal.

C. occidentàlis, Linn. Tall shrub with leaves in 2's or 3's, oval-pointed, petioled, with stipules between: heads of whitish flowers about 1 in. in diameter. Usually along streams and pond banks.

\section{Xlviil. CAPRifoliāCEA. Honeysuckle Family.}

Erect or twining shrubs, or sometimes herbs, with opposite mostly simple leaves: flowers epigynous, 5-merous, regular or irregular, tubular or rotate; stamens usually as many as the lobes of the corolla and inserted on its tube; ovary 2-5-loculed, ripening into a berry, drupe, or eapsule. About 15 genera and 200 species. Characteristic plants are honeysuckle, elder, viburnum, snowberry, weigela, twin-flower.

A. Corolla long-tubular.

B. Fruit a berry (often 2 together) several-seeded: leafmargins entire or wavy edged: sometimes eonnate.....1. Lonicera 
BB. Fruit a linear-oblong capsule, 2-valved, many-seeded:

leaf-margin serrate ........................ Diervilla

AA. Corolla shallow, usually rotate.

в. Leaves simple............................. Viburnum

Bв. Leaves pinnately compound.................. Sambucus

\section{LONICÈRA. HONEYSUCKLE.}

Erect or twining shrubs, with tubular, funnelform, more or less irregular flowers (often 2-lipped); corolla bulging on one side near the base; stamens 5: fruit a berry, usually 2 together from 2 contiguous flowers.

\section{a. Erect.}

L. canadénsis, Marsh. Open, smooth bush, 3-5 ft.: leaves cordateoblong, not sharp-pointed, entire: flowers less than $1 \mathrm{in}$. long, soft yellow, the lobes nearly equal: berries red. Common in woods. Blooms in very early spring.

L. tatárica, Linn. Tartarian honeysuckle. Tall shrub (to $12 \mathrm{ft}$.): leaves cordate-oval, not long-pointed, entire: flowers pink or red (sometimes nearly white), 2-lipped, all the lobes oblong. Asia, but common in yards. Spring.

\section{aa. Twining.}

L. japónica, Thunb. (L. Halliàna of gardens). Fig. 554. Weak twiner, with oblong or ovate entire nearly evergreen leaves: flowers small, on short pedicels, fragrant, opening white or blush but changing to yellow. Japan; much cultivated.

L. Periclymenum, Linn. Probably the commonest of the old-fashioned climbing honeysuckles (from Old World); strong and woody: leaves oblongovate, not joined by their bases, entire, dark green above and pale beneath: flowers large, reddish outside and yellow inside, very fragrant, in a dense,

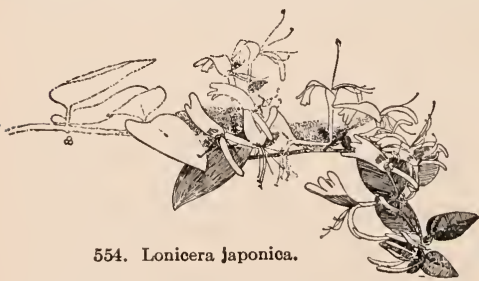
long-stalked cluster.

L. sempérvirens, Ait. Trumpet or coral honeysuckle. Fig. 148. Glabrous twining shrub, with leaves evergreen, oblong, entire, glaucous, upper pairs joined at base about the stem, appearing perfoliate: flowers nearly sessile, in rather distant whorled clusters on terminal spikes, the corolla trumpet-shape, tube almost regularly 5 -lobed, $1 \frac{1}{2}-2 \mathrm{in}$. long, searlet without, yellowish within; stamens and style not much, if any projecting. Moist or low ground, often cultivated. 


\section{Diervílla. Bush Honeysuckle.}

Erect, low shrubs or bushes: leaves simple, opposite, ovate or oblong, aeute-pointed, serrate, deciduous: flowers in axillary or terminal cymes, or solitary; calyx-tube slender, limb of 5 slender, persistent lobes; corolla funnelform, 5 lobes almost regular; stamens 5 ; ovary inferior, 2-celled, 1 filiform style: fruit slender 2-eelled many-seeded pod, crowned with calyx.

D. Lonicèra, Mill. Bushy shrub, 1-4 ft.: leaves oval to ovate, taperpointed, on short petioles: peduneles terminal or in upper axils, mostly 3flowered: corolla slender, tubular, greenish yellow (honey color), not over $3_{4}$ in. long. Banks. Summer.

D. hýbrida, Hort. Weigela. Shrub, $2-8$ ft.: leaves oval, aeute coarsely serrate, rather rough above and soft below, short-petioled: flowers funnelform, 1-11/2 in. long; tube downy without; 5-lobed; the limb spreading. A group of common garden shrubs, derived from 2 or more Japanese species, with white, pink, or red showy flowers.

\section{VIBÚRNUM. ARROW-WOOD.}

Ereet shrubs, with simple leaves and small whitish flowers in broad cymes: stamens 5; stigmas 1-3: fruit a small 1-seeded drupe.

\section{a. Flowers all alike in the cyme.}

V. Lentàgo, Linn. Sheepberry. Fig. 305. Tall shrub (to $20 \mathrm{ft}$.): leaves ovate-pointed, finely and sharply serrate, shining above, on long margined petioles: fruit $1 / 2$ in. or more long, black. Common.

V. acerfòlium, Linn. Dockmackie. Arrow-wood. Six ft. or less: leaves 3-lobed and maple-like, downy beneath: cyme small and slender-stalked: fruit flat and small. Woods.

\section{aa. Flowcrs larger on the margin of the cyme.}

V. Ópulus, Linn., var, americanum, Ait. High-bush cranberry. Erect, $10 \mathrm{ft}$. or less: leaves 3-lobed and toothed: outer flowers sterile and large: fruit an acid red edible drupe. Swamps. In cultivation all the flowers have become sterile, resulting in the "snowball." Compare Figs. 264, 265.

V. tomentòsum, Thunb. ( $V$. plicàtum of gardens). Japanese snowball. Leaves not lobed, shallow-toothed, thickish, plieate: heads of sterile flowers axillary, globular. Japan.

V. alnifòlium, Marsh. Hobblebush. About $5 \mathrm{ft}$., with straggling branches, often arehing to ground and rooting, thus making loops or "hobbles:" flowers resenble those of wild hydrangea, in flat-topped cymes, with marginal flowers larger, sterile and showy, white: leaves very large, round or heart-shaped, finely serrate, petioles and veinlets seurfy: drupes coral-red, becoming purple, not edible. Cold woods and swamps.

\section{SAMBÜCUS. Elder.}

Strong shrubs, with pinnate leaves and sharp-serrate leaflets: flowers in dense corymbose eymes; calyx-teeth very small or none; corolla shallow, open; stamens 5 ; stigmas 3 : pith prominent in the stems, Common. 
S. racemòsa, Linn. Red elder. Pith and berries red: flowers in spring in pyramidal clusters: leaflets lanceolate, downy beneath.

S. canadénsis, Linn. Common elder. White elder. Pith white: berries black-purple, in late summer, edible: flower-clusters convex or nearly flat, in summer: leaflets oblong, smooth.

\section{XLiX. CAMPANULĀCEAE. Bellflower Family.}

Herbs (with us): leaves alternate, simple, without stipules: flowers regular and perfect, mostly bell-shaped corollas, 5-lobed or 5angled; calyx 5-lobed; stamens 5, distinct; ovary 2-5-celled; style 1; stigmas 2-5: fruit a capsule. Some 1,200 or more species.

A. Corolla (of the conspicuous flowers) wheel-shape: early

flowers not opening (cleistogamous)............. Specularia

AA. Corolla bell-form: flowers all alike............. Campanula

\section{SPECULÀRIA.}

Annual herbs, with erect, angled stems, simple or branching: leaves entire or toothed: flowers sessile or nearly so, axillary, solitary or clustered, the early ones cleistogamous and small, the later expanding, light blue, 5-lobed, wheel-shaped corolla; filaments shorter than the anthers.

S. perfoliàta, DC. Stems erect, simple or branched, 10 in. to $3 \mathrm{ft}$. tall, leafy, the leaves rounded heart-shaped or broadly ovate, with clasping bases: flowers solitary, 2 or 3 together in leaf-axils. More or less weedy.

S. Spéculum, DC. Venus' looking-glass. Low garden annual, with stem branching diffusely: flowers purplish lilac to rose-colored or white, solitary and terminal: leaves oblong, crenate.

\section{Campánula. Bellflower. Harebell.}

Flowers solitary or raccmed or spiked, blue or white, not cleistogamous: calyx 5-lobed; corolla bell-shaped: pod roundish, opening at sides (Fig. 283).

C. aparinoìdes, Pursh. A weak, reclining, Galium-like perennial, found among grasses in moist meadows: stem very slender, triangular, angles bearing rough backward-pointing prickles: leaves small, lance-linear, entire: flowers very small, about $1 / 3$ in. long, white, on spreading pedicels.

C. rotundifòlia, Linn. Common harebell. Perennial from slender rootstocks, nearly or quite glabrous, 5-12 in. high: root-leaves rounded or cordate, often withering before blooming season, the stem-leaves linear to narrow-lanceolate, entire: flowers few or solitary on slender pedicels, nodding when open; corolla bell-shaped, with pointed lobes, $1 / 2-2 / 3$ in. long, blue. Rocky places, northward.

C. Mèdium, Linn. Canterbury bell. Cultivated from Europe, annual or biennial, erect to $3 \mathrm{ft}$., rather hairy, branching or simple: leaves lanceolate, rather coarsely-toothed: flowers $2-3$ in. long, single or double, blue; stigmas 5; sepals leafy-appendaged at base. 


\section{LOBELiĀCEA. Lobelia Family.}

Herbs: leaves alternate or radical, simple: flowers seattered, racemed or panicled, often leafy-bracted; ealyx-tube adherent to ovary; corolla irregular, monopetalous, 5-lobed, usually split on one side; stamens 5 , usually united, at least by anthers, about the 1 style; stigma 2-lobed: fruit a capsule, loeulieidally 2-valved.

\section{LOBÈLIA.}

Flowers often showy, axillary and solitary, or in terminal bracted racemes; corolla as if 2-lipped; stamens generally unequal, monadelphous, 2 or all of the 5 anthers bearded at the top. Many species.

L. cardinàlis, Linn. Cardinal flower. Indian pink. A showy plant of swampy or moist soil, also cultivated: tall, simple stem, 2-4 ft., with showy, deep-red flowers (rarely pale colored), about $1 \mathrm{in.} \mathrm{long,} \mathrm{bracted,} \mathrm{in}$ terminal racemes: leaves sessile, lance-oblong, slightly toothed.

L. Erìnus, Linn. The common, pretty, annual trailing or spreading Lobelia of gardens and greenhouses: flowers many, small, very blue, usually with white throats (varying to whitish): lower leaves spatulate; upper narrow, toothed.

L. syphilítica, Linn. Stem erect to 1-3 ft., angular, heavy: leaves oblong-ovate, irregularly serrate: flowers in terminal, leafy raceme; flowers intense blue (or white), 1 in. or more long; calyx hairy or hispid, lobes auricled at base, dentate. Perennial, in low or marshy grounds or along streams. Late summer.

L. spicàta, Lam. Erect smoothish stems, 1-3 ft., sparingly leafy, the terminal raceme with linear, small bracts: leaves oblong, upper small and narrow: flowers small, pale blue; calyx-lobes not auricled at base, entire. Dry, sandy soil.

L. inflàta, Linn. Indian tobacco. Erect, 9-12 in., rather hairy, branching: leaves ovate, toothed: flowers small, $1 / 3 \mathrm{in}$. iong, pale blue, in loose, racemes, leafy-bracted: capsules inflated, large. Common in fields; juice pungent-poisonous.

\section{Li. COMPÚSite. Composite or Sunflower Family.}

Mostly herbs, many of them very large, very various in foliage: flowers small, densely packed into an involuerate head, 5-merous; the corolla of the outer ones often developed into long rays; stamens 5 , the anther's united around the 2 styles: fruit dry and 1-seeded, indehiseent, usually crowned with a pappus which represents a ealyx. The largest of all phenogamous families, eomprising about one-tenth of all flowering plants,-about $\$ 00$ genera and 11,000-12,000 species. Common composites are sunflower, aster, goldenrod, boneset, dahlia, chrysanthemum, marigold, eompass plant, thistles, dandelion, lettuce. 
A. Heads with all flowers strap-shaped (with rays) and perfect: juice milky: leaves alternate.

B. Flower-heads terminal on leafless, hollow stalk

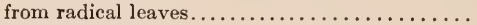

1. Taraxacum

вв. Flower-heads terminal on leafy stalks: leaves

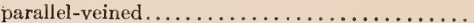

2. Tragopagan

ввв. Flower-heads in corymbs or elusters.

c. Heads never yellow (usually blue or white): pappus of blunt scales................ 3. Cichorium

cc. Heads usually yellow (in one case blue).

D. Achenes beaked: pappus copious, white, soft, hair-like: leaves sometimes bristly or prickly edged

\section{Lactuca}

DD. Achenes not beaked.

E. Pappus soft, white: leaves usually auricled and clasping at base, and prickly on edges and under ribs........... 5. Sonchus

EE. Pappus stiff, brownish, leaves not spiny... 6. Hicracium

AA. Heads with tubular and mostly perfect disk flowers, the rays, if any, formed of the outer strap-shaped and imperfect flowers: in cultivated species, all the flowers may become strap-shaped (head "double"): juice not milky.

B. Fruit a completely closed and bur-like involucre, containing 1 or 2 small achenes: flowers imperfect (see also No. 23).

c. Involucre-bur large, and sharp-spiny

7. Xanthium

cc. Involucre-bur small, not sharp-spiny........ 8. Ambrosia

BB. Fruit not formed of a closed and hardened involucre (although the involucre may be spiny, as in Aretium and Cnicus).

c. Pappus none: achenes not awned.

D. The leaves opposite.

E. Leaves simple: flower-heads small: flowers blue or white............... 9. Ageratum

EE. Leaves compound: flower-heads large, various colors, mostly of ray florets......10. Dahlia

EEE. Leaves dissected: heads showy.........11. Cosmos

EEEE. Leaves various: rays usually about 8, neutral and yellow. (See Coreopsis, 21.)

DD. The leaves alternate.

E. Foliage finely divided.

F. Heads small (about $1 / 2$ in.): achenes flattened....................12. Achillea

FF. Heads good-sized (about 1 in.): achenes oblong, angled or ribbed........... Anthemis 
EE. Foliage leaves entire, toothed, or broadlobed.

F. Achenes curved or horse-shoe-shaped....14. Calendula FF. Achenes straight.

G. Torus flat or slightly convex......15. Chrysanthemum Gg. Torus conical.

H. Rays yellow: flowers large, $2-3$ in...16. Rudbeckia нн. Rays not yellow: flowers about 1 in. across: plant low.........17. Bellis

cr. Pappus of 2 thin early deciduous seales...... 18. Helianthus ccc. Pappus a short crown, or achenes awned at the top with ( 2 or more) awns.

D. Achenes angled or ribbed, crowned with cuplike or lobed pappus: foliage strongly "tansy" seented .................. Tanacetum

DD. Achenes more or less flattened, and awned at summit, with usually 2 or 4 awns.

E. Awns barbed downward: achenes various, narrowed at top, and awned, but not really beaked ....................... Bidens

EE. Teeth not downwardly barbed: (sometimes achenes awnless.)............21. Coreopsis cccc. Pappus of many bristles.

D. Plant very prickly 22. Cirsium

DD. Plant not prickly.

E. Involucre priekly and bur-like........23. Aretium

EE. Involuere not bur-like or prickly.

F. Torus bristly (chaff or bracts amongst

the florets)................24. Centaurea

FF. Torus naked.

G. Rays present.

н. Flowers yellow.

I. Leaves all radical: rays numerous and fertile...............25. Tussilago

II. Leaves on stems, alternate.

J. Heads small, in large elusters or panieles............26. Solidago

JJ. Heads large and broad: leaves large on stem and in a basal clunip................27. Inula

нн. Flowers not yellow.

I. Seales of the involucre unequal...28. Aster

II. Seales equal in length.........29. Erigeron

III. Seales in several rows, more or less leafy................ Callistephus Gg. Rays none. 
н. Plants cottony-white, or downylooking.

I Heads mostly diœeious.

J. Leaves basal and also on stem: pappus thickened at summit and more or less barbed or plumed.................. Antennaria

JJ. Stems leafy: pappus not thickened at summit: some sterile flowers, usually in center of the fertile heads...........32. Anaphalis

11. Heads not diœcious: outer flowers pistillate, central perfect......33. Gnaphalium

Hн. Plants not cottony-white.

I. Flower-heads showy, spicate or racemed, rose-purple: leaves alternate.................. Liatris

II. Flower-heads small, in cymes or corymbs.

J. Flowers white or pale purple:

leaves mostly opposite......35. Eupatorium

Jj. Flowers purple: leaves alternate....................... Vernonia

\section{TARÁXACUM. DANDELION.}

Stemless herbs, the 1-headed scape short, leafless and hollow: florets all perfect and strap-shaped: fruit ribbed, the pappus raised on a long beak. Variable plants.

T. officinàle, Weber (T. Dens-leonis, Desf.). Common dandelion. Figs. 8, 302. Perennial, introduced from the Old World: leaves long, pinnate or lyrate: heads yellow, opening in sun.

\section{TRAGOPÒgON. Goat's BEARd.}

Biennials or perennials, stout, smooth, often glaucous, with long, grasslike leaves clasping the stem: flowers all ligulate, in large solitary heads, purple or yellow, terminal on long peduncle, with single involucre of many bracts, which are equal and lanceolate, joined at bases: pappus in one series, long and plumose: achenes linear, mostly with long slender beaks, 5-10-ribbed or angled: flowers open in early morning, usually closed at midday. Juice milky.

T. porrifòlius, Linn. Salsify. Oyster-plant. Biennial; involucral bracts much longer than the rays: stems $2-3 \mathrm{ft}$. high, hollow and thickened upward: flowers purple. Europe. Cultivated for the edible tap-root. Sometimes wild.

T. praténsis, Linn. Similar to preceding, but flowers yellow and involucral bracts not longer than rays. Europe. Fields and waste places, eastern and middle states. 


\section{CICHÒRIUM. CHICORY.}

Tall, branching perennials, with deep, hard roots: florets perfect and strap-shaped: fruit lightly grooved, with sessile pappus of many small, chaffy scales.

C. Íntybus, Linn. Common chicory. Runs wild along roadsides (from Europe); 2-3 ft.: leaves oblong or lanceolate, the lowest pinnatifid: flowers bright blue or pink, 2-3 together in the axils on long nearly naked branches.

\section{LACTÙCA. LetTuCE.}

Coarse weedy plants: stems tall and leafy, simple or branching, carrying small panicled heads of insignificant flowers: juice milky: stem-leaves alternate, entire, or pinnately divided with lobes and margins and under midrib often spinc-tipped: involucre cylindrical, with bracts in 2 or more unequal rows; flowers all ligulate and perfect, with the ligules truncate and 5-toothed: achenes oval to linear, flattened, 3-5-ribbed on each face, smooth, abruptly narrowed into a beak: pappus abundant, white or brownish and soft.

L. canadénsis, Linn. Common in rich soil, 3-9 ft. tall: leaves smooth, lanceolate to spatulate, sessile or clasping, margins entire, sinuate, or runcinately pinnatifid, the radical leaves petiolate-all smooth and glaucous; flowers pale yellow, in small heads $(1 / 4-1 / 2$ in. long), the heads more or less diffusely panicled. Biennial or annual.

L. villòsa, Jacq. Three to $8 \mathrm{ft}$.: leaves ovate to lanceolate, pointed and serrate, teeth mucronate, sometimes hairy on under midrib, the petioles winged, more or less sinuate or clasping and arrow-shaped: inflorescence a panicle of numerous small heads; rays bluish: achenes short-beaked or beakless: pappus brownish. Biennial or annual.

L. Scariola, Linn. Prickly lettuce. Fig. 86. Glabrous and rather glaucousgreen, with tall, stiff, erect stem, branching, usually somewhat prickly: leaves oblong or spatulate, dentate or pinnatifid, sessile, or auricled and clasping, with margins and under midrib spiny: heads small, 6-12-flowered, but numerous, the rays yellow; involucre narrow, cylindric: achenes flat, ovate-oblong, with long filiform beak. Europe. A common coarse biennial weed.

L. sativa, Linn. Garden lettuce. Cultivated for the tender root-leaves as a salad: flowers yellow on tall small-leaved stems.

\section{Sónchus. Sow Thistle. Milk Thistle.}

Coarse, succulent weeds, smooth and glaucous or spiny, with leafy stem, resembling wild lettuce, but achenes truncate, not beaked, and the flowers always ycllow: involucre bell-shape in several unequal series; rays truncate, 5-toothed. All from Europe.

S. oleràceus, Linn. Annual, from fibrous roots, 1-5 ft., with pale yellow flowers in heads $2 / 3-1$ in. in diameter: leaves various, mostly on lower part of stem, petiolate or clasping by an auricled base, the lobes acute; in shape lanceolate to lyrate-pinnatifid, margins spinulous.

S. arvénsis, Linn. Perennial with creeping rootstocks: flowers bright 
yellow in showy heads: leaves various, but spiny on margins, and generally with clasping, auricled bases: bracts of the involucre bristly.

S. ásper, Hill. Spiny-leaved sow thistle. Annual weed: resembles $S$. oleraceus closely, but the clasping auricles are rounded at base, stem-leaves

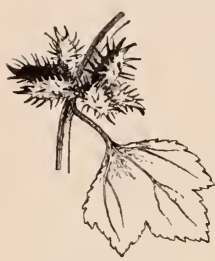

555. Xanthium canadense. not so divided and more spiny.

\section{HIERÀCIUM. HAWKWEED.}

Hairy, or glandular-hispid, or glabrous perennials, with radical or alternate entire leaves: head of 12-20 yellow or orange ligulate flowers, solitary or panicled; involucre in one or several series, unequal; rays truncate and 5-toothed: achenes oblong, striate, not beaked; pappus single or double, delicate, tawny or brownish, stiff, not plumose. Large number of species widely spread.

H. venòsum, Linn. Rattlesnake-weed. Smooth, slender, leafless or with 1 or few leaves, 1-2 ft., forking into a loose, spreading corymb of heads: leaves thin, glaucous, radical and tufted, or near base on stem, oblong or oval, nearly entire, slightly petioled or sessile, sometimes purplish or marked with purple veins: achenes linear, not narrowing upward. Dry woods.

H. aurantiacum, Linn. Orange hawkweed. Devil's paint-brush. A very bad weed in meadows East, from Europe: hirsute and glandular: leaves narrow: heads deep orange: achenes oblong, blunt.

\section{XÁNTHIUM. CLOTBUR.}

Coarse homely annual weeds with large alternate leaves: flowers monœcious: in small involucres; sterile involucres composed of separate scales, in short racemes; fertile involucres of united scales forming a closed body, clustered in the leaf-axils, becoming spiny burs.

X. canadénse, Mill. Common clotbur. Fig. 555. One to $2 \mathrm{ft}$., branching: leaves broad-ovate, petioled, lobed and toothed: burs oblong-conical, 1 in. long, with 2 beaks. Waste places.

X. spinòsum, Linn. Spiny clotbur. Pubescent, with 3 spines at the base of each leaf: bur $1 / 3$ in. long. with 1 beak. Tropical America.

\section{AMBRÒSIA. RAGWEED.}

Homely strong-smelling weeds, monœcious: sterile involucres in racemes on the ends of the branches, the scales united into a cup; fertile involucres clustered in the axils of leaves or bracts, containing 1 pistil, with 4-8 horns or projections near the top. Following are annuals:

A. artemisiæfòlia, Linn. Common ragweed. Figs. 416,556 . One to 3 ft., very branchy; leaves opposite

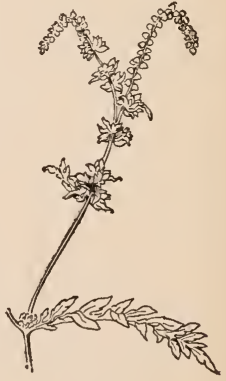

556. Ambrosia artemisiæfolia. 
or alternate, thin, once- or twice-pinnatifid: fruit or bur globular, with 6 spines. Roadsides and waste places.

A. trifida, Linn. Great ragweed. Three to $12 \mathrm{ft}$., with opposite 3-lobed serrate leaves: fruit or bur obovate, with 5 or 6 tubercles. Swales.

\section{9. agératum. Ageratum.}

Small diffuse mostly hairy herbs, with opposite simple leaves: heads small, blue, white or rose, rayless, the involucre cup-shaped and composed of narrow bracts; torus flattish; pappus of a few rough bristles.

A. conyzoìdes, Linn. (A. mexicanum of gardens). Annual pubescent herb, with ovate-deltoid scrrate leaves: cultivated (from tropical America) for small and numerous clustered soft heads.

\section{DÁHLIA.}

Stout familiar garden herbs, tall and branching, from tuberous roots: leaves opposite, pinnately divided: ray flowers in natural state are neutral or pistillate and fertile; disk flowers perfect; involucre double, outer scales distinct and leaf-like, the inner united at base; receptacle chaffy; pappus none. In the big cultivated dahlias, most of the flowers are rays.

D. variábilis, Desf. Figs. 257, 258. Several feet, with fine large heads of flowers, colors various; heads solitary: leaves pinnate, leaflets unequal, 3-7, ovate-acuminate, coarsely serrate. Mexico.

\section{1. cósmos.}

Handsome tall plants, 4-5 ft. high, cultivated for the fine foliage and late flowers: leaves opposite, very finely dissected, thrice-compound, the leaflets extremely narrow, and sessile: flower-head with double involucre; the outer bracts dark green, calyx-like, 8 in number, the inner scales erect, with recurved tips; ray flowers, usually 8 , neutral, white, pink; disk flowers perfect, tubular, yellow; receptacle chaffy: achenes flattened, beaked. Mexico.

C. bipinnàtus, Cav. Rays 1-2 in. long, crimson, rose or white, the disk yellow. The commonest species.

C. sulphùreus, Cav. Both rays and disk yellow.

\section{ACHILlEA. YarRow.}

Low perennial or annual herbs: heads corymbose, many-flowered, white or rose, with fertile rays; scales of involucre overlapping (imbricated); torus flattish, chaffy; pappus none.

A. Millefòlium, Linn. Yarrow. Stems simple below, but branching at the top into a large rather dense umbel-like flower-cluster: leaves very dark green, twice pinnatifid into very fine divisions: rays 4-5. Fields everywhere.

\section{3. Ánthemis. Chamomle. Fig. 417.}

Strong-scented, branching herbs with finely pinnatifid leaves and many-flowered heads, solitary on peduncles: ray flowers white or yellow, pistillate or neutral, the edge of corolla entire or 2 -3-toothed: disk flowers 
perfect, fertile, yellow, corolla 5-cleft; receptacle convex, partially chaffy; involucral bracts small, dry, in several series, outermost shortest: achenes round or ribbed, smooth: pappus none or a slight border. There are a number of cultivated plants in this genus.

A. Còtula, DC. May-weed. Annual, bushy, erect, 1-2 ft.: heads terminal, corymbed, $1 \mathrm{in}$. broad; rays usually white, neutral; disk flowers yellow: leaves alternate, mostly sessile, finely pinnatifid. Roadsides. Europe.

\section{4. caléndula. Pot Marigold.}

Erect, quick-growing annuals, with terminal large yellow or orange heads with pistillate rays: involucre of many short green scales; torus flat; pappus none: achenes of the ray florets (those of the disk florets do not mature) curved or coiled.

C. officinàlis, Linn. Common pot marigold. A common garden annual from the Old World, with alternate entire sessile oblong leaves: 1-2 ft.

\section{CHRYsánthemuM. Chrysanthemum.}

Erect herbs, annual or perennial, with alternate lobed or divided leaves: rays numerous, pistillate and ripening seeds; torus usually naked, flat or

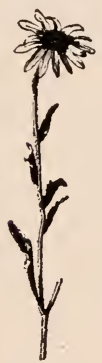

557. Rudbeckia hirta. convex; pappus none.

\section{a. Achenes of ray florets winged.}

C. morifòlium, Ram. (C. sinénse, Sabine). Greenhouse chrysanthemum. Tall and mostly strict, with lobed, firm and long-petioled alternate leaves: flowers exceedingly various. China.

\section{aa. Achenes not winged.}

C. Leucánthemum, Linn. Whiteweed. Ox-eye daisy. Fig. 189. Perennial, with many simple stems from each root, rising 1-2 ft., and bearing alternate oblong sessile pinnatifid leaves: heads terminating the stems, with long white rays and yellow disks. Fields everywhere in the East, and spreading West.

\section{RUDBÉCKIA. CONE-FLOWER.}

Perennial or biennial herbs, with alternate leaves and showy yellow-rayed terminal heads: ray florets neutral; scales of involucre in about 2 rows, leafy and spreading; torus long or conical, with a bract behind each floret: achenes 3 -angled, with no prominent pappus. Strong field plants.

R. hirta, Linn. Black-eyed Susan. Ox-eyed daisy in the East. Fig. 557. Biennial, 1-2 ft., coarse-hairy, leaves oblong or oblanceolate, nearly entire, 3-nerved: rays as long as the involucre or longer, yellow, the disk brown; torus conical. Dry fields.

R. laciniàta, Linn. Two to $7 \mathrm{ft}$, , perennial, smooth, branching: leaves pinnate, with 5-7-lobed leaflets, or the upper ones 3-5-parted: rays 1-2 in. long; torus becoming columnar. Low places. 


\section{BÉllis. Garden Daisy.}

Low tufted herbs with many-flowered heads, solitary on scapes: leaves spatulate, petioled: flowers both radiate and tubular, mostly double, with margins of the rays various, quilled, and otherwise modificd in the cultivated forms: ray flowers white or pink, pistillate; disk flowers yellow, perfect with tubular corolla, limb 4-5-toothed: achenes flattened, wingless, nerved near margins.

B. perénnis, Linn. English daisy. European garden daisy. Fig. 200. Flower-head on a scape 3-4 inches high, from radical leaves, $3 / 4-1$ in. in diameter, with numerous linear rays, white, pink, bluish. Europe. Perennial. Cultivated in gardens or on lawns. April to November.

\section{HeliánthuS. Sunflower. Figs. 3,4 .}

Stout, often eoarse perennials or annuals, with simple alternate or opposite leaves and large yellow-rayed heads: ray florets neutral; scales of involucre overlapping, more or less leafy; torus flat or convex, with a bract embracing each floret: achene 4-angled: pappus of 2 seales (sometimes 2 other smaller ones), which fall as soon as the fruit is ripe.

\section{a. Disk brown.}

H. ánnuus, Linn. Common sunflower. Tall, rough, stout annual, with mostly alternate stalked ovate-toothed large leaves: seales of involuere ovateacuminate, eiliate. Minnesota to Texas and West, but everywhere in gardens.

H. scabérrimus, Ell. Prairie sunflower. Stout perennial (2-6 ft.), rough: leaves oblong-lanceolate, entire or serrate, rough and grayish, thick and rigid: heads nearly solitary, with 20-25 rays. Prairies, Michigan, west.

aa. Disk yellow (anthers sometimes dark).

H. gigantèus, Linn. Tall, to $10 \mathrm{ft}$., rough or hairy: leaves mostly alternate, lanceolate-pointed, finely serrate or quite entire, nearly sessile: scales linear-lanceolate, hairy; rays pale yellow, 15-20. Low grounds.

H. divaricàtus, Linn. Figs. 3, 4, 23, 28. Small for the genus, 1-4 ft.: leaves opposite, ovate-laneeolate, 3-nerved, sessile, serrate, rough and thickish: rays 8-12, 1 in. long. Common in dry thickets.

H. tuberòsus, Linn. Jerusalem artichoke. Bearing edible stem-tubers below ground: 5-10 ft.: leaves ovate to oblong-ovate, toothed, long-petioled: scales not exceeding the disk: rays 12-20, large. Pennsylvania west, and cultivated.

\section{TANACÈTUM. TANSY.}

Tufted perennials, with finely divided leaves and strong odor: involucre of overlapping dry scales; torus convex; heads small, nearly or quite rayless, the flowers all seed-bearing: achenes angled or ribbed, bearing a short crown-like pappus.

T. vulgàre, Linn. Common tansy from Europe, but run wild about old houses: 2-4 ft.: leaves 1-3-pinnately cut: heads ycllow, pappus-crown 5-lobed. 


\section{Bìdens. Bur-marigold. Beggar's Ticks. Pitchforks.}

Annual or perennial, similar to Coreopsis, including weeds known as Spanish-needles or stick-tights: leaves opposite: flowers mostly yellow; involucre double, outer scales large and leaf-like; heads many-flowered; ray flowers 4-8, neutral, or none; disk flowers perfect, tubular: achenes flattened or slender and 4-angled, crowned with 2 or more rigid downwardly

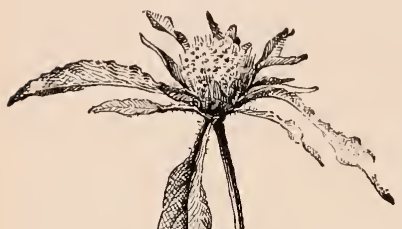
barbed awns.

B. frondòsa, Linn. Figs. 418,558 . Smooth or sparsely hairy, $2-6 \mathrm{ft}$. tall, branching: leaves 3-5-divided, or upper simple; leaflets stalked, lanceolate, serrate: outer involucre longer than head; bracts foliaceous: achenes wedge-ovate, flat, 2-awned. In moist places. Annual.

B. læ̀vis, BSP. Smooth branching annual, 6 in. to $2 \mathrm{ft}$., usually abundant along ditches: leaves sessile, simple, lanceolate, acuminate, serrate, the bases sometimes united: outer involucral bracts exceeding the inner, but shorter than the yellow, oval or oblong rays: rays about 1 in. long, 8 or 10 in number: achenes small, wedgeshaped, truncate, prickly on margins, with 2 rigid downwardly barbed awns.

B. bipinnàta, Linn. Spanish needles. Annual: stem quadrangular, erect, branching freely: leaves 1-3 times pinnate, leaflets lanceolate, pinnatifid: heads small on slender peduncles; rays short, pale yellow, 3, 4 or more: achenes smooth, 3-4-grooved, 2- or 6-awned (awns barbed).

558. Bidens

frondosa.

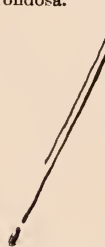

\section{COREÓPSIS. TICKSEED.}

Low herbs with opposite, sometimes alternate leaves: heads of tubular and ray flowers solitary, or corymbed on long peduncles; involucre double, bracts all united at base, the 8 outer ones usually leafy; the inner erect; receptacle chaffy; ray flowers neutral, usually yellow; disk flowers tubular, perfect, yellow or purple; pappus of 2 short teeth or a crown-like border, or none: achenes flat, often winged, 2-toothed or 2armed. A number of rather showy but somewhat weedy plants.

C. tinctòria, Nutt. Calliopsis. Annual or biennial, glabrous, erect, 1-3 ft.: disk flowers dark purple; ray flowers about 8 , yellow with purple bases, the edges coarsely 3 -toothed: leaves alternate, 2 or 3 times pinnatelydivided; the lower petioled, the upper sessile and often entire: heads $1-11 / 2$ in. wide, on slender peduncles. A favorite in gardens. Ray flowers variable in shape and coloring.

C. tripteris, Linn. Tall coreopsis. Tạll and leafy stems, 4-9 ft.: disk and 
ray flowers all yellow; heads small, numerous, 1-11/2 in. broad, corymbed, giving a spicy odor when bruised. Perennial. Weed, common.

C. lanceolàta, Linn. Perennial, native and cultivated: nearly or quite glabrous: leaves oblong or linear, mostly entire, obtuse: heads large, yellowrayed, on very long stems.

\section{CÍRSiUM. Thistle.}

Perennial or biennial herbs, with pinnatifid, very prickly leaves: florets all tubular and usually all perfect; scales of the involucre prickly; torus bristly; pappus of soft bristles, by means of which the fruit is carried in the wind. Several species in our territory.

C. lanceolàtum, Hill. Common thistle. Figs. 253-255. Strong, branching biennial: leaves pinnatifid, decurrent, woolly beneath: heads large, purple, with all the involucre-scales prickly. Europe.

C. arvénse, Scop. Canada thistle. Fig. 409. Lower, perennial and a pestiferous weed: leaves smooth or nearly so beneath: flowers rose-purple, in small, imperfectly dicecious heads, only the outer seales prickly. Europe.

\section{3. ÁRCTIUM. BURDOCK.}

Coarse biennials or perennials, strong-scented, with large dock-like simple leaves: head becoming a bur with hooked bristles, the florets all tubular and perfect; torus bristly; pappus of short, rough, deciduous bristles.

A. Láppa, Linn. Burdock. Common weed from Europe, with a deep, hard root, and bushy top $2-3 \mathrm{ft}$. high: leaves broad-ovate, somewhat woolly beneath, entire or angled.

\section{4. centaurèa. Star-thistle. Centaurea.}

Alternate-leaved herbs, the following annuals, with single heads terminating the long branches: heads many-flowered, the florets all tubular but the outer ones usually much larger
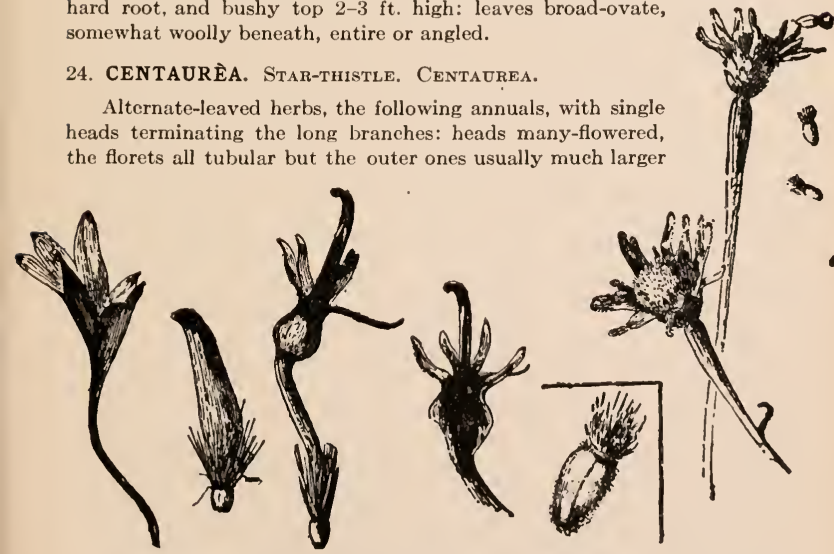

559. Centaurea Cyanus. At the left is an outer or ray floret; then follow three details of a disk floret; then follows the fruit. 
and sterile; scales of involucre overlapping; torus bristly: achenes oblong, with bristly or chaffy pappus. Cultivated.

C. Cỳanus, Linn. Corn-flower. Bachelor's button. Figs. 256, 559. Gray herb: leaves linear and mostly entire: heads blue, rose or white. Europe.

C. moschàta, Linn. Sweet sultan. One to $2 \mathrm{ft}$., smooth: leaves pinnatifid: pappus sometimes wanting; heads fragrant, white, rose or yellow; large. Asia.

\section{TUSSILÀgo. Coltsfoot.}

Low stemless hairy perennials from rootstocks: scapes simple in early spring, scaly-bracted, each bearing a single dandelion-like head: leaves radical, appearing later, orbicular-angled or toothed, white-woolly at first: ray flowers in several rows, pistillate, fertile; disk flowers tubular, staminate, sterile; involucre nearly simple, or 1-rowed achenes of ray flowers, cylindrical, 5-10-ribbed; pappus abundant, soft, hair-like, white.

T. Fárfara, Linn. Yellow heads in very early spring before the leaves. A common weed East, found in low, damp places and along cool banks. Europe.

\section{SOlidÀGO. Goldenrod.}

Perennial herbs, with narrow, sessile leaves: heads yellow, rarely whitish, few-flowered, usually numerous in the cluster, the ray-florets $1-16$ and pistillate; scales of involucre close, usually not green and leaf-like; torus not ehaffy: achene nearly cylindrical, ribbed, with pappus of many soft bristles. Of goldenrods there are many species. They are characteristic plants of the American autumn. They are too critical for the beginner.

\section{InUla. Elecampane.}

Large and tall coarse perennial herbs, with large, showy yellow flowerheads 2-4 in. diameter, sunflower-like: leaves large, simple, alternate, and also radical in clumps: heads contain both perfect tubular, and pistillate ray florets, in one row; receptacle not chaffy: achenes 4-5-ribbed: pappus in one row, bristles hair-like.

I. Helènium, Linn. Four to $6 \mathrm{ft}$., rising from a clump of large, ovate, dock-like leaves on heavy petioles; stem-lcaves sessile or clasping: heads solitary, terminal; involucre bracts ovate, leaf-like, woolly. Weed in damp pasture and along roadside. Summer.

\section{8. ÁSTER. Aster. Fig. 252.}

Perennial herbs, with narrow or broad leaves: heads with several to many white, blue or purple rays in a single series, the ray florets fertile; scales of involucre overlapping, usually more or less green and leafy; torus flat: achene flattened, bearing soft, bristly pappus. Asters are conspicuous plants in the autumn flora of the country. The kinds are numerous, and it is difficult to draw specific lines. The beginner will find them too critical.

\section{ERÍgERON. Fleabane.}

Annual, biennial or perennial erect herbs, with simple, sessile leaves: heads few- to many-flowered; rays numerous in several rows and pistillate; 
seales of involuere narrow and equal, scarcely overlapping, not green-tipped; torus flat or eonvex, naked; pappus of soft bristles.

\section{a. Rays very ineonspicuous.}

E, canadénsis, Linn. Horse-weed. Mare's-tail. Fig. 560. Tall, erect, weedy, hairy annual, with strong seent: leaves linear and mostly entire or the root-leaves lobed: heads snall and very numerous in a long panicle, the rays very short.

aa. Rays prominent: common fleabanes.

E. ânnuus, Pers. Usually annual, 3-5 ft., with spreading hairs: leaves eoarsely and sharply toothed, the lowest ovate and tapering into a margined petiole: rays numerous, white or tinged with purple, not twice the length of the involuere.

E. ramòsus, BSP. Daisy fleabane. Usually annual, with appressed hairs or none: leaves usually entire and narrower: rays white and numerous, twiee the length of the involuere.

E. pulchéllus, Michx. Robin's plantain. Perennial leafystemmed herb, softly hairy, producing stolons or rooting branches from the base, the simple stems, from a eluster of rather large, roundish, short-petioled, serrate, root-leaves; stem-leaves few, entire, sessile and partially elasping: heads 1-7, on long peduncles; rays numerous, linear or spatulate, purplish or pinkish. April to June.

30. Callístephus. China Aster.

Erect, leafy annuals, with large solitary heads bearing

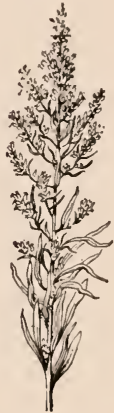

563. Erigenon canadensis. numerous white, rose or purple rays: seales in several rows or series, usually leafy; torus flat or nearly so, naked; pappus of long and very short bristles.

C. horténsis, Cass. Common China aster, now one of the commonest of garden annuals, in many forms: leaves sessile and coarsely toothed. China.

\section{ANTENNÀria. Everlasting.}

Perennial little herbs with eottony leaves and stems: flowers diocious, in many-flowered small heads, solitary or raeemose or elustered (much resembling Gnaphalium, but distinguished by the diocious heads); iuvoluere with dry imbricated bracts in several rows, usually woolly-white or colored; pappus in a single row, that of the sterile flowers thiekened and plumed at summit. Several confused species, or forms of one speejes, mostly in open, clry places.

A. plantaginifòlia, Rieh. Mouse-ear everlasting. Noticeable on dry soil and in open plaees, as white cottony patches: stoloniferous root-leaves soft white when young, later green above but hoary beneath, oval to spatulate, petioled, 3-veined: flowering stem simple seape-like, 4-8 in. high, bears small, bract-like, appressed leaves, and heads in a small, erowded, terminal corymb; seales of involuere whitish. 
32. ANÁphalis. Everlasting.

Cottony-white herbs, very similar to the preceding, but pappus not thickened at summit, and usually a few perfect but sterile flowers in center of the head: stem leafy. Perennial.

A. margaritàcea, Benth. \& Hook. Pearly everlasting. One to $2 \mathrm{ft}$.: heads in corymbs at summit, diøecious, but a few imperfect staminate flowers in the center of the fertile heads: leaves sessile, taper-pointed, broad-ovate to linear-lanceolate: involucre scale pearly white, rounded. Common in dry soil.

\section{GNaphàlium. Everlasting. Cudweed.}

Cottony-white herbs, with small head of many whitish flowers, surrounded by involucre of white or colored scales, in many series: flowers all fertile, outer pistillate, central perfect: no chaff on receptacle; pappus a row of slender bristles. Common in dry fields.

G. polycéphalum, Michx. Common everlasting. Annual, with leaves lanceolate, margins wavy, upper surface not very cottony: scales of involucre white or yellowish white, a few perfect flowers in the center of each head.

G. decúrrens, Ives. Biennial or annual, with many perfect flowers in center of each head: stem ereet, 1-2 ft.: leaves lance-linear, both sides cottony, bases partially clasping and running down the stem.

\section{Liàtris. Blazing Star. Button Snakeroot.}

Perennial herbs, with simple erect stems from tuberous or corm-like roots: leaves entire, alternate, rather rigid, sometimes vertical on the stem, and resinous-dotted: flowers few to many, in racemed or spicate heads; flowers all alike, rose-purple, tubular; corolla 5-lobed, lobes long and slender; pappus of many hair-like bristles, plumose or barbed: achene slender, tapering to base: involucral bracts in several rows, unequal.

L. scariòsa, Willd. Stem stout, 2-5 ft. tall: leaves lanceolate, the lower long-petioled, the upper more linear and rigid: heads few to many, 30-40flowered, about 1 in broad: scales of involucre numerous, with rounded tips; often colored and rather rough on the margins; flowers bright purple. Dry soil.

L. pycnostàchya, Michx. Heads 3-15-flowered: flowers rosy-purple on a spike 3-4 ft. high: flowers begin to open at top of the spike and continue opening downward: scales with purplish tips. A western species, cultivated; very showy.

\section{EUPATÒRIUM. THOROUGHWORT.}

Erect perennials, with simple leaves: heads small and rayless, clustered, all the florets perfect; scales not leafy; torus flat or low-conical, naked: achene 5-angled: pappus a single row of soft bristles. Low grounds.

E. purpùreum, Linn. Joe Pye weed. Tall, with purplish stem and lanceolate-toothed leaves in whorls of 3-6: heads flesh-colored, in dense corymbs. Swamps, growing 3-10 ft. 
E. perfoliàtum, Linn. Boneset. Thoroughwort. Fig. 171. Two to $4 \mathrm{ft}$., hairy: leaves opposite and sessile, laneeolate: flowers white, in elusters.

36. VERNÒNIA. IRONWEED.

Coarse perennial herbs, with tall strong leafy stems: leaves alternate (seldom opposite), sessile: flowers 15 to many in a head, heads corymbed, all tubular, perfect, purple (rarely white or pink); involuere shorter than flowers, with several series of scales; receptacle not ehaffy; pappus double, the inner series bristle-like, the outer of short, small, scale-like bristles: achenes eylindrical, several-ribbed.

V. novaboracénsis, Willd. A coarse weed, 3-6 ft.: heads about $1 / 2 \mathrm{in}$. long: braets of involuere, some or all, with slender long or awned flexuous points, brownish purple: leaves many, rough, lanceolate or lance-oblong, 2-9 in. long, serrulate, sessile, all along stem: flowers deep purple in spreading, flat-topped eymes: achenes somewhat hairy. Late summer.

V. fasciculàta, Michx. Tall, coarse weed, 3-10 feet, with deep purple flowers in heads (20-30-flowered), corymbed; involuere eampanulate, seales usually obtuse, not awn-like. Summer and autumn. 



\section{INDEX AND GLOSSARY}

\section{Numbers in parenthesis refer to paragraphs}

Aborted: crowded out, (316).

Abronia, Fig. 18.

Abutilon, 372, Figs. 182, 520.

Acacia, leaf, 108, Fig. 163.

Accessory buds: more than one in an axil, (88).

Accessory fruit: other parts grown to the pericarp, (311), 161.

Acclimatization: adaptation to a climate at first injurious, (367).

Acer, 376, Figs. 523-526.

Acetic acid, 271.

Achene: dry, indehiscent, one-seeded pericarp, (313).

Achillea, 437.

Acorn, 155, 178 .

Acorus, 328.

Actæa, 359.

Acuminate: taper-pointed, (211).

Acute: sharp-pointed, (211).

Adder's-tongue, 331; fern, 198, Fig. 368.

Adiantum, 323.

Adventitious buds: those appearing on occasion, $(54,124)$.

Ecidia, 191. Ecidiospore, 191.

Aërial roots, 10, Figs. 12-14.

Esculus, 377.

Ageratum, 437.

Aggregate fruit: one formed by the coherence of pistils that were distinct in the flower, (321).

Agrimonia, 387.

Agrimony, 169, 387.

Ailanthus, leaf-scars, 37, Figs. 57; seeds, 168.

Air-plants, 11.

Alcanin, 273.

Alder, 345.

Aleurone grains, 275, Fig. 445 .

Alfalfa, $3,7,79,94,137,172,251,383$, Figs. 21, 246, 529; nodules on root, 78 . Algæ, 181, 183, 185, 201, 207, 263, 266. Alkaloids, 271.

Almond, 61, 251, 271; bud, 39, Fig. 68 .

Alnus, 345.

Alpine plants, 229.

Alsike clover, 382.

Alternate leaves, 47.

Alternation of generations, 182, 201.

Althea, $148,372,373$.

Alyssum, 160, 367, 368, Fig. 519.
Amaranth, 170, Fig. 411.

Amaryllidaceæ, 335.

Ambrosia, 436, Figs, 416, 556.

Amelanchier, 391.

Amceba, 266. Amceboid, 266.

Ampelopsis, leaves of, 100, Fig. 155.

Amphibious, 208.

Amylo-dextrine, 275. Amylose, 271.

Anacharis, 85, Fig. 439 .

Analogy: related in function or use, (223).

Anaphalis, 444.

Anemone, 356; fruit, 156.

Anemonella, 357.

Angelica, 398 .

Angiosperms, 327.

Aniline for staining, 73 .

Annual: of one scason's duration, (10).

Annular, 267.

Antennaria, 443 .

Anthemis, 437, Fig. 417.

Anther: pollen-bearing part of the stamen, $(270)$.

Antheridia, 181, 187. Antheridiophore, 194.

Anthodium: flower-head of the Compositæe, (251).

Antirrhinum, 106.

Antitropic: against the sun, (243).

Apetalous: petals missing, $(273,290)$.

Aphyllon, 90, Fig. 131.

Apical; at the apex or top, (317).

Apios, 385.

A pium, 399

A poeynaces, 418.

Apparatus, 301.

Apple, 20, 32, 68, 251, 254, 391; acid, 271; bud, $36,39,40$, Fig. 71 ; bud-variation, $23 \mathrm{~s}$; cells, 263, 265; foliage, 65 ; fruit, 162, Fig. 295; inflorescence, 123, Fig. 294 ; leaf, 83 ; leaf-sear, 37 ; pear-graft, 28; phyllotaxy, 48, Fig. 84 ; pruuing, Figs. 102, 104; thorns, 10s; tree, 14. $64,93,220$, Fig. 17 .

Apricot, 251, 366; bud, 37, 39, 41, Figs. 55,68 ; fruit, 161.

Aquatic, 207; society, Fig. 401.

Aquilegia, 358, Fig. 517.

Arabis, 388, Fig. 536.

Aracex, 327.

Arboriculture, 257.

Arborvitæ, 326, Figs. 404, 405, 455. 
Arbutus, trailing, 425.

Archegoniophore, 194. Archegonium, 181.

Aretium, 441.

Arisæma, 327.

Aristolochiaceæ, 348.

Arrow-root, starch, 274, 275.

Arrowwood, 429.

Artichoke, Jerusalem, 439.

Arum, family, 149, 327; water, 328 .

Asarum, 349.

Ascending stems, 14 .

Asclepiadaceæ, 417. Asclepias, 283, 418.

Ascus, 190.

Ash, 421; branching, 56, Fig. 92; fruit, 156; leaf, Fig. 141; mountain, 391; phyllotaxy, 48; seeds, 168 .

Ash in plants, 77.

Asparagus, 3, 285, 289, 333, Figs. 457, 458; leaves, 107, Figs. 159-162.

Aspen (poplar), expression in, 66.

Aspidium, 289, 323, 324, Figs. 331, 332, 480.

Asplenium, 323.

Assimilation: making of protoplasm, $(185,186)$.

Aster, 233, 442; China, 443; inflorescence, 120, 150, 151; wild, 252, Fig. 146.

Atropin, 271.

Auricula, 422.

Autumn leaves, 233.

Avens, 386.

Axil: upper angle which a petiole or peduncle makes with the stem which bears it, (87).

Axillary, 119, Fig. 201.

Azalea, 425; anther, 135, Fig. 220.

Bachelor's button, 151, 442, Figs. 256, 559.

Bacterium (pl. bacteria), 91, 263, 278, Fig. 136.

Ballast plants, 170 .

Balloon-vine, 376.

Balsam, 33, 166, 286; garden, 375 ; for mounting sections, 303 .

Bamboo, forest, Fig. 437.

Baneberry, 359.

Banyan, 11, 20, Fig. 15.

Baptisia, 383.

Barberry, 360; anther, 135, Fig. 221; family, 360; rust, 191, 192, Figs. 355, 356; spines, 109, Fig. 168 .

Bark, 293; forms of, 65.

Barley, 152, 250, Fig. 261; germination, 173.

Basal: at the base or bottom, (317).

Basidium, 191.

Basswood, 37, 292; phyllotaxy, 48, Fig. 464.

Bast, 280, 281, Fig. 450.
Bean, castor, $4,171,175,178,271,273,352$,

Figs. 313-316; common, 3, 7, 166. 250,

384, Figs. 2, 530; germination, 171, $173,174,178$, Figs. 308-312, 322; legume, 157; Lima, 175, 384, Fig. 531; scarlet runner, $174,178,384$; sleep of, 49 ; twiner, $115,116$.

Beard-tongue, 406.

Bedstraw, 112, 426.

Bee balm, 400 .

Beech, 64, 67, 343; drop, 90; European, 98; fruit, 155; leaf, Fig. 151; monœcious, 138.

Beefsteak geranium, Fig. 41.

Beet, 7, 33, 250, 251; cells, 265; starch in, 31 ; sugar-, 251, 273.

Beggar's ticks, 440, Fig. 558,

Begonia, cells, 265; cuttings, 21, 27, Fig. 41 ; leaf, 298, Fig. 144; stomates, 301, Fig. 473.

Belladonna, 271.

Bell-flower, 430 ; family, 430.

Bellis, 439.

Bellwort, 332 .

Berberidaceæ, 360 .

Berry: pulpy, indehiscent, few- or manyseeded fruit, (319).

Betula, 344.

Bi-collateral, 288.

Bi-compound, 96.

Bidens, 440, Figs. 418, 558.

Biennial: of two seasons' duration, (10).

Bilberry, 424.

Bindweed, 244, 412.

Birch, 231, 344.

Birthroot, 333.

Birthwort, family, 348.

Bishop's cap, 394.

Bitter-eress, 367.

Bittersweet, 248, 409, Fig. 424; climbing, 112; false, twiner, 115, Fig. 179.

Blackberry, 20, 251, 390; cutting., 23; fruit, 160, 161; pruning, 61; and Lirds, 168.

Black-eyed Susan, 438, Fig. 557.

Black haw, Fig. 305.

Bladder-nut, 378.

Bladder-wort, 71, 207.

Blade: expanded part of leaf or petal, (206).

Blazing star, 444.

Bleeding of plants, 73 .

Bleeding-heart, 3,364 .

Blight, 92. Blight-canker, 92.

Bloodroot, 363 ,

Blueberry, 424 .

Blue-eyed grass, 338.

Blue-eyed Mary, 406.

Blue-grass, 246.

Bluets, 427.

Bole: trunk, (140). 
Boneset, 445, Fig. 138; bracts, 171.

Borage family, 412 .

Boreal plants, 229.

Borraginaccæ, 412.

Boston ivy, leaves, 100, Fig. 155; tendril, 113.

Bougainvillea, 110.

Bouncing Bet, 354; fruit, Fig. 282.

Box, leaf, Fig. 149.

Box-elder, 376; phyllotaxy, 47, 48, Fig. 84.

Bracts: much redueed leaves, (231).

Brake, 180, 267, 323, Figs. 139, 335, 456.

Bramble, 389.

Branched stem, 15, Fig. 21.

Brassica, 365, Fig. 518.

Briars, elimbing, 112; priekles, 109.

Bridal wreath, 121, 392, Fig. 193.

Bristles, 109.

Bryophyllum, leaf cuttings, 21.

Bryophyte, 183.

Buckeye, 377.

Buckwheat, 76, 251, 350, Fig. 513; family, 349 ; flower, 130 ; fruit, 156 ; pollination, 139.

Bud, Fig. 165; dormant, 54 ; propagation by, 21 ; resting, 36 ; -seales, 111 ; -scars, old, 54, Fig. 91; struggle for existence, 52 ; winter, $21,36,61$; and light, 50 ; -variations, 237.

Bulb: thickened part, made up of seales or plates, $(80)$; phyllotaxy, 48 ; scales, 111.

Bulbel: bulb arising from a mother bulb, (81).

Bulblet: aërial bulb, 21, (\$1).

Burdock, 7, 67, 169, 242, 243, 441, Fig. 306.

Burning bush, 294.

Bur-marigold, 440, Fig. 558 .

Burs, 169.

Bur-seed, 413.

Burst of spring, 40, Fig. 72 .

Bushes: low and thiek shrubs, (15).

Butter-and-eggs, 137, 145, 405, Figs. 227, 544.

Buttercup, 3, 208, 233, 357; achene, 156 , Fig. 268; family, 355; flower, Figs. 202, 203; pistil, 130, Fig. 207

Butterfly weed, 418.

Butternut buds, 37.

Button-bush, 427.

Button snakeroot, 444.

Buttonwood, 294.

Buttresses, bracing, 9, Fig. 10.

Cabbage, 12, 16, 251; fruit, 160; head, 37, 38, Fig. 59; water pores, 299.

Cacti, Fig. 371.

Caffein, 271.

Calamus, 328.
Calcium, 76; oxalate, 271, 275.

Calendula, 438.

Calla, 328, Figs. 486, 487; inflorescence, 150; lily, 328, Fig. 486.

Calliopsis, 440.

Callistephus, 443.

Callus, 62.

Caltha, 358.

Calypogon, 342.

Calyptra, 197.

Calyx: outer circle of floral envelopes, (265); lobes, (266).

Cambium: the growing or nascent tissue lying between the xylem and phloem of the fibro-vascular bundle (481), and therefore on the outside of the woody trunk, since the active fibro-vaseular bundles are in the young outer tissues (72), 62 .

Campanula, 430; capsule, Fig. 283.

Campanulaceæ, 430.

Campion, 354.

Canada thistle, 19, 22, 242, 244, Fig. 409.

Candytuft, 368, Fig. 192.

Canker, 92.

Canna, 18, Fig. 29.

Cannabis, 348 .

Canterbury bell, 430.

Caoutchouc, 271.

Caprifoliacex, 427.

Capsella, 368 .

Capsicum, 410, Fig. 547.

Capsule: compound pod, (316).

Caraway, 399.

Carbohydrate, 85 .

Carbon, 76, 82; dioxid, 77, 82 .

Cardamine, 367.

Cardinal-flower, 431.

Cardiospermum, 376.

Carnation, 254, 255, 353; cutting, 25, Figs. $34,36$.

Carpel: a simple pistil; one of the units of a compound pistil, (271).

Carrot, 3, 33, 242, 243, 398, Fig. 410: umbel, 121, 122, Fig. 194.

Carum, 399.

Caryophyllaeeæ, 353.

Cassia, 385; flower, 146, Fig. 247.

Castalia, 361.

Castanea, 343.

Castilleja, 407.

Castor bean, 4, 271, 273, 352; germination, 171, 175, 178, Figs. 313-316.

Castor-oil, 273; inelusions, 275, 276; plant, 352.

Catalpa, pods, 160, Fig. 2S4; seeds, 168, Fig. 301.

Catchfly, 354.

Catkin: scaly-bracted deciduous spike with declinous flowers, (252). 
Catmint, 403.

Catnip, 131, 243, 403, Figs. 213, 414.

Cat-tail, 3; seeds, 168, Fig. 304; stems, 285 ; swamp, 232.

Caulicle: stemlet of the embryo, (332).

Cedar, 326, 327, Fig. 485; and light, Fig. 76; fruit, 164; and birds, 168; apple, 192.

Celandine, 265, 363.

Celastrus, twiner, 115.

Celery, 249, 399; cell, 265.

Cell, 263; multiplication, 268, Figs. 442 , 443 ; -sap, $72,76,265$; -wall, 88,264 , 266, Fig. 267.

Cellulose, 266, 271.

Celtis, 347.

Centaurea, 441, Fig. 559.

Centrifugal: away from the center, (258), Fig. 199.

Centripetal: toward the center, (258), Figs. 197, 198.

Cephalanthus, 427.

Cerastium, 355.

Cercis, 351.

Chamberlain, quoted, 303.

Chamomile, 437.

Chara, 266.

Charcoal, 82.

Charlock, 243, 366, 368, Fig. 413.

Cheat, Fig. 412.

Checkerberry, 424.

Cheeses, 147, 148, 244, 372, Fig. 248.

Chelone, 406.

Chenopodium, Fig. 408.

Cherry, 20, 251, 387, 388, Fig. 539; fruit, 161 ; inflorescence, 123; phyllotaxy, 48 ; and birds, 168 .

Chess, 242, Fig. 412.

Chestnut, 343; fruit, 155, Fig. 267; monœcious, 138; -oak graft, 28.

Chickweed, 242, 355, Fig. 516; mouseear, 355 .

Chicory, 435.

Chinese sacred lily, 336, Fig. 494.

Chionanthus, 421.

Chlorin, 76, 82.

Chlorophyll, 83, 270.

Chloroplast, 264.

Choke cherry, 389.

Choripetalæ, $3 \leftarrow 2$.

Chromosome, 268.

Chrysanthemum, 150, 151, 153, 438.

Cichorium, 435.

Cider, acid, 271.

Cilia, 186, 266.

Cinchona, 271.

Cinquefoil, 386.

Cion: the bud or branch used in grafting. (70).

Circæa, 397.

Cirsium, 441.
Citric acid, 271.

Cladophyllum: leaf-like branch, (225).

Clasping: leaf partly or wholly surrounding stem, (207).

Claytonia, 371 .

Cleavers, 426.

Cleft, 96. Cleft-graft, 29.

Cleistogamous flowers: small closed selffertilized flowers, (286).

Clematis, 155, 287, 359; and light, Fig. 77 ; tendril, 115, Fig. 178.

Climate, and plants, 212; and variation, 238.

Climbing, plants, 112; plants and light, 43; stems, 14.

Close fertilization: secured by pollen from same flower; self-fertilization, (278).

Close-pollination, 134

Clotbur, 169, 230, 436, Fig. 555.

Clover, 4, 7, 68, 221, 249, 251, 382, Figs. 187, 527; bracts, 110, Fig. 173; chlorophyll, 83; inflorescence, 120; roots, nodules on, 78; sleep of, 49, Fig. 85 ; pollination, 137.

Cobea, 115.

Cockle, 242, 354

Coco-grass, 244.

Coffee, 135, Fig. 201; tree, 100.

Cohosh, anther, 271.

Coleus, 75, 287; chlorophyll, 84 ; cuttings, $23,25,26$; cells, 265; starch in, 86 .

Collateral, 288.

Collection, making a, 279.

Collenchyma, 280.

Collinsia, 406.

Collodion, 303, Fig. 476.

Colonies, 230.

Color of foliage, 233.

Coltsfoot, 442.

Columbine, 358, Fig. 517; fruit, 157.

Columella, 188.

Column: body formed of union of stamens and pistil in orchids, (300).

Columnar trees, 64, Fig. 112.

Commelina, 334. Commelinaceæ, 334.

Companion cells, 280.

Compass plant, 50, 297.

Complete flower: all parts present, (273).

Complete leaf: having blade, petiole, stipules, (206), Fig. 145.

Compositæ, 150, 431.

Compositous flowers, 150.

Compound leaves, 95 .

Compound pistil: of more than one carpel united, (271).

Concentric, 288.

Cone-flower, 438.

Conical trees, 64 .

Coniferæ, 271, 324.

Conjugation, 186. 
Connate, 97, Fig. 148.

Convallaria, 334 .

Convolvulaceæ, 411.

Convolvulus, 412; family, 411.

Coral root, 90, 93, Fig. 132.

Corallorhiza, Fig. 132.

Cordate: heart-shaped, (211).

Coreopsis, 440.

Cork oak, 294.

Corm: a solid bulb-like part, (82).

Cormel: a corm arising from a mother corm, (82).

Cormlet: aërial eorm, (\$2).

Corn, 8, 11, 139, 212, 213, 250, 254, 271, 279,285 , Figs. 14, 230, 231, 427, 448, 452,454 ; ash in, 77 ; broom, 139,250 , Figs. 233, 429; field, 221, 227, Fig. 385; germination, $133,134,135,171,173$, 175, 178, Figs. 317-321, 378; monœcious, 139, Fig. 230; North and South, 212, Fig. 378; phyllotaxy, 48; roots, 7 , 296; stalk, 17; starch, 274, 275; stems, 267 ; stomates, 301 ; syrup, 272 ; transpiration in, 81 ; water in, 76 ; wilting, 81 ; as weed, 241.

Corn-coekle, Fig. 181.

Corn-flower, 442; flowers, 151, Figs. 256, 559.

Corolla: inner circle of floral envelopes, (265).

Corpse plant, 425.

Corydalis, 364 .

Corymb: short and broad, more or less flat-topped, indeterminate cluster, (254), Figs. 192, 193, 197.

Corymbose inflorescence: outer flowers opening first; indeterminate, (248).

Cosmos, 437.

Cotton, 67, 147, 148, 249, 251, 271, Fig. 115; fibers, 263.

Cotyledon: seed-leaf, (332).

Couch-grass, Fig. 27.

Cowpea, 251, 384, Figs. 273, 532; nodules on root, 78 .

Cowslip, 358, 422.

Crab-apple, 391.

Cranberry, 424; high-bush, 429.

Cranesbill, 373.

Cratægus, 392.

Creeper: a trailing shoot which takes root throughout its length, (56).

Creeping stems, 14, Fig. 18.

Crenate: shallowly round-toothed, (212).

Cress, fruit, 160; winter, 366.

Crinkle-root, 367 .

Crocus, 4, 34, 35, 338, Figs, 52, 53, 497.

Crops, 249.

Cross-fertilization: secured by pollen from another fluwer, (278).

Cross-pollination: transfer of pollen from flower to flower, (278).
Crowfoot, 357 ; family, 355.

Crown: that part of the stem at the surface of the ground, (37); -tuber, 32 , Fig. 47.

Cruciferæ, 160, 365.

Cryptogam: flowerless plant, as fern, moss, fungus, 185,321 , (353).

Crystals, 275. Crystaloids, 275.

Cucumber, 251, 287; collenchyma, 280; fruit, 162 ; pits, 267 ; root-pressure, 74 ; squirting, 167, 280; tendrils, 114.

Cudweed, 444.

Cupuliferæ, 342.

Currant, 395, Figs. 540-542; bud, Fig. 58; cuttings, 23, 26, Fig. 40; fruit, 160 ; stem, 294, Fig. 465.

Cuscuta, 412, Fig. 553.

Cutting: severed piece of a plant designed to propagate the plant, (51), (61), Figs. 29, 33-41; hardwood, 26; softwood, 23.

Cutting-bed, 25, Fig. 36.

Cutting-box, 25, 29.

Cutting sections, 303.

Cycas, 301.

Cyclamen, 265, 423.

Cycloloma, 170.

Cyclone plant, 170.

Cydonia, 391.

Cyme: broad, more or less flat-topped, determinate cluster, (257), Figs. 196, 199.

Cymose inflorescence: central flowers opening first; determinate, (256), Fig. 195.

Cynoglossum, 413.

Cypress, swamp, Fig. 435; vine, 411, Fig. 551.

Cypripedium, 340.

Cystolith, 276.

Cytoplasm, 263.

Daffodil, 336,

Dahlia, 33, 271, 437; double, 151, 153, Fig. 257, 258.

Daisy, 242, 244, 439; flowers, 150; ox-eye, 438, Fig. 189; rays, 143; English, scape, 125, Fig. 200.

Dalibarda, 140.

Dandelion, 3, 7, 13, 241, 242, 246, 434, Figs. 8, 275; flowers, 150; rays, 151; scape, 125; seeds, 168, Fig. 302; tissue, 283.

Darwin, quoted, 221, 240.

Darwinism, 240.

Date, seed, 271.

Datura, 410, Fig. 275.

Daucus, 398.

Day flower, 334.

Day-lily, 331, 332, Figs. 279, 491, 492.

Deciduous: falling, (216). 
Decompound, 96.

Decumbent stems, 14.

Decurrent: running down the stem, (207), Fig. 147.

Dehiscence: opening of seed-pod or anther, (279), (312), 159.

Deliquescent: trunk or leader lost in the branches, (40), Fig. 17.

Delphinium, 359.

Dentaria, 366; pod, 155, Fig. 266.

Dentate: sharp-toothed, (212).

Dependent plants, 90 .

Dermatogen, 279.

Desert vegetation, Fig. 371.

Determinate: definite cessation of growth at the apex, (256), Fig. 195.

Deutzia, 61, 394.

Devil's paint-brush, 436.

Dewberry, 20, 390, Figs. 30, 170; fruit, 161.

Dextrin, 271.

Diadelphous: in two groups, (297).

Dianthus, 353, Fig. 515.

Dicentra, 364.

Dichogamy: stamens and pistils maturing at different times, (280).

Diclinous: imperfect; having either stamens or pistils, (274).

Dicotyledons, 342 .

Diervilla, 429.

Digestion: changing of starchy materials into soluble and transportable forms, (183).

Digitalis, 407.

Digitate, 96, Figs. 140, 142, 144.

Diœeious: staminate and pistillate flowers on different plants, (284).

Dispersal of seeds, 166 .

Dissecting apparatus, 132, Figs. 215-217.

Divergence of character, 221..

Divided, 96.

Dock, 3, 242, 243, 244, 350.

Dockmackie, 429.

Dodder, 91, 94, 116, 412, Fig. 553.

Dodecatheon, 422.

Dogbane, 419 ; family, 418.

Dog's-tooth violet, 330, Fig. 490.

Dogwood, bracts, 110; osier, Fig. 5; tree, Fig. 383.

Dormant buds, 54, Fig. 91.

Double flowers, 153 .

Dragon-root, 327.

Dragon's head, false, inflorescence, Fig. 185.

Drupe: fleshy one-seeded indehiscent fruit; stone fruit, (320).

Drupelet: one drupe in a fruit made up of aggregate drupes, (321).

Dryopteris, 179, 324, Figs, 331, 332.

Ducts, 263.

Dusty miller, 354.
Dutch ease-knife bean, 178 .

Dutchman's breeches, 364 .

Dutchman's pipe, 116, 349; family, 348 .

Dwarf plants, 212.

Earth parasites, 2.

Echinospermum, 382.

Echium, 415.

Ecology: habits and modes of life of animals and plants, (397).

Egg-cell, 133, 187.

Eggplant, 160, 410, Fig. 288.

Eglantine, 390.

Elaboration, food, 82.

Elater, 196.

Elder, 4, 125, 282, 429; box, 47, Fig. 84 ; pith, 263; poison, Fig. 422.

Elecampane, 442.

Elliptic, 98, Fig. 151.

Elm, 14, 64, 218, 222, 287, 346, Figs. $507-509$; flower, 130,143 ; foliage, 65 ; fruit, 156; germination, 178; phyllotaxy, 47, 48, Fig. 84 ; seed, 168; shoot, history, 57, 58, Figs. 96-100; trunk of, 65.

Elodea, 85, 265, 266, Fig. 439.

Embryo: the plantlet in the seed, (332).

Embryology, 106.

Emersed, 207.

Emetin, 271.

Enchanter's nightshade, 397.

Endodermis, 279.

Endogenous stems, 285.

Endosperm: food in the seed outside the embryo, (333).

Entire: margin not indented, (212).

Environment: surroundings; conditions in which organisms grow, (354), 212.

Enzymes, 87, 277

Eosin for staining, 73.

Epicotyl: that part of the caulicle lying above the cotyledons, (340).

Epidermal tissue, 279, 283.

Epidermis of leaf, 297.

Epigæa, 425.

Epigeal: cotyledons rising into the air in germination, (339).

Epigynous: borne on the ovary, (307).

Epilobium, 397.

Epipactis, 341.

Epiphyte, 11, 93.

Equisetaceæ, 199. Equisetum, 199, 202, Fig. 369.

Erect stems, 14

Ericaceæ, 423.

Erigenia, 399.

Erigeron, 442, Fig. 560.

Erythronium, 330, Fig. 490

Eschscholtzia, 362 .

Essential organs: stamens and pistils, (269). 
Eupatorium, 444, Fig. 138.

Euphorbia, 273, 275, 352.

Euphorbiaceæ, 351.

Eutropic: in the direction of the sun's course, (243), Fig. 179.

Evening primrose, 3, 243, 396, Figs. 276, 415.

Evergreen: remaining green, (216).

Everlasting, 443.

Evolution, 240.

Excurrent: the trunk or leader continued through the top, (39), Fig. 19.

Exogenous stems, 286.

Exosmosis, 73.

Explosive fruits, 166.

Exposure, 215.

Expression in plants, 65.

Fagopyrum, 350, Fig. 513.

Fagus, 343.

Fall of leaf, 97, 299.

False annual: perennial by means of bulbs, corms, or tubers, (13).

Farm forestry, 258.

Fastigiate trees, 64, Fig. 112.

Fats, 271, 273.

Fehling's solution, 272.

Fern, 18, 183, 205, 209, 224, 321, Fig. 479; Christmas, 179, 323, Figs. 331, 332; cinnamon, 322, Fig. 479; flowering, 322; lady, 323; maidenhair, 180, Fig. 336; marsh shield, 324 ; ostrich, 323 ; polypode, 180, Figs. 333, 334; royal, 322 ; sensitive, 322, 323, Fig. 337; shield, 324; fronds, 179; in good and poor light, 42 , Figs. 73,74 ; discussed, $179,198,202$; prothallus, 180, Fig. 339 .

Fertilization: impregnation of the ovule, (276).

Fertilizer, 77.

Fibrous tissue, 281.

Fibro-vascular bundles, 283.

Ficus elastica, 277, Fig. 447.

Field crop, 249.

Fig, climbing, Fig. 78.

Figwort, 406; family, 404.

Filament: stalk part of the stamen, $(270)$.

Filices, 321 .

Film, moisture, 75 .

Fir, 64 .

Fire-blight, 92.

Fireweed, 230; purple, 397.

Five-finger, 386.

Flag, 338; garden, 299, Fig. 496; sweet, 328.

Flagella, 266.

Flax, 249, 250, 251, 271.

Fleabane, 442.

Fleur-de-lis, 338.

Flora: plant population of a country or plaze; also a book describing this population, (355).
Floral envelopes, 127.

Florets: individual flowers of composites and grasses, (303), Figs. 255-258.

Floriculture, 250.

Flower, parts of, 127; -branches, 118; -bud, 39 ; -cluster, 118; -stem, 125.

Foliage, 2, 65, 95.

Follicle: dry, dehiscent pericarp opening on the front suture, (314).

Food elaboration, 82.

Food, reservoirs, 31 ; supply and variation, 238.

Forest, 256, Figs. 387-394, 398.

Forget-me-not, 414.

Formalin, 303. Formic acid, 271.

Forms of plants, 64 .

Forsythia, 61, 420.

Foul-gas, 83.

Foxglove, 407.

Fragaria, 387, Figs. 533, 534.

Framework, 2, 67, Figs. 3, 4.

Fraxinus, 421.

Freesia, 339, Fig. 498.

Free-swimming, 207.

Fringe-tree, 421.

Frog spittle, 185.

Frond: leaf of fern, (345).

Fruit-bud, 39, Figs. 61, 62, 70, 71.

Fruits, 155.

Fuchsia, 17, 397; and light, 43; bracts, Fig. 172; cuttings, 25, 26; flower, 128; Fig. 205; inflorescence, 119, Fig. 183; phyllotaxy, 48; water-pores, 299.

Fumariaceæ, 363.

Fumitory, 364.

Function of leaves, 95.

Function: what a plant or a part does; its vital activities.

Fundamental tissue, 283.

Fungi, 91, 183, 187, 201, 263, 266, Figs. $135,137$.

Funiculus, 171.

Funkia, 332, Figs. 491, 492.

Funnelform, 144, Fig. 240.

Galanthus, 336, Fig. 495.

Galium, 426; climbing, 112 .

Gall, 92 .

Gametophyte, 181, 201.

Gamopetalæ, 400.

Gamopetalus: corolla of one piece, (267), Fig. 204.

Gamosepalous: calyx of one piece, (267), Fig. 204.

Gaultheria, 424.

Gaylussacia, 424.

Gemmæ, 194.

Generation: period from birth to death, (8).

Gentian, 417; family, 417. Gentianacese, 417. 
Geraniaceæ, 373.

Geranium, 17, 287, 298, 301, 373, Figs. 470, 472; chlorophyll, 83 ; cutting 3,23 , 25,26 , Figs. $33,38,39$; family, 373 ; inflorescence, Fig. 195; and light, 43; starch in, 86 .

Germander, 402.

Germination, 70, 171, 172 .

Geum, 386.

Gherkin, 251.

Gilliflower, 366.

Gill-over-the-ground, 403.

Ginger, 18.

Ginger, wild, 99, 349.

Glabrous: not hairy.

Gladiolus, 34, 35, 339, Figs. 54, 499.

Glandular, 298.

Glaucous: covered with a "bloom" or a whitish substance.

Gleditschia, 381.

Globe-flower, 390.

Globoid inclusions, 275.

Glomerule: dense head-like cyme, (257).

Gloxinia, leaf-cuttings, 21.

Glucose, 85, 271, 272.

Glucoside, 271.

Glume, 152.

Gnaphalium, 444.

Goat's-beard, 434.

Golden bell, 61 .

Goldenrod, 3, 150, 232, 233, 442.

Goober, 141, 251.

Gooseberry, 160, 395.

Goose-grass, 426.

Gourd, 251; collenchyma, 280.

Graft: a branch or bud made to grow on another plant, $27,(60)$, Figs. 32 , 42-44.

Grafting-wax, 29.

Grape, 282; cane, Fig. 460; crystals, 275, 276 ; cuttings, 23, 26; fruit, 160, Fig. 176; hyacinth, 331; leaves, 100 ; root, Fig. 467; sugar, 272; tendrils, 114, 117 , Fig. 176; sap-pressure, 74; sympode, Fig. 180.

Grass, 17, 231, 232, 249; flowers, 151; blue-eyed, 338; leaf, Fig. 150; family, 152 ; pink, 342 .

Grasses, 285; leaves of, 98, 102; phyllotaxy, 49 ; pollination, 138 ; roots of, 7 ; starch, 274.

Grass of Parnassus, 394.

Gratiola, 407.

Greek valerian, 417.

Greenbrier, tendril, 115; stem, 285.

Gromwell, 414.

Ground cherry, 409.

Ground ivy, 403.

Ground-nut, 385.

Guinea squash, 410.

Gum-resin, 271, 273.
Gymnosperm: seed naked (not in an ovary); applied to pines, spruces, etc., $(326), 324$.

Habenaria, 341.

Habitat: particular place in which a plant grows, (355).

Habit: the looks, appearance, general style of growth, (36).

Hackberry, 347.

Hair-grass, 170.

Hairs, 298.

Halophytic societies, 228.

Harbinger of spring, 399 .

Hardhack, 392.

Hardwood cutting, 26.

Harebell, 430.

Haustoria, 91, Fig. 137.

Hawkweed, 244, 436.

Hawthorn, 108, 392; -pear graft, 27.

Hazel, 138.

Head of tree, form of, 65.

Head: short, dense spike, (251), Figs. $187,188,197$.

Heart-seed, 376.

Heart's-ease, 369.

Heath, 93; family, 423.

Hedeoma, 401.

Hedera helix, 277, 287, 300, Fig. 468.

Hedge hyssop, 407.

Helianthus, 439.

Heliotrope, 413. Heliotropium, 413.

Heliotropism: turning toward the light, (101).

Hematoxylin, 266, 303.

Hemerocallis, 331 .

Hemlock, 213, 271, Fig. 484; poison, 247; water, 247.

Hemp, 249, 251, 348.

Henna root, 273.

Hepatica, 156, 233, 356.

Herb, 3.

Herbaceous: not woody, (11); perennial, 3.

Herbarium, 311, Fig. 478.

Herb Robert, 374.

Herbicides, 246.

Heredity, 239.

Heterœecism, 192.

Hibiscus, 62, Fig. 152.

Hickory, 50, 155; bud, 39, 111, Figs. 63, 64,87 ; inflorescence, 121 ; leaf-scars, 37 ; monœecious, 138.

Hieracium, 436.

Hilum, or seed-scar, 171.

Hip: fruit of the rose, (323), Fig. 292.

Hobblebush, 429.

Hog-peanut, 140, Fig. 238.

Hollyhock, 4, 372; flower, 136, 147 , 148, 153, Figs. 222, 223, 263; cells, 265. 
Holly, phyllotaxy, 48; tree, Fig 380; stomates, 299.

Honesty fruit, 160.

Honey locust, 381; buds, 37; leaf, 100; thorns, 108; tree, Fig. 117.

Honeysuckle, 62, 428, Fig. 554; buds, 37 ; family, 427; leaves, Fig. 148; phyllotaxy, 48; swamp, 425; Tartarian, 37, 53 ; twiner, 115.

Hop, 115, 116, 251, 348, Fig. 179.

Hop clover, 383 .

Horehound, 403.

Horse-chestnut, 377 ; bud, 36, 111; fruit, Fig. 277; germination, 178; infloreseence, 123; leaf, 99 ; leaf-sear, 37.

Horse-mint, 400.

Horse-radish, 367.

Horsetails, 199, Fig. 369.

Horse-weed, 443, Fig. 560.

Horticultural crop, 249.

Host, 78, 91 .

Hound's tongue, 169, 243, 413.

House-leek, 20; phyllotaxy, 48.

Houstonia, 427.

Huckleberry, 424; anther, 135.

Humulus, 348.

Humus, 210.

Hyacinth, 35, 331; crystals, 276; grape, 331 ; inflorescence, Fig. 186; scape, 125.

Hydrangea, 62, 125, 131, 394; doubling, 153.

Hydrogen, $76,82$.

Hydrophyllaceæ, 415.

Hydrophytic society, 228, Fig. 395.

Hypericaceæ, 370.

Hypericum, 371.

Hyphæ, 91, 188.

Hypocotyl: that part of the caulicle lying below the cotyledons, (338).

Hypogeal: cotyledons remaining beneath the ground in germination, (339).

Hypogynous: borne on the torus, or under the ovary, (307).

Hypoxis 337

Iberis, 368 .

Immersed, 207.

Impatiens, 375; collenehyma, Figs. 449 , 521,522 ; water-pores, 299, 301; seeds, 166.

Imperfect flower: having either stamens or pistils, (274).

Inclusions, 275.

Indehiscent: not opening, (312).

Independent plants, 90.

Indeterminate: growing on from the apex, (248).

Indian hemp, 419.

Indian pink, 431.

Indian pipe, $90,425$.

Indian tobacco, 431 .
Indian turnip, 149, 327.

India-rubber plant, 271, 276, 297, Fig. 447.

India wheat, 350 .

Indigo, 271; false, 383.

Indusium, 179, Fig. 338.

Inferior, 152.

Inflorescence: mode of flower-bearing; less properly, a flower-cluster, (260).

Innoeence, 406.

Insects and flowers, 136, Fig. 227.

Inula, 442. Inulin, 271.

Involucre: a whorl of small leaves or bracts standing close underneath a flower or flower-cluster, (299).

Iodine test for starch, 86, 274.

Ipecac, 271.

Ipomœea, 411, Figs. 551, 552.

Iridaceæ, 337 .

Iris, 338 , Fig. 496 ; cells, 265; family, 337 ; leaf, 297; stems, 285.

Iron, 76 .

Ironweed, 445.

Irregular flower: some parts in one series different, (275).

Irrigation, 215.

Isoëtes, 200, 202, Fig. 370 .

Ivy, 10, 100, 113, 277, 287, 292, 297, 299, 300, Figs. 174, 468, 471; Boston, 100 , 113, Fig. 155; Kenilworth, 405; Fig. 545; poison, 11, 113, 247, Fig. 421.

Jack-in-the-pulpit, 149, 276, 327, Fig. 251. Jacob's ladder, 417.

Jamestown-weed, 410.

Japan quince, 97, 392 .

Japan rose, 390.

Jeffersonia, 360.

Jerusalem artichoke, 439 .

Jewel-weed, 166, 230, 280, 375, Figs.449, 521,522 .

Jimson-weed, 243, 410, Fig. 275.

Joe Pye weed, 444.

Johnny-jump up, 369.

Johnson-grass, 244.

Jonquil, 336.

Judas tree, 381 .

Juneberry, 391 ; and birds, 168.

June-grass, 241.

Juniper, 164, 326.

Kafir, 139, 250, Fig. 234.

Kale, 251.

Kalmia, 425.

Karyokinesis: indirect division or transformation of the nucleus, being one means of cell multiplication; mitosis, 269, (448).

Kentucky coffee tree, 100.

Kerria, 390.

Key-fruit, 156. 
Kinghead, 243.

Knotweed, 130, 143, 351, Fig. 210.

Kohlrabi, 33, 251, Fig. 48.

Labiatæ, 144, 400. Labiate, 144.

Laboratory advice, 301; table, Fig. 477.

Lactuca, 435.

Lady's-slipper, 148, 340, Fig. 250.

Ladies' tresses, 341.

Lady's thumb, 351, Fig. 514.

Lake-cress, 21.

Lambkill, 425.

Lanceolate, 99.

Landscape and plants, 210.

Lappula, 413.

Larch, 326, Figs, 462, 463; European, 326.

Larix, 326.

Larkspur, 4, 359; flower, 137, Figs. 224226; fruit, 157, Figs. 269, 270.

Lateral flowers, 119, Fig. 182.

Lathyrus, 263, 381.

Laticiferous tissue, 282.

Laurel, 425.

Layer: a branch which takes root and gives rise to an independent plant, (55).

Layers of branches, 56, Figs. 93, 94.

Leaf, bud, 39, Figs. 70, 71; -cutting, 21, 27 . Fig. 41 ; fall of, 299 ; how to tell, 103 ; -spot, 92; parts of, 97.

Leaflet: one part in a compound leaf, (204).

Leaf-scars, 37, 300, Fig. 57.

Leaves, arrangement of, 47 ; fall of, 299 ; general account, 95 ; polar, 50; propagation by, 21; sleep of, 49 ; structure, 297.

Legume: simple pericarp dehiscing on - both sutures, (315).

Leguminosæ, 78, 146, 157, 379.

Lemon, acid, 271.

Lens, 132, 248; stand for, Figs. 214, 425.

Lenticels, 294.

Leonurus, 403.

Lepidium, 368.

Lespedeza, 251.

Lettuce, 435; wild, 50, 243, 435, Fig. 86.

Leucojum vernum, 337.

Liatris, 444.

Lichen, 94, 183, 193, 209, Fig. 373.

Licorice, wild, 426.

Life-history: sum of the events in the life of a plant, (7).

Light and plants, 42, 223, Figs. 73-78, 81-85.

Ligneous: woody, (11).

Lignin, 266,
Ligule of isoëtes, 201.

Ligustrum, 421.

Lilac, 4, 61, 420, Fig. 72 ; bud, 111; inflorescence, 125 ; phyllotaxy, 48 ; stomates, 299.

Liliaceæ, 145, 146, 328 .

Lilium, 329, Figs. 488, 489.

Lily, 4, 20, 329, Figs, 488, 489; bulb, 33; calla, I328, Fig. 486; day-, 331, 332, Figs. 279, 491, 492; Easter, 330; family, 328; germination, 133; leaves, 102 ; stomates, 301; tiger, 21, 33, 330, Fig. 31; straw, 332; Turk's-cap, 330, Fig. 489 ; water-, $3,98,205,207,361$; wild orange-red, 330 ; wood, 330.

Lily-of-the-valley, 18, 334 .

Linaria, 405, Figs. 544, 545.

Linear, 98, Fig. 150.

Linnæus, 308.

Lipped, 144.

Lithospermum, 414.

Liverleaf, 356. Liverworts, 193, 201.

Lobed, 96, 100, Fig. 143.

Lobelia, 431; family, 431. Lobeliaceæ, 431.

Locule: compartment of a pistil, (310).

Loculicidal: dehiscence between the partitions, (317).

Locust, 380; buds, 37; honey, tree, Fig. 117; prickles, 109; seed, 166; sleep of, 49; thorns, 108.

Lodicule, 152.

Lonicera, 428, Fig. 554.

Loosestrife, 423.

Loquat, 251.

Lotus, starch, 274.

Lucerne, 383, Fig. 529.

Lungwort, 414.

Lupine, 384.

Lupinus, 384 .

Lychnis, 354.

Lycopersicum, 410.

Lycopus, 400.

Lysimachia, 423.

Maclura, 347.

Macrospore, 182 .

Madder family, 426 .

Magnesium, 76 .

Maianthemum, 333.

Maidenhair, 180, 323, Fig. 336 .

Maize, 3, 8, 11, 48, 129, 152, 171, 1.75, 250 , Figs. 9, 14, 230, 231, 317-321.

Malic acid, 271.

Mallow, 147, 148, 244, 372, Fig. 248; family, 372 .

Maltose, 272.

Malva, 372

Malvaceæ, 148, 372 .

Mandrake, 18,361 .

Mangrove, 12, 20, Fig. 16. 
Maple, 14, 47, 64, 67, 218, 241, 273, 376, Figs. 79, 80, 523-526; branching, 56; buds, $37,39,40,41,111$; family, 375 ; flowering, 373; foliage, 65; fruit, 156; germination, 178, Figs. 323-330; leaf, Figs. 143,157 ; leaf-scar, 37 ; phyllotaxy, 48 ; sap-pressure, 74 ; sced, 168 ; trunk, 65.

Marchantia, 193, 197, 202, Figs. 358364.

Mare's-tail, 443, Fig. 560.

Marigold, marsh, 358; pot, 438.

Marrubium, 403.

Marsh-cress, 367.

Marsh mallow, 148, 372.

Marsh marigold, 358.

Matthiola, 366.

May-apple, 18, 22, 361; anther, 135.

Mayflower, 356,425

Maypop, 162.

Mayweed, 230, 243, 438, Fig. 417.

Meadow grass, 3.

Meadow rue, 357.

Meadow-sweet, 392.

Medicago, 383, Fig. 529.

Medick, 383.

Medlar, 251.

Medullary rays, $278,286$.

Melilotus, 383, Fig. 528 .

Melon, 251; fruit, 162; tendrils, 114.

Menispermum, stem, 287, 289, 294.

Mentha, 401, Fig. 543.

Meristematic, 278.

Mermaid-weed, 208.

Mertensia, 414.

Mesophyll, 272, 297.

Mesophytic society, 228, Fig. 396.

Micropyle, 171.

Microscope, slides, Fig. 476.

Microspore, 182.

Microtome, 303.

Midrib, $96,98$.

Mignonette, inflorescence, 120.

Mildew, 91, 189, 190, Figs, 348-351.

Milk thistle, 435 .

Milkweed, 418; family, 417; fruit, 157, Fig. 271; seeds, 168, Fig. 303; tissue, 283.

Milkwort, 378; family, 378.

Millet, 152, 250, Fig. I62.

Milo, Fig. 234.

Mimulus, 407, Fig. 546.

Mineral nutrients, 69,75 .

Mint, 401; family, 400; phyllotaxy, 48.

Mistletoe, 93, 94, 299.

Mitchella, 427.

Mitella, 394.

Mitosis, 269.

Mitrewort, 394; ialse, 393.

Mixed buds, 40; flower-clusters, 123.

Moccasin flower, 340 .
Mock orange, 62, 395.

Mock pennyroyal, 401.

Monadelphous: in one group, (297).

Moneywort, 423.

Monkey-flower, 407, Fig. 546.

Monocotyledons, 102, 327.

Moncecious: staminate and pistillate flowers on the same plant, (284).

Monopodial: axial growth continued by growth from terminal bud or persistence of the leader, 117.

Monotropa, 425.

Moonflower, 115, 411, Fig. 552.

Mloonseed, stem, 287, 292, Figs. 455-457.

Moose-wood, 377.

Morning-glory, 15, 111, 412; family, 94 ; flower, 144, Fig. 240; twiner, 115, 116.

Morphin, 271.

Morphology, 105.

Morus, 347, Fig. 511.

Mosses, 94, 183, 196, 201, 209, 234.

Motherwort, 403.

Mold, 90, 187, 188.

Mountain-ash, 391.

Mounting sections, 303.

Mucilage, 271.

Muck, 210.

Mucor, 188, Figs. 344-347.

Mulberry, flowering, 389 ; leaves, 100 ; shoot, Fig. 88; white, 348, Fig. 511; wild, 347.

Mullein, 3, 15, 243, 405, Fig. 22; hairs, 298; inflorescence, 120; leaf, Fig. 147; pink, 354 .

Muscari, 331.

Muscus, 271.

Mushroom, 90, 187, 247, 249, Figs. 133, $134,419,420$.

Muskmelon seedlings, Fig. 156.

Musquash-root, 247.

Mustard, 243, 247, 251, 365, Fig. 518; family, 365; fruit, 160; inclusions, 275; pod, 155.

Mycelium: vegetative part of a fungus, (194), 188, Fig. 137.

Mycorrhiza, 93, Fig. 132.

Myosotis, 414.

Myrtle, 419 .

Myxomycetes, 266.

Nagelia, 298.

Naked flower: no floral envelopes, (273).

Narcissus, 35, 336; double, Fig. 494.

Nasturtium, 374; flower, 131, Fig. 211; leaf, Fig. 140; tendril, 115.

Natural selection, 240.

Nectarine, 237.

Nectary, 137.

Needle for dissecting, 132, Fig. 215.

Nepeta, 403. 


\section{Nerium, 419.}

Netted-veined, 95.

Nettle, 230, 348; acid, 271; cells, 265; family, 345 .

Nettle-tree, 347.

Nicotiana, 411, Fig. 550.

Nicotin, 271.

Nightshade, 276, 409; family, 408.

Nine-bark fruit, 157.

Nitella, 266.

Nitrogen, 76, 82, 249.

Node: a joint; the space between two joints is an internode.

Nodules, 78, Figs. 126, 127.

Nucleolus, 264.

Nucleus, 186, 263.

Nut-grass, 244.

Nutrient, water as, 76 .

Nux vomica, 271.

Nymphæaceæ, 361 .

Oak, 14, 93, 233, 271, 286, 287, 343, Figs. 500-506; branching, 56; -chestnut graft, 28; expression in, 66; family, 342 ; inflorescence, 121, Fig. 228; monœcious, 138; poison, 248, Fig. 423; transpiration in, 70; where grows, 207.

Oakesia, 332.

Oats, 250, Fig. 426; inflorescence, 121, 152, Fig. 191; lodged, Fig. 382; roots, 7 ; seed, 172; starch, 274, 275.

Oblong, 98, Fig. 149.

Obovate, 99.

Obtuse: blunt, (211).

(Ecology: see ecology.

Enothera, 396.

Offset: a plant arising close to the base of the mother plant, (56).

Oils, 271, 273.

Okra, 148.

Old-hen-and-chickens, 20.

Old-man vine, 359.

Oleaceæ, 420.

Oleander, 419; leaf, 297.

Olericulture, 250.

Olive, family, 420; fruit, 161.

Onagraceæ, 397.

Onion, 4, 271, 276, 277; bulb, 33, 34, 35, Figs. 49-51; cells, 264; germination, 178.

Onoclea, 322 .

Oögonia, 187.

Ö̈spore, 187.

Operculum, 198.

Ophioglossaceæ, 198.

Ophioglossum, 198, Fig. 368.

Opium, poppy, 271.

Opposite leaves, 47.

Orange, mock, 62, 395; osage, 48, 108, 347 , Fig. 510 ,
Orbicular, 99, Fig. 153.

Orchid, 271, 341 ; epiphytes, 11,94 ; family, 339; flowers, 143, 148, Fig. 250:

leaves, 102; roots, Fig. 13; stems, 285.

Orchidaceæ, 339.

Orchis, 341.

Ornithogalum, 331.

Osage orange, 48, 108, 347, Fig. 510; phyllotaxy, 48.

Osier, 4 ; dogwood, Fig. 5.

Osmorrhiza, 399.

Osmosis, 71, Figs, 123, 124. Osmotic pressure, 72.

Osmunda, 322, Fig. 479.

Oswego tea, 400.

Ovary: seed-bearing part of a pistil, (272), Fig. 209.

Ovate, 99, Fig. 152.

Overgrowth, 232.

Oxalic acid, 271.

Oxalis, 49, 166, 374, Fig. 300.

Ox-eye daisy, 438, Fig. 189.

Oxygen, 76; liberation of, 77, Fig. 130.

Oyster plant, 434.

Pæonia, 358.

Paint-brush, 244.

Painted cup, 407.

Palet, 152.

Palisade cells, 297.

Palisades of Hudson, Fig. 372.

Palm, 15, 65, Fig. 113; choked by fig, Fig. 78.

Palma Christi, 352.

Palmate, 96, Fig. 140.

Panicle: branching raceme, (253).

Panicum, 170.

Pansy, 370; flower, Fig. 212.

Papaver, 271, $362 . \quad$ Papaveraceæ, 362.

Paper bamboo, forest, Fig. 437.

Papilionaceous flowers, 146, Fig. 245.

Pappus: peculiar calyx of composites, (304).

Paraffin, 303.

Parallel-veined, 95.

Paraphyse, 197.

Parasite, 90, 200, Figs. 131, 136; vs. graft, 22.

Parenchyma, 266, 278, 297.

Parnassia, 394.

Parsley, 121, 399; family, 397.

Parsnip, 3, 33, 121, 398.

Parted, 96.

Partridge-berry, 427.

Passion flower, 162.

Pastinaca, 398.

Pea, 3, 79, 97, 247, 250, 381, Fig. 426; black, 384, Fig. 532; everlasting, 166, 381 , Fig. 272; experiment in respiration, 89; flowers, 146, Fig. 206; germination, 171, 173, 174, 178, Fig. 322; 
legume, 157; nodules on root, 78 ; pistil, 129, Fig. 206; stoek, 384, Fig. 532; sweet, 254, 263, 381, Fig. 245; tendril, 114, Fig. 177.

Peach, 2, 32, 251, 271, 287, 387, 388, Figs. 105, 431, 476, 535; bud, 37, 3!), 40,41 ; crystals, 276 ; fruit, 161 ; foliage, 65 ; family, 379 ; inclusions, 275; leaf, 99; phyllotaxy, 48; and nectarine, 237; pruning, Figs. 103, 105, 108.

Peanut, 141, 157, 251, Figs. 237, 238, $274,430$.

Pear, 251, 272, 391; bud, 36, 39, 40, 111, Figs. 56, 61, 62, 65-67, 70; diseases of, 92 ; fruit, 162, 266, Fig. 293; form of, 68, Figs. 118, 119; inflorescence, 123, Fig. 196; leaf-scar, 37; phyllotaxy, 48; quince graft, 27; selerenchyma, 282; thorns, 108.

Peat, 210.

Pedicel: stem of one flower in a cluster, (261).

Peduncle: stem of a flower-cluster or of a solitary flower, (261).

Pelargonium, 374 .

Peltate: attached to its stalk inside the margin, (209), Figs. 135, 140.

Pentamerous: in 5's, (291).

Pentstemon, 406.

Peony, 358; fruit, 157; stomates, 299.

Pepo: fruit of pumpkin, squash, etc., (325).

Pepper-grass, 243, 368.

Pepper, red, 4, 410, Fig. 547.

Peppermint, 401.

Pepper-root, 367.

Perennial: of three or more seasons' duration, (10).

Perianth: floral envelopes of lily-like plants (more properly of monocotyledonous plants), (295).

Periblem, 279.

Puricarp: ripened ovary, (311).

Perichetia, 197.

Perigynous: borne around the ovary, (306).

Peristome, 198.

Peritheeium, 190.

Periwinkle, 419.

Persimmon, 271.

Persistent: ren-aining attached, (216).

Personate, 145, Fig. 243.

Peruvian bark, 271.

Petal: one of the separate leaves of a eorolla, (266), Fig. 209.

Petiole: leaf-stalk, (206).

Petiolule: stalk of a leaflet, (208).

Petunia, 410, Figs. 548, 549.

Phaseolus, 384, Figs, 530, 531.

Phellogen, 293.

Plicnogam: seed-bearing or flowering plant, (353), 324 .
Philadelphus, 395.

Pliloem, 283.

Phlox, 144, 233, 416, Fig. 241; family, 416.

Phosphorus, 76.

Photosynthesis: the making of organio matter from $\mathrm{CO}_{2}$ and water, in the presence of light, $(177,178)$.

Pliyllodium: leaf-like petiole, (226), Fig. 163.

Phyllotaxy: arrangement of leaves and flowers on the stem, (112).

Physalis, 409.

Physostegia, infloreseence, Fig. 185.

Pieea, 325, Fig. 483.

Pie-plant, 350.

Pigeon-grass, 243.

Pigweed, 3, 67, 239, 242, 243, Figs. $406,408,411$.

Pine, 15, 93, 162, 232, 249, 281, 394, Figs. $10,19,421-423,451,462,481^{\circ}, 482$; and cone, Fig. 299; foliuge, Fig. 15s; germination, 171; and light, 44; needles, 102; pollination, 13s; shoot, Fig. 158; stem, Figs. 461, 466; trees, Figs, 388 , 390 ; wood strueture, 267, Fig. 440.

Pine-sap, 425, 426.

Piney, 258.

Pink, 4, 159, 353; family, 353; fire, 354 ; grass, 342 ; wild, 354 .

Pinnæ, 321. Pinnules, 321.

Pinnate, 95, Fig. 141.

Pinnatifid, 97.

Pinus, 324, Figs. 481, 482.

Pinxter flower, 425.

Pistil: ovule-bearing or sced-bearing organ, (271), Figs. 206-209.

Pistillate: having pistils and no stamens, (2'74), Figs, $190,229,230$.

Pisum, 381.

Pitchforks, 440, Fig. 558.

Pits, 267.

Plane tree, leaf-scar, Fig. 474.

Plankton, 207.

Plantain, 243, infloreseenee, 120.

Plant-breeding, 240.

Plant-food, defined, 69.

Plant society, 228.

Plastid, 263, 264.

Plerome, 279.

Pleurisy root, 418.

Plum, 20, 251, 254, 387, 388, Figs. 537, 53s; blossom, 162, Fig. 209; bud, 39; drupe, 161, Fig. 289; phyllotaxy, 45; pollination, Fig. 21s; thorns, 108.

Plumule: bud in the embryo, (332).

Plur-ammual: of one seuson's duration because killed by frost, (14).

Pod: dehiscent periearp, (312).

Podophyllum, 361.

Pogonia, 342. 
Poinsettia, 352; bracts, 110; starch, 273, 274.

Poisonous plants, 247.

Polarity, 50.

Polemoniaceæ, 416.

Polianthea, 337.

Pollards, 56, Fig. 92.

Pollen germinating, Figs. 218, 219.

Pollen: spores borne by the stamen, (270), 133, Figs. 218, 219.

Pollination: transfer of pollen from stamen to pistil, (278).

Pollinium: pollen in a coherent mass, (301).

Polyanthus, 422.

Polygalaceæ, 378.

Polygonaceæ, 349.

Polygonatum, 334 .

Polygonum, 351, Fig. 514; climbing, 112.

Polyhedral, 263.

Polypetalous: corolla of separate parts or petals, (267).

Polypode, 180, 323, Figs. 333, 334.

Polypodium, 180, 323.

Polyporus, Fig. 135.

Polysepalous: calyx of separate parts or sepals, (267).

Polystichum, 323.

Polytrichum commune,196, Figs. 365-367.

Pome: fruit of apple, pear, etc., (324).

Pomology, 250.

Pond-lily, 361.

Poplar, 231; bud, 36; cuttings, 26; diœcious, 138; inflorescence, 121; Lombardy, 64; phyllotaxy, 48; seeds, 168.

Poppy, 326; family, 362; opium, 271, 362.

Pores, 79, 83, 88 .

Portulaca, 159, 371; fruit, Fig. 280.

Portulacaceæ, 371.

Potassium, 76.

Potato, 4, 16, 19, 32, 35, 68, 77, 160, 249, 251, 254, 409, Fig. 24; cells, 265; cuttings, 23; flower, 144, Fig. 242; inclusions, 275 ; phyllotaxy, 49 ; sprouts, $31,84,90$, Fig. 45 ; starch, 31, 274, 275, Fig. 42; stem, 287; sweet, 16, 32, Fig. 204 ; -tomato graft, 28.

Potentilla, 386.

Pot marigold, 438.

Prickles, 109, Figs. 169, 170.

Prickly ash, 109, Fig. 169.

Prim, 421.

Primrose, 422; family, 422.

Primula, 298, 422. Primulaceæ, 422.

Prince's feather, 351.

Privet, 62, 421.

Promycelium, 191.

Propagation by buds, 21; leaves, 21; rhizomes, 18 ; roots, 19.

Prosenchyma, 280.
Proserpinaca, 208.

Proteids, 271. Protein, 271.

Proterandrous: anthers maturing first, (280), Fig. 222.

Proterogynous: pistils maturing first, (280).

Prothallus, 180, Fig. 339.

Protococcus, 263.

Protonema, 198.

Protoplasm, 70, 88, 186, 263.

Prunella, 402.

Pruning, 59, 60.

Prunus, 387, Figs. 535-539.

Pseud-annual: perennial by means of bulbs, corms, or tubers, (13).

Pteridophyte, 183.

Pteris, 267, 289, 323, Fig. 456.

Puccinia, 190, 192, Figs. 352-357.

Puccoon, 414.

Pulse family, 379.

Pumpkins, 251, 289; and collenchyma, 280; corn, 221, Fig. 385; flower, 144; fruit, 162; germination, 174; hairs, 298; leaf, 100; roots, Fig. 121.

Purslane, 159, 241, 242, 243, 371; family, 371.

Pusley, 371.

Pussies of willow, 121, Fig. 60.

Pyrus, 391.

Pyxis: pod opening around the top, (317), Fig. 280.

Quack-grass, 18, 19, 242, 244, Fig. 27.

Quercus, 343, Figs, 500-506.

Quillwort, 200.

Quince, 251, 271, 391; fruit, 162; Japanese, 97 ; -pear graft, 27.

Quinin, 271.

Raceme: simple elongated indeterminate cluster with stalked flowers, (249), Figs. 184, 197.

Radicula, 367.

Radish, 7, 12, 17, 33, 69, 70, 75, 368, Figs. 11, 120; and light, 43, Fig. 75; fruit, 160.

Ragweed, 209, 230, 233, 243, 436, Figs. $416,556$.

Ranunculaceæ, 355 .

Ranunculus, 357.

Rape, 251.

Raphanus, 368 .

Raphe, 172.

Raphides, 276.

Raspberry, 20, 21, 251, 389; and birds, 168; fruit, 160, 161, Fig. 290; leaf, Fig. 142; pruning, 61, Figs. 106, 107.

Rattlesnake plantain, 341 .

Rattlesnake-weed, 436.

Ray: outer modified florets of some composites, (305). 
Receptacle, 128; of liverwort, 194; of moss, 197.

Receptive stigma, 134.

Redbud, 381.

Redroot, 242, Figs. 406, 411.

Regular flower: the parts in each series alike, (275).

Reinforeed fruit: other parts grown to the periearp, (311), 161.

Reniform, 99.

Respiration: taking in $\mathrm{O}$, giving off $\mathrm{CO}_{2}, 82$, (187); in seeds, 173.

Resting bud, 36,61 .

Resting-spore, $1 \mathrm{S6}$.

Rheum, 350.

Rheumatism root, 360 .

Rhizoid, 186.

Rhizome: underground stem; rootstock, (44), Figs. 22-24, 27-29; propagation by, 1s; starch in, 31 .

Rhododendron, 425; anther, 135.

Rhodora, 425.

Rhubarb, 3, 45, 350, Figs, 81,82 ; bud, 36.

Rhus, Figs. $421,423$.

Ribbon grass, 86.

Ribes, 395, Figs. 540-542.

Rice, 152, 249, 250; stareh in, 274, 275.

Richardia, 328, Fig. 486.

Ricinus, 352.

Rings of annual growth, 111.

Robinia, 3S0; spines, 109.

Robin's plantain, 443 .

Rock eress, 366.

Root, 2, 7, 69, Fig. 120; action, 69; aërial, 10, Figs. 12-14; climbers, 112, Fig. 174; cutting, 20; growth, Figs. 25, 26; -hairs, 9, 69, Figs. 11, 121, 122, 125; -pressure, 73,81 ; propagation by, 19 ; strueture, 69,295 ; system, 7 ; tubers, 32 .

Rootlets, 69, Figs. 120, 125.

Rootstock: subterranean stem; rhizome, (4) ; propagation by, 18.

Rosa, 390.

Rosaceæ, 385.

Rose aeacia, 62, 380.

Rose, 4, 249, 251, 390; climbing, 112; eutting, Fig. 35; family, 385; hip, 161 , Fig. 292; mallow, 373; -moss, 371, Fig. 280 ; of Sharon, 62,373 ; prickles, 109 ; swamp, 390 ; variation, 238.

Rotate, 144, Fig. 242.

Round-headed trees, 64, Figs. 111, 112.

Rubber, 249.

Rubiaeeæ, 426.

Rubus, 389 .

Rudbeckia, 438, Fig. 557.

Rue anemone, 357.

Rumex, 350, Fig. 512.

Runner: a trailing shoot taking root at the nodes, (56).
Russian thistle, 170, 243, Fig. 114.

Rust, 91, 190, Figs. 352-357.

Rutabaga, 251.

Rutland beauty, 412.

Rye, 249; flower, 151, 152, Fig. 260; -pollination, 138.

Sage, common, 401; searlet, 110, 401.

Salsify, 33, 434 .

Salt-loving societies, 228.

Salverform, 144, Fig. 241.

Salvia, 401.

Samara: indehiscent winged pericarp, (312).

Sambueus, 429.

Sand-dune plants, Fig. 397.

Sanguinaria, 363 .

Sap, 72; descent of, 87; -pressure, 73

Saphrophyte, 90, Figs. 133-135.

Sapindaceæ, 375.

Saponaria, 354.

Sassafras, 143.

Savin, 327.

Saxif ragaeeæ, 393.

Saxifrage, 276, 393.

Sealariform: with elongated mark ngs, (446).

Sealy bulb, 33 .

Seape: leafless peduncle arising from the ground, (262), Fig. 200.

Sclerenehyma, 267, 282.

Selerotic tissue, 282.

Seore-eard, 254.

Seramblers, 112.

Serophularia, 406.

Serophulariaceæ, 404.

Seutellaria, 402.

Seaweeds, 181, 185.

Secondary thickening, 291.

Sedges, leaves, 102.

Seed, coats, 171; dispersal, 166; dormant, 2 ; starch in, 31 ; -variations, 237.

Segments, 145.

Seleetion, 239.

Self-fertilization: secured by pollen from same flower; close-fertilization, (278).

Self-heal, 402.

Self-pollination: transfer of pollen from stamen to pistil of same flower; closepollination, (278).

Seneca snakeroot, 379 .

Senna, 385.

Sensitive fern, Fig. 437.

Sepal: one of the separate leaves of a calyx, (266), Fig. 209.

Septicidal: dehiseence along the partitions, (317).

Serrate: saw-toothed, (212).

Service berry 391

Sessile: not stalked, (207), Fis. 201.

Shadbush, 391. 
Shade and plants, 223.

Shadows in trees, 66.

Sharon, rose of, 62,341 .

Sheepberry, 429.

Shelf fungus, Fig. 135.

Shepherdia, hairs, 298, Fig. 469.

Shepherd's purse, 242, 368; capsule, 160, Fig. 286.

Shoot: a new plant from root of old plant, (53).

Shooting star, 422.

Shrubs: plants that remain low and produce shoots from base, (15).

Sickle-pod, 366.

Sieve tissue, 280.

Silene, 354

Silicle: short fruit of Cruciferæ, (318).

Silique: long fruit of Cruciferæ, (318).

Silkweed, 418.

Silviculture, 257.

Simple leaf, 95, Fig. 138.

Simple pistil: of one carpel, (271), Fig. 207.

Simple stem, 15, Fig. 20.

Sisyrinchium, 338.

Skulleap, 402.

Skunk cabbage, 149, 150, 233, 276, 327 . Fig. 446.

Sleep of leaves, 49.

Slips, 23.

Smartweed, 130, 143, 156, 230, 351, Fig. 514.

Smilacina, 333.

Smilax of florists, 107, 333, Fig. 493.

Smilax tendril, 115.

Snakehead, 406.

Snapdragon, 145, 406, Fig. 243.

Snowball, 131, 153, Figs. 264, 265; Japanese, 429.

Snowberry, Fig. 287.

Snowdrop, 336, Fig. 495.

Snowflake, 337.

Soapberry family, 375 .

Soapwort, 354 .

Societies, 228.

Sod society, 231, Fig. 399.

Softwood cutting, 23.

Soil and plants, 209, 213.

Solanaceæ, 408.

Solanum, 112, 248.

Solidago, 442.

Solitary flowers, 119, Fig. 181.

Solomon's seal, 18, 334; false, 333; twoleaved, 333 .

Sonchus, 435.

Soredia, 193.

Sorghum, 139, 152, 250, 273, 275, Figs. $20,232-234$.

Sori, 9, 191.

Sorrel, 166, 243, 350, Fig. 512.

Sow thistle, 435.
Soybean, Fig. 126.

Spadix: thick or fleshy spike of certain plants, (302), Figs. 198, 251.

Spanish moss, 94.

Spanish needles, 440.

Spathe: bract surrounding or attending a spadix, (302), Fig. 251.

Spatterdock, 362.

Spatulate, 99.

Spearmint, 402, Fig. 543

Species, 308.

Specularia, 430.

Speedwell, 408.

Spencer, quoted, 240.

Spermaphytes, 183.

Spermatozoids, 197.

Sperm-cell, 187.

Sphagnum moss, 210, Fig. 374.

Spider-lily, 301.

Spiderwort, 264, 266, 335, Fig. 438; family, 334 .

Spike: compact, more or less simple, indeterminate cluster, with flowers sessile or nearly so, (250), Figs. 185,186 , 197.

Spikelet: a secondary spike; one of a compound spike, (306).

Spikenard, false, 333.

Spines, 108, 109, Fig. 168.

Spiranthes, 341.

Spirea, 392; inflorescence, 121, Fig. 193.

Spirogyra, 185, 186, 201, 263, 265, Figs. $340,341$.

Spleenwort, 323.

Sporangia, 186; of ferns, 179; stamens, 129.

Sporangiophore, 188.

Spore: a simple reproductive body, usually composed of a single detached cell containing no embryo, 5, 92, (344), 187.

Spore-case, 179.

Sporodinia, 189.

Sporogonium, 195.

Sporophyll, 183.

Sporophyte, 181, 201.

Spring beauty, 371 .

Spruce, 14, 15, 64, 98, 232, 325, Fig. 483; and light, 44; leaf, 102.

Spruce, 162; cone, Fig. 298; seed, Fig. 297.

Spurge, 110, 352; family, 351 .

Squash, 251, 289; fruit, 162, Fig. 296; germination, 171, 178; cell, 264, 265; leaf, 100;prickles, 109; root-pressure, 74.

Squaw-vine, 427.

Squirrel corn, 364 .

Stamen: pollen-bearin organ, (270), Figs. $206,209$.

Staminate: having stamens and no pistils, (274), Figs. 228-230.

Stand, dissecting 132, Fig. 217. 
Stand for lens, 132, Fig. 214.

Staphylea, 378.

Stareb, 271; and sugar, 246; as plantfood, 64 ; discussed, 273 , Fig. 444; how made, 78,85 ; storage of, 31 .

Star-grass, 337.

Star of Bethlehem, 331.

Star-thistle, 441.

Stellaria, 355, Fig. 516.

Stellate, 263, 298.

Stem: how elongates, 16; growth, Figs. 25, 26: system, 13, Fig. 17; tubers, 32 .

Stemless plants, 14.

Sterile flower: no stamens or pistils, (274).

Steven, quoted, 303.

Stiek-seed, 413.

Stick-tight, 169, 243, 413, Fig. 418.

Stigma: part of the pistil whieh reeeives the pollen, (272), Fig. 209.

Stipel:"stipule of a leaflet, (208).

Stipule: a eertain basal appendage of a leaf, (206).

St. John's-wort, 130, 371, Figs. 208, 278; family, 370 .

St. Peter's wreath, 392.

Stock, 366.

Stock: the part on which the cion is grafted, (70).

Stolon: a shoot which bends to the ground and takes root, (56).

Stoma, 301. Stomate, 79, 83, 88, 192, $298,301$.

Stone fruit, 161.

Strawberry, 15, 20, 232, 249, 251, 387, Figs. 533, 534; fruit, 160, 161, Fig. 291.

Straw lily, 332.

Strict stem system, 15.

Struggle for existence, $52,218$.

Strychnin, 271.

Style: elongated part of the pistil between the ovary and stigma, (272), Fig. 209.

Stylophorum, 363.

Suberin, 266.

Subterranean stem, 15; propagation by, 18.

Suckers, 54 ; of fungi, 91.

Sugar, 270; cane, 250, 273, Fig. 428.

Sulfur, 76 .

Sumac, 300; poison, 248, Fig. 422.

Summer-spore, 190.

Sundrops, 396.

Sunflower, 3, 19, 233, 267, 439, Figs. 3, 4, 23, 28; family, 431 ; inflorescence, $120,150,151,153$, Fig. 188; transpiration in, 79 .

Sunlight and plants, $42,88,223$.

Supernumerary buds: more than one in an axil, (88).

Survival of the fittest, 240.
Swarm-spore, 186.

Sweet alyssum, 160, 368, Fig. 519.

Sweet briar, 390 .

Sweet Cicely, 399.

Sweet clover, 243, 251, 383, Figs. 184, 528.

Sweet potato, 16, 32, 412, Fig. 204.

Sweet sultan, 442 .

Sweet William, 353, Fig. 515.

Swelling, 92.

Syeamore, 294; leaf-scar, Fig. 474.

Symbiosis, 193.

Symplocarpus, 327.

Sympode, 117, Fig. 180. Sympodial: axial growth continued by successive lateral shoots, 117.

Syngenesious: anthers united in a ring, (304).

Syringa, 395, 420 .

Table for laboratory work, Fig. 477

Tabular, 263.

Tamaraek, 326.

Tanacetum, 439.

Tangle-berry, 424.

Tannin, 271.

Tansy, 439.

Tap-root, 7, Fig. 8.

Taraxacum, 434.

Tare, 381.

Tea plant, Fig. 90.

Teasel, $3,244$.

Tecoma, eapsule, Fig. 285.

Teleutospore, 191.

Tendrils, climbers, 112, 113, Figs, 175177 ; roots as, 10 ; as leaves, 105 .

Terminal bud, 37, 50, Figs. 58-87.

Terminal flowers, 119, Fig. 181.

Terrestrial, 207.

Teucrium, 402.

Thalietrum, 357.

Thallophyte, 183, 185.

Thallus, 185.

Thinning, 258, Figs. 432, 433.

Thistle, 150, 169, 243, 441, Figs. 253255; Canada, 19, 22, 242, 244, 441, Fig. 409; Russian, 170, 243, Fig. 114; seed, 168 ; inflorescence, 120.

Thorns, 108, Figs. 164, 167.

Thoroughwort, 444.

Thuja, 326, Fig. 485.

Thyrse: eompound eluster with main axis indeterminate and branches determinate, (259).

Tiarella, 393.

Tickseed, 440.

Tiers of branches, 56, Figs. 93, 94.

Tiger lily, 21, 33, Fig. 31 .

Tillandsia, 94.

Timber crop, 249, 256.

Tissues, 278. 
Toad-flax, 19, 22, 244, 405, Fig. 544; flower, 145; fruit, Fig. 281; pollination, 137, Fig. 227.

Toadstools, 187.

Tobacco, 251, 271, 411.

Tomato, 4, 75, 251, 410; fruit, 160; -potato graft, 28.

Tooth-wort, 366, Fig. 266.

Torus: part or organ to which the parts of the flower are attached; upper end of the flower-stalk, (268).

Touch-me-not, 166, 375, Fig. 449.

Toxylon, 347 , Fig. 510 .

Tracheids, 281.

Tradescantia, 264, 265, 266, 276, 335, Fig. 438; stomates, 299.

Tragopogon, 434.

Trailing stems, 14, Fig. 18.

Transpiration: giving off of water, (157, 166), Figs. 128, 129.

Trees: plants that produce one main trunk and an elevated head, (15); and wind, 213, Figs. 379-381; forms of, 64, Figs. 111-113, 116-119; roots, 7 .

Trifolium, 382, Fig. 527.

Trillium, 145, 233, 332, Fig. 244.

Trimerous: in 3's, (291).

Tropæolum, 374.

Trumpet-creeper, 10, 113, 160, Figs. 12 , 285.

Truncate: squared as if cut off, (211), Fig. 154.

Trunk, form of, 65 .

Tsuga, 326, Fig. 484.

Tuber: short congested part, (78).

Tuberose, 337.

Tulip, 330 .

Tulip-tree, leaf, Fig. 154; seed, 168.

Tumble-grass, 170.

Tumble-weeds, 170.

Tunicated bulb, 33 .

Turnip, 33, 251, Fig. 47; fruit, 160; root-hairs, 12; starch in, 31 .

Turtlehead, 406.

Tussilago, 442.

Twiners, 112, 115.

Twin-leaf, 360.

Type, 236.

Ulmus, 346, Figs. 507-509.

Umbel: corymbose cluster with branches of about equal length and arising from a common point, (255).

Umbellet: secondary umbel, (255).

Umbelliferæ, 121, 122, 247, 397.

Uncinula, 189.

Undergrowth, 232.

Undulate: wavy, (212).

Uredospore, 192.

Urtica, 348.

Urticaceæ, 345.
Utricularia, 71, 207.

Uvularia, 332.

Vaccinium, 424.

Vacuole, 264.

Valvest separable parts of a pod, (312)

Variation, 236.

Variety, 236.

Vascular, 263, 278, 282.

Vase-form trees, 64, Fig. 112.

Vaucheria, 186, 187, 263, Figg. 342, 343.

Velum, 201.

Velvet leaf, 373 .

Venation: veining, (203).

Venus' looking-glass, 430.

Verbascum, 298, 405.

Verbena, 403; cutting, 25, Fig. 37.

Verbenaceæ, 403.

Vernonia, 445.

Veronica, 408.

Verticillate: with three or more leaves or flowers at one node, (113).

Vervain, 403; family, 403.

Vetch, 251, 381; nodules on root, 78 .

Vetchling, 381.

Viburnum, 429.

Vicia, 381.

Vigna, 384, Fig. 532.

Vinca, 419.

Violaceæ, 369.

Violet, 3, 233, 249, 369; cleistogamous, 140, Fig. 236; seeds, 166; family, 369 .

Viper's bugloss, 415.

Virginia creeper, tendril, 113, 114, 117, Fig. 175.

Virgin's bower, 359 .

Wahoo, 294.

Wake-robin, 332 .

Wallflower, fruit, 160 ; hairs, 298

Vralnut, 155; buds, 37, 138; inflorescence, 121, Fig. 190.

Wandering Jew, 335.

Water arum, 328 .

Water cress, 367.

Water hoarhound, 400.

Waterleaf, 415 ; family, 415 .

Water-lily, 3, 98, 205, 207, 361; family, 361 ; and mineral nutrients, 69,75 ; fungi, 266.

Watermelon, 251.

Watersprout, 54 .

Wax-work, twiner, 115.

Weeds, 220, 230, 241.

Weigela, 61, 429 .

Wheat, 77, 152, 221, 242, 249, 250, 254; field, 68, 225, Fig. 384; flower, 151, Fig. 259; germination, 173; inclusions, 276 , Fig. 445; India, 350; starch, 274, 275; roots, 7 ; rust, 189,190 , Figs. $352-357$. Whiteweed, 150, 242, 438, Fig. 189. 
Whorl: three or more leaves or flowers at one node, (113).

Wild geranium, Fig. 195.

Wild oat 8,332 .

Willow: buds, 39 , Figs. 60,91 ; cutting3, 21,26 ; dicecious, 138; expression in, 66; inflarescence, 117, Fig. 229; leaf, 99, Fig. 145; mildew, 189, Figs. 348351 ; phyllotaxy, 48; pussies, 121, Fig. 60 ; seeds, 168.

Willow-herb, 394.

Wilting, 80.

Wind and plants, 138, 213.

Windflower, 356.

Winter bud, $36,50,61$.

Winter-cress, 366.

Wintergreen, 424, Fig. 22; anther, 135; fringed, 140.
Wistaria, 115, 380.

Witeh-hazel, 166.

Wood-sorrel, 166, 374 .

Wood tissue, 281.

Woody structure, 3 .

Xanthium, 436, Fig. 555.

Xerophytic society, 228.

Xylem, 283.

Xylol, 302, 303.

Yarrow, 437.

Yeast, 263.

Yew, fruit, 164.

Zebrina, 335.

Zone societies, 233, Fig. 403.

Zygospore, 186. 



\title{
PRACTICAL PHYSICS FOR SECONDARY SCHOOLS
}

\author{
By N. HENRY BLACK, of the Roxbury Latin School, Boston, and \\ Prof. HARVEY N. DAVIS, of Harvard Universily
}

Cloth, 12mo., illustrated, 488 pages, list price, $\$ 1.25$

\begin{abstract}
"In preparing this book," say the authors in the Preface, "we have tried to select only those topies which are of vital interest to young people, whether or not they intend to coutinue the study of physies in a college course.

"In particular, we believe that the chief value of the informational side of such a course lies in its applications to the machinery of daily life. Everybody needs to know something about the working of electrical machinery, optical instruments, ships, automobiles, and all those laborsaving devices, such as vacuum cleaners, fireless cookers, pressure cookers, and electric irons, which are found in many American homes. We have, therefore, drawn as much of our illustrative material as possible from the common devices in modern life. We see no reason why this should detract in the least from the educational value of the study of physics, for one can learn to think straight just as well by thinking about an electrical generator, as by thinking about a Geissler tube. . . . . .

"To understand any machine clearly, the student must have clearly in mind the fundamental principles involved. Therefore, although we have tricd to begin each new topic, however short, with some concrete illustration familiar to young people, we have proceeded, as rapidly as seemed wise, to a deduction of the general principle. Then, to show how to make use of this principle, we have discussed other praetical applications. We have tried to emphasize still further the value of prineiples, that is, generalizations, in science, by summarizing at the end of each chapter the principles discussed in that chapter. In these summaries we have aimed to make the phrasing brief and vivid so that it may be easily remembered and easily used."

The new and noteworthy features of the book are the admirable selection of familiar material used to develop and apply the principles of physical science, the exceptionally clear and forceful exposition, showing the hand of the master teacher, the practical, interesting, thought-provoking problems and the superior illustrations.
\end{abstract}

\section{THE MACMILLAN COMPANY}

\section{4-66 Fifth Avenue, NEW YORK CITY}

BOSTON

ATLANTA

DALLAS

CHICAGO

SAN FRANCISCO 


\section{CHEMISTRY AND ITS RELATIONS TO DAILY LIFE}

By LOUIS KAHLENBERG and EDWIN B. HART Professors of Chemistry in the University of Wisconsin

Cloth, 12mo., illustratea, 393 pages, list price, \$1.25

If the contributions of chemical science to modern civilization were suddenly swept away, what a blank there would be! If, on the other hand, every person were acquainted with the elements of chemistry and its bearing upon our daily life, what an uplift human efficiency would receive! It is to further this latter end that this book has been prepared. Designed particularly for use by students of agriculture and home economics in secondary schools, its use will do much to increase the efficiency of the farm and the home. In the language of modern educational philosophy, it "functions in the life of the pupil."

Useful facts rather than mere theory have been emphasized although the theory has not been neglected. The practical character of the work is indicated by the following selected chapter headings:

II. The Composition and Uses of Water.

IV. The Air, Nitrogen, Nitric Acid and Ammonia.

IX. Carbon and Its Compounds.

XII. Paints, Oils and Varnishes.

XIII. Leather, Silk, Wool, Cotton and Rubber.

XV. Commercial Fertilizers.

XVI. Farm Manure.

XX. Milk and Its Products.

XXI. Poisons for Farm and Orchard Pests.

\section{THE MACMILLAN COMPANY}

64-66 Fifth Avenue, NEW YORK CITY

BOSTON

ATLANTA

DALLAS

CHICAGO

SAN FRANCISCO 


\title{
Warren's Elements of Agriculture
}

\author{
By G. F. WARREN, Professor of Farm Management and \\ Farm Crops, New York State College of Agriculture at Cor- \\ nell University \\ Cloth, 12 mo, 456 pages, \$1.10 net
}

Written by Professor G. F. Warren, who is in charge of the Department of Farm Management and Farm Crops in the New Vork State College of Agriculture, Cornell University, an authority on questions pertaining to practical agriculture.

Professor Warren is, moreover, a farmer. He grew up on a farm in the middle West and is living at the present time on a farm of three hundred and eighteen acres, which he supervises in connection with his work at the University.

The "Elements of Agriculture" is a text that does not "talk down" to the pupil. It gives agriculture rank beside physics, mathematics, and the languages, as a dignified subject for the course of study.

In Warren's "Elements of Agriculture" there is no waste space. It is written with the ease that characterizes a writer at home in his subject, and it is written in a style pedagogically correct. The author has been a teacher of high school boys and girls and knows how to present his subject to them.

Experts in the teaching of agriculture the country over have been unanimous in praise of the text. For instance:

Mr. J. E. Blair, Supt. of Schools, Corsicana, Texas :

"An examination of Warren's 'Elements of Agriculture' convinces me that it is a book of uncommon merit for secondary schools as well as for the private student. It is thoroughly scientific in matter, and is written in an attractive style, that cannot fail to please as well as instruct.'

\section{Supt. E. S. SмIтн, Whiting, lowa :}

"I am very much pleased with Warren's 'Elements of Agriculture.' In my opinion it is the only book on the market that presents the work of agriculture suitably for high schools; too many books are too simple and do not give enough work; a book for high schools must be more than a primer."

\section{THE MACMILLAN COMPANY}

Publishers 64-66 Fifth Avenue New York 


\section{New Physical Geography}

\section{BY RALPH S. TARR}

Late Professor of Physical Geography in Cornell University

$$
\text { Cloth, I2mo, fully illustrated, pp. 457. \$I.00 nei }
$$

Some points of interest in connection with this book are:

I. The author has an international reputation as an authority in the field of geology and physical geography.

2. In both content and method of presentation the book makes a strong appeal to the human interest of the pupil. It is well written.

3. It gives particular attention to the geography of the United States.

4. The illustrations are numerous, superior in quality, and significant, and they are used systematically throughout the book.

5. Topic summaries, topical outlines, and review questions following each chapter make its use easy for both pupil and teacher.

6. Experience shows that it possesses to an unusual degree those qualities that make a book a success in the classroom. It is widely used with great satisfaction.

\section{THE MACMILLAN COMPANY \\ Publishers 64-66 Fifth Avenue Now York}






THIS BOOK MAY BE KEPT OUT TWO WEEKS

And is subject to a fine of Five Cents a day thereafter. It was taken out on the day indicated below: 
$6 \times 3 \times 3$

$100 \%$

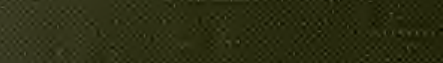

80.80

Fi:

82

2...

ig.

8

86

(4) $8 \%$
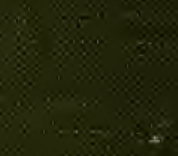